\title{
Knowledge, Science, and Literature in Early Modern Germany
}

Gerhild Scholz Williams Stephan K. Schindler 
Knowledge, Science, and Literature in Early

Modern Germany 


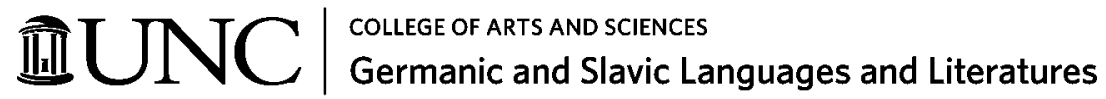

From 1949 to 2004, UNC Press and the UNC Department of Germanic \& Slavic Languages and Literatures published the UNC Studies in the Germanic Languages and Literatures series. Monographs, anthologies, and critical editions in the series covered an array of topics including medieval and modern literature, theater, linguistics, philology, onomastics, and the history of ideas. Through the generous support of the National Endowment for the Humanities and the Andrew W. Mellon Foundation, books in the series have been reissued in new paperback and open access digital editions. For a complete list of books visit www.uncpress.org. 


\section{Knowledge, Science, and Literature in Early Modern Germany}

GERHILD SCHOLZ WILLIAMS AND

STEPHAN K. SCHINDLER

UNC Studies in the Germanic Languages and Literatures Number 116 
Copyright (C) 1996

This work is licensed under a Creative Commons CC BY-NC-ND license. To view a copy of the license, visit http://creativecommons. org/licenses.

Suggested citation: Williams, Gerhild Scholz and Stephan K. Schindler. Knowledge, Science, and Literature in Early Modern Germany. Chapel Hill: University of North Carolina Press, 1996. DoI: https:// doi.org/ 10.5149/9781469656472_Williams

Library of Congress Cataloging-in-Publication Data Names: Williams, Gerhild Scholz and Schindler, Stephan K. Title: Knowledge, science, and literature in early modern Germany / by Gerhild Scholz Williams and Stephan K. Schindler. Other titles: University of North Carolina Studies in the Germanic Languages and Literatures; no. 116.

Description: Chapel Hill : University of North Carolina Press, [1996] Series: University of North Carolina Studies in the Germanic Languages and Literatures. | Includes bibliographical references and index.

Identifiers: LCCN 95026583 | ISBN 978-1-4696-5646-5 (pbk: alk. paper) | ISBN 978-1-4696-5647-2 (ebook)

Subjects: German literature - Early modern, 1500-1700 - History and criticism - Congresses. | Literature and science - Germany - History - Congresses. | Knowledge, Sociology of Congresses.

Classification: LCC PT238 .K56 1996 | DCC 306.4/2/09430903 
To

James F. Poag and

James E. McLeod 



\section{Contents}

1. Introduction

Gerhild Scholz Williams and Stephan K. Schindler

Part I, Policies, Formations, and Archives of Knowledge

2. The Protection of Invention: Printing Privileges in Early Modern Germany

Elaine C. Tennant

3. Zwischen Repräsentation und Regierungspraxis:

Transformation des Wissens in Maximilians Weiskunig

Jan-Dirk Müller

4. Before Winckelmann: Toward the Origins of the Historiography of Art

Thomas DaCosta Kaufmann

\section{Part II. Metaphorology, Poetics, and Philosophy}

5. Die "fließende" Rede und der "gefrorene" Text:

Metaphern im Spannungsfeld von Mündlichkeit und Schriftlichkeit

Horst Wenzel

6. Johannes Kepler: Poetic Inspiration and Scientific

Discovery

C. Stephen Jaeger

7. Der scheiternde Platonismus in Giordano Brunos Heroici Furori

Walter Haug

\section{Part III. Adapting Traditional Knowledge} to New Science

8. Der Umgang mit dem Wunderbaren in der Natur:

Portenta, Monstra und Prodigia in der Zoologie des Mittelalters und der frühen Neuzeit-

Die Gleichzeitigkeit des Ungleichzeitigen

Thomas Cramer 


\section{Contents}

9. Die Wissenschaft von den Hexen: Jean Bodin und sein Übersetzer Johann Fischart als Demonologen Gerhild Scholz Williams

10. Science and Pseudoscience: Athanasius Kircher's Mundus Subterraneus and His Scrvtinivm . . . Pestis Gerhard F. Strasser

\section{Part IV. Science and the Body}

11. Carnal Knowledge: Writing about Sex in Early Modern Germany James A. Parente, Jr.

12. Carnal Knowledge and the Populating of Paradise: Johann Gottfried Schnabel's Insel Felsenburg Lynne Tatlock

13. "Selbstbeschmutzung": Der Gelehrte und sein Leib/Körper in Adam Bernds Eigene Lebens-Beschreibung (1738)

Stephan K. Schindler $\quad 285$

Index 305 


\section{Foreword}

"Always news, rarely good news, but, if things always remained the same, God would not have to send us so many unheard-off warning prophets in all the elements." Early modern Europe experienced significant political, social, and religious upheaval as competing claims about the purpose, methods, and authority of knowledge vied for public attention. Commenting on contemporary culture and the political and intellectual issues of their day, early modern writers constructed panoramas in print devoted to the recurring themes of wonders, the occult, emerging scientific thinking, and gender and social mores. Knowledge about the nature of God, the natural world, and men and women demanded scholarly and princely attention. It also gained increasingly the acclaim of the literate public. European and pan-European events, reports of common superstitions, beliefs in occult causes and signs, and accounts of God's communication with His people were widely disseminated in print and increasingly in the mainstay of the new media, the weekly and monthly newspaper. $^{2}$

Early modern central Europe (1500-1700) is an epoch marked by exhilarating as well as terrifying tensions between what was and what was to come. Contemporaries, among them the Neapolitan writer and philanthropist Giovan Battista Manso (1560-1645), hailed this period, specifically the seventeenth century, with infectious enthusiasm for its discoveries of new and hitherto unknown worlds ("neue und unvorstellbare Himmel"). ${ }^{3}$ Spurred by the invention of wondrous machines like the telescope and the microscope, which opened outward and inward horizons, scholars and patrons anticipated rapid advancement in all areas of knowledge.

Moreover, the study of human physiology led to a better understanding of the workings of the human body, and research in alchemical processes created more efficacious medicines. In short, contemporaries were enthusiastically welcoming a period that would be the envy of ensuing generations. At the close of this historical period, the German philosopher and mathematician Gottfried Wilhelm Leibniz (1646-1716) confirmed the sentiments expressed at its outset. He agreed that it had indeed been a century of great and important changes generated by the emergence of many new ideas and inventions to which he had significantly contributed. ${ }^{4}$ 
The age was primarily driven by an interest in the history of science, in theories of the creation and manipulation of life, and in knowledge generation and knowledge management, which included the evolution of encyclopedism. The period's wars, plagues, and discoveries; its expansionist drive and its crazy and indulgent fashions; and its physicality, religious intolerance and grinding poverty - in short, the way new science coexisted in the same (re)searching mind with traditional and occult beliefs - all speak to the student and scholar of today with intellectual urgency, encouraging their reconsideration. In short, it appears that we detect a bit of ourselves, of our own time in its passage in the endless factionist strife, in the fear and fascination with the strange and the wondrous, in the many new beginnings. ${ }^{5}$ Accordingly, the essays in this book explore several recurrent themes: the convergence of the old and the new, science and the occult, gender and social order, the local and the global, communication about and the interpretation of wonders.

Our interest in this distant period does not come without its challenges. Succeeding generations have alternately admired, pitied, or scorned this period for its purported love of exaggerated forms in literature and the visual and architectural arts, its fascination with the occult, its passion for collecting everything. Some observers smiled in admiration; others turned away, dismissive of their predecessors' efforts at joining natural philosophy, history, mathematics, rhetoric, and theology in a universal science of knowing. They disparaged the century's eagerness to collect, order, and categorize uncounted and diverse specimen in its overflowing chambers of wonders (Wunderkammern), early iterations of today's museums. Even when succeeding generations of writers and philosophers made use of the information gathered in these vast encyclopedias and memory books, scholars of later decades tended to view these versions of early modern databases, the endless lists of disparate items arranged alphabetically or numerically, commentaries, and lists of quotes taken from authorities with only mild interest occasionally bordering on condescension. ${ }^{6}$

Still, the global and local, male and female, the scientific, the occult, and the superstitious, all mingle and course through seventeenth-century thought and writing. An example as amusing as it is enlightening is Johannes Praetorius's ${ }^{7}$ discussion of the purported ability of witches to create weather juxtaposed with a scientific tract by his contemporary Athanasius Kircher about lightening and thunder, magnetism and meteors. ${ }^{8}$ The modern reader will appreciate a mindset that was able to accommodate assumptions and expectations that seem to us mutually exclusive as the Praetorius and Kircher examples demonstrate.

The age these essays address, variously called the early modern, the baroque 
age, the classical age, the golden age, the age of Shakespeare, and the age of the scientific revolution, witnessed an intensely productive and sometimes hostile intermingling and intertwining of the old and the new. For several decades, these were held in balance before each moved to its separate domicile in history. Not the hypothetical victory of progress over tradition or superstition, until recently considered quintessentially early modern, inspired the age, rather the fascination with the sowohl als auch, the both and either, seemed much more pronounced during the seventeenth century than at any other time before or since. ${ }^{9}$ Nowadays, the early modern has become a cipher for a way of reflecting on history and change that resonates with us and our thinking. Increasingly bent on dominating the known world, yet ever mindful of its social and political volatility, and now increasingly interested in ecocriticism, medical humanities, and climate studies, the early modern reflects its own deep ambivalence and imperial grandeur in its awareness, as Hardt and Negri termed it, that it was a "fragile, baroque century" (77). ${ }^{10}$

Consequently, the essays in this volume can be seen as shaping a tableau of what frequently appears as the epithet for this period, the crisis of the early modern age. ${ }^{11}$ While the debate among historians about the crisis or crises of the early modern has cooled considerably since the mid-seventies and early eighties, the term crisis, referring to various aspects of the century's politics and culture, regularly reappears in the literature. ${ }^{12}$ It is here that Hardt and Negri locate the cradle of modernity, the birth of modern Europe. ${ }^{13}$

The fate of the people unfolded within the space that scholars and theologians described in the traditional analogy of micro- and macrocosm; mankind, the microcosm, lived within and, at the same time, mirrored the macrocosm, God and all of His creations. The records show that contemporaries believed that this century, more than any previous one, was marked by the appearance of uncounted prodigies and wonders, by comets and celestial portents. Either predicative or explicative, these comets and wonders accompanied the course of world events like an endless, albeit confusing, conversation between humankind and the divine, assiduously elucidated in print for all who could and wanted to understand. ${ }^{14}$

Secrets of nature and the established ways of knowing continued to live alongside the excitement generated by all manners of new scientific, geographical, and astronomical discoveries vying for readers' and scholars' attention as well as for dominance in public consciousness. ${ }^{15}$ These ways of knowing did not exclude each other nor did they impede each other's movement toward alternative models of explanation. ${ }^{16} \mathrm{New}$ discoveries in all areas of knowledge also did not consign previous ways of knowing to oblivion just yet. Whether 
concluded by scholars or surmised by the laity, the concept of the world as a system of signs that carried many often conflicting meanings continued to encourage, and even demand, dissimilar explanatory models. In the minds of individuals, order and disorder in nature kept on signaling grave future events, great misfortunes, and horrific disasters. Moreover, as natural signs of transcendent origin, they provided messages about what God had in store for His people. The oft-made experience that the understanding of a prediction and the event that eventually emerged often did not coincide remains secondary to the fact that meaning had to be assumed. ${ }^{17}$ Natural history, a relatively recent addition to the forms of knowledge production of the seventeenth century, introduced a plethora of new information as a result of explorations abroad and experimentation at home. ${ }^{18}$

The early modern era was also the time when all knowledge increasingly was transferred and communicated in daily, weekly, monthly, or annual newsprint, such as Zeytungen, local and international Relationen, Diarien, and Avisen, which had become widely available by the middle of the century. ${ }^{19}$ At this time over thirty German cities produced regular newsprint in German, some of them several different ones. ${ }^{20}$ Added to these were the publications of the various national and international learned societies that began to appear the second half of the century. ${ }^{21}$ These journals opened windows to the world near and far by providing reports on important world events; on politics, wars, social concerns, demographic changes; and on strange natural phenomena, monster births, murders, and other noteworthy events.

Moreover, collecting, reordering, and organizing knowledge in vast compilations variously called Theatrum, Universalbibliothek, Pandecten, or commonplace books, lovers of knowledge also arranged countless specimen of natural wonders on the shelves of their museums (Wunderkammern). ${ }^{22}$

Finally, as becomes clear from the essays in this volume, knowledge, as a cultural anthropology of thought, connected all levels of discourse and all fields of inquiry. It was inscribed as much in cerebral and rational processes as in the historical constructions of the body. Moreover, knowledge on its way to becoming science generated conflicts that were communicated in a variety of discourses. This discursive multiplication represents an abiding emotional and intellectual accomplishment of the early modern period and furnishes the basic and underlying concept of this volume's investigations.

Gerhild Williams 
1. “'Immer was Neues - Selten was Gutes...' denn bliebe man bey dem Alten / so würde der eyvernde Gott ietzt wohl nicht so viel unerhörte Straff-Propheten zu uns senden / aus allen Elementen," Johannes Praetorius, Unerhörtes Prodigium von der hoch-blauen Seide / So bey Laucha um Naumburg / unlängst auffm Acker häuffig angetroffen worden (Halle: 1665), 1.

2. Gerhild Scholz Williams, Mediating Culture in the Seventeenth-Century German Novel: Eberhard Werner Happel, 1647-1690. (Ann Arbor: Michigan University Press, 2014).

3. "(Ich glaube) dem Allerhöchsten danken zu müssen, der mich in dieses glückliche Jahrhundert treten ließ," [I have to thank the Most High for being born into this fortunate century] from Giovan Battista Manso in a letter to Paolo Beni of Padua, Napoli, March 1610, cited by Wolfgang Schmale, "Das 17. Jahrhundert und die neuere europäische Geschichte," Historische Zeitschrift 264, 3 (1997): 587-613, here 587.

4. "Finis saeculi novam rerum faciem aperuit." G. MacDonald Ross, Leibniz (Oxford: Oxford University Press, 1984).

5. Frank Fehrenbach, "Verspiegelung der Künste: Zur Revision des Barockbegriffs," Die Frankfurter Allgemeine Zeitung 67 (20 März 2002): N3.

6. Helmut Zedelmaier, Bibliotheca universalis und Bibliotheca selecta: Das Problem der Ordnung des gelehrten Wissens in der frühen Neuzeit (Köln: Böhlau Verlag, 1982); Helmut Zedelmaier, "Von den Wundermännern des Gedächtnisses: Begriffsgeschichtliche Anmerkungen zu 'Polyhistor' und 'Polyhistorie." in Die Enzyklopädie im Wandel vom Hochmittelalter bis zur Frühen Neuzeit., ed. Christel Meier, (München: Fink, 2002), 421-45; Ann Blair, The Theatre of Nature: Jean Bodin and Renaissance Science (Princeton: Princeton University Press, 1997), 4-5.

7. Gerhild Scholz Williams, Ways of Knowing in Early Modern Germany: Johannes Praetorius as a Witness to his Time, Literary and Scientific Cultures of Early Modernity (Aldershot: Ashgate, 2006).

8. Johannes Praetorius, Blockes-Berges Verrichtung / Oder Ausführlicher Geographischer Bericht / von den hohen trefflich alt-und berühmten Blockes-Berge: ingleichen von der Hexenfahrt / und Zauber-Sabbathe (Leipzig/Frankfurt/M: Johann Scheiben/Friedrich Arnsten 1668), 156-89.The relationship of German to Latin in his tracts is variable; even his German writings often contain a fair amount of Latin quotes and paraphrases. Occasionally, it also works the other way, that is, a Latin text is interspersed with German.

9. Schmale talks about the tension between a noch immer and an auch schon that marks the so-called crisis of the seventeenth century (607).

10. Michael Hardt and Antonio Negri, Empire (Cambridge: Harvard University Press, 2000); trans. Empire: Die neue Weltordnung (Frankfurt/M.: Campus Verlag, 2002). Hardt and Negri note in their discussion of the rise of eurocentrism, "European [and now by extension, American, GSW] mastery is always in crisis-and this is the very same crisis that defines European [American GSW] modernity" (77).

11. For example, Hartmut Lehmann in Krisenbewußtsein und Krisenbewältigung in der Frühen Neuzeit - Crisis in Early Modern Europe: Festschrift für Hans-Christoph Rublack, ed. Monika Holtz und Sabine Hagemaier (Frankfurt/m-Berlin-Bern: Lang, 1992), 3-11, here 5-6.

12. Aside from the texts noted above, see Schilling (1999), 273, 274 ["Krisenphänomene"], 275 ["modernisierende Veränderungskrise"], 278, to only name two instances among many; Geoffrey Parker, Europe in Crisis, 1598-1648 (Oxford: Blackwell, 2001; $2^{\text {nd }}$ reprint); Geoffrey Parker, Empire, War and Faith in Early Modern Europe (London: Penguin, 2002), 5.

13. "Modernity itself is defined by crisis" (76) and "In the seventeenth century the concept 


\section{xiv Foreword}

of modernity as crisis was definitely consolidated" (77) in Hardt and Negri, Empire. Antonio and Michael Hardt Negri, Empire (Cambridge (Frankfurt/M.): Harvard UP (Campus Verlag), 2001).

14. Sara J. Schechner, Comets, Popular Culture, and the Birth of Modern Cosmology (Princeton: Princeton University Press, 1997); Christina Hofmann-Randall, Monster, Wunder und Kometen: Sensationsberichte aus Flugblättern des 16. bis 17. Jahrhunderts (Erlangen: Universitätsbibliothek, 1999); Paul Mauelshagen, "Illustrierte Kometenflugblätter in wahrnehmungsgeschichtlicher Perspektive," in Das illustrierte Flugblatt in der Kultur der Frühen Neuzeit: Wolfenbütteler Arbeitsgespräche 1997, ed. Wolfgang Harms and Michael Schilling, Mikrokosmos: Beiträge zur Literaturwissenschaft und Bedeutungsforschung (Frankfurt/M: Peter Lang, 1998), 101-35.

15. John Henry, The Scientific Revolution and the Origin of Modern Science, ed. Richard Overy, Studies in European History (London: MacMillan Press, 1997). Along with much helpful information about seventeenth-century science and culture, Henry provides an excellent review of the debate among historians of the last thirty years about how revolutionary the Scientific Revolution really was.

16. Kaspar von Greyerz, "Alchemie, Hermetismus und Magie: Zur Frage der Kontinuitäten in der wissenschaftlichen Revolution," in Hartmut Lehmann und Anne-Charlott Trepp (1999), 421-25. "Okkulte und exakte Wissenschaften," in Die okkulten Wissenschaften in der Renaissance, ed. August Buck, Wolfenbütteler Abhandlungen zur Renaissanceforschung 12 (Wiesbaden: Harrassowitz, 1992), 21-43.

17. Hermann Wellenreuther, "Gedanken zum Zusammenhang von Kommunikation und Wissen im 17. Jahrhundert," in Im Zeichen der Krise: Religiosität im Europa des 17. Jahrhunderts, ed. Hartmut Lehmann und Anne-Charlott Trepp (Göttingen: Vandenhoeck \& Ruprecht, 1999), 315-18, here 314; Thomas Klingebiel, "Apocalyptic, Prodigienglaube und Prophetismus im Alten Reich: Einführung," in Im Zeichen der Krise,17-33, here 17 and 19.

18. Brian Vickers, ed., Occult and Scientific Mentalities in the Renaissance (Cambridge: Harvard University Press, 1984), Introduction.

19. Karl Schottenloher, Flugblatt und Zeitung: Ein Wegweiser durch das gedruckte Schrifttum. Bd. 1 Von den Anfängen bis zum Jahre 1848 (München: Klinckhardt \& Biermann, 1985), 225250; Johannes Weber, Avisen, Relationen, Gazetten: Der Beginn des europäischen Zeitungswesens, vol. 25, Bibliotheksgesellschaft Oldenburg (Oldenburg: Bibliotheks und Informationssystem der Universitaet Oldenburg, 1997); Straßner 1997. 1 lists more than thirty-one names for the new print medium.

20. Elger Blühm, “Die ältesten Zeitungen und das Volk," in Literatur und Volk, ed. Wolfgang Brückner (1985), 741-51, here 742 .

21. Philosophical Transactions of the Royal Society (from 1665); Journal de Sçavans (Paris 1665-1938); Bibliotheca de scriptoribus et scriptis Hebraicis (1675-1693): see Handbuch der historischen Buchbestände, 88, 89.

22. Jan-Dirk Müller, "Universalbibliothek und Gedächtnis," 285; also Helmut Zedelmaier, Bibliotheca universalis und Bibliotheca selecta: Das Problem der Ordnung des Gelehrten Wissens in der Frühen Neuzeit (Köln: Böhlau Verlag, 1992); Flemming Schock, Die Text-Kunstkammer. Populäre Wissenssammlungen des Barock am Beispield der "Relationes Curiosae" von E.W. Happel, vol. 68, Beihefte zum Archiv für Kulturgeschichte (Cologne: Böhlau, 2011). 


\section{WORKS CITED}

Negri, Antonio and Michael Hardt. Empire. Cambridge (Frankfurt/M.): Harvard UP (Campus Verlag), 2001.

Schock, Flemming. Die Text-Kunstkammer. Populäre Wissenssammlungen des Barock am Beispield der "Relationes Curiosae" von E.W. Happel. Vol. 68, Beihefte zum Archiv für Kulturgeschichte. Cologne: Böhlau, 2011.

Williams, Gerhild Scholz. Mediating Culture in the Seventeenth-Century German Novel: Eberhard Werner Happel, 1647-1690. Ann Arbor: Michigan University Press, 2014.

_-_. Ways of Knowing in Early Modern Germany: Johannes Praetorius as a Witness to his Time, Literary and Scientific Cultures of Early Modernity. Aldershot: Ashgate, 2006. 

Knowledge, Science, and Literature in Early Modern Germany 



\section{Introduction}

\section{Gerhild Scholz Williams and Stephan K. Schindler}

This volume contains the amended papers presented at the Twelfth St. Louis Symposium on German Literature in April 1994. Scholars from the United States and Germany had been invited to explore the ways in which early modern people produced and organized knowledge, how they encoded science, and how this encoding appeared in literature.

Early modern Europe experienced much political, social, and religious upheaval as competing claims about the purpose, methods, and authority of knowledge vied for public attention. Popular knowledge, pseudosciences, information produced and guarded by the scholarly elites, and knowledge about the nature of God, about the natural world, about man and woman were transmitted orally or in written form. They all demanded scholarly and princely attention and public status. Print communication, information about astrological predictions, doctrinal struggles, and political jealousies and ambitions responded to and influenced the struggle for dominance among learned and lay communities. When confronted with new, foreign, or seemingly strange systems of knowledge-as was the case with discoveries, the witchcraze, the reforming movements, and the changing perceptions about sex, gender, and the body-many traditions and time-honored opinions had to be defended against these intruding and competing epistemologies.

Struggling to collect and organize information from around the world, scholars produced immense compendia of knowledge that were increasingly looked upon as property, to be protected from unauthorized copying and selling. The licensing and censoring of knowledge as a cultural product that was subject to political, social, religious, and economic changes became a growing concern among the political and religious elites (Tennant).

Science represents the attempt to systematize and schematize knowledge and information, sharing with both the inescapable effects of the same epochal shifts and changes. Renaissance science, whether it was articulated in Kepler's poetic inspirations (Jaeger), in Bruno's Platonism (Haug), or in Kircher's efforts to reconcile geography and microscopy 


\section{Gerhild Scholz Williams and Stephan K. Schindler}

with theology (Strasser), reacted to the interconnectedness of science and knowledge by producing numerous discursive options.

Early modern scholars struggled to fit received knowledge into concepts of the wondrous, the magical, and even the satanic within the precepts of contemporary scientific understanding, confirming thereby that knowledge was local, historical, and plural. The vast compendia of knowledge they produced associate the real with the fictitious (Cramer) to render authoritative the results of their labors. Nothing was too remote or too distant that it did not merit study and classification. This included demonology, the academic and scientific study of demons, magic, and witchcraft (Williams).

In all cases under discussion here we observe the attempt of science to advance knowledge in the interest of specific political groups and social classes. Rather than serving as a transcendental force for progress, science affirms claims to power. It does so most insistently if these claims are articulated by wealthy burghers, the nobility, or the Holy Roman Emperor himself (Müller).

Metaphors that explicate changes in early modern media, such as the transfer from manuscript to book culture, serve as a reminder of the historicity of discourse and of discursive representation (Wenzel). Renaissance invention of historicity established new sites of intellectual authority. With it came new techniques of inquiry and of selfpresentation, and new fields of intellectual endeavor (Kaufmann).

Knowledge, as a "cultural anthropology of thought," ${ }^{1}$ interconnects all levels of discourse and all fields of inquiry; it is inscribed as much in cerebral, rational processes as in the historical construction of the body. Human sexuality and emotions, the affects of social discourse, the effects of social and sexual discipline imposed on the body, as well as the preoccupation with bodily functions, are incorporated into the construction of the early modern family and of the state (Tatlock, Schindler). Many modern scholars find this vast range of interaction of knowledge and science fascinating and challenging, on occasion even unsettling. However, instead of confronting and examining the great variety of discourses on love, desire, and sexuality in early modern German and Latin literature, scholars occasionally seek refuge in traditional literary analysis in an attempt to avoid probing the ideological categories that might have prompted their use. In so doing, they obscure our path toward cultural knowledge and understanding (Parente).

Knowledge on its way to becoming science generates conflicts that are communicated in a variety of discourses. This discursive multiplicity represents an abiding emotional and intellectual accomplishment of 
the early modern period. It furnished the basic and unifying concept of our investigations.

This book could not have been published without the generous support of Washington University and the Deutsche Forschungsgemeinschaft, which made possible the gathering of colleagues from Germany and the United States on the campus of Washington University in St. Louis. We are grateful to the anonymous readers of the manuscript for helpful comments, to Paul Roberge for expertly guiding us through the publication process, and to the University of North Carolina Press for accepting our volume for publication. We thank Lynne Tatlock for her support. Thanks are due as well to Elizabeth Fyfe and Debbie Kurtz and to the graduate students of the German Department of Washington University, especially Jennifer Drake and Troy Wiwczaroski, for their assistance.

Finally, we would like to express our deep appreciation to our colleagues and friends James F. Poag and James E. McLeod whose intelligence, creativity, unflagging encouragement, and good humor helped to build and maintain an energetic, committed, and collegial department. To them we dedicate this book on the occasion of their birthdays.

St. Louis, July 1995

\section{Note}

1. Roy Porter, "Introduction," in Science, Culture, and Popular Belief in Renaissance Europe, ed. Stephen Pumfrey, Paolo L. Rossi, and Maurice Slawinski (Manchester: Manchester University Press, 1991), p. 2. 

Part I. Policies, Formations, and Archives of Knowledge 



\title{
2. The Protection of Invention: Printing Privileges in Early Modern Germany
}

\author{
Elaine C. Tennant
}

For at least a century after the invention of movable type, numerous features of the traditional manuscript culture of the Middle Ages continued to inform the ways society managed the circulation of information and the ways it thought about the information that it managed. Some of the inherent possibilities of the new print medium were immediately obvious to both members of the new printing fraternity and to authorities who defined the circumstances under which printing could take place. But much of the potential-and many of the difficultiesimplicit in the rise of print culture emerged only gradually over the course of a century or so.

An evolving awareness of the distinctive possibilities of the print medium, for example, can be documented in the changing look of printed books from the age of the incunable into the early sixteenth century, long before printers, publishers, and authors began to articulate their notions of a printed book as something different from a manuscript. Similarly artifacts from both the new print culture and the continuing manuscript culture of the late fifteenth and the sixteenth centuries in Germany preserve evidence of concerns about the very nature of printed information and its resistance to conventional mechanisms of control, long before such concerns are actually formulated as problems. The conservative manuscript culture of the late Middle Ages and the emerging print culture of the modern era run headlong into each other in German chanceries throughout the sixteenth century. In fact, the manuscript and print cultures literally intersect in one contemporary chancery instrument, the so-called printing privilege, privilegium or freiheit, which preserves with surprising vividness traces of contemporary thinking about the nature and control of material that was published. That instrument is the topic of this essay. 


\section{Elaine C. Tennant}

\section{A great new little book that teaches arithmetic for business (Ayn new kunstlich Buech ... welches lernet . . . rechnung auff kauffmanschafft) (fol. Ar)}

In 1521 a certain Henricus Grammateus, a scribe from Erfurt and a master of the seven liberal arts, published a little handbook on, among other things, the new Italian method of bookkeeping that was revolutionizing business practices throughout Europe. ${ }^{1}$ The story of this little book - a small octavo that fits nicely in the hand-is one that modern academics will be quick to recognize. Henricus Grammateus was a notyet-acclaimed mathematician at the University of Vienna, who had nevertheless achieved some modest recognition in the academy as the proctor (procurator) of the university's Saxon Nation and, as such, was one of those who voted to elect the rector. ${ }^{2}$ But when it came to publishing his book, he looked to senior colleagues to smooth his way into print. Specifically he turned to the architect Johann Tscherte, a senator of the city of Vienna, who was also a bridge builder for the emperor. ${ }^{3}$ Henricus reminded Tscherte that he had been the one to encourage him to publish his mathematical rules, and he dedicated the book to Tscherte, asking him kindly to take it "under his protection." In making this appeal Henricus also asked Tscherte to convey his greetings to his "teacher and lord, Jörg Tannstetter, doctor of the seven liberal arts and of medicine." 4 Tannstetter, who is better known to us by his humanist Latin name, Collimitius, was ordinarius for mathematics at the University of Vienna, where he had served as rector, and he was a member of the renowned Danubian Sodality. ${ }^{5}$ He was also one of Maximilian's court physicians. In brief, Henricus had friends in high places, and his rechenbüchlein was indeed published under an imperial privilege, executed by Jacob Spiegel, and granted to the Vienna bookdealer Lucas Alantsee. The book was printed by Johannes Stüchs in Nuremberg.

Almost all of this story can be read directly from the book itself. Printed at the foot of the title page is the terse announcement: "With Imperial grace and Privilege; this book is not to be reprinted within six years." ${ }^{6}$ And the flipside of that folio is filled completely by Tscherte's coat of arms. ${ }^{7}$ The second folio, recto and verso, is taken up with Henricus's dedication of the volume, in which he reviews the history of the project and appeals to Tscherte to protect the book. All this prefatory material is in German (figs. 1-3). At the end of the volume, Henricus offers his labors to "all friends of the liberal arts"; he asks brotherly correction for any flaws in the work that may have occurred due to his lack of diligence; and he warns printers again-on pain of considerable 
damages, as specified in the imperial privilege that follows-not to reprint the work within six years. ${ }^{8}$ Henricus's apologia for the book and his summary warning are also in German. They are followed by the full Latin text of the letter of privilege. The original privilege is, according to the text reproduced in the little volume, a charter under seal issued at the behest of Emperor Maximilian (with the "per regem pro [se]" and the "ad mandatum Cæsaræ" formulas), ${ }^{9}$ over the signature of Jacob Spiegel in Augsburg on July 20,1518. In this edition of the rechenbüchlein Johannes Stüchs prints Spiegel's name where the signature occurs on the manuscript original of the privilege, and he closes the book with his own printer's colophon and device (figs. 4-6).

By comparison with ambitious illustrated folio imprints from the period-works like Maximilian's Theuerdanck or Leonhard Fuchs's herbal-the little accountancy treatise of Henricus Grammateus looks unremarkable. A sober, finely executed project, it belongs not among the sumptuous "coffee table books" of the sixteenth century but rather to that fascinating and underexplored group of early modern do-ityourself treatises, which achieved unprecedented status and circulation during the first century of print culture in Europe. As the first German work on bookkeeping, ${ }^{10}$ however, and as an early German imprint published under fully documented imperial privilege, Henricus's rechenbüchlein provides perfect testimony to two key vectors of the information explosion that occurred in Europe following the invention of movable type. The first of these vectors is the absolute increase in the amount and variety of information that becomes accessible publicly in the first century or so after the invention of printing. The second is the attempt to manage that knowledge in the emerging print culture, where mechanical reproduction facilitates the dissemination of information in unprecedented amounts and at unprecedented speed.

In the rest of this essay I will pursue these two considerations by looking first at how the medieval German privilegium was adapted to manage this flood of information. Then, from the character and application of the privilege itself, I will attempt to derive some sense of what that legal mechanism was employed to foster and protect. Finally, I will look at the compatibility of the information to be managed and the mechanisms designed to manage it in the emerging print culture of German-speaking Europe before 1600. In doing so I will also consider briefly the effectiveness of the privilege system as an instrument for controlling information in this period. The rechenbüchlein of Henricus Grammateus will be my vade mecum to the privilege system, and the privilege system in turn my guide to the notions that informed some of the legal attempts to manage information in sixteenth-century 
Germany. I will use J. L. Austin's theory of performatives to raise questions about how well the privilege system worked and why.

\section{To explore further in this art (weiter jnn sulcher kunst zu speculirn) (fol. Q2r)}

Before turning to the question of privileges or freiheiten as such, let us pause for a moment to remind ourselves of the enormous increase in both the kinds and quantities of information that were becoming available to even semiliterate audiences in Europe in the early sixteenth century. One thinks of the rediscovery of whole areas of classical scholarship, of the navigational advances that contributed to the discovery of the Americas, of the previously unimagined knowledge that encounters with New World cultures contributed to European thinking. One thinks of the technological advances in metallurgy, of the new challenges to medicine, of new systems of reckoning and banking, of dramatic new ways to make and lose fortunes. There were the bold attempts to reconcile science and wonders, some of which were heralded and rewarded as laudable contributions to the common good, some of which were suppressed as threatening to the social order. And then, of course, there was the new printing technology itself, which offered all this information to audiences within the population who even a century earlier would have had little or no access to the scientific, intellectual, and theological advances made in their time.

Printing transmitted the inherited wisdom of many established fields of learning, and it established new fields of endeavor by publishing their technical methodologies. The coincidence of advances in so many areas that produced new information on the one hand with the rise of print culture on the other makes it very little surprising that people at the beginning of the sixteenth century were thinking about their ideas as never before. Authors high and low, practical and philosophical were self-consciously concerned about publishing their new revelations, their new sciences and ways of doing things, for the good of audiences who would pursue them. This latter concern is even expressed in the rechenbüchlein of Henricus, who says finally of his text, "I have written solely for the young beginners in the art of mathematics, [and] I believe that I will have given some of them a reason to explore [speculirn] in this art." ${ }^{11}$ Similarly in Maximilian's Weißkunig we find this posture of seeking, speculation, and pondering recommended as the attitude required of a responsible prince; it is what the young White King must learn to do in order to be a fit ruler. ${ }^{12}$ And, of course, there is 
Faustus who remains emblematic for the age. He enters his pact with Mephostophiles precisely because neither the gifts bestowed on him from above nor the teaching of men can give him the skill to fathom the elements (literally "die Elementa zu speculieren"). ${ }^{13}$ We will come back to Faustus and his problems a little later.

\section{Take this my book under your protection (solch mein buech vnnder ewer schuotz ... annemen) (fol. A2v)}

The dramatic increase in information and the advances in transmitting it stimulated an enthusiasm for learning and exploring, but these developments also threatened to inundate Germany with a free flow of uncensored and unattributed print materials of the most various kinds. As Michael Giesecke has pointed out, two complementary instruments of legal control were adapted from their medieval antecedents to deal with the spate of information in this period. ${ }^{14}$ Existing censorship mechanisms were expanded and made more aggressive, and the privilege instrument was applied to protect various links in the chain of mechanical information reproduction and dissemination. It is this second mechanism that affords such interesting access to early modern thinking about the nature of the material that was becoming public by means of the print medium. ${ }^{15}$

In simplest terms a privilege or freiheit is a law designed to treat the individual rather than the general case. ${ }^{16}$ It is a legal instrument that was used in Germany from the period of the Hohenstaufens right on into the modern era to confer sovereign favor on individuals without establishing a general precedent. The fact that a privilege could be conferred arbitrarily by a ruler on an ad personam basis, however, in no way precluded its systematic use for entire categories of legal issues. Privileges were used regularly, for example, to confer fiefs on individuals or raise them to the nobility, and in the early modern period the privilege became the chancery mechanism of choice for dealing with the legal issues that began to emerge around the new printing industry. ${ }^{17}$

Despite the inherent flexibility of the privilege as a legal instrument, virtually all early privileges related to printing have a few features in common. They are basically limited monopolies conferred by authorities in response to petitions submitted by individuals involved with some aspect of the printing trade. The privileges confer on the grantee exclusive rights to some property related to printing for a specified amount of time. They simultaneously prohibit the infringement of the protected right for the period specified in the letter of privilege, and 
Zynnew kunftlich Buech welches gar gewí sono bebeno

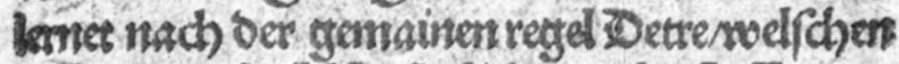

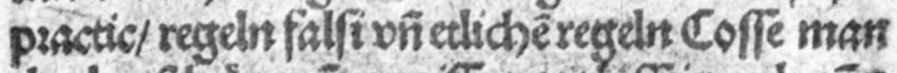

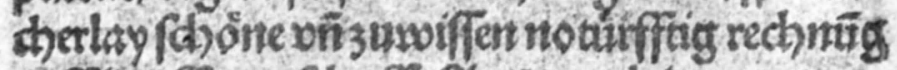

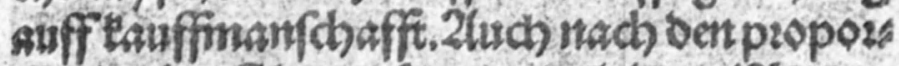

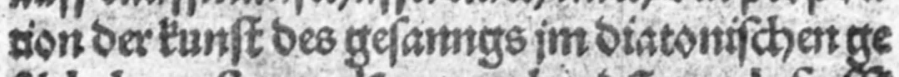

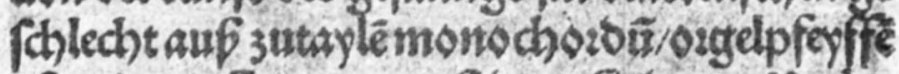
in anber joffrument auf ber erfintoung pytbo gore, DOeytter if bierinten Begriffen Buech balts

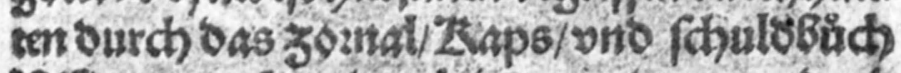

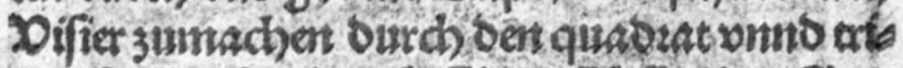
angel mit vil antoem lif figen frictent oer Geos meney. Gentadit anffoer loblichen boenfoin

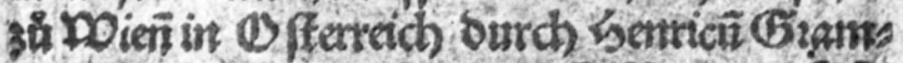

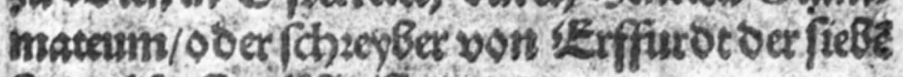
freyentinffen thatfter.

\section{Dít lkayferliché gnaben ono 1) sáuilegien oas buecbnicht nacb ju trucké in fecbsjaré}

Fig. 1. Title page with announcement of imperial privilege ( fol. Ar). Courtesy, The Bancroft Library. 
this on pain of a specified penalty, usually a rather significant one. ${ }^{18}$ They almost invariably prohibit reprinting (nachdrucken) of one or more aspects of the property protected for the duration of the privilege. These are just about all the features that early modern German printing privileges have in common. If we look, however, at the many usual ways in which such privileges differed from each other, the obstacles to studying them systematically become apparent. ${ }^{19}$

Both clerical and secular authorities conferred privileges. Within the German-speaking realm bishops, archbishops, cities, princes, electors, and the emperor all issued privileges. Elsewhere in Europe the pope, the Italian city-states, and the kings of France and Spain conferred privileges. The jurisdiction of a privilege extended only as far as the authority of its grantor, however, with the result that some petitioners sought multiple privileges for the same property, particularly where the project in question represented a major financial investment.

The categories of property protected by privileges were surprisingly various. Some privileges were granted to protect physical aspects of the printing process such as Greek, italic, or musical type fonts. Privileges were occasionally conferred to protect a specific technique such as chiaroscuro printing. ${ }^{20}$ Some were awarded for entire categories of texts or fields of knowledge, such as all works in classical languages, all Reichstagsakten, all philosophical, medical, historical, or mathematical works. And occasionally a blanket privilege was conferred to protect all the works produced by a given printer. Images were often mentioned separately in privileges because they were expensive to produce originally but cheap to reproduce or pirate. And, of course, privileges were given to protect a single work or the works of a specific author living or dead. Sometimes privileges were even awarded "on spec" - that is, not only for the works that an author had already written but also for all those that he might write in a given field. ${ }^{21}$

From a modern point of view the diversity of the petitioners who got these monopolies is quite as noteworthy as the overlapping categories for which privileges were awarded. Essentially anyone who had a vested or vestable interest in a printing project might apply for and, if successful, receive a privilege that, depending on its terms, protected the project as a whole or some aspect of the project. Thus the artist who designed a woodcut series, the printer who wanted to print the text of an author living or dead, the living author of a text, or, interestingly, the publisher or editor-proofreader (verleger or kastigator) ${ }^{22}$ working with a printer might receive a privilege. And to make the picture more varied still, the privileges were in many cases transferable. So if an author had secured a privilege protecting his own text but happened not to be a 


\section{Elaine C. Tennant}

printer, he could specifically assign his privilege to a printer for one or more editions of the work in question. In our original point of reference, the rechenbüchlein of Henricus Grammateus, we see that although his treatise does appear under imperial privilege, neither he the author nor Stüchs the printer is the privilege holder. It is rather the Vienna bookdealer Lucas Alantsee who is holding the privilege that the anxious Henricus invokes twice in the edition (fig. 5). And the privilege itself, which was executed in 1518 under the aegis of Maximilian I, is being applied to a work that was not published until the reign of Charles V.

\section{I am compelled to have printed (Bin ich \\ geursacht... in den truck zugeben) (fol. A2v)}

Before proceeding to other aspects of the privileging process, we should perhaps consider the implications of those parts of the system already reviewed. The early modern German privilege system is often mentioned in passing in discussions of, among other topics, more recent European copyright law. In this context it is sometimes characterized as a sort of regional precopyright mechanism driven by economic motives, uninformed by moral scruples, regulated by inadequate legal instruments, and lacking any notion of what the posteighteenth-century world has come to think of as intellectual property. Such characterizations tend to designate all privileges as "printer's" or "reprinting" privileges, and to argue that no meaningful notion of authorial rights (Urheberrecht) developed in the age of privileges. ${ }^{23}$ Although we have not yet examined enough pieces of the privilege puzzle to deal with all of these assertions, we can begin to clear away some of this underbrush.

First of all, it is important to note that early modern German privileges are awarded for kunst - art, invention, knowledge, industry-in the widest sense of this term. A new system of bookkeeping, a new translation of Pliny, a new method for casting gun barrels or printing chiaroscuro, not to mention the creation of a new text or a set of woodcuts-all these things are protected alike by the same legal instrument in the sixteenth century because they are all, despite their different media, valued forms of invention. The sixteenth-century notion of the creator or Urheber would seem then not to be underdeveloped or incipient, as has been alleged, but easily as inclusive as the modern concept. In the early modern period the privilege system treats inventions in all media with the same legal instrument, and the various media and kinds of invention are not ranked hierarchically. The fact that Roman law, which was being adopted increasingly in Germany in the sixteenth 
century, was not well suited to dealing with intangible property ${ }^{24}$ does not mean that it did not recognize and protect such property.

A second important feature of the privilege system, which was established irrefutably by the work of Hansjörg Pohlmann in the early 1960 s, is that privileges systematically protected the property of authors, artists, and musicians in the early modern period just as they protected the property of printers and publishers. Pohlmann documented more than 250 privileges before 1600 granted just to Urheber and just through the imperial chancery. If we remember that this figure represents only one category of individuals who received privileges through a single sixteenth-century German chancery, it becomes clear that our modern notion of Urheber is certainly represented among the recipients of early modern privileges but that it in no way defines the total group of sixteenth-century German privilege holders. That group included a significantly more varied range of individuals involved with the production of print projects than just the artist and the printer. The sixteenth-century notion of the inventor-creator, like the sixteenthcentury notion of invention-creation, was larger and more flexible, and not necessarily less sophisticated, than the more recent concepts through which some modern scholars have attempted to approach these phenomena.

\section{To publish for the ignorant and the particular enthusiasts of the art (den vnwissenden vnd sondern liebhabern der kunst an den tag zubringen) (fol. A2r)}

The considerations expressed in many of the German petitions and privileges relating to print property in the early modern period were as much shaped by these contemporary notions of investigation (speculirn) and invention (kunst) as they were colored by the purely commercial considerations that many modern scholars have used to characterize the privilege system. Giesecke's penetrating analysis explains that early modern authors did not seek privileges for personal advantage but rather because they wished to make their previously private, secret knowledge accessible to a wider public. But it could only become standard practice for private individuals to make their knowledge public if they were not too severely disadvantaged by making their revelations. It was thus, he continues, in the public interest to strengthen the rights of the individual by means of the privileging system. ${ }^{25}$

We see this logic demonstrated over and over again in the surviving evidence that documents individual applications for and conferrals of privilege. The petitioner generally refers to a new invention or creation 
that he has produced at some expense of energies or resources. He expresses to the privileging authority both his desire to share this kunst with some greater audience and his regret that he cannot do so without some legal assistance or protection. The privilege grantor in turn acknowledges both the value of the invention to some larger public audience and the inventor's investment of intangible or tangible resources or both. The grantor in conferring the privilege expresses both his assumption that the common good is served by the publication of the new invention and his willingness to compensate the inventor for his efforts by awarding him a limited monopoly on the rights to that invention.

Again the handbook of Henricus Grammateus provides a good set of examples. The dedication of the book to Tscherte may, for the purpose of this analysis, be seen as the equivalent of a formal application through a chancery for a privilege (figs. 2 and 3). In it Henricus reminds his patron that Tscherte had admonished him to publish his handy rules for arithmetic and geometry for the sake of the ignorant as well as the particular enthusiasts of mathematics, so that "not only the knowledge, but also the usefulness of it [mathematics], can be learned and received." ${ }^{26}$ It is on the basis of his willingness to follow Tscherte's suggestion that he make his knowledge available to a public audience that Henricus appeals to him for protection. In the closing material at the end of volume, Henricus declares his public-spiritedness by explaining that his book is published to give "young beginners in the art of mathematics ... a reason to explore further in this art" (fig. 4). ${ }^{27}$ The imperial privilege at the end of the volume is a little more difficult to read out because it is a multipurpose document that protects a number of the printing projects with which Lucas Alantsee was involved, and it does not name specifically the work of Henricus Grammateus (figs. 5 and 6). Nevertheless, the logic of the document responds to the kind of plea expressed by Henricus to Tscherte. The privilege grants to Alantsee a limited monopoly on various publishing projects because he has been willing to make available to the public the result of his labors. ${ }^{28}$

\section{With imperial grace and privilege (Mit \\ Kayserlichen gnaden vnd Priuilegien) (fol. Ar)}

The actual process of securing a privilege was initiated, as I have mentioned, with a petition from the privilege seeker to the granting authority. ${ }^{29}$ This application from below for protection represents an early modern modification of the medieval privilegium, which was tradition- 
ally conferred as a benefaction or prerogative from above..$^{30}$ If the petition was approved, the granting authority executed the privilege in the form of a manuscript charter, usually both signed and sealed, frequently with a hanging seal. ${ }^{31}$ Fees were charged for the privileges; in some cases they seem to have been rather high, in others, within the range of what chanceries normally charged to execute charters. ${ }^{32}$

What recipients did with the privileges they secured varied considerably. In most cases the printer announced somewhere on a protected work (usually on the title page in the case of books) that the imprint appeared "with the grace and privilege" of the granting authority. In many cases that is all the publishers did, so that neither the duration of the privilege, the specific prohibitions articulated in it, nor the penalty for infringement could or can be read from the imprint itself. Some privilege holders printed separately the texts of their letters of privilege and displayed them in their printshops or on the doors to their exhibits at the Frankfurt book fair. ${ }^{33}$ And some of them, as we saw in the case of the rechenbüchlein of Henricus, reproduced the full text of the privilege, right down to its chancery notations, as a part of the work for which its protection was claimed.

With the imperial chancery it is sometimes possible to trace an entire process of privileging from the original application or Antragsurkunde (some of which are preserved), to the copy of the privilege granted as it may have been recorded in the Reichsregister (not all of them were), to the actual work. Reference to the privilege, if not also a summary of its text, is usually printed somewhere on the work itself. ${ }^{34}$ More often than not, however, the actual work printed under privilege contains all the evidence that survives from the entire privileging process. If, as in the case of Henricus's rechenbüchlein, the designers of the project decided to publish along with the work itself, the full documentation of its privileging protection, it may include summaries or full texts of both the original petition and the privilege granted. In such cases, as we have seen, it may be possible to reconstruct much of the application process that precedes the publication. On the other hand, if the publishers of a book under privilege did no more than announce on the title page that the imprint was published "Mit Kayserlichen gnaden vnd Priuilegien," it is often impossible to determine the exact terms of either the petition or the privilege. The inability of the reader-consumer to get behind this sort of mechanically reproduced chancery shorthand-the cum privilegio formula- to the original circumstances and the actual terms under which a work was privileged is not just an inconvenience to modern scholars. It was also, as we shall see, a source of considerable unease in the print culture of early modern Germany. 


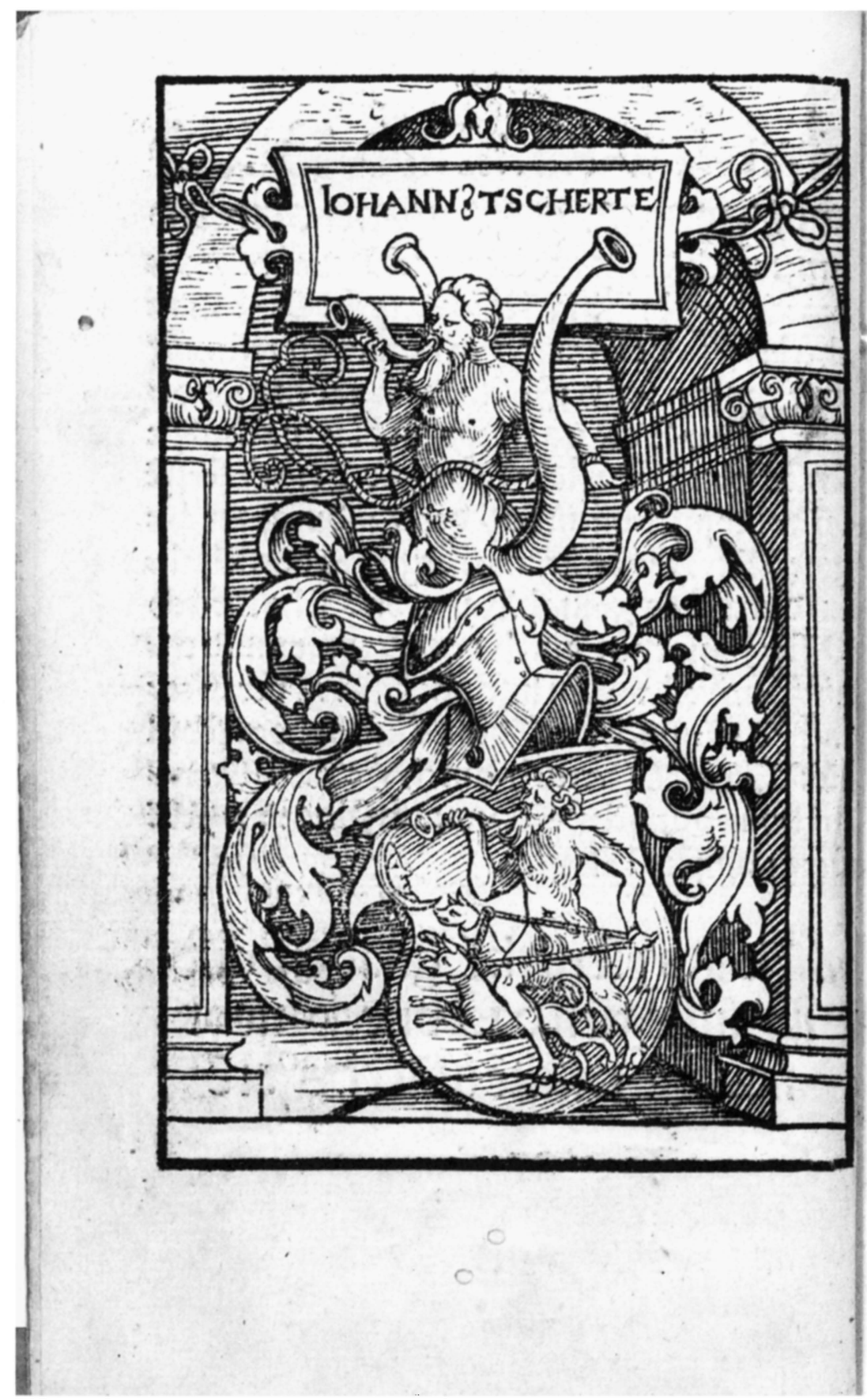

Fig. 2. Left: Johann Tscherte's arms ( fol. Av). Right: Henricus Grammateus's appeal for patronage and protection ( fol. A2r). Courtesy, The Bancroft Library. 


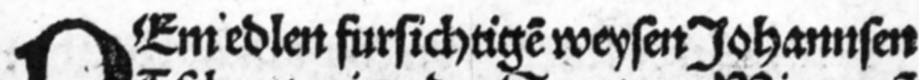
Tf hertteainer Des Sentats 3 in Do iemt vii

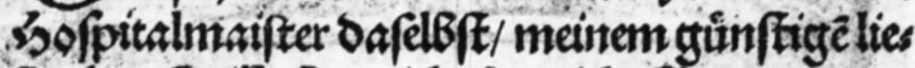

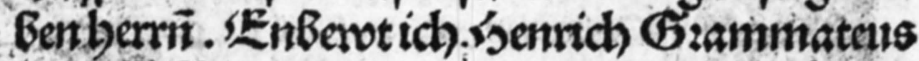

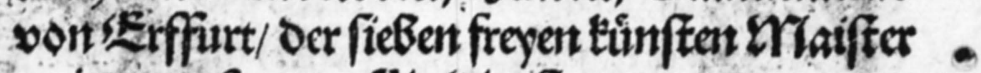
meint ongefpart wollig oien fete zunozant.

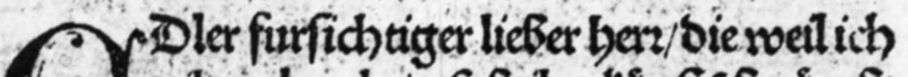

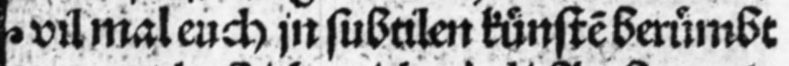
geboat bab id mich als liebbaber vito embigiger erterner euch suiertentumé Befly/fen/:vĩ nit allain Dermaffen/ woieidh Beridht/ Oonder vil

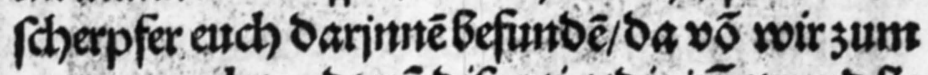

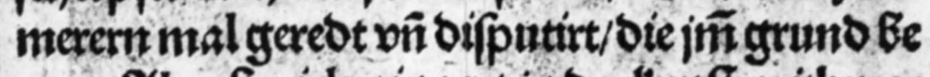
weert.2lls aber ich ait 3 eyt int ber timf f arithmes tica vin geometria etlich) (h) onne vno Bebenoeres geln in villerlay fachen sienfflich 3ufaummê ges

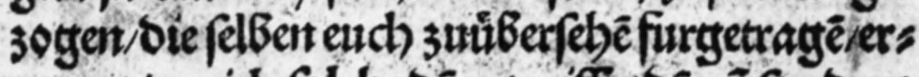

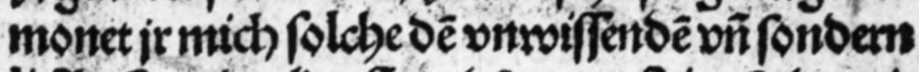

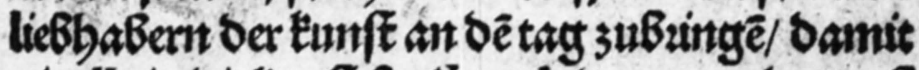

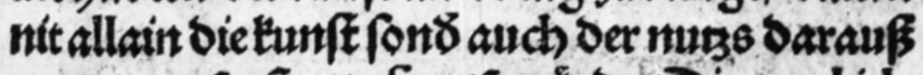
vernommê vî̃ entpfantyể wirtoe/Die noeylich etuch als ainem milbert gegerent mir entp fintoeny Der Oo nichts vos mir (wes ich Beegere) verbozo gen/Das ich Behersigt vno Dar Durdh Beroegen Dyfemein arbait auch miltigtlich oarzugebers 


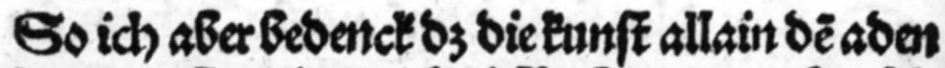
lichể verffenbigéauch liebbabenoè gemittē fols

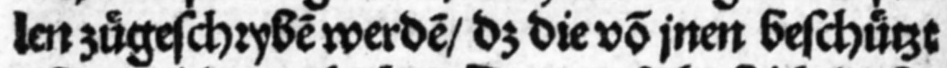
vii int roiroent geb altert. Demmad b bab ich oyfes

- Bitch mit feiner jinbaltuntry euth als meinem

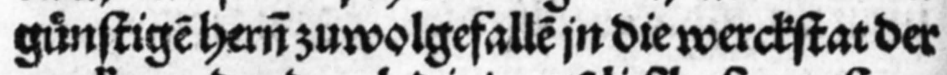
tructerey Oarourch oie jungê liebhaber aup ew

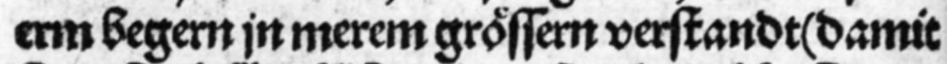
fie defter böher lieb jin dent vĩ andern thinften ge

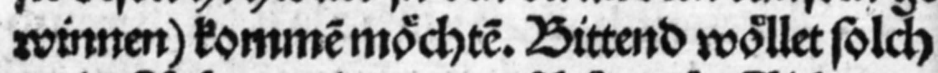

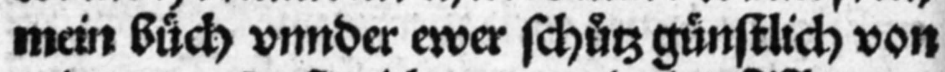

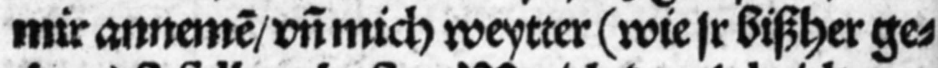
than) Befollyen babent/ WO O idh oas (als id) ants 3 weyffiel) (pirre woiroe/zsintich geurfacht antoer

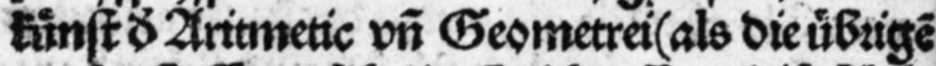
regenn Coffe) roelche bain nicht alle ju biếe büh

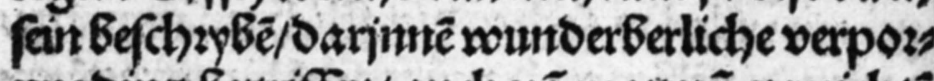
gne oing betriffent/ audh vã woag vin gervichtê

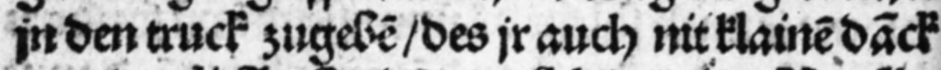

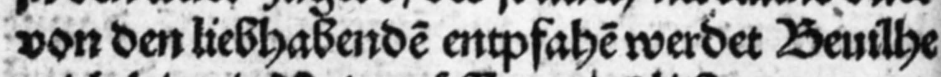
mich biemit. Dnto griffet meine lieben precepto

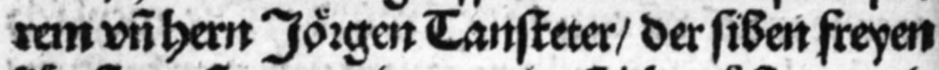

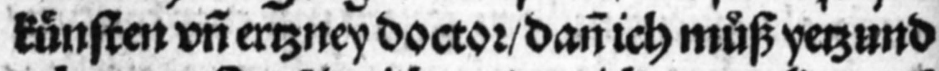

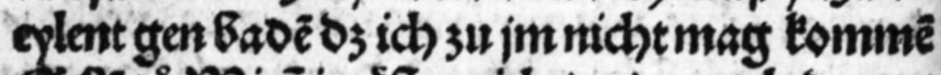

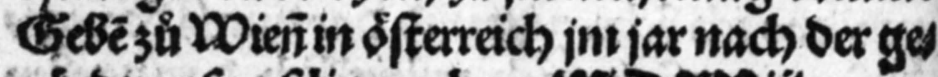
parotenfers feliggmachers, ars XXV iaj.

Fig. 3. Left: Henricus Grammateus's appeal to Johann Tscherte (fol. A2v). Right: Students learning arithmetic for business (fol. A3r). Courtesy, The
Bancroft Library. 


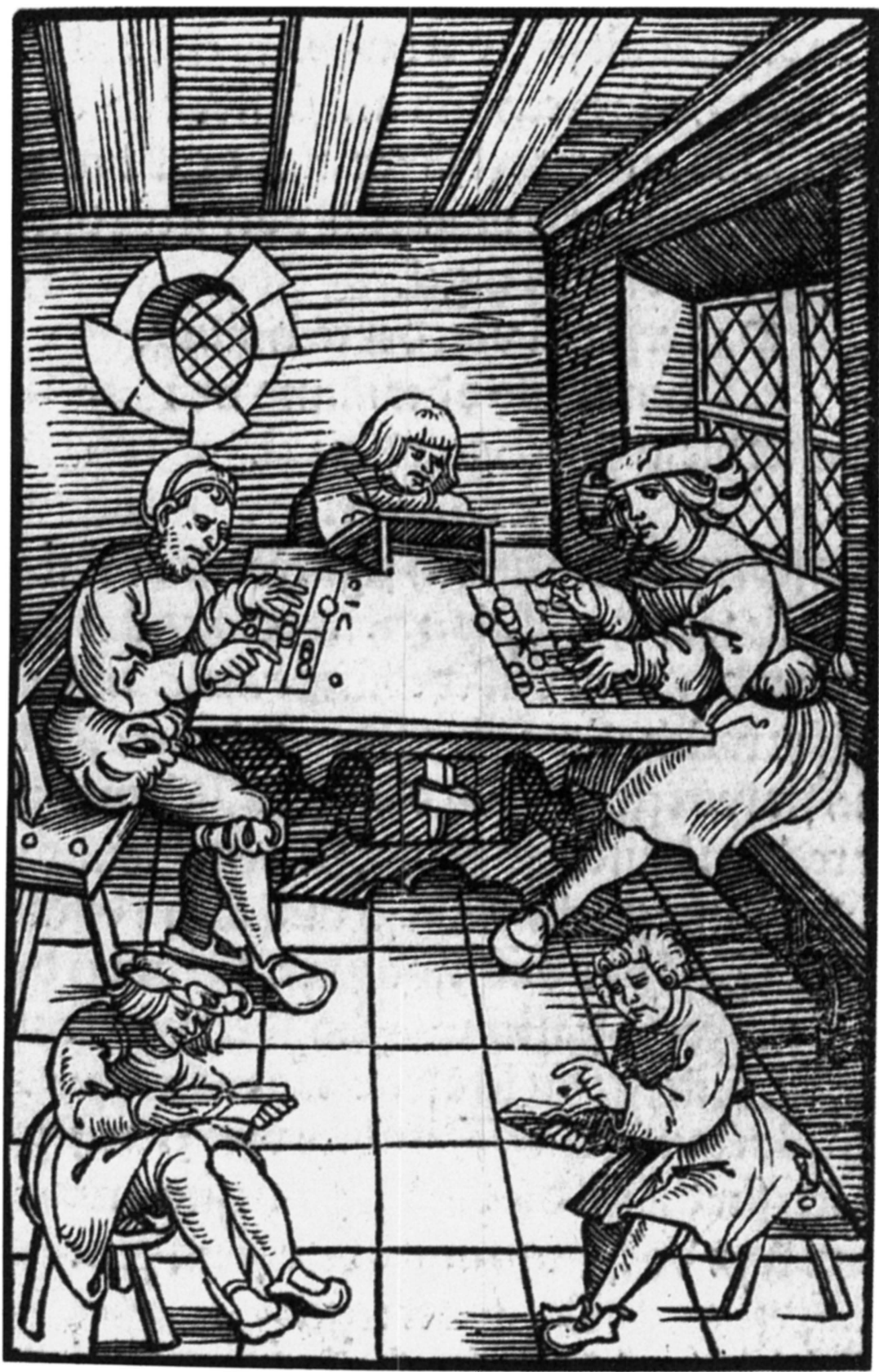




\section{And I admonish all bookprinters not to reprint this book within six years (Auch vormain ich alle buchtrucker sulches buch nicht nach zu trucken jn sechs jaren) (fol. Q2r)}

The privilege system promoted the development and publication of new invention or new knowledge by protecting the investment of the inventor, a part of which was the fee he paid for his privilege. The penalty fines for infringement were generally split evenly between the privilege-granting authority and the injured party. The infringement with which virtually all these privileges are concerned is nachdrucken, a concept that I have to this point glossed rather neutrally as "reprinting." I have done so because, although the German term is used only pejoratively in the privileges under examination, the kinds of unauthorized reprinting that may be covered by this concept in the sixteenth century are more various and differentiated than I can address in an essay of this length. Let me just say in passing that traditional notions of imitation, interpretation, translation, and copying (in the sense of manuscript reproduction) survive alongside differently conceived notions of print piracy, forgery, and outright theft at this time. There is evidence that some authors were concerned about what knowledge was actually in the public domain and what might be fair use of another's creation. And there are dramatic cases in which inventors protested that their literally "privileged" published creations had been treated by nachdrucker as public-domain shareware.

Instead of pursuing the implications of individual reprinting practices in this period, however, I would like to consider how the larger phenomenon of reprinting, which is the major preoccupation of virtually all printing privileges awarded before 1600, affected early modern German attempts to manage information and to control the quality of information that was published. To this point I have described the privilege system exclusively from the standpoint of information production, that is, in terms of what this legal instrument did for inventors and publishers of information and for the authorities that at once protected and profited from the new inventions. The privilege is a guarantee to the authorized publisher of his rights to the property it protects. To the would-be printing pirate, it is a warning to refrain. But to the consumer of printed materials, it is something else again. The appearance of the words cum privilegio or mit Priuilegien on a print artifact said to its buyer, reader, or viewer, "This imprint is authentic; it is the authorized version; it is the genuine article."

The authenticity of information became a matter of increasing concern as print culture expanded and the wider implications of mechani- 
cal reproduction, both authorized and unauthorized, became more apparent. Printing changed the proximity of the inventor to his work, and it produced artifacts whose characteristics were not immediately intelligible in terms of the standards of manuscript culture. When a medieval manuscript copyist reproduced as exactly as possible the model he imitated, he was creating with his own hand a unique original artifact. In the world of printed artifacts the notions of uniqueness and originalness (not originality) gradually underwent significant revision. Whether one takes a case like Dürer, who had his own press and supervised his own printing projects, or one like Henricus Grammateus, who was but the first link in the chain that eventually resulted in the printing of his book, there is at the very least the medium of print itself between the hand of the inventor and his invention; and the invention, whether a woodcut or a rechenbüchlein, is produced in multiple copies. What then came to constitute originalness and uniqueness in a medium in which the hand of the inventor may not ever have touched his invention in the form in which it was published or sold, and when inventions were sold in multiple exemplars that were for all intents and purposes equivalent? Who was the inventor of an artifact that passed though the hands of a writer, an editor-proofreader, and a printer on its way to the public? And what constituted authenticity in the print medium that made pirating so easy, so profitable, and so little apparent to the unsuspecting consumer?

Giesecke has looked at some of these questions primarily from the standpoint of the author. He demonstrates that, precisely during this period when the circumstances of the printing trade were such that authors were likely not to have had control over various aspects of the publication of their texts, the relationship between the author and his text in many cases became as close as that of a father and child (Giesecke's simile). Authors looking for a way to maintain publicly their connection with their published works had recourse to the timehonored validation mechanisms of the chancery world-seals and signatures. Using typographic equivalents to invoke these traditional chancery mechanisms, authors and artists like Luther and Dürer, not to mention printers, created printed symbols or monograms to identify those print artifacts with which they wanted to be associated personally or which they wished to have published as authorized. Some of these devices, like the stamped version of Emperor Maximilian's signature, which was in restricted use in the imperial chancery after 1507,35 were actually translations from the manuscript to the print medium. Others, like the Luther rose, were designed originally for the print medium and have no specific antecedents in the manuscript tradition, 
liniê:ac.vî.ac. fo matrotag. vî. ah. Sez einres gel over linial int das punct. 0 . jn feter Benoegüg

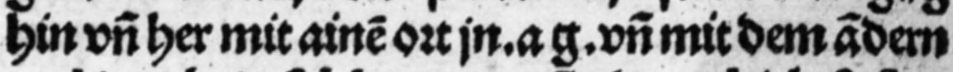
tayl jn. ab.jn oldcher mayntigg oas gleich of ferm - over weit fey. f. wo oempunct jut ber liniê a g als vil ober lang if vom. f. sum punct jn Der lintien ab. vin alfo fain fimber 3 roo proportionirt linien

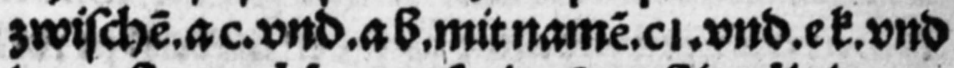
Der cubus weldher entefpzintyêt aus ber linien.ac wort fidh baber $3 u$ beme cubum on 5 bem. a B.jn Derpzopoztion octupla: vî \& c.cuBus 3 u. I c.cus Gum iff jut der pzopoztion quaso aupla veno 3 ums cubrit.et. Oupla/vin als fins fintoen vir linien 3 th vierlay cub:als bain erf heint jn der figur ber ba plation.

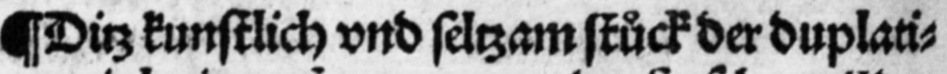

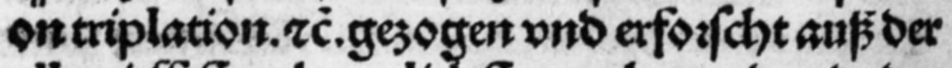
aller tieffeftert/beymlichfent outh vnmo enot oer Geometrey/ fey gef henctit in funberbayt allen (charff finnigen/ wolcher banotwerd" bintibing if mit oem circtel/richtf cheyt/ vno winctelma als oentwiroigen 34 eynter grōffern fpeculation anber bing oem gemaynem nus biententot. Ein belchlus des gantjē Buchs

Fig. 4. Left: "The end of the entire book" ( fol. Qv). Right: Dedication of the volume to young beginners in the art of mathematics. Admonition to printers 
Dit5 Bucb fey gefchenckt allen liebbabern freicr kunftoñ but firūt

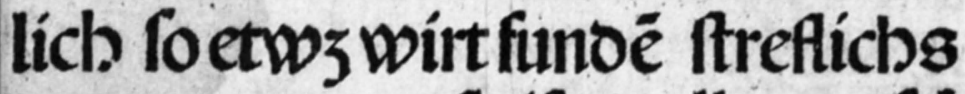
von wegen onfleí/ wullen osfelbig bruoerlich cozrigirn vino ber fern oañ ích bab allayn gefchribé voz die jungen anfenger in $\delta$ küft mathematica/ícb meine aucb wer oe etlicben geben ain vrfacb wei ter junn fulcber kunft $\mathbf{z u}$ fpeculim Yeoocb ít mein boffinúg bab auff liulche jeyt genug getban+'Dlucb vozmain ícb alle bucbtrucker fult cbes bucb nicbt nach ju trucken in fecbs jarñ nacb feynéaufgang bey grofler pen bebalten in lkap rerlichen piunilegien wie oañ ber nacb wirt geleben in oem latein.

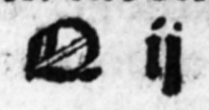

not to reprint the book within six years (fol. Q2r). Courtesy, The Bancroft Library. 
although they depended for their effectiveness on the larger authenticating practices of the chancery world from which they derived. ${ }^{36}$

\section{These documents are secured with the}

stamp of our seal (Harum . . literarum Sigilli

nostri impressione munitarum) (fol. Q3v)

If we shift our focus back now to the privilege system and back to the consumers of printed materials at this time, it becomes clear that mechanically reproduced inventors' seals and signatures have to do with more than an inventor's desire to retain some control over his invention even as he releases it for publication. These symbols point to a much more fundamental feature of the relationship between the manuscript and print cultures that coexisted and interacted with each other in sixteenth-century Germany. The privilege system provided, among other things, a mechanism by which the authenticity of multiple mechanically reproducible artifacts could be verified. The authenticity or authorized status of printed artifacts emerged as a significant issue as both producers and consumers of printed materials in this period gradually came to realize that an authorized imprint was the closest equivalent in the new print culture to the original or unique artifact that had played such a central role in the manuscript tradition. It would be difficult to overemphasize the extent to which the characteristics and possibilities of the emerging print technology were for the first several decades of its development understood in the terms of the manuscript culture that preceded it. The privileging system that was applied to print property is an excellent case in point. It depended in all of its essential features on the conditions and practices of manuscript culture. The petitions for privileges were handwritten letters. The privileges themselves were manuscript charters, signed and sealed by hand. When they were registered, the privileges were recorded by hand in manuscript codices. Their authority depended on their utterly unique status. But this was not immediately clear to the various parties concerned with managing information in the first century of printing.

Returning again to the handbook of Henricus Grammateus, we can see how early printers attempted to solve the issue of authenticating printed materials and how their ad hoc solutions instead exacerbated the problem in a way that echoed down through the sixteenth century in Germany. As you remember, Henricus, after telling his reader twice that his little book was protected by an imperial privilege, reproduced the privilege in full at the end of the volume. The text of the privilege 
closes with the statement that the document at hand is executed with Maximilian's seal, at the instruction and on behalf of the emperor himself. Below the text come the chancery formulas, and below these the printed name of Jacob Spiegel. Maximilian's seal, however, is nowhere in sight, nor is Spiegel's calligraphic signature (fig. 6). The printed text then is not quite the privilege it claims to be; it is rather a reproduction that reports the circumstances or terms of that privilege; and it is a symbol or representation that invokes the authority of the original handwritten document.

The appearance of such printed representations undermined the authority of the very chancery privileges that they invoked. As soon as publishers began to approximate and reproduce mechanically the unique authenticating mechanisms that validated their otherwise all too easily reproducible artifacts, the procedure that was intended to protect invention in print property was effectively subverted. The printers' own products demonstrated that authenticating devices themselves could easily be replicated. And this demonstration, however involuntary on the part of the printers, created the need for a more secure procedure for authenticating the status of printed information than the simple mechanical imitation of devices that belonged to the chancery culture ${ }^{37}$ These printed symbols signified by invoking the authorities they cited, but they were not identical with the elements that they represented. Original seals, signatures, and charters of privilege were, like speech acts, performatives. They simultaneously executed and represented authority. Printed reproductions did not.

The imperial privilege that was supposed to protect Henricus's rechenbïchlein proclaims confidently that "these documents are secured with the stamp of our [Emperor Maximilian's] seal." It is not clear, however, that contemporary consumers of printed texts like the little accountancy textbook were either reassured or deterred by claims of this kind. Modern speech-act theory may help to explain the relationship between original letters of privilege, seals, and signatures and their mechanical representations in early modern imprints. It may suggest how sixteenth-century consumers of printed materials reacted to these new representative forms of authority. And it may also clarify how forms like printed seals or signatures (including those appended to the privilege in the rechenbüchlein), which entered the Western tradition as curiosities during the first decades of printing and immediately contributed to a crisis in information control, have established themselves as authenticating conventions in modern print and legal culture.

Fully executed manuscript privileges were, like speech acts, performatives. As distinguished from descriptive or constative statements, 


\section{Elaine C. Tennant}

performatives simultaneously articulate and accomplish an action. Speech acts are a special class of performatives, which at once state and execute an action through the spoken words of the actor (e.g., "By the power vested in me, I now pronounce you man and wife"). Other performatives, like the sealing of the privilege that governs Henricus's rechenbüchlein, have the same dual nature as speech acts (i.e., they simultaneously accomplish and bear witness to the performance of some action), but they are enacted in some medium other than the spoken word. Endorsing signatures and authenticating seals are performatives of this less specific kind. Printing privileges belong to this latter more general category of performatives. A privilege at once spelled out the terms of the benefit that was to be awarded the recipient named in the charter, and it also conferred that benefit on him. Central to the concept of performative, as it was originally articulated by J. L. Austin, ${ }^{38}$ are the underlying notions of intention and of a community within which given actions are recognized and accepted as having performative status. Performatives are only effective within communities that recognize them, and they do not function if they are not recognized.

Privileges in Germany before the age of printing were executed in accordance with cultural conventions and chancery prescriptions that conform to Austin's requirements in almost every respect. Even though the privilege was, as we have seen, a relatively flexible legal instrument, it had by the High Middle Ages already become the regular device that ruling authorities used to deal with certain kinds of legal situations. If we consider, for example, how the emperor raised an individual to the nobility in medieval Germany, we see that this action was governed by several conventionalized steps that closely parallel those conditions identified by Austin as necessary for the successful performance of speech acts. As noted earlier, it had become customary in medieval Germany to use the privilege rather than some other legal mechanism as the means of raising someone to the nobility. Charters of privilege, like other standard chancery documents, were written (rather than spoken) according to traditional formulas that were handed down from one generation of scribes to the next either through direct instruction or by means of Kopialbücher. To ennoble an individual by means of a chancery privilege then involved the writing of certain words, by chancery scribes (certain persons) at the direction of the ruler (in certain circumstances). The issuance of such a charter required that the text be accurate in terms of both the standard chancery formulas and such specific details as the name of the individual to be ennobled and the date on which the privilege was conferred; and it required the handwritten signature and/or the seal of the ruler or his authorized 
agent (particular persons in particular circumstances executing the procedure correctly). Another requisite feature of a performative is that it be an expression of intention. In the conferral of a medieval German patent of nobility, the manuscript charter may be seen as evidence of the emperor's intention to ennoble his subject, and the subject's subsequent conduct in the manner of a nobleman as evidence of both the subject's intention to participate in the convention governing the procedure of ennoblement and also of the successful execution of that performative.

Taken together these individual steps in the act of ennobling-the selection of the privilege as the legal instrument, the preparation by chancery scribes of the manuscript charter with correct formulas and data, the signature and / or seal of the ruler, and the subsequent behavior of the subject as a member of the nobility-reflected and confirmed the cultural convention that underlay the procedure in medieval Germany and that allowed the performative of ennobling to function within that society. The preceding review of this procedure in terms of Austin's definition suggests that his requisite conditions for the execution of a successful performative may be further reduced to two. First, there must exist an underlying cultural convention whose characteristics are sufficiently unambiguous to permit members of the culture to recognize individual realizations of the convention as belonging to the performative category of that convention. Second, any individual realization of a performative convention must exhibit enough recognizable features of the convention for members of the culture to identify it and assign it to the same. ${ }^{39}$

Bearing in mind now that privileges were performatives in medieval German society and that, in order for a performative to function successfully, its features must be recognizable to the members of the culture in which it is a convention, let us return to the question of printing privileges and printed privileges. Briefly stated, they correspond much less closely to the requisite conditions for successful performatives than did their medieval manuscript antecedents. The most obvious difference between the manuscript privileges of the Middle Ages and the printed representations of early modern printing privileges is, of course, the print medium itself, but this is by no means the only difference. The conventional chancery procedure for executing a privilege, like the one that protects the rechenbüchlein, appears to have been much the same as the one that governed the execution of a medieval patent of nobility. But the very extension of the use of the privilege to protect the new aspects and varieties of invention that developed along with print culture introduced new circumstances into the convention governing 
this performative. In addition, the advent of the new technology caused new words to be introduced into the privileging procedure so that the traditional chancery formulas associated with this performative no longer sounded like they used to. Printing privileges articulated prohibitions (e.g., nachdrucken), described occupations (e.g., kastigator), and aimed to protect certain kinds of property (e.g., Greek or musical type fonts, all works by a given author or in a given subject area), none of which were mentioned in privileges written before the rise of print culture. Different from their medieval precursors, early modern printing privileges were generally executed in response to an application or petition from the prospective privilege holder. And printing privileges, once issued, were published by means and in ways unimagined in earlier centuries.

The "privilege" appended to Henricus's rechenbüchlein demonstrates these new developments. That privilege, as I have noted, is actually not a privilege but a reproduction, and it is used to protect a property (Henricus's book, including tables, illustrations, and the like) that is not even named in the text of the instrument. ${ }^{40}$ Printing privileges and their printed representations differed then from earlier medieval privileges in terms of the procedure by which they were secured, their specific formulations, the medium in which they were published, and the kinds of properties to which they were applied.

\section{In the power of this letter (in Krafft diß Brieffs) (p. 854)}

Individuals involved with all phases of the new printing industry attempted to safeguard their interests in printing projects by reproducing on the imprints themselves some features of the privilege that protected their publications. They imitated in print the traditional authenticating mechanisms that belonged to the conservative manuscript world of the chanceries. The attempt to transfer these mechanisms from parchment, ink, and wax into the medium of print was not altogether successful, however, since it did not obviate the continuing need for the original artifacts in their original forms. The printed reproductions seem rather to have reinforced that need in ways that we have not altogether outgrown to this day. The feature of the original signatures and seals that did not transfer with uniform effectiveness into the print medium was their uniqueness and, hence, their authenticating authority. At this moment of transition between manuscript and print cultures, notions of authenticity and legal authentication were, as I have mentioned, very closely tied to notions of uniqueness and originalness. 
As pirated editions of all kinds vied in the marketplace with authorized imprints, the owners of legitimate privileges could only assert their claims in increasingly shrill tones to an audience that was in large part not listening. It soon became clear that these new privileges were not working the way the old ones had.

Perhaps the new privileges were not perceived by all early modern readers as bearing the same authority that handwritten privileges did. We have seen that printing privileges differed in significant ways from the kinds of privileges that chanceries had executed throughout the Middle Ages. One wonders whether, given so many modifications, the printing privileges bore sufficient resemblance to their medieval antecedents for early modern German audiences to have recognized them not just as allusions to the chancery privilege of old but as authentic and therefore effective realizations of the same underlying cultural convention. Was a printing privilege-or its printed imitation-still enough of a privilege in its sixteenth-century German context to function as a performative? The flood of unauthorized reprinting that early modern printing privileges attempted to contain suggests that the answer to this question must have been, "Not altogether," or "Not at first."

Privilege holders and consumers of print materials alike seem to have been uncertain about the authority of printed privileges and about their effectiveness as guarantees. Printers were anxious to assert the authenticity of their imprints and the authority of their printing privileges, but many of them soon discovered that it took more than a modest allusion on the title page-cum privilegio or mit Kayserlichen gnaden ond Priuiligien - to secure the monopolies to which their privileges entitled them (fig. 1). As printed privileges proved to be of limited effectiveness, publishers came to realize that printed imitations, like the Latin text of the privilege protecting Henricus's rechenbüchlein, did not fully replace unique handwritten charters of privilege or personally executed authenticating mechanisms. Though they continued to make reference to their privileges on the imprints themselves, publishers began to treat these references to privilege protection as representative of rather than equivalent to the original manuscript charters of privilege. Later in the century, for example, some printers would state specifically on an imprint just where the original manuscript privilege that protected the edition might be examined; some even noted that the original charters of privilege are written on parchment. ${ }^{41}$ Statements of this kind, which invoke the authority of the original manuscript privilege, suggest that for at least some early modern privilege holders, the site of authority in the privileging procedure remained 


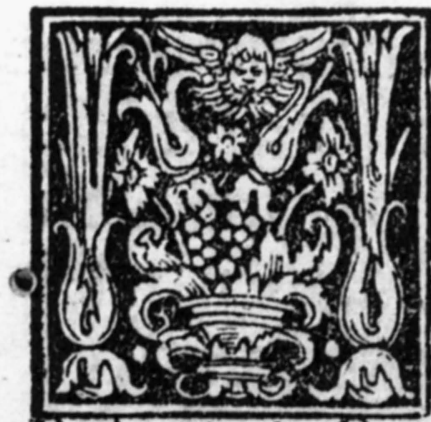

Âtrimilianus oiuí na fauente clemétia, romas norum Imperator, femper Auguftus, ac Germanix, Hungarix, Dalmatix, Cro atix. \& c. Rex, Archidux Auftrix, Dux Burgundix Brabantia, \&cc.Comes Palatinus \&chonefto fis deli nobis dilecto LVCAE ALANTSAE ciui noftro,\& Bibliopola Vienneñ.gratiă noltram cxfaream \& omne bonti. Vidimus tabulas geos graphicas, VADIANIS cổmentarif̧s in Poms ponium Melam adiunetas nobis tuo noiz oblas tas.Que ut nobis mirum in modum placuerunt Ita vehementer cupim", ut ea forma ad omnium bonarfi literarum ftudioforum vfum publicens tur.Quod \& fi te haud grauare noftri gratia etia impenfis magnis facturum fciamus. Netamen priuata res tua incommodetur, quandoquidem indignum cenfemus laborem, impenfas, 8 offis cia tua pari aliorum opera fecundaria editionis defraudari, maxime vbi iúsus votumq noftrí intercedit prafenti noftro cafareo edicto, oms nibus, $\&$ fingulis, cuiufcung conditionis exiftát Calchographis, \& librorum imprefforibus vbis libet locorum in facro Romano imperio,etiam

Fig. 5. The imperial privilege granted by Emperor Maximilian to Lucas Alantsee in July 1518 ( fols. Q2v-Q3r). Courtesy, The Bancroft Library. 
in terris noftris hxreditarijs conftitutis, fub poet nainfrafcripta diftrictius inhibem', ne prafatas Tabulas, $x$ infigne etiam PLYNII opus quod tuis accepimus impenfis, a Thoma Anshelmo diligéti adınodum Calcographo, in Municipio noftro cxfareo Hagenogiñ.ad Hermolai Bars bari caftigationem, vna cî̉ CAMERTIS noftri, vt laboriofifsima, ita maxime vtili Tabula, in pris mis,necnon alia opera,qux iuxta privilegium \& gratiam nuper tibi factam poft prafentici das tam fub noie, \& fignis tuis edes, per Sexennium a data editionis cuiuslibet talium Tabularum, operum, feu librorum imprimere, aut alibi ims prefsa, intra Imperij \& ditionín noftrarum limis tes, $x$ ineorundem locis venundare prafumat audeat feu attentet. Nő obftantibus quibuscígs in contrariú emanatis aut concefsis. Mandantes omnibus \& fingulis noftris \& facri Imperij fides libus dilectis, cuiufcunq̧ ftatus, conditōis, \& digs nitatis etiam fi Archiepifcopalis, Pontificalis, Archiducalis, Ducalis, Marchionalis, Baronalis Nobilitaris,\& alterius cuiufcungs praeminểtix Magiftratus feu officij, fiue ecclefiaftci,fiue fecu haris extiterint, fub poena indignationis noftre \& facri Imperijgrauifsime, atop decem Marchage auri puri, pro vna Fifco noftro imperiali, \& pro 
altera medietatibus tibi LVCAE totiens quoties.

- huicinhibitioni,voluntati, \& gratix noftræx côs trafactum fuerit,applicandarum vt in pramifsis tibi oportuno fauore adfiftát, ac omnes \& fingus Sos contra hanc gratiam, \& inhibitioné noftram quicquam facere prafumëtes huiufmodi indigs nationis noftrx \& pon $x$ fententiam noftro no mine incurrifse protinus declarent, $8 x$ cohibeant fub artificio imprefforum non vtendi, amifsiöis quoque talium librorum fic(vt præmittitur)cōs tra hancnoftram conceffionem, gratiam \& pris uilegium imprefsorum \& adductorum Teqz vbi eos per te vel tuos requifiueris, tenore prafens tium, aut harum tranfsumpto autêtico, cui eam fidem adhiberi volumus. Qux his noftris pras: fentibus adhiberi folet $\&$ debet, prafata noftra Gratia \& Priuilegio frui \& gaudere linant, \& ab alijs pariterobferuari faciant, in quantum \& ipfi pdietas poenas euitare maluerint. Harum teftis monio literarum Sigilli noftri impreffione mus nitarum. Datu in ciuitate noftra lmperiali Aus gufta, die vicefima Menlis Iulij, Anno do mini Millefimo quingentefimo decimooctauo. Regs norum noftrorum Roma. XXXIII.Hungarix vero.XXXIX.

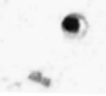

Fig. 6. Lucas Alantsee's 1518 printing privilege with mechanically reproduced chancery formulas, authenticating signature, and printer's device ( fols. Q3v-Q4r). Courtesy, The Bancroft Library. 


\section{Per re gem p}

\section{Ad mandatum Cxfara Maieftatis proprium.}

\section{Iacobus Spiegels}

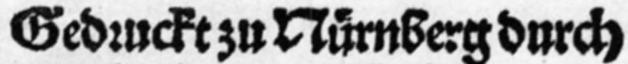 \\ Jobantmem Stiths

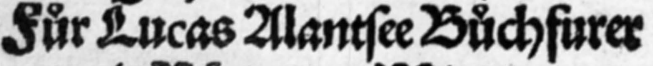

vno 25 irryer 34 DDien.

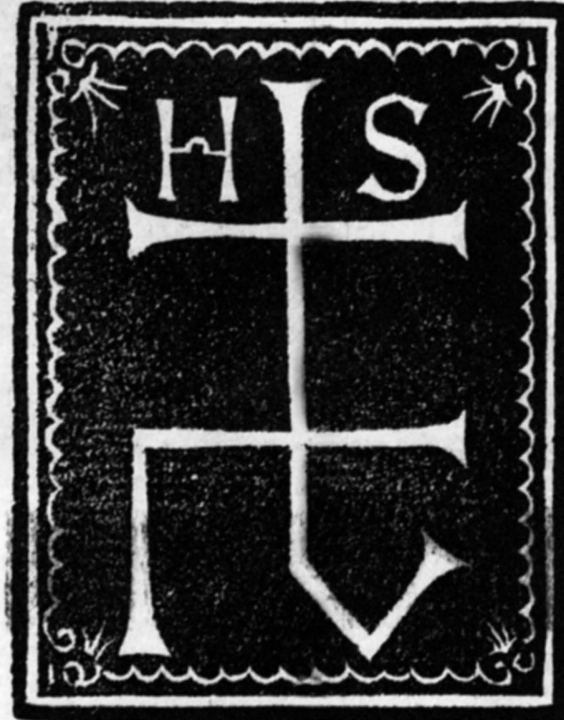


inextricably bound to the unique artifact that, in modern terms, functioned unambiguously in that society as a performative. Ironically the proliferation of printed privileges and the ambiguity of their performative status enhanced rather than diminished the role of the original handwritten privilege in the new system that attempted to control printed information.

A couple of literary examples document how the anxiety over the control, protection, and authentication of information increased in Germany during the first century and a half of the interaction between manuscript and print cultures.

The first example occurs in the 1474 edition of Thüring von Ringoltingen's Melusine. The passage I have in mind is one of Melusine's first instructions to her prospective bridegroom Reymund. He has accidentally killed his uncle, and Melusine tells him not only how to save his life but how also to make their common fortune. She tells Reymund to request a fief from his uncle's heir, Bertram. As if anticipating later challenges to the authenticity, if not to the legitimacy of the transaction, she has Reymund request "a well-sealed letter, which will include what the bequest has been or why it has been made." She urges him further to make sure that the letter includes "the day and the year with the proper date written in" and then to withdraw "when the bequest was made, registered, and sealed." 42 Melusine's stipulations match in surprising detail a standard chancery procedure that is documented in the Reichskanzleiordnungen from the end of the century, ordinances that prescribe how imperial scribes should execute charters authenticating legal transactions. ${ }^{43}$ They also conform nicely to Austin's notions of the particular procedures that underlie performatives. Reymund follows Melusine's instructions to the letter and is awarded the desired fief. In a second passage a little farther on in the text, the execution of the charter is described with additional detail that is entirely in accordance with late fifteenth-century chancery practice in the empire. Bertram has the letter of fee prepared, and he authenticates it not only with his own hanging seal, but also with the seals of several counts, lords, and knights. The date, year, and day are also written on the document, and all this before witnesses. ${ }^{44}$

I have cited these passages from Melusine because they reflect wonderfully through the prism of fiction what sort of awareness there was in late medieval Switzerland of both the need to authenticate certain kinds of information and the mechanisms that were available for doing so. They also show that the individual features of the authenticating convention were well enough known in this culture to find their way even into the narrative stream of a novel. Melusine demands her letter of fee "sealed and delivered," if not authenticated by a signature. And 
the nobles in Bertram's entourage insist that unless each one affix his own hanging seal to the document, it will be invalid. ${ }^{45}$ Apparently Bertram and his company (or their creator) ${ }^{46}$ know that hanging seals, one of the most ceremonious forms of chancery authentication, obviate the need for signatures, particularly when witnesses endorse the document. And in the world of the novel this meticulously executed document does the trick. Despite the unusual circumstances under which Reymund requests his fief and the exceptional way in which he claims his territory, the text records not so much as a murmur of doubt about the authenticity of his charter. This text captures many features of a late medieval procedure for authenticating information, including the specific chancery mechanisms (seals, dating formulas, etc.). The procedure shows no influence of the rise of print culture, even though it happens, by coincidence, to be preserved in one of the early monuments of printing.

The situation a little more than a century later looks very different indeed. For a second example I return now to the problem of Faustus. In the Faustbuch published in 1587, the pact letter that Faustus signs with Mephostophiles is for all intents and purposes, and allowing for the quasi-fictional nature of the text, a perfect chancery document. The circumstances of the Faust plot, like those in the tale of Melusine, require the execution of a document that can stand up to any scrutiny and equivocation. In each of these narratives a contract with an otherworldly dimension is secured in the natural world of the text by using the legal mechanisms of chancery. The fictional situations are similar, but the scenes are written under different circumstances. A century of printing, reprinting, pirating, and all kinds of other disquieting interruptions to the control of authenticated information has occurred in the meantime. The need for something that is utterly genuine still exists, and so does the need for a means to authenticate it. But what is now the site of authority, and how can it be established when seals are represented, signatures reproduced, and privileges themselves pirated? ${ }^{47}$ The text of Faustus's letter, like Reymund's letter of fee, includes a number of the elements specified in the great Reichskanzleiordnungen of the late fifteenth century, elements that reflect the underlying convention of the performative. The name, the circumstances, the terms, and the date are all spelled out in detail. But these traditional chancery elements are no longer of themselves sufficient to guarantee the authenticity of so weighty a legal contract. Authority in this situation, as in the medieval chancery tradition that shapes it, still lies, as the old legal formulation states, "in the power of this letter" (in Krafft diß Brieffs)—so long as the charter remains unique.

In the age of nachdrucken, however, the preservation of uniqueness 
has become a challenge. Mephostophiles nevertheless contrives to have Faustus produce a charter so unique that it seems virtually proof against any possible reproduction and hence any refutation. The charter is written in Faustus's own blood-a truly irreproducible substance-and in his own hand. But even these extraordinary measures taken to insure the authenticity of the document are not quite sufficient to protect its authority from challenge. Indeed seventeen years after executing the pact, Faustus himself is able to renegotiate the terms, and Mephostophiles allows him to sign a second letter like the first, framed with the appropriate chancery formulas and signed with his own blood. In the end the authority of the contract written in blood does prove sufficient to guarantee the damnation of Faustus, but the fact that the pact has had to be reaffirmed points to the extent to which traditional systems of authentication have been undermined in Germany by this time. A century of printing has had its effect. It hasn't made it impossible to verify the authenticity of information. But it has made it a good deal more difficult to do so. ${ }^{48}$

In the more than four hundred years that have passed since the publication of Henricus's rechenbüchlein and the Faustbuch, many of the inherent possibilities of the print medium that were only beginning to be recognized in the sixteenth century have been fully explored and developed. The mechanisms for protecting invention in the realm of print property, however, appear at first glance not to have changed much in all that time. As in the early modern period, print property today is still ultimately authenticated or secured by mechanisms that continue the manuscript tradition of the medieval chanceries. The permission to publish with this essay reproductions of pages from Henricus's handbook, for example, was granted, in response to a handwritten petition from me, by the head of photoduplication services of The Bancroft Library, who signified his consent by affixing his handwritten signature to my request form. This unique original document accompanied my manuscript to the press. The procedure was not terribly different from the one that Lucas Alantsee followed in 1518 to secure the privilege that was ultimately used to protect Henricus's handbook a few years later.

The copyright symbol that protects the essays in this volume can be seen as a direct descendant of the cum privilegio or mit Kayserlichen gnaden formulas discussed earlier. Like the early modern announcements of print privileges, the copyright symbol on present-day imprints declares that the rights to the invention represented by the individual print artifact are protected; and like the cum privilegio tag, the modern copyright warning rarely spells out in complete detail the pre- 
cise terms of the printing monopoly or the penalties for its infringement. The modern symbol, like its early modern antecedents, represents or refers to unique original documentation that is the basis for the authority claimed in the symbol.

Another early modern mechanism for authenticating print property, which appeared as a novelty in the first decades of printing and has come to be a standard feature of certain parts of modern print culture, is the mechanically reproduced signature, either calligraphic or typeset. The authority of these printed signatures today-whether on payroll checks, paper currency, or the like-still depends ultimately on the unique handwritten original that is on file somewhere, just as the authority claimed in the rechenbüchlein privilege published with Jacob Spiegel's printed signature depended on the existence of the original manuscript charter that he had signed by hand.

Yet for all these formal similarities between the early modern and modern mechanisms used to manage and authenticate print property, there are significant differences between the two systems. These have to do with the way that Western society has gradually come to regard printed material more in terms of the inherent properties of the print medium and less in terms of the manuscript tradition. While the execution of legal performatives in modern Western society continues to require some sort of interaction between the manuscript and print cultures that we have considered in detail with regard to early modern German printing privileges, the site of authority in this procedure has shifted as society has come to regard print artifacts differently.

The deconstructionist critique of speech-act theory points up this shift without attempting to account for it historically. Building on Jacques Derrida's notion that iterability is the fundamental characteristic of performatives, ${ }^{49}$ Jonathan Culler has argued somewhat perversely that "imitation is not an accident that befalls an original but its condition of possibility," and that "the iterability manifested in the inauthentic, the derivative, the imitative, the parodic, is what makes possible the original and the authentic." ${ }^{50}$ In terms of the mechanisms of authentication that we considered earlier, this would mean that it is the printed version of Lucas Alantsee's privilege or of Jacob Spiegel's signature that makes the original manuscript version of each possible. Or it would mean that because the fictional Reymund in Thüring von Ringoltingen's Melusine received a properly executed privilege (his letter of fee), it was possible for actual letters of fee to be written.

Culler's explanation fails to explain the fundamental relationship between the "original" and the "imitation." Both are specific realizations of an underlying cultural convention. Neither makes the other possible; 
they are both made possible by the underlying convention; and the existence of both confirms the underlying status of that convention. In terms of Alantsee's privilege, the medieval German convention of using the privilegium as an all-purpose legal instrument makes possible both the handwritten original charter of privilege and the printed imitation of that privilege that appears in Henricus's rechenbüchlein. But this is a modern assessment of the sixteenth-century problem we have been considering. The fact that printing privileges and printed privileges were not taken seriously by numbers of people involved with the printing industry in early modern Germany suggests that they may not in fact have accepted these new privileges as reflexes or realizations of the medieval convention of privileging.

Culler's discussion of modern printed signatures elaborates his notion of the relationship between the "original" and "imitative" iterations of performatives, and it demonstrates a modern dislocation of authority in certain mechanisms governing the control and authentication of mechanically reproduced information:

It is tempting to think of checks signed by a machine as perverse exceptions irrelevant to the fundamental nature of signatures.... But such cases could not occur if they did not belong to the structure of the phenomenon in question and far from being a perverse exception, the check signed by machine is a logical and explicit example of the fundamental iterability of signatures. ... we can ... cash checks signed by a machine and receive a salary even though the signatory never saw the check nor entertained a specific intention to pay us the sum in question. ${ }^{51}$

The implication of Culler's remarks is that in contemporary Western society the printed or imitative realization of the cultural convention of the personal signature has achieved a performative status equal to that of the original handwritten realization. This is in fact true, not only of payroll checks, but also of paper currency (e.g., United States federal reserve notes bear the mechanically reproduced signatures of the treasurer of the United States and the secretary of the Treasury), of academic diplomas, and a host of other modern printed performatives.

This was not yet the case, however, in early modern Germany. Printed privileges, signatures, seals, and monograms were not yet uniformly accepted as performatives. These new printed mechanisms of authentication won their performative status only gradually as information technology began to develop away from the conditioning premises of manuscript culture and realize the potential of the print medium. In terms of the physical indications on the volumes them- 
selves, the copyright that protects this book and the privilege that governed the rechenbüchlein of Henricus Grammateus appear to be virtually equivalent. They would appear to be specific realizations of the same underlying cultural convention. But this is not so. Sixteenthcentury German printing privileges were as often as not ineffective. Modern copyrights have, on the other hand, until the most recent wave of software, video, and photocopy piracy, been relatively stable performatives in Western society for more than a century. Although the protection of invention in modern print culture continues to be secured by archaic legal mechanisms in which manuscript and print culture intersect much as they did in the early sixteenth century, these mechanisms today are realizations of different cultural conventions that have accommodated features of mechanical reproduction not yet fully appreciated in the age of privileges.

\section{Notes}

1. Henricus Grammateus oder Schreyber von Erfurt, Ayn new kunstlich Buech welches gar gewiß vnd behend lernet nach der gemainen regel Detre/welschen practic/ regeln falsi ond etlichen regeln Cosse mancherlay schoene ond zuwissen notuerfftig rechnung auff kauffmanschafft. Auch nach den proportion der kunst des gesanngs jm diatonischen geschlecht auß zutaylen monochordum/orgelpfeyffen vnd jnstrument auß der erfindung Pythagore. Weytter ist hierjnnen begriffen buechhaltten durch das zornal/Kaps/ond schuldbuoch Visier zumachen durch den quadrat vnnd triangel mit vil andern lustigen stuecken der Geometrey. Gemacht auff der loeblichen hoen schuol zuo Wienn in Osterreich durch Henricum Grammateum/oder schreyber von Erffurdt der sieben freyen kuensten Maister [Nuremberg: Johannes Stüchs, 1518-21]. The copy of the text that I have used in preparing this essay is a part of the collection of The Bancroft Library at the University of California at Berkeley (call number HF 5644 S4). Section titles throughout the essay are take from this edition of Henricus's rechenbüchlein except for the last one, which is taken from the Faustbuch (see n. 13). Early New High German and Latin abbreviations have been resolved; marked vowels are presented as digraphs. The translations are my own. Phrases cited from the rechenbüchlein may be seen in their original contexts in figures 1-6.

2. Joseph Ritter von Aschbach, Die Wiener Universität und ihre Humanisten im Zeitalter Kaiser Maximilians I. (Vienna: Wilhelm Braumüller, 1877), pp. 460, 30.

3. See Franz Unterkircher et al., Maximilian I. 1459-1519. Ausstellung, BiblosSchriften 23 (Vienna: Österreichische Nationalbibliothek, 1959), p. 143.

4. "Bittend woellet solch mein buech vnnder ewer schuotz guenstlich von mir annemen / vnd mich weytter (wie jr bißher gethan) befolhen haben / . . . Vnd gruesset meinen lieben preceptorem vnd hern Joergen Tansteter / der siben freyen kuensten vnd ertzney doctor /" (fol. A2v). 
5. See Aschbach, Die Wiener Universität, pp. 449, 437.

6. "Mit Kayserlichen gnaden vnd Priuilegien das buech nicht nach zu trucken in sechs jaren" (fol. Ar).

7. Several coats of arms were designed for Tscherte, including one in 1519 and one, attributed to Dürer, which has been dated variously between 1521 and 1523. Concerning the latter, see items 456 and 457 in Unterkircher, Maximilian I., p. 143; and H. Tietze and E. Tietze-Conrat, Kritisches Verzeichnis der Werke Albrecht Dürers, vol. 2.2 (Basel: Holbein-Verlag, 1938), pp. 45, 190 (item 900). The arms from the rechenbüchlein (fig. 2) appear to be a rather rough adaption of the design attributed to Dürer. In the rechenbüchlein woodcut, Tscherte's name has been substituted for the Legend "Soli Deo Gloria," which appears in the Dürer arms. I agree with others who have dated the rechenbüchlein to 1521. See, for example, A. F. Johnson and V. Scholderer, Short-Title Catalogue of Books Printed in the German-Speaking Countries and German Books Printed in Other Countries from 1455 to 1600 Now in the British Museum (London: Trustees of the British Museum, 1962), p. 796. The latest date that appears on any part of the book itself is 1521 . The chapter of the volume that is devoted to commercial bookkeeping includes examples of three different kinds of ledgers that businessmen should know how to maintain. Each of these sample documents, the Zornal, the Kaps, and the Schuldt Buech is dated 1521 (fols. Nr, N6r, and Or). If this dating of the rechenbüchlein is correct, and if the Tscherte arms included in it are in fact derived from the design attributed to Dürer, then Dürer's arms for Tscherte must have been completed by 1521 .

8. "Ditz buch sey geschenckt allen liebhabern freier kunst vnd bit fruntlich so etwaz wirt funden streflichs von wegen vnfleiß / wullen daz selbig bruderlich corrigirn vnd bessern dann ich hab allayn geschriben vor die jungen anfenger jn der kunst mathematica / ich meine auch werde etlichen geben ain vrsach weiter jnn sulcher kunst zu speculirn yedoch ist mein hoffnung hab auff sulche zeyt genug gethan. Auch vormain ich alle buchtrucker sulches buch nicht nach zu trucken jn sechs jaren nach seynen außgang bey grosser pen behalten jn Kayserlichen priuilegien wie dann her nach wirt gesehen jn dem latein" (fol. Q2r).

9. On the implications of the notational conventions used in the chanceries of Maximilian to authenticate official documents, see Elaine C. Tennant, The Habsburg Chancery Language in Perspective, University of California Publications in Modern Philology 114 (Berkeley: University of California Press, 1985), pp. 105-12.

10. See David Murray, Chapters in the History of Bookkeeping Accountancy and Commercial Arithmetic (Glasgow: Jackson, Wylie \& Co., 1930), pp. 193-97.

11. "dann ich hab allayn geschriben vor die jungen anfenger jn der kunst mathematica / ich meine auch werde etlichen geben ain vrsach weiter jnn sulcher kunst zu speculirn" (fol. Q2r).

12. See Elaine C. Tennant, "'Understanding with the Eyes': The Visual Gloss to Maximilian's Theuerdank," in Entzauberung der Welt. Deutsche Literatur 1200-1500, ed. James F. Poag and Thomas C. Fox (Tübingen: Francke, 1989), pp. 213-14. 
13. References in this essay to the Faustbuch (Frankfurt a. M.: Johann Spies, 1587) and to Thüring von Ringoltingen's Melusine (Augsburg: Johannes Bämler, 1474) are according to the edition by Jan-Dirk Müller in Romane des 15. und 16. Jahrhunderts, Bibliothek der Frühen Neuzeit 1 (Frankfurt a. M.: Deutscher Klassiker Verlag, 1990). Faustus explains his association with Mephostophiles as follows: "Nach dem ich mir fuergenommen die Elementa zu speculieren / vnd aber auß den Gaaben / so mir von oben herab bescheret/ vnd gnedig mitgetheilt worden / solche Geschickligkeit in meinem Kopff nicht befinde / vnnd solches von den Menschen nicht erlehrnen mag / So hab ich gegenwertigen gesandtem Geist / der sich Mephostophiles nennet / ein Diener deß Hellischen Printzen in Orient / mich vntergeben /" (p. 854).

14. Michael Giesecke, Der Buchdruck in der frühen Neuzeit. Eine historische Fallstudie über die Durchsetzung neuer Informations- und Kommunikationstechnologien (Frankfurt a. M.: Suhrkamp, 1991), p. 445.

15. Before describing what a privilege was and how in general terms the privileging system worked, I should note in passing that all discussions of printing privileges before 1600 in Germany are in some measure anecdotal and will probably continue to be so. For reasons that will become clearer, there is no comprehensive inventory of imprints that were published under privilege before 1600 . Nor is there a comprehensive register of the privileges that were issued to individuals involved with the various aspects of the printing trade in this period. Much less is there a single comprehensive collection of the actual texts of individual charters of privilege that were issued. These gaps in formal bibliography and diplomatics are likely never to be closed. This does not mean, however, that we do not know a good deal about how the privilege system functioned with respect to print culture in early modern Germany. Intermittently over at least two hundred years various scholars have made investigations and partial inventories of works printed under privilege in German-speaking Europe in this period. Particularly useful with regard to the issues under consideration in this essay are Karl Schottenloher, "Die Druckprivilegien des 16. Jahrhunderts," Gutenberg-Jahrbuch 8 (1933): 89-110; Hansjörg Pohlmann, "Neue Materialien zum deutschen Urheberschutz im 16. Jahrhundert," Archiv für Geschichte des Buchwesens 4 (1961): 89-171, and "Der Urheberrechtsstreit des Wittenberger Professors Dr. med. Kaspar Peuker mit dem Frankfurter Verleger Sigmund Feyerabend (1568-1570)," Archiv für Geschichte des Buchwesens 6 (1965): 593-680; and Giesecke, Der Buchdruck in der frühen Neuzeit, chap. 5.5, especially pp. 445-52.

16. Schottenloher, "Die Druckprivilegien des 16. Jahrhunderts," p. 109, explains the legal connotations of the privilege as follows: "Privileg war hier und wird noch heute verstanden als völlig willkürliche, unberechenbare Verleihung von Vorrechten aus fürstlicher Gunst und Gnade, wie dies auch noch der feudalistischen Herkunft und Einstellung des Mittelalters entsprach; d. h. also eine mehr oder weniger unwägbare Bevorrechtigung einzelner Begünstigter vor anderen weniger Glücklichen, denen eine derartige Gunst unerreichbar blieb. Im ganzen demnach eine juristisch äußerst fragwürdige Institution, die auch noch im 16. und 17. Jahrhundert völlig die Züge des Mittelalters 
zu tragen schien und auch überwiegend der Eigenart einer gunstweisen Erteilung von Stadt- und Lehnsrechten oder Adelserhebungen $u$. ä. entsprechen mochte." See also Heinrich Otto Meisner, Urkunden- und Aktenlehre der Neuzeit, 2d ed. (Leipzig: Koehler \& Amelang, 1952), p. 178.

17. In Venice privileges were granted to printers as early as 1469 ; the first German municipal printing privilege may have been as early as 1488; and one of the earliest imperial privileges was granted to Conrad Celtis for his edition of Hroswitha in 1501. See Rudolf Hirsch, Printing, Selling and Reading (Wiesbaden: Otto Harrassowitz, 1967), pp. 79-80, 85.

18. The fine announced in the privilege that protects Henricus's rechenbüchlein, for example, is ten marks of pure gold (fig. 5).

19. The following summary derives in large part from the list of abstracts of some 159 sixteenth-century printing privileges that Schottenloher published in 1933 (in "Die Druckprivilegien des 16. Jahrhunderts"), the lists of more than 200 imperial Urheberprivilegien from before 1600 that Pohlmann published in 1961 and 1965 as well as the texts of a number of those privileges reproduced in the first of these essays ("Neue Materialien zum deutschen Urheberschutz im 16. Jahrhundert"), and on my own experience with various sixteenth-century imprints from German-speaking Europe that are now a part of The Bancroft Library collection.

20. Hirsch, Printing, Selling and Reading, p. 87.

21. See Schottenloher, “Die Druckprivilegien des 16. Jahrhunderts," p. 99, item 50.

22. For the implications of these terms see Lore Sprandel-Kraft, "Über das Verhältnis von Autor und Druckherr in der Inkunabelzeit," Archiv für Geschichte des Buchwesens 24 (1983): 362.

23. Pohlmann's review of the misinformation that has proliferated about the privilege system remains, I believe, the most thorough and telling ("Neue Materialien zum deutschen Urheberschutz im 16. Jahrhundert," pp. 89-92). The fact that Giesecke was obliged once again in his 1991 analysis of the privilege system (in Der Buchdruck in der frühen Neuzeit) to correct many of these assumptions, this despite Pohlmann's impressive revisionist work on Urheberprivilegien, is a testimony to the hardiness and longevity of scholarly misinformation. My own pastiche draws on Pohlmann's summary as well as on hasty remarks by Hirsch (Printing, Selling and Reading, p. 81) and others. See, for example, Monika Toeller, "Die Buchmesse in Frankfurt a. Main vor 1560. Ihre kommunikative Bedeutung in der Frühdruckzeit" (Ph.D. diss., University of Munich, 1983), p. 171.

24. See Pohlmann, “Neue Materialien zum deutschen Urheberschutz im 16. Jahrhundert," pp. 98-99, 101-2.

25. See Giesecke, Der Buchdruck in der frühen Neuzeit, p. 461: "Diejenigen Autoren, die um Privilegien nachsuchen, tun dies gerade nicht aus Eigennutz, sondern weil sie ihr bis dato noch oft höchst privates, geheimes Wissen der Allgemeinheit zugänglich machen wollen. Die Vergesellschaftung von privatem Eigentum braucht die Rückendeckung der Gesellschaft bzw. ihrer Repräsentanten. Nur wenn der Privatperson aus dieser Offenbarung eines 
Teils ihrer selbst keine allzu schwerwiegenden Nachteile entstehen, kann die Sozialisierung der Informationen zu einer selbstverständlichen Gepflogenheit werden. Eine Stärkung der 'Rechte' der Privatperson lag insofern im wohlverstandenen Interesse der Gemeinschaft."

26. "Als aber ich ain zeyt jn der kunst arithmetica vnd geometria etlich schoene vnd behende regeln jn villerlay sachen dienstlich zusammen gezogen / die selben euch zuuebersehen furgetragen / ermonet jr mich solche den vnwissenden vnd sondern liebhabern der kunst an den tag zubringen / damit nit allain die kunst sonder auch der nutzs darauß vernommen vnd entpfangen wuerde/" (fol. A2r).

27. "Ditz buch sey geschenckt allen liebhabern freier kunst vnd bit fruntlich so etwaz wirt funden streflichs von wegen vnfleiß / wullen daz selbig bruderlich corrigirn vnd bessern dann ich hab allayn geschriben vor die jungen anfenger jn der kunst mathematica / ich meine auch werde etlichen geben ain vrsach weiter jnn sulcher kunst zu speculirn yedoch ist mein hoffnung hab auff sulche zeyt genug gethan," (fol. Q2r).

28. "Que ut nobis mirum in modum placuerunt Ita vehementer cupimus, ut ea forma ad omnium bonarum literarum studiosorum vsum publicentur. Quod \& si te haud grauare nostri gratia etiam impensis magnis facturum sciamus. Ne tamen priuata res tua incommodetur, quandoquidem indignum censemus laborem, impensas, \& officia tua pari aliorum opera secundariæ editionis defraudari,..." (fol. Q2v) ("Inasmuch as these please us wonderfully, we emphatically desire that those copies be published for the use of all students of good letters. We acknowledge that you should in no way incur great expenses on our account, lest your private affairs be inconvenienced, and because we consider it unworthy that your labor, expenses, and services should be defrauded by a second publication done by others, ...").

29. While some of these applications survive (see Pohlmann, "Neue Materialien zum deutschen Urheberschutz im 16. Jahrhundert," p. 115), the traces of many of them are preserved only in the references to them that occur in the copies of the privileges that were recorded in registers, reproduced separately by the privilege holders, or reproduced in the actual imprints under privilege.

30. Pohlmann, "Neue Materialien zum deutschen Urheberschutz im 16. Jahrhundert," p. 115.

31. On the significance of hanging seals used to authenticate chancery documents of this kind, see Tennant, The Habsburg Chancery Language, pp. 73, 105-12.

32. See Elizabeth Armstrong, Before Copyright: The French Book-Privilege System, 1498-1526 (Cambridge: Cambridge University Press, 1990), p. 15; and Pohlmann, "Neue Materialien zum deutschen Urheberschutz im 16. Jahrhundert," p. 126.

33. See Schottenloher, “Die Druckprivilegien des 16. Jahrhunderts," p. 109, item 143; and Toeller, Die Buchmesse in Frankfurt a. Main vor 1560, p. 172.

34. Pohlmann, “Neue Materialien zum deutschen Urheberschutz im 16. Jahrhundert," p. 115.

35. Concerning the silver stamps that were used in the imperial chancery to 
produce Maximilian's signature as well as various chancery validation formulas, see Tennant, The Habsburg Chancery Language, pp. 109-10.

36. Giesecke, Der Buchdruck in der frühen Neuzeit, pp. 445-49. The printer's device of Johannes Stüchs (fig. 6) is an example of an authenticating symbol, like Luther's rose, that was designed originally for the print medium.

37. Printed imitations of chancery signatures and formulas as well as new authenticating devices that were designed specifically for the print medium were easily forged or copied. Both the Luther rose and the Dürer monogram were used on pirated and unauthorized imprints during the sixteenth century, although the Luther device seems generally to have been more widely respected and thus less often copied than some devices of this kind that were in use during the period. See Jane O. Newman, "The Word Made Print: Luther's 1522 New Testament in an Age of Mechanical Reproduction," Representations, no. 11 (Summer 1985): 109.

38. J. L. Austin, How to Do Things with Words, 2d ed., ed. J. O. Urmson and Marina Sbisà (Cambridge, Mass.: Harvard University Press, 1975), pp. 14-15. In his classic discussion of what we have come to call speech acts, Austin outlines the conditions that are necessary to bring off a successful performative:

(A.1) There must exist an accepted conventional procedure having a certain conventional effect, that procedure to include the uttering of certain words by certain persons in certain circumstances, and further, (A.2) the particular persons and circumstances in a given case must be appropriate for the invocation of the particular procedure invoked. (B.1) The procedure must be executed by all participants both correctly and (B.2) completely. (Г.1) Where, as often, the procedure is designed for use by persons having certain thoughts or feelings, or for the inauguration of certain consequential conduct on the part of any participant, then a person participating in and so invoking the procedure must in fact have those thoughts or feelings, and the participants must intend so to conduct themselves, and further (Г.2) must actually so conduct themselves subsequently.

39. In linguistic terms the underlying convention and its individual realizations could be said to stand more or less in the emic/etic relationship to each other. The convention (the emic construct of the performative) is never evident in the culture to which it belongs except as it is realized in individual or specific (i.e., in etic) manifestations.

40. There may also have been some question about the validity of original manuscript privilege that is invoked by the printed text appended to the rechenbüchlein since Maximilian had been dead for three years by the time the book appeared. It was established custom in the chancery culture of both the empire and the Vatican to break or cancel the personal seals of the emperor or the pope when he died; but the custom was as often as not observed in the breach. See Erich Kittel, Siegel (Braunschweig: Klinkhardt \& Biermann, 1970), p. 159. It is impossible to know from the imprint of the rechenbiuchlein which of 
Maximilian's various seals was used to execute Alantsee's privilege in 1518 (i.e., whether the charter was authenticated with one of Maximilian's personal seals or with a corporate seal from one of the Habsburg chanceries). Given the relative newness of printed privileges like the one appended to Henricus's handbook, one can only speculate about whether contemporary German readers would have accepted either the authority of a printed version of the handwritten privilege or the authority of the original privilege that had been issued under the auspices of a ruler already deceased.

41. See Schottenloher, “Die Druckprivilegien des 16. Jahrhunderts," p. 104, items 97 and 98.

42. "So soltu ÿe gedencken auff die stund vnd on verziehen/ das dir darumb des selben tags guott versiglet brieff werden / darinn begriffen seÿ was die gab oder warumb sÿ dir seÿ gegeben / vnd den tag vnd das iar mit rechtem datum darinn geschriben Vnd wenn die gab also geben / verbriefft vnd versigelt wirt / so soltu dich denn ein klein enthalten vnd dannen geen / ..." (Müller, Romane des 15. und 16. Jahrhunderts, p. 27, lines 5-10).

43. The Reichskanzleiordnung of 1494 , for example, stipulates, in a section describing the duties of scribes and secretaries, that no letters, particularly those written on parchment, may be corrected "in sensitive areas" ("an argwonigen stetten"), namely in the places in the text that specify "names, amounts, dates, and the like" ("im namen oder zunamen in der suma der zall im datum tags oder iars und dergleichen sachen") without being copied over. See Gerhard Seeliger, "Die älteste Ordnung der deutschen Reichskanzlei. 1494. Oktober 3. Mecheln," Archivalische Zeitschrift 13 (1888): 4. This stipulation allows us to identify those features of a chancery charter that had to be executed correctly in order for it to be accepted as authentic and therefore as an effective performative by an early modern audience. For a more general description of the chancery procedures for executing charters, see Tennant, The Habsburg Chancery Language, pp. 72-73.

44. "Also ließ er jm ze stund einen brieff machen / der auch gar meÿsterlich gestellet ward / das ir ÿeglichen bedaucht / hienge sein insigel auch nit daran / es waer nichts vnd waren all willig Vnd da nun der brieff also wolgestellet und versigelt ward mit des graffen meren jnsigel / mit sampt der anderen herren vnd Ritter jnsigel / vnd das datum des iares vnd tags schon ward auch darinn geseczt mit den gezeügen" (Müller, Romane des 15. und 16. Jahrhunderts, p. 31, lines 8-14).

45. "ir ÿeglichen bedaucht/ hienge sein insigel auch nit daran/ es waer nichts" (ibid., p. 31, lines 9-10).

46. Thüring von Ringoltingen would certainly have known these contemporary chancery practices well from his long career in public service in Bern (as a member of the Großer Rat, as Schultheiß, etc.). For the details of his biography, see ibid., pp. 1020-22.

47. One of the often-repeated and well-documented anecdotes from the age of privileges recounts how two citizens from Strassburg, a publisher and a printer, forged or "reissued" their own lapsed privilege in order to avoid 
having to pay for its renewal. They were found out but saved by legal niceties from punishment. See Schottenloher, “Die Druckprivilegien des 16. Jahrhunderts," p. 92.

48. The author of the Faustbuch did not, of course, invent the devil's pact signed in blood as a response to the emerging print culture of sixteenthcentury Germany. But his elaborate reformulation of this venerable plot element does reflect contemporary procedures and concerns that are related to the control and authentication of information. The transformation of the traditional pact into a correctly executed chancery document causes Faustus's signature and the blood in which it is written to evoke new meanings in this early modern text, which was created in a period when traditional mechanisms for authenticating legal documents and other texts were being undermined. In addition to his transformation of the pact into a chancery letter, the author's reduplication of the pact scene calls into question the effectiveness of the legal contract (the first pact letter), which is presumed to be absolutely binding within the world of the text. Mechanisms of authentication have been seriously eroded when even the legendary pact signed in blood must, despite its utter conformity to contemporary chancery conventions, be renewed in order to maintain its efficacy.

49. See Jacques Derrida, "Signature Event Context," in Margins of Philosophy, trans. Alan Bass (Chicago: University of Chicago Press, 1982), pp. 307-30. In this essay, which he first presented as a paper to the Congrès international des Sociétés de philosophie de langue française in 1971, Derrida develops in detail his notion of iterability. See especially pp. 314-15.

50. Jonathan Culler, On Deconstruction: Theory and Criticism after Structuralism (Ithaca, N.Y.: Cornell University Press, 1982), p. 120: "Imitation is not an accident that befalls an original but its condition of possibility. There is such a thing as an original Hemingway style only if it can be cited, imitated, and parodied. For there to be such a style there must be recognizable features that characterize it and produce its distinctive effects; for features to be recognizable one must be able to isolate them as elements that could be repeated, and thus the iterability manifested in the inauthentic, the derivative, the imitative, the parodic, is what makes possible the original and the authentic."

51. Ibid., p. 126. 


\section{Zwischen Repräsentation und Regierungspraxis: Transformation des Wissens in Maximilians Weiskunig}

Jan-Dirk Müller

\section{Transformation des Wissens}

Für die Epochenschwelle zwischen Mittelalter und früher Neuzeit gelten Veränderungen in der Ordnung und Organisation des Wissens als wichtigste Indikatoren. Dabei lassen sich vor allem vier untereinander verflochtene Tendenzen ausmachen: die Tendenz zur Pragmatisierung, zur Empirisierung, zur Ausdifferenzierung und zur Publizität von Wissen.

Pragmatisierung: Der akademische Betrieb der mittelalterlichen Universitäten ist auf die sogenannten freien Künste (artes liberales) und die darauf aufbauenden theoretischen Disziplinen Theologie, Medizin und Jurisprudenz eingeschränkt. Er grenzt in der Tendenz (wenn auch kaum tatsächlich, wie spätmittelalterliche Universitätsprogramme zeigen) "unfreie", d. h. der Daseinsvorsorge oder sonst praktischer Anwendung dienende Typen von Wissen wie die artes mechanicae aus und achtet die anwendungsbezogenen Teile der theoretischen Disziplinen geringer. (Ich erinnere an den Streit der gelehrten Ärzte mit Wundärzten oder sonstigen Heilberufen oder an die Polemik der Artisten gegen die gewinnorientierte, will sagen praktisch nutzbare Rechtswissenschaft.) Das akademische Wissen ist autoritätsfixiert und schriftgebunden; es wird durch Auslegung kanonischer Schriften erlernt. Das praktische Wissen ist dagegen meist schriftlos und wird handelndnachahmend vermittelt. Diese-ohnehin nur idealiter geltende-Verteilung löst sich seit dem 15. Jahrhundert immer mehr auf. Das akademische Wissen wird durch Übersetzung und Bearbeitung für die Praxis verfügbar gemacht, und das Praktikerwissen wird verschriftlicht, bildet seine eigenen Autoritäten aus und wird zunehmend auch durch schriftliche Anleitung weitergegeben. ${ }^{1}$

Empirisierung: Die Konkurrenz, die das akademische, autoritativ abgesicherte Wissen erhält, hat neue Prinzipien der Ermittlung und 
Sicherung von Wahrheit zur Voraussetzung. Neben oder an die Stelle von Autorität tritt Autopsie oder allgemeiner experiencz. ${ }^{2}$ Mit der Verschriftlichung des Praktikerwissens werden Erfahrungen, die in einzelnen Handlungen gewonnen wurden, kumulierbar und allgemein kommunizierbar; ein über längere Zeiträume entwickelter Brauch löst sich von face-to-face-Situationen ab; was vielerorts und zu vielen Zeiten erkannt wurde, kann verglichen werden, und die einzelne Erkenntnis wird korrigierbar. Ein trial-and-error-Verfahren kann sich erst unter der Bedingung verbreiteten Schriftgebrauchs erfolgversprechend ausbilden. Auch autoritativ vermittelte theoretische Kenntnisse können auf ihre empirische Sachhaltigkeit und Tauglichkeit überprüft werden: akzeptiert oder verworfen. Operationalität und Überprüfbarkeit (oft noch in der rudimentären, manchmal sogar nur behaupteten Form von Autopsie) werden zum Kriterium der Wahrheit. Projekte wie Bacons Instauratio magna zielen auf kritische Sichtung und Zusammenführung empirisch gewonnener Wissensbestände, wenn auch Empirie vorwissenschaftlich verstanden wird und sich geregelte Verfahren $\mathrm{zu}$ ihrer Verifikation allererst noch auszubilden haben.

Ausdifferenzierung: Das mittelalterliche System des universitären Wissens umfaßt, geht man von der Gliederung der Fakultäten aus, relativ wenige Disziplinen. In ihrem Rahmen werden auch Themen abgehandelt, die zwischen dem 15. und 17. Jahrhundert Gegenstand besonderer Disziplinen werden, etwa Geschichte als Teil der artes liberales. Jenseits der universitären Disziplinen ist der Grad der Differenzierung im Mittelalter noch geringer: Tier- und Pflanzenkunde schließen theologisches und moralphilosophisches Wissen ein; ein Büchsenmeisterbuch kann technische und chemische Kenntnisse mit kaufmännischen (wie erwirbt man günstig guten Salpeter?) vereinen; die Kriegskunst enthält auch Elemente aus Architektur oder Astrologie. Noch im 16. Jahrhundert faßt eine Disziplin wie die Geographie Kenntnisse aus der Mathematik, der Geschichte, der Botanik oder der Zoologie mit den Erfahrungen von Ortskundigen oder Reisenden zusammen. Anfangs zeichnet sich der Zuschnitt einer neuen Disziplin oft nur undeutlich $a b$; es entstehen ungewohnte Kombinationen, Amalgamierungen und Grenzziehungen.

Schließlich Publizität: Mittelalterliches Wissen ist prinzipiell arkan, d. $h$. an besonders dazu legitimierte Gruppen wie Priester, Universitätsabsolventen, Herrschaftsträger, aber auch Handwerkerzünfte gebunden. Sein Arkancharakter wird durch mehr oder weniger verfestigte Barrieren geschützt (z. B. durch die Gelehrtensprache Latein, das kirchliche Monopol auf Auslegung der Bibel, Verschlüsselungsstrategien). Mit der Verschriftlichung, verstärkt dann durch den Buchdruck, 
wird der Arkancharakter gefährdet und schließlich aufgehoben. ${ }^{3}$ Doch gibt es dagegen starke Gegenkräfte; zu erinnern ist an die frühen Versuche der Zensur, die Diffusion von Wissen zu kontrollieren, aber auch an die Konjunktur von Geheimwissenschaften von der Hieroglyphenkunde bis zu den Spielarten der Magie, die ebenso faszinierend wie gefährlich scheinen und bezeichnenderweise verboten oder jedenfalls wenigen Privilegierten vorbehalten werden. Allgemeine Zugänglichkeit von Wissen und emphatischer Schutz des Wissensprivilegs in bestimmten Fällen gehören im 16. Jahrhundert zusammen.

Diese vier Tendenzen prägen sich um 1500 in den verschiedenen sozialen und kulturellen Ordnungen sehr unterschiedlich aus. Hier ist ein Fall zu kommentieren, der recht weit von den spektakulären wissenschaftstheoretischen Umbrüchen und wissensorganisatorischen Neuorientierungen zwischen dem 13. und 16. Jahrhundert entfernt ist, an dem aber ablesbar ist, wie wenig bei der Transformation der Ordnungen des Wissens mit geradlinigen Entwicklungen und klaren Abgrenzungen zwischen alt und neu, "humanistisch" und "spätmittelalterlich" zu rechnen ist. ${ }^{4}$ Mein Gegenstand ist eine Schrift, die nur indirekt auf die skizzierten Veränderungen reagiert und dabei erkennen läßt, wie mühsam und widersprüchlich jener Prozeß verläuft, wenn man einmal die Sphäre der großen Vordenker zwischen Roger und Francis Bacon oder zwischen Nikolaus von Cues und Paracelsus verlassen hat. Ich handle vom Erziehungsprogramm im GedechtnusWerk Maximilians I. ${ }^{5}$

Maximilian I. (1459-1519), 1487 zum König des Römischen Reichs Deutscher Nation gewählt, folgte seinem Vater Kaiser Friedrich III. von 1493-1519 als König und erwählter Römischer Kaiser. Nachdem Pläne einer Krönung durch den Papst sich nicht verwirklichen ließen, proklamierte er sich 1508 selbst in Trient zum Kaiser. Seit der Jahrhundertwende ging er daran, sein Leben und die Geschichte seiner Regierung in einer Reihe von literarischen und künstlerischen Projekten darstellen zu lassen. Materialgrundlage waren Diktate, die Maximilian selbst zwischen den Regierungsgeschäften Sekretären diktierte. Doch wurde dieser Stoff verschlüsselt und nach vielfältigen literarischen Mustern stilisiert, z. B. in einem Ritterroman (Heldenpoch); in Versen (Theuerdank); in einem Liebesroman (Freydal, Fragment); verschiedenen Holzschnittwerken (Triumphzug, Triumphbogen [Ehrenpforte]); einem monumentalen Grabmal. Am umfangreichsten war der in Prosa geschriebene Weiskunig angelegt, der die Geschichte der Vermählung seiner Eltern, seine eigene Jugend und die Kriege und wichtigsten Ereignisse seiner Regierungszeit darstellen sollte. Sieht man von dem Grabmal ab, dann waren diese Werke alle für die Reproduktion im 
Druck gedacht und wurden mit prächtigen Holzschnitten ausgestattet, an denen die hervorragendsten Künstler wie Albrecht Dürer, Hans Burgmair, Hans Schäuffelein, Albrecht Altdorfer und andere mitwirkten. Sie gehören zur bedeutendsten Druckgraphik der frühen Neuzeit und haben immer weit größere Aufmerksamkeit gefunden als die teils recht steifen Texte. Für die Geschichte der frühen Neuzeit sind diese jedoch nicht weniger signifikant.

\section{Der princeps litteratus}

Kaiser Maximilian I. läßt sich und seine Taten im Ritterepos Theuerdank und im Prosaroman Weiskunig verschlüsselt feiern. Während der Theuerdank $^{6}$ eine Kette ritterlicher Abenteuer erzählt, die der junge Fürst zu bestehen hat, enthält der Weiskunig vor allem seine Kriege und politischen Unternehmen. Diesen vorangestellt ist erstens die Geschichte der Eltern und zweitens die der Jugend des Helden, der schon in zartem Alter Zeichen seiner späteren Größe erkennen läßt. Der wichtigste Gegenstand dieses zweiten Teils ist freilich die lernung, der Erwerb von Wissen.

Das Erziehungsprogramm ist weit über das übliche Maß ausgedehnt, und es weist eine seltsame Ordnung auf. In den lateinischen Vorstufen des Textes, der sogenannten "Lateinischen Autobiographie", gibt es nur wenige Bemerkungen dazu. ${ }^{7}$ Sie werden erstens ausgebaut in Cod. 2892, einem vollständigen Entwurf der Jugendgeschichte in der Volkssprache. ${ }^{8}$ Zweitens hat Maximilians gelehrter secretarius Joseph Grünpeck die in der "Autobiographie" nur angedeuteten Gegenstände der lernung in ein humanistisch geprägtes Bildungsprogramm umgegossen ${ }^{9}$, und drittens hat der kaiserliche Geheimschreiber Marx Treitzsaurwein in seiner Bearbeitung des Weiskunig (Cod. Vind. 3032) ${ }^{10}$ die verstreuten Nachrichten zum Bild des ubertreffenlichn gelertn Herrschers ausgebaut. Von Stufe zu Stufe verändert sich dabei das Konzept von Wissen, wobei unterschiedliche Aspekte des eingangs skizzierten Transformationsprozesses in den Vordergrund rücken.

Joseph Grünpecks "Historia Friderici IV. et Maximiliani" nutzt zwar das ältere Material und bleibt daher in der Ausdifferenzierung der Wissensgebiete hinter späteren Fassungen der Erziehungsgeschichte zurück, doch integriert sie es in einen geschlossenen Entwurf, der Wissen und Bildung ins Zentrum des Herrscherportraits stellt und in Maximilian ein zeittypisches Ideal des Herrschers entwirft, das weniger in die Geschichte der Wissenschaft als in die der Bildung gehört. Grünpeck stilisiert Maximilian zum princeps litteratus. Gering ist das Inter- 
esse an Pragmatisierung und Empirisierung von Wissen. Wissen ist im wesentlichen auf die intellektuellen Fähigkeiten konzentriert. An der Spitze stehen zwar die "Hofkünste" Jagd, Turnier und (Masken-)Fest, doch sind sie Teil höfischer Lebensform und erscheinen nicht, wie später im Weiskunig, als Gegenstand von lernung. Es folgen Kapitel "De eius literariis ociis presertim cosmographie et historiarum studiis", zu seiner Schriftstellerei (überschrieben u. a. mit "De eius subtilitate ingenii, scienciarum varietate, rerum experienciis") und schließlich zu seiner "memoria" (S. 91-93). Memoria ist das wichtigste Vermögen des Gelehrten in einem traditionalen Wissenschaftsbetrieb. ${ }^{11}$ Sie erlaubt ihm, Elemente der Tradition zu wechselndem Gebrauch verfügbar zu halten. Humanistische Lernprogramme unterscheiden sich in diesem Punkt nicht wesentlich von älteren mittelalterlichen. Die excellentissima memoria faßt Maximilians intellektuelle Fähigkeiten zusammen.

Dabei besteht ein gewisses Spannungsverhältnis zwischen den Ankündigungen der Kapitelüberschriften und den darunter subsumierten Eigenschaften und Kenntnissen. Grünpeck zitiert gewissermaßen eine Hohlform humanistischer Bildung, in die das teils nur spärlich vorhandene Material eingepaßt wird. Die litterarum studia, der Kernbereich der studia humanitatis, werden immerhin noch mit Kosmographie und Geschichte gefüllt, Disziplinen, die im mittelalterlichen Fächerkanon vernachlässigt waren und die als realitätsbezogen sich einer besonderen Wertschätzung in humanistischen Bildungsprogrammen erfreuten. Die Geschichte vermittelt-so auch Grünpeck-über exempla die für den Regenten ${ }^{12}$ erforderlichen virtutum alimenta. Wissen ist pragmatisch, jedoch in einem fundamental moralphilosophischen Sinn: Die Geschichte im Verstand der Humanisten (und nicht die dynastisch-genealogischen Studien, die Maximilian tatsächlich betrieb) leitet zum guten Leben an.

Da der Fürst seine Taten diktieren kann, schreibt Grünpeck ihm ganz allgemein Beherrschung der Rhetorik: sprachliche Gewandtheit, elegante Ausdrucksweise, Zusammenstimmen der Rede (lingue promptitudo, verborum elegantia und sententiarum concinnitas) zu und stilisiert ihn so zum humanistischen Literaten. Seine scientiarum varietas und rerum experiencia werden ganz pauschal behauptet, wobei die Zusammenstellung immerhin zeigt, daß Grünpeck neben Gelehrsamkeit Erfahrungswissen stellt. Als Beispiele für seine memoria erscheinen untypischerweise sein glänzendes Personengedächtnis, seine gute Erinnerung an in der Jugend erworbenes Schulwissen und die Beherrschung moderner Fremdsprachen.

Grünpeck geht es weniger um einzelne Kenntnisse. Er unterschlägt das pragmatische Interesse nicht, deutet das empirische wenigstens an 


\section{Jan-Dirk Müller}

und stellt zwei neue Disziplinen heraus, die sich im alten Universitätskanon eben zu verselbständigen beginnen. Seine Aufmerksamkeit aber gilt vor allem der Bildung des Fürsten zum Menschen, mündend in einen bestimmten Habitus, den er wie viele Gesinnungsgenossen humanitas nennt: "De eius affabilitate, humanitate et erga omnes libera audiencia", lautet die Überschrift eines Kapitels. Der rastlose Lerneifer oder die Beschäftigung selbst mit inferioren Tätigkeiten ("quas humiles domini despicerent") runden als eher seltsame Eigenheiten das Charakterportrait ab (S. 95), ohne etwas zum humanistischen Bild des princeps litteratus beizutragen. Dieses Bild grenzt aufs Ganze gesehen jene Elemente aus, die in der frühen Neuzeit den Wissensfortschritt vor allem stimulieren: technische Brauchbarkeit, empirische Überprüfbarkeit und Spezialisierung. Hier wenn irgendwo kann man vom uomo universale sprechen. Die Bilder dagegen, die Maximilian in der Volkssprache von sich entwerfen läßt, behaupten eher als eine universale Bildung das Spezialistentum des Fürsten für alles und jedes.

\section{Wissen für den Herrn eines großen Hauses}

In der frühen volkssprachlichen Bearbeitung der Erziehungsgeschichte (Cod. Vind. 2892) wird Wissen aus der Perspektive einer spätmittelalterlichen Hofhaltung gesehen. Die Auswahl ist praxisorientiert, aber in einem alten Sinne der Sorge für den großen herrscherlichen Haushalt: Was sollte ein Fürst und großer Herr alles können und wissen für die Aufgaben im Land und für das Leben am Hof? Die Situation, die es zu bewältigen gilt, bestimmt Zusammenhang und Ordnung der Kenntnisse. Das akademische Wissen der Gelehrten steht ganz am Rande. Völlig fehlt das bei Grünpeck und im Weiskunig dominierende Moment des Zurschaustellens, das Wissen als Ausweis herrscherlicher Größe feiert.

Das wichtigste Thema wird gleich zu Anfang herausgestellt: "Wie ain vast mechtiger koning sein leben nach Ratt vnd vnderweyssung seines vattern furrtt", des Vaters, der seiner Weisheit wegen "der alt weuss koning" heißt (Bl. $2 \mathrm{v}-3 \mathrm{r}$ ). ${ }^{13}$ Einer Widmung ${ }^{14}$ und einer Vorrede, die die Anlage der Schrift erläutert, folgt zunächst in erzählender Form die Geschichte der Erziehung (ab Bl. 12v) ${ }^{15}$, angefangen von kindlichen Spielen ${ }^{16}$ über die Bestellung der ersten Lehrer (Bl. 12v), die Charakteristik des lernbegierigen jungen Fürsten (Bl. $12 v-13 r){ }^{17}$ bis zum Elementarunterricht im Schreiben (Bl. 13r), dem sich ohne genauere zeitliche Abfolge andere Disziplinen anschließen.

Hof und Herrschaftszentrum sind stets Bezugspunkt. Breiten Raum 
nehmen die verschiedenen ritterlichen Kampfsportarten ein (Bl. 16r$18 \mathrm{v})$. Bei der Baukunst geht es-unter Berufung auf Vitruv-vor allem um militärische oder militärisch verwendbare Bauten (Bl. 15r). Breit ausgeführt sind verschiedene Formen des Zeitvertreibs bei Hof, zur Vertreibung der Melancholie und zur Erholung, etwa durch Musik und Masken (Bl. 15r/v, 17r/v). Es gibt Astrologie (als für die politische Prognostik unentbehrlich), Schwarze Kunst (als verbotenes Wissen von magischer Weltbeherrschung), secretari-Kunst, nicht aber Theologie, Philosophie 18, Geschichte. Schreiben ("vast gütt geschrifft") ist eine erlernenswerte, da nützliche Tätigkeit, die den Fürsten von den Fähigkeiten anderer unabhängig macht; aus dem gleichen Grund lernt er die secretari-Kunst (Bl. 14v) oder die Sprachen seiner Völker (Bl. 20r/v), um nicht auf den Kanzler, Dolmetscher oder sonstige Helfer angewiesen zu sein. ${ }^{19}$

Deutlich überwiegt also ein pragmatisches Interesse an Wissen. Dabei kreuzen sich zwei zeittypische Tendenzen: auf der einen Seite die Differenzierung des Regierungsapparats, die immer mehr und immer spezialisiertere Kenntnisse erfordert; auf der anderen Seite die wachsende Konzentration von Herrschaftsfunktionen beim Fürsten und in seiner nächsten Umgebung, wie sie sich in der Tendenz zum absolutistischen Staat durchsetzt. Maximilian (oder die Entwerfer seines Bildes für Mit- und Nachwelt) lösen das Problem auf merkwürdige Weise: Müßte die Ausdifferenzierung praktisch relevanten Wissens eigentlich zur Vermehrung des Regierungspersonals führen (was im frühneuzeitlichen Staat tatsächlich geschieht), so suchen sie im Gegenteil den höheren Bedarf an Wissen im Idealbild eines Fürsten aufzufangen, der als Einzelperson diesen Bedarf deckt. Die Tendenz zur Ausdifferenzierung wird also nicht institutionell, sondern personell verarbeitet.

Grundsätzlich wird, anders als bei Grünpeck und seinem humanistischer Standeskultur verpflichteten Bild des Herrschers, nicht zwischen "standesgemäßen" und "nicht-standesgemäßen", zwischen verantwortlichen und subalternen Fertigkeiten unterschieden, so daß Schreiben und Sekretärskunst, die ja später Domäne der nichtadeligen Helfer des Fürsten bei Hof werden, hier zu seinem Lernprogramm gehören. Wissen ist für jedermann brauchbar. So dient die Astrologie auch den "erdtpawenden" (Bl. 14r), den Bauern also. Wenn es heißt, vormals hätten die Kinder von Fürsten alle Handwerke lernen müssen, dann liefern die Begründung dafür nicht die vielfältigen späteren Regierungsaufgaben des Herrschers, sondern die Notwendigkeit für ihn, sich auch in einem etwaigen Exil den Lebensunterhalt verdienen zu müssen..$^{20}$ "Wissen" ist zwar noch ganz von der Person her gedacht, 
aber es ist nicht mehr ständisch differenzierend (z. B. in "freie" und "unfreie" Künste aufgespalten), es hebt ständische Schranken gerade auf.

Die einzelnen Disziplinen sind einem pragmatischen Interesse folgend aufgeteilt. Ein besonders instruktives Beispiel ist die Medizin, gefaßt als Diätetik ("behaltưng natürliches lebens", Bl. 15v). Sie umfaßt Typen von Kenntnissen, die später der Weiskunig säuberlich trennt: theoretische Medizin, Sorge für Nahrung, damit dann auch die Ausrichtung von Festmählern, folglich allgemein die Einrichtung von Festen. Auf den Rahmen der akademischen Disziplin wird nur flüchtig angespielt, wenn als Basis richtiger Lebensführung der humoralpathologische Tatbestand der complexion genannt wird. Hauptsächlich geht es um praktische Folgerungen, vorzugsweise bei "pankheten", darunter auch um das rechte Auftragen von "gespeyß" und "getranckh" (Bl. 15v).

Wo es eine wissenschaftliche Systematik gibt wie bei den septem artes liberales, tritt sie hinter dem praktischen Interesse zurück. Zwar weiß der Verfasser aus Fürstenspiegeln, daß die sieben freien Künste alle untereinander verkettet sind (Bl. 13r), doch von einer verkettendsystematisierenden Darstellung ist er weit entfernt. Er erwähnt zunächst nur die Grammatik, dann betont er die Brauchbarkeit der sechs übrigen, nicht nur für die Gelehrten ("geschrifft"), sondern für jedermann ("allen gestenden vnd werkhlewten"), denn sie lehren den rechten Umgang mit "reden" und mit der "zal". Das zeigt allein schon, wie Trivium und Quadrivium auf ihren alltagspraktisch relevanten Kern: Schreiben und Rechnen reduziert werden. ${ }^{21}$ Nachdem nochmal Grammatik und Rhetorik erwähnt werden, wird der Rest des Kapitels (etwa die Hälfte) der allgemein "zu Unrecht" ("als geryngest") geachteten Musik gewidmet, denn sie ist bei Hof von praktischer Bedeutung, indem sie dem Fürsten traurige Gedanken vertreibt und ihm im Feld und in der Kirche dient. Auch die Basis des universitären Wissenskanons wird so den Interessen des Hofes eingefügt.

\section{Weiskunig I: Wissen als Wettkampf}

Treitzsaurweins ausgearbeitete Fassung des Weiskunig trägt allein schon durch ihren Umfang im Vergleich zu dieser Vorstufe der Ausdifferenzierung unterschiedlicher Wissensbereiche weit stärker Rechnung. Pragmatisches Interesse und Bemühen um Empirie konkurrieren mit älteren Vorstellungen vom Wissen. Eine seltsam zwiespältige Stellung zwischen Tradition und Neuorientierung nimmt der Text zur Frage der Publizität von Wissen ein. 
Vorgestellt werden in Rubriken die einzelnen Disziplinen, die der junge Fürst nacheinander zu durchlaufen hat. So verschmelzen Erziehungsgeschichte und Erziehungsmodell $\mathrm{zu}$ einem narrativ organisierten Fürstenspiegel, der zugleich ein Panegyricus auf den Fürsten ist. ${ }^{22}$ Die Darstellung der Kindheit ist-zumal in den Holzschnittentypologisch auf die Kindheit Jesu bezogen. ${ }^{23}$ Noch die Überleitung zum Lernprogramm lehnt sich an das bei Lukas entworfene Bild des zwölfjährigen Jesus im Tempel an: "so nam er doch in kurzer zeit an gueten tugend und syten dermassen so ser auf" (S. 221). Damit nehmen die sich hier anschließenden Disziplinen den Platz religiöser Schriftauslegung ein, durch die der zwölfjährige Jesus die jüdischen Schriftgelehrten übertrumpft und durch die er sich als Rabbi und künftiger Messias erweist. Das religiöse Modell wird "umbesetzt": "Wissen" ist das Feld, auf dem sich die mythische Auserwähltheit des Heros erweist. Oder auch umgekehrt: die rationale Qualifikation durch Wissen wird mythisch überhöht.

Nur am Anfang noch wird der religiöse Grund allen Wissens thematisiert: Der junge Weiskunig dringt so tief in theologische Geheimnisse ein, "das er seinen maistern dermassn frag furleget, die sy ime nit kunden verantwurten" (S. 222). Doch wird mit dieser Bemerkung nur eine Folge von Szenen präludiert, in denen er sich als in allem und jedem seinen Lehrern überlegen erweist. Lernung/lerung wird nämlich einem agonalen Prinzip unterworfen. So schreibt der junge Fürst mit anderen Schreibern um die Wette, wobei er sie "mit der peldung uberschrib" (S. 222), und er wetteifert mit ihnen um die schönste Schrift. Kompromißhaft werden (ritterliche) Ehrkonkurrenz und praktisch brauchbare Fertigkeit aufeinander bezogen. Geschwindigkeit und Schönheit sind Vorzüge, die mit dem funktionalen Gebrauch der Schrift nur locker verknüpft sind, jedoch den Heros auszeichnen (Achilleus, Sivrit). So wird das Schreibenlernen zum Äquivalent eines ritterlichen Wettkampfs.

Wissen wird nicht diskursiv entfaltet, sondern szenisch unter Beweis gestellt. So wie sich im Mittelalter die virtus des Herrschers sichtbar, in seiner Repräsentation erweist, im herrscherlichen adventus, im Zeremoniell, der Festkrönung, dem Kirchgang, dem festlichen Mahl usw., d. h. in Situationen gesteigerter Existenz, so wird hier Wissen "repräsentiert", als Auftritt "in-szeniert". Weder der Prozeß des Lernens noch der Habitus des Wissens ist die Hauptsache, sondern das herausgehobene Ereignis, in dem beides zur Erscheinung kommt, unmittelbar im Sieg über Konkurrenten und Gegner oder indirekt, indem der Held sie durch tiefsinnige Sprüche entwaffnet. Erkennbar ist darin das zumal in Herrscherviten der Zeit beliebte Muster der facta et dicta in der Tradition des Valerius-Maximus. 
Die Beliebtheit dieses Musters läßt sich daraus erklären, daß es erlaubt, feudal-ritterliche Formen herrscherlicher Selbstdarstellung und die Ansprüche an den princeps litteratus zur Anschauung zu bringen. Das literarische Darstellungsprinzip wird im Weiskunig durch die Bilder gestützt. Die einzelnen Disziplinen werden grosso modo auf zweierlei Weise verbildlicht: Einmal wird gezeigt, wie der Fürst sie ausübt (das gilt z. B. von den verschiedenen Übungen mit Waffen: Bogenschießen, Stechen usw.). Oder aber es wird der Augenblick gezeigt, in dem seine Überlegenheit zutage tritt, im Gespräch mit dem Gelehrten, den Fachleuten, dem militärischen Führer oder in der Verkündigung von Wahrheit aus der Herrscher- und Prophetenposition heraus (Holzschnitt Nr. 22). Agonales Prinzip und szenische Vergegenwärtigung binden das Wissen zurück an hergebrachte Formen, herrscherliche virtus zur Anschauung zu bringen.

Der junge Weiskunig kann mehreren Sekretären zugleich diktieren. Darin zitiert der Weiskunig ein altes Muster, das zugleich wie bei Grünpeck seine überragende memoria bezeugt. Sie verknüpft ihn mit Julius Caesar ${ }^{24}$, der Maximilian als erster und berühmtester Vorgänger auf dem römischen Kaiserthron gilt. Über Caesar schreibt Petrarca im zweiten Buch seiner Rerum memorandarum libri unter dem Titel memoria: "Epystolas de rebus maximis quaternas dictabat aliis, ipse manu propria quintam scribens; at si calamum eximeres, septenas pariter dictabat" ${ }^{25}$. Dank seiner trainierten memoria kann Caesar komplexe Sachverhalte so zerlegen und neu ordnen, daß er jederzeit fehlerlos von einem Text in den anderen übergehen kann; man memoriert die richtige Ordnung der einzelnen Textelemente unabhängig von ihrer diskursiven Reihenfolge. Andererseits, mit Caesar ist ein heroisches Exemplum aufgerufen, an dem sich der Fürst agonal zu messen hat, freilich auf intellektuellem Feld.

"Nun het der jung weiß kunig die aigenschaft, das er in den riterspilen ainen yeden ubertreffen wolt" (S. 231), "das ime der preiß gegeben wurde" (ebd.), oder wenigstens, "das er in ainem jedem andern gleichmässig sein wolt" (S. 222), heißt es. Ritterlicher Wettstreit um Ehre wird universal. Man kennt diese Übertragung-Wetteifern im Wissen statt Wetteifern im Kampf-schon aus Abaelards Historia calamitatum. ${ }^{26}$ Was aber im 12. Jahrhundert Zeichen des erwachenden Selbstbewußtseins einer neuen intellektuellen Elite war, die sich an die Stelle der feudal-höfischen setzen wollten, vollzieht sich hier unter umgekehrtem Vorzeichen: Das Gelehrten- und Praktikerwissen wird zum Leitbild auch des ritterlichen Heros stilisiert.

Der Gegner im Wettstreit muß dabei nicht eine einzelne Person sein, sondern ist auch schon einmal die im meister repräsentierte gelehrte Tradition insgesamt: Der junge Fürst "wurde in kurzer zeit in densel- 
ben siben freyen kunsten ubertreffenlichen gelert, dann er verstund die weiter, wann die durch die geschrift begriffen sein" (S. 223). Einen Sieg über die Tradition feiert er sogar in der Leitwissenschaft des Bildungssystems, der Theologie: "so ubertraf dannoch sein verstand ... die lerung" (S. 222).

Zwanghaft enden viele Kapitel mit der Beteuerung, daß der junge Fürst alle anderen Könige überbietet. Der Überbietungszwang kann sich verselbständigen, wie das Kapitel über Musik zeigt: Wie schon in der älteren Erziehungsschrift, wo die Musik die Hälfte des Raums für die sieben freien Künste beansprucht, geht es allein um Kirchen- und Kriegsmusik. Beide sind jetzt in Königen personifiziert: in den herrscherlichen Exempeln David (geistliche Musik) und Alexander dem Großen (militärische Musik). Beide schlägt der Weiskunig auf ihrer Domäne: "das dann ainem kunig die zwo höchsten tugend sein" (S. 229). Und weil er gerade dabei ist, überbietet er, dem Text zufolge, auch noch Julius Caesar, der mit Musik nichts zu tun hat, aber in die gleiche Reihe großer Herrscherexempla gehört. Vergleichsmaßstab ist diesmal anstelle der Musik die Zahl der Feinde. Das agonale Prinzip setzt sich gegenüber dem Zusammenhang der Disziplin durch. Ein "erlich gemuet" (S. 221) wird Wissen ebenso entschlossen angreifen wie die Feinde.

Auch der feudale Begriff der arebeit, nicht "Arbeit", sondern "labor", Mühsal, die der Held zu überwinden hat, wird neu interpretiert als intellektuelle Anstrengung: "er laß auch geschrift, die da saget von den vergangen geschichten ... darynnen er mit grosser mue [!] das gehaim wissen fand" (S. 223). Der Wert des Wissens ist gesteigert, indem es das Ergebnis einer heroischen Anstrengung (tolerare labores) ist. Anders als "Arbeit" im bürgerlichen Sinne entspringt diese Anstrengung allein freiem Entschluß, nicht der not, wie unablässig betont wird: Der junge Weiskunig lernt schreiben, "wiewol im nit not was . . darynnen er kainen verdrieß het, sonder es was ime ain kurtzweil" (S. 222). Kurzweil meint spielerisches Kräftemessen. Wissen muß, um ins Bild des Fürsten integriert werden zu können, Wissen des 'Freien' sein, und so werden auch alle Künste, die das Mittelalter von den freien unterschieden hatte, weil sie zur Bewältigung des Daseins notwendig sind, zu "freien" erklärt.

\section{Buch und Geheimnis}

Seine Lehrer übertrifft der Held durch rätselhafte und dunkle, und das heißt nach Meinung des Erzählers tiefsinnige Reden. Das Rätsel ist schon den Sangspruchdichtern des 13. Jahrhunderts die spezifisch 
laikale Alternative zum verborgenen Wissen der meisterpfaffen. Durch Rätselreden partizipiert der Fürst an der Aura gelehrten Wissens. Wissen ist grundsätzlich dunkel und geheim. Es muß daher durch auslegung entschlüsselt werden. ${ }^{27}$ Den Rätselsprüchen ist deshalb oft eine auslegung beigegeben, die entweder der junge Fürst selbst oder der Meister gibt, der in seinen Aussprüchen den verborgenen Wissensschatz erkennt und hebt.

Wissen zeigt sich im scharfsinnigen und daher nicht jedem verständlichen Wort (der scharpf red) und in der Auslegungskompetenz. Auslegung setzt eine vorgängige Wahrheit voraus, die nur gefunden werden muß. Diese Wahrheit ist in Worten (verba), seltener in den Eigenschaften der Dinge (res) verschlüsselt. Auf der Auslegungskompetenz in den heiligen Schriften beruht die Autorität der Kirche und ihrer Diener. Indem er durch auslegung arkaner Rede sein Wissen beweist, adaptiert der Held die Rolle des Priesters und Gelehrten.

Das Paradox besteht nun darin, daß dieses Arcanum ausgestellt wird-durch den Druck publik gemacht werden sollte-, so daß der Leser zwar tatsächlich nichts Geheimes erfährt, wohl aber in der vor ihm sich vollziehenden Entschlüsselung von Rätseln Teilhaber am Arkanwissen des Fürsten wird und diesen als souveränen Besitzer solchen Arkanwissens erfährt. Nicht Wissensinhalte werden publiziert, sondern der Arkancharakter von Wissen insgesamt.

Diese auratische Form von Wissen verdichtet sich im Mittelalter in Zaubererfiguren wie Merlin, Vergil oder Klingsor. Ein Rest der in diesen Gestalten verkörperten ambivalenten Faszination des Wissens zeigt sich in der gefährlichen und verbotenen Schwarzen Kunst. Ihr ist nur der fürstliche Heros selbst gewachsen; ihm ist es vorbehalten, trotz des Verbots sie kennenzulernen und aus eigener Einsicht zu verwerfen ${ }^{28}$; sein Alter ego Theuerdank schlägt in Kapitel 9 selbst den Teufel im Disputieren.

Wissen ist-auch dies ein Rückgriff auf die Tradition-zunächst Wortwissen. Als Wortwissen erscheinen selbst handwerkliche Fertigkeiten. So bekundet der Fürst seine Kompetenz in "gepew von stainwerch" dadurch, daß er dem Meister aufzählt, "wie vil hawptgepew mit dem stainwerch weren", nämlich "das erst zu dem lust, das ander zu der notturft, das drit zu der sterk". Aus der schlichten Aufzählung der Arten und Funktionen von Bauten erkennt angeblich der Fachmann, "das er den grund der pawerey mit dem stainwerch begriffen het" (S. 228). Erst danach ist von der Praxis, vom Errichten solcher Gebäude die Rede, das der Fürst planen (nach seinem angeben) und dank seinen handwerklichen Kenntnissen (nutz!) leiten kann. Wie dies $\mathrm{zu}$ geschehen hat und worin genau jene technische Kompetenz besteht, erfährt man nicht. 
Aus dem im dunklen Wort verkapselten Kern kann eine Disziplin als ganze entwickelt werden. So wird z. B. das "gehaim wissen und erfarung der welt" (S. 223) - eine theologisch fundierte Regierungskunst, wie man vielleicht vereinfachend sagen kann-auf eine Anzahl von Punkten gebracht, in denen alles Wißbare beschlossen ist. ${ }^{29}$ Die letztlich noch magische Auffassung vom Wort als Gefäß von Wissen schließt ein, daß dem Wort prophetische Bedeutung zugeschrieben wird. Es kann "kunftig werk" anzeigen (S. 222: Erfolge des Heerführers). Dem Einsichtigen offenbart auch die richtig gedeutete res "ain verporgne weishait": Den Falken, der den Reiher schlägt, erkennt der Fürst als Bild seiner eigenen Aufgabe, die Feinde zu überwinden (S. 233).

Buchwissen hat sogar schriftlose Tradition zu legitimieren, so etwa ritterliche Übungen und Divertissements. ${ }^{30}$ Ein Buch nämlich mahntgleich zweimal-den Fürsten: "du kunig nym war der valken und der hirschen und ergötz dich in den gejaitn [Jagd], das dir zugeben ist, das du nit einfallest in die sundlichen und weltlichen laster" (S. 232-33). Was althergebrachtes Vergnügen scheint, verdankt sich buchgeleiteter Einsicht. Dafür daß die Falkenbeize "ain offner lust und ain verporgne weishait" ist, spricht nach Auskunft dieses Buches dreierlei: Sie ist ein körperliches exercitium, ein Bild fürstlichen Handelns (im Falken, der den Reiher schlägt), und es fördert die Regierungspraxis. ${ }^{31}$ Höfisches Vergnügen und Nutzen werden durch ein allegorisches Wissen überwölbt, das sich auf die Autorität des Buches beruft.

\section{Praktisches Erfahrungswissen}

Doch ist solche Rückbindung an mittelalterliches Traditionswissen nur die eine Seite, Interesse an Empirie und an praktisch verwertbaren Kenntnissen kommt hinzu. Schon der Katalog der zu erlernenden Disziplinen sprengt den Rahmen älterer Fürstenspiegel. Alles Wißbare scheint gleich wichtig. Als Grundlage allen akademischen Wissens lernt der Held die (lateinische) Grammatik und die übrigen freien Künste, dann das "gehaim wissen und erfarung der welt", das auf gelehrte Fürstenspiegel verweist, dann Medizin, allesamt qualifizierbar als theoretische Disziplinen. Hinzutreten Training des jungen Adligen in ritterlichen Vergnügen (Turnier, Jagd), in verschiedenen Kampfarten, in militärischen Zweckbauten ("nutz der gepew mit zimerwerch") oder in Strategie (im Kapitel über das "malen", s. u.), in vorbildlicher Hofhaltung (Essen und Trinken, Maskenfeste und Bankette, Turniere, Bauten), schließlich in der Regierung (Kanzlei, Münzwesen, Bergbau, Fremdsprachen). ${ }^{32}$ Einzelne Disziplinen wie Astrologie, Musik, Gram- 
matik oder secretari-Kunst erscheinen zweimal, einmal innerhalb der Wissenssystematik und dann noch einmal selbständig unter dem Aspekt ihrer praktischen Bedeutung für das Regieren.

Das Wortwissen der Gelehrten dominiert also nicht. Wichtiger als die lernung (wohl zu übersetzen: als die Einführung in die traditionelle Schriftkultur) ist der verstand (z. B. S. 226), der die Überlegenheit des Fürsten über die Schulgelehrsamkeit begründet; er "bedacht . . . selbs" (S. 229), heißt es immer wieder. Mit verstand ist ein anderer Typus von Wissen aufgerufen. Er beruht nicht auf Autorität, sondern auf Beobachtung: "das wissen ist mer dann der unerkundigt rat" (S. 229). Neben den Begriff der lernung treten daher Begriffe wie erfarung, erfragung, erkundigen u. ä., insgesamt gerichtet auf den Erwerb von praktischen Fertigkeiten: "In sölicher erfragung lernet er aus ime selbs den grunt des schin der perkwerch ... Der jung weiß kunig het die erfarung und wissenhait, die andern kunig verporgen ist" (S. 231). Die eigene Erfahrung befähigt ihn zu "anzaigen und underweisung" für andere (S. 231) oder erlaubt ihm sogar, selbst etwas zu erfinden, "newfindig" zu sein (S. 229).

Selbst die Erziehung zum christlichen Glauben, hat sich vor einem praktischen Zweck auszuweisen: Nicht nur gilt christliche Nächstenliebe als Regententugend ("dann welher in seiner regirung unrechtlich streit und ungleich gericht fueret, das ist ain verlierung der zeitlichn und ewigen eer"), sondern die religiöse Unterweisung hat nebenher das Erlernen von Latein zu fördern ("ine die latein und darynnen am allerersten die zucht und forcht gotes und darnach die heilig geschrift ... zu lernen und underweisen", S. 221).

Zweifach lesbar ist das Astrologiekapitel. Schon dadurch daß sie durch ein eigenes Kapitel ausgezeichnet wird, wird sie aus dem ursprünglichen akademischen Zusammenhang der sieben freien Künste herausgelöst und zur Handlungswissenschaft deklariert. ${ }^{33}$ Als solche hat sie zwei Ziele. Das erste ist Weisheit (der Weiskunig habe immer in Übereinstimmung mit kosmischen Gesetzen gehandelt, heißt es: "nach zugebung und erleidung der zeit. ... Ich nenn und haiß den jungen weisen kunig in seiner handlung nit ein mensch, sonder ich haiß ine die zeit $^{34}$, aus ursach: er hat gehandlt, das der menschen gemuet ubertrifft und sich der zeit geleicht etc.", S. 224). Das zweite Ziel ist kluges InBetracht-Ziehen aller Umstände. Die Astrologie soll Grundlagen zur Planung künftigen Handelns liefern. Wenn im 15. und 16. Jahrhundert ihre Zuverlässigkeit immer wieder bestritten wird, dann ändert das nichts daran, daß ein Bedarf an prognostischer Kompetenz und an einer Orientierung der Politik an rational anzustrebenden Zielen besteht. Das Erlernen der Sternkunst bedeutet aus dieser Perspektive, 
daß der Fürst sich um die langfristigen, planerischen Grundlagen seiner Politik kümmert. (Daß der Hazardeur Maximilian tatsächlich solchen Anforderungen nicht gerecht wurde, sagt über die Intention überhaupt nichts.)

Theoretisches Wissen wird von praktischen Orientierungsbedürfnissen überformt. Streicht man etwa bei der Medizin die Rätselsprüche weg, mit denen die tiefe Erkenntnis ihres grundes angezeigt werden soll, durchstößt man also die Aura des gelehrten Arkanwissens, dann bleiben zwei praktische Interessen übrig: Selbstmedikation und Schutz vor Giftanschlägen. Latein-die Wissenschaftssprache schlechthintritt, wie bemerkt, als Nebenergebnis religiöser Unterweisung an den Rand, doch eigener Kapitel wert sind die für die Regierung nützlichen verschiedenen Landessprachen der Territorien. Die "schön red", wie die Rhetorik genannt wird (S. 227), erscheint in ihrer regierungspraktischen Funktion: als Teil des "secretari ambt".

Gerade an Disziplinen, die man heutzutage den schönen Künsten zurechnet, kann man den Praxisbezug von lernung sehen. Malen lernt der Fürst, um geographische Zeichnungen ("die landschaften des ertrichs") anfertigen zu können, eine Fertigkeit, die dem militärischen Anführer zustatten komme: "das ain yedlicher grosser herr und heerfuerer malen solle kundn" (S. 228). Erst an zweiter Stelle ist von der Förderung der Künste die Rede, auch sie überdies bezogen auf einen praktischen Zweck, nämlich die legitimierende Darstellung von Herrschaft für Mit-und Nachwelt: "Er hat auch die grossen kinstler der malerey und schnitzerey underhalten und vil kunstliche werch malen und sneiden lassen, die in der welt in seiner gedächtnus aber mit verkerten namen beleiben werden" (ebd.). ${ }^{35}$

Weder im Gesamtprogramm noch in den einzelnen Kapitel sind Funktionsbereiche von Wissen sauber getrennt: Weisheit steht neben Maximen der Lebensklugheit, Handwerkliches neben abstrakt Theoretischem, Repräsentation neben Regierungstätigkeit. Doch lassen sich zwei Zentren ausmachen, die Ehre des Herrschers, der alle durch seine intellektuellen und körperlichen Fähigkeiten übertrifft, und seine Aufgaben als Heerführer und Landesherr. Beide Ziele können in Spannung zueinander treten. Das eine wird durch glanzvolle Verausgabung von Kräften erreicht, das andere durch ökonomischen Umgang mit ihnen.

\section{Sparen von Zeit und Geld}

Die lernung steht unter dem Gebot einer sinnvollen Nutzung der Zeit: "und damit er in seiner jugent kain zeit umbsonst versawmbet, da 
bevalch der alt weiß kunig den maistern seinen sun, die siben freyen kunst zu lernen" (S. 222). Das feudale Prinzip einer achtlosen Vergeudung von Ressourcen hat ihrer überlegten Einteilung Platz gemacht. Man hat nicht unbegrenzt Zeit. Die eine Beschäftigung steht der anderen im Weg ${ }^{36}$ : "Und in der zeit seiner regirung hat er in dem schreiben kain verdrieß gehabt; er hat auch mit seiner hand sovil geschriben, wann ich ungeverlich die anzal seines schreibens hierin anzaigen solle, so wurde mir nit wol glauben geben, aus ursach der grossen krieg halben, die er daneben stätiglichen in seiner regirung gefuert hat" (S. 222).

Hier kommt ein weiteres praktisches Moment zum Vorschein, das mit dem spielerischen Messen der Kräfte auf einem Gebiet, wo sich gewöhnliche Menschen aus not abplagen müssen, nichts mehr zu tun hat: Es gilt, ein beschränktes Zeitbudget ökonomisch einzusetzen. Dabei geht es um das Prinzip einer angemessenen Relation von Aufwand und Ergebnis: "Seine maister bewegten auch, das nit guet oder nutzlichen were, ine mit diser lerung [d. h. den sieben freien Künsten] weiter zu beladn; dann wann man ainen menschen mer lernen wil, dann not thuet, das ist ain uberfluß und ain verhinderung anderer werk" (S. 223). Nicht allein, daß er die sieben freien Künste lernt, ist hervorhebenswert, sondern daß er sie "in kurzer zeit lernet" (S. 222), der Aufwand also nicht zu hoch ist. Sogar die religiöse Erziehung wird nicht weiter ausgedehnt als nötig: Als der Vater merkt, daß der Sohn seinen Lehrern in Kenntnis der Bibel voraus ist, "nam er ine von derselben lernung, aus ursach das er in der heiligen geschrift genugsamlich gelert was und andere sachen fur sich name, damit er in ainem uberfluß der lerung die zeit nit versawmet" (S. 222). Zwar steht die Erziehung zu Gottesfurcht und Nächstenliebe herausgehoben an der Spitze des Erziehungsprogramms ${ }^{37}$, andererseits hat der "Religionsunterricht", so könnte man modernisierend sagen, in der Stundentafel nur einen Platz unter anderen, er muß "genugsamlichen" Kenntnisse vermitteln, nicht mehr. ${ }^{38}$

Dieses Kalkül betrifft außer der Zeit auch das Geld: Daß der Fürst "kainen kosten" bei der Selbstdarstellung für die Nachwelt spart, muß er gegen den Vorwurf der Verschwendung rechtfertigen: "das gelt, das er auf die sachen der gedächtnuss leget, were verloren" (S. 225). Das geschieht, indem er Verhältnis von Nutzen und Aufwand abschätzt: Ohne den Aufwand für die gedechtnus gehe der Mensch mit seinem Tod dahin; "darumb so wird das gelt, so ich auf die gedechtnus ausgib, nit verloren, aber das gelt, das erspart wird in meiner gedachtnus, das ist ain undertruckung meiner kunftigen gedächtnus" (S. 226). Verausgabung zum Zweck der Ehre und des Nachruhms kalkuliert man 
eigentlich nicht: je toller der Aufwand, desto besser. ${ }^{39}$ Das ist hier anders. Zwar trägt letztlich die Ehre den Sieg davon, doch im Rechenschaftsbericht für eine kritische Mitwelt muß sie sich am Kriterium angemessener Investition messen lassen.

Wieder kreuzen sich Bemühen um eine rationale Herrschaft und Bemühen um deren glanzvolle Zurschaustellung. Die Spannung zwischen diesen beiden Motiven bestimmt die meisten Kapitel. Die Beherrschung der munz z. B. (kunst und erfarung) äußert sich zum einen in einem geordneten Münzwesen, das Münzentwertung (pöse munz) und Abhängigkeit von fremder Geldpolitik (frembde munz) zur Mehrung des camerguet bekämpft; zum anderen aber auch im Schlagen von Schaumünzen (grosse munz), die das erlich gemuet (den auf Ehre gerichteten Sinn) unter Beweis stellt (S. 230). ${ }^{40}$

Sogar die miltigkait, die Freigebigkeit in alter feudaler Tradition, unterliegt dieser doppelten Zweckbestimmung. Man könnte fragen, was sie in diesem Katalog praktischer Fertigkeiten überhaupt zu suchen habe. Offenbar ist sie als eine zentrale Fürstentugend aus älteren Fürstenspiegeln unverzichtbar. Doch gilt sie, wie alles andere auch, als erlernbare Tugend. Der junge Weiskunig ist idealer Herrscher im Sinne des hohen Mittelalters, wenn er nach kuniglichn eren alles gelt, das er vom Vater erhält, under die grafen, herrn, ritter und knecht verteilt. Allerdings, schon daß miltigkait sich in gelt ausdrückt, zeigt die Entfernung vom alten feudalen Versorgungssystem. Auffälliger noch: Wo die mittelalterlichen Lobredner der Großen nie genug bekommen von der Freigebigkeit des Herrschers, da warnt der alte König vor übermäßiger Vergeudung. Der Sohn antwortet zwar, wie dies der ideale mittelalterliche Herrscher tun sollte: "ich wird nit werden ain kunig des gelts, sonder ich wil werden ein kunig des volks und aller der, die gelt haben" (S. 227), und er weist das Horten eines Schatzes zurück ("die schätz, so ander kunig und fursten gehabt haben, sein durch den weisen kunig aufgethan und zerstört worden"). Doch versucht er, die milte auch rational zu begründen. Freigebigkeit nämlich bringt militärischen Nutzen: "alles das gelt, das er aufzuheben hat gehabt, hat er miltiglichen under sein kriegsfolk fur und fur getailt" (S. 227) und es dadurch zum Kampf motiviert; milte "rechnet sich."

Gleichzeitig ist sie eine der "Disziplinen", in denen der Held seinen Konkurrenten, den König von Frankreich übertrifft. ${ }^{41}$ Beweismittel ist überraschenderweise wieder durch ein Buch, ein Buch über die milte, die schriftliche Rechenschaft über das, was sich der Kalkulation von Nutzen und Erfolg entzieht. Treitzsaurwein nämlich verweist auf ein solches Buch, außerhalb des Weiskunig, das er selbst verfaßt habe: "Ich als ainer, der das puech geschriben hat, gib von seiner miltigkait 
gezewgnus, davon ich ain aigen puechl geschriben hab, dann es hat sich nit gepurt in diz puech zu schreiben" (S. 228). Ein seltsamer Gedanke: eine genaue Rechnungslegung nicht über die Einnahmen und Ausgaben, wie dies bei solidem Finanzgebaren des Herrschers notwendig wäre, sondern ausgerechnet über das, was nicht rechnet, wenn es sich verausgabt: die miltigkait.

Die Ehre hat in Maximilians Gedechtnus-Werk das letzte Wort, und als monströse Repräsentation seines Herrschaftsanspruchs ist es in die Kunstgeschichte eingegangen. Doch mißt sich diese Ehre an einer Welt, die primär schon den Nutzen kalkuliert. Repräsentation und kalkulierte Praxis sind unauflöslich ineinander verschränkt. Die entgegengesetzten Tendenzen werden noch einmal miteinander vermittelt, wenn auch nur in einem hybriden Erziehungsprogramm für den Fürsten. Vermittelt werden aber auch unterschiedliche Typen von Wissen, pragmatisches und auratisches, buchgestütztes und durch Erfahrung erworbenes, eine mythische Weisheit und ein ausdifferenzierter Bestand an Kenntnissen, allgemein zugängliches und geheimes. In Maximilians Erziehungsgeschichte bilden sich die Transformationen frühneuzeitlichen Wissens ab, obwohl sie der Legitimation eines rückwärtsgewandten Programmes gilt. Dieses trägt in den verschiedenen Fassungen der zunehmenden Ausdifferenzierung von Wissen Rechnung. Wissen wird öffentlich ausgestellt, doch nicht um seiner selbst willen, als allgemein zugängliches Mittel der Bewältigung von Welt, sondern als Schauwert fürstlicher Ehre.

\section{Anmerkungen}

1. Den folgenden Ausführungen liegen Vorträge in Göttingen zugrunde. Ich verzichte im folgenden aus Raumgründen auf ausführlichere Nachweise. Einige Fallstudien und weiterführende Literatur bei Jan-Dirk Müller, Hg., Wissen für den Hof: Der spätmittelalterliche Verschriftungsprozeß am Beispiel Heidelberg im 15. Jahrhundert (München: Fink, 1994).

2. Vgl. meine älteren Überlegungen: Jan-Dirk Müller, “Curiositas und erfarung der Welt im frühen deutschen Prosaroman", in Literatur und Laienbildung im Spätmittelalter und in der Reformationszeit: Symposion Wolfenbüttel 1981, hg. v. Ludger Grenzmann u. Karl Stackmann (Stuttgart: Metzler, 1984), S. 25271, hier S. 258-61.

3. Vgl. Michael Giesecke, Der Buchdruck in der frühen Neuzeit: Eine historische Fallstudie über die Durchsetzung neuer Informations- und Kommunikationstechnologien (Frankfurt a. M.: Suhrkamp, 1991).

4. Vor allem ist die traditionelle Auffassung zu korrigieren, daß dem eher 
traditionellen Bildungswissen des Humanismus die praktisch-empirisch orientierte frühneuzeitliche Wissenschaft entgegenzusetzen sei, ist sie doch Teil humanistischer Bildungsprogramme; vgl. August Buck, "Der Wissenschaftsbegriff des Renaissance-Humanismus", in Studia humanitatis. Gesammelte Aufsätze 1973-80, hg. v. Bodo Guthmüller (Wiesbaden: Athenaion, 1981), S. 193206. Maximilians Erziehungsprogramm nimmt insofern unterschiedliche Tendenzen in der zeitgenössischen Transformation des Wissens auf.

5. Maximilian I., Der Weiskunig, hg. v. Theodor Musper, 2 Bde. (Stuttgart: Kohlhammer, 1956).

6. Maximilian I., Theuerdank: Faksimile, hg. v. Theodor Musper u. a. (Plochingen-Stuttgart: Müller \& Schindler, 1968); vgl. Jan-Dirk Müller, Gedechtnus: Literatur und Hofgesellschaft um Maximilian I. (München: Fink, 1982).

7. Maximilian I., "Fragmente einer lateinischen Autobiographie", hg. v. Alwin Schulz, Jahrbücher der Kunsthistorischen Sammlungen des Allerhöchsten Kaiserhauses 6 (1888), S. 421-46.

8. Copj des Ersten Tayll vnd anfang dis puech des weyssen kung (Cod. Vind. 2892).

9. Joseph Grünpeck, "Historia Friderici IV. et Maximiliani I.", Der österreichische Geschichtsforscher 1 (1838): 64-97.

10. Diese Redaktion liegt allen Weiskunig-Drucken zugrunde. Die späteren fragmentarisch gebliebenen Bearbeitungsversuche beziehen sich nicht auf das Erziehungsprogramm, das entsprechend in den Codices nach 1512 fehlt.

11. Mary Carruthers, The Book of Memory: A Study of Memory in Medieval Culture (Cambridge: Cambridge University Press, 1990).

12. Er wird nicht princeps, sondern rei publicae amator (Freund des Gemeinwesens) genannt: ebenfalls ein Tribut an eine antifeudale, antik inspirierte Herrschaftslehre.

13. Der Name wird von weise abgeleitet: Der Vater wurde weit und breit "für den weisesten gescheczt", weshalb er "der alt weyss koning" heißt (Bl. 3r); ähnlich Bl. 4r. Später wird "weys" als Turnierfarbe gedeutet (so durchgängig im Weiskunig).

14. Sie richtet sich an den offenbar noch recht jungen Prinzen Karl (V.) und knüpft an wohlbekannte Fürstenspiegeltopoi an (Bl. 1r): "dem nach vnd ain yeder mensch betrachten soll was geschicks wesens vnd natur er sey." Es folgt-in aristotelischer Tradition-das Argument, daß der Mensch von Natur ein Gesellschaftswesen sei und daher zum Dienst an den anderen Menschen verpflichtet, dann die causa scribendi: zur Erziehung des jungen Fürsten beizutragen, da am Fürsten sich die anderen Menschen ausrichteten.

15. Nachdem zuvor in heroischer Tradition von wunderbaren Zeichen erzählt wurde, die Geburt und Kindheit des jungen Fürsten begleiteten (Bl. $11 \mathrm{r} / \mathrm{v}$ ), von der wunderbaren Namengebung (Bl. 11v) und von der Gottesfurcht, die der alte König als grundlegende Tugend eines jeden Fürsten ansieht, der sich seines Glücks nicht überheben darf (Bl. 12r/v).

16. Dieser Absatz ist ausdrücklich von einem späteren Platz, an dem er gestrichen wurde (Bl. 13r), nach vorne gezogen worden (Bl. 12v), was den Plan einer chronologischen Anlage beweist. 
17. Humanistischer Pädagogik nahe stehen die Ausführungen zu einer Erziehung ohne Zwang.

18. Vgl. dagegen das Kapitel "gehaim wissen vnd erfarung der welt" im Weiskunig.

19. Dies ist ein gängiges Argument der Fürstenerziehung; vgl. den Brief des Enea Silvio Piccolomini an Sigismund von Tirol vom 5. Dezember 1443 in Enea Silvio Piccolomini, Briefe, übers. v. Max Mell (Jena: E. Diederichs, 1911), S. $88-89$.

20. "Damit ob auß vnfal vnd glückes widerwertigkeyt sich begäbe . . . das ainer oder aine auß den von seinem Reich oder fürstentümb weichen müst oder vertriben / das er oder sye jr lebenlang die narưng in der armùt künnde gewinnen" (Bl. 14v).

21. Diese Tendenz setzt sich fort: Die loyca (Dialektik) dient zur Unterscheidung zwischen wahr und falsch und gut und böse (!).

22. Die Darstellung ist abhängig von Fürstenspiegeln. Nur ist didaktische Rede narrativ organisiert, d. h. an das Personal der Geschichte gebunden. So ist es der junge Weiskunig, der die Verbindung der sieben freien Künste untereinander erkennt, oder es ist die Rede seines Vaters, die an einen Eingangstopos von Fürstenspiegeln anklingt: "Wiewol ain jeder kunig ist wie ain ander mensch, so muessen doch die kunig, die selbs regieren, mer wissen dann die fursten und das volk, damit das ir regierung by inen beleib" (S. 223). In einer bayerischen Fürstenspiegelkompilation heißt es z. B.: "Wie woll all menschen erstlich entsprungen aus einer würczel Adam, davon sy geleich edel und pawren benennet sind" (Gerd Brinkhus, Eine bayerische Fürstenspiegelkompilation des 15. Jahrhunderts [München: Artemis, 1978], S. 81).

23. Sakrale Muster vor allem in den Holzschnitten 16 und 18; typologische Residuen werde ich-in Auseinandersetzung mit burgundischer Hofhistoriographie-in einem künftigen Beitrag untersuchen.

24. Carruthers, The Book of Memory, S. 7.

25. Franceso Petrarca, Rerum memorandarum libri. Edizione critica per cura di Giuseppe Billanovich (Florenz: Sansoni, 1945), S. 43-44. Die Fortsetzung des Passus hat eine gewisse Verwandtschaft mit dem Schnelligkeitsrekord: "Que quidem velocitas ne ac volubilitas promptissimi ingenii an amplissime firmitas memorie potius dici mereatur, incertus sum; siquidem celeritas ingenii, tenacitas memorie laus est." Vgl. Plinius, Naturalis historiae. Libri VII (Leipzig: Teuben, 1909), 25.91.

26. Abaelard, Die Leidensgeschichte und der Briefwechsel mit Heloisa, übertr. u. hg. v. Eberhard Brost, mit einem Nachwort von Walter Berschin (Darmstadt: Wissenschaftliche Buchgesellschaft, 1984), S. 9.

27. Dies leitet sich aus der Übertragung der Struktur akademischer Lehre auf laikalen Unterricht ab, der als Auslegung (Glossierung) von Basistexten organisiert ist; vgl. Jan-Dirk Müller, “Bild-Vers-Prosakommentar am Beispiel von Fechtbüchern: Probleme der Verschriftlichung einer schriftlosen Praxis", in Pragmatische Schriftlichkeit im Mittelalter: Erscheinungsformen und Entwicklungsstufen, hg. v. Hagen Keller, Klaus Grubmüller u. Nikolaus Staubach (München: Fink, 1992), S. 251-82, hier S. 256-57. 
28. Dargestellt ist die Entscheidungssituation zwischen den Vertretern himmlischer und höllischer Lehre und den "zwei Büchern" eines gottgefälligen und eines teuflischen Wissens auf Holzschnitt Nr. 25.

29. Nämlich: "der erst, von der almechtigkait gots; der ander, von dem einfluss der planeten; der drit, von der vernunft des menschn; der viert, von der zu vil senftmuetigkait in der regirung; der funft artikl, zu streng in dem gewalt" (S. 223). Ähnlich die Spruchweisheiten zur Notwendigkeit von Wissen für den Herrscher (ebd.), zum Verhältnis von Herrscher und Regierungsapparat (S. 224), zu den Grundlagen der Gesundheit (S. 226).

30. Das ist im volkssprachlichen Text weit auffälliger als in der lateinischen Maximilian-Panegyrik, also etwa in Johannes Cuspinians "Caesares", wo die exorbitante Jagdlust, die Turnierleidenschaft und andere "ritterliche" Disziplinen gegenüber der gelehrten Welt zu verteidigen sind (vgl. Müller, Gedechtnus, S. 229).

31. Während der Jagd ist der König jedermann zugänglich; sonst würde, bedeutet der Weiskunig seinem Kritiker an anderer Stelle, dieser "gar selten mit mir redn und ain anderer, der jetzt mynder ist dann du, dem wurdest du mit grosser begerung nachlaufen" (S. 233). Dieser Aspekt wird hier nicht genannt, er findet sich jedoch auch in Grünpecks "Historia" ("De eius affabilitate", S. 93-94).

32. Nahezu nebenher enthält der Weiskunig eine Anzahl von Hinweisen auf konkrete Regierungsmaßnahmen, z. B. das Hegen vom Aussterben bedrohter Jagdtiere.

33. Dies geschieht freilich auch im universitären Rahmen; vgl. die gelehrten Abhandlungen, auf die sich die Prognostiken des kurpfälzischen Hofkaplans Mathias von Kemnat stützen (München: Bayrische Staatsbibliothek, Clm 1817).

34. Diese Aussage harrt noch der Deutung: Wird Maximilian zum KronosSaturn stilisiert, und stehen dahinter humanistische Vorstellungen von der Genialität des Melancholikers, wie sie in Dürers berühmtem Stich "Melencolia I" Bild werden?

35. Gemeint ist die Verschlüsselung der Namen in Theuerdank und Weiskunig.

36. Ähnlich fragt der Erzähler an späterer Stelle noch einmal, wie die knappe Zeit die vielen Aktivitäten überhaupt zuließ, etwa beim Schreiben von Briefen: "die ganz regirung aller seiner kunigreich und land ist allain von ime beschehen, neben allen den grossen kriegen, die er in $\mathrm{f}<\mathrm{r}>\mathrm{embe}$ nacion und land gefuert hat" (S. 227).

37. So schon Cod. Vind. 2892, wo durchweg noch jenes kalkulatorische Moment gegenüber Zeit und Geld fehlt.

38. Dies gilt für lernung überhaupt: Der Doktor der Heilkunst zeigt dem alten König an, "was sein sun in der erzney weiter lernet, das were ain uberfluß" (S. 226), und damit wird der Unterricht beendet.

39. Zu erinnern ist z. B. an das Prunkschiff im "Moritz von Craûn" und die Tollheit, mit der der Protagonist um seine Dame wirbt; die Dichtung ließ Maximilian im Ambraser Heldenbuch aufzeichnen.

40. Ähnlich die Bewertung ökonomischer Ressourcen: Die Bergwerke pro- 


\section{Jan-Dirk Müller}

duzieren zwar Edelmetalle, werfen aber dank guter Ordnung vor allem jedes Jahr eine genau bezifferte Summe für die fürstliche Kammer aus (S. 231), und zwar nicht nur durch Edelmetalle, so daß also die Stoffe auch die in höfischer Repräsentation Verwendung finden, durch nichts ausgezeichnet sind.

41. Allerdings steht diese Behauptung in auffälligem Kontrast zu den langen, erfolglosen Kriegen gegen den König von Frankreich, der mit seinen Ressourcen planvoller umgeht. Von ihm heißt es: Er "ubernam sich seins gelts" (er hat nämlich mehr davon) und "grif seinen schatz an" und bringt ein mächtiges Heer zusammen, um sich am Weiskunig zu rächen. So könnte dieser den Wettstreit um den rationaleren Einsatz ökonomischer Mittel verlieren. Und sogleich kehrt die Argumentation vom rationalen Kalkül zur Konkurrenz um Ehre: Statt vom Geld ist von der unbezahlbaren Tapferkeit der "allerstreiperisten Teutshen" die Rede. Mit wenig Geld und wenig Truppen habe der Weiskunig mehr ausgerichtet, weil er jede kleine Summe ("hundert guldin") sofort unter ihnen verteilt habe; diese Tapferkeit und unbedingte Ergebenheit "das ist sein schatz" (S. 227). Zwischen der rationalen Einsicht, daß Kriegsführung Geld braucht, und dem Appell an nicht weiter zu berechnende Tugenden schwankt der Text hin und her, immer das Ziel im Visier, auf die eine oder die andere Weise die ruhmvolle überlegenheit des Helden darzutun. 


\title{
4. Before Winckelmann: Toward the Origins of the Historiography of Art
}

\author{
Thomas DaCosta Kaufmann
}

Johann Joachim Winckelmann's claim that he founded a completely new kind of art history has been described as one of the foundational myths characteristic of the Enlightenment; despite the recent attention he has received, little has been done to dispel this myth. ${ }^{1}$ This chapter, a summary of the author's recent research, attempts to point the way to a newer understanding of the origins of the historiography of art before Winckelmann. A search for these origins can be fruitfully pursued in the vastly underexamined German world of scholarship of the late seventeenth century and early eighteenth century, a period following the appearance of the first substantial collection of lives of the artists in German, Joachim von Sandrart's Teutsche Akademie of $1675 .{ }^{2}$ A starting point for this research was the observation that formal critical and historical discussion of the visual arts similar to that found elsewhere in Europe came comparatively late to the German-speaking world. Yet within the space of less than fifty years there appeared the origins of philosophical aesthetics signaled by Alexander Gottlieb Baumgarten, of the historiography of architecture with Johann Bernhard Fischer von Erlach, and of the history of art with Winckelmann. A substantial field of art criticism, represented by such authors as Moses Mendelssohn and G. E. Lessing also developed at this time. ${ }^{3}$

Although much less familiar than comparable literature from other parts of the continent, in Central Europe writings treating the visual arts poured forth in profusion in the late seventeenth and especially in the early eighteenth century. As exemplified by Sandrart, the abundance of literature on the arts can be regarded as part of a conscious effort to reconstruct culture and society after the devastation of the Thirty Years' War. Sandrart's work further exemplifies that the production of a German literature on the arts resulted from the assimilation of European models, French, Italian, Dutch. This is a pattern familiar from accounts of other fields of cultural endeavor. In addition to collections of lives of artists in the manner of Vasari or Karel von Mander's Schilder-boeck, there appeared in Germany lives of the architects in 
the tradition of J. F. Félibien, whose work in translation J. J. Marperger continued and applied to Central Europe. ${ }^{4}$ There also appeared art theory, represented soon after Sandrart's basic text by translations of Henri Testelin and Roger De Piles, produced in the same circle of the Nuremberg academy to which Sandrart belonged, and of Charles du Fresnoy by Samuel Theodore Gerike for the Berlin academy. ${ }^{5}$ Art instructional literature was also produced in the ambit of the Nuremberg and Augsburg academies by artists and architects such as members of the Preissler family and J. G. Bergmüller. ${ }^{6}$ Finally, as in France during the course of the early eighteenth century, German-language journals commenting on the visual arts began to appear. ${ }^{7}$

The standard handbook on Kunstliteratur by Julius von Schlosser comments little on this literature; rather, it sends the reader to K. K. Eberlein's somewhat misnamed if not misleading dissertation of 1916, "Die deutsche Litterärgeschichte der Kunst im 18. Jahrhundert." Eberlein's was the last full treatment of the subject. ${ }^{8}$ Eberlein did cite numerous sources on the arts, among them genres in which some discussion of its history appeared. These included what Eberlein described as the traditions of the polyhistor, museography, travel accounts, encyclopedias, and "academies." These are handbooks for noblemen, such as the Geoffnete Ritterplatz and its related volumes. These traditions all deserve more attention because of their importance for historiography, and because they are not as clearly distinguished from each other as Eberlein suggested; as he also correctly noted, these interests may have paved the way for the appearance of professional art history and art criticism in the late eighteenth century.

But, although there was much discussion about the visual arts in Germany before Winckelmann, how could a change in conception specifically of the historiography of art have occurred? The transformation of the conceptualization of the history of art involved a newer understanding of history and of art. A good deal has been learned about these subjects in the past eight decades. Several subjects not studied by Eberlein or really elucidated in relation to the history of art by many other scholars have proved especially fruitful for investigation. Pursuits that will lead closer to the origins of a new conceptualization of the history of art involve an investigation of universal history, including philosophical and literary history as they were understood (and not as these terms have been misappropriated) by Eberlein and others; the nature of antiquarian and historical scholarship before Winckelmann, particularly at several German universities and gymnasia; and finally the development of writing on what can be identified as a history of arts and especially of visual art before Winckelmann. 


\section{Universal History and the Historiography of Art}

In his critique of predecessors who used the term history of art without an understanding of art, Winckelmann acknowledged that works dealing with the topic, however unsatisfactorily in his eyes, did exist. Winckelmann cited a book by Pierre Monier published in 1698, Histoire des arts, leurs origines, chutes et leur rétablissement. ${ }^{9}$ This book traces the history of the translatio artium from the Garden of Eden to the Garden of Versailles. Taking his story up to the time of the rule of Louis XIV, Monier applies a universal historical scheme to the visual arts. This procedure remained in use for histories of culture until at least $\mathrm{M}$. F. Dandré Bardon's universal history related to the arts of design of $1765 .{ }^{10}$

It is also known that Winckelmann was not the first to employ the term "history of art" (or art history, Geschichte der Kunst or Kunstgeschichte) even in the German language. The term Geschichte der Kunst was, as Eberlein also noted, used as the title of a periodical (Geschichte der Natur und der Kunst) that began publication in Breslau (Wroclaw) in 1717 and continued there for several years. ${ }^{11}$ What has not been noticed was that this periodical was largely devoted to natural history and, more important, that its editor, Johann Kanold, was the same person who had previously edited a book entitled Historiographia: this is the pseudonymous C. F. Neickel's discussion of Kunst- und Wunderkammern..$^{12}$ The periodical Geschichte der Natur und der Kunst is also called a Sammlung von Natur und Medizin; and this very title recalls the world of collections of which the so-called Kunst- und Wunderkammer is the most notorious contemporaneous example. The periodical's mixture of essays not only devotes attention to the visual arts and to collections, including painting and porcelain production, and to an account of the installation of the Kunst- und Naturalien-Cabinett in Dresden, but does indeed not appear unlike the Kunst- und Wunderkammern familiar to its authors. ${ }^{13}$ One of the authors who contributed to the Geschichte der Natur und der Kunst, Johann Christian Kundtmann, wrote two descriptions of collections in Breslau (Wroclaw) in which he mentioned his contributions to the periodical. ${ }^{14}$

Discussions of the Kunstkammer in the late seventeenth and eighteenth century are universal in describing collections throughout the world and tracing the history of collecting. ${ }^{15}$ Histories of Kunstkammern could also be the subject of university dissertations. ${ }^{16}$ Similarly, a later periodical, Neue Versuche nutzlichen Sammlungen zu der Natur- und Kunstgeschichte, contains accounts of artistic inventions, archival studies of important artists such as the architect Giovanni Maria Nosseni, and accounts of "Gothic" altarpieces, for example the one attributed to 


\section{Thomas DaCosta Kaufmann}

Master HW (Hans Witten?) in Ehrenfriedersdorf. ${ }^{17}$ Later works employing the title "history of arts" also treat the history of the visual arts as a part of a history of all the arts and sciences; the same pertains to the sections of the Neueröffnete Ritterplatz, a compendium of knowledge about the arts and other human activities. ${ }^{18}$

The outlines of the tradition of universal history as it influenced art history deserve further attention, as the scheme created by universal history continued to be employed in Winckelmann's time and entered into his consciousness. As it was understood from the sixteenth century onward, the theoretical project of universal history included the possibility of writing a history of the visual arts as part of a history of all times and places. Francis Bacon articulated what is probably for English speakers the most famous endorsement of this possibility in his tract on the advancement of learning. Bacon proposed that histories of all the arts should be written. Approximately at the same time, the Gdansk scholar Bartholomäus Keckermann wrote on the nature of history, stating that universal history included all the arts, their invention, progress, outstanding artists, and individual examples of artwork. Not only Keckermann's book but also Bacon's text were known in Germany; Bacon's plan and his call for a history of the various arts and sciences were cited by many later writers in the tradition of universal history. Best known among them is D. G. Morhof, who refers to Bacon in the introductory passages of his Polyhistor. ${ }^{19}$

According to the scheme of universal history, history can treat all subjects and areas of the world (i.e., be universal), or one subject or place in particular. Under the rubric of literary history, of historia literaria, of the history of scholarship, as it was most generally understood at the time, appeared both historia philosophica and historia artificialis. Historia artificialis provided the possibility of writing a history of the arts. This meant the traditional liberal arts, the intellectual disciplines; but it included in the conception also the notion of the mechanical or, as they came ultimately to be defined, the visual arts. Eighteenthcentury writers realized that the visual arts could be part of the more general discussion. Their writings may contain not only a theoretical outline of a historia artificialis, which in the words of one historian is said to contain lives of the artists, the origin, progress, invention, and loss of the arts, a tradition related to Renaissance discussions of invention. ${ }^{20}$ Other books in this tradition also present fairly extensive historical accounts of the visual arts, including discussions of medieval art, and of artists such as Albrecht Dürer. ${ }^{21}$

The tradition of integrating a history of the visual arts into literary history continued up until the 1780 s, and perhaps longer. ${ }^{22}$ Collections 
of lives of the artists can also be counted under this rubric. As the divisions of history were defined by Martin Schmeizel, lives of the artists would be a form of singular history, a part of universal history. ${ }^{23}$ In similar manner, lengthy lives of painters, sculptors, architects, and engravers appeared in French publications such as those gathered by Abbé Lambert's 1751 Histoire littéraire of the reign of Louis XIV. ${ }^{24}$ Studies of the historiography of art have long since established that a historical framework underlies the tradition of vitae of the artists since Vasari; conversely, works such as Lambert's suggest that within the tradition of universal history there could be complete biographies, not merely perfunctory mentions of the arts. This point has not been recognized by historiographic scholarship to date..$^{25}$

Moreover, although their opinions were expressed in a somewhat stereotypical manner, many of the schemes given in universal histories followed a historical pattern similar to that employed since Vasari and modified by later writers such as G. P. Bellori. They do this even when they do not assume the Vasarian form of accumulations of artists' lives. These histories trace a pattern of origin, rise, decline, birth, rebirth, decline, and renewal. This is the pattern Winckelmann was to adopt. ${ }^{26}$

But how could this older type of philosophical or literary history, which treated the visual arts as one of many arts, develop not merely into a different kind of histoire philosophique, familiar in other eighteenthcentury writings, ${ }^{27}$ but into a more specific kind of systematized history of the visual arts? One answer is that it combined history with visual material. Although Monier does not bring us to Winckelmann, we do not seem far from Johann Bernard Fischer von Erlach. When the universal scheme informs a selection of images of monuments used to illuminate history, Fischer's Entwurff einer Historischen Architektur of 1721 appears. This is the first work to mention a history of architecture in its title. ${ }^{28}$

\section{Antiquarianism and the Early Historiography of Art}

Sources for images in Fischer's work have been traced to the antiquarian tradition in Italy, ${ }^{29}$ but it is equally important to trace the sources of his notion of history. It is also important to understand how comparable developments may be found in the tradition of antiquarianism in the German-speaking world, although antiquarianism is not as familiar here as it is in Italy, France, or even England. So-called antiquarian studies could involve a critique of texts and of objects, practicing both the philological and the visual approach. ${ }^{30}$ The distinction between 
antiquarian and art-historical interests also can not be drawn as sharply. For example, the compilation of handbooks of artists' monograms by Sigmund Apin in Altdorf or Johann Friedrich Christ in Leipzig, while resembling antiquarian endeavors, obviously contained what can be called an art-historical dimension. Christ specifically said that his compendium was meant to support the construction of a history of art. $^{31}$

Significantly, these activities (not just antiquarianism, whose presence in this context has also been ignored) and the discussion of the visual arts enjoyed an active life at German universities (and gymnasia). One example among many is provided in the work of Christoff Gottlieb Schwarz, who in 1705 at Leipzig presented a dissertation on ornament in the books of the ancients dealing not only with codicology, binding, calligraphy, and covers, but also with what may be called manuscript illumination. He lectured on this subject on numerous occasions as professor in Altdorf. He was also not the first to concern himself with dissertations on the arts. ${ }^{32}$ The material in Schwarz's dissertations is culled from Latin, Greek, and Hebrew manuscripts. He deals with the use, history, text, and images of manuscripts. His work combines textual discussion with an analysis of the visual. Since his topic is ornament, it can not be considered merely historical or literary.

The same may be said for a dissertation on a consular diptych defended in Altdorf by Gustav Philipp Negelein with Schwarz acting as praeses. Negelein's studies also continue an earlier tradition. He relies specifically on a treatise by Christian August Salig whose title page indicates that he used the Herzog August Bibliothek in Wolfenbüttel for the research presented in his compendium on diptychs. ${ }^{33}$

This tradition of the study of diptychs goes back to the work of the Liège Jesuit Alexander Wilthelm in the mid-seventeenth century ${ }^{34}$ It is incorrect to describe this supposedly antiquarian study as devoid of interest in questions of style. While the antiquarian pursuits of numismatists resemble those of the early modern connoisseur in that they were concerned with authentication, Wilthelm's approach to ivories recalls Morelli's famed method of connoisseurship. Morelli's method is the approach to the attribution of works of art wherein the division of hands is based on the analysis of an artist's treatment of significant details. Wilthelm also provides an almost Morellian image of the artistic treatment of hands holding boxes in diptychs as signs of their date. ${ }^{35} \mathrm{He}$ uses visual particulars to date works.

When faced with a "Gothic" diptych, Wilthelm describes its style not as Gothic in the sense of the Gothic destroyers of Rome, but Gothic in the sense of the Reims cathedral, with which he compares it. He then 
compares the diptych to the Church of Saint Lambert in Liège. Analyzing what came to be called period style, Wilthelm arrives at the correct conclusion that it is a work of the same period as the church, the late thirteenth or fourteenth century. By a process that he himself describes as one of observation and visual evaluation, Wilthelm undertakes a stylistic analysis. ${ }^{36}$

Beside studies of diptychs and manuscripts, other objects that may be described as being of interest to art history include Martin Schmeizel's study on crowns, a subject discussed by other authors as well. ${ }^{37}$ Other works deal with paintings, while treatises on ancient sculpture are of such abundance that they must be left to another occasion to be examined. ${ }^{38}$ It should nevertheless be noted that several treatises on libraries and sculpture adduce modern examples; it will not do to write these off as antiquarian treatments of the past. ${ }^{39}$

A perusal of many of these works, such as that by the Wolfenbüttel gymnasium director Johann Reiske, also suggests that these essays often employ a similar combination of methods, of textual examination and response to objects, that is little different from those of the better-known Abbé Montfaucon with whom Reiske engaged in a controversy. ${ }^{40}$ Although systematic in their approach, such works often include a chronological element. In this regard, it is difficult to distinguish the antiquarian from the historical since the writing of history could also be systematic.

With treatments of individual types of objects that would later be defined as the concerns of art history we have not yet left antiquarianism to reach a distinctive history of art. But it should also be said that, even within the earlier historical and antiquarian traditions, there existed accounts of individual genres, for example, of painting, that offered chronological accounts of these genres. ${ }^{41}$ As demonstrated not only by Reiske's work but also by essays that appeared in the periodical Neue Versuche, concerns with the history of objects and media-what later became art history-also had a place here. Similarly, other treatises handled the history of painting as a background to studying privileges of painters, pointing to the connection between legal and historical studies of art. ${ }^{42}$

\section{Aesthetics, Jurisprudence, and Art History}

These scholarly treatises parallel the better-known art-theoretical and biographical discussions since the Renaissance of the arti del disegno, meaning painting, sculpture, and architecture that distinguish what we 
call the fine or visual arts. But Winckelmann's insistence on art as an independent entity removes art from other craft traditions, placing it in its own realm. Thus, what was needed for a new history of art was not only a definition of history, but a new concept of art. Such a new definition was provided by the development of philosophical aesthetics since Baumgarten in which discourse art came to be defined as a separate realm, related to a sensuous form of knowledge.

Conceptions of art and of history are bound up in their evolution. In his little-known class lectures at Halle, the contents of which are known from a publication of 1750, Baumgarten said: "Es wird nicht undienlich sein, eine kleine Einleitung in die Geschichte der Ästhetik zu geben. Die ganze Geschichte der Maler, Bildhauer, Musikverständigen, Dichter wird hierher gehören, denn alle diese verschiedenen Teile haben ihre allgemeinen Regeln in der Ästhetik." 43

Furthermore, through the reception of writings by Abbé Batteux during the course of the eighteenth century, the visual arts were listed under the category of the fine arts. This process occurred in Germany as it did elsewhere, but in Germany the idea of fine arts was combined with that of aesthetics. In his 1765 dissertation about classical poetry, Ernst Huch specifically linked Baumgarten's idea of aesthetics with Batteux's concept of fine arts. ${ }^{44}$ Moreover, Huch was concerned with the visual arts because, in 1773, he published a book that considered painting a liberal art. ${ }^{45}$ Aesthetics thus also was part of the evolution of the concept of the "fine arts" and its reception in Germany. ${ }^{46}$ Both existed before Winckelmann.

Additional definitions of art and beauty that also treat art from a historical standpoint can be found before the time of Baumgarten. They come from yet another tradition where the issue of judgment is also crucial: from legal studies and juridical treatises. They do so in several ways.

First, it seems almost a corollary to the reconsideration of law, by figures like Samuel Pufendorf in the later seventeenth century, that objects, indeed statues, were treated in reference to their legal status as legal symbols. A series of dissertations devoted to a discussion of Roland statues originated at several juridical faculties in the seventeenth century. These tracts involved an empirical examination of the objects in relation to a historical and philosophical inquiry, namely their origin and hence their role as symbols of legal guarantees. ${ }^{47}$ These studies presented a critique of an object as a basis for historical judgment.

Beyond this critique, several juridical dissertations were also written on what was just or allowable for images. These seem to stem from the post-Reformation debate on the permissibility of images; they appear 
frequently in the first years of the eighteenth century. They deal specifically with the historical circumstances in which images could be made in antiquity. They were even incorporated into systems of study. 48

The extension of the field of jurisprudence also allowed for tracts more specifically devoted to considerations of categories of art. In Jena in 1692 Hulderich Rothmaler presented a treatise De Pictura, which considers the art of painting, and the rights and privileges of painters. ${ }^{49}$ Finally, a series of treatises was devoted to the judgment of what is beautiful and of the use of the senses in law. These dissertations appear to coincide in time with a newer definition of criticism as it developed in these years; this theme needs more thorough investigation..$^{50}$

\section{History of Art in and around the German Universities before Winckelmann}

Some of these treatises originated at Altdorf. Since the Altdorf academy (Nuremberg's university) was associated with the Nuremberg academy of artists, it is no accident that many of the interests directed toward a history of art were represented there ${ }^{51}$ Georg Andreas Will, for example, wrote a dissertation (1742) on Baumgarten's aesthetics, which he then later read to the Nuremberg academy. He sought to ground aesthetics in the work of his predecessors, and to demonstrate its roots in antiquity. As professor of Schöne Wissenschaften at Altdorf from the 1750s, Will lectured regularly on Baumgarten's aesthetics. He also wrote and lectured on universal historical schemes, where he allowed for a history of art. He also wrote a history of the Nuremberg academy of art, as well as treatises of Nuremberg art collections. ${ }^{52} \mathrm{Al}-$ though Will's drive to systematize did not lead him to undertake more detailed analyses, it does not take much to arrive at the establishment of university chairs in art history.

Actual art-historical works were, however, undertaken by other contemporaries, both within and without the university. Five years before Winckelmann's Geschichte, Friedrich August Krubsacius published his Gedanken on the Ursprunge, Wachstum und Verfall der Verzierung, a work that applied a critique derived from a notion of aesthetics similar to that of Winckelmann's to a universal history of ornament. Krubsacius's Gedanken clearly combined observation with the study of texts and an aesthetic prejudice, as did Winckelmann. ${ }^{53}$

One further figure should be mentioned, J. F. Christ. In his life of Cranach, published in 1726, Christ used earlier texts and monuments 
that he had actually seen. This life was conceived not as part of a series of biographies, but of what Christ elsewhere announced was to be a history of newer painting. Already in this biography Christ revealed some of his historiographic principles; he spoke of schools and he related chronological divisions in history to style. As part of his duties as professor at Leipzig, he lectured regularly on art as a part of the history of literature, and he used monuments to discuss history and also history to discuss monuments. He worked on the four popular arts, including drawing. He owned a collection and he drew himself. In his 1747 book on monograms, compiled from observation of original works, he spoke specifically about constructing a history of art based on epochs, nations, schools, and individual masters.

Christ's significance has been recognized, though not emphasized sufficiently. ${ }^{54}$ Not noted has been his debt to an earlier tradition. He brought together several elements that we have been considering. Anticipating Winckelmann, those include not only a concern with the history of Greek art, but an involvement with antiquarian study; an interest in universal history; literary history; and a concern with style and iconography applied directly to what Christ calls a history of art. Christ's history of art is founded on certain fundamental principles. It does not seem a big step from Christ to Winckelmann, who knew his work.

An even closer step toward Winckelmann is taken by another professor who taught on similar subjects. This is Johann Heinrich Schulze, professor of medicine, eloquence, and also, significantly, of antiquities (Altertümer) at the University of Halle. Schulze's best-known publication is probably his Anleitung zur älteren Munzwissenschaft of 1766. The continuation of Schulze's title, Worin die dazu gehörigen Schriften beurtheilet, und die Alterthümer aus Münzen erleuteret werden, gives a good indication of the construction of this work and its standard procedure of explicating antiquities from their depiction on coins. As the introduction to Schulze's book by his son explains, it also taught ("wie man eine ächte alte Münze von einer nachgemachten unterscheiden soll") how one should distinguish an authentic old coin from a copy; hence, it presented a method of connoisseurship. ${ }^{55}$

The introduction to Schulze's book also notes that, although the book was published in 1766, it had been written in $1738^{56}$ : this was the year in which Schulze taught on the subject in Halle. ${ }^{57}$ While it is known that Schulze gave instruction on antiquities and especially on numismatics in Halle, the contents of his private Collegium, a class on MuntzWissenschaft und die daraus erläuternde Griechische und Römische Alterthümer, are unknown. A rediscovered copy of an Einladungs-Schrift to 
this class allows some insights into Schulze's teaching. As might be expected, Schulze taught how one could learn about the customs of the ancient world through its remains, of which the best sources are coins. Before Winckelmann and the Comte de Caylus, whom modern historians sometimes credit with this breakthrough, Schulze seems to have taught how a history of culture and of art could be read from coins and what might be called their style. ${ }^{58}$ This insight into a history of the arts was gained from the practice of connoisseurship whereby date and location could be determined by the visual characteristics of the coins themselves, even without reference to inscriptions. Schulze's comments merit quotation at length: "Das Abnehmen der Künste zu unruhigen und elenden Zeiten, und wie sich solche bald wieder erholet haben, sobald Ruhe und Friede nur in etwas hergestellet worden; bemercket ein ieder beym ersten Anblick von selbsten, wenn er nur die Reihe der Kayser durch siehet. Ja man kann darinnen durch Übung so weit kommen dass man auch in Müntzen, wo kein oder wenig Schrift mehr zu sehen aus der Bildung und den Zügen die darauf vorkommen, die Zeit wenn sie geschlagen sey, und wohin man sie ohngefehr zu rechnen habe ziemlich genau errathen kann [sic]." 59

While Schulze was not unique in offering this kind of instruction at universities, there is a specific reason why his teaching is significant. In 1738, Johann Joachim Winckelmann attended the University of Halle. It is known that he attended Schulze's classes. ${ }^{60}$ Other than his presentation of objects to the future art historian, the impact of Schulze on Winckelmann has been underplayed. ${ }^{61}$ Now that we have a better idea of what Schulze may actually have taught, we may conjecture more about the possible effect of his teaching on Winckelmann. If Winckelmann attended Schulze's Collegium as well as his lectures, he must have learned about the connection between connoisseurship, antiquarianism, and art history. A comprehensive history of art history before Winckelmann remains to be written, but Wilthelm and Schulze suggest that in this history the importance of connoisseurship, as taught and practiced by antiquarians in scholarly circles, may prove to be of greater significance than has yet been recognized.

\section{Conclusion}

This represents one of several corrections that can already be made in currently prevailing theses regarding Winckelmann and the origins of the modern historiography of art. It is clearly a misstatement that ignores the role of people like Christ and Schwarz to argue that before 
Winckelmann the discussions of ancient art were left to nonspecialists or men of letters outside the university. ${ }^{62}$ Mention of specialization in this context begs the question. The change in historiography involved the disruption of the notion of universal history, the gradual disappearance of topica, which was the result of the eighteenth-century development of specialized histories. The discussion of visual art in the context of historia philosophica or literaria, as well as the combined speculation on the general and the specific concerns with objects by men like Schwarz and Christ shows this process to be going on before Winckelmann. What needs to be explained is how philosophical history was redefined as a histoire philosophique. As Schwarz and his followers in Altdorf indicate, and as Wilthelm's work suggests, style and iconography were not always treated separately. Philology and archaeology, history and antiquarianism seem, from their inceptions, to have been closely linked. Winckelmann may have advanced new conceptions; and he certainly presented the most useful and complete handbook of antique monuments yet available. But Winckelmann was widely read and certainly knew much of what has been mentioned here. His accomplishments may look rather different when viewed against those of his predecessors whose stories deserve reconsideration. Although Winckelmann enjoyed a tremendous reception, he was not alone. When, in 1782, Christian Friedrich Prange mentioned books on the history of art, Winckelmann was only one of many figures who were considered to have written on the subject, and he did not stand beyond criticism. 63

\section{Notes}

This chapter is a revised version of the lecture delivered at the Washington University Conference on German Studies, April 9, 1994. An earlier version was presented at the Katholieke Universiteit, Nijmegen, February 11, 1994; later versions were presented on May 17, 1994, at the Philipps-Universität, Marburg (in German), May 26, 1994, at the Universitá di Studi, Trieste (in Italian), December 8, 1994, at the Forschungsschwerpunkt Geschichte und Kultur Ostmitteleuropas, Berlin (in German), and February 10, 1995, at the Institute of Fine Arts, New York University. As explained herein, this essay results from ongoing research. For this reason, and because complete bibliographical references would exceed even further the space allotted to this chapter, full citations of the extensive primary literature with which this research is concerned is reserved for future publications; even though the notes here may seem lengthy, I have tried to keep all citation to a minimum. It is hoped that the present publication may serve as a preliminary orientation. Research for 
this chapter has been supported by a fellowship from the John Simon Guggenheim Memorial Foundation and an invitation to be a visitor at the Herzog August Bibliothek, Wolfenbüttel.

1. For the description of Winckelmann's self-made myth, see above all the chapter, "Fast ein Poet: Johann Joachim Winckelmanns Begründung der Kunstgeschichte," in Wolf Lepenies, Autoren und Wissenschaftler im 18. Jahrhundert (Munich: Hansen, 1988), pp. 91-120, especially pp. 104-20. General overviews of the historiography of art continue to assert that Winckelmann introduced a completely new era in the history of art: this thesis is for example restated in the most recent edition of Udo Kultermann, Geschichte der Kunstgeschichte. Der Weg einer Wissenschaft, 3d ed. (Munich: Prestel, 1990), p. 53. In addition to Lepenies, Autoren und Wissenschaftler, other recent works on Winckelmann include by the same author: "Der andere Fanatiker. Historisierung und Wissenschaftlichung der Kunstauffassung bei Johann Joachim Winckelmann," in Ideal und Wirklichkeit der bildenden Kunst im späten 18. Jahrhundert, ed. Herbert Beck, Peter C. Bol, and Eva Maek-Gérard, Frankfurter Forschungen zur Kunst, 11 (Berlin: Mann, 1982), pp. 21-29. Relatively recent treatments of the subject include Herbert von Einem, "Winckelmann und die Wissenschaft der Kunstgeschichte," and Max L. Baeumer, "Klassizität und republikanische Freiheit in der ausserdeutschen Winckelmann-Rezeption des 18. Jahrhunderts," in Johann Joachim Winckelmann 1717-1768, ed. Thomas W. Gaehtgens (Hamburg: Felix Meiner, 1986), pp. 315-26, 195-211. Michael Fried, "Antiquity Now: Reading Winckelmann on Imitation," October 37 (Summer 1986): 87-97. See more recently Francis Haskell, "Winckelmann et son influence sur les historiens," and Michel Espagne, "La diffusion de la culture allemande dans la France des Lumières. Les amis de J.-G. Wille et l'echo de Winckelmann," in Winckelmann: La naissance de l'histoire de l'art à l'époque des Lumières. Actes du cycle de conférences prononcées à l'Auditorium du Louvre du 11 décembre 1989 au 12 février 1990, ed. Edouard Pommier (Paris: Louvre, 1991), pp. 83-99, 101-35; Maria Fancelli, "Winckelmann nel guidizio di Goethe," in J. J. Winckelmann tra letteratura e archeologia, ed. Maria Fancelli (Venice: Marsilio, 1993), pp. 31-45. Outstanding among recent publications on Winckelmann is the work of Alex Potts, including Flesh and the Ideal: Winckelmann and the Origins of Art History (New Haven, Conn.: Yale University Press, 1994). Previous publications by Potts on Winckelmann include "Political Attitudes and the Rise of Historicism in Art Theory," Art History 1, no. 2 (June 1978): 191-213; "Winckelmann's Construction of History," Art History 5, no. 4 (December 1982): 377-406; "Vie et mort de l'art antique: historicité et beau idéal chez Winckelmann," in Pommier, Winckelmann, pp. 9-38. Pott's dissertation, "Winckelmann's Interpretation of the History of Art in Its Eighteenth Century Context" (Ph.D. diss., Warburg Institute, University of London, 1977), also contains unpublished material of value.

2. Joachim von Sandrart, L'Academia Todesca ... (Frankfurt a. M.: Merian, 1675).

3. I also believe that it is necessary to study the French, English, Italian, and Dutch traditions, all of which were related to the German. I think, however, 


\section{Thomas DaCosta Kaufmann}

that it is not enough simply to attach the German developments to their better-known French and especially Italian antecedents from Vasari to Bellori, although they no doubt depend in many ways on these predecessors. Consequently, this essay and my research, for the time being, concentrate on German (and Netherlandish) authors.

4. J. P. Marperger, Historie und Leben der berümtesten Baumeister (Hamburg: Schiller, 1711).

5. For Testelin, see Anmerckungen der furtrefflichen Mahler unserer Zeit über die Zaichen- und Mahlerey Kunst (Nuremberg: J. J. Sandrart, 1698); for De Piles, Historie und Leben der berühmesten europaeischen Mahler (Hamburg: Schiller, 1710). For Du Fresnoy, Gerike, Kurtzer Begriff der theoretischen Mahlerkunst (Berlin: Rudiger, 1699).

6. For an example of the publications of the Nuremberg Preisslers, see Johann Daniel Preissler, Die durch Theorie erfundene Practic . . . (Nuremberg: Preissler, 1721). Johann Georg Bergmüller, Anthropometria (Augsburg, 1723).

7. This topic was last treated in a thorough study by Ernst Herbert Lehmann, Die Anfänge der Kunstzeitschrift in Deutschland (Leipzig: Hiersemann, 1932).

8. Kurt Karl Eberlein, Die deutsche Litterärgeschichte der Kunst im 18. Jahrhundert. Ein Beitrag zur Geschichte der Kunstwissenschaft (Karlsruhe: Müller, 1919). Julius von Schlosser, Die Kunstliteratur; ein Handbuch zur Quellenkunde der neueren Kunstgeschichte (Vienna: Anton Schroll, 1924), p. 437; the point remains unaltered in later editions-see, for example, Otto Kurz, ed., La letteratur artistica, 3d ed. (Florence: Nuova Italia, 1955).

9. Winckelmann's reference to Monier comes after his critique of his predecessors' efforts. See Winckelmann, Geschichte der Kunst des Altertums (Dresden: Walter, 1764), p. x.

10. [Michel-François] Dandré Bardon, Traité de Peinture suivi d'un Essai sur la Sculpture. Pour servir d'Introduction à une Histoire Universelle, relative à ces Beaux Arts (Paris: Desant, 1765).

11. Eberlein, Deutsche Litterärgeschichte, does not, however, describe the nature of Geschichte der Natur und Kunst. Sammlung von Natur- und Medicin. Wie auch hierzu gehörigen Kunst und Literatur-Geschichten, whose introduction to the first volume (1717) makes clear that the history of the arts is here understood in a Baconian sense.

12. [Kaspar Friedrich Jenckel], C. F. Neickelio, Museographia ..., edited with additions by Johann Kanold (Leipzig and Breslau: Michael Hubert, 1737).

13. See Sammlung von Natur- und Medicin (Winter 1718): 730; (March 1721): 355 .

14. Johann Christian Kundmann [Kundtmann], Promptuarium Rerum Naturalium et Artificialium Vratislaviense (Breslau: Michael Hubert, 1726). Kundtmann, Nummi Singulares . . . (Breslau and Leipzig: Michael Hubert, 1731), p. 3.

15. See, for example, D. Michael Bernhard Valentini, Natur- und MaterialienKammer . . . (Frankfurt a. M.: Zimmer, 1704), Einleitung.

16. One defended at Altdorf by Friedrich Sigismund Wurffbain, probably written by the praeses, Professor D. G. Möller, demonstrates such an interest, 
while it also describes the history of collecting: Dissertatio de Technophysiotameis-von Kunst- und Naturalien-Kammern (Altdorf, 1704).

17. Neue Versuche nutzlicher Sammlungen zu der Natur- und Kunstgeschichte sonderlich von Obersachsen (Schneeberg, 1747). See, for example, "Sammlung von Neuen Natur und Kunst-Erfindungen, und andern Kunst-Stücken," Neue Versuche 6 (1749): 493; "Kurtze Nachricht, von dem Leben, des berühmten Johannes Mariae Nosseni, Churfürstlichen Sächs. Baumeister," Neue Versuche 1 (1747): 25-31. “M. G. F. Müllers' Bericht, wegen derer am Altar zu Ehrenfriedersdorff befindlichen merckwürdigen Alterthümer. Nebst einer Figur," Neue Versuche 5 (1748): 371-77.

18. See, for example, Kern-Historie aller Freien Kunsten und Schönen Wissenschaften, Vom Anfang der Welt, bis auf unsere Zeiten (Leipzig: Wolfgang Deer, 1748). In the books belonging to the so-called Neu-eröffnete Ritterplatz there are histories of painting and sculpture contained, for example, in the Neu-eröffnete Historie der Modernen Medaillen (Hamburg, 1702), p. 206.

19. Bartholomaeus Keckermann, "De Natura et Proprietatibus Historiae Commentarius," in Opera Omnia 2 (Genoa: Aubert, 1614), pp. 1309-88; Daniel Georg Morhof, Polyhistor, 2d ed., vol. 1 (Lübeck: Böckmann, 1695), p. 10; Morhof is also aware of the probable initiator of this sort of discussion, Mylaus: see p. 13.

20. Dieterich Hermann Kemmerich, Neueröffnete Academie der Wissenschaften . . (Leipzig: Thomas Fritsch, 1711), pp. 444-45. Eberlein, Deutsche Litterärgeschichte, pp. 20-21, was also aware of this tradition, and of Kemmerich.

21. To give just one example: Johann Friedrich Reimann Versuch einer Einleitung in die Historia Literaria, vol. 1, pt. 2 (Halle: Renger, 1708), p. 29.

22. A late example of this tradition is Georg Andreas Will, Entwurf einer vollständigern Literar-Geschichte in fünf Abtheilungen (Altdorf and Nuremberg: Du Monat, 1784), p. 37. There are however many earlier examples.

23. Martin Schmeizel, Praecognita Historiae Civilis in quibus natur et Indoles Historiae civilis Explicantur... (Jena: Kaltenbrunner, 1720), especially p. 91.

24. [Claude François] Lambert, Histoire Littéraire du Règne de Louis XIV., 3 vols. (Paris: Prault, Guilyn Quillan, 1751). A German translation also exists: Des Herrn Abt Lamberts Geschichte der Regierung Ludwigs XIV, 3 vols., trans. Gotthold Joseph Hübler (Leipzig and Copenhagen: Mummers, 1759-61).

25. See Potts, “Winckelmann's Interpretation," $1: 26$, and for the general context of art history and antiquarianism, Arnaldo Momigliano, "Ancient History and the Antiquarian," Journal of the Warburg and Courtauld Institutes 13 (1950): 285-315.

26. For Winckelmann and the Vasarian tradition, see Ulrich Muhlack, Geschichtswissenschaft im Humanismus und in der Aufklärung: Die Vorgeschichte des Historismus (Munich: Beck, 1991). For Winckelmann and G. P. Bellori, see Erwin Panofsky, Idea: A Concept in Art Theory, trans. J. J. S. Peake (Columbia: University of South Carolina Press, 1968), first published as "Idea": Ein Beitrag zur Begriffsgeschichte der älteren Kunsttheorie in 1924.

27. Momigliano, "Ancient History and the Antiquarian," speaks instead of "philosophic historians" such as Montesquieu and Voltaire. 
28. While Werner Oechslin has long been preparing a comprehensive study of Fischer von Erlach's sources (see further the next note), later developments influenced by Fischer's book deserve further attention; they are the subject of the author's own research.

29. George Kunoth, Die historische Architektur Fischers von Erlach, Bonner Beiträge zur Kunstwissenschaft 5 (Düsseldorf: Schlunn, 1956); Werner Oechslin, "Fischer von Erlachs 'Entwurff einer Historischen Architectur': Die Integration einer erweiterten Geschichtsauffassung in die Architectur im Zeichen des erstarkten Kaisertums in Wien," in Wien und das europäische Barock: Akten des XXV. Internationalen Kongresses für Kunstgeschichte, Wien, 4.-10. September 1983, ed. Elisabeth Liskar (Vienna, Cologne, and Graz: Hermann Böhlaus Nachfolger, 1986), pp. 77-81.

30. This statement responds to the interpretation of Winckelmann as presented by Potts following Momigliano, who argues that Winckelmann joined two antiquarian methods, linking the philological study of texts with the archaeological investigation of monuments: see further note 62 .

31. Sigmund Jacob Apin, Anleitung wie man die Bildnisse berühmter und gelehrter Männer mit Nutzen sammeln und dagegen gemachten Einwendungen gründlich begegnen soll (Nuremberg: Adam Johann Felsschen, 1728); Johann Friedrich Christ, Anzeige und Auslegung der Monogrammisten ... (Leipzig, 1747), p. 2. While in someone like Christ the interests are closely related, the question remains how what we might identify with the art historical developed in relation to the antiquarian. One clue may be provided by studies that originated at the German universities of categories of objects and their ornamentation.

32. See first the Leipzig dissertation of Christoph Gottlieb Schwarz, "Disputatio Prima de Ornamentis Librorum apud Veteres," published in the same year (Altdorf: Kohl, 1705). Schwarz's writings on the subject are collected in De ornamentis librorum et varia rei librariae veterum supellectile dissertationum antiquarium ... , ed. Johann Christian Leuschner (Leipzig: Langenheim, 1756). At Altdorf D. G. Möller had preceded him in promoting dissertations dealing with topics related to the visual arts and collecting: see notes 16 and 51 .

33. Gustav Philipp Negelein, "De Vetusto Quodam Diptycho Consulari et Ecclesiastico" (Ph.D. diss., published in Altdorf: Hesselius, 1742). Christian August Salig, De Diptychis Veterum tam Profanis, quam Sacris, Liber Singularis ... (Halle: Renger, 1731).

34. Alexander Wilthem, Diptychon Leodiense ... (Louvain: Joannes Mathia Hovius, 1659). Wilthem, Appendix ad Diptychon Leodiense (Liege: Hovius, 1660).

35. See Wiltehm, Appendix, p. 18. In Morelli's method, features such as hands, earlobes, eyebrows, and the like, details that an artist supposedly repeats without conscious application, are thought to be signs of his authorship. The literature on Morelli has begun to grow. For an excellent introduction to this method, see Edgar Wind, Art and Anarchy (London: Faber and Faber, 1963).

36. Wilthem, Appendix, p. 21. This discussion of Wilthem is elaborated and illustrated in my "Antiquarian Connoisseurship and Art History before Winckelmann: Some Evidence from Northern Europe," in Shop Talk: Essays in 
Honor of Seymour Slive, ed. Cynthia P. Schneider, William W. Robinson, and Alice I. Davies (Cambridge, Mass: Harvard University Art Museums, 1995), pp. 130-32, 340.

37. Schmeizel, Commentatio Historica de Cornis tam Antiquis, quam Modernis usque reiis. Speciatim de Origine et Fatis Sacrae, Angelicae et Apostolica Regni Hungariae Coronae (Jena: Gollner, 1712). Schmeizel anticipated the first postwar art history dissertation at Princeton that was also written on the crown of St. Stephen of Hungary. See also another contemporary dissertation on the crown of Hungary promoted by D. G. Möller, Conrad Deichler, “Disputatio Circularis de Corona Hungarica" (Ph.D. diss., Altdorf, 1709).

38. An early, little-known example of what might be called antiquarian character is Johannes Schlemm, praeses, Franciscus Wilk, "De Imaginibus Veterum" (Diss., Jena, 1664).

39. Johann Georg Roeser, praeses, Johann Samuel Stryke, "De Statuis Principium" (Diss., Wittenberg, 1687).

40. Johann Reiske, Epistola qua Exercitationes suas de Imaginibus Jesu Christi adversus censuram Jo. Mabillonii vindicat (Leipzig: Wohlfahrt, 1692). Reiske, Exercitationes Historicae de Imaginibus Jesu Christi (Jena: Bauhofer, 1685).

41. Such an account is the history of painting presented by Friedrich Wilhelm Bierling, De Iudicio Historico (Rinteln: Enax, 1703). Significantly, Bierling's treatment is found in his work on historical judgment, which Momigliano, in "Ancient History and the Antiquarian," p. 298, singles out as typifying the response to the debate over historical pyrrhonism ca. 1700. This debate, Momigliano argues, facilitated the accommodation of antiquarianism to historical studies.

42. See, for example, Ge. Theoph. Boerner, Super Privilegiis Pictorum (Leipzig: Jacobs, 1751).

43. Printed in Bernard Poppe, "Alexander Gottlieb Baumgarten. Seine Bedeutung und Stellung in der Leibniz-Wolffischen Philosophie und seine Beziehungen zu Kant. Nebst einer bisher unbekannten Handschrift der Ästhetik Baumgartens" (Ph.D. diss., Münster [Borna-Leipzig], 1907), p. 67.

44. Ernst Ludov. Dan. Huch, Virgilii Horatiique nonnulla loca a structuris Celeb. Baumgartenii . . . (Leipzig: Io. Christoph. Coerner, 1756).

45. Ernst Ludwig Daniel Huch, Unterschied der freien und mechanischen Malerey (Halle: Gebauers Witwe und Joh. Jacob Gebauer, 1773).

46. The classic treatment of this subject is by Paul Oskar Kristeller, "The Modern System of the Arts," in Renaissance Thought and the Arts (Princeton: Princeton University Press, 1980), pp. 163-227 (second edition of Renaissance Thought II [New York: Harper Torchbooks, 1965]).

47. The earliest of these that I have found is Johannes Gryphiander, De Weichbilds Saxonicis, Sive Colossis Rulandis Urbium Quarundum Saxonicarum, Commentarius Juridicus (Strassburg: Hassenstein, 1666).

48. One example is J. Samuel Luppius, "De Iure Imaginum apud Veteres Romanos" (Diss., published in Wittenberg: Schroeder, 1711).

49. Peter Müller, praes., Hulderich Sigismund Rothmaler, "De Pictura" (Diss., Jena, 1692), subsequently published (Jena: Paul Erich, 1712). 
50. See, for example, Samuel Stryk, De Jure Sensuum Tractatus (Frankfurt an der Oder: Conrad, 1721). I have discussed aspects of these questions in my concluding commentary to D. Gamboni and O. Cristin, eds., Crises de l'image religieuse-Krisen religiöser Kunst (Paris: Editions de la Maison des Sciences de 1'homme, forthcoming).

51. This subject is introduced, and many of the writings discussed, by Wolf Eiermann, "Die Veröffentlichungen der Nürnberger Mahleracademie von Jacob von Sandrart bis Johann Justin Preisler (1662-1771)" (Master's thesis, Friedrich-Alexander-Universität Erlangen-Nürnberg, 1992). See also Eiermann, "Kunst und Wissenschaft-Kunst als Wissenschaft. Die Nürnberger Mahler-Academie und die Universität Altdorf im 17./18. Jahrhundert," Frühneuzeit Info 4, no. 1 (1993): 97-98.

52. The range of Will's publications, including those mentioned here, can be gleaned from his Nürnbergisches Gelehrten-Lexikon, Supplement Band, ed. Christian Conrad Nopitsch (Nuremberg, 1806). Will's dissertation exists only in manuscript form as the text of a public lecture, "Oratio sollemnis de Aesthetica Veterum," Stadtbibliothek Nürnberg, Williana, Will 5.1130.2.

53. See Kurbsacius, Gedanken von dem Ursprunge, Wachstume und Verfalle der Verzierungen in den schönen Kunsten, d. i. der Bau-Schniz Maler- und Kupferstichkunst (Leipzig: Breithkopf, 1759).

54. For the appreciation of Christ, see, for example, Potts, "Winckelmann's Interpretation", 1:94. Schlosser, Kunstliteratur, p. 429, had already taken Christ into account (although his bibliographic references, p. 440, are not quite accurate). Older literature discussing Christ and presenting some of the writings here mentioned includes Edmund Dörfel, Johann Friedrich Christ. Sein Leben und seine Schriften. Ein Beitrag zur Gelehrtengeschichte des 18. Jahrhunderts (Leipzig: Breitkopf and Härtel, 1878). Wilhelm Waetzoldt, Deutsche Kunsthistoriker. 1. Von Sandrart bis Rumohr (Berlin: Volker Spiess, 1986), pp. 45-51 (first edition Leipzig: E. A. Seeman, 1921).

55. Johann Heinrich Schulze, Anleitung zur älteren Munzwissenschaft worin die dazu gehörigen Schriften beurtheilet und die Alterthümer aus Münzen erleutert werden (Halle, 1766); the quotation comes from p. 37. The discussion of Schulze, an addition to the lecture as delivered in St. Louis, repeats material that will have appeared in my "Antiquarian Connoisseurship and Art History before Winckelmann: Some Evidence from Northern Europe."

56. Schulze, Anleitung, p. 1.

57. Carl Justi, Winckelmann und seine Zeitgenossen, 2d ed. (Leipzig: F. C. W. Vogel, n.d.), pp. 52-54, describes the work and teaching of Schulze, including reference to his lectures.

58. For a recent interpretation of the contribution of Caylus to the understanding of the past through its images, see Francis Haskell, History and Its Images: Art and the Interpretation of the Past (New Haven, Conn.: Yale University Press, 1993).

59. Schulze, Einladungs-Schrift zu einen Collegio Privato über die MuntzWissenschaft und die daraus erläuternde Griechische und Römische Alterthümer (Halle, 1738), pp. 1 and 8-9 (whence the quotation). 
60. The evidence is present in the "Auszüge aus Matrikel und KollegienVerzeichnis der Universität Halle," printed in Johann Joachim Winckelmann, Briefe, ed. Hans Diepolder and Walther Rehm, vol. 4 (Berlin: Akademie Verlag, 1957), pp. 376, 565 n. 214.

61. See Justi, Winckelmann und seine Zeitgenossen, pp. 53-54.

62. This statement represents a paraphrase (and quotation from vol. 1, p. 16) of Potts, "Winckelmann's Interpretation of the History of Art in Its Eighteenth Century Context." Potts continued to distinguish between the "philological" and "archaeological" in "Winckelmann's Construction," p. 377, and "Vie et mort," p. 34 n. 3. Potts's Flesh and the Ideal is less concerned with Winckelmann's relation to his predecessors. The roots of Potts's argument, also found in Haskell's History and His Images, in turn, are based on Momigliano's magisterial and influential essay, "Ancient History and the Antiquarian." Momigliano saw the change in historiography of the eighteenth century as the unification of historical and antiquarian studies, as the combination of philosophic history with the antiquarian's method of research, which resulted from a movement outside the university, a process that was influenced by men such as Winckelmann, and that was largely completed by the nineteenth century.

63. Christian Friedrich Prange, Die Schule der Mahlerey (Halle: Johann Christian Hendel, 1782), p. 17. 

Part II. Metaphorology, Poetics, and Philosophy 



\title{
5. Die "fließende" Rede und der "gefrorene" Text: Metaphern im Spannungsfeld von Mündlichkeit und Schriftlichkeit
}

\author{
Horst Wenzel
}

Die Versuche, eine mittelalterliche Poetik zu rekonstruieren, konzentrieren sich vorwiegend auf die explizite Rede, auf die Schriften der Kirchenväter und auf die wenigen theoretischen Äußerungen in volkssprachlichen Werken des hohen und des späten Mittelalters. ${ }^{1}$ Dennoch ist zu konstatieren, daß es eine kohärente Theorie der Schrift im Mittelalter nicht gegeben hat. Umso wichtiger erscheinen im Vorfeld begrifflicher Rede die metaphorischen Hinweise darauf, was eine solche Theorie umfassen könnte. Ein entsprechendes Forschungsprogramm hätte nach der Aneignung und Wiedergabe von heiligem und profanen Wissen (Inspirationsmetaphern, Körpermetaphern, Speisemetaphern), dem Status von Rede und Schrift (Flußmetaphern, Frostmetaphern), dem Sammeln und Konservieren von Zeugnissen und Informationen (Bienenmetapher), der Konstruktion und Funktion von Texten (Baumeistermetapher, Textilmetapher, Bogenmetapher) zu fragen. Aufschlußreich erscheinen mir besonders die Metaphern des Einspeisens, Auswerfens und Wiederkäuens, des Fließens und Gefrierens, die bereits sehr früh belegt sind, sich in der Renaissance besonderer Beliebtheit erfreuen und ihre Bedeutung bis heute nicht verloren haben.

Dieses Phänomen der "langen Dauer" fügt sich weder dem alten Epochenschema von Mittelalter, Renaissance und früher Neuzeit noch dem Gesetz des Medienwechsels: Körpermetaphern als Schriftmetaphern finden wir sehr früh bezeugt, danach in der Zeit des beginnenden Buchdrucks in einer großen Vielfalt und Fülle belegt, aber auch unter den medialen Bedingungen der Gegenwart verwendet. Das wirft die Frage nach der Funktion der Metapher im allgemeinen und in der Zeit medialer Umbrüche besonders auf. 


\section{Horst Wenzel}

\section{Einspeisen, Auswerfen und Wiederkäuen}

Die Notwendigkeit, daß sich der Vortragende dem vorgegebenen Text unterordnet, daß er ihm seine Stimme und seinen gesamten Körper leiht, kommt archetypisch in dem berühmten Bild aus der JohannesApokalypse (Off. 10.9) zur Darstellung, wonach sich der Apostel das Buch einverleibt, es materiell verschlingt ${ }^{2}$, um dann die "fremden Wörter" aus dem eigenen Inneren heraus zum Erklingen zu bringen. Die Apokalypse des Heinrich von Hesler (gegen und nach 1300) malt diesen Vorgang besonders eindringlich aus:

Die stimme mir aber zu sprach durch siner barmenden beruch:

"Ganc nim daz offenstende buch,

Daz der engel in der hant hat

Der uf dem mer und erden stat."

An sin wort ich mich verliez,

Daz buch ich mir geben hiez.

Der engel der gab iz mir;

"Nim" sprach her "ich sage iz dir;

Du salt iz vrezzen also ruch,

So tut iz bitter dinen buch, nach mezelicher stunde

Wirt ez in dinem munde

Glich dem honige suze."

Daz buch nim ich mit nuze

Vrezzende iz in minen munt;

Do gewan iz alda ze stunt

Des suzen honiges smacken

Zwischen minen kenebacken

Und bittert in minem buche, glich als iz were ein suche.

Do sprach mit unterscheide

Der engel: "anderweide,

Sam ich da von dir beschiet,

$\mathrm{Nu}$ mustu predigen der diet.

Volken, kunigen, zungen

Von allen samenungen." 3

In der Exegese dieser Stelle geht Heinrich von Hesler auf das Motiv der Einspeisung noch einmal kommentierend ein:

Daz her iz buch in vrezzen hiez,

Daz quit sus: die schrift durch grabe, 
swaz der sin verborgen habe, daz du den gar durchmezzes

Und als ein ezzen ezzes

Mit girden deiner sinne;

So blibet dar nicht inne

Tunkels, lestu dich hungern; ${ }^{4}$

Die Erforschung des Buches soll sich als ein Akt des Aufgrabens und Umgrabens, die Aneignung des Sinns als ein Vorgang körperlicher Lust vollziehen, ja, leibhaftiger Gier, weil nur dann nichts außerhalb, nichts unverdaut bleibt von der kostbaren "Speise". Das Schema erinnert an die Eucharistie, die Verwandlung des Brotes in das lebendige Wort (den Leib Christi) durch den Ritus der Kommunion. Auch das Motiv der Süße und der Bitternis wird in diesem Sinn erläutert-die Süße als die lebendige Aufnahme des Wortes, die Bitternis als Verfolgung und schließlich als Tod der Glaubenszeugen. Dem Motiv des bitteren und süßen Wortes entspricht die Bitterkeit des Gesetzes (Altes Testament) und die Süße des Evangeliums (Neues Testament) ${ }^{5}$, aber im Zentrum steht hier das Verschlingen des Buches als Voraussetzung und Bedingung dafür, ein anderer zu werden, als Vorgang einer conversio also, die es Johannes ermöglicht, den Auftrag Gottes zu erfüllen, Völkern und Königen in Sprachen ("zungen") aller Art zu predigen. Ähnlich schildert Hesekiel im Alten Testament seine Berufung zum Propheten Israels, die ihm von der Stimme Gottes mitgeteilt wird:

Du aber, Menschensohn, höre, was ich zu dir sage.... öffne deinen Mund, und iß, was ich dir gebe. Und ich sah: Eine Hand war ausgestreckt zu mir; sie hielt eine Buchrolle. Er rollte sie vor mir auf. Sie war innen und außen beschrieben, und auf ihr waren Klagen, Seufzer und Weherufe geschrieben. Er sagte zu mir: Menschensohn, iß, was du vor dir hast. Iß diese Rolle! Dann geh, und rede zum Haus Israel! Ich öffnete meinen Mund, und er ließ mich die Rolle essen. Er sagte zu mir: Menschensohn, gib deinem Bauch zu essen, fülle dein Inneres mit dieser Rolle, die ich dir gebe. Ich aß sie, und sie wurde in meinem Mund süß wie Honig. Er sagte zu mir: Geh zum Haus Israel, Menschensohn, und sprich mit meinen Worten zu ihnen!

(Hesekiel 2.8-3.4)

Die Inkorporation des Buches gibt dem Körper eine neue Stimme. Hesekiel wird zu dem Gefäß einer Rede, die ihm der Engel überbracht hat. Der homöostatische Prozeß der Aneignung und der Wiedergabe, der physischen Aufnahme dessen, was "behalten" werden soll, charak- 
terisiert den Prozeß der Tradierung in einer Gedächtniskultur, die auf die mechanische Reproduktion von Wissen ganz oder weitgehend verzichten muß. Die Memorierbarkeit traditioneller Wissensbestände bleibt gebunden an die körperliche Einspeisung und Wiedergabe. Solange eine Theorie dieses Verfahrens fehlt, beschreiben einprägsame und bildkräftige Metaphern den Prozeß der Wissensspeicherung und -weitergabe.

Der metaphorischen Einverleibung des Buches korrespondiert bereits im Alten Testament (4. Mos. 5.23) eine magische Reinigungsprobe für mögliche Ehebrecherinnen, eine materielle Schriftverwendung, die auch für andere Kulturkreise belegt ist. In buddhistischen Religionsgemeinschaften werden heute noch Gebetsformeln und Rezepte auf schmale Papierstreifen geschrieben und verschluckt, um dann im Inneren des Körpers ihre Wirkung zu entfalten. Ähnlich wird die Schrift von den Gesetzgebern und Priestern des Alten Testaments als Pharmakon verwendet. Der Priester mischt heiliges Wasser mit dem Staub des gefährdeten Hauses und wäscht mit dieser Tinktur die Buchstaben vom Papier. Diese Medizin wird der Frau eingegeben, damit der fremde Same sichtbar werde, der in ihr vermutet wird. Ist sie unrein, so wird ihr der Bauch anschwellen und die Hüfte schwinden, ist sie jedoch rein, so kann ihr die Prozedur nicht schaden: "Sobald er sie das Wasser hat trinken lassen, wird das fluchbringende Wasser in sie eindringen und bittere Schmerzen bewirken, falls sie unrein und ihrem Mann untreu geworden ist: Es wird ihren Bauch anschwellen und ihre Hüften einfallen lassen, so daß die Frau in ihrem Volk zum sprichwörtlichen Beispiel für einen Fluch wird. Wenn sie aber nicht unrein geworden, sondern rein ist, dann wird sich zeigen, daß sie unschuldig ist, und sie kann weiterhin Kinder bekommen" (4. Mos. 5.23-25). An die altjüdischen Vorschriften über die Reinigungsprobe und das Fluchwasser ${ }^{6}$ erinnert noch der mittelalterliche Brauch, durch das Trinken von Reliquienwasser die Aura des Heiligen dem Körper selbst einzuverleiben und darin wirksam werden zu lassen.

Für die christliche Kirche hat Augustinus die Speisemetaphorik gerechtfertigt: "Gott ist für Augustin interior cibus (Conf. I 13.21.5), die Wahrheit Nahrung (Civ. Dei XX, 30.21) und Speise (Conf. IX 10.24.12)"7. Ein einprägsames Beispiel dafür liefert die Bible moralisée (1275) mit ihrer typologischen Deutung von Ex. 16.4. Danach kommen die Söhne Israels an einen schönen Ort, an dem es viele Palmen und zwölf reiche Quellen gibt. Die zwölf Quellen präfigurieren die zwölf Apostel, die die guten Kleriker mit dem Wasser der christlichen Lehre tränken. Das Manna, das Gott auf die Söhne Israels herabregnen läßt, bezeichnet das Manna des Evangeliums, den Leib und das Blut Christi, 
das er an sein Volk gibt, damit es geheilt und wiederhergestellt werde. Wie die Söhne Israels in der Wüste Wasser und Manna zu sich nehmen, das Gott ihnen in ihrer Not gesandt hat, trinken die guten Christen das Wort und sie essen den Leib Christi. Ihre Lehrer informieren sich aus den heiligen "Quellen", damit sie "fließend" reden, schreiben oder lesen.

Die weite Verbreitung der Speisemetaphern macht eindringlich klar, wie stark die Inkarnation des Logos und die Inkorporation des Wissens durch Hand, Augen und Ohren (Schrift, Bild und Wort) miteinander verbunden waren, wie sehr darum auch die Aneignung des Wortes überhaupt als Einspeisung in den Körper selbst verstanden wurde. Curtius führt unter dem Stichwort "Speisemetaphern" bereits eine Reihe antiker Belege an: "Pindar rühmt von seiner Dichtung, sie bringe etwas zum Essen. Aischylos nannte seine Tragödien 'Schnitten von den großen Gastmählern Homers' (nach Athenaios VIII 347 e). Plautus und Cicero brauchen epulae metaphorisch. Das Wort Satire (satura) bedeutet 'gemischte Schüssel'" 8 . Die christliche Kirche hat diese Bilder aufgenommen und vielfältig abgewandelt in einem Prozeß der Tradierung und der Modifikation, der auch im späten Mittelalter in Bewegung bleibt. So lesen wir in einer aktuellen Untersuchung zur Gesprächskultur der Renaissance: "Reading is a process of nutrition and digestion; it appropriates earlier texts, recycles them and remakes them in order to feed the new works" ${ }^{9}$. Nach Jeanneret, der die Speisemetaphern bei Rabelais und seinen Zeitgenossen untersucht hat, erklärt sich die auffallende Vorliebe für dieses Motiv damit, daß die lectio im Refektorium die leibliche Speisung der Mönche mit ihrer geistigen "Ernährung" verband. ${ }^{10}$ Plausibler erscheint es jedoch, daß Rabelais den Prozeß der Spiritualisierung umkehrt und die Einspeisung des Wortes wörtlich nimmt, indem er sich ausschließlich auf die Signifikanten bezieht. Im 47. Kapitel des 5. Buches von Gargantua und Pantagruel läßt er die edle Priesterin Bakbuk für den "hungrigen" und "durstigen" Panurg das Wort der Göttlichen Flasche auslegen:

Die Philosophen, Kanzelredner und Doktoren eurer Welt speisen euch durch die Ohren mit schönen Worten; hier trichtern wir euch unsere Lehren stofflich durch den Mund ein. Darum sage ich nicht zu dir: Lies dies Kapitel, höre diese Auslegung, sondern ich sage: Schmeck dies Kapitel, schluck diese schöne Auslegung. Ein alter Prophet des jüdischen Volkes aß vorzeiten ein Buch und wurde auf diese Weise bis an die Zähne ein gelehrter Mann; du wirst jetzt trinken und bis an die Leber gelehrt werden. Sperr also deine Kiefer auf!"-Und nachdem Panurg sein Maul aufgerissen hatte, nahm Bakbuk das silberne Buch, das wir für ein wirkliches Buch 
gehalten hatten, das aber ein sogenanntes Brevier war, das heißt eine kreuzbrave, landläufige Flasche mit Falerner Wein, und ließ die ihn bis auf den letzten Tropfen aussaufen. ${ }^{11}$

Die Metapher der geistigen Speisung wird hier in ihr Gegenteil verkehrt, die geistige Nahrung, die das Brevier zu versprechen scheint, erweist sich als vortrefflicher Falerner Wein. Während sich im Abendmahl der Wein in Christi Blut verwandelt, wird das Versprechen auf geistige Speisung hier in die Materialität des leiblichen Genusses überführt. Der kontinuierliche Gebrauch der Speisemetaphorik schließt also keinesfalls aus, daß die konkrete Situation ihrer Verwendung sich ändert, der zeitgenössische Diskurs erkennbar wird. Das betrifft die Antike und das Mittelalter, aber auch die Verbindung der beiden Traditionen in den verschiedenen Bewegungen der Renaissance.

Der Gebrauch der Speisemetaphorik reicht über das späte Mittelalter weit hinaus und ist in erstaunlicher Vielfalt bis in die Gegenwart $\mathrm{zu}$ beobachten. Beispiele finden sich bei Shakespeare und Erasmus ("Wenn du in Briefen schlemmtest", an Joh. Mombaert 1497), aber auch bei Nietzsche und bei Herder. ${ }^{12}$ Sprichwörtlich reden wir heute noch von "Leselust" und "Wissensdurst", wir kennen Leute, die die "Weisheit mit Löffeln gefressen haben" und Kinder, die "ein Buch verschlingen." Auf dem Buchmarkt kursiert "Der Buchtrinker" von Klaus Huizinga und in einer aktuellen literaturwissenschaftlichen Untersuchung findet sich die Arbeitstechnik Arno Schmidts wie folgt beschrieben: "Kurz, seine Texte zehren allesamt von anderen Texten ... deren Ingredienzen . . . Schmidt waidgerecht zerlegt und im Zettelkasten zubereitet, genüßlich verspeist und in Brotarbeiten wiederkäut, dann der eigenen Geisteswelt und dem selbsterwählten Traditionskörper einverleibt, um sie schließlich im Schöpfungsakt in erzählerisch aufbereiteter Gestalt wieder auszuscheiden"13. Hier geht es gerade nicht um eine vortheoretische Beschreibung, sondern um die Veranschaulichung und Versinnlichung eines Verfahrens, dessen Komplexität andernfalls nur in der hochabstrakten Sprache der Wissenschaft beschrieben werden könnte. In dieser Umkehrung erweisen Jagd- und Küchenmetaphorik, das Bild des Einspeisens und Wiederkäuens, der Inkorporation und Exkorporation ihr Darstellungs- und Deutungspotential für "literarische" Verfahren bis in die jüngste Gegenwart.

Schon bei Martianus Capella (5. Jh.) ${ }^{14}$ findet sich das Motiv der "Einspeisung" des Buches auf einprägsame Weise variiert. Er läßt die schriftgesättigte Jungfrau Philologia, bevor sie den Gott Mercurius heiraten und selbst Unsterblichkeit gewinnen darf, in einem Akt der vorehelichen Reinigung alle (irdischen) Bücher ausspeien. Athanasia, 
die Unsterblichkeit, nötigt sie zu diesem konvulsischen Akt des Schriftausstoßes. So erbricht die Philologie die in ihr aufbewahrte Weisheit in Form von Büchern aller möglichen Sprachen, einige aus Papyrus, andere in Leinen gebunden, einige in Pergament, andere aus Baumrinde. Ein Großteil dieser Bücher wird von der Schar anwesender Jungfrauen wieder aufgenommen, vor allem von den Artes liberales, aber auch von den Musen selbst, denn es finden sich darunter Werke zu Musik, Astronomie, Geometrie, Mathematik und Kosmographie, das ganze System der weltlichen Wissenschaft.

Notker der Deutsche (950-1029) hat in seiner Übersetzung von Martianus Capellas De nuptiis Philologiae et mercurii auch die Reinigung der Philologia in das christliche Mittelalter tradiert:

At illa omni nisu magnaque ui . quicqid intra pectus semper senserat . euomebat . Tô erspêh sî sâr hírlicho sí péitendo al dáz. tés sî ín íro guuár uuárd. Tum uero illa nausia . ac uomitio. laborata . conuertitur in copias omnigenum literarum. Dára-nâh uuárd . táz sî mít árbeiten irspê . ze állero sláhto bûochen. Uuánda fóne éinemo fonte rationis . chóment álle bûohlíste. Cernere erat . qui libri . quantaque uolumina . quot linguarum opera ex ore uirginis defluebant. Tar máhtist tu séhen . uuîo mánigív bûoh súnderigiu . únde zesámine-gebúndeniu . únde uuîo mánigero sprâchon scrífte ûzer íro múnde fûoren. Alia ex papiro . que cedro i.resina cedri perlita fuerat uidebantur. Súmelichiv vuâren geuuórht ûzer demo egypzisken bíneze. dér mít cêdrinemo flîede besmízen uuás. táz er nefûleti. Alii libri carbasinis implicati uoluminibus. Súmelichiu bûoh peuuvndniu in lînien bízucchen. Ex ouillis quoque multi tergoribus. Ió scáphinis pérgaminis mánigiv. Rari vero in phillire cortice subnotati. Unmanigíu uuâren gescríben án déro ríndun dés póumes phillire . álso iz ív síto uuás. Erantque quidam sacra nigredine colorati. Uuâren súmelichiu mít tínctun gescríbeniu. Quorum litere animantium credebantur effigies. Téro bûocho scrífte . óugton dero lîbhafton bílde ${ }^{15}$

Die Aneignung der Schrift und ihre Wiedergabe wird in diesem Sinne konsequent mit körperlicher Einverleibung und Hervorbringung verbunden. Notker bewahrt dabei die Vorstellung, daß die Schrift die Bilder lebendiger Wesen ("effigies") vermittelt: "óugton déro lîbhafton bilde."

Dem konvulsischen Auswürgen der Bücher steht die Vorstellung von der Hervorbringung des Wortes in einem oralen Geburtsakt nahe. Das Wiesel, so berichtet schon Plutarch, empfängt durch die Ohren und gebiert durch den Mund. Diese Geschichte, die einen ägyptischen 
Ursprung haben könnte, wird im christlichem Schrifttum zum Sinnbild des Schülers, der die Worte seines Lehrers durch das Ohr empfängt und das geistige Kind dieser Empfängnis in der Rede seines Mundes zur Welt bringt. ${ }^{16}$ Die Nähe zur Mariensymbolik, zur Geburt Christi aus dem Logos, erscheint offensichtlich, die vor dem Hintergrund antiker Traditionen in ihrer eigenen Historizität erkennbar wird.

In der lateinischen und in der volkssprachlichen Dichtung des Mittelalters findet sich die Rezeption der Schrift in Übereinstimmung mit diesem physiologischen Konzept als eine Aneignung des Wortes dargestellt, die alle körperlichen Sinne einbegreift. So hofft der Priester Wernher für seine Mariendichtung,

daz si ez alle muosen lesen

die gotes chint wellen wesen, unt ouch mugen schouwen

laien unde frouwen, smecken unt ergrunden

von dem frônen chinde. ${ }^{17}$

Die Metaphorik der Einspeisung und Wiedergabe geistlicher Worte korrespondiert mit den Metaphern der Erinnerung. Als Vorgang der Meditation war das Lesen geistlicher Texte zugleich ein Akt der ruminatio (= Wiederkäuen), ein körperlicher, motorisch gestützter Prozeß des Memorierens, der Wahrnehmungen reaktivierte und vertiefte. $R u$ minatio als Terminus, der primär die Form der Nahrungsaufnahme und der Verdauung von Wiederkäuern kennzeichnet, besetzt im großen Feld der Speisemetaphorik den Aspekt der mentalen Betrachtung und Verarbeitung des geistlichen und weltlichen Wortes. Augustinus bezeichnet das Gedächtnis als Magen der Seele (venter memoriae), in dem die geistlichen Worte verarbeitet werden müssen, damit sie ihren Geschmack vollständig entfalten, und schon Quintilian (30-96 n. Chr.) sieht die Vorzüge der Lektüre gegenüber der wörtlichen Rede in der Möglichkeit des Zurückgreifens, der Wiederholung, des sorgfältigen Auskostens und Einverleibens: "lectio libera est nec actionis impetu transcurrit, sed repetere saepius licet, sive dubites sive memoriae penitus adfigere velis. repetamus autem et tractemus et, ut cibos mansos ac prope liquefactos demittimus, quo facilius digerantur, ita lectio non cruda, sed multa iteratione mollita et velut confecta memoriae imitationique tradatur"18. Es könnte durchaus sein, daß Quintilian sich bereits auf die allegorische Auslegung der Mosischen Speisegesetze stützt, wie sie im Brief des Pseudoaristeas (um 125 v. Chr.) bezeugt wird. Die Bestimmung, man dürfe nur die Tiere essen, die gespaltene Klauen haben, Paarzeher sind und wiederkäuen (Lv. 11.3), enthält 
dabei auch folgende Passage: "Alle [Tiere], die zweihufig sind und wiederkäuen, stellen für die Einsichtigen die Erinnerung dar. Denn wiederkäuen ist nichts anderes als die Erinnerung an Leben und Bestehen. Denn er [Mose] glaubt, daß das Leben durch die Nahrung besteht. Darum mahnt er durch die Schrift also: Gedenke des Herrn, deines Gottes, der an dir das große und wunderbare getan hat" 19 .

Die Metapher des Wiederkäuens, die für die Aneignung und Wiedervergegenwärtigung der Schriftlektüre steht, führt primär auf antike und auf christlich-jüdische Quellen zurück, wird im Mittelalter viel verwendet und bleibt über die Renaissance hinaus lebendig. Besonders anschaulich beschreibt Petrarca seine Studien als Einspeisung und körperliche Aneignung: "I ate in the morning what I would digest in the evening; I swallowed as a boy what I would ruminate upon as a man. These writings I have so thoroughly absorbed and fixed, not only in my memory but in my very marrow, these have become so much a part of myself that even though I should never read them again they would cling in my spirit, deep-rooted in its inmost recesses" 20 .

"Meditieren" als sinnerfassendes Lesen und Schreiben heißt eben nicht nur, sich streng an den Satz zu halten, sondern zugleich alle seine Worte abzuwägen, abzuschmecken, um ihren Sinn ganz zu ergründen. Ist das Schreiben ein abwägendes Sprechen, das eine akustische Wahrnehmung in visuell sichtbare Zeichen umsetzt, so ist das Lesen ein abwägendes Hören, das die Sprache aus dem visuellen Bild des Textes reaktiviert. Indem man vor sich hinsagt, was man liest, hört man die Sätze mit den Ohren, die man mit den Augen sieht, die voces paginarum..$^{21}$ Die Sensomotorik des Sprechens und der akustische Eindruck des gehörten Wortes prägen sich dem Gedächtnis leichter ein als der visuelle Eindruck des geschriebenen Wortes. Die zeitliche Verzögerung des Sprechaktes gegenüber der visuellen Wahrnehmung gibt dabei Gelegenheit $\mathrm{zu}$ reichen assoziativen Bewegungen im Magen (venter) der Memoria. Memoria und Imaginatio verknüpfen die gehörten Worte und Sätze mit erinnerten Worten und vorgestellten Bildern (schouwen) zu einer Gesamtwahrnehmung, die den Akt des Lesens zugleich zu einem Akt der Andacht und Betrachtung werden läßt. Der Meditierende macht sich den Inhalt eines Textes ganz zu eigen, indem er ihn aufnimmt und sich im Akt des Wiederkäuens vergegenwärtigt, welche Fülle der Wahrnehmung sich mit dem (christlichen) Wort verbindet, um seinen Sinn umfassend zu ergründen und vollständig auszukosten. ${ }^{22}$ Korrespondierend dazu verweist die Bienenmetapher, die im Mittelalter häufig zur Verbildlichung der klösterlichen Schriftkultur verwendet wird, auf den wichtigen Prozeß des Sammelns und Zusam- 
mentragens, aber zugleich auf den Vorgang der Verarbeitung (ruminatio) des zusammengetragenen Werkstoffes für den Neuaufbau von Honigzellen oder -waben, dem verbreiteten Bild für Bücher und für Bibliotheken. ${ }^{23}$ Wenn Bernhard von Clairvaux als doctor mellifluus bezeichnet wird, als honigfließender Lehrer, so referiert diese Metapher auf die Honigbiene, die den sorgfältig gesammelten Nektar zu Honig verwandelt und als Nahrung für die heranwachsende Brut einsetzt.

Der Nachklang einer ganzheitlichen sensorischen Wahrnehmung, der in der Terminologie der Zeitgenossen faßbar wird, scheint für den Umgang mit dem geschriebenen Wort und für die Aneignung des Wortes aus der Schrift von konstitutiver Bedeutung. Die Wahrnehmung (der Zeichen) mit den Augen, die Aufnahme (des Tones) über das Ohr, der Nachvollzug des Sprechens (das Schmecken) mit den Lippen, die Sensomotorik des Körpers im Rhythmus der Wortfolge und die Internalisierung des Blickes im Prozeß des Nachsinnens kennzeichnen das ganzheitliche Erfassen eines Schriftwerkes, das sehr viel mehr ist als die bloße Aufnahme von Information. In diesem Sinne heißt es bei Leclerq: "Für die Alten heißt meditieren einen Text lesen und ihn 'par coeur' -in der stärksten Bedeutung dieses Ausdrucks-lernen, also mit seinem ganzen Wesen-mit seinem Leib, weil die Lippen ihn aussprechen, mit dem Gedächtnis das ihn festhält, mit dem Verstand, der seinen Sinn begreift, mit dem Willen, der ihn in die Tat umzusetzen verlangt" 24 .

Die Aneignung der Schrift als ein Ganzheitserlebnis für Körper und Geist zu deuten, erscheint auf der Grundlage der zeitgenössischen Schriftmetaphern als notwendiges Postulat und als eine vielsprechende Aufgabe der mittelalterlichen und spätmittelalterlichen Poetik. Das gilt besonders dann, wenn man mit Zumthor davon ausgeht, daß jeder dichterisch-fiktive Text vor dem 15. Jahrhundert "in seiner Tiefenstruktur eine Zielgerichtetheit" birgt, die auf mündlicher Überlieferung beruht: "Der Text will gesprochen werden, will sich durch die Stimme entfalten. In einem solchen Kontext muß daher jeder Umgang mit dem Text-gleichgültig ob er sich im Gesang, im Vortrag oder in öffentlicher Lektüre vollzieht-unabhängig vom Grad der Theatralisierung als Performanz aufgefaßt werden" 25 . In diesem Sinne betont Zumthor mehrfach ${ }^{26}$, daß der gesprochene Text durch und um den Körper des Interpreten herum Profil gewinnt: "Autour d'un corps humain par l'opération de sa voix, de tous les facteurs sensoriels, affectifs, intellectifs d'une action totale, à la fois spectacle et participation" 27 . Zusätzlich zur Metaphorik des Speisens und des Wiederkäuens ist hier die Dramaturgie der Körper, das gemeinschaftsstiftende Moment einer szenischen Aufführung von Sprache, besonders hervorgehoben. 
Die Verwendung von Körpermetaphern steht unter dem Gesetz des historischen Wandels, erweist sich aber als ein Phänomen der longue durée. Einerseits wird das semantische Feld der körperorientierten Kommunikation verändert und beeinflußt durch Metaphern, die auf neue Technologien verweisen (auf den Buchdruck: "ausprägen" und "Ausdruck"; auf Funk und Telephon: "keinen Anschluß finden", "eine lange Leitung haben"; auf elektronische Datenverarbeitung: "Elektronengehirn", "Menü" usw.), andererseits demonstriert die Konstanz des bildlichen Sprachgebrauchs die Heterogenität des Gleichzeitigen, die vielfältigen Modi der Kommunikation, die miteinander wirksam sind: orale, scriptographische, typographische und elektronische Verfahren. Neben den neuen Bildern von Kanälen, Schnittflächen und elektronischen Netzen stehen die Metaphern der Einspeisung und des Auswerfens/Ausstoßen für Vorgänge der Typographie und der elektronischen Medien, aber auch weiterhin für die Prozesse des Hören, Sehens und Erinnerns. In der Diskussion werden manche zweifelhaften Argumente "geschluckt", und deshalb bleiben manche Thesen "unverdaut".

\section{Die lebendige und die gefrorene Rede}

Der Gegensatz zwischen der Flächigkeit des Textes ("visual design") und der Zeitlichkeit des Tons ("temporal sequence of sound") demonstriert die Umwandlung der "lebendigen" Rede in das "tote" Material des Speichermediums, die zugleich als Voraussetzung dafür erscheint, daß die Kommunikation zeitlich (und räumlich) verschoben wieder aufgenommen werden kann. Diese Überführung der "flüssigen" menschlichen Rede in einen starren ("static, fixed") Aggregatzustand und die Möglichkeit ihrer Rückverwandlung ist früh gesehen und in eindrucksvollen Metaphern beschrieben worden.

Die metaphorische Verknüpfung der "fließenden" Rede mit dem Bild des Wassers und des Ursprungs einer Rede oder Nachricht mit dem Bild der Quelle findet sich in Texten der Antike und des Mittelalters gut belegt. Die Flußmetapher deutet auf die Dimension der Zeit, auf die lebendige Bewegung und den Lauf der Gedanken im gesprochen verklingenden Wort. Die christliche Gemeinschaft wird seit den Zeiten des Alten Testamentes durch die Taufe gestiftet und erneuert und damit für jeden einzelnen Christen die Verbindung des Wassers mit dem lebendigen Wort bestätigt und individuell begründet. Gott ist nicht nur das lebendige Wort, sondern auch der Ursprung und die Quelle der von ihm ausströmenden Gnade (fons et origo, vgl. Psalm 35; 


\section{Horst Wenzel}

Jer. 2.13; Joh. 4.13-14). Maria, die Mutter Gottes, gilt in Anlehnung an das Hohelied 4.12 als fons signatus, als versiegelter Brunnen. In der geistlichen Auslegung, die Otfrid von Weißenburg seiner Erzählung über die Hochzeit von Kana anschließt, nützt er die Gelegenheit, die spirituelle Bedeutung von Wasser und Wein ausführlich zu entwickeln:

Zéllu ih thir ouh hiar tház bi thiu stéininun fáz:
hérza iz sint gidigano thero gotes drútthegano.
Siu sint ínnana hól, héileges giscríbes fol,
mit thiu sie únsih ía gilícho drenkent fráuualicho.
Lútaran brúnnon so scénkent sie uns mit uúnnon.
skal iz géistlichaz sín, so skénkent sie uns then gúatan uuin
Uuidar thiu ouh thánne; thie man firnément alle:
so múgun sie mit rúachon uns ságen in then búachon. ${ }^{28}$

Otfrids eigenes Verständnis seiner Dichtung zielt darauf ab, das Quellwasser der Überlieferung in den Wein der spirituellen Bedeutung zu verwandeln, der mit Christus in die Welt gekommen ist.

$\begin{array}{ll}\text { uuil du uuórolt zellen, } & \text { sus máht thih al bithénken, } \\ \text { in zúa uuisun drénken. } & \text { Thaz giscríp in ríhti } \\ \text { irfúlli thu io mit máhti, } & \text { so kúalist du dih ófto } \\ \text { mit brunnen rédihafto. } & \text { Ioh húgi filu hárto } \\ \text { thero géistlichero uuórto, } & \text { so drenkist dráhta thine } \\ \text { mit frónisgemo uuine. } & \end{array}$

In der Bible moralisée finden sich zahlreiche Beispiele solcher Metaphern. In Ex. 2.15-16 wird erzählt, daß sieben Mädchen ihre Tiere an einer Quelle tränken wollen, aber von den Hirten zurückgedrängt werden. Moses hilft den Mädchen, damit sie auch an den Brunnen gelangen. Der Kommentar erläutert: “Daß Moses die Hirten zurückdrängt und die Mädchen zu dem Wasser kommen, bedeutet, daß Jesus Christus die Teufel zurückdrängt und die Tugenden kommen nach vorn und trinken von der Göttlichkeit. . . . Daß die sieben Mädchen ihren Tieren Wasser geben und sie tränken, bedeutet, daß die Tugenden das Volk Gottes mit den Geboten Gottes und der Süßigkeit des Evangeliums und der Heiligen Schrift tränken" ${ }^{30}$. Hugo von Trimberg verwendet im Renner die Brunnenmetapher im Rückblick auf die großen Lehrautoritäten der Vergangenheit:

Wenne wort, diu tiefe sint gewegen,

Der süln hôhe meister pflegen,

Der sin von vollen brunne fliuzet

Und wîten in diu lant sich giuzet: ${ }^{31}$ 
Bis heute sprechen wir von "trüben Quellen" einer schlecht bezeugten Information, vom "Strom der Überlieferung", von einem "flüssigen Stil" des Vortrags usw.

Das gilt nicht im gleichen Maße für die Bildlichkeit der stillgestellten, schriftlich festgelegten Rede, für die Metaphern von Schnee und Eis. Verweist die Flußmetapher auf Bewegung und Lebendigkeit, so verweist die Metapher der Erstarrung, des gefrorenen Flusses auf die Dimension des Raumes, auf die stillgestellte, festgelegte Rede im toten, aber wiederzubelebenden Buchstaben. In einem charakteristischen Bild, das sich bei Ordericus Vitalis (1075-etwa 1143) findet, erscheint die Schrift wie eine gefrorene Sprache, abgelöst von den sie konstituierenden Handlungszusammenhängen und doch darauf zurückverweisend: "Mit dem Verlust der Bücher geraten . . . im Lauf der sich wandelnden Welt ... die Taten der Alten in Vergessenheit, wie Hagel oder Schnee, die in den Wassern eines rasch dahineilenden Flusses schmelzen und durch die Strömung hinweggeschwemmt werden, um niemals wiederzukehren" ${ }^{32}$. Ist es der Strom der Zeit, der einfriert in der Schrift, so vergeht mit dem Verlust der Bücher die Überlieferung wie Hagel oder Schnee, der sich in Wassser auflöst und verschwindet.

Schon Ovid hat das Buch als ein gefrorenes Gespräch bezeichnet ("accipe conloquium gelido Nasonis ab Histro", Pont. 2.4.1), und in diesem Sinne bleibt die Dimension der Schrift dem figurativen Wortgebrauch inhärent, auch wenn das Motiv des gefrorenen Wortes nicht ausdrücklich mit der Schrift assoziiert wird. So findet sich im Parzival Wolframs von Eschenbach eine Passage, die beiläufig das Problem von Wahrheit und Lüge behandelt. Bevor ein Wort ("ein maere") verfälscht werde, so konstatiert er, bliebe es besser herrenlos ("âne wirt") im Schnee. Wer es unrechtmäßig (unsachgemäß) als Wahrheit zu verbreiten suchte, würde sich deshalb den Mund daran verletzen. Demnach wird das externalisierte Wort, das heimatlos auf Eis liegt ("ûf eime snê"), nur dann tatsächlich flüssig oder warm, $d$. h. aber auch verwendbar, ohne zu verletzen, wenn es den richtigen Herrn ("wirt"Hausherr, Gastgeber) findet:

valsch lügelîch ein maere,

daz wane ich baz noch waere

âne wirt ûf eime snê,

sô daz dem munde wurde wê,

derz ûz vür wârheit breitet. ${ }^{33}$

Im Cortegiano des Balthasar Castiglione wird von einem Kaufmann aus Lucca berichtet, der am Dnjepr Zobelpelze kaufen will. Wegen des Kriegszustandes zwischen Polen und Russen müssen die Verhandlun- 
gen von Ufer zu Ufer, über den tiefgefrorenen Fluß hinweg geführt werden:

Nachdem sie einander durch einige Zeichen erkannt hatten, begannen die Moskauer laut zu rufen und den Preis zu verlangen, den sie für ihre Zobelpelze wollten; die Kälte war aber so heftig, daß sie nicht verstanden wurden. Denn ehe die Worte zum anderen Ufer gelangten, wo sich der Luccaner und seine Dolmetscher befanden, erstarrten sie in der Luft und blieben dort gefroren hängen, so daß die Polen, die die Gewohnheit kannten, sich entschlossen, mitten auf dem Fluß ein großes Feuer zu entzünden, weil dies nach ihrer Meinung die Grenze war, bis wohin die Stimmen noch warm gelangten, ehe sie vom Eis aufgefangen wurden. Der Fluß war auch noch so fest, daß er das Feuer gut ertragen konnte. Nachdem dies geschehen war, begannen die Worte, die eine Stunde lang eingefroren gewesen waren, zu schmelzen und wie im Mai der Schnee von den Bergen murmelnd herabzukommen. Und plötzlich wurden sie sehr gut verstanden, obwohl die anderen Männer schon abgezogen waren. ${ }^{34}$

Am Hof des Herzogs von Urbino wird diese Episode als Beispiel einer angenehm zu hörenden Lügengeschichte erzählt, aber das Bild der materiell im Raum hängenden Signifikanten ist ohne Anschauung der Schrift kaum denkbar.

Eine ähnliche Passage findet sich bei Rabelais in Gargantua und Pantagruel. Auf dem einsamen Nordmeer hören die irritierten Reisenden unidentifizierbare Stimmen. Sie sind darüber sehr erschrocken, doch der Steuermann beruhigt sie, indem er ihnen die befremdliche Erfahrung als ein Naturphänomen erklärt:

"Herr, Ihr braucht nicht zu erschrecken. Hier beginnt das Eismeer, wo Anfang vorigen Winters zwischen den Arimaspen und den Nephelibaten eine große, blutige Schlacht geschlagen wurde. Alle Worte und alles Geschrei der Männer und Weiber, das Aneinanderschlagen der Schwerter, das Dröhnen der Schilde und der Harnische, das Wiehern der Rosse, kurz, der ganze Lärm der Schlacht gefror damals. Jetzt, wo der harte Winter vorüber ist, taut das nun alles bei dem warmen, milden Wetter wieder auf und wird hörbar."- "Bei Gott", sagte Panurg, "ich glaube, so ist es. Aber könnten wir nicht auch etwas davon zu sehen kriegen? Ich erinnere mich, doch gelesen zu haben, daß drunten am Berg, auf dem Moses das Gesetz der Juden empfing, das Volk die Stimme mit den Augen sah."- "Seht, seht", sagte Pantagruel, "da sind noch einige 
nicht aufgetaut." Damit warf er uns ein paar Hände voll gefrorener Worte aufs Deck. ${ }^{35}$

Gesprochene Sprache bindet sich an die Erfahrung unmittelbar gegenwärtiger Personen. Die Stimme löst sich aus dem Körper des Sprechenden wie aus einem tönenden Instrument und findet Resonanz in einem Gegenüber. Rücken Sprecher und Hörer auseinander, werden sie getrennt durch Raum und Zeit (am anderen Ufer, Anfang des vorherigen Winters), so erscheint die Sprache kalt und sichtbar als gefrorene Form, materiell faßbar in ihren Bruchstücken und Fragmenten. Sie hat ihren Aggregatzustand verändert, wird nicht über die "warme" (luftige, fließende) Stimme hörbar, sondern sichtbar durch "kalte" (eisige, erstarrte, tote) Buchstaben. Fehlt der Kommunikation die Wärme der Lebendigkeit, friert die Stimme ein wie das lebendige Wasser unter dem Zugriff des Frostes: “Die Bedingung der Möglichkeit für Verfestigung im Medium der Schrift ist die Reduktion" ${ }^{36}$. Was wir Schrift nennen, impliziert die Ablösung der Kommunikation von allen körpersprachlichen Indizes wie Stimmhöhe, Artikulationstempo, Kontaktsignale, Gestik, Mimik oder Habitus. Texte sind charakterisiert durch die Dauer im Wandel, durch ihre erstarrte Gestalt. Derart befördert die Schrift ein Stück gefrorener Gegenwart in eine offene Zukunft oder wir "erwärmen uns" für ein altes Buch als einem Stück neu erlebter Vergangenheit. In diesem Sinne heißt es auch bei Kelber in seiner brillanten Studie zum Markus-Evangelium: "The objectifying, controlling power of the written medium, while taking the life out of spoken language, can freeze oral forms and preserve them in fossilized profiles" ${ }^{37}$. Gesprochene Worte sind unsichtbar. Sie erreichen eine dauerhafte Visualisierung ("permanent represential embodiment") nur unter der Preisgabe ihrer eigentlichen Natur, welche der Ton ist. ${ }^{38}$ Wie unsere Beispiele zeigen, geht dieser Wechsel gleichzeitig einher mit der Verräumlichung von Zeit. Der Ton, der sich hörbar in der Zeit realisiert, wird zum Buchstaben, der sichtbar im Raum steht. Die "gefrorene Sprache" wird erst wieder hörbar, aber zugleich auch unsichtbar, wenn die Atmosphäre "warm" wird, wenn die Buchstaben aufgetaut und als Sprachhandlung wieder verlebendigt werden. Mit dieser Metaphorik werden Phänomene der Sprachlosigkeit und der erneuten Kommunikation (vgl. noch heute "eine frostige Atmosphäre", "das Eis brechen"), die Konservierung des Wortes im Text und seine Wiederbelebung in der lectio besonders anschaulich beschrieben.

Eine Modifikation dieses Bildgebrauchs überliefert die Geschichte des Barons Münchhausen, dessen eingefrorenes Posthorn in der Wärme 
der Gaststube auftaut und fröhliche Weisen von sich gibt. Die Aktualisierung einer Tonkonserve im raumerfüllenden Klang, die hier mit einer Melodie assoziiert wird, findet sich auch im Libro de buen amor im Bild eines Musikinstrumentes gefaßt: "De todos instrumentos yo libro so pariente; bien o mal, qual puntares, tal te dira çiertamente; qual tu dezir quisieres, y faz punto, y tente; sy me puntar sopieres, sienpre me avras en miente" ${ }^{39}$. So greifen die Metaphern ineinander und verweisen auf ein größeres Bildfeld mündlicher und schriftlicher Verständigung, das einigen Aufschluß über die zeitgenössische Einschätzung der verschiedenen Modi von Kommunikation verspricht. Die Metaphern des Einspeisens, Auswerfens und Wiederkäuens einerseits, des Fließens und Erstarrens anderseits verweisen zurück auf die Mündlichkeit, sind aber bereits aus der Perspektive der Schrift gesehen. Die erste Metapherngruppe hält im Bild der Verkörperung fest an einer Vorstellung, wonach das Wort "Fleisch" werden muß, um tatsächlich Gestalt zu gewinnen. Der Wechsel der Aggregatzustände, der die zweite Gruppe der Metaphern auszeichnet, scheint demgegenüber den Wechsel von der Mündlichkeit zur Schriftlichkeit stärker zu thematisieren. Auch hier reicht die Verwendung der Metaphern bis in die Gegenwart; es scheint jedoch einen relativen Höhepunkt der Metaphernverwendung im 15. und 16. Jahrhundert zu geben. Vieles deutet darauf hin, daß die Zeiten großer Medienumbrüche mit einem gesteigertem Metapherngebrauch einhergehen, mit einer Akkumulation und Modifikation ganzer Bildfelder. Das könnte erklären, warum die Körpermetaphern, der Rückbezug auf körperliche Vorgänge und primäre Naturerfahrungen für verschiedene Medien bildgebend bleiben und immer neu adaptiert werden können (Datenfluß, Datenträger, einspeisen usw.). Die Metaphern der Mündlichkeit und Schriftlichkeit stehen in einem Verhältnis der Gleichzeitigkeit und der Nachzeitigkeit zueinander, verweisen auf die wechselseitige Modifikation von Körpergedächnis ("brain memory"), Schriftgedächtnis ("script memory"), Buchdruck ("print memory") und elektronischen Medien im diachronen und synchronen Zusammenhängen. Damit stellt sich jedoch grundsätzlich die Frage nach der Funktion der Metaphern im Spannungsfeld von Sprache und Gedächtnis.

\section{Zur Funktion der Metapher}

Schon Homer wird von Aristoteles dafür gerühmt, daß er mit Hilfe der Metapher das Unbelebte verlebendigt und in Bewegung versetzt habe: "Alles läßt er leben und sich bewegen, denn energeia (In-Wirksamkeit- 
begriffen-sein) und kinesis (Bewegung) sind ein und dasselbe" (Aristoteles, Rhetorik, 1412 a). ${ }^{40}$ In diesem Sinn versteht er die wirkende Kraft der Metapher als ein "Vor-Augen-Führen" bzw. "Verlebendigen", nicht im Sinne visueller Wahrnehmung, aber als Erstellung von mentalen Bildern auf der Grundlage sensorischer Wahrnehmungsfähigkeit. Die Schönheit der Metapher liegt in dem, was sie "vor Augen führt." Ricoeur interpretiert: "What is suggested here is a kind of pictorial dimension, wich can be called the picturing function of metaphorical meaning" 41 .

Für Blumenberg ist das Metaphorische ein für die Substruktur der Sprache und damit für die "Substruktur des Denkens" konstitutiver Faktor. Er unterscheidet jene Metaphern, die in sich "Restbestände" prälogisch-mythischen Denkens bewahrt haben und mit dem Instrument der wissenschaftlichen Metaphorologie rekonstruierbar sind, von den "absoluten Metaphern", die sich nicht in Begrifflichkeit auflösen lassen und damit auch durch nichts ersetzbar sind. ${ }^{42}$ Die postulierte Metaphorologie soll faßbar machen, "mit welchem 'Mut' sich der Geist in seinen Bildern selbst voraus ist und wie sich im Mut zur Vermutung seine Geschichte entwirft" 43 . Sein Verständnis der "vorauseilenden Metapher" verbindet sich derart mit dem qualitativen Gesichtspunkt der Welterschließung: "Wenn wir schon einsehen müssen, daß wir nicht die Wahrheit von der Wissenschaft erwarten dürfen, so wollen wir doch wenigstens wissen, weshalb wir wissen wollten, was zu wissen nun mit Enttäuschung verbunden ist. Metaphern sind in diesem Sinne Leitfossilien einer archaischen Schicht des Prozesses der theoretischen Neugierde, die nicht deshalb anachronistisch sein muß, weil es zu der Fülle ihrer Stimulation und Wahrheitserwartungen keinen Rückweg gibt" ${ }^{44}$. Die Metapher geht der gesicherten Erkenntnis antizipierend voraus und signalisiert damit die Aufgaben der wissenschaftlichen Begriffsbildung: "Es ist in der Funktion der Metapher begründet, daß sie etwas Vorausgreifendes, über den Bereich des theoretisch Gesicherten Hinausgehendes hat" ${ }^{45}$. Vom Mythos zur Wissenschaft führt die Bewegung bei Blumenberg im Sinne einer aufklärenden (aufklärerischen) Metaphernforschung, einer wissenschaftlichen Metaphorologie.

Wilhelm Köller hat dagegen die Leistung der Metapher als gegenläufige Tendenz zur Formalisierung der Sprache hervorgehoben. ${ }^{46}$ Damit ist, und das scheint mir berechtigt, die Umkehrung der antizipatorischen Tendenz erfaßt, die Blumenberg hervorgehoben hat: Was in den "jungen" Kulturen als Komplexitätssteigerung der Sprache in Richtung auf eine zunehmende Abstraktion gedeutet werden kann, erscheint aus der Perspektive der stärker formalisierten und höher 
abstrahierten ("alten") Sprachen als eine Rückbindung an das sensorische Vorstellungsvermögen des Menschen; als Rekurs auf die ikonische Potenz der Sprache.

Gegenüber Blumenberg und Köller zeigt sich an den Metaphern unseres Beobachtungsfeldes eine zusätzliche Funktion: die Metaphern überbrücken die kategorialen Gegensätze medialer Systeme. Die Metaphern der Schrift, des Buchdrucks und der elektronischen Medien demonstrieren für den reflexiven Zugriff eine technologisch bedingte Distanz vom Raum der sensorischen Wahrnehmung, sichern jedoch auf der Ebene der Bildlichkeit die Integration in die Erfahrung des Menschen mit dem Menschen (einspeisen, auswerfen) und seiner natürlichen Umwelt (Wasser, Frost). Schon die Metaphern der Schriftlichkeit koppeln unterschiedliche Erfahrungsfelder und führen die abstrakteren (technischen) Verhältnisse zurück auf eine Ebene konkreter, durch Konsens gesicherter Erfahrung. Ein solcher Kopplungsbedarf erscheint immer dann besonders groß und die Produktivität der Metaphernbildung besonders deutlich, wenn die mediale Situation sich grundlegend verändert. Die Metaphorisierung der Schrift ist dafür nur ein erstes Beispiel und verweist auf eine Tendenz, die sich auch in der sprachlichen Aneignung des neuen Mediums zeigt, das im 16. und 17. Jahrhundert zunehmend an Raum gewinnt. Die Körpermetaphorik bleibt mit der Schrift gekoppelt, verbindet sich aber auch mit der Technik der Druckerpresse: "Auswerfen", "Ausstoßen", "Ausstoß", "Ausdruck" usw. können körperliche oder maschinelle Vorgänge beschreiben.

Die Kopplungsfunktion der Metaphern ist jedoch nicht auf szientifische Weise mißzuverstehen. Sie gibt durchaus Raum für (unterschiedliche) Wertungen. Schließlich heißt es von einem, der "redet wie ein Buch", mitunter auch, daß er "lügt wie gedruckt." Der Druck verändert die strengen Selektionsregeln der handschriftlichen überlieferung und sprengt die etablierten Grenzen der Gedächtnisökonomie, die von der Schrift bereits erweitert worden sind. Das Gültige und das Ungültige bleibt in Bibliotheken erhalten und wird als Nachlaß auf die Erben abgewälzt. Insofern hat der Druck mit der Frage nach Wahrheit und Lüge tatsächlich viel zu tun. Der Siegeszug der Schreibcomputer hat diese Tendenz verstärkt und das Verhältnis von verbaler und technisch gestützter Kommunikation in eine neue Qualität überführt. Das Wort von der "Schnittfläche" ("interface") zwischen Mensch und Maschine demonstriert, daß die Kommunikation von Angesicht zu Angesicht sich zur Selbstwahrnehmung im Spiegel der Maschine gewandelt hat. Tröstlich mag es dabei sein, sich zu vergegenwärtigen, $\mathrm{da}$ schon das Buch als externalisiertes menschliches Gedächtnis mit dem Körperschema ("corpus") assoziiert worden ist. 
Metaphern haben für die sprachliche Erfassung unserer Gegenwart und unserer Geschichte eine hohe Aussagekraft. Eco formuliert die These, "che la metafora abbia qualcosa a che fare con la nostra esperienza interna del mondo e con i nostri processi emotivi" ${ }^{47}$, daß die Metapher mit unseren Erfahrungen in der Welt und unseren emotionalen Einstellungen viel zu tun hat. Folgerichtig kommt er zu dem Schluß, daß die Metaphern immer in einem gegebenen kulturellen und intertextuellen Umfeld funktionieren, aber nicht übertragbar sind in eine andere Erfahrungswelt: " $\mathrm{Ci}$ sono dunque metafore che possono funzionare in un dato universo culturale e intertestuale, ma che sono inconcepibili in un universo diverso" 48 .

\section{Anmerkungen}

1. Walter Haug, Literaturtheorie im deutschen Mittelalter. Von den Anfängen bis zum Ende des 13. Jahrhunderts: Eine Einführung (Darmstadt: Wissenschaftliche Buchgesellschaft, 1985).

2. Das Motiv selbst findet sich schon in der Antike in einer Traumdeutung des Artemidor. Danach bringt das Verzehren von Büchern "Erziehern und Sophisten und allen, die vom Reden oder Büchern leben, Nutzen. Allen anderen Menschen prophezeit es den baldigen Tod" (Gabriele Wissig-Bavig, Die Anrede an das Buch in der römischen Dichtung. Studien zum Verhältnis des Dichters $z$ u seinem Werk, Europäische Hochschulschriften, Reihe 15, Bd. 40 [Frankfurt a. M.: Peter Lang, 1991], S. 168).

3. [Die Stimme aber sprach zu mir in erbarmender Fürsorge: “Geh, nimm das aufgeschlagene Buch, das der Engel in der Hand hält, der auf dem Meer und auf dem Land steht." Seinem Wort habe ich mich anvertraut und ließ mir das Buch geben. Der Engel gab es mir. "Nimm", sprach er "du sollst es roh (rauh / hart) verschlingen, so wird es deinem Bauch bitter werden, aber nach einer mäßigen Stunde wird es in deinem Mund wie süßer Honig sein." Das Buch nehme ich zu meinem Vorteil, verschlinge es durch meinen Mund. Da bekam es alsbald den Geschmack des süßen Honigs zwischen meinen Kinnbacken und den Geschmack der Bitternis in meinem Bauch, als hätte ich eine Krankheit. Da sprach der Engel mich auf diese Veränderung an: "Auf eine andere Weise, als ich zuletzt von dir ging, mußt du nun dem Volke predigen: Völkern, Königen, Sprachen aller Gemeinschaften."] Die Apokalypse Heinrichs von Hesler, aus der Danziger Handschrift, hg. v. Karl Helm, Dichtungen des Deutschen Ordens 1; Deutsche Texte des Mittelalters, 8 (Berlin: Weidmann, 1907), Sp. 15301-3. Zum Essen und Trinken der Wörter vgl. auch Michael Camille, "Visual Signs of the Sacred Page: Books in the Bible Moralisée", Word E Image 5 (1989): 117-18.

4. [Daß er ihn aufforderte das Buch zu verschlingen, das bedeutet: Die Schrift sollst du durchforschen (umgraben) nach ihrem verborgenen Sinn, damit du den ganz erfährst und wie eine Speise in dich aufnimmst mit dem 
Verlangen aller deiner Sinne. Wenn du mit Hunger daran gehst, so bleibt für dich nichts im Dunkeln.] Hesler, Apokalypse, Sp. 15376-77.

5. Klaus Lange, "Geistliche Speise. Untersuchungen zur Metaphorik der Bibelhermeneutik", Zeitschrift für deutsches Altertum 95 (1966): 111-12.

6. Manfred Schneider, Liebe und Betrug: Die Sprachen des Verlangens (München: Hanser 1992), S. 368-80.

7. Ernst Robert Curtius, Europäische Literatur und lateinisches Mittelalter (Bern: Francke, 1973), S. 145.

8. Ebd., S. 144.

9. Michel Jeanneret, A Feast of Words: Banquets and Table Talk in the Renaissance, übers. v. Jeremy Whiteley u. Emma Hughes (Cambridge: Cambridge University Press, 1991), S. 129.

10. Ebd., S. 112-17.

11. François Rabelais, Gargantua und Pantagruel, hg. v. Ludwig Schrader (München: Hanser, 1964), 2:322.

12. Aleida Assmann, "Fest und Flüssig: Anmerkungen zu einer Denkfigur", in Kultur als Lebenswelt und Monument, hg. v. Aleida Assmann und Dietrich Harth (Frankfurt a. M.: Fischer, 1991), S. 11-26.

13. Robert Weninger, "Allegorien der Naturwissenschaft oder: Intentionalität versus Intertextualität als Problem der Arno-Schmidt-Forschung", in Arno Schmidt am Pazifik: Deutsch-amerikanische Blicke auf sein Werk, hg. v. Timm Menke (München: Edition Text und Kritik, 1992), S. 26.

14. James A. Willis, De Martiano Capella emendando, Mnemosyne, Suppl. 18, Bd. 2 (Leiden: Brill, 1970), S. 135-38.

15. [Da spieh sie alles aus, was ihr die Brust verstopfte, wie sie fühlte. So geschah es, daß sie mit Mühen alle Arten von Büchern ausbrach. Denn von einem Quellgrund der Vernunft ("fonte rationis") kommt alle Weisheit der Bücher. Da hättest du sehen können, wie viele einzelne Bücher und Sammelwerke und wie viele Werke verschiedener Sprachen aus ihrem Munde fuhren. Einige waren aus Papyrus (der ägyptischen Binse) gemacht, der mit Zedernharz beschmiert war, damit er nicht faulte. Einige Bücher waren in Leinen gebunden, andere aus dem Pergament von Schafen, wenige waren auf der Rinde des Baumes "phillire" geschrieben, wie es der Brauch war. Einige waren mit Tinte beschrieben. die Schrift dieser Bücher führte Bilder der Lebenden vor Augen.] Notker der Deutsche, Martianus Capella "De nuptiis Philologiae et Mercurii", in Werke, hg. v. James C. King (Tübingen: Niemeyer, 1979), 4:124-25. Vgl. Herbert Backes, Die Hochzeit Merkurs und der Philologie: Studien zu Notkers Martian-Übersetzung (Sigmaringen: Thorbecke, 1982), S. $152-54$.

16. Engelbert Kirschbaum, Lexikon der christlichen Ikonographie (Rom: Herder, 1968-76), 4:529.

17. [Daß alle, die Gottes Kinder werden wollen, Laien und auch Frauen, lesen (hören) mögen und schauen, schmecken und ergründen von dem Sohn] Priester Wernher, Maria: Bruchstücke und Umarbeitungen, hg. v. Carl Wesle, 2. Aufl. besorgt durch Hans Fromm (Tübingen: Niemeyer, 1969), S. 141-42.

18. [Die Lektüre ist unabhängig und läuft nicht mit dem Ungestüm der 
vorgetragenen Rede ab, sondern sie kann immer wieder zurückgreifen, falls man Zweifel hat oder man es dem Gedächtnis fest einprägen will. Zurückgreifen aber wollen wir und grundsätzlich es immer wieder neu vornehmen, und wie wir die Speisen zerkaut und fast flüssig hinunterschlucken, damit sie leichter verdaut werden, so soll unsere Lektüre nicht roh, sondern durch vieles Wiederholen mürbe und gleichsam zerkleinert unserem Gedächtnis und Vorrat an Mustern (zur Nachahmung) einverleibt werden.] Marcus F. Quintilianus, Ausbildung des Redners, hg. u. übers. v. Helmut Rahn, Teil 1 [Buch 1-6], Teil 2 [Buch 7-12] (Darmstadt: Wissenschaftliche Buchgesellschaft, 1972-75), Buch 10.1:19.

19. Pseudo Aristeas-Brief, §142-44. Zitiert nach Hermann L. Strack u. Paul Billerbeck, Kommentar zum neuen Testament aus Talmud und Midrash. 3. Bd. Die Briefe des Neuen Testaments und die Offenbarung Johannes (München: Beck, 1926), S. 387.

20. Frencesco Petrarca, Lettere, hg. v. Giuseppe Fracassetti, 5 Bde. (Florenz: Le Monnier, 1863-67), 5:422. Zitiert nach Jeanneret, A Feast of Words, S. 138.

21. Josef Balogh, “Voces paginarum: Beiträge zur Geschichte des lauten Lesens und Schreibens", Philologus 82 (1927): 84-109, 202-40.

22. Zu ruminatio vgl. Jean Leclerq, Wissenschaft und Gottverlangen: Zur Mönchstheologie des Mittelalters, aus dem Französischen übertr. v. Johannes und Nicole Stöber (Düsseldorf: Patmos, 1963), S. 84-89. Zur Metapher des Wiederkäuens und zu venter als Synonym für memoria vgl. Mary J. Carruthers, The Book of Memory: A Study of Memory in Medieval Culture, Cambridge Studies in Medieval Literature, 10 (Cambridge: Cambridge University Press, 1990), S. 164-72.

23. Carruthers, The Book of Memory, S. 35.

24. Leclerq, Wissenschaft und Gottverlangen, S. 26.

25. Paul Zumthor, "Mittelalterlicher 'Stil': Plädoyer für eine 'anthropologische' Konzeption", in Stil: Geschichten und Funktionen eines kulturwissenschaftlichen Diskurselements, hg. v. Hans Ulrich Gumbrecht u. Karl Ludwig Pfeiffer (Frankfurt a. M.: Suhrkamp, 1986), S. 484. Als performanzbezogene Elemente zieht Zumthor eine Reihe von Unterscheidungen in Betracht: "Im Blick auf den 'Interpreten', den Vortragenden, sind dies Ton, Modulierung und Spiel der Stimme, Mimik, Gestik, gegebenenfalls Kleidung oder 'Accessoires'.Beim Hörer handelt es sich um Erwartung und die sie begründenden vorgängigen Kenntnisse, um seelisch-körperliche Reaktionen beim Zuhören.Schließlich spielen die zeitlichen und räumlichen Verhältnisse eine wichtige Rolle" (S. 485-86).

26. Ebd., S. 486. Vgl. Maurice Merleau-Ponty, Phänomenologie der Wahrnehmung, aus dem Französischen übers. v. Rudolf Boehm, Phänomenologischpsychologische Forschungen, 7 (Berlin: de Gruyter, 1966), S. 176; Thomas Luckmann, "Das Gespräch", in Das Gespräch, hg. v. Karlheinz Stierle u. Rainer Warning, Poetik und Hermeneutik, 11 (München: Fink, 1984) S. 54.

27. Paul Zumthor, La poésie et la voix dans la civilisation médiévale (Paris: Presses Universitaires de France, 1984), S. 48. Auch die visuelle Organisation der materiellen Zeichenträger selbst ist dabei von Bedeutung. Schon Trithemius lobt 


\section{Horst Wenzel}

die alten Schreiber, die auf das Schreiben so große Sorgfalt verwandten, daß sie nicht nur richtig schrieben, sondern darin so vollkommen waren, daß sie ihre Codices in schöner Differenzierung durch Hervorhebungen, Trennungszeichen und Schmuckinitialen aufteilten, so daß man sich allein schon durch ihren Anblick zur Lektüre angeregt fühlt.

28. [Ich will dir auch erklären, was die steinernen Krüge bedeuten: im gläubigen Verständnis sind es die Herzen der Anhänger Gottes. Innen sind sie hohl, gefüllt mit heiliger Schrift, womit sie uns stets Köstliches zu trinken bieten. Klares Quellwasser, das schenken sie uns auf köstliche Weise; soll man es aber in geistlicher Weise benennen, so schenken sie uns anderseits auch guten Wein. Diese Männer verstehen es alle: So können sie voll Sorgfalt aus den Büchern zu uns sprechen.] Otfrid von Weißenburg, Liber Evangeliorum, 2.9, V. 11-18.

29. [Willst du die ganze Weltgeschichte durchgehen, dann kannst du dich vollständig versorgen, dir zweierlei Trank verschaffen. Folge stets ohne Vorbehalt mit all deiner Kraft der (Heiligen) Schrift! Dann sorgst du oft auf verständige Weise für kühlenden Trunk. Zugleich bedenke wohl den geistlichen Sinn der Worte, so läßt du deinem Geist heiligen Wein zukommen.] Ebd. V. 89-94. Vgl. Friedrich Ohly, "Geistige Süße bei Otfried", in Schriften zur mittelalterlichen Bedeutungsforschung (Darmstadt: Wissenschaftliche Buchgesellschaft, 1983) S. 106. Die allegorische Ausdeutung des geistlichen Wortes mit dem Wein, wobei dem literalen Sinn der Schrift die Metapher des Wassers vorbehalten bleibt, hat sich allerdings nicht endgültig durchgesetzt. Bei dem Zisterzienser Arnulf von Bohéries etwa heißt es: "Die Heilige Schrift ist der Brunnen Jakobs, aus dem man Wasser heraufzieht und es dann im Gebet austeilt" (Speculum Monachorum, 1, P. L. 184, 1175, nach Leclerq, Wissenschaft und Gottverlangen, S. 86).

30. Bible moralisée: Codex Vindobonensis 2554 der Õsterreichischen Nationalbibliothek Transkription und Übersetzung v. Hans-Walter Stork Saarbrücker Hochschulschriften, 9 (St. Ingbert: W. J. Rührig, 1988), S. 69.

31. [Um tiefe Worte sollen sich große Lehrer kümmern, aus vollen Brunnen fließt der Sinn und ergießt sich weit in alle Lande ... Renner, V. 13941-44.

32. Nach Ordericus Vitalis, The Ecclesiastical History of England, übers. v. T. Forster (London: H. G. Bohn, 1854) 2:284-85. Vgl. Michael T. Clanchy, From Memory to Written Record: England 1066-1307 (Cambridge, Mass.: Harvard University Press, 1979), S. 117; Jack Goody, Die Logik der Schrift und die Organisation von Gesellschaft, übers. v. Uwe Opolka (Frankfurt a. M.: Suhrkamp, 1990), S. 266. Zurückzuverfolgen ist das Motiv bis zu Plutarch, von dem nur zu vermuten ist, daß er bereits aus der Perspektive des Schriftstellers (der Schriftlichkeit, des litteratus) argumentiert: "Antiphanes sagte scherzend, in einer bestimmten Stadt frören die Worte wegen der Kälte im Augenblick des Aussprechens ein; später tauten sie dann auf, und die Menschen hörten, was sie im Winter zueinander gesprochen hatten. So sei es auch, meinte er, mit dem, was Platon zu jungen Menschen sagte: die allermeisten von ihnen begriffen es, wenn überhaupt, dann erst spät, erst als alte Männer" (Plutarch, Quo- 
modo quis suos in virtute sentiat profectus, 7, nach Rabelais, Gargantua und Pantagruel, S. 406).

33. [Lügenerzählungen sollte man obdachlos im Schnee aussetzen, so daß dem der Mund wehtäte, der sie als Wahrheit zu verbreiten suchte.] Parzival, 7, V. 17-22.

34. Baldesar Castiglione, Das Buch vom Hofmann. [Il Libro del Cortegiano], übers. v. Fritz Baumgart, mit einem Nachwort von Roger Willemsen (München: Fink, 1986), S. 183-84. Im Original heißt es:

Così conosciutisi l'un l'altro dopo alcuni cenni, li Moscoviti cominciarono a parlar alto e domandare il prezzo che volevano de' loro zibellini, ma tanto era estremo il freddo, che non erano intensi; perché le parole, prima che giungessero all'altra riva, dove era questo luchese e i suoi interpreti, si gelavano in aria e vi restavano ghiacciate e prese di modo, che quei Poloni che sapeano il costume, presero per partito di far un gran foco proprio al mezzo del fiume, perché a lor parere quello era il termine dove giungeva la voce ancor calda prima che ella fosse dal ghiaccio intercetta; ed ancora il fiume era tanto sodo, che ben poteva sostenere il foco. Onde, fatto questo, le parole, che per spacio d'un'ora erano state ghiacciate, cominciarono a liquefarsi e descender giù mormorando, come la neve dai monti il maggio; e così sùbito furono intese benissimo, benché già gli omini di là fossero partiti" (ebd., Buch 2, Kap. 55, S. 200-1).

35. François Rabelais, Gargantua und Pantagruel, hg. v. Horst Heintze u. Edith Heintze, 2 Bde. (Frankfurt a. M.: Insel, 1974), 2:169-70. Bei Jean Guiton, der auf Plutarch verweist und weitere Quellen nennt, heißt es bereits: "Le mythe qui nous occupe pourrait s'interpreter ainsi les paroles, méme invisibiles, demeurent; elles peuvent disparaître pour un temps, mortes en apparence, elles n'en vivent pas moins, perpétuant les actes périssables; les cris survivent à la bataille et l'homme, quand il joue avec ces forces étranges devient un créateur, un poète" (Jean Guiton, "Le Mythe des paroles gelées", The Romanic Review 31 [1940]: 15). Zustimmend Leo Spitzer, "Rabelais et les 'rabelaisants'", Studi Francesi 4 (1960): 402-5. Zur Vervollständigung vgl. die klimatologische Argumentation von Abraham C. Keller, "The Geophysics of Rabelais' Frozen Words", in Renaissance and Other Studies in Honor of William Leon Wiley, hg. v. George Bernard Daniel, Studies in the Romance Languages and Literatures, 72 (Chapel Hill: University of North Carolina Press, 1968) S. 151-65.

36. Assmann, "Fest und Flüssig", S. 189.

37. Werner H. Kelber, The Oral and the Written Gospel: The Hermeneutics of Speaking and Writing in the Synoptic Tradition, Mark, Paul, and Q (Philadelphia: Fortress Press, 1983), S. 44.

38. Ebd., S. 33.

39. [Ich, das Buch, bin ein Verwandter der Musikinstrumente: gut oder schlecht, je nachdem wie Du auf mir spielst, werde ich klingen; was Du sagen möchtest, das mußt Du auf mir spielen; und wenn Du auf mir zu spielen 


\section{Horst Wenzel}

verstehst, dann mußt Du immer an mich denken.] Juan Ruiz, Arcipreste de Hita, Libro de buen amor, übers. v. Hans Ulrich Gumbrecht, Klassische Texte des romanischen Mittelalters, 10 (München: Fink, 1972), nach Hans Ulrich Gumbrecht, Eine Geschichte der spanischen Literatur (Frankfurt a. M.: Suhrkamp, 1990), S. 103-4, 1079.

40. Vgl. Aristoteles, Rhetorik, übers. v. Franz G. Sieveke (München: Fink, 1980), S. 194.

41. Paul Ricoeur, "The Metaphorical Process as Cognition, Imagination, and Feeling", in On Metaphor, hg. v. Sheldon Sacks (Chicago: University of Chicago Press, 1979), S. 142.

42. Hans Blumenberg, "Paradigmen zu einer Metaphorologie", Archiv für Begriffsgeschichte 6 (1960): 9-10.

43. Ebd., S. 11.

44. Hans Blumenberg, Schiffbruch mit Zuschauer: Paradigma einer Daseinsmetapher (Frankfurt a. M.: Suhrkamp, 1979), S. 77.

45. Hans Blumenberg, "Beobachtungen an Metaphern", Archiv für Begriffsgeschichte 15 (1971): 212.

46. Wilhelm Köller, Semiotik und Metapher: Untersuchungen zur grammatischen Struktur und kommunikativen Funktion von Metaphern, Studien zur Allgemeinen und Vergleichenden Literaturwissenschaft, 10 (Stuttgart: Metzler, 1975) S. 195-96.

47. Umberto Eco, I limiti dell' interpretatizione (Mailand: Bompiani, 1990), S. 150.

48. Ebd., S. 157. Vgl. George Lakoff u. Mark Johnson, Metaphors We Live By (Chicago: University of Chicago Press, 1980). 


\title{
6. Johannes Kepler: Poetic Inspiration and Scientific Discovery
}

\author{
C. Stephen Jaeger
}

Welches Genie das grösste wohl sei? Das grösste ist dieses, Welches, umstrickt von der Kunst, bleibt auf der Spur der Natur. ${ }^{1}$

The emergence of a "New Historicism" in literary studies in the past years has generated anxiety of a kind that comes with paradigm shifts. ${ }^{2}$ One of the causes of anxiety is the fundamental, ordinarily implicit thrust of that trend, to question the claim of empirical rationalism as the foundation of serious literary studies and to assert the role of imagination as a basic critical function. Even less explicit because more deeply hidden in the motor forces of this trend is the assumption that events in human affairs, and even physical reality itself, possess, beyond the surface appearance of unpredictability, a poetic deep-structure that betrays a planning and ordering consciousness operating both as artist and engineer, in a way that the empirical disciplines do not willingly credit as "scientific." The "new historical" study of literature proceeds from the assumption of literary structures in reality and human experience. That assumption is explicit in the idea of a "poetics of culture" (which Greenblatt prefers to "New Historicism"). This idea sets an agenda of humanistic study, a broadly comparative enterprise to infer from all forms of representation-including social, political, artistic - an underlying "poetics." Within this enterprise, literature is a particularly rich bearer of congruences that mirror that external work of art, reality. This conception of a general aesthetic of representation makes literary interpretation something quite different from the quasi-scientific text study grounded on the twin pillars of philology and "Literaturwissenschaft," different also from the new critical enterprise of severing the text from anything outside of it, and akin to but beyond the late romantic, deconstructionist project of textualizing reality.

The primacy of the imagination does not necessarily diminish the rigor of literary studies and the general validity of its insights. Still, its claim of a place in the methodological premises of criticism is a cause 
of deep skepticism to a generation that feels the anchor of its discipline cut away and literary studies left adrift in the tides of arbitrariness.

The idea that empirical rationalism has privileged access to the truth and that its discoveries are more firmly grounded than those of the critical imagination has a life cycle; it represents a historical phase of Western thought. The two alternate in their domination of inquiry, as Aristotelianism alternates with Platonism. Occasionally they cooperate. Literary studies in America are at present in a phase where, after radical questioning of their rationalistic premises, they are moving toward a conception that gives the imagination priority over scientific or quasi-scientific method as the basic faculty of critical commentary.

This trend coincides with a strain in current theory of science, which sees the poetic imagination as a force in the construction of nature. The aesthetic sense is not only at work in the perception and interpretation of reality, but in the making of it. It follows from this assumption that the imagination must have a high value for the research scientist in reconstructing its laws. The recent book by Robert Pollack, Signs of Life, to take only one example, analyzes the structure of DNA using a linguistic model. The author speaks of the grammar and syntax of molecules, and suggests that DNA strands represent a kind of natural poetry. ${ }^{3}$

If the universe is poetically constructed, then scientists and literary scholars have a lot to talk about. This kind of dialogue has received strong stimulus from the side of literary studies in the writings of Katherine Hayles and in the recent collection of essays she edited, Chaos and Order: Complex Dynamics in Literature and Science. ${ }^{4}$

The conception of nature and significant human experience as works of art has a long history, which has yet to be written. The last decades of the twentieth century will have some modest claim to attention in such a study when it is written. It will certainly include a renewed interest in the writings of Johannes Kepler in this period. ${ }^{5}$ Kepler was an astronomer and mathematician who seemed in his conceptualizing of science barely to distinguish between an empirical and a poetic/musical mode. He regarded the cosmos as a decidedly musical, architectonic composition, and made his discoveries about its structure in a mode that looks to modern viewers like musical/poetical inspiration. This study looks at the context of discovery in Kepler. He is a model case of a scientist in whom the assumption of the "poetic structure of the world" and the poetical mode of the investigator's mind produced results of immense importance of empirical, rational science. ${ }^{6}$

Fortunately Kepler liked to talk about his work. The later division of the scientist's life into private searcher and public discoverer (Newton $)^{7}$ did not exist for him. He published his discoveries imbedded in narratives of the process that led to them. 
As a young man he thought he had discovered the secret of the architecture of the heavens. He described his approach to the discovery in the preface of his book, The Cosmographic Mystery (1596; 2d ed., 1621). As a student at the University of Tübingen he was introduced to the Copernican universe in the lectures of his mathematics professor, Michael Mästlin. He began to gather arguments for the superiority of the Copernican model over the Ptolemaic. This phase continued over a number of years, and he compared the task with that of Sisyphus. Finally he was able to take some time from his post as teacher of mathematics at the Protestant school in Graz to devote himself entirely to his studies. His conviction that the heavenly bodies at rest-sun, fixed stars, and intermediate space-were patterned on the Trinity led him to pursue Trinitarian models as an explanation for the number, the size, and the motions of the planets. After long study and many fruitless thought experiments, he turned to God and swore to the maker of the universe with many vows and oaths that, if he revealed to him the workings of the universe, he, Kepler, would defend the truth of the Copernican system. Finally one day, as he was in the middle of a lecture on planetary motion, the answer came to him: geometrical figures hold the key to the size, number, and spacing of the planets. He experimented with triangles, squares, and pentagons, placing them as spacers in intervals that corresponded to the presumed distance between the planets. He realized the approach was wrong, but it brought him to the final question prior to plenary discovery: why use plane figures when dealing with a three-dimensional system? He began to experiment with solid geometrical bodies, and these unlocked to him the mystery of cosmic architecture. The five so-called regular solids are the key.

Ancient philosophers and mathematicians had puzzled over the fact that there are only five regular solids, that is, figures constructed of plane polygons (the cube, for instance, constructed of squares) in which each surface is identical with every other, and the whole fits together in perfect symmetry with no gaps, can be inscribed in a sphere such that each of its corners touches the surface of the sphere, and can circumscribe a sphere such that the sphere touches each of its surfaces exactly in the middle.

The model of the five solids is the key, and once the plans for the construction of the universe are revealed to him in brilliant illumination, he explains them to the reader "in the very words in which it was conceived at that moment." 8 He imagines a demiurge-God sitting in his workshop planning out the universal building with the regular solids on his worktable. When God ran out of regular solids, he stopped making planets; when he reached the bounds of inner and outer circle in 
any one of the figures, he stepped out of his workshop and set the planet in place in a size and distance from the previous that reproduced the very proportions determined by the network of solids and superscribed spheres. It almost seemed to Kepler as if God himself had learned his art of universe building from human architects. He promises to reveal in his work "how God, like one of our own architects, approached the task of constructing the universe with order and pattern, and laid out the individual parts accordingly, as if it were not art which imitated Nature, but God himself had looked to the mode of building of Man." 9

This glimpse into the workshop of the demiurge was granted him not by persistent reasoning induction but by divine grace. In the dedicatory letter to the 1621 edition of Mysterium, he cautions the reader not to take the book as a contrivance of his own intellect, but rather "just as if it had been dictated to my pen, an oracle fallen from heaven, every chapter of the little book was recognized at once, by those who understood it, as important and quite true (as manifest works of God usually are)." 10 Kepler himself just meditated; he "touched the seven-stringed psaltery of Creative Wisdom" and gave voice to the writings in the book of Nature, putting into words the glory of God as proclaimed by the heavens themselves.

We see Kepler here caught between the megalomania and humility of the man who takes himself to be the mouthpiece of a god, often the dilemma of discoverers who understand their ideas as a completely extrapersonal merit, a gift from some outside source. In his later work, Harmonices Mundi (1619), he again explains the circumstances surrounding his perception of world harmony, and he again resorts to the idea of inspiration: God himself had implanted in him, he relates, an "enormous desire" to investigate the heavenly harmonies, and he "inspired his mind" (mentem inspiraverat). Here Kepler places himself in a line of descent from physicists whom God had elected personally to receive his revelation: fifteen hundred years earlier he had chosen Ptolemy as his vessel (who also had written a book on the heavenly harmony). Now he has chosen Kepler as the successor of the famous Egyptian astronomer: "Nature itself wanted to reveal itself to men in various centuries as its interpreters," and it can only be God's finger that pointed two astronomers independently (Kepler read Ptolemy only after writing most of his Harmonics) to the insight into the musical nature of cosmic composition. Now Kepler depicts himself standing at the very threshhold of the final revelation: eighteen months previous he had glimpsed the first light, three months before the bright day, and a few days prior to writing, "the full sun of a most wonderful vision": 
"nothing restrains me any longer. I am free to indulge in sacred raving [sacer furor], free to fling into the face of mortal men the open confession that I have stolen the golden vessels of the Egyptians to set up for my God a tabernacle far from the borders of Egypt. .. . The die is cast, the book is written, whether for the present generation or for posterity, it is no matter. Let it wait one hundred years for its reader; God himself waited six thousand years for his!" 11

Kepler's discoveries came to him in a torrent of emotion. The insight into the musical harmony of the world came in a state of "sacred raving." The moment of discovery has this ecstatic character, as he is glad to point out. The mystery of the five solids caused him a delight that he "will never be able to express in words." 12 He wrote to Michael Mästlin, on August 1, 1595, telling him of the discovery. It came to him, he says, so powerfully that he "shed profuse tears." 13 And again writing to Mästlin on October 3 of the same year: "Behold how close I come to the truth. And doubt not that as often as something like this comes to me, I shed tears abundantly." ${ }^{14}$ In the Epitome of Copernican Astronomy he speaks of the "unbelievable delight" that fills him when he recognizes and contemplates the beauty of his idea. ${ }^{15}$

There are fewer clearer insights into Kepler's self-conception as a scientist than the hieratic atmosphere he builds around the experience of discovery: his scientific work is a quest after the ideas of the creator; and if he receives insight into them, it is by special grace that God grants to Kepler as his elect astronomer. He investigates with a sense of religious mission, part of which is to mediate between God's mysteries and mankind. Truth comes in the divine rage (sacer furor) of Platonic inspiration. He is the new Moses. He is the interpreter of the book of nature, chosen personally by God on high for the task. Kepler imagines God first selecting Ptolemy as the chosen one to receive the insight into world harmonics, and then patiently biding his time until the second coming of an elect astronomer, Kepler. He describes this sense of election in a striking passage from the Astronomia Nova (1609): "There is . . a certain determination of destiny that works in secret, leads particular men up to the various arts and sciences, and lends them a sense of certainty that they, while a part of the work of creation, still participate in divine providence." 16

"Participation in divine providence" is a bold formulation. It points to a strain in Kepler's thinking that he has in common with both inspired geniuses and inspired madmen: absolute certainty of the truth of his insights. His confidence in his thoughts is absolute because they are not his; he is just following a path that has been cleared before him and opened to him by a much greater mind. In the epigram that intro- 
duces the Mysterium Cosmographicum he quotes verses that he ascribes to Ptolemy: "I know that I am mortal and ephemeral. But when I search for the close-knit encompassing convolutions of the stars, my feet no longer touch the earth, but in the presence of Zeus himself I take my fill of ambrosia which the gods produce." ${ }^{17}$ The hieratic tone of Kepler's thinking shows again in the priest's role in which he regularly cast himself. He and other elect astronomers are "priests of the highest God" whose sacred book is Nature itself. ${ }^{18}$ His sanctuary and realm of worship are the mystery of nature. He imagines his book, Cosmographic Mystery, as "standing guard at the gates of the temple where Copernicus performs the sacred rites at the high altar." ${ }^{19}$ He leads his generation to the cosmic mysteries through new astronomies, as Moses led the Jews out of Egyptian captivity. His book on celestial harmony, following the Egyptian Ptolemy, is "gold from Egypt" to adorn the temple of Jehovah.

The god of astronomers is everywhere at work in Kepler's life. Any coincidence that favored his work is explained as divine intervention and the furthering of a higher plan. He knows that Tycho Brahe's observations on planetary motion are vital to his work, but he fears the trip to Denmark. Lo and behold, Brahe plans a trip to Prague, and Kepler takes this for an act of "divine guidance." They meet just at the time when Brahe is preoccupied with the motions of Mars, the same problem on which Kepler has just reached an impasse. Again, divine guidance is at work. God has sent him the required help at the critical moment. ${ }^{20}$

It is possible to see this hieratic overlay as the reassertion in astronomy of his earlier sense of a religious calling. Kepler's first ambition as a student was to become a Protestant minister, and when he gave it up to become a mathematics teacher, he had written to Mästlin: "I wished to become a theologian: it was long a source of torment to me. Behold now how God is glorified by my work in astronomy." 21

But also Kepler had a strong sense of identification with pagan philosophers. He sees himself in a line of descent from Pythagoras, Plato, and Euclid, 22 though his role is far more modest. He, Galileo, Copernicus, the moderns, are placed in the world in order to correct some minor errors of the great ancients, which they made for lack of good data. ${ }^{23}$

Kepler wrote poetry, and his poems are a part of this complex of a priesthood of ancient and modern astronomers. Many of his poems are hymnic praises of the creator. His models were the psalms of David. In his dedicatory letter to the first edition of the Mysterium, he explains the whole enterprise as parallel to that of the psalmist, the main theme 
of both being the glory of God visible in the heavens. The heavens proclaim God's glory, but without a voice. Kepler's task is to provide them with one. ${ }^{24}$

Kepler's conception of his activity as searcher and finder of divine mysteries fits a widespread model of inspiration and discovery. Nietzsche's description of the experience resonates clearly with Kepler's:

[Inspiration consists in] . . . the sense of being merely an incarnation, merely a mouthpiece, merely a mediator of higher forces. The notion of Revelation-in the sense that all at once, with ineffable certainty and subtlety, something becomes visible, audible, something that shatters and overthrows the very depths of your beingthis is an objective description of a factual state of affairs. One listens without searching; one receives without asking the identity of the giver; like a flash of lightning a thought lights up, with necessity, in the right form and no hesitating-I never had any choice. An ecstasy whose enormous tensions discharge themselves in a stream of tears. In its grip your pace is now hectic, now serenealways out of your control: you are beside yourself, only partially, you are intensely aware of shudders and gooseflesh down to the tips of your toes. . . . Every thought presents itself as the most exact, the most correct, the simplest expression. ${ }^{25}$

The experience is common to artists and scientists. The comparison of Kepler and Goethe on inspiration and the role of poetic design in nature is also useful. The poet-scientist and the astronomer-mathematicianpoet share a conception of nature as musically composed, at the same time concealing and revealing the inner laws of its construction. Both men explicitly locate their inspiration in this conception of nature: a world constructed on principles of harmony, proportion, according to a grand design conceived by a master artist. Discovery then becomes a process of reconstituting in the human mind the poetry of nature. ${ }^{26}$ That process is no more open to arbitrariness than any other mode of investigation, perhaps less so, since the assumption of chaos or indeterminacy, given a poetic structure of nature, represents an error every bit as great as the converse.

Kepler also described this process in detail, and Hallyn has offered a wide-ranging reading of it:

An inner conception precedes and governs the Creation of the material world. It determines the form of the world and ... in the second half of the sixteenth century art theoreticians insistently transposed this conception of the divine Creator to their realm. The 
concrete work of art, the disegno esterno ... is seen as dependent on the disegno interno ... which is its inner and prior conception, its model and source ... corresponds to the a priori apprehension of a beautiful form, and constitutes an act of production rather than reproduction. ${ }^{27}$

We can observe Kepler's conception of the world as a work of art and the scientist as a kind of critic by looking briefly at his ideas of cognition. They are laid out in a passage on a priori knowledge in the Harmonices Mundi:

to know is to compare external things perceived by the senses with the internal ideas and to judge that the one corresponds to the other. ... How then did these notions make their way into the mind? I respond that the ideas or relationships of the harmonies in their entirety are ... present in those who enjoy that faculty of cognition, but they cannot by any means be received inwardly through discursive reasoning; rather they arise from a natural instinct and are inborn in them [i.e., in men gifted with cognition], as in plant-forms the number of petals is inborn in the flower and of seed cells in the apple. ${ }^{28}$

An interesting Keplerian variation to this Neoplatonist scheme is the idea that implanted knowledge is instinctual. Such instincts link humans with animal and plant forms. The chicken has a fear of the hawk that is activated just by the sight of its enemy; it requires no lessons or training in recognizing hawks. The instincts are a purely animalistic or vegetative faculty. As the chicken recognizes the hawk a priori, menat least some men-possess the sense of number, musical harmony, and geometrical relationships. ${ }^{29}$ These implanted instincts show the functioning of what Kepler calls a "creative force" (vis creatrix), a power informing every living creature and driving it toward a characteristic and predetermined telos. Its strict and inalienable working is evident, for instance, in the six-cornered shape of every snow flake; it is visible in the invariably symmetrical cells of the beehive. ${ }^{30}$ Cognition in humans is as passive and automatic as the building of cells for the bee or the developing of petals for the flower.

But one function of the vis creatrix is reserved exclusively for the human species and distinguishes it from lower forms: artistic expression. Human beings can themselves form harmonies, symmetries, and shapes in imitation of the ideas within. They can compose music and make their bodies perform pleasing and harmonious gestures in accord with the implanted harmony. ${ }^{31}$ And insofar as this willed creation of 
order imitates higher order and harmonies, it must make use of those intellectually present archetypes. Men can also write verse, in which the expression of harmony is carried by the rhythm and sounds of the words. ${ }^{32}$ The composition of poetry calls on the ideas inborn in the soul, which send forth refractions of harmony and thus mediate between heavenly and earthly harmonies.

Human cognition, then, is identical with animal and vegetable in terms of its dynamics, but it is of a higher order. Instincts serve only self-preservation in the chicken, but they permit humans to converse with God in poetry and music. The vision of harmony brings them joy by reminding them of the eternal principles of the universe; they rejoice to feel the presence of harmony, beauty, simplicity in their minds: "we share this brand of cognition with God, at least insofar as we perceive something of these things in earthly life. It is foolish to fear that we make man into God by saying so, since the counsels of God may be incomprehensible, but His visible works are not." 33 Human cognition imitates divine. Mathematics is the prime example: "Geometry is unique and eternal, and it shines in the mind of God. The share of it which has been granted to man is one of the reasons why he is the image of God." 34

In this notion of human imitating divine cognition, we have, I believe, the core of what earlier studies called "Kepler's mysticism." But at the same time it is the core of his rationalism. The phrase "mysticism" in this case only has content and meaning if the world is rational and comprehensible. ${ }^{35}$ If Kepler was a "mystic" for believing in the regularity of the universe, then so were Newton, Goethe, and Einstein. Goethe also noticed the individual and artist-like will to form implanted in everything living, and described man's ability to perceive the secret law hidden behind the veil of variety. ${ }^{36}$ Einstein's muchquoted comment that "the eternal mystery of the world is its comprehensibility" restates the same "mystical" insight into the rationality of the universe. ${ }^{37}$

Now, of course, Kepler's inspired discovery, the five regular solids as the key to the "cosmographic mystery," an idea that he never completely abandoned, was out and out wrong. The hypothesis would eventually have faced falsification on the grandest scale: the discovery of more planets is crushing refutation. God only made five perfect solids, and he would have run out of them before he ran out of planets.

The immensity of Kepler's error, viewed against the immensity of faith in it, suggests that the whole tissue of ideas leading to his "sacred raving" was really a tissue of error, as fallible as prophecies made in asylum-variety raving. But in his case, precisely the tissue of error 
was the matrix of discovery. Kepler's three laws of planetary motion emerged from this matrix, which we could at the least generous call a highly productive, fruitful error. The five-solids hypothesis yielded, for the first time, "a universal physical law based on terrestrial mechanics to comprehend the whole universe in its quantitative details." ${ }^{38}$ The result is "a breathtaking conception of unity ... perhaps even more striking than Newton's for the simple reason that Kepler had no predecessor." ${ }^{39}$ His hypothesis harmonized an impressive array of ideas: a whole line of thought since Pythagoras fell into place and made sense: the mystical importance of numbers, the secret of the five geometrical solids, the music of the spheres and the general conception of a harmonic cosmos, the heliocentric theory.

We have a puzzling situation in which a man committed to scrupulous testing of theory clings to inspired ideas that turn out to be preposterous. This underscores the point that inspiration is indifferent to the truth. The experience is common to geniuses and maniacs. Kepler's inspiration was a response to grand visions of order. The idea of the five solids reduced an enormously varied set of phenomena to simplicity. It satisfied his criteria for the thoughts of God: mathematical perfection made visible. Whatever the ontological value of the idea of an ordered and designed universe, it had an immense heuristic value, and created the circumstances under which poetic inspiration could produce scientific discovery. Wrong though the "cosmographic mystery" was, it ordered the vast machinery of the heavens according to simple and beautiful principles, and beautiful principles had for Kepler the quality of the thoughts of God.

The productive cooperation of a poetic and an empirical-scientific mode of thought in Kepler supplies a parallel to the current search for a "poetics" of science, history, and culture, and it suggests the firm grounding of that trend. The comparison tends to legitimize a mode of thought that can find aesthetics in the structure of nature, of history, and of culture, and that can envision, conversely, an empirical grounding of poetry, art, and narrative. The contrary, rationalist idea that the composition of poetry and the discovery of scientific laws are essentially different processes of the mind deserves a critical view. Kepler is a model case of their essential similarity.

\section{Notes}

1. Johann Wolfgang Goethe, "Xenien aus dem Nachlass," no. 48, Gedenkausgabe der Werke, Briefe und Gespräche, ed. Ernst Beutler (Zurich: Artemis, 194871), 2:504 (henceforth cited as GA). 
2. Literature on the subject is mushrooming. Some major reflections appear in The New Historicism, ed. H. Aram Veeser (New York: Routledge, 1989). On the critics of this trend see Walter B. Michaels, "The Victims of New Historicism," Modern Language Quarterly 54 (1993): 111-20. Cautioning against the narrowing of critical focus through politicizing critical discourse is Peter Brooks, "Aesthetics and Ideology: What Happened to Poetics?" Critical Inquiry 20 (1994): 509-23.

3. Robert Pollack, Signs of Life: The Language and Meanings of DNA (Boston: Houghton Mifflin, 1994). This trend was featured in a newspaper article recently: "Academic Disciplines Increasingly Entwine, Recasting Scholarship," New York Times, March 23, 1994, p. A-19. The trend is criticized in its relation to "postmodernist" cultural studies by William Clark in an ironic review ("Poetics for Scientists") of F. Hallyn's The Poetic Structure of the World: Copernicus and Kepler, in Studies in History and Philosophy of Science 23 (1992): 181-92; his review is about "the project of a 'poetics' of science" (p. 182); "Hallyn may be placed in a broad 'postmodern' project to restore the postmodern status of poetics in the economy of knowledge. ... Such a poetics might even hubristically subvert the Modern Era's notion of science, efface the borders between science and literature, make science fiction" (p. 182); "'Poetics of . .' has become part of the postmodern mantra, and thus, eo ipso, possessed of equivocal sense" (p. 183). His treatment of Hallyn as "eruditio à la mode," and as a member of "the California school," casts him smugly and unfairly as a kind of new-age flake, forcing knowledge into eccentric, archaic classifications. Hallyn, however, is a fairly sober observer of Kepler's presuppositions of investigation. If anyone is a new-age flake, it is surely Johannes Kepler himself.

4. N. Katherine Hayles, ed., Chaos and Order: Complex Dynamics in Literature and Science (Chicago: University of Chicago Press, 1991), with an extensive bibliography. See also her Chaos Bound: Orderly Disorder in Contemporary Literature and Science (Ithaca, N.Y.: Cornell University Press, 1990).

5. See the essays in Four Hundred Years: Proceedings held in Honour of Johannes Kepler, ed. A. Beer and P. Beer, in Vistas in Astronomy 18 (1975), and Internationales Kepler-Symposium, Weil der Stadt 1971, ed. Fritz Krafft, Karl Meyer, and Bernhard Sticker (Hildesheim: Gerstenberg, 1973). On the cultural context of Kepler see especially Anthony Grafton, "Humanism and Science in Rudolphine Prague: Kepler in Context," in Literary Culture in the Holy Roman Empire, 1555-1720, ed. James A. Parente, Jr., Richard E. Schade, and George C. Schoolfield, University of North Carolina Studies in the Germanic Languages and Literatures, 113 (Chapel Hill: University of North Carolina Press, 1991), pp. 19-45.

6. Much groundwork has been done for a study of inspiration and discovery in Kepler. See Arthur Koestler, The Sleepwalkers: A History of Man's Changing Vision of the Universe (New York: Macmillan, 1959), pp. 225-422; Gerald Holton, Thematic Origins of Scientific Thought: Kepler to Einstein (Cambridge, Mass.: Harvard University Press, 1973), pp. 69-90; Fernand Hallyn, The Poetic Structure of the World: Copernicus and Kepler (New York: Zone Books, 1990).

7. See Holton, Thematic Origins, p. 19. 
8. Johannes Kepler, Gesammelte Werke, 20 vols., ed. Walter von Dyck, Max Caspar, and Fritz Hammer (Munich: Beck, 1938-88), 1:13; (henceforth cited as GW). English passage adapted from Johannes Kepler, Mysterium Cosmographicum: The Secret of the Universe, trans. A. M. Duncan (New York: Abaris, 1981), p. 69.

9. Mysterium, trans. Duncan, pp. 53-55; GW 1:6.

10. Mysterium, trans. Duncan, p. 39.

11. Harmonices Mundi, 5. Prooemium, GW 6:289-90.

12. Mysterium, trans. Duncan, pp. 68-69; GW 1:13.

13. To Mästlin, August 1, 1595, GW 13:28.

14. To Mästlin, October 3, 1595, GW 13:38.

15. Epitome Astronomiae Copernicanae, Dedicatory Letter, GW 7:8.

16. Astronomia Nova 2.7, GW 3:108. There is a recent translation: Johannes Kepler, New Astronomy, trans. William H. Donahue (Cambridge: Cambridge University Press, 1992). I have consulted but not cited from this translation.

17. Mysterium, trans. Duncan, p. 36; GW 1:3: “Quotidie morior, fateorque: sed inter Olympi / Dum tenet assiduas me mea cura vias: / Non pedibus terram contingo: sed ante Tonantem/ Nectare, divina pascor et ambrosia." See F. Seck, "Kepler als Dichter," in Internationales Kepler-Symposium, pp. 427-50, especially pp. 440 and $449-50$.

18. To Herwart, March 26, 1598, GW 13:193. And again, in Epitome, Dedicatory Letter, GW 7:9: “constitutem me veluti sacerdotum Dei Conditoris ex parte libri naturae intelligam."

19. GW 7:9.

20. Astronomia Nova 2.7, GW 3:109.

21. To Mästlin, October 3, 1595, GW 13:50. On Kepler's religious sense of mission, see Holton, Thematic Origins, p. 85.

22. In a long dissertation on the superiority of the pagans to the moderns he places himself at the end of their line: "the prodigies will naturally be Pythagoras, Plato and Euclid. .. . Trailing far behind the ancients will be Kepler." Kepler's Conversation with Galileo's Sidereal Messenger, trans. Edward Rosen, Sources of Science, 5 (reprint, New York: Johnson, 1965), pp. 37-38.

23. This ranking predominates in Kepler's definition of moderns against the ancients. It did not prevent him from correcting the ancients, but without a sense of superiority (in contrast to the texts cited by Grafton arguing Kepler's sense of superiority to the ancients, in "Humanism and Science," pp. 39-42).

24. Cf. also the poem that ends the Mysterium. It is a hymn of praise to the creator written distinctly in the style of the psalms. Mysterium, trans. Duncan, pp. 224-25; GW 1:80.

25. Friedrich Nietzsche, Ecce Homo, "Also Sprach Zarathustra," in Sämtliche Werke. Kritische Studienausgabe in 15 Bänden, ed. Giorgio Colli and Mazzino Montinari (Berlin: de Gruyter, 1980), 6:339-40.

26. An important statement of this conception in Goethe's essay, "Erfinden und Entdecken," GA 17:752: "Everything we call 'invention' or 'discovery' in a higher sense is the decisive exercise or activation of a primal sense of truth 
which, developed unconsciously over a long period of time, leads in an unexpected flash to fruitful insight. It is a revelation developing from within and confirming itself externally. It lets man glimpse his god-like nature. It is a synthesis of world and mind, which gives the most blissful assurance of the eternal harmony of existence." He developed his ideas on inspiration in poetry and science in a conversation with his friend Eckermann, from March 11, 1828, GA 24:678-79: "Any productivity of the highest kind, every significant insight, every invention, every great thought that bears fruit and produces consequences, stands in no one's power and is elevated above any human force. . . . In such cases man is often to be regarded as a tool of a higher world order, as a vessel found worthy of receiving the divine influence." Goethe envisioned a single principle uniting all creation. Like Kepler, he found a pure expression of that unity in the laws of musical harmony. In a letter from 1810 he expressed the hope that he could join theory of musical composition with his own ideas on nature to create a kind of Grand Unified Theory (to Georg Sartorius, July 19, 1810, GA 19:610): "Zelter is here at the moment, and no doubt his presence will favor my old urge to tie harmonics to my own interests, so that it can be synthesized with the rest of physical phenomena and with the theory of colors. If a few great formulas can be worked out successfully, then everything will be One, unfold from One, and return to One."

27. Hallyn, The Poetic Structure of the World, pp. 171-72.

28. Harmonices Mundi 4.2, GW 6:226.

29. Harmonices Mundi 4.7, GW 6:277.

30. The Six-Cornered Snowflake (Oxford: Clarendon Press, 1966), p. 17.

31. Harmonices Mundi 4.2, GW 6:228.

32. Harmonices Mundi 4.3, GW 6:231-32.

33. Letter to Herwart, April 9-10, 1599, GW 13:309.

34. Conversations with Galileo's Sidereal Messenger, p. 43.

35. Cf. R. S. Westman, "Kepler's Theory of Hypothesis and the 'Realist Dilemma,'" Vistas in Astronomy 18 (1975): 717-18: "[Kepler's] enthusiastic promulgation of the polyhedral hypothesis, frequently misunderstood by historians who relegate it to the 'mystical' side of Kepler's personality, was, in fact, a rational attempt to show that the Copernican ordering and spacing of the planets was no accident; that it literally reflected the decision of a purposeful, architectonic God who could only have embodied his goodness and perfection in the most beautiful of all possible geometrical forms, the five Platonic solids."

36. "Metamorphose der Tiere," GA 1:519-20 [all members are formed after eternal laws, and the most exotic form preserves secretly the archetype]: "Freue dich, höchstes Geschöpf der. Natur, du fühlest dich fähig, / Ihr den höchsten Gedanken, zu dem sie schaffend sich aufschwang, / Nachzudenken. Hier stehe nun still und wende die Blicke / Rückwärts, prüfe, vergleiche, und nimm vom Munde der Muse, / Dass du schauest, nicht schwärmst, die liebliche, volle Gewissheit." The sentiments could come straight from Kepler.

37. Albert Einstein, "Physics and Reality," in his Ideas and Opinions (New 
York: Bonanza, 1954), p. 292. This is close to Goethe's idea that everything factual reveals unchanging laws: "Do not seek anything behind phenomena.

They themselves are the theory." ("Beobachten und Denken," GA 17:723).

38. Holton, Thematic Origins, p. 71.

39. Ibid., p. 72. 


\title{
7. Der scheiternde Platonismus in Giordano Brunos Heroici Furori
}

\author{
Walter Haug
}

Am 17. Februar 1600 ist Giordano Bruno auf dem Campo dei Fiori in Rom als Ketzer verbrannt worden. Es war dies das dramatische Ende eines dramatischen Lebens: 1548 bei Nola in der Campagna geboren, ist er 1562 in das Dominikanerkloster von Neapel eingetreten. 1572 empfing er die Priesterweihe, 1575 wurde er Doktor der Theologie. Doch im Jahr darauf muß er wegen Anfeindungen aus dem Kloster fliehen. Es folgt ein rastloses Wanderleben-immer wieder befehdet, vertrieben, gehetzt-quer durch Europa: Chambéry, Genf, Toulouse, Paris. Auch in Tübingen hat er-1579-vergeblich Fuß zu fassen versucht. Dann ein kurzer, aber sehr produktiver Aufenthalt in London: 1583-85. Zurück nach Paris, darauf drei Jahre Wittenberg, als Lehrer der Philosophie. Helmstedt, Prag, Frankfurt. 1591 kehrt er nach Italien zurück; in Venedig denunziert, wird er verhaftet und nach Rom ausgeliefert. Sieben Jahre schleppt sich für den Eingekerkerten der Prozeß hin, der, da Bruno nicht bereit ist zu widerrufen, mit dem Tod auf dem Scheiterhaufen endet. ${ }^{1}$

Sein reiches Oeuvre, über 50 Titel, hat geradezu eruptiven Charakter. Es kommt alles in einem Jahrzehnt zustande, zwischen 1582 und der fatalen Rückkehr nach Italien 1591. ${ }^{2}$

Man pflegt in der neueren Bruno-Forschung zwischen zwei Gruppen von Werken zu unterscheiden. ${ }^{3}$ Die eine besteht aus Abhandlungen, die sich mit unterschiedlichsten Themen beschäftigen: Kommentare zu Raimundus Lullus, Traktate über Mnemotechnik, didaktisch-kritische Untersuchungen zu antiken und neueren Philosophen, Werke zur Magie u. a. m. Als zweite Gruppe faßt man jene Werke zusammen, in denen Bruno eigene Konzepte entwickelt. Es sind dies vor allem die sechs italienischen Dialoge, die in England entstanden und publiziert worden sind, dazu drei lateinische philosophische Gedichte mit Prosakommentaren, veröffentlicht im Jahre 1591.

Dieses gesamte Oeuvre ist in jenen 10 Jahren entstanden, in denen man Bruno quer durch Europa getrieben hat. Und es trägt den Stempel des Lebens, aus dem es herausgewachsen ist, oder hart formuliert: Was 
Bruno hier aus sich herauswirft, spiegelt in seiner Unordentlichkeit, seiner Impulsivität, seiner Widersprüchlichkeit gewissermaßen den Stil seines persönlichen Weges. Jedenfalls ist es bis heute niemandem gelungen, eine Linie in diesem Werk zu finden; Entwicklungsstadien lassen sich nur mit einiger Willkür ausmachen, und von so etwas gar wie einem System kann nicht die Rede sein.

Bruno war von einer unvorstellbaren Belesenheit-die Quellenforschung zu seinem Werk hat das aufgedeckt, die Pionierarbeit verdanken wir Felice Tocco ${ }^{4}$, der letzte große Überblick stammt von Antonio Corsano ${ }^{5}$. Aber was Bruno schier unersättlich zusammenrafft, bleibt in seiner Verarbeitung disparat, oft nur halbdurchschaut, ja falsch verstanden. In der Deutschen Vierteljahrsschrift für Literaturwissenschaft und Geistesgeschichte von 1924 findet sich eine gnadenlose Abrechnung mit Brunos Oeuvre von keinem Geringeren als Leonardo Olschki. ${ }^{6}$ Ein paar zentrale Sätze aus Olschkis "Würdigung": "Sein [Brunos] Denken [ist] fortwährend in ruhelosem Flusse und sein Geist immer bereit, das zu zerstören, was er anbetete. Das copernikanische Weltsystem ist in seinen Lehren ebenso eine Episode, wie das platonische, das demokritische und das cusanische; und wenn er sich bald zum einen, bald zum andern zu bekennen scheint, so handelt es sich niemals um eine endgültige Wandlung, sondern um den wechselnden Standpunkt des Gelegenheitsdogmatikers und Dilettanten, der die Willkür für geistige Freiheit und für philosophische Vorurteilslosigkeit hält"?

Trotz dieses vernichtenden Verdikts ist Bruno inzwischen zu einer Schlüsselfigur für den Übergang zwischen Mittelalter und Moderne avanciert, wofür Hans Blumenberg gewiß einer der Hauptverantwortlichen ist. ${ }^{8}$ Das ist selbstverständlich nur möglich, wenn man auf eine Gesamtdarstellung verzichtet und jene Züge herausgreift, die retrospektiv als Symptom für die neuzeitliche Wende in Anspruch genommen werden können. Es ist hier nicht der Ort, über die Legitimität eines solchen Verfahrens zu streiten. Wie immer man darüber urteilen mag, es dürfte durchaus gerechtfertigt, ja empfehlenswert sein, sich diesem heterogenen Werk über Einzelinterpretationen zu nähern, über Interpretationen dieses oder jenes'Werks, dieses oder jenes Themas, dieses oder jenes Bezugs. Hier sind in neuerer Zeit denn auch die aufschlußreichsten Arbeiten zu verzeichnen. ${ }^{9}$ Dabei mag es jedem Interpreten anheim gestellt bleiben, über seinen Zugriff den "'wahren' Bruno" zu finden-dieses Wort vom "'wahren' Bruno" stammt aus Stephan Ottos Zugriff über den Dialog De l'infinito, universo et mondi. ${ }^{10}$ 
Ich werde mich freilich hüten $\mathrm{zu}$ sagen, daß ich im folgenden "meinen wahren Bruno" vorstellen möchte, aber vielleicht doch den Bruno in seiner letzten geistigen Volte, den Bruno des sechsten italienischen Dialogs, der Heroici Furori. Dabei gilt mein Interesse einem Aspekt, der soweit ich sehe, kaum eine eindringlichere Beachtung gefunden hat. Ich denke an das Verhältnis von Philosophie und Poesie, oder man könnte auch sagen, das Verhältnis von Bild und Denken, von Mythos und Reflexion. Die Problematisierung dieses Verhältnisses ist in den Heroici Furori zweifellos am weitesten vorangetrieben, und dies-und daraus ergibt sich auch mein Fragehorizont-in platonistischer Perspektive. Ich setze aber schon etwas früher ein, um den erforderlichen philosophiegeschichtlichen Hintergrund skizzieren $\mathrm{zu}$ können, nämlich beim ersten italienischen Dialog, dem Aschermittwochsmahl.

Der Titel La Cena de la Ceneri ist eine kontrastive Anspielung auf die Saturnalia des Macrobius, jenen großen Abgesang auf das antike Heidentum. Macrobius hat als Zeitgenosse Augustins noch einmal versucht, eine neuplatonisch konzipierte Heliosreligion durchzusetzen. Bruno plaziert seinen Dialog bedeutungsvoll an das Ende jener aufständigen Zwischenzeit, die im Christentum den römischen Saturnalien entspricht, an das Ende des Karnevals, und dabei unternimmt er es, seinerseits ein heliosorientiertes Weltbild zu entwerfen. Aber das ist nun keine Heliosmythologie mehr wie bei Macrobius, denn man hat mit dem Aschermittwoch die Saturnalien, den Karneval, hinter sich gelassen; es hat die Fastenzeit begonnen, d. h., der Heliozentrismus ist nun nicht mehr heidnisch-mythologisch, sondern christlich-kosmologisch zu verstehen. Dabei macht Bruno sich zum Anwalt des Kopernikus. Zugleich freilich vereinnahmt er, wie zu zeigen sein wird, in eigentümlicher Weise doch die antike Mythologie.

Man pflegt den Beginn der Neuzeit gerne mit des Kopernikus De Revolutionibus Orbium Coelestium von 1543 anzusetzen: Durch die Einsicht, daß die Erde sich um die Sonne bewegt, sei der Mensch aus dem Zentrum des Universums verstoßen worden, was eine grundlegend neue Orientierung notwendig machte, eine nicht mehr kosmosbeżogene, sondern subjektbezogene Orientierung. ${ }^{11}$ Diese These hat langfristig gesehen sicherlich eine gewisse Berechtigung. Zunächst fand Kopernikus jedoch nur ein geringes Echo. Er saß bescheiden und zurückhaltend im ostpreußischen Frauenburg und scheute sich, seine Entdeckung zu publizieren. De Revolutionibus ist erst nach seinem Tod erschienen. Und im übrigen war das Werk in seiner mathematischen Argumentation sehr schwierig. Es dauerte mehr als ein halbes Jahrhun- 


\section{Walter Haug}

dert, bis die Kirche gemerkt hat, was hier geschehen war; das Werk kommt erst 1616 auf den Index, der übrigens erstmals gerade im Jahr von De Revolutionibus, also 1543, herausgegeben wurde.

Aber des Kopernikus Konzept setzt sich mit Keplers Astronomia Nova 1609 (die Epitomae, 1618-21) und Galileis Dialogo 1632 durch, wenngleich auch Kepler auf den Index kommt und Galilei widerrufen muß. Aber der erste, an dem der Konflikt offen aufbrach, war Giordano Bruno. Bemerkenswerterweise jedoch weniger wegen des kopernikanischen Heliozentrismus, sondern wegen einer These, die weit über Kopernikus hinausging. Denn Bruno propagiert im Aschermittwochsmahl nicht nur das heliozentrische Weltbild, er vertritt zugleich die Idee eines unendlichen Kosmos mit unendlich vielen Welten. Die Begründung ist die, daß einem unendlichen Gott eine unendliche Schöpfung korrespondieren müsse. Der dritte italienische Dialog De l'infinito, universo et mondi führt dieses Thema dann weiter aus. ${ }^{12}$

Brunos Idee der Unendlichkeit des Kosmos hat nicht mehr viel mit jener abstrakten astronomischen Mathematik des polnischen Domherrn in Ostpreußen zu tun, die man als gelehrtes Denkspiel auf sich beruhen lassen konnte, diese Idee zerstörte vielmehr radikal die überkommenen Vorstellungen vom Verhältnis zwischen Himmel und Erde. Auch wenn im Mittelalter niemand mit philosophischer Bildung sich Gott auf einem Thron über den Himmelssphären sitzend vorstellte, so gab es doch die Idee einer sehr konkreten kosmischen Hierarchie, entscheidend geprägt durch Dionysius Areopagita, dessen Einfluß und Aktualität sich in immer neuen Kommentaren niedergeschlagen haben: Bekanntlich haben sich die größten Geister über die Jahrhunderte hin mit Dionysius auseinandergesetzt. ${ }^{13}$

Man konnte diese konkrete Kosmologie mehr oder weniger entschieden platonistisch umdenken, also aus dem konkreten Gebäude der himmlischen Sphären einen ontologischen Stufenbau machen. Eine zweite Möglichkeit war die Psychologisierung zu einem inneren Weg, einem Itinerarium mentis in Deum. Man dachte also in dieser platonischchristlichen Tradition im Prinzip hierarchisch, auch wenn der kosmische Stufenbau dabei schließlich nur noch als Metapher erscheinen mochte.

Brunos Vorstellung eines unendlichen Kosmos war jedenfalls nicht mehr mit dem traditionellen Bild eines Aufstiegswegs vereinbar. Das Verhältnis von Gott und Welt wurde unanschaulich. Und das führte zu einer Problematisierung des Übergangs zwischen Welt und Gott. Diese Problematisierung bricht freilich nicht erst mit Bruno auf, wenngleich sie bei ihm eine besondere Vehemenz zeigt, sondern sie hat eine längere Vorgeschichte. Ich muß etwas in sie ausgreifen. 
Hinter der traditionellen, hierarchischen Vorstellung-ob man sie nun mehr kosmologisch, ontologisch oder psychologisch sah-stand die Idee einer Kontinuität zwischen dem Irdischen und dem Himmlischen, zwischen dem Endlichen und dem Ewigen, eine Kontinuität, die der platonischen Tradition verpflichtet war und die ja auch das Dionysische Corpus prägte: Das Göttliche spiegelt sich im Irdischen; es gibt einen Weg über die Erscheinungen zu dem, was an Ewigem hinter ihnen steht. Diese Idee hat dann durch die Erneuerung des Platonismus in der italienischen Renaissancephilosophie nochmals eine Radikalisierung erfahren. Es kommt zu einer dezidierten Betonung der Kontinuität, wenn Ficino fließende Übergänge zwischen den Stufen des Seins ansetzt. ${ }^{14}$ Die Kraft aber, die es ermöglicht, die Übergänge in einem kontinuierlichen Prozeß zu bewältigen, ist der Eros.

Doch das ist nur der eine Aspekt der Geschichte des hierarchischen Modells. Denn es gab, von dem Augenblick an, als man es verchristlichte, auf dem Aufstiegsweg einen kritischen Punkt, denn der christliche Gott, dem gegenüber die Differenz-wie es in der Formel des Laterankonzils von 1215 hieß-immer größer war als die Ähnlichkeit, dieser christliche Gott war nicht über einen ungebrochen kontinuierlichen Prozeß zu erreichen. Es gab einen Punkt, an dem das menschliche Streben, seine Ratio, sein Wille an ihre Grenze gelangten und sich eine Kluft auftat, die nur von Gott, von seiner Gnade her, überbrückt werden konnte. Je konsequenter man aber von diesem Punkt her dachte, um so fragwürdiger mußte der Weg bis zu diesem Punkt erscheinen. Was half die eigene Anstrengung, wenn es entscheidend doch nur darauf ankam, daß Gott einen über den Abgrund zwischen dem Endlichen und dem Ewigen herüberholte? Hatte das, was man selbst zu dem Prozeß beitragen konnte, überhaupt Gewicht? So kam es zur Radikalisierung des Sprungs bei den Mystikern des 13./14. Jahrhunderts: Eckhart ist der Paradefall. Er verwirft jeden Weg, jede Vermittlung, sämtliche Heilsmittel. An die Stelle des Aufstiegs tritt der Umbruch in den Abgrund des menschlichen Seins, in dem dieses Sein sich mit dem Sein Gottes berührt. ${ }^{15}$

Etwa 150 Jahre später hat Nicolaus Cusanus das Problem dann erkenntnistheoretisch neu gefaßt. Das menschliche Denken korrespondiert nicht unmittelbar mit der Ordnung des Seienden, sondern es besitzt eine Struktur eigener Art, in der es gewissermaßen gefangenbleibt, so daß es auf dem Weg zur transzendenten Wahrheit sich selbst im Wege steht. Cusanus spricht von der "Mauer des Paradieses", in deren Tor die Ratio Wache hält. Nur wer die Ratio überwindet, vermag durch die Mauer durchzustoßen. Dieses Sich-Selbst-Transzendieren des Denkens als einzige Möglichkeit, zur Wahrheit zu gelangen, ist 
die erkenntnistheoretische Umformulierung der traditionellen Bruchstelle, die auch hier nur durch einen göttlichen Gnadenakt zu überwinden ist. ${ }^{16}$

Es gibt also in der christlichen Tradition des platonistischen Hierarchiemodells zwei sich widerstrebende Tendenzen, zum einen den immer wieder sich vordrängenden Gedanken eines kontinuierlichen Weges, der in der italienischen Renaissance nochmals forciert wird, und zum andern das sich verstärkende Differenzbewußtsein, das in der deutschen Dominikanermystik radikalisiert wird und in Cusanus fast zur selben Zeit einen neuen Höhepunkt erreicht, als Ficino sein Gegenbild entwirft. ${ }^{17}$

Giordano Bruno ist gute 100 Jahre später gewissermaßen der Erbe der beiden sich widerstreitenden Tendenzen. Er übernimmt aus dem italienischen Platonismus den Gedanken des Eros als der zum Höchsten treibenden Kraft, und er teilt mit Cusanus das Bewußtsein von der gegenüber der objektiven Wahrheit eigenständigen Struktur des menschlichen Denkens. Daß das zu Schwierigkeiten führen mußte, liegt auf der Hand. Der Versuch zur Verbindung endete in einem geistigen Drama, zu dem sich nicht so leicht etwas Vergleichbares finden läßt. Es ist meines Erachtens auch nur verständlich aus der angedeuteten spezifischen geistesgeschichtlichen Konfliktsituation heraus.

Am eindrucksvollsten läßt sich die gespannte Dramatik des Brunonischen Denkens an den Heroici Furori demonstrieren. Hier wird der Widerspruch bis zum Zerbrechen hochgetrieben.

Formal besteht das Werk aus zweimal fünf Dialogen. Vorangestellt ist eine Widmung an den englischen Freund und Gönner, Sir Philip Sidney, den Dichter der Arcadia. Diese Widmung beginnt mit einer maßlosen Invektive gegen die sinnliche Liebe. Die bekannten Topoi der Liebe als Krankheit werden dabei ebenso diffamierend ins Spiel gebracht wie die Bilder der Vergänglichkeit irdischer Schönheit aus der contemptus-mundi-Literatur. Und der vulgären Begierde stellt Bruno dann eine ganz andere Liebe gegenüber, die "furori heroici", die er auch "divini" nennt. Dieser Auftakt ist offenkundig nichts anderes als die traditionelle platonische Gegenüberstellung der zwei Veneres, ${ }^{18}$ und diese Tradition wird denn auch gleich mit dem Signum versehen, das sie über die Jahrhunderte hin markiert: dem Phaidros-Bild von den Flügeln, die den göttlich Liebenden über das Irdische emportragen. ${ }^{19}$

Und wenn Bruno dann doch für seine Charakterisierung der heroischen Leidenschaft Bilder bei der irdischen Liebe borgt, so verweist er vorbeugend vorweg schon auf das Hohelied. Er sagt, er hätte sein Werk am liebsten "Cantica" genannt, denn wie dort liege den erotischen Bildern, die er brauche, ein verborgener Sinn zugrunde. Sie seien 
also figurativ, metaphorisch, zu verstehen. Und so scheut er sich denn nicht, in einem prachtvollen petrarkistischen Sonett zu Beginn des zweiten Dialoges gerade jene Phänomenologie des Erotischen heranzuziehen und in einem höchsten Maße zu steigern, die er unter profanem Aspekt verworfen hat. Er sagt hier: "Meine Hoffnungen sind Eis, mein Verlangen kocht, ich zittere vor Kälte, und gleichzeitig stehe ich in brennenden Flammen, ich bin stumm und erfülle den Himmel mit glühenden Schreien. Funken springen mir aus dem Herzen, Wasserströme fließen mir aus den Augen, ich lebe und sterbe, ich lache und klage; die Wasser sind lebendig, und der Brand stirbt nicht" ${ }^{20}$. Und dieses Hochspielen der Gegensätze wird dann im sich anschließenden Dialog erläuternd weitergeführt: Es gibt keine Freude ohne Bitternis, und wenn es die Bitternis nicht gäbe, gäbe es auch die Freude nicht; die Trennung erst ermöglicht die Lust der Vereinigung. Und im Bewußtsein sei dieser Umschlag stets gegenwärtig. Als Lösung aber komme keinesfalls die weise Mitte der "temperanza" in Betracht, der heroisch Liebende suche vielmehr den Exzeß der Gegensätze. Und später wird dann auch für diese qualvolle Steigerung das Zeugnis des Hohenliedes angerufen: das schon dort beschriebene Spiel zwischen dem sich schenkenden und dem sich entziehenden Geliebten. Das heißt: Brunos erotisches Ineinander von Beglückung und Verzweiflung, von Leben und Tod führt sowohl die überkommene weltliche wie die geistiggeistliche Liebesphänomenologie in ihrem ganzen sinnlichen Bilderreichtum auf einen höchsten Gipfel, dies aber-und das ist das überraschend Neue-mit dem Ziel, den Exzeß am Ende zusammenbrechen zu lassen. Im Zentrum des 3. Dialogs des ersten Teils steht die These vom notwendigen Scheitern dieser in die übersteigerung getriebenen Erotik.

Das wird in einem berühmten, gerade auch zu dieser Zeit gängigem Bild zur Darstellung gebracht: im Bild vom Falter, der "des Lichts begierig" in der Kerzenflamme verbrennt. ${ }^{21}$ Aber während die Emblembücher des 16. Jahrhunderts damit insbesondere die verderbenbringende Lust veranschaulichen (s. Abb. 1) ${ }^{22}$, bejaht Bruno für seine heroische Liebe den Flammentod. Es ist der Abgrund der Gottheit, "l'abisso della divinitá" 23 , die den Erkennenden verschlingt. Das höchste Ziel ist nur um den Preis des eigenen Untergangs zu erreichen. Und das Heroische dieses Aktes beruht darauf, daß man ihn bewußt unternimmt. Denn der Falter, der in der Flamme verbrennt, oder der Hirsch, der auf seinem Weg zum Wasser vom Pfeil getroffen wird, oder das Einhorn, das in seiner Liebe zur Jungfräulichkeit gefangen und gefesselt wird, sie alle wissen nicht, was ihnen bevorsteht. Der heroisch Liebende hingegen weiß um die Flammen, er weiß um die Pfeile und 


\section{BREVIS ET DAMNOSA VOLVPTAS.}

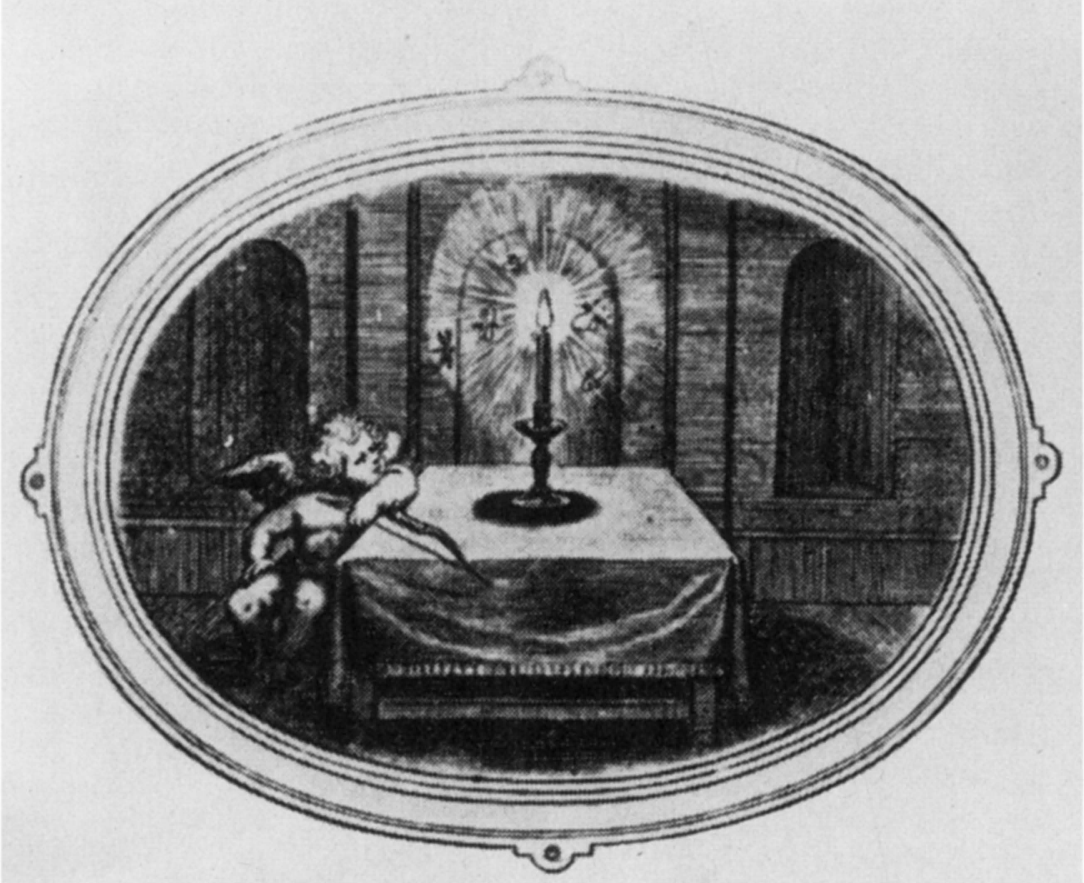

Abb. 1. BREVIS ET DAMNOSA VOLVPTAS. Lumina delectant culices, perimuntque petita; / Sic nobis specs est optima causa mali. Courtesy, Olin Library, Washington University.

die Fesseln: "Aber von einer höchst empfindsamen und doch höchst klarsichtigen Leidenschaft geführt, liebt er das Feuer mehr als die Kühle, die Wunde mehr als das Heilsein, die Fesseln mehr als die Freiheit. ... Denn das Feuer ist das glühende Verlangen nach dem Göttlichen, der Pfeil ist der Strahl, der von der Schönheit des himmlischen Lichtes ausgehend den Menschen trifft, und die Fesseln sind die Erscheinungen des Wahren, die unsern Geist mit der höchsten Wahrheit vereinen" 24 .

Deshalb die Forderung: Lieber am höchsten Ziel scheitern, als bei weniger erhabenen Zielen Erfolg haben. Und so bricht das PhaidrosBild vom Aufflug der Seele in die Vorstellung vom unabdingbaren Absturz desjenigen um, der zum Höchsten strebt. Der Daedalusmythos liefert das Bild dafür, und Bruno kommentiert: "Welches Leben könnte mehr sein als ein solcher Tod?" 25 
Das also ist der Grundgedanke dessen, was Bruno "heroici furori" nennt: die Bejahung des Zusammenbruchs, zu dem der platonischerotische Aufstieg aus seiner Sicht führt, ja unabdingbar führen muß.

Am faszinierendsten wird dieser zusammenbrechende Weg der heroischen Liebe zur absoluten Wahrheit dann im 4. Dialog des 1. Teils ins Bild gebracht; dieses Bild führt nicht nur die erotische Philosophie Brunos in prägnantester Verdichtung vor Augen, sondern es dient zugleich dazu, das Darstellungsverfahren zu reflektieren. Und damit komme ich zum eigentlichen Zentrum meines Interpretationsversuchs. Nach dem Falter, der in seiner Sehnsucht nach dem Licht verbrennt, dem Hirsch, der auf dem Weg zum Wasser vom Pfeil getroffen wird, dem Einhorn, das durch seine Liebe in die Falle geht, und dem Absturz des Himmelsfliegers-nach all dem zieht Bruno nun noch den Mythos von Aktäon heran-Aktäon, der auf der Jagd Diana nackt beim Baden sieht und von ihr in einen Hirsch verwandelt wird, so daß ihn seine eigenen Hunde zerreißen. ${ }^{26}$

Auch hier steht am Beginn ein Sonett, das das Thema in gedrängter Form einführt:

Alle selve i' mastini, e i' veltri slaccia

Il giovan' Atteon, quand' il destino

Gli drizz' il dubio et incauto camino,

Di boscareccie fiere appó la traccia.

Ecco trá l'acqui il piu bel busto et faccia,

Che veder poss' il mortal et divino,

In ostro et alabastro et oro fino

Vedde, e'l gran cacciator dovenne caccia.

Il cervio ch' á piu folti

Luoghi drizzav' i' passi piu leggieri,

Ratto voraro i' suoi gran cani et molti.

I' allargo i' miei pensieri

Ad alta preda, et essi á ma rivolti

Morte mi dan con morsi crudi et fieri. ${ }^{27}$

Der sich anschließende Dialog präzisiert und differenziert wie üblich die Interpretation: Aktäon bedeutet den menschlichen Intellekt, der sich auf die Jagd begibt nach der göttlichen "sapienza". Die Hunde bedeuten sein Denken und seinen Willen. Der Waldteich, in dem Diana badet, bedeutet den Spiegel der Ähnlichkeit, durch die das Verhältnis zwischen dem Irdischen und dem Göttlichen gekennzeichnet ist. Die Farben, in denen sich die Schönheit Dianas manifestiert-Rot, Alabaster und Gold-stehen für die göttliche Macht, die göttliche Schönheit und die göttliche Weisheit. Die Jagd wird gedeutet als das Bestreben 
des Intellekts, sich das, was er erkennt, anzuverwandeln. Aber dieses Bestreben muß scheitern, denn der Jäger wird von der Liebe zu seinem Objekt ergriffen, und in der Liebe verwandelt er sich in das Geliebte. Er wird zur Beute seines eigenen Strebens, er wird von seinem eigenen Streben zerrissen. Doch im Tod, d. h. im ekstatischen Gipfelpunkt seines Furors, wird er eins mit seinem göttlichen Ziel.

Man kann diese Unio mit dem Göttlichen als mors mystica, als ekstatisches Austreten aus der Zeitlichkeit im neuplatonischen Sinne verstehen. Werner Beierwaltes ist bei seiner Interpretation des AktäonSonetts in dieser Weise vorgegangen, um Brunos Konzept konsequent in die Tradition zurückzubinden. ${ }^{28}$ So überzeugend sich diese Anknüpfung darstellt, so groß ist die Gefahr, daß dabei das Neue in Brunos Position aus dem Blick gerät. Ich versuche, es über die Bedeutung $\mathrm{zu}$ fassen, die das eigenartige poetische Verfahren für seinen philosophischen Entwurf besitzt.

Wie verhalten sich also bei Bruno Philosophie und Mythos, diskursives Denken und Bild zueinander? Er geht, wie das Beispiel des Aktäonmythos es veranschaulicht, in der Regel so vor, daß er sein Thema jeweils zunächst in einem Sonett faßt-es sind zum größten Teil eigene Gedichte ${ }^{29}$ - , um dann in einem Lehrdialog in Prosa zwischen einer Figur, die für Bruno steht, und einer andern, die mehr oder weniger nur als Stichwortgeber fungiert, das Sonett auszulegen-ein nicht eben gewöhnliches Verfahren für einen Philosophen.

Und doch kommen hier zwei Elemente zusammen, die durchaus traditionell sind, wenngleich die Art ihrer Kombination auffällig ist. Zum einen steht dahinter die in der antiken Schultradition wie in der christlichen Exegese angewandte allegorische Mythen- und Weltdeutung. Zum andern wirkt die Idee des poeta theologus ein, die mit der Allegorese zusammenspielen konnte und die in der Poetik der italienischen Renaissance eine neue, ganz zentrale Bedeutung gewonnen hat. ${ }^{30}$

So folgt denn, auf den ersten Blick-um beim obigen Beispiel zu bleiben-die Deutung des Aktäonmythos der üblichen allegoretischen Technik, und zwar bis hin zu der charakteristischen Aufsplitterung in eine Vielfalt von Detaildeutungen, die sich nicht restlos in einen durchgängigen Sinnzusammenhang fügen. Doch bei genauerem Zusehen gibt es gravierende Unterschiede, und dies hängt mit Brunos spezifischem poeta-theologus-Konzept zusammen.

Die traditionelle Allegorese geht entweder von einem historischen oder naturgeschichtlichen Faktum oder von einer dichterischen Figur aus, wobei in allen Fällen gilt, daß es Gott ist, der einen zweiten, tieferen Sinn in die Gegenstände gelegt hat. So wird die Opferung Isaaks verstanden als Präfiguration der Passion Christi, d. h., Gott hat Abra- 
hams Opfergang als historisches Faktum bis in Einzelheiten hinein so gestaltet, daß er über seinen historischen Sinn hinaus auf das Heilsgeschehen des Neuen Testaments verweist. Oder wenn im Physiologus gesagt wird, daß der Löwe seine Spur mit seinem Schwanz verwische, damit ihn die Jäger nicht finden, so hat Gott dieser Eigenart des Löwen den Verweis darauf eingeschrieben, daß Christus durch seine Geburt als Mensch die Spur seiner Göttlichkeit verwischt, so daß der Teufel ihn nicht entdecken und die Erlösung verhindern kann. Oder wenn das Sirenenabenteuer der Odyssee in der Weise allegorisch interpretiert wird, daß man Odysseus am Mastbaum auf Christus am Kreuz deutet, der das Schiff der Kirche durch die Verlockungen der Welt hindurch zum Hafen des Paradieses führt, so wird damit vorausgesetzt, daß Gott der Dichtung Homers, ohne daß dieser sich dessen bewußt geworden wäre, einen heilsgeschichtlichen Sinn unterlegt hat. Es gilt somit: Alles was ist, ist von Gott auf den einen Sinn, auf das Heilsgeschehen des Neuen Testamentes hin geschaffen worden. ${ }^{31}$ Und so geht es denn für den christlichen Interpreten von Geschichte, Welt und Mythos darum, diese in allem Seienden verborgene geistige Bedeutung aufzudecken.

Auch Bruno zieht für seine Auslegungen Materialien unterschiedlicher Art heran: Naturvorgänge-der Nachtfalter, der sich im Licht verbrennt-, aus dem Physiologus die Beschreibung des Einhornfangs, aus der mythischen Tradition die Geschichten von Aktäon und Daedalus usw., aber er setzt diese Materialien zunächst einmal selbst in Dichtung um, und das impliziert, daß er anders als Homer und die andern vorchristlichen poetae theologi um den zweiten Sinn seiner Poesie weiß, denn er produziert ihn ja mit. Sein Verfahren ist deshalb eher emblematisch als allegoretisch zu nennen, und so überrascht es denn auch nicht, daß er im 5. Dialog des ersten und in den Dialogen 1 und 2 des zweiten Teils zu einer dezidiert emblematischen Technik übergeht, wobei er das emblematische Verfahren seiner Form nach imitiert, es aber zugleich literarisiert.

Damit ist Folgendes gemeint: Das Emblem besteht bekanntlich aus der Dreierkomposition von Inscriptio, Pictura und Subscriptio. Die Inscriptio fungiert als Motto einer bildlichen Darstellung, und die Subscriptio erläutert dann mehr oder weniger ausführlich den Zusammenhang (als Beispiel: Abb. 1). Bruno behält dieses emblematische Dreierschema bei, aber er ersetzt die konkrete Pictura durch eine Bildbeschreibung. Und das für seine Dialoge charakteristische Eingangssonett dient ihm nun als Subscriptio.

Als Beispiel das vierte Emblem des 5. Dialogs: Hier zieht er noch einmal das Bild vom Falter und der Flamme heran. Der Gesprächspartner Brunos fragt, was der Falter bedeute, der um die Flamme kreise und 
was der Sinn des Mottos sei, das "Hostis non hostis" lautet. Die Frage bietet also die Bildbeschreibung und die Inscriptio. Und darauf folgt die dialogische Antwort: Der Falter fliege ahnungslos in die Flamme, "hostis" beziehe sich auf das Feindlich-Tödliche des Feuers, "non hostis" auf die Liebe des Falters. Und dann wird nach der Subscriptio gefragt, worauf diese sich in Sonettform anschließt; sie sagt-paraphrasiert-folgendes: Ich bekenne mich zu meiner Liebe, obschon ich durch sie leide. Es gibt im Leben nichts, was soviel Süße und Beglükkung in sich trägt wie die Qual und der Tod um der Liebe willen, wozu mich meine Natur, mein Wille und mein Schicksal zwingen. Und alle drei Teile werden dann jeweils dialogisch kommentiert: Der Falter und der "furioso" gleichen sich in ihrer Zuneigung zur mörderischen Flamme, heißt es zu Beginn, während das Subscriptio-Sonett den Unterschied deutlich macht: Der Falter würde die Flamme fliehen, wenn er wüßte, daß sie ihm den Tod bringt. Der Liebende hingegen weiß um seinen Untergang und nimmt ihn doch mit Freude auf sich.

Es handelt sich also um eine literarische Imitation des emblematischen Verfahrens mit dialogischen Erläuterungen. Dabei ist die Technik jedoch nicht immer genau dieselbe. So gibt es Zwischenformen zwischen dem strengen emblematischen Schema und der Sonettexegese. Zum Beispiel bei einem Emblem, das so beschrieben wird: zwei Sterne, die aussehen wie zwei strahlende Augen. Dazu das Motto "Mors et vita". Dann folgt ein Sonett, das sich wie ein Liebesgedicht aus petrarkistischer Tradition anhört: "Man kann auf meinem Gesicht die Qualen sehen, die die Hand der Liebe eingeschrieben hat. Du quälst mich, indem du deine liebevollen Augenlichter hinter den schönen Lidern verbirgst, so daß der bewölkte Himmel nicht mehr hell werden kann. Bei deiner Schönheit, bei meiner Liebe, bei Gott beschwöre ich dich, habe Mitleid mit mir, o göttliches Licht. Wenn dir daran liegt, daß ich lebe, öffne die Tore deiner Augen; und schau mich an, o Schönheit, wenn du mir den Tod geben willst" 32 .

Anders als beim "Hostis non hostis"-Emblem ist nicht schon vor der Subscriptio der eigentliche Sinn, der Bezug auf den "furioso", angedeutet. Die Deutung auf den eigentlichen Sinn schließt sich erst an das Sonett an: Das Gesicht, auf das die Qualen der Liebe eingeschrieben sind, ist die Seele. Sie ist völlig auf die Gaben von oben angewiesen. Psalmen klingen an: "Ohne dich ist meine Seele wie die Erde ohne Wasser" (Ps. 143) usw. Wenn Gott die Augen schließt, ist der Himmel des menschlichen Denkens bewölkt, und dieses kann das Dunkel des verborgenen Sinns nicht durchdringen. Es folgt die Bitte, Gott möge die Qualen beenden, die Augen öffnen, auch wenn der Strahl seiner Blicke tödlich sein wird. Der Tod des Liebenden aber meint ein Sterben in höchster Freude, denn es ist das ewige Leben. 
Mit dieser spirituellen Interpretation eines typischen petrarkistischen Liebessonetts nähert sich Bruno wieder sehr stark der traditionellen Hohelied-Exegese, die er sich ja zum Vorbild genommen haben will. Und doch ist der Ansatz nicht allegoretisch sondern emblematisch.

Was bedeutet diese Wende vom allegorischen zum emblematischen Verfahren für Brunos Darstellungs- und Interpretationsweise? Der Unterschied zwischen der Emblematik und der Allegorese besteht darin, daß der Allegoretiker in einer von Gott im heilsgeschichtlichen Horizont mit Sinn erfüllten Wirklichkeit diesen Sinn aufdeckt, während der Emblematiker sich erst ein Bild, und dies im ganz konkreten Sinne, schafft, um dieser Pictura dann seine deutende Subscriptio hinzuzufügen. Diese Picturae können aus der Welt, der Geschichte oder der literarischen Tradition geholt werden, sie können aber auch ad hoc konstruiert sein, in jedem Fall aber hat man es mit einem freien Spiel zwischen Bild und Sinn zu tun. Es kann zwar auch bei den Emblematikern von einem Aufdecken des Sinns in den Bildern die Rede sein. Doch bezieht sich dies auf ein metaphorisches Verständnis der Dinge dieser Welt in einem allgemeinen und $d . h$. freien moralischen Horizont. Dabei soll nicht übergangen werden, daß es auch in der christlichen Allegorese den moralischen Sinn gibt, so daß es hier zu einer gewissen Grenzverwischung kommen kann. Doch dies rechtfertigt es nicht, das Emblem zu eng an die Allegorese heranzurücken, wie dies in der Emblemtheorie seit Henkel /Schöne üblich ist. ${ }^{33}$

Brunos Procedere deckt sich mit dem emblematischen Verfahren grundsätzlich insofern, als auch er nicht mehr wie der Allegoretiker eine vorgegebene Welt und Dichtung auf einen in sie eingeschriebenen Sinn hin auslegt, sondern selbst sinnträchtige Bilder produziert. Und es ist dieser poetische Akt, über den er sich mit der Wahrheit verbunden weiß, die sich in seiner Dichtung darstellt. Aber Bruno geht nun noch einen entscheidenden Schritt über das emblematische Konzept hinaus. Denn sein poetisches Verfahren versteht sich ja als ein dezidiert philosophischer Akt. Die Erkenntnis führt dabei-so könnte man meinen-in guter platonischer Tradition über das Bild. Aber anders als in dieser Tradition weist das Bild nicht weiter. Diana im Bade steht für die Natur, und die Natur ist zwar der Spiegel der Wahrheit, aber es ist eine Wahrheit, die unzugänglich bleibt. Sie kann in ihrer Unendlichkeit mit endlichen Mitteln nicht erfaßt werden. Man kommt nicht über den Spiegel hinaus. Die Jagd Aktäons bedeutet den Erkenntnisprozeß angesichts dieser Blockade, der Prozeß erreicht sein Ziel nicht, sondern er bricht in sich zusammen.

Die Wahrheit liegt also im Erzeugen von Bildern, die nicht zur Wahrheit führen, vielmehr wird im Scheitern dieses Bildererzeugens 


\section{Walter Haug}

die Wahrheit erfahrbar gemacht. Man könnte sagen, das sei noch einmal negative Theologie, aber nun unter dem Aspekt subjektiver Bildproduktion, doch besser würde man von negativer Poesie sprechen. Es wird nicht mehr in den Bildern die Wahrheit entdeckt, indem man sie übersteigt, die Erscheinungen sind nicht mehr ontologisch verankert, sondern die Poesie verwendet ihre Materialien rein metaphorisch, sie sind Fiktionen, Entwürfe der subjektiven Einbildungskraft. An die Stelle der Welt tritt die Poesie, die sich selbst auslegt, und wenn sie dies tut, muß sie, um sich zu verstehen, letztlich ihr eigenes Verfahren reflektieren. Alle Bilder zielen deshalb auf die Frage nach dem Verhältnis zwischen poetischer Subjektivität und absoluter Wahrheit, wobei diese Subjektivität in ihrer Schöpferkraft der letzte Boden ist, auf dem man stehen kann, d. h. im Grunde natürlich nicht stehen kann. Der platonische Eros als Triebkraft hat keine Welt mehr, er wird deshalb auf sich selbst zurückgeworfen und erfährt dabei sein Scheitern, um darin sein einziges noch mögliches Ziel zu finden. Oder poetologisch gesagt: Der erotische Impuls erzeugt im Horizont der Imagination Bilder, um imaginierend doch nur sich selbst zu finden und dabei im Bild des Scheiterns-die Aktäonsjagd-das Scheitern des Bildes vorzuführen, dies in der verzweifelten Hoffnung, gerade durch die Vehemenz des Zusammenbruchs doch noch über sich selbst hinauszukommen.

Der Furor, der sich heroisch selbst verzehrt, bleibt also die einzige Wahrheit, die realisierbar ist. Das bedeutet, daß in der Selbstaufhebung des Bilddenkens jener Sprung steckt, der die Differenz negativ überwindet. Die Poesie wird dadurch zur Praxis einer negativen Philosophie, die in ihrem Weg über die Bilder radikal platonisch sein will, die aber zugleich den Weg preisgibt, auf den der platonische Ascensus angewiesen ist. Das ist der Kern des dramatischen Widerspruchs, durch den diese philosophische ästhetik oder ästhetische Philosophie gekennzeichnet ist.

Vergleichen wir nocheinmal mit Cusanus: Cusanus gelangte im Prozeß seines Denkens bis zur "Mauer des Paradieses", um sich dort vor das Postulat gestellt zu sehen, die Gesetzlichkeit des Denkens in der coincidentia contradictoriorum zu übersteigen. Bruno kann ein solches Transzendieren nicht mehr leisten. Er wird an der Grenze der Erscheinungen, die seine eigenen Produktionen sind, auf die subjektive Schöpferkraft zurückgeworfen. An die Stelle des Überstieges tritt der Zusammenbruch, denn eine in dieser Weise produktiv gefaßte Subjektivität kann nur über die Selbstzerstörung zurückgelassen werden.

Ferdinand Fellmann hat die Heroischen Leidenschaften als den zentralen philosophischen Text Brunos bezeichnet. ${ }^{34}$ Man möchte dem 
zustimmen und dies damit begründen, daß hier das konsequenteste Resultat jenes Doppelansatzes vorliegt, von dem ich bei meiner Interpretation ausgegangen bin, des Ansatzes einerseits beim Differenzbewußtsein in der Tradition Eckhart-Cusanus und des Ansatzes andererseits bei der erotischen Philosophie des italienischen Platonismus. Es war meines Erachtens die Unversöhnlichkeit dieser beiden Ansätze, die den Denker Bruno radikal auf die schöpferische Subjektivität zurückgeworfen hat, so daß, wie Fellmann sagt, hier erstmals eine Anthropologie ohne ontologische Basis zustande gekommen ist. ${ }^{35}$ Der Mensch definiert sich nunmehr allein durch den emotionalen Freiraum, der dadurch entsteht, daß die erotisch-philosophische Bewegung auf sich selbst zurückschlägt. Diese Reflexion verdankt übrigens nicht wenig der Tradition der höfischen Liebe, in der immer schon die Unerreichbarkeit der Geliebten dazu führte, daß sich ein Reflexionsraum öffnen konnte, in dem die Liebe sich selbst zu fassen suchte. Neu ist jedoch, daß das Philosophieren sich hier genuin als ein poetisches Verfahren gibt, das sich als ein philosophisches interpretiert. Der Ort, an dem beides eins wird, ist die Imagination, die das philosophische Sehen im platonistischen Sinne in ein poetisches Bilddenken verwandelt, das aber nicht mehr über sich hinausführen kann, nicht allegoretisieren kann, sondern in sich gefangen bleibt und deshalb seinen eigenen Zusammenbruch betreiben muß. Und es erreicht ihn um so gewisser, je leidenschaftlicher die Imagination sich hochspielt, je stärker die Sinnlichkeit der Bilder die Phantasie beflügelt. Und hierbei zeigt sich wohl die Distanz zur platonischen Tradition am deutlichsten: Der Anblick der Schönheit-der Schönheit Dianas im Bade-ist kein Weg mehr zu einer objektiven Wahrheit, sondern die Schönheit vernichtet den Betrachter. Das Glück und die Qual der Jagd nach der Wahrheit liegt nunmehr allein in der Selbsterfahrung des Subjekts, einer Selbsterfahrung, die über die schöpferische Einbildungskraft läuft.

Und doch bleibt Brunos ästhetisches Verfahren, wie gesagt, letztlich ein philosophisches. Denn die genuine fiktive Poesie bedarf keiner Exegese-aber natürlich der Interpretation. Der erste entschiedene Verfechter der neuen poetologischen Position war Mussato gewesen, einer der Lehrer Boccaccios. ${ }^{36}$ Bruno gehört nicht in diese Tradition, er will ja eine objektive Wahrheit, auch wenn sie ihm versperrt ist und er nur den subjektiven Akt des Bilddenkens findet, und dies ohne die Möglichkeit zu haben, zur Wahrheit des Fiktionalen weiterzugehen. So gelangt er zum emblematischen Kompromiß der ausgelegten Fiktion. Ich bin versucht zu sagen, das sei eine charakteristisch barocke Lösung: die poetische Mobilisierung der ganzen Sinnlichkeit, gesteigert bis zu 
dem Augenblick, an dem sie ihre Maske abwirft und das Gerippe in Erscheinung tritt, das für den Umbruch in die absolute Wahrheit steht. Doch dies nur als ein flüchtiger Zukunftsblick zum Schluß, den ich aber nicht forcieren möchte.

\section{Anmerkungen}

1. Zur Biographie: Giovanni Aquilecchia, Giordano Bruno (Rom: Istituto della Enciclopedia Italiane, 1971).

2. Zum Oeuvre: Aquilecchia, Giordano Bruno. Bibliographie: Virgilio Salvestrini, Bibliografia di Giordano Bruno (1582-1950), 2. Aufl. v. Luigi Firpo (Florenz: Sansoni, 1958); Nachträge dazu von Andrezej Nowicki in Atti dell'Accademia di Scienze Morali e Politiche della Società Nazionale di Scienze, Lettere ed Arti in Napoli 79 (1968): 505-26; 80 (1969): 199-230; 81 (1970): 325-44; 83 (1972): 319-450.

3. Paul-Henri Michel, Hg. und Übers., Giordano Bruno, Des Fureurs Hérö̈ques, 2. Aufl. (Paris: Société d'Edition "Les Belles Lettres", 1984), S. 17-18.

4. Felice Tocco, Le opere latine di G. Bruno esposte e confrontate con le italiane, Pubblicazioni del R. Istituto di Studi superiori pratici e di perfezionamento in Firenze (Florenz: coi tipi dei Successori Le Monnier, 1889).

5. Antonio Corsano, Il pensiero di Giordano Bruno nel suo svolgimento storico (Florenz: Sansoni, 1940).

6. Leonardo Olschki, "Giordano Bruno", Deutsche Vierteljahrsschrift für Literaturwissenschaft und Geistesgeschichte 2 (1924): 1-79.

7. Ebd., S. 42.

8. Hans Blumenberg, Die Legitimität der Neuzeit (Frankfurt a. M.: Suhrkamp, 1966), S. 433-585.

9. Zum Beispiel Paul Richard Blum, Aristoteles bei G. Bruno: Studien zur philosophischen Rezeption (München: Fink, 1980); Frances A. Yates, Giordano Bruno and the Hermetic Tradition (Chicago: University of Chicago Press, 1964); Ferdinand Fellmann, "Einleitung" zu Giordano Bruno, Von den Heroischen Leidenschaften, übers. v. Christiane Bacmeister (Hamburg: Meiners, 1989).

10. Stephan Otto, Renaissance und frühe Neuzeit, hg. v. Rüdiger Bubner, Geschichte der Philosophie in Text und Darstellung, 3 (Stuttgart: Reclam, 1984), S. 306.

11. Blumenberg, Legitimität der Neuzeit.

12. Otto, Renaissance und frühe Neuzeit, mißt diesem dritten Dialog nicht zu Unrecht eine zentrale Bedeutung zu.

13. Zuletzt dazu: Kurt Ruh, Geschichte der abendländischen Mystik I (München: Beck, 1990), S. 71-82 und "Die Mystica Theologia des Dionysius Pseudo-Areopagita im Lichte mittelalterlicher Kommentatoren", Zeitschrift für deutsches Altertum 122 (1993): 127-45, hier S. 129-32.

14. Vgl. Otto, Renaissance und frühe Neuzeit, S. 262.

15. Vgl. dazu Walter Haug, "Grundformen religiöser Erfahrung als epochale Positionen: Vom frühmittelalterlichen Analogiemodell zum hoch- und spät- 
mittelalterlichen Differenzmodell", in Religiöse Erfahrung: Historische Modelle in christlicher Tradition, hg. v. Walter Haug u. Dietmar Mieth (München: Fink, 1992), S. 75-108, hier S. 79-85.

16. Walter Haug, “Die Mauer des Paradieses: Zur mystica theologia des Nicolaus Cusanus in De visione Dei", Theologische Zeitschrift 45 (1989): 216-30.

17. Um ganz genau zu sein: Ficinos platonische Schriften fallen in die 60er/70er Jahre des 15. Jahrhunderts, Cusanus' Schriften gehören in die 40er/50er Jahre. Ficino ist von Cusanus beeinflußt worden.

18. Angelegt bei Platon, vom Christentum übernommen, nochmals scharf herausgearbeitet von Ficino. Vgl. George D. Economou, "The two Venuses and courtly love", in In Pursuit of Perfection: Courtly Love in Medieval Literature, hg. v. Joan M. Ferrante u. a. (London: Kennikat Press, 1975), S. 17-50.

19. Platon, Phaidros, $246 \mathrm{~d}$.

20. "Gelate hó spene, et gli desir cuocenti: / A' un tempo triemo, agghiaccio, ardo et sfavillo, / Son muto, et colmo il ciel de strida ardenti, / / Dal cor scintill', et da gl' occhi acqua stillo; / Et vivo et muoio, et fò ris' et lamenti: / Son vive l'acqui, et l'incendio non more, ..." Ich zitiere nach der Ausgabe von Michel, Giordano Bruno, hier S. 159.

21. Ersles Sonett des 3. Dialogs (Michel, Giordano Bruno, S. 181).

22. Arthur Henkel u. Albrecht Schöne, Hgg., Emblemata: Handbuch zur Sinnbildkunst des XVI. und XVII. Jahrhunderts (Stuttgart: Metzler, 1967; Supplement und Sonderausgabe, 1978), Sp. 911-12.

23. Michel, Giordano Bruno, S. 181.

24. "Ma vien guidato da un sensatissimo et pur troppo oculato furore, che gli fá amare piu quel fuoco che altro refrigerio, piu quella piaga che altra sanitá, piu qué legami che altra libertade ... atteso che questo fuoco é l'ardente desio de le cose divine, questa saetta é l'impression del raggio della beltade della superna luce, questi lacci son le specie del vero che uniscono la nostra mente alla prima veritá" (Michel, Giordano Bruno, S. 181, 183).

25. So im 5. Sonett des 3. Dialogs, Teil 1: "Non temer l'alta runia" (Michel, Giordano Bruno, S. 193).

26. Der Mythos dient seit der Renaissance zur Veranschaulichung unterschiedlicher Theoreme.

27. [In den Wäldern läßt der Jüngling Aktäon, / vom Schicksal auf den gefährlichen Weg gewiesen, / die Hetzhunde und die Windhunde los / auf die Spur der wilden Waldtiere. / / Und da, in der Mitte des Wassers, sieht er das Schönste, / Brust und Antlitz, was ein Sterblicher oder ein Gott sehen kann, / in Rot und Alabaster und feinem Gold, / und der große Jäger wird zur Beute. / / Und als Hirsch, ins tiefste Dickicht / die behenden Schritte lenkend, wird er sogleich zerrissen / von der großen Meute seiner mächtigen Hunde. / / So richte ich meine Gedanken auf die höchste Beute, / doch jene, auf mich zurückgewendet, geben / mir den Tod mit grausam wilden Bissen.] Michel, Giordano Bruno, S. 205.

28. Werner Beierwaltes, "ACTAEON. Zu einem mythologischen Symbol Giordano Brunos", Zeitschrift für philosophische Forschung 32 (1978): 345-54.

29. Der Dichter Tansillo, der Gesprächspartner im ersten Teil, zitiert eine 


\section{Walter Haug}

Reihe von Sonetten, die er selbst verfaßt hat; vgl. Michel, Giordano Bruno, S. $452-53$.

30. Zum poeta theologus (im Zusammenhang mit Albertino Mussato): Ernst Robert Curtius, Europäische Literatur und lateinisches Mittelalter, 3. Aufl. (Bern: Francke, 1961), S. 225-26. Vgl. auch August Buck, Klaus Heitmann u. Walter Mettmann, Hgg., Dichtungslehren der Romania (Frankfurt a. M.: Athenäum, 1972), S. 14-25.

31. Es sei an die klassische Formulierung des Alanus ab Insulis erinnert: "Omnis mundi creatura, quasi liber et pictura nobis est et speculum" (Patrologia Latina 210, Sp. 579).

32. Henkel u. Schöne, Emblemata, Sp. 23-24.

33. Ebd.; vgl. die Vorbemerkungen (1967) im Supplement und in der Sonderausgabe, S. xiv- $x x$.

34. Fellmann, "Einleitung", S. xxviii.

35. Ebd., S. xv.

36. Vgl. Anm. 29. 


\section{Part III. Adapting Traditional \\ Knowledge to New Science}





\section{Der Umgang mit dem Wunderbaren in der Natur: Portenta, Monstra und Prodigia in der Zoologie des Mittelalters und der frühen Neuzeit-Die Gleichzeitigkeit des Ungleichzeitigen}

\section{Thomas Cramer}

At least a handful of large animals surely remain to be discovered in tropical forests. Indians and rubber tappers in the western Amazon report a terrifying, manlike creature with shaggy red hair and a chemical defense capable of paralyzing opponents. ${ }^{1}$

Im 30. Kapitel des 6. Buches seiner Cosmographey schreibt Sebastian Münster "von wunderbarlichen dingen so im Morenlandt gefunden werden" 2 . Unter die afrikanischen Wunder zählt er auch die monströsen Menschenarten, die er vorher schon, wie seit der Antike üblich, in Indien beheimatet hatte: "Man schreibt auch sonst von vielen vnd mancherleyen Monstris so in diesem Land sollen gefunden werden/ besunder daß etliche Menschen keine Lefftzen haben/ sonder brauchen Zeichen wie die Stummen. Etliche sollen nit mehr dann ein Aug in der Stirnen haben / etliche haben kein Kopff / sonder jhre Augen stehen inn der Brust/ etliche haben nicht mehr dann ein Fuß/ vnd mit demselbigen lauffen sie schneller dann die zweyfüssigen Menschen" 3 . Der zugehörige Holzschnitt zeigt nebeneinander einen Skiapoden, einen Kyklopen, eine Mischgeburt von Pygmäen und doppelköpfigen Riesen, einen Kopffüßler und einen Kynokephalen. Im darauffolgenden Satz äußert Münster seine Skepsis: "Aber dieser Wunder hat man kein gewisse Kundtschafft/ wiewol etliche dapffere Männer auß den Alten darvon geschriben haben/ vnd angezeigt/ daß sie in der Natur werden funden" ${ }^{4}$. Schon zuvor hatte er bei der Beschreibung Indiens den Verdacht geäußert, bei den monstris handele es sich um Erdichtungen der Alten. ${ }^{5}$ 
Sätze wie diese gelten mit Recht als Indiz für eine Korrektur des überlieferten durch die Kategorie der erfarung ${ }^{6}$, eine Beglaubigung oder auch Falsifizierung des Wortes durch den visuellen Eindruck, eine Ersetzung und Kontrolle der Buchautorität durch das empirisch Erfaßte, das seine Wahrheit erst dann erweist, wenn es wahrgenommen werden kann. In genügender Belegdichte aneinandergereiht, ergeben solche Sätze das Bild eines von Friedrichs II. Falkenbuch bis in das Ende des 16. Jahrhunderts kontinuierlich fortschreitenden Aufklärungs- und Rationalisierungsprozesses. Für die wunderbaren Menschenrassen hat Rudolf Wittkower eben diesen Prozeß in einer (auch als Quellensammlung) grundlegenden Abhandlung nachgezeichnet. ${ }^{7}$ Danach wären die in der antiken Naturbeschreibung von Ktesias bis Plinius geschilderten Menschenrassen mehr oder minder unverändert in die früh- und hochmittelalterlichen Naturkompendien übernommen worden, um schließlich unter dem Druck wachsender Skepsis wegen fehlender bzw. nicht herzustellender Erfahrung im Laufe des 16. Jahrhunderts als Fiktionen entlarvt, als Affenarten definiert oder schlicht als Mißbildungen erklärt zu werden.

Skeptische Äußerungen, wie sie sich lange vor dem 16. Jahrhundert finden, haben den Status des "aufgeklärten Zwischenspiel[s]" 8 , so etwa Aulus Gellius' (geb. ca. 130) vernichtender Kommentar zu den einschlägigen Büchern, die er auf dem Buchmarkt von Brindisi vorfand: "Atque ego auide statim pergo ad libros. Erant autem isti omnes libri Graeci miraculorum fabularumque pleni, res inauditae, incredulae, scriptores ueteres non paruae auctoritatis" ${ }^{\prime}$. Nachdem er ausgeführt hat, bei den "res incredulae" handele es sich um die Schilderung von Kyklopen, Skiapoden, Kynokephalen, Monoculi und dergleichen, gibt er sein Urteil ab: "Haec atque alia istiusmodi plura legimus; sed cum ea scriberemus, tenuit nos non indoneae scripturae taedium" 10 .

Bei intensiver Lektüre erweist sich die Anzahl der "aufgeklärten Zwischenspiele" in den mittelalterlichen und der Beispiele für unkritischen Traditionalismus in den frühneuzeitlichen Quellen als so groß, daß das Bild vom kontinuierlichen Aufklärungs- und Rationalisierungsprozeß empfindlich gestört wird. Es handelt sich um einen höchst komplexen Denkvorgang, der vor allem von den Parametern Natur und Wunder, Autorität und Verifizierung, Überlieferung und Erfahrung bestimmt wird. Den verschlungenen Wegen dieses Prozesses gehe ich an einigen Beispielen nach. Nicht nur die Frage nach der Art und Weise des Umgangs mit dem Wunderbaren steht zu der Debatte; ihr voraus geht die Frage nach dem Wunderbaren selbst: Welche Phänomene werden $\mathrm{zu}$ welcher Zeit und aus welchen Gründen als außerhalb der natürlichen Ordnung stehend und damit in ihrer Exi- 
stenz anzweifelbar oder verifizierungsbedürftig empfunden? Warum tauchen gegebenenfalls Zweifel am Vorhandensein von Menschen mit nur einem Auge auf der Stirn auf, während zur gleichen Zeit niemand auf den Gedanken kommt, Tiere mit pferdeartigem Leib und einem ellenlangen Horn auf der Stirn könne es nicht geben, obwohl sie doch ebensowenig wie die Kyklopen je beobachtet worden sind? Warum bezweifeln gegen Ende des 16. Jahrhunderts Naturforscher die Existenz des Basilisken, während sie gleichzeitig die Drachen zu vorher ungekannter Artenvielfalt erblühen lassen und systematischer zoologischer Beschreibung würdigen? Die Beantwortung dieser Fragen wird nicht erleichtert dadurch, daß es von der Antike bis in die Neuzeit einen ganzen Katalog von Begriffen zur Bezeichnung außernatürlicher Phänomene gibt, die oft synonym gebraucht werden und jedenfalls nicht systematisiert oder gegeneinander abgegrenzt sind: prodigia, mirabilia, ostenta, portenta, monstra. Dies wird jedoch offensichtlich nicht als Problem empfunden, da die Frage nach dem Wunderbaren selbst sich nicht oder nicht systematisch stellt. Erst 1557 stößt sich Johannes Herold (geb. 1511) im Vorwort seiner Übersetzung von Conrad Lycosthenes (1518-61) Prodigiorum ac ostentorum chronicon an der Vielzahl und Vagheit der Begriffe: "Dann vnser sprach / mit sechs buchstäbigen zweyer z'samenschlagungen eintzigem wörtlin Wunder/ alles in sich faßt/ das so Griechen/ so Latiner gar khaum in zweintzigen erschrocklich thonenden worten begreiffen mögen"11. Herolds Versuch, 21 Begriffe inhaltlich voneinander abzugrenzen, resultiert indessen nur in einer Systematisierung verschiedener Arten der Vorausdeutungen, Visionen und Vorzeichen (lediglich die Monstra definiert er als wundergeburten).

Im 16. Buch der Civitas Dei diskutiert Augustin die Frage, ob die monstrosa hominum genera von Adam abstammen könnten ${ }^{12}$, die man in Mosaiken an der Hafenstraße von Karthago abgebildet sehen und von denen man in vielen Büchern lesen könne. Die Erörterung liefert bis weit in die Neuzeit hinein entscheidende Beurteilungskriterien vor allem darin, daß sie Raum läßt für grundsätzliche Skepsis gegenüber dem überlieferten: "Sed omnia genera hominum, quae dicuntur esse, credere non es necesse"13. Augustinus gibt zunächst keinerlei Hinweise darauf, wo ihm Skepsis angebracht erscheint (lediglich die Existenz von Antipoden bestreitet er mit Argumenten der aristotelischen Geographie), gleichzeitig aber liefert er die entscheidende Definition für "Natürlichkeit" und Wunder: Als natürlich gilt das Gewohnte, als mirabile das wegen seiner Seltenheit Außergewöhnliche: "Apparet tamen quid in pluribus natura obtinuerit et quid sit ipsa raritate mirabile" 14 . 


\section{Thomas Cramer}

Daraus folgt, daß die wunderbaren Völkerschaften lediglich Abweichungen vom Gewohnten sind ${ }^{15}$, gleichsam kollektive Mißgeburten und damit ebenso "erfahrbar" wie die Mißbildungen, die Augustin selbst gesehen hat, wie etwa einen Mann in Hippo Zaritus mit verkrüppelten Händen und Füßen ${ }^{16}$ : "Si aliqua gens talis esset, illi curiosae atque mirabili adderetur historiae ${ }^{17}$.... Non itaque nobis uideri debet absurdum, ut, quem ad modum in singulis quibusque gentibus quaedam monstra sunt hominum, ita in uniuerso genere humano quaedam monstra sint gentium" ${ }^{18}$. Augustinus befindet sich mit dieser Argumentation nicht allzuweit entfernt von den Koryphäen der modernen Naturbeschreibung im 16. und 17. Jahrhundert: In seiner anthropologisch-ethnologischen Enzyclopädie von 1614 behandelt der Jurist Heinrich Kornmann ${ }^{19}$ die wunderbaren Völkerschaften im Kontext der Mißgburten; Ulysse Aldrovandi (gest. 1604) beschreibt ein am 1. November 1562 in Villefranche geborenes weibliches monstrum acephalon als (erwachsenes) Exemplar der kopflosen Rasse. ${ }^{20}$

Noch ein in zweierlei Hinsicht folgenreiches Einordnungskriterium liefert Augustinus durch seine einfache und klare Definition des Menschen als animal rationale atque mortale: die Abgrenzung menschlicher Lebewesen gegen tierische und damit eine Einengung des Bereichs, auf den die Kategorie des Wunderbaren als des Außergewöhnlichen überhaupt angewendet werden kann: "Nam et simias et cercopithecos et sphingas si nesciremus non homines esse, sed bestias, possent illi historici de sua curiositate gloriantes uelut gentes aliquas hominum nobis inpunita uanitate mentiri" ${ }^{21}$. Damit ist die Kategorie des mirabile auf den Menschen beschränkt, weil nur für ihn der Maßstab des Gewöhnlichen, des Normalen gilt. Diese anthropomorphe und anthropozentrische Perspektive hat zur Konsequenz, daß für das Tierreich eine Einteilung in "Natürliches" und Wunderbares gar nicht zur Debatte stehen kann, weil ein Maßstab für die Einteilung in "Gewöhnlich" und "Außergewöhnlich" fehlt. Eine Untersuchung des historischen Wandels im Umgang mit dem Wunderbaren wird also darauf zu achten haben, wo die anthropozentrische Orientierung verlassen wird, wo und aus welchen Gründen auch im Bereich der Zoologie die Kategorie des Wunders und damit der sie kontrollierenden Erfahrung mit der Konsequenz der Verifizierung oder Falsifizierung auftaucht.

Augustinus' anthropologische Definition stellt damit noch ein weiteres wichtiges Urteilskriterium bereit: Es muß lediglich der Nachweis geführt werden, es handele sich bei einem Lebewesen gar nicht um ein animal rationale, bei den wunderbaren Rassen nicht um Menschen, sondern um Tiere. Gelingt dies, ist man der Notwendigkeit des Verifizierens (durch Erfahrung oder andere Mittel) enthoben. Eben diese 
Denkfigur liefert dem 16. Jahrhundert ein wichtiges Instrument zur Bewältigung des Wunderbaren. Der Gesnerus redivivus von 1669 handelt die Kynokephaloi ohne nähere Begründung unter den Affen ab, obwohl sich die Beschreibung ihres Aussehens deutlich an die Darstellung der Menschenrasse bei Plinius 22 anlehnt: "Cynocephalus. Hundskopff. . . . Dieser Affen Nahmen kompt daher/ weil sie einen Hundskopff haben / da sie sonst fast an allen Gliedern dem Menschen gleich sehen. ... Diese Thier haben keine Stimm / klappern mit den Zänen gar laut: Underm Kynn sind sie bärtig und haben gantz scharpffe Klauen an den Händen" ${ }^{23}$. Wie wenig allerdings eine solche Beschreibung der Hundskopfmenschen als Paviane repräsentativ für einen verbreiteten Kenntnisstand oder eine herrschende mentale Disposition ist, zeigt sich an der etwa gleichzeitig von Lycosthenes / Herold mitgeteilten Entdeckung der Kynokephalen in der Neuen Welt, in Santa Cruz, die wörtlich den alten Beschreibungen entsprechen; also der Verifizierung ihrer Existenz durch "Erfahrung": "In der Newgefundnen welt/ dort gegen Mitnacht/ zum Heiligen Creütz / hatt der künig $v ß$ Portugall durch sein schiffung leüth funden/ die rauhe hundßköpff mit langen esels ohrn hattend / der mittel leyb ist mentsch / mit armen vnd händen/ die hufft vnd schenckel wie ein pferd/ klauwen wie ein khu. Reden nit/ bellen aber lauth" 24. Der gleiche Johannes Herold hatte aber schon drei Jahre früher im Diodorus Siculus-Teil seiner Heydenwelt von 1554 die Meinung übernommen, bei den Kynokephalen handele es sich nicht um Menschen, sondern um Tiere, nämlich Paviane: “Die thier / so man Cynocephalos oder hundsköpff nennet/ die seind sonst dem menschen am leyb nit fast vngleich/ auch nimpt es sich menschlicher stimm an / ein wild / vnzämig thier / $d z$ kein vernunfft hatt / kein augprawen/ ist erschrockenlich grausam anzusehen. Von Natur so hat das weyblin vsserhalb des leybs sein gepurt glid unbedeckt" 25. Begleitet wird diese Aussage aber vom Holzschnitt aus Münsters Cosmographia, der die Vertreter der wunderbaren Menschenrassen versammelt. ${ }^{26}$ Nur zwanzig Jahre zuvor zeigt Sebastian Franck, der ausdrücklich nur den "angenumnen, glaubwirdigen, erfarnen [!] weltschreibern" 27 vertraut und "die lugenhafft histori S. Brandon reyß vnnd Mörfart Dietrichs von Bern oder die poppen Joannis de monte villa" 28 ablehnt, keinerlei Bedenken, unter Berufung auf Plinius von den Völkern Afrikas zu sagen: "etlich haben kein haubt/ sunder aug vnnd mund an der brust" 29 .

Augustinus selbst faßt seine Kriterien für die Beurteilung des Wunderbaren in drei Punkten zusammen: (1) Grundsätzlich können Nachrichten über wunderbare Menschenrassen erlogen sein. (2) Grundsätzlich ist zu fragen, ob es sich um Menschen- oder um Tierarten handelt 
(Bei Tieren stellt sich die Frage nach dem Wunderbaren nicht.) (3) Sofern es Menschen sind, stammen alle gleichermaßen von Adam ab, erscheinen also als wunderbar durch Abweichung vom Normalen: "Aut illa, quae talia de quibusdam gentibus scripta sunt, omnio nulla sunt; aut si sunt, homines non sunt; aut ex Adam sunt, si homines sunt" 30 .

Isidor von Sevilla übernimmt grundsätzlich die Argumentationsmuster von Augustin, präzisiert sie jedoch begrifflich und fügt einen weiteren Aspekt hinzu. Im 11. Buch der Etymologien behandelt das lange dritte Kapitel die Portenta ${ }^{31}$, das sind "Gigantes, Cynocephali, Cyclopes, et cetera" ${ }^{32}$. Augustin wörtlich zitierend ${ }^{33}$, hebt er dessen Beschreibung ins Grundsätzliche: "Portenta . . . non sunt contra naturam, quia divina voluntate fiunt, cum voluntas Creatoris cuiusque conditae rei natura sit. Vnde et ipsi gentiles Deum modo Naturam, modo Deum appellant. Portentum ergo fit non contra naturam, sed contra quam est nota natura" ${ }^{34}$. Isidor entwirft einen präzisen Katalog der Merkmale, an denen eine Abweichung von der nota natura erkennbar wird. ${ }^{35}$ Er umfaßt zehn Punkte, die unter den Begriffen Disproportionalität, Heteromorphie und Heterogenität zu subsummieren sind.

Als neue Gruppe führt Isidor die fabulosa portenta ein, "quae non sunt sed ficta" ${ }^{36}$. Ein Beispiel neben den Chimären, den Kentauren und dem Cerberus sind die Sirenen, "ex parte virgines, ex parte volucres, habentes alas et ungulas" ${ }^{37}$. Secundum veritatem handele es sich um Hafenhuren, die Reisende bis auf den letzten Pfennig ausnehmen und deshalb zu literarischen Allegorien des Schiffbruchs stilisiert worden seien. Mit Flügeln und Krallen seien sie dabei versehen worden, quia amor volat et vulnerat. Isidor gibt nirgendwo an, welche Kriterien die Klassifizierung eines Wunderwesens als literarische Allegorie erlauben oder notwendig machen. Das ändert nichts daran, daß er eine grundsätzlich wichtige und zukunftsträchtige Möglichkeit der rationalisierenden Interpretation des Wunderbaren bereitstellt. ${ }^{38}$ Der Gesnerus redivivus bedient sich ihrer bei der Beurteilung der Sphinx ("Jungfrau=aff"):

Dann ob wol etliche schreiben/ daß solche Thier bey den Traglodytern/ so man heutiges Tags das Königreich Seylam nennet/ und auch in der Gegend deß Landes Habesch gefunden werden/ ist dannoch jhrer keiner/ der fürgeben könne/ daß er es gesehen habe [!]. Derhalben ich der Meynung bleib/ daß diese Gestalt deß Thiers ein Gediecht der alten Aegyptier sey ... Michael Psellus vermeynt/ es hätten die Poeten diese Wundergestalt also beschrieben/ umb dadurch zu erkennen zu geben/ wie der Mensch durch mancherley kräfftige Qualitäten und Arten/ zu einem 
rechten Menschen würde. Als nemblich durch den Sinn/ durch die Vernunfft/ durch den verstand und die Gedanken/ durch die Einbildung/ und Begreiffung oder Gelehrsamkeit wodurch er gleichsam zu einem Mittelding wird zwischen einem vernünfftigen und unvernünfftigen Thiere. ${ }^{39}$

Der Erforschung der Natur kommt es zu, das Wunderbare aus dem Schwebezustand zwischen Wahrscheinlichkeit und Unwahrscheinlichkeit zu erlösen. Ist es als Bestandteil der Natur erweisbar, dann reduziert sich das Wunderbare auf das Exotische, das als Abweichung von der Norm Ungewohnte. Ist der Erweis nicht zu erbringen, ist das Wunderbare als poetisch-fiktional bzw. schlicht lügenhaft anzusehen. An diesem Erkenntnisziel ändert sich bis in die frühe Neuzeit wenig. Auch steht von vornherein fest, daß der Erkenntnisvorgang ein Verifizierungsprozeß durch historisch je unterschiedlich definierte "Erfahrung" ist, bei dem auf die Naturbeschreibung der alte historiographische Beglaubigungstopos ex visu non ex auditu übertragen wird. ${ }^{40}$ Die tiefgreifendste Veränderung vollzieht sich nicht so sehr im Erkenntnisvorgang als in der Auswahl der Erkenntnisgegenstände,dessen, was unter dem Gesichtspunkt der Rationalisierung des Wunderbaren überhaupt erklärungs- und erörterungsbedürftig erscheint.

Zum erstenmal konsequent aufgegeben wird die Bindung des Attributs monstruosus an den Menschen um die Mitte des 13. Jahrhunderts bei Thomas von Cantimpré als Resultat grundlegender, höchst eigenständiger und gegen Augustin gerichteter Überlegungen zum Wunderbaren in der Natur, die er zu Beginn des Liber de monstruosis hominibus orientis anstellt. Die augustinische Ausgangsfrage "si homines illi de Adam ... descenderunt" beantwortet er mit einem kategorischen "respondendum est quod non" ${ }^{41}$. Aus der konsequenten Anwendung der augustinischen Definition des Menschen als animal rationale mortale nämlich resultiert notwendig die Einsicht, daß sich die Zugehörigkeit zur Menschenrasse nicht durch äußere Merkmale, etwa das Vorhandensein menschlicher Körperteile, bestimmt, sondern durch verstandesgesteuerte Verhaltensweisen: "neque tantum forma, sed actus et habitus hominem manifestant" 42 . Da die Monstra, mit Ausnahme der bocksfüßigen Satyrn, deren Vertreter dem heiligen Antonius seinen Gottesglauben und seine Erlösungssehnsucht offenbart hat ${ }^{43}$, durchweg in ihrem Habitus nicht von der ratio, sondern vom sensus estimationis in corde bestimmt werden, sind sie nicht der Menschen, sondern der Tierwelt zuzurechnen: "Animalibus vero monstruosis animam inesse non credimus" ${ }^{44}$, denn nach Augustin verfügt nur ein animal rationale mortale über eine Seele.

Durch den Nachweis, es handele sich bei den Monstra nicht um 
Menschenrassen, sondern um Tiere, ist der Begriff aus seiner anthropologischen Bindung erlöst. Die im 13. Jahrhundert zunehmende Bedeutung der ratio als Leit- und Zentralbegriff läßt der augustinischen Definition eine ganz neue Bedeutung zuwachsen mit dem Ergebnis, daß nicht mehr das Erscheinungsbild, sondern Habitus und Verhaltensweisen die entscheidenden Kriterien für die Zugehörigkeit zu Menschen- oder Tierwelt bilden. Daraus folgt, daß der Begriff monstruosus nicht mehr wie bei Augustin oder bei Isidor die Abweichung von der gewohnten (anthropomorphen) Norm bezeichnet. Verallgemeinert: was den von der aristotelischen Logik bestimmten Gesetzen der Wahrscheinlichkeit widerstrebt, ist monstruosus oder gerät in den Verdacht fabulosus zu sein.

Aus diesem Gesichtspunkt ergeben sich folgende Kategorien für die Zuordnung von Tieren zu den Monstra: (1) Tiere, die aus heterogenen Bestandteilen zusammengesetzt sind, gleich ob menschliche und tierische oder von verschiedenen Tierarten stammende. Hierzu rechnet Thomas den Onocentaurus, "animal . . . monstruosum et natura biforme. Habet enim caput velut asini, corpus autem velut hominis" 45 , die "cefusa, monstrum ... quod Cesaris tempore Rome ductum est" 46, ein Tier mit Menschenarmen, und den in Äthiopien beheimateten Pegasus "semivolucris: Equi formam habet, alas ut aquila sed multo maiores, caput armatum cornibus et adeo monstruosum, ut ipso cuncta fere animantia terreat" ${ }^{\prime \prime}$.

Noch ein weiteres Kriterium qualifiziert den Pegasus zum Monstrum: (2) Der Verstoß gegen das Naturgesetz, die Wahrscheinlichkeit, wozu auch die Maßstäblichkeit bzw. die Harmonie der Körperteile zueinander zählt. Der cacus, ein flammenspeiendes, schweineartiges Borstentier in Arcadien, ist ein Monstrum ${ }^{48}$, weil es nach dem Gesetz der Natur zumindest erklärungsbedürftig ist, warum es von den eigenen Flammen nicht verzehrt wird. Keine Rolle spielt bei Thomas von Cantimpré ein drittes Kriterium, das für das 16. Jahrhundert zunehmend wichtig wird: (3) Widersprüche und Abweichungen in den Quellen.

Im übrigen bleiben diese drei Kriterien unverändert bis ins 17 . Jahrhundert die Grundlage für Beurteilung und Einordnung in der Naturkunde. Einem Wandel unterliegen lediglich die Konsequenz und Systematik ihrer Anwendung und die daraus zu ziehenden Schlußfolgerungen. In beidem ist Thomas weit von den Naturforschern des 16. Jahrhunderts entfernt. Ist bei ihm der Pegasus als Vierfüßer mit Flügeln ein Monstrum, so bleibt, gleichermaßen beschaffen, dem Greifen, ebenfalls ein semiavis ${ }^{49}$, eine solche Einordnung erspart. Der Verstoß gegen die ratio führt bei ihm lediglich zu einer Klassifizierung im Bereich des 
Außerordentlichen, nie aber zum Zweifel an dem Vorhandensein des Phänomens selbst. Hier verharrt er in dem augustinischen Denkmuster, nach dem es hinreichend ist, ein Lebewesen als nicht menschlich zu erweisen, um sich alle weitere Notwendigkeit der Verifizierung zu ersparen. Dort, wo eben dieser Zweifel konsequent das Denken bestimmt, führt er im 16. Jahrhundert zur Verbannung des Wunderbaren aus der Natur. Das bedeutet zugleich, daß es immer dann seinen Platz behält, wo es nicht evident dem Gesetz der ratio widerspricht.

Diesen Prozeß verfolge und differenziere ich an Beispielen, geordnet unter die drei Kategorien des Urteils: Von allen Mischwesen gerät der Onocentaurus ${ }^{50}$ als erstes in den Verdacht des Außernatürlichen und damit schließlich des Fabulösen. Hier wirkt sicherlich noch die alte anthropozentrische Orientierung nach, die ein animal biforme aus menschlichen und tierischen Bestandteilen vor allen anderen fragwürdig macht. Nachdem Isidor in einem Satz ${ }^{51}$ und Bartholomäus Anglicus (ca. 1235) ausführlich ${ }^{52}$ neutral über das animal compositum berichtet haben, qualifiziert Thomas von Cantimpré mit ihm erstmals ein Tier als monstruosus, ohne indessen seine Existenz zu bezweifeln. Diese Ansicht übernimmt wörtlich Vincenz von Beauvais (ca. 1255), der noch ein Augenzeugnis hinzuzufügen weiß: "hoc animal nostris temporibus a Soldano Babyloniorum transmissum est Imperatori Friderico" ${ }^{53}$. Diese Passage (unter Beibehaltung der Zeitangabe "nostris temporibus"!) übernimmt der Hortus sanitatis ${ }^{54}$. Damit allerdings liegt die Qualifizierung des Onocentaurus als Monstrum keinesfalls fest. Albertus Magnus, sonst Thomas von Cantimpré wörtlich zitierend, läßt das Attribut monstruosus fort ${ }^{55}$ und reiht damit den Onocentaurus wieder unter die ganz gewöhnlichen Tiere ein. Albertus' Übersetzer, Walter Hermann Ryff (gest. 1548), der sonst mit seiner Quelle durchaus kritisch oder ironisch umgeht, hat 1545 keinerlei Bedenken, kommentarlos und wörtlich zu übersetzen: "Onecentaurus als man spricht ist ein vermischet Thier/ denn er hatt ein kopff wie ein Esel/ vnnd ein leib wie der menschlich Cörper gestaltet. Wiewol ettlich schreiben/ man findt solche Thier/ so an dem oberen halben theil des leibs einem menschen / vnnderhalb aber einem Pferdt gleich seien"56. Fast zur gleichen Zeit verweist Conrad Gesner (1516-64) das Tier mit Hohn ins Reich der Fabel:

Onocentavrvm quisquis uidit, non incredibile ducet, quod fama peruagatum est, Centauros fuisse, neque fictores atque pictores in eorum descriptione errasse. Verum siue reuera fuerint, siue omnia cera flexibilior \& ad fingendum habilior, fama illos finxerint, praetereo. Que uero de onocentauro fama accepi, haec sunt. Eum 


\section{Thomas Cramer}

homini ore \& promissa barba similem esse, simul \& collum \& pectus, humanam speciem gerere: mammas distantes tanquam mulieris ex pectore pendere: humeros, brachia, digitos, humanam figuram habere: dorsum, uentrem, latera, posteriores pedes, asino persimiles: \& quemadmodum asinum, sic cinereo colore esse. ${ }^{57}$

Gesner gibt keine Gründe für sein Urteil, sie lassen sich jedoch aus seinen Formulierungen ablesen. Wenn es sich bei den Onocentauri um falsch dargestellte Kentauren handelt, dann sind sie dichterische Fiktionen, denn schon Isidor von Sevilla hatte für letztere festgestellt: "Centauris autem species vocabulum indidit, id est hominem equo mixtum, quos quidam fuisse equites Thessalorum dicunt, sed pro eo quod discurrentes in bello velut unum corpus equorum et hominum viderentur, inde Centauros fictos adseruerunt" ${ }^{\prime 58}$. Diese rationale Erklärung Isidors übernimmt Gesner (offenbar auf dem Umweg über Joachim Camerarius [1500-1574]) in seinem Artikel über das Pferd: “Centauros (inquit Camerarius) equitationem primos usurpasse perhibent, saltem ut ex equis pugnarent: adque hanc accomodant fabulam monstrosae formae, qua illi a poëtis introducuntur" 59 . Wenn noch nie jemand einen Onocentaurus gesehen hat, so ist dies für Gesner weniger Anlaß als Bestätigung des Zweifels, der sich grundsätzlich einstellt, wo Erscheinungen sich nicht in eine nach den Gesetzen der ratio geordnete Natur einfügen. Deshalb hält er für den Onocentaurus, falls die Analogie zum Kentauren nicht verfängt, noch zwei weitere Erklärungsmodelle bereit: entweder handelt es sich um die irrtümliche Zuordnung abergläubischer Visionen zu den natürlichen Tieren, oder, wenn es ihn in rerum natura wirklich gibt, der Onocentaurus ist eine Affenart: "Credibile est enim stultos \& superstitiosos quondam homines, uarias apparitiones \& daemonum species naturali animalium genri temere adnumerasse. Quod si qui in rerum natura onocentauri, satyri, lamiae \& similes ferae extant, ex simiarum genere eas omnes esse crediderim: ut suo loco copiosus exequemur"60. In den Gesnerus redivivus ist der Onocentaurus nicht mehr aufgenommen.

Aus dem gleichen Grund wie der Onocentaurus, der Heterogenität seiner Körperteile wegen, gerät der Greif ${ }^{61}$ schon bei Plinius in Verdacht, ein erdichtetes Wesen zu sein: "Gryphas volucres auritas aduncitate rostri fabulosos reor" ${ }^{\prime 2}$. Die mittelalterlichen Beschreibungen ignorieren diese Meinung jedoch ausnahmslos und beschreiben den Greifen, gestützt auf Solinus und Isidor, als real existierenden, schatzhütenden Vogel mit gefiedertem Löwenleib, Adlerflügeln und Adlerkopf. Lediglich Albertus Magnus äußert eine gewisse Zurückhaltung, was den Erkenntnisstand betrifft: "Griphes aues esse magis tradunt hystorie quam experta philosophorum vel rationes physice" 63. Walther 
Ryff jedoch weist in seiner Übersetzung Albertus' Bericht durch eine Parenthese ohne weiteren Kommentar ins Reich des Märchens. Den Satz "Habitat autem in hyperboreis montibus", übersetzt er wörtlich: "Diser Vogel soll sich im Hiperbischen [sic] gebürg erhalten", um in Klammern hinzuzufügen: "(das ist drei meil hinder dem Schlauraffenlandt)" 64 .

Conrad Gesner eröffnet seinen Artikel über den Greifen mit dem skeptischen Plinius-Zitat, was ihn nicht hindert, in enzyclopädischer Vollständigkeit alle antiken und mittelalterlichen Beschreibungen ohne Stellungnahme zu referieren. ${ }^{65}$ Nur bei der Erörterung der Frage, warum in allen Sprachen die Bezeichnung für dieses Tier gleich sei, tritt Gesners grundsätzlicher Zweifel am eignen Gegenstand zutage: "Cur enim nomen rei nunquam visae, aut nusquam (vt suspicamur) extanti, aut certe in ipsorum regionibus nusquam, indere homines voluissent? Nam quod Graecorum vanitas indiderit mirum non est, quae centauros etiam \& sphinges \& alia huiusmodi nomina confixerit" 66 .

Gesners Argumentation ist die gleiche wie beim Onocentaurus: Mangelnde Augenzeugenschaft in Verbindung mit der Analogie zu anderen Wesen, deren fabulöse Herkunft als sicher gelten kann, sind Anlaß zu Verdacht. Dennoch: Gesners Artikel über den Greifen ist einer der längsten im Liber de avibus. Im Referat der verschiedenen $\mathrm{Au}-$ toritäten und Schilderungen nimmt der Vogel für den Leser eine Präsenz an wie in keiner naturkundlichen Abhandlung zuvor. Das Gewicht der gelehrten Autoritäten verdrängt bei der Lektüre den Zweifel aufgrund fehlender Erfahrung in Anwendung des kritischen Leitsatzes aus Gesners Vorwort: "Et quod plurium testimonio confirmatur, id certe fidem magis meretur." ${ }^{67}$ So gerät der eigene Vorbehalt lediglich zu einer verbalen restrictio mentalis, die mehr oder minder leichtgewichtig und unverbunden neben Tatsachenformulierungen steht.

Exemplarisch ablesbar ist diese Unentschiedenheit an der Beschreibung Sebastian Münsters im Kapitel 69 der Cosmographia. Er beginnt mit einer zurückhaltenden "Soll"-Formulierung, mit der die Verantwortung für die Nachricht auf andere verlagert wird, um unvermittelt mit einer konstatierenden Tatsachenschilderung fortzufahren: "Von dem Greiffen schreiben auch viel / den man in India soll finden. Er hat vier Füß vnd Klauwen daran wie ein Löw. Am hindern seines Leibs ist er Schwartz/ vnd vornen Rot/ hat weiß Flügel/ vnnd ein krummen Schnabel wie ein Adler" ${ }^{\prime 6}$. Beglaubigt wird die Beschreibung durch das danebenstehende Bild.

Genau die gleiche Struktur, nur in Umkehrung der Reihenfolge von reservatio und Tatsachenbericht, weist die Beschreibung von Michael 
Herr ${ }^{69}$ auf, der doch fast sein ganzes Vorwort einer Auseinandersetzung mit dem Problem der Autoritäten widmet (s. u.) und der dort die potentielle Nachprüfbarkeit durch Besichtigung ausdrücklich zum Prinzip der Auswahl seiner Gegenstände deklariert. Gegen diesen Grundsatz verstoßend, widmet Herr sein 34. Kapitel dem Greifen und beginnt mit einer uneingeschränkten Tatsachenfeststellung: "Greiffen seind vierfüssige thier/ schier allenthalben gleich dem Löwen/ mit dem Kopff dem Adler. Dieweil sy aber gefüderte flügel haben / werden sy von etlichen gezält vnder das geschlecht der vögel"70. Es folgt die traditionelle Beschreibung des Aussehens und der wunderbaren Verhaltensweisen, die Herr erst mit dem Schlußsatz relativiert: "Doch sagen etlich/ vnd Plinius selbs/ es seyen eittel fablen vnnd erdichtungen / was von disem thier geschriben wirt/ vnd mehr erdicht zum lust vnd kurtzweil der seltzamkeyt/ dann erfarnis [!] der warheyt"71. Nicht Existenz und Aussehen sind mit dieser Formulierung infrage gestellt, sondern die Geschichte von den Greifen als Schatzhütern. Der Verzicht auf die medizinische Nutzanwendung, sonst stets Bestandteil von Herrs Beschreibungen, zeigt, daß es nach des Autors wahrer Meinung Greifen gar nicht gibt (wobei die Überschrift wieder in charakteristischem Widerspruch zum Text steht): “Was vom Greiffen genommen/ vnd nutzlich zur arzney gebraucht werden mag// Dieweil etlich der natürlichen ding fleissige erkündiger/ darfür haben/ dz/ was man von dem Greiffen sagt/ ein erdicht fabelwerck sey/ wie auch von den pferdten mit flügeln / Pegasi genant/ den Syrenen vnd andern deren ding mehr/ so wirt auch nichts geschriben was von den Greiffen vnd dergleichen/ gut vnd dienstlich der artzney sein möge" 72 .

Weit weniger Anlaß zu Bedenken als die Heterogenität der Gestalt scheint der Verstoß gegen das Wahrscheinlichkeitsprinzip oder das Gesetz der Natur zu geben. Dieser Tatsache verdankt der Basilisk ${ }^{73}$ sein vergleichsweise langes und unangefochtenes Leben. Kein antiker oder mittelalterlicher Naturkundiger äußert Zweifel an seinen wunderbaren Eigenschaften oder gar seiner Existenz. Plinius' Schilderung, die bereits von monstrum spricht, ist der Ausgangspunkt einer mehr als anderthalb Jahrtausende währenden Tradition, die nur ausschmückt aber kaum modifiziert:

Eadem et basilisci serpentis est vis [d. i. durch den Blick zu töten]. Cyrenaica hunc generat provincia, duodecim non amplius digitorum magnitudine, candida in capite macula ut quodam diademate insignem. sibilo omnes fugat serpentes nec flexu multiplici, ut reliquae, corpus inpellit, sed celsus et erectus in medio incedens. necat frutices, non contactos in modo, verum et adflatos, exurit herbas, rumpit saxa: talis vis malo est. creditum quondam ex equo oc- 
cisum hasta et per eam subeunte vi equitem modo, sed equum quoque absumptum. atque huic tali monstro-saepe enim enectum concupivere reges videre-mustellarum virus exitio est: adeo naturae nihil placuit esse sine pare. iniciunt has cavernis facile cognitis soli tabe. necant illae simul odore moriunturque, et naturae pugna conficitur. ${ }^{74}$

Solinus hält sich eng an diese Beschreibung ${ }^{75}$, Isidor erklärt den Namen $^{76}$, die mittelalterlichen Naturbeschreiber übernehmen unverändert ihre Quellen. Albertus Magnus beschreibt lediglich die kronenartige Kopfzeichnung eindrucksvoller und macht damit eine der Begründungen für den Namen plausibler: "Basiliscus serpens est qui ad interpretationem latinam regulus vocatur, quod idem in greco sonat basiliscus. Causa autem nominis duplex est. Una quidem quasi coronatum caput habere videtur: habet enim additamentum supra caput guttatum albo \& hyacintino colore velut quibusdam interlucentibus gemmis sit diademate regali coronatus" 77 . Sebastian Münster behandelt den Basilisken unter Berufung auf Plinius im Kapitel über das "Landt Cyrene" 78 und fügt als erster (?) eine Illustration hinzu, die in mehrere naturkundliche Werke der Folgezeit übernommen worden ist. Auf ihr stellt sich der Basilisk als Tier mit acht Krallenfüßen, einem Schlangenleib und einem Spitzkopf mit Hahnenschnabel und -gehänge, gekrönt von einer veritablen Krone vor. Der Hahnenkopf verrät die Herkunft des Bildes: Im Liber de natura rerum verweist Thomas von Cantimpré auf eine Basiliskenart, die er im capitulo de gallo abhandelt. ${ }^{79}$ Dort formuliert er vorsichtig und mit deutlichen Vorbehalten:

Gallus senescens in etate decrepita facit ovum ex se, unde basiliscus procreatur. Sed in hac generatione oportet, ut multa concurrant. In fimo calido et multo ponit ovum, et ibi fovetur vice patris. Post multum vero temporis exit pullus et invalescit per se sicut solent pulli anatum. Habent autem huiusmodi animalia caudas ut coluber, residuum vero corporis ut gallus habet. Dicunt autem hii, qui huiusmodi animalis creationem se vidisse dixerunt, quod testa ovi nulla est, sed habet pellem validissimam et fortem adeo, ut possit resistere validissimis ictibus. Opinio quorundam est quod, postquam ediderit gallus ovum, id fovet coluber aut bufo. Sed hoc ambiguum est et incertitudini relinquimus. Hoc tantum habemus in scriptis antiquorum, quod quoddam basilisci genus ab ovo generatur, quod gallus decrepitus et senescens ediderit. ${ }^{80}$

Diese Passage wird von Vincenz von Beauvais gleich zweimal zitiert, unter dem Artikel "Basilisk" und dem Artikel "Hahn" 81, stößt aber als naturgesetzlich unmöglich schon bei Albertus Magnus auf vehemente 


\section{Thomas Cramer}

und kategorische Ablehnung: "Dicunt etiam quidam quod generantur de ouo galli: sed hoc verissime falsum est \& impossibile" 82 .

Was in der zweiten Hälfte des 13. Jahrhunderts als zoologisch unmöglich erkannt und abgelehnt wurde, führt dennoch im 16. Jahrhundert zu einer anstandslos weitergereichten Bildtradition. Mehr noch: diese Bildtradition bringt ihrerseits wieder Beschreibungen hervor. Herold übernimmt in seiner Lycosthenes-Übersetzung das Bild aus Sebastian Münster zu folgendem Text: "Jetzt kommen wir an die kriechende / darunder dann das grausamest vnd seltzamst der Basilisck / wöllicher ettwo in den wüstinen Africe gefunden worden. Vff dem kopff hatt derselbig ettlich weysse flecken/ die glitzen/ waren gleich wie ein kron. Er hatt aber gantz ein spitzkopff/ rauhen schnabel/ sein farb sampt den augen etwas schwartz" ${ }^{33}$. Der letzte Satz stammt nicht aus der verbalen Beschreibungstradition, sondern gibt den Bildeindruck wieder: Die Bilderfahrung tritt an die Stelle der Wirklichkeitserfahrung.

Walter Ryff im Thierbuch Alberti Magni formuliert in der Übersetzung die Ablehnung der Theorie von Hahnenei wie gewöhnlich noch etwas drastischer als Albertus: "Das aber ettliche weitter fuergeben/ wie der Basilisc auß einem Hanen ey geboren werde/ das ist ganz falsch vnd erlogen/ vnnd vnmüglichen" ${ }^{84}$. Diese Aussage wird illustriert von dem prächtigsten Hahnenbasilisken, den die Bildtradition des 16. Jahrhunderts zu bieten hat. ${ }^{85}$ Das Bild stellt vor Augen, was der Text dementiert. Auf der gleichen Seite nebeneinandergestellt, repräsentieren sie ganz unterschiedliche Traditionen und Erkenntnisstufen und damit die Gleichzeitigkeit des Ungleichzeitigen.

Selbst der höchst rationalistische Ulysse Aldrovandi zeigt sich von Albertus' Verdikt unbeeindruckt. Nicht nur übernimmt noch die Ausgabe von 1640 der Serpentum et draconum libri duo die Illustration aus Sebastian Münster, Aldrovandi bemüht sich auch um eine Erklärung des Thomas von Cantimpré, die in ihrer Phantastik nicht minder abwegig ist als die Nachricht selbst: "Ex Authore libri de natura rerum, genus quoddam Basilisci nuncupatur illud, quod ex ouo galli decrepiti generatur. Immo hanc oppinionem videtur confirmare Chrystophorus Encelius alias vir vnde quaque doctissimus, qui in opere de re metallica duas Basilisci species, nempe domesticam \& syluestrem constituit. Inquit enim, quod gallus gallinarum syluestrium . . . rostrum in os faemellae inferens, sperma more viperarum infundit. Hincque credibile esse arbitratur" 86 . Selbst das am deutlichsten ablehnende Zeugnis des 16. Jahrhunderts, Jacques Grévins (ca. 1540-70) Auseinandersetzung mit den Lehrmeinungen über den Basilisken in seinem Buch über die Gifte ${ }^{87}$, ist ein Dokument des Schwankens zwischen naturwis- 
senschaftlicher Rationalität und traditionsverpflichteter Autoritätsgläubigkeit, in dem fast jeder Satz den vorhergehenden widerruft. Anlaß zum Zweifel an der Existenz des Basilisken überhaupt ist ihm Albertus' ausdrücklich erwähntes Verdikt über das Hahnenei. Dennoch reicht es nicht aus, das Vorhandensein dieses Tieres mit seinen bemerkenswerten (admirandae), wenn schon nicht wunderbaren Eigenschaften gänzlich zu bestreiten:

Diversae \& admirandae, quas varij Basilisco attribuunt autores, proprietates, in causa fuerunt, vt cogitarem historiam ipsius vel fabulosam esse, aut scriptores saltem qui aliquid de eo commentati sunt, vel literis prodiderunt vnquam \& oleum \& operam perdidisse. Affirmare enim velle cum Galeno, in libro de Theriaca, Basiliscum oculorum radio tantum, \& sibilo simplici eos qui vel audiunt vel vident, vel ab eo conspiciuntur interimere... . Galenus, etiam libro $X$ de medicamentis simplicibus, se eum nunquam vidisse fatetur, \& historiam eius in dubium vocare videtur. Et profecto non minus a ratione alienum est, asserere eum ex antiqui galli ouo gigni, quemadmodum vulgus credit, aniles enim hae sunt fabulae, \& ex diametro cum rationibus naturalibus, vt egregie Albertus Magnus scriptum reliquit, pugnant. Quae fidem etiam mihi faciunt, haec omnia esse falsa. . . . Neque propterea affirmare ausim, nullos omnino inueniri Basiliscos. Existimo tamen minus perniciosos esse, quam vulgo habentur. Verum quidem est eos ex serpentibus venenosissimos esse. ${ }^{88}$

Wie beim Basilisken sind es nicht fehlende Augenzeugenberichte, sondern die naturwissenschaftlichen Unwahrscheinlichkeiten, verbunden mit unterschiedlichen Angaben bei den Autoritäten, die beim Phönix ${ }^{89}$ Anstoß erregen: seine lange Lebensdauer und seine Wiedergeburt im Feuer. Schon Plinius, dessen Beschreibung im übrigen bis zum Ende des 16. Jahrhunderts immer wieder nahezu unverändert übernommen wird, läßt deshalb Zweifel zu: "Aethiopes atque Indi discolores maxime et inenarrabiles ferunt aves et ante omnes nobilem Arabiae phoenicem, haud scio an fabulose, unum in toto ore nec visum magno opere" 90 . Mit diesem Satz wird auch Conrad Gesner seinen Phönixartikel beginnen, um dann Plinius' Beschreibung zu übernehmen, sie mit Hilfe vieler anderer Nachrichten zu einer vierseitigen Darstellung auszubauen und sie mit dem Satz abzuschließen: "Phoenicem haud esse penitus fabulosum, legimus in Commentarijs nauigationum. In mediterraneis Indiae reperiri. Semenda vocatur ab incolis, Scaliger" ${ }^{91}$.

Plinius' Beschreibung legt das Bild des Vogels für alle Zeiten fest. Danach hat er die Größe eines Adlers, einen goldglänzenden Hals mit 
Federbüscheln, ist sonst purpurn, sein Schwanz bläulich mit einzelnen rosa Federn. Auf dem Kopf hat er einen Federbusch. Seine Lebensdauer beträgt 540 Jahre. Im Alter baut er sich ein Nest aus Zweigen des Zimtstrauches und des Weihrauchs, auf dem er stirbt. Aus seinen Gebeinen entsteht ein kleiner Wurm und aus diesem wieder ein kleiner Vogel. ${ }^{92}$ Die Nachricht vom Flammentod des Phönix macht Isidor für das Mittelalter verbindlich. Bartholomäus Anglicus, Thomas von Cantimpré und Vincenz von Beauvais übernehmen diese Quellen wörtlich. Nur für Albertus Magnus ist die allegorisch gedeutete, naturgesetzliche Unwahrscheinlichkeit des Todes und der Wiedergeburt Anlaß zu vorsichtiger Distanzierung. Der Vogel sei für die Theologen interessanter als für die Naturforscher, und die Nachrichten über ihn werden in indirekter Rede referiert: "Fenicem auem esse arabie in orientis partibus scribunt hi qui magis theologica mistica quam naturalia perscrutant. Dicut autem hanc auem sine masculi \& sexus commixtione solam in sua esse specie: \& conuenire in orbem \& trecentis 40 annis viuere solitariam. Est autem vt dicunt aquiline magnitudinis caput habens vt pauo: sauces etiam habens cristatos circa collum: fulgore aureo purpureus est: caudam habens longam purpurei coloris pennis quibusdam roseis \& interscripta sicut interscribit cauda pauonis" 93 .

Von Albertus Magnus' Zurückhaltung zeigen sich indessen die folgenden Generationen der Naturkundigen bis zum Ende des 16. Jahrhunderts gänzlich unbeeindruckt. Konrad von Megenberg berichtet vom Phönix als einer unbezweifelten Tatsache ${ }^{94}$, der Hortus sanitatis zitiert Isidor, Ambrosius und Solinus ${ }^{95}$ und fügt eine Illustration des Vogels in seinem brennenden Nest bei. Das gleiche tut Sebastian Münster bei seiner Beschreibung der Fauna Arabiens und gibt sogar an, man habe erfahren ${ }^{96}$, der Vogel lebe 540 Jahre. Anschließend vermischt er, ungeachtet des Bildes, das den Vogel auf dem Scheiterhaufen zeigt, die plinianische und die isidorische Tradition von den beiden Todesarten des Phönix: "Vnd so er alt wird / macht er ein Holtzhauffen von Casia vnnd Zimmet/ vnnd verbrennt sich selbs darinnen/ damit er sich erjüngert. Dann auß seiner Feißte vnnd Beynen wechßst zum ersten ein Würmlin/ vnd darnach wird darauß ein blutt Vögelin/ vnd zu letst ein gefiderter Vogel" 97. Sebastian Franck zählt den Phönix ganz selbstverständlich unter den Erscheinungen Indiens auf:" "India gibt auch Sittich/ den vogel Phenix/ allerley edel gesteyn/ wurtz/ specerey" ${ }^{98}$. Lycosthenes / Herold zitieren bzw. übersetzen wörtlich Plinius, ohne allerdings dessen zweifelnden Eingangssatz zu erwähnen: "Arabia allein / vnnd eben die gantz weyt weldt/ hatt doselbst disen vogel/ der Phönix genannt. Er ist inn der grösse eines Adlers/ vmb den halß glitzt er wie gold" ${ }^{\prime 9}$. So bleibt es als einzigem dem Albertus-Übersetzer 
Walther Ryff vorbehalten, die vorsichtige Zurückhaltung seiner Quelle ins Drastische umzusetzen:

Fenix soll ein Vogel sein inn der Landtschafft Arabie gegen Orient oder auffgang der Sonnen gelegen/ vonn diesem Vogel schreibt man trefliche Philosophische lugen / die ein jeglicher Phantast mit heiliger Göttlicher Schrift vnterstehet zu beweren/ vnnd mit diesem werck mancherlei ort heiliger geschrifft zuerkleren/ vnd fürnemlich gibt man für/ das dieser Vogel on alle vermischung odder zuthuung menlichs odder weiblichs geschlecht geboren werden soll / vnd soll dieser vogel also on seins gleichen auff dreihundert vnnd viertzig Jar leben mögen/ vnd wie sie weitter darvon gemeinsamlich liegen/ soll dieser Vogel inn der grösse sein eins Adlers / sein kopff wie eins Pfawen gestaltet/ er sol auch sonderlichen mit leistem gezieret sein/ mit schönem goldtfabem halß / mit purpurfarb angesprengt/ von schönen purpur farben feddern / mitt Rosinfarben gesprengt . . . denn soll er in solches nest sich nidder lassen/ vnnd sich am heissen Sonnenschein wol erschwingen/ so lanng das er die heissen streimen des Sonnen scheins / sich durch den wider glast inn den spieglen der feddern / wie inn einem fewrspiegel erzünden vnd fewr geben/ daruon das nest angezündet wirdt/ vnd also mit dem Vogel verbrennet (Gott tröst sein liebe seel). ${ }^{100}$

Diese in der Parenthese ironisch kommentierten "Philosophischen lugen" werden beglaubigt durch ein eindrucksvolles Bild des Phönix in seinem brennenden Nest.

Die Vermehrung der Beispiele ergäbe den immer wieder gleichen Befund: Die Naturbeschreibung des 16. Jahrhunderts steht im Spannungsfeld zwischen Autorität der Überlieferung einerseits und Erfahrung andererseits, zwischen tradiertem Buchwissen und der Verifizierung durch Augenschein. Wenn letztere schon für Plinius ein wichtiges Wahrheitskriterium war, braucht dies für das 16. Jahrhundert doch nicht $\mathrm{zu}$ bedeuten, daß die Kategorie des numquam vidisse zum bedeutungslosen Topos verkommen sei.

Kaum eine Quelle des 16. Jahrhunderts versäumt es, sich auf dem Titelblatt oder im Vorwort auf die Erfahrung als das Wahrheitskriterium schlechthin zu berufen. überall dort freilich, wo das Verhältnis von Erfahrung zur überlieferten Lehrmeinung erörtert wird, zeigt sich, daß erstere kaum je als Korrektiv der Erkenntnis fungiert. Siegmund Feyerabend kündigt im Vorwort zu Schallers Neuw Thierbuch eine wissenschaftliche Tierbeschreibung des Autors an (im Gegensatz zum vorliegenden Buch, das lediglich ein Vorlagenbuch für bildende Künstler 
sein soll) ${ }^{101}$ : "Jedoch aber hat vorgemeldter Author ein zimliche weitleufftige Thier beschreibung zusammen bracht/ darinn eins jeden Thieres Art/ Natur vnnd eigenschafft / nutzbarkeyten etc. sampt viel treffenlichen Historien auß viel gelehrten Scribenten vnd täglicher erfahrung angezogen/ vnnd fein ordentlich beschrieben worden" ${ }^{102}$. Die additive Formel "auß viel gelehrten Scribentem vnd täglicher erfahrung" kann als bezeichnend gelten. Es handelt sich weder um alternative, noch um sich wechselseitig kontrollierende Quellen der Erkenntnis, sondern um eine neutrale Doppelformel, in der die Erfahrung allenfalls als Ergänzung der Autorität fungiert. Wenn Sebastian Franck auf dem Titelblatt des Weltbuchs angibt, er habe sein Material "auß angenummnen/ glaubwirdigen erfarnen weltschreibern/ müselig zuhauff tragen"103, so reduziert sich die Doppelformel in charakteristischer Weise zu einer qualifizierenden Attribuierung, die gleichzeitig dem Erfahrungsbegriff jeden spezifischen Sinn nimmt. Denn die "erfarnen weltschreiber" sind für ihn nicht in erster Linie die modernen Entdeckungsreisenden, sondern die alten Autoritäten. Unter den "Auctores in diesem werck citiert vnd angezogen" nennt er zunächst "Plinius, Herodot, Ysidorus" und erst danach "Christophorus Columbus". Damit wird die Verantwortung für die Erfahrung auf die Autorität verlagert und ein lediglich behauptetes Kriterium für deren Glaubwürdigkeit. Walther Ryff stilisiert Albertus Magnus zum empirischen Naturforscher: "Denn er der Thierer eigenschafft/ nit allein bei anderen Philosophen gelesen/ sonder so viel jm möglich selbs ersucht/ vnd/ wie er solches offtmals in diesen seinen büchern bekennt/ erfaren hat" ${ }^{104}$. Michael Herr dagegen lehnt Albertus ab, da er nicht über die "erfarnis" von "anzeygern" verfügt habe: "Dann das Albertus eyn solche erfarnis von vnzalbaren anzeygern gehabt hat/ findet man weder bey jm selbs oder andern geschriben / ist auch weder gleüblich noch müglich / das zu solchen Barbarischen zeytten / . . sich eyniger Künig oder Fürst . . . vnderwunden hette zuerkündigen"105. Die Verifizierung durch Augenschein ist also keine heuristische Kategorie, die das schreibende Subjekt für sich oder für seine Zeitgenossen verbindlich macht. Sie wird als moderner Beriff zurückverlagert auf die traditionellen Quellen und dient dazu, den zeitlichen Abstand aufzuheben. Durch ihre Klassifizierung als "erfarne weltschreiber" werden Plinius, Isidor und die übrigen Autoritäten der antiken und mittelalterlichen Wissenschaft zu Zeitgenossen der Wissenschaft des 16. Jahrhunderts. Nur das macht es erklärbar, daß die naturkundlichen Schriften des Mittelalters fast ausnahmslos im 16. und 17. Jahrhundert zum Teil in repräsentativer Form gedruckt werden, nicht aus antiquarischem oder historischem Interesse, sondern als aktuelle wissen- 
schaftliche Werke: Albertus Magnus 1519 u. ö., Konrad von Megenberg 1536 u. ö., Bartholomäus Anglicus 1601, Vincenz von Beauvais 1624.

Auch dort, wo die empirische Verifizierbarkeit ausdrücklich zum Programm der Darstellung erhoben wird, erweisen sich die Autoritäten am Ende als stärker. Michael Herr zieht aus den Divergenzen der vorfindlichen Tierbeschreibungen die Konsequenz, nur solche Tiere darzustellen, die jedermann sehen und von deren Existenz und Eigenschaften man sich durch Augenschein überzeugen, d. h. die kritische Kontrolle über den Text durch empirische Wahrnehmung selbst ausüben kann:

Erstlich ist nicht mein meynung gewesen/ alle thier/ deren von gemelten Lerern gedacht wirt / zubeschreiben/ darumb das sy in jhrem schreiben offt vngleich vnd widereinander seind/ auch in den nammen nit zusamen stimmen/ vnd der sachen gar nichts eyns seind/ Sollichs aber beschicht gemeynklich in beschreibungen deren thier / so gantz frembd vnd unbekant / jha auch eim gedicht vnd fabelwerck gleich sehen / vnd offtmals nichts anders seind / welches ein gemeynuerständiger wol brüfen oder mercken mag. Hab mich also solcher vngleicheyt müssigen wöllen/ vnd nit auf die ban bringen/ darauß mehr gelächters vnnd gespey/ dann frucht vnd nutzbarkeyt dem Leser entstohn wurde/ sunder mich der beschreibung deren thier vndernommen/ in welcher sy der sachen des mererteyls/ in anzeygung der natur/ art/ eygenschafft vnd nammen/ die gwißlich vnder den geschöpfften vnd Creaturen der natur befunden werden / eyns seind. Hab darumb deren thier beschreibung zum ersten für mich genommen/ die niemants unbekant seind/ vnnd ob schon etlich der selbigen in disen landen nit gezeüget seind/ auch nimmermehr gezeüget werden mögen / ... so werden sy doch zu zeyten zu vns in vnser land gebracht/ vnnd also von vns gesehen / als Löwen / Helffanten / Camelthier etc. / das an den selbigen keyn zweifel ist. ${ }^{106}$

Das dieser programmatischen Vorrede vorgeheftete Titelblatt zeigt das dekorative Bild eines Einhorns, dem auch ein langes Kapitel gewidmet ist neben ausführlichen Beschreibungen der Greifen (unter Hinweis darauf, Plinius habe gemeint, es seien "eittel fablen" 107), des Salamanders mit seiner wunderbaren, feuertötenden Natur, der Stellio nach Bernhard Breydenbachs (im 16. Jahrhundert stereotyp reproduzierter) Abbildung ${ }^{108}$ und der Drachen,-alles Tiere, die zweifellos niemand "von uns" gesehen hat. Das ist jedoch nur scheinbar inkonsequent und widersprüchlich, denn die potentielle Zeitgenossenschaft der Augenzeugen ist nur eine beiläufige Forderung ohne Verbindlichkeit, sobald 
die Verantwortung für die empirisch-sinnliche Wahrnehmung auf die Autoritäten verlagert werden kann, selbst wenn dies über drei Stationen geschehen muß. Von Plinius über Aristoteles auf dessen unbekannte Informanten: "sag ich, das ich diß thierbuch zum mehrern theyl auß dem Plinio gezogen/ der kundschafft gibt/ das Aristoteles seine thier historien oder bücher/ auß gewisser vngezweiffelter erfarnis gschriben hat/ deren/ die dasselbig so sy jm angeben haben/ selbs entpfindtlich gesehen/griffen vnd getast haben"109. Die behauptete Wahrnehmung anderer ersetzt vollgültig den eigenen Augenschein. Mit anderen Worten: Erfahrung ist keine kritische Kategorie, kein erkenntnissteuerndes Korrektiv, sondern eine Beglaubigungskategorie post festum. ${ }^{110}$

Diese These läßt sich an jenen Tieren belegen, die ohne Zweifel nie jemand "gesehen, griffen vnd getast" hat, und die dennoch in den naturkundlichen Werken des 16 . Jahrhunderts ein so vielfältiges Leben führen wie nie zuvor, weil sie keine der naturgesetzlichen Wahrscheinlichkeit oder auch nur der "Gemeinverständigkeit" widersprechenden Eigenschaften haben, und weil die Autoritäten an ihrer Existenz nie gezweifelt haben: das Einhorn, der Onager und der Drache.

Das Einhorn ${ }^{111}$ erfreut sich in der mittelalterlichen und frühneuzeitlichen Zoologie eines ebenso unangefochtenen Daseins wie Kühe, Schafe oder Ziegen. ${ }^{112}$ Die Malerei des 17. Jahrhunderts läßt es zusammen mit zahmen und wilden Tieren Noahs Arche besteigen. ${ }^{113}$ Zur Debatte steht allenfalls seine Identifikation mit bzw. seine Unterscheidung vom Rhinoceros.

Plinius unterscheidet beide Tiere genau. Das Rhinoceros beschreibt er ziemlich naturgetreu, gibt aber an, seine Farbe sei gelblich wie Buchsbaum (color buxeus). ${ }^{114}$ Diese Farbe wird, dank der mittelalterlichen Identifikation von Rhinoceros und Einhorn auf letzteres übergehen. Das Einhorn hingegen erweist sich schon durch sein Aussehen als wunderbares Tier: “Orsaei Indi ... venantur, asperrimam autem feram monocerotem, reliquo corpore equo similem, capite cervo, pedibus elephanto, cauda apro, mugitu gravi, uno cornu nigro media fronte cubitorum duum eminente. hanc feram vivam negant capi"115. Diese Beschreibung, bei Solinus fast wörtlich wiederholt ${ }^{116}$, wird von den mittelalterlichen Autoren stereotyp übernommen ${ }^{117}$, sofern sie sich nicht überhaupt nähere Angaben ersparen. ${ }^{118}$ Isidor, der keine genauere Beschreibung gibt, liefert, wohl auf Megasthenes zurückgreifend, dem Mittelalter neben der Identifikation von Rhinoceros und Einhorn die Angabe von der im Verhältnis zu seiner Stärke geringen Körpergröße und erwähnt die Möglichkeit, das wilde Tier im Schoß 
einer Jungfrau zu zähmen. ${ }^{119}$ Lediglich Albertus Magnus stellt eine Ausnahme dar, indem er das Einhorn, sonst Plinius folgend, als Spalthufer klassifiziert: "Vnicornis animal est moderate quantitatis respectu sue fortitudinis, buxei coloris et fisse in duo vngule pedis" 120 .

Diese beiläufige Angabe dürfte für die Folgezeit von entscheidender Bedeutung sein. Nach Plinius' Beschreibung ist das elephantenfüßige und schweinsschwänzige Einhorn ein deutlich heteromorphes Tier, das ipso facto ebenso Verdacht erregen müßte, fabulosus zu sein wie die Greifen oder der Pegasus. Das Gegenteil ist der Fall: Die Beschreibungen werden so modifiziert, daß die anstößigsten Elemente der Heteromorphie getilgt werden: "Mit dem leib vergleichet sich das thier Eynhorn einem pferdt/ mit dem kopff einem hirtzen/ mit der farb dem buchßbeümen holtz/ hat mitten an der stirnen eyn seer scharpff/ spitzig/ lang vnd schlecht horn/ von dem jhm auch der namm gegeben ist/ mit disem horn beschirmpt vnnd wehret es sich wider seine feynd/ gleich wie auch der ochs mit seinem gehörn"121. Mit diesem Vergleich gelingt es Michael Herr beiläufig noch, das Einhorn in die Reihe der ganz normalen, alltäglich erfahrbaren Tiere zu stellen, über die er nach dem Programm seines Vorworts eigentlich berichten will. Wenn es in seinem Verteidigungsverhalten dem banalen Ochsen gleicht, so kann auch Isidors Bericht über seine Zähmung (unter Weglassung von Isidors reservierender Berufung auf die Schriftsteller!) wörtlich übernommen und als Faktum dargestellt werden: "Diß thier mag mit keym gwalt oder geschickligkeyt der jäger gefangen werden / sunder man stellet jm entgegen ein junckfraw/ vnd so das thier daher laufft/ vnnd die junckfraw ersihet/ wirt es gleich demüttig vnd zam / thut sich zu ir/ legt jr das haupt in den geren/ vnd entschlafft/ also fahet man es on alle mühe"122. Die Beschreibung wird der naturgesetzlich definierten Wahrscheinlichkeit angepaßt und damit der Anlaß zu Zweifel beseitigt. ${ }^{123}$ Mehr noch: es gehört offenbar zu den wunderbarsten Eigenschaften des Einhorns, daß es alle sonst gültigen kritischen Kategorien außer Kraft setzt.

In der Unterschrift zur Illustration des Einhorns konzediert Gesner, daß es eine Vorstellung vom Aussehen dieses Tieres überhaupt nur aufgrund ikonographischer Konventionen gibt: "Figura haec talis est, qualis à pictoribus fere hodie pingitur, de qua certi nihil habeo"124; und er beginnt das Kapitel mit dem Satz: "Monoceros, hoc est unicornis fera, ab alijs aliter describitur" 125. Beides zusammengenommen, die mangelnde Verifizierbarkeit und die Divergenz der Autoritäten, führt in anderen Fällen unweigerlich zu Zweifeln an der Existenz des Lebewesens überhaupt, hier wird sie nur als Konsequenz der Artenvielfalt 


\section{Thomas Cramer}

des Einhorns gedeutet. Sie artikuliert sich in einer seitenlangen Aufzählung unterschiedlicher und voneinander abweichender Beschreibungen. Der Gesnerus redivivus, weit davon entfernt, "nach der gewissen erfahrung" zu korrigieren, setzt die Beschreibungen zusätzlich ins Bild um. Er bietet zehn Illustrationen von Einhörnern aller Art: pferde-, spalthufige und löwenfüßige, mit langen, spitzen, kurzen, stumpfen und gedrehten Hörnern, mit wallenden und gestutzten Mähnen, mit Bocksbärten, Stummel- und Pferdeschwänzen. Die Widersprüchlichkeit ist zu einer scheinbar wissenschaftlichen Genauigkeit in der Differenzierung geworden, die den Charakter der präzisen Beobachtung behauptet.

Selbst der Verstoß gegen den Grundsatz der Verifizierung durch Augenzeugenschaft ist im Falle des Einhorns entschuldbar: "Minus autem mirum de fera tam peregrina \& toto a nobis arbe diuisa, nec unquam in Europam adducta, diuersa ab Europaeis scriptoribus auritis fere omnibus non oculatis memoriae prodita esse" ${ }^{126}$. Verwunderlicher sei es schon, daß zeitgenössische Reisende unterschiedliche Berichte lieferten. Aber wo die Erfahrung fehlt, wird sie fiktional hergestellt. 1484 hat die Pilgergruppe, der Felix Fabri und Bernhard von Breydenbach angehörten, nach der Durchquerung der Sinai-Wüste ein Einhorn beobachtet, das wörtlich die Angaben Isidors bestätigt. Fabris Bericht läßt in der Angabe der Beobachtungsparameter (Beobachtungszeit, Umgebung, Beobachtungsbedingungen, -entfernung) an Genauigkeit nichts zu wünschen übrig:

Circa meridiem vidimus in montis cujusdam cacumine bestiam stare, quae contra nos deorsum respiciebat. Nos vero hanc videntes aestimavimus esse camelum et mirabamur, quomodo camelus in solitudine viveret et, verbum inter nos ortum est, an etiam cameli silvestres reperientur? Calinus autem ad nos accessit, bestiam illam rhinocerotem vel unicornu esse asseruit, demonstrans nobis unicum ejus cornu de fronte ejus procedens. Cum magna diligentia hanc nobilissimam bestiam respeximus et vehementer dolebamus, quod non proximior nobis fuit, ut magis determinate eam inspexissemus. Est enim bestia haec singularissima in multis conditionibus: in primis dicitur, quod sit bestia saevissima et unum cornu quatuor pedum habet in medio frontis ita acutum et validum, ut quidquid petierit aut ventilet aut perforet. ${ }^{127}$

Die letzte Passage zitiert wörtlich Isidors Beschreibung (s. Anm. 114). Sie ist in einer Weise angefügt, daß sie als Präzisierung einer notgedrungen ungenauen Beobachtung wirkt. Die Autorität bestätigt die Er- 
fahrung, nicht umgekehrt. Erhart Reuwich, Reiseteilnehmer und Illustrator von Breydenbachs Reisebericht, setzt unter seinen Holzschnitt, der unter anderm das Einhorn darstellt, die Unterschrift: "Hec animalia sunt veraciter depicta sicut vidimus in terra sancta." Das Bild zeigt ein spalthufiges Einhorn mit Pferdeleib und überlangem gedrehtem Horn in Seitenansicht, wie es die Beobachter nach den von Fabri geschilderten Bedingungen keinesfalls sehen konnten.

Der einzige mittelalterliche Bericht über die tatsächliche Beobachtung eines Einhorns, nämlich eines Rhinoceros, im Reisebericht des Marco Polo, bleibt für die Vorstellung von seinem Aussehen offenbar völlig folgenlos. Das angeblich so verbindliche Zeugnis eines "erfarnen weltschreibers" ist angesichts des Gewichts der verbalen und bildlichen Tradition bedeutungslos: "do sint ouch vil einhorn, dy luczil cleyner sint wen di elephant, sundir sy han hor sam di buffil oder das wisint unde vuze als eyn elephant, das houbt sam eyn swyn krum czu der erdin; sy wonen gerne in deme wazzir und in den pfülin und han eyn horn mittin an der stirnen unde das ist grob unde swarcz . . . und di sint schuylich obil an czu seen sam di merwundir" ${ }^{128}$.

Wann das Einhorn definitiv aus der realen Fauna verschwunden ist, läßt sich nicht genau feststellen. Die Beobachtungen durch stereotyp als "glaubwürdig" qualifizierte Reisende reichen jedenfalls bis in die Mitte des 19. Jahrhunderts. Sehr zurückhaltend äußert sich Zedlers Universallexikon von 1734: “Ob sich nun über dieses anietzo beschriebene Einhorn [Narwal-Zähne] noch ein Vnicornu verum in der Welt finden lasse, welches an der Stirne eines vierfüßigen, und einem Pferde gleich sehenden Thieres (wie bis dahero viele geglaubt und vorgegeben haben) hervor schüsse? wird von klugen und vorsichtigen Naturkündigern nicht unbillig gezweiffelt, wie geschäfftig sich auch Catelanus in seinem Buch vom Einhorn erwiesen"129. Die Entdekkungsreisen des 19. Jahrhunderts indessen bestätigen die Existenz des Tieres; so Ersch-Grubers Allgemeine Encyclopädie von 1840:

Einhorn (Monoceros) 1. Der Name eines noch wenig bekannten Thieres, einem Pferde ähnlich, mit einem langen und geraden Horne auf der Mitte der Stirn (Plin. H.N. VIII, 21), das in Gedichten des Mittelalters häufig erwähnt und als sehr schnell und wild beschrieben wird, aber ganz von dem Nashorn (Rhinoceros), mit welchem es sonst verwechselt worden, verschieden ist. Die Naturforscher haben es lange für eine Erdichtung gehalten, bis neuere und glaubwürdige Reisende sein Dasein im Innern von Afrika bestätigt haben; doch soll es auch hier nur selten und 


\section{Thomas Cramer}

einzeln gefunden werden. ... Den neuesten Bericht darüber s. in A. v. Kattes Reisen nach Abyssinien (Reisen und Landesbeschreibungen b. Cotta 15. Lieferung. Morgenblatt 1838 Nr. 209). ${ }^{130}$

Von Ersch-Gruber offensichtich abgeschrieben ist der Artikel in der Allgemeinen Realenzyclopädie für das katholische Deutschland von 1847:

Einhorn heißt bei den Alten (Aristoteles, Plinius, Aelian) ein vierfüßiges Thier in der Gestalt eines Pferdes, mit einem langen geraden Horne auf der Stirne, das, nach ihrer ferneren Beschreibung, sehr rasch, wild und unbändig sei, gewöhnlich Menschen, denen es begegne, tödte, von einer reinen Jungfrau sich aber fangen und gängeln lasse usw. Es haben lange die neueren Naturforscher die Existenz desselben gänzlich bezweifelt. Indessen kommen in den neuesten Zeiten glaubwürdige Nachrichten aus Afrika, wo das E. einzeln, aber selten gefunden wird. ${ }^{131}$

Für die Außerkraftsetzung aller kritischer Kategorien beim Einhorn sehe ich nur einen plausiblen Grund: seine Existenz (wie die des Drachen und des Onager) ist durch das Alte Testament an sieben Stellen beglaubigt. ${ }^{132}$ (Das Argument wird allerdings durch das Faktum relativiert, daß auch der Basilisk im Alten Testament mehrfach genannt wird.) Die Verbindlichkeit der Autorität der Bibel auch und gerade im 16. Jahrhundert braucht nicht zu verwundern. Dennoch handelt es sich dabei im Zusammenhang mit der zoologischen Beschreibung nur um einen extremen und nicht weiter diskussionsbedürftigen Fall des Autoritätenproblems überhaupt. Wenn "Erfahrung" nur eine nachgeordnete Bestätigungskategorie ist, dann ist sie selbst kaum erörterungsbedürftig und erschöpft sich im "Gesehenhaben", ohne daß dessen Bedingungen und Bedingnisse durch Täuschung, Wahrnehmungssteuerung, Meßgenauigkeit, Vorerwartung, Perspektive u. v. m. überhaupt zur Debatte stünden. Fabri leitet aus der von ihm beklagten Unzulänglichkeit der Beobachtungsverhältnisse keinen Augenblick Zweifel über die Beschaffenheit des beobachteten Gegenstandes ab, eine Folgerung, die der moderne Beobachter allererst ziehen würde. Das Schema von Bestätigung der Autorität durch "Erfahrung" funktioniert auch im Beobachtungsvorgang selbst. Wohl aber bedarf es unter dem Gesichtspunkt der Glaubwürdigkeit einer Diskussion des Autoritätsbegriffs, und die Intensität der überlegungen dazu ist eine entschieden neue Qualität der zoologischen Schriften des 16. Jahrhunderts.

Auch wenn es im Einzelfall bei divergierenden Meinungen durchaus zu Abwägungen und Entscheidungen kommt, findet sich doch bei keinem mittelalterlichen Autor eine grundsätzliche Erörterung des 
Glaubwürdigkeitsproblems. Es kennzeichnet im Gegenteil die Struktur der Abhandlungen, daß Referate bzw. Zitate der einzelnen Quellen unvermittelt nebeneinandergesetzt werden, ohne sie gegeneinander abzuwägen, widersprüchliche Meinungen zu erörtern oder argumentativ eine Entscheidung herbeizuführen. Das gesamte Speculum naturale von Vincenz von Beauvais ist ein solches Quellenmosaik; im Prinzip bestimmt dieses Verfahren auch noch die Struktur der Historiae animalium von Conrad Gesner.

Die mittelalterliche Gleichrangigkeit der Autoritäten weicht im 16. Jahrhundert dem Bedürfnis nach ihrer Einschätzung, Bewertung und Hierarchisierung. Kaum ein Vorwort entzieht sich der Erörterung des Problems. Dazu gehört allererst die Nennung der Quellen vorab, auf die man sich bezieht und der Begründung für ihre Auswahl. Gesners konservativ kompilierendes Verfahren zeigt sich $u$. a. daran, daß er zu Beginn der Historiae animalium nicht weniger als 251 Autoritäten auflistet, auf die er sich bezieht. Im Vorwort zum 3. Buch, einer Art Anweisung für das Verfassen wissenschaftlicher Schriften, äußert er sich über den Sinn der Autorennennungen: Sie ermöglichen die Bewertung unter dem Gesichtspunkt der Glaubwürdigkeit: "Authorum nomina vbique adscribat: non solum vt suum cuique reddatur, quod homines gratos decet, cum omnes iuuandi \& bene merendi animo scripserint: sed etiam propter rerum certitudinem. plus enim aut minus cuique creditur, prout alius alio doctrina, aut experientia, aut quo vixit saeculo prior aut posterior fuerit. Et quod plurium testimonio confirmatur, id certe è fidem magis meretur" ${ }^{\prime 13}$. Das ist eine fast vollständige Aufzählung der Bewertungskriterien, die das 16. Jahrhundert zur Verfügung hat. Im konkreten Anwendungsfall erweisen sie sich allesamt als heuristisch fragwürdig, weil sie mehr oder minder Behauptungscharakter haben. Von der Anwendung des Erfahrungsbegriffs auf die Autorität war in diesem Zusammenhang schon die Rede.

Das von Gesner postulierte Mehrheitsprinzip ist zwar nicht tragfähig aber bequem, weil es die weitere Argumentation erspart. Die Berufung auf den tatsächlichen oder angeblichen Konsens der Gelehrten ist daher besonders beliebt. Er genügt für Walther Ryff als Begründung für eine Vergegenwärtigung der 300 Jahre alten De animalibus libri von Albertus Magnus durch die deutsche Übersetzung: "hat mich die selbigen inß Teutsch zubringen ... für gutt angesehen / vorab dieweil viel fürtreflicher gelerter leut/ . . . sich auf diesen Albertum referieren vnnd zihen/ ... Auch wo etwas zweifelhaftigs vnd vnuerstendigs von andern geschrieben/ suchen die gelerten desselbigen in diesem eyn entscheid bei dem Alberto"134. Die "eynhellige zusammenstimmung viler gelerten" 135 ist für Michael Herr der Grund, den 
gleichen Albertus Magnus als Autorität abzulehnen: "Item der selbig Albertus Magnus vnderstadt sich mit vnnutzer beweisung bey zu bringen das die kleinen leüthlin oder zwerglin so inn Ethiopia seind/ Pigmei gnant/ vnd mit dem geflügel streitten/ keyne menschen seyen/ vnd das bestreit wider gemeyne und eynhellige zusammenstimmung viler gelerten, vnder welchen Aristoteles sagt/ das die Kränch mitt den kleynen leütlin/ Pigmei genant/ streitten"136. Herr stützt seine Bewertung durch das historische Argument. Kann man aus der Formulierung "saeculo prior aut posterior" schließen, daß Gesner von der Vorstellung eines Erkenntnisfortschritts, d. h. einem linearen Geschichtsbild ausgeht, kehrt Herr das Bewertungsmuster im Sinne der humanistischen Geschichtsvorstellung um: Wer im finsteren Mittelalter geschrieben hat, ist allemal weniger glaubwürdig als eine antike Quelle:

Nun aber/ damit ich widerker zu meinem fürnemmen/ sprich ich/ das es vnmüglich sein mög/ das zu solcher vngehobleter grober zeyt/ offt gemelter Albertus Magnus ... hab künden vnd mögen / on fäl/ mangel vnd irrthumb/ schreiben vnd leren ... sunder ist sich vil mehr zuuerwundern/ das bey solcher vngefüger vnd vnzierlicher zeit/ er solche grosse vnd gwaltige ding von der natur hat leren vnd schreiben künden. . . . So ich aber weyß / das ich mit vil hohgelerten der meynung binn / das den alten / wie sy droben genant/ vnd fürnämlich dem Aristoteli / mehr dann dem Alberto zuglauben sey. ${ }^{137}$

Ist die Glaubwürdigkeit der Quelle zusätzlich noch mit dem Kriterium der "erfarnis" zu sichern, dann überträgt sich deren Autorität auf das eigene Werk: "Darauß alleyn bewert wirt / das diß buch auß Aristotele vnnd Plinio herfliessend / in spaltigen meynungen nit minder / sunder mehr glaubwirdig dann andere/ so auß hörsagenden beschreibern vnd lerern genommen / in kurtzer zeit in Teütsch außgangen"138. Der letzte Satz läßt vermuten, es handele sich bei den anti-albertinischen Passagen in Herrs Vorwort um einen direkten Angriff auf Ryffs fast gleichzeitig erschienenes Thierbuch Alberti Magni. Stimmt dies, so spitzt sich, zumindest in diesem Fall, die wissenschaftliche Diskussion auf das Problem der richtigen oder falschen Autorität zu und damit auf die Frage, welche Qualitäten den zeitlichen Abstand aufheben und den jeweiligen Autor zum wissenschaftlichen Zeitgenossen machen. Die Beliebigkeit der Kriterien und ihrer Anwendung kann beliebige Gleichzeitigkeiten herstellen. ${ }^{139}$ Sie sind deshalb nicht hinreichend erklärt durch die Formel, daß Erkenntnisse unter Umständen lange brauchen, bis sie sich in den Köpfen festsetzen, und daß es unterschiedlich bor- 
nierte oder aufgeschlossene Wissenschaftler gibt. ${ }^{140}$ Sie sind vielmehr selbst Indikatoren für die Parameter eines nicht in historischer Linearität verlaufenden Erkenntnisprozesses.

Die Kategorie des Wunderbaren, unter welchem Begriff auch immer, spielt bei der Beschreibung der einzelnen Lebewesen im 16. Jahrhundert keine Rolle mehr. Joachim Camerarius definiert das Phänomen in seiner theologisch fundierten langen Abhandlung über die ostenta ${ }^{141}$ in völliger Übereinstimmung mit Augustin als "contra consuetum cursum naturae"142. Inhaltlich aber verengt er den Begriff (wie auch Herold, s. o.): Er spricht von "ostentis, id est, coelestibus prodigiis" nur als von Erscheinungen mit einer "praesignificatio futurorum"143. Daher erörtert er fast ausschließlich die Kometen und (am Rande) die Träume.

Eine solche Verlagerung des Begriffs prodigium auf den Bereich der Mantik, d. h. auf Erscheinungen, die mehr oder weniger deutlich Einblick in die Absichten Gottes gewährten, hat ihren Grund nicht darin, daß Wunderbares aus der Naturbeschreibung wegrationalisiert worden wäre. Allein Aldrovandis eindrucksvolle Drachenzoologie aber auch die hier angeführten Beispiele sind Beweis genug, daß man durchaus bereit ist, Wunderbares im Sinne des nicht durch Augenschein Verifizierbaren als vorhanden zu akzeptieren, ohne es allerdings "wunderbar" zu nennen. In dieser nomenklatorischen Verschiebung und Verweigerung spiegelt sich eine der wesentlichen Veränderungen in der Naturanschauung des 16. Jahrhunderts im Vergleich zum Mittelalter wider. ${ }^{144}$

Das Mittelalter hatte zur Klassifizierung von in Büchern oder in der Realität vorfindlicher Naturphänomene einen ganzen Katalog von Einteilungskriterien, die sich nicht genau gegeneinander abgrenzen lassen und damit sich selbst wie die mit ihnen belegten Gegenstände der Systematisierung entziehen. Begriffe wie "gewohnt", "natürlich", "wunderbar", "fabulosus", "lügenhaft" teilen die Welt in Bedeutungsfelder mit verfließenden Rändern ein, aber nicht in ein System.

Das 16. Jahrhundert mit seinem Bedürfnis nach Systematisierung, fast ins Parodistische getrieben bei Agrippa von Nettesheim und auf vielen Gebieten des Denkens sichtbar (z. B. bei der Systematisierung der Allegorie zur Emblematik), verengt das Spektrum der Klassifizierungskriterien auf die Alternative "wahr" und "falsch" (bzw. "glaubwürdig" und "unglaubwürdig"). In dieser Systematik hat das Wunderbare als ein die Grenze zwischen wahr und falsch, zwischen probabilis und fabulosus überbrückendes Phänomen keinen Platz mehr. Für die Zwecke der Darstellung unterscheidet Conrad Gesner daher auch ganz konsequent die "zwei Kulturen": die wissenschaftliche der 
vera aut maximè probabilia und die literarische der poetica. ${ }^{145}$ Beide sind genau auseinanderzuhalten: "Quae ad philologiam, Grammaticam \& poeticam spectant, non omittat, sed separet" ${ }^{146}$. In der wissenschaftlichen Epitome, die das für wahr Befundene resümiert, hat die zweite Kultur nichts mehr zu suchen: "Ex his Commentarijs postea fiet Epitome, ita vt certa tantum \& vera, aut maximé probabilia accurate deligantur, \& sicut dixi, rerum duntaxat cura habeatur, non etiam verborum. Quicquid ad philologiam aut Grammaticam facit, poetica, prouerbia, similia, fabulae, superstitiosa, superflua, dubia, falsa, obscura, pugnantia, \& quicquid est huiusmodi omittantur"147. Ist das Wunderbare damit aus der wissenschaftlichen Naturbeschreibung ausgeschlossen, so ist es damit doch nicht aus der Natur verbannt. Im Gegenteil: zwar können das Einzelwesen oder einzelne Eigenschaften nicht mehr als wunderbar bezeichnet werden, aber dafür ist die Natur als ganze ein Wunder. Damit hat der Begriff seine Bedeutung gegenüber Augustin und auch gegenüber dem Mittelalter gänzlich verändert: Er bezeichnet nicht die Außergewöhnlichkeit der Einzelerscheinung oder gar ein Phänomen contra naturam, sondern ist dort, wo er nicht in die Mantik transferiert wird, eine umfassende Metapher für die unendliche schöpferische Vielfalt Gottes geworden. In diesem Sinne definiert sich der Gesnerus redivivus "als ein rechtes Wunder- und Kunst-Buch / ja als ein sonderbarer Spiegel der wunderbaren Allmacht und vätterlichen Vorsorge Gottes dyeß Allerhöchsten / in Anschauung der so mancherley und doch alle von einander gantz unterschiedlicher verwunderlicher Gestalten / Farben / Naturen und Eigenschafften an allen diesen Thiern"148. Herr und Ryff sprechen pauschal von "wunderbarlicher seltzamer art / natur / krafft vn eygenschafft aller vierfüssigen thier" 149 bzw. von "wunderbarlicher natur und art der lebendigen geschöpff Gottes" 150 . Im Gesamtwunderwerk der Natur sind daher ein Basilisk, ein Greif oder ein Einhorn, sofern es sie überhaupt gibt, wohl exotischer aber grundsätzlich nicht wunderbarer als ein Schaf oder ein Pferd. Entscheidend ist nicht die Frage nach ihrer Klassifizierung, sondern die nach ihrer Existenz, nach wahr oder falsch und damit die Einordnung in das System der Wissenschaften, die Naturwissenschaften oder die Litterae.

\section{Anmerkungen}

1. Malcolm Browne, "Legendary Giant Sloth Sought by Scientists in Amazon Rain Forest", New York Times, 9. February 1994, S. C-1. 
2. Cosmographey Oder beschreibung Aller Länder ... Erstlich durch Herrn Sebastian Münster ... verfasset (Basel, 1588), S. 1413.

3. Ebd.

4. Ebd.

5. Ebd., S. 1349: "Es haben die Alten auch gar vil seltzame Monstra erdichtet, die in diesem landt sollen erfunden werden."

6. Die Wirkungen dieser Kategorie im 16. Jahrhundert, aber auch ihre Grenzen und ihre Komplexität sind dargestellt von Jan-Dirk Müller, " 'Erfarung' zwischen Heilssorge, Selbsterkenntnis und Entdeckung des Kosmos", Daphnis 15 (1986): 307-42; vgl. weiter Christel Meier, "Argumentationsformen kritischer Reflexion zwischen Naturwissenschaft und Allegorese", Frühmittelalterliche Studien 12 (1978): 116-59. Vgl. auch einzelne Beiträge in Dietrich Huschenbett $\mathrm{u}$. John Margetts, Reisen und Welterfahrung in der deutschen Literatur des Mittelalters (Würzburg: Königshausen und Neumann, 1991).

Zur Entwicklung von Zoologie und Naturbeschreibung vgl. Geoffroy Atkinson, Les nouveaux horizons de la Renaissance française (Paris: E. Droz, 1935); Emile Callot, La Renaissance des sciences de la vie au 16e siècle (Paris: Gardet, 1951); Pierre Delaunay, La zoologie au XVIe siècle (Paris: Hermann, 1962); Georges Petit u. Jean Théodoridès, Histoire de la zoologie (Paris: Hermann, 1962); William P. D. Wightman, Science and Renaissance, 2 Bde. (Edinburgh: Oliver and Boyd, 1962); Raymond Bloch, Les prodiges dans l'antiquité classique (Paris: Presses Universitaires de France, 1963); Marie Boas-Hall, Die Renaissance der Naturwissenschaften 1450-1630 (Gütersloh: Mohn, 1965); Joan Barclay Lloyd, African Animals in Renaissance Literature and Art (Oxford: Clarendon Press, 1971); Francis Klingender, Animals in Art and Thought to the End of the Middle Ages, hg. v. Evelyn Antal u. John Harthan (Cambridge, Mass.: MIT Press, 1971); Claus Nissen, Die zoologische Buchillustration: Ihre Bibliographie und Geschichte, 2 Bde. (Stuttgart: Hiersemann, 1978); Maria Suutala, Tier und Mensch im Denken der deutschen Renaissance (Helsinki: SHS, 1990). Ein unentbehrliches Material- und Quellenlexikon ist Malcom South, Hg., Mythical and Fabulous Creatures: A Source Book and Research Guide (New York: Greenwood Press, 1987) mit vielen weiteren Literaturangaben. Wichtig als Quellensammlung auch Claude Lecouteux, Les monstres dans la littérature allemande du Moyen Age: Contribution à l'étude du merveilleux médiévale, 2 Bde. (Göppingen: Kümmerle, 1982). Vgl. weiter Daniel Cohen, The Encyclopedia of Monsters (New York: Dodd \& Mead, 1982); Willene B. Clark u. Meradith T. McMunn, Hgg., Beasts and Birds of the Middle Ages: The Bestiary and Its Legacy (Philadelphia: University of Pennsylvania Press, 1989); Beryl Rowland, Animals with Human Faces: A Guide to Animal Symbolism (London: G. Allen \& Unwin, 1974). Grundlegend für die hier behandelten Fragestellungen ist Jean Céard, La nature et les prodiges: L'insolite au XVIe siècle, en France (Genf: Droz, 1977); weiter Christoph Gerhardt, "Gab es im Mittelalter Fabelwesen?", Wirkendes Wort 38 (1988): 156-71 (mit weiteren Literaturangaben). Vgl. weiter Monstres et prodiges au temps de la Renaissance (Paris: Diffusion J. Touzot, 1980) darin besonders Jean-Claude Margolin, "Sur quelques prodiges rapportés par Conrad Lycosthène", S. 42- 
54; Valerie I. Flint, "Monsters and the Antipodes in the Early Middle Ages and Enlightenment", Viator 15 (1984): 65-80; Steve Baker, Picturing the Beast: Animals, Identity and Representation (Manchester: Manchester University Press, 1993); Marie-Hélène Huet, Monstrous Imagination (Cambridge, Mass.: Harvard University Press, 1993); Michel Jeanneret, "Rabelais, les monstres et l'interpretation des signes", in Writing the Renaissance: Essays on Sixteenth-Century French Literature in Honor of Floyd Gray, hg. v. Raymond La Charité, French Forum Monographs, 77 (Lexington, Ky.: French Forum, 1992), S. 65-76; Katarzyna Zalewska, "Deformatio naturae: Die Seltsamkeiten der Natur in der spätmittelalterlichen Ikonographie", Miscellanea Medievalia 21 (1992): 930-38; Waller B. Wigginton u. Trent D. Stephens, "The Monsters and Theology of Isidore of Seville, Ulisse Aldrovandi, and Modern Science", Rendezvous 25 (1989): 67-82.

7. Rudolf Wittkower, “Die Wunder des Ostens: Ein Beitrag zur Geschichte der Ungeheuer", zuletzt in Allegorie und Wandel der Symbole in Antike und Renaissance, hg. v. Rudolf Wittkower (Köln: DuMont, 1983), S. 87-150.

8. Ebd., S. 131.

9. A. Gellii Noctes Atticae, 2 Bde., hg. v. P. K. Marshall, (Oxford: Clarendon Press, 1968), Buch 9.4, 1:281. [Ich eilte sofort begierig zu den Büchern. Es waren durchweg griechische Bücher, voll von Wundergeschichten, unerhörten und nicht zu glaubenden Dingen; und das von alten Schriftstellern nicht geringer Autorität.]

10. Ebd., 1:283. [Dies und vieles gleicher Art las ich; aber als ich es niederschreiben wollte, packte mich der Ekel vor solch unnützen Schriften.] Gleichwohl fühlt er sich verpflichtet, über die miracula zu berichten, schiebt aber die Verantwortung Plinius zu, dessen Autorität nicht übergangen werden könne, weil seine Schilderungen nicht auf Hörensagen oder Lektüre, sondern auf Erfahrung (!) beruhten: "Libitum tamen est in loco hoc miraculorum notare id etiam, quod Plinius Secundus, uir temporibus aetatis suae ingenii dignitatisque gratia auctoritate magna praeditus, non audisse neque legisse, sed scire sese atque uidisse in libro naturalis historiae septimo scripsit" [Es gefällt mir aber, an dieser Stelle das von den Wunderdingen aufzuführen, von dem Plinius Secundus, ein Mann, dem zu seiner Zeit dank der Würde seines Geistes hohe Autorität zukam, im 7. Buch der naturalis historia schreibt, er habe es nicht gelesen oder gehört, sondern habe es gesehen und wisse es] (ebd.).

11. Conrad Lycosthenes, Wunderwerck oder Gottes vnergründtliches vorbilden . . . Auß Herrn Conrad Lycosthenis latinisch zusammen getragner beschreybung/ mit grossem fleiß/durch Johann Herold/ vffs treüwlichst inn vier Bücher gezogen vnnd Verteütscht (Basel: Petri, 1557), Vorrede, Bl. Avf.

12. Sancti Aurelii Avgvstini de civitate dei; Aurelii Avgvstini opera pars XIV, 2, Corpus Christianorum Series Latina, 48 (Turnholti: Typographi Brepols, 1955), S. 508-10. Zu den Monstra bei Augustin vgl. u. a. Céard, La nature et les prodiges, S. 3-30.

13. Sancti Aurelii Avgvstini, S. 508. [Man braucht nicht an alle Menschenrassen zu glauben, deren Existenz behauptet wird.] 
14. Ebd., S. 509. [Es erscheint das als Natur, was sich bei den meisten findet, und das als wunderbar, was selten ist.]

15. Ebd., S. 509-10: “Sicut ergo haec ex illo uno negari non possunt originem ducere, ita quaecumque gentes in diuersitatibus corporum ab usitato naturae cursu, quem plures et prope omnes tenent, uelut exorbitasse traduntur, si definitione illa includuntur, ut rationalia animalia sint atque mortalia; ab eodem ipso uno primo patre omnium stirpem trahere confitendum est, si tamen uera sunt quae de illarum nationum uarietate et tanta inter se atque nobisum diuersitate traduntur" [Wie man ihre Abstammung von einem (Menschen) nicht abstreiten kann, so muß man auch daran festhalten, daß alle Völkerschaften, die durch die Verschiedenartigkeit ihrer Erscheinung aus dem gewohnten Weg der Natur gleichsam herausspringen, den die meisten oder fast alle einhalten, alle von dem einen, gleichen und ersten Stammvater abstammen, sofern sie nur der Definition (des Menschen) genügen, vernunftbegabte und sterbliche Lebewesen zu sein, und sofern es wahr ist, was von der Verschiedenartigkeit jener Völkerschaften erzählt wird und ihrer Unterschiedlichkeit untereinander und von uns].

16. Ebd., S. 509: "Apud Hipponem Zaritum est homo quasi lunatas habens plantas et in eis binos tantummodo digitos, similes et manus" [Bei Hippo Zaritus lebt ein Mensch, der gleichsam mondsichelförmige Füße hat und an jedem nur zwei Zehen, ebenso sind die Hände].

17. Ebd., S. 509. [Wenn irgendein ganzes Volk so beschaffen wäre, würde (ein Bericht davon) in die Geschichte der Seltsamkeiten und Wunder aufgenommen werden.]

18. Ebd., S. 510. [Deshalb braucht es uns nicht abwegig zu erscheinen, daß, wie es in einzelnen Völkern wunderliche Bildungen bei den Menschen gibt, es bei der gesamten Menschheit wunderliche Völker gibt.]

19. Henricus Kornmann, De miraculis vivorum seu de varia natura (Frankfurt, 1614).

20. Hinweis bei Wittkower, "Die Wunder des Ostens", S. 132.

21. Sancti Aurelii Avgvstini, S. 510. [Denn wüßten wir nicht, daß Affen, Meerkatzen und Sphinxe keine Menschen sind, sondern Tiere, könnten uns jene Geschichtenschreiber, sich ihrer Seltsamkeiten rühmend, ungestraft vorlügen, es handele sich um menschliche Völker.]

22. Plinii Secundi Naturalis Historiae Libri XXXVII, hg. u. übers. v. Roderich König (München: Heimeran, 1973), Buch 7, S. 26: "In multis autem montibus genus hominum capitibus caninis ferarum pellibus velari, pro voce latratum edere, unguibus armatum venatu et aucupio vesci" [Auf vielen Bergen aber wohnt ein Menschenschlag mit Hundeköpfen, der sich in Felle wilder Tiere kleidet, statt der Sprache Gebell von sich gibt und, mit Krallen bewehrt, von der Jagd und vom Vogelfang lebt] (ebd., S. 27).

23. Gesnerus Redivivus auctus \& emendatus. Oder: Allgemeines Thier=Buch / ... vormahls durch den Hochberühmten Herrn Conradum Gesnerum In Lateinischer Sprache beschrieben / und nach ihm / Durch den Hochgelehrten Herrn Conradum Forerum M.D. ins Teutsche versetzt (Frankfurt, 1669), S. 13. 
Gesners lateinischer Urtext formuliert, unter Berufung auf die Autoritäten, noch etwas vorsichtiger: "Cynocephali capite sunt canino, caetera membra hominis habent, Aelianus. Galenus in Anatomicis administrationibus, Praestat (inquit), simiarum homini quam similliarum artus dissecare, cum te in exemplo exercere institues: sin ea non detur, aliquam ei proximam deligito: aut si nulla omnino simia reperiatur, cynocephalum, uel satyrum, uel lyncem. ... Cynocephali sunt qui in Mappa mundi canini homines uocantur, Albertus" (Conradi Gesneri Historiae Animalium. Tiguri apud Christ [Froschoverum, 1551], Buch 1, S. 971).

24. Lycosthenes / Herold, Wunderwerck, S. 560. Lycosthenes und sein Übersetzer haben auch sonst keine Mühe, die Wunderwesen als Menschenrassen zu akzeptieren, obwohl sie an anderer Stelle von den Hundsköpfen sagen: "mit dem bellen / zeigend sie an / das sie mehr thier dann mentschen seind" (S. 12); "Schatthöppel (= Skiapoden) / sollen gefunden werden / die nur einen schenckel / vnd auch nur einen aber gantz breyten fuß / haben auch kein gleych in khnüen / vnd aber von der schnelle jres hoppens kan man nit gnug sagen. In der hitz legen sie sich nider/ bedecken sich mit jrem fuß / der jnen den gantzen leibn überschattet vnd frist gibt" (S. 569); “Vnder den mittägischen gezirck in Scythia / da seind leüt die habend kein haupt / sonder augen / nasen / mund / stath jnen alles an der prust gleich ob dem bauch. Ich gebe jnen den namen Brustbutzen / dann sye seind frylich seltzam anzusehen" (S. 10).

25. Johannes Herold, Heydenweldt/ vnd irer Götter anfängklicher vrsprung (Basel: Heinrich Petri, 1554), "Diodorus Siculus", Buch 4, S. 137.

26. Vgl. auch Wittkower, "Die Wunder des Ostens", S. 124.

27. Sebastian Franck, Weltbuch: Spiegel ond bildtniß des gantzen erdbodens (Tübingen: Ulrich Morhart, 1534), Titelblatt.

28. Ebd., Bl. 1v.

29. Ebd., Bl. 7v.

30. Sancti Aurelii Avgvstini, S. 510. [Entweder sind solche Dinge, die über die Völker geschrieben werden, gänzlich falsch; oder, wenn es sie gibt, sind sie keine Menschen; oder, wenn sie Menschen sind, dann stammen sie auch von Adam ab.]

31. Isidori Hispalensis Episcopi Etymologiarum sive originvm libri XX, hg. v. W. M. Lindsay, 2 Bde. (Oxford: Oxford University Press, 1966).

32. Ebd., Buch 11, 3, 13.

33. Ebd.; vgl. Sancti Aurelii Avgvstini, S. 509: "Sicut autem in singulis gentibus quaedam monstra sunt hominum, ita in universo genere humano quaedam monstra sunt gentium."

34. Isidori Hispalensis Episcopi, Buch 11, 3, 1-2. [Die Wunderwesen sind nicht gegen die Natur, denn sie sind durch göttlichen Willen erschaffen, da der Wille des Schöpfers und dessen Erschaffenes die Natur ist. Deshalb nennen die Völker Gott bald Natur, bald Gott. Ein Wunderwesen ist also nicht gegen die Natur geschaffen, sondern nur gegen die bekannte Natur.]

35. Ebd., Buch 11, 3, 7-11.

36. Ebd., Buch 11, 3, 28. 
37. Ebd., Buch 11, 3, 30-31. [Zum Teil Jungfrauen, zum Teil Vögel mit Flügeln und Krallen.]

38. Isidors Äußerung verweist die Sirenen keinesfalls definitiv ins Reich des Fiktionalen. Unter anderen lehnt Vincenz von Beauvais diese Meinung ausdrücklich ab: "Syrenas tamen has non in veritate belluas, sed meretrices quasdam Isido. fuisse descripsit, quae transeuntes ad egestatem deducebant. Sed \& philosophi \& sanctorum expositorum nonnulli contrarium sentiunt, vera monstra marina esse dicentes" [Isidor schreibt, die Sirenen seien in Wahrheit keine Tiere, sondern Huren, die die Vorbeigehenden zur Ausschweifung verführten. Aber die Philosophen und einige Theologen meinen das Gegenteil und sagen, es seien wirkliche monstra marina] (Vincentius Bellovacensis, Speculum naturale [Douai: Balthasar Beller, 1624; Nachdruck Graz: Akademische Drucks- und Verlagsanstalt, 1964], Sp. 1314).

39. Gesnerus redivivus, S. 20. Zur Sphinx vgl. South, Hg., Mythical and Fabulous Creatures, S. 179-92.

40. Zur literarischen Verarbeitung solcher sich wandelnder (und stärker theologisch konnotierter) "Erfahrungs"--Prozesse vgl. Werner Röcke, "Die Wahrheit der Wunder: Abenteuer der Erfahrung und des Erzählens im 'Brandan' und 'Apollonius'-Roman", in Wege in die Neuzeit, hg. v. Thomas Cramer (München: Fink, 1988), S. 252-69.

41. Thomas Cantimpratensis Liber de Natura Rerum, Teil 1, hg. v. H. Boese (Berlin: de Gruyter, 1973), S. 97. [Ob diese Menschen von Adam ... abstammen; die Antwort lautet: nein.]

42. Ebd., S. 97.

43. Ebd., S. 97:

Consideremus ergo quid Ieronimus dicat, quod deserta orientis huiusmodi animalia ferre consueverunt. Quod patuit ipso narrante Ieronimo in Vita beati Pauli primi heremite, ubi dicit beato Antonio querenti Paulum monstrum in heremo occurrisse, cuius superior pars homo cum fronte cornibus asperato, inferior vero pars in caprarum pedes desinebat. Et dixit monstrum Antonio: Mortalis ego sum unus de accolis heremi, quos delusa gentilitas faunos, satyros et incubos vocat. Legatione fungor gregis mei, ut pro nobis communem dominum depreceris, quem olim in salutem hominum venisse cognovimus, et "in omnem terram exiit sonus" eius. Et ne, inquit Ieronimus, hoc fabulosum quis estimet, nostra etate in Alexandria huiusmodi animal captum est. Hinc ergo videndum est, si illud animal quod Antonius vidit animal fuerit rationale mortale. Et constat secundum Ieronimum, quod deum ita evidenter confessum est.

[Wir müssen jedoch bedenken, was Hieronymus sagt, daß wüste Gegenden solche Lebewesen hervorzubringen pflegen. Das ergibt sich aus der Erzählung eben dieses Hieronymus in der Vita des heiligen Paulus, des ersten Eremiten, wo er sagt, dem heiligen Antonius sei bei einem Besuch bei Paulus ein Monstrum in der Wüste begegnet, dessen unterer Teil jedoch in Ziegenfüßen endete. Dieses Monstrum sagte zu Antonius: "Ich bin ein Sterblicher, einer der Wüstenbewohner, die das 


\section{Thomas Cramer}

verblendete Volk Faunen, Satyrn und Teufel nennt. Ich bin von meiner Herde abgesandt, damit du für unsere Gemeinschaft den Herrn bittest, von dem wir wissen, er sei einst zum Heil der Menschen gekommen, und sein Schall ging aus in alle Welt." Und damit niemand glaube, sagt Hieronymus, dies sei erdichtet: $\mathrm{Zu}$ unserer Zeit ist in Alexandria ein solches Lebenwesen gefangen worden. Daraus ist zu ersehen, daß das Lebewesen, das Antonius sah, ein animal rationale mortale war. Und es steht nach Hieronymus fest, daß es sich zu Gott bekannt hat.] Es ist bemerkenswert, daß auch Hieronymus die Existenz von Satyrn zusätzlich durch Augenzeugenschaft verifizieren muß.

44. Ebd., S. 97. [Deshalb glauben wir nicht, daß den wirklich monströsen Lebewesen eine Seele innewohnt.]

45. Ebd., S. 154. [Ein monströses Lebewesen von zweiförmiger Beschaffenheit. Es hat nämlich einen Kopf wie ein Esel und einen Körper wie ein Mensch.]

46. Ebd., S. 121. [Ein Monstrum, das zu Caesars Zeiten nach Rom gebracht worden ist.]

47. Ebd., S. 160. [Der Pegasus, ein Halbvogel. Er hat die Gestalt eines Pferdes, Flügel wie ein Adler, aber viel größer, einen hörnerbewehrten Kopf und ist so monströs, daß sich fast alle Lebewesen vor ihm fürchten.]

48. Ebd., S. 120.

49. Ebd., S. 202.

50. Zu den Centauren und Verwandten vgl. Judith J. Kollmann, "The Centaur", in South, Hg., Mythical and Fabulous Creatures, S. 225-42; Juliet CluttonBrook, Horse Power: A History of the Horse and the Donkey in Human Societies (Cambridge, Mass.: Harvard University Press, 1992).

51. Isidori Hispalensis Episcopi, Buch 11, 3, 39.

52. Bartholomäus Anglicus, De rerum proprietatibus (Frankfurt: Wolfgang Richter, 1601; Nachdruck Frankfurt a. M.: Minerva, 1964), S. 1096-97.

53. Vincentius Bellovacensis, Speculum naturale, Sp. 1435. [Dieses Tier ist in unseren Zeiten dem Kaiser Friedrich vom Sultan der Babylonier geschenkt worden.]

54. Hortus sanitatis (Venedig, 1511; Nachdruck Würzburg: JAL-Reprint, 1978), Kap. 107.

55. Albertus Magnus, De Animalibus libri 26 novissimi impr., hg. v. Antonius Zimara (Venetiis: Scotus, 1519), Bl. 182r: “Onocentaurvs vt dicunt animal est compositum: caput enim asini \& corpus hominis habens: quidam etiam dicunt inueniri corpore equino \& superiore parte humana" [Das Tier mit Namen Onocentaurus ist zusammengesetzt: es hat den Kopf eines Esels und den Leib eines Menschen. Einige sagen, es fände sich auch mit Pferdeleib und menschlicher Oberhälfte].

56. Thierbuch Alberti Magni. Von Art Natur vnd Eygenschafft der Thierer ... durch Waltherum Ryff verteutscht (Frankfurt: Cyriacus Jacobi, 1545), Bl. Gij.

57. Gesnerus redivious, Buch 1, S. 23. [Wer einen Onocentaurus zu sehen bekäme, brauchte nicht für unglaubwürdig zu halten, was durch die Fama 
verbreitet wird, (und müßte nicht annehmen,) daß es sich eigentlich um Centauren handelte und daß die Geschichtsschreiber und Maler in ihrer Beschreibung geirrt hätten. Ich übergehe, ob sie Wirklichkeit sind oder vielgestaltiger als Wachs und geeigneter für die Erfindung, wie die Fama sie erschaffen hat. Was ich durch die Fama vom Onocentaurus erfahren habe, ist folgendes: Dem Menschen ähneln sie im Gesicht und durch einen langen Bart, gleicherweise ist ihr Hals und ihre Brust nach menschlicher Art beschaffen. Getrennte Brüste wie bei einer Frau hängen an ihrer Brust. Die Schultern, die Arme, die Finger sehen aus wie beim Menschen. Der Rücken, der Bauch, die Seiten, die Hinterbeine ähneln dem Esel und sind ihm gleich, so ist er auch aschenfarbig.]

58. Isidori Hispalensis Episcopi, Buch 11, 3, 37. [Die Art der Centauren wird durch ihren Namen angezeigt: Ein Mensch mit einem Pferd vermischt, die, wie man sagt, die Reiterei der Thessalier gewesen sein sollen. Aber für diejenigen, die so in den Krieg zogen, daß gleichsam Mensch und Pferd zu einem Körper verschmolzen schienen, dienten die Centauren als Erdichtungen.]

59. Gesnerus redivizus, Buch 1, S. 550. [Die Kentauren, sagt Camerarius, sollen als erste die Reiterei erfunden haben, nämlich, daß sie zu Pferde kämpften. Und von daher haben sie sich die Fabel ihrer monströsen Form zugelegt, die ihnen von den Poeten nahegebracht wurde.]

60. Ebd., S. 23. [Man kann auch annehmen, daß manche törichte und abergläubische Menschen verschiedene Erscheinungen und Dämonen der natürlichen Tierwelt willkürlich zugerechnet haben. Sollten aber in der Natur Onocentauren, Satyrn, Vampire und dergleichen wilde Wesen existieren, dann bin ich der Meinung, daß sie alle Affenarten sind, welche an ihrer Stelle ausführlich behandelt werden.]

61. Zum Greifen vgl. Waltraud Bartsch, "The Griffin", in South, Hg., Mythical and Fabulous Creatures, S. 85-102.

62. Plinii Secundi Naturalis Historiae, S. 96. Zur Ikonographie vgl. Anna Bisi, Il grifone: Storia di un motivo iconografico dell'antico oriente mediterraneo (Rom: Centro di studi semitici, 1965).

63. Albertus Magnus, De Animalibus, Bl. 192v. [Daß die Greifen Vögel sind (oder: Daß die Vögel Griphes existieren?) berichten mehr die Historien als die Erfahrungsberichte der Philosophen oder die Abhandlungen der Naturkundigen.]

64. Thierbuch Alberti Magni, Bl. Oiijb.

65. Gesnerus redivivus, Buch 3 ("De avibus"), S. 540-42.

66. Ebd., S. 542. [Warum haben die Menschen einer Sache einen Namen beilegen wollen, die sie nie gesehen haben und die nirgendwo (wie wir argwöhnen) existiert, zumindest nicht in deren Regionen? Denn daß die Einbildungskraft der Griechen, die sich ja auch Centauren und Sphinxen und andere solche Bezeichnungen ausgedacht hat, (einen solchen Begriff) erfand, ist nicht zu verwundern.]

67. Ebd., ("Ad lectorem Praefatio"), S. 4. [Was durch das Zeugnis mehrerer bestätigt wird, verdient sicherlich mehr Glauben.]

68. Münster, Cosmographey Oder beschreibung Aller Länder, S. 1341. Auf Münster bezieht sich ausdrücklich Georg Schaller: “Gleich wie du sichst hie stehen 
gar steiff / / Also ist von gestalt der Greiff./ Wie vns die Griechen zeigen an // In Indian jhr wohnung han. / Munsterus auch beschreiben thut// Das diß Thier hab ein Löwen muth./ Hat vier Füß/ auch Löwens klawen / / Wie du hie thust sein gstalt anschawen. / Der hinder theil seins Leibs schwartz ist// Vorn rot / hoch auff die Berg er nißt. / Die Flügel weiß / / wie ein Fisch$\mathrm{grad} / /$ Ein Schnabel wie ein Adler hat. / Auß dem Erdtrich grebt er Goldt// Drumb jhm die Indianer holdt" (Georg Schaller, Ein new Thierbuch./ Eigentliche und auch/gründliche Beschreibung allerley vier und zwey füssigen Thieren [Frankfurt: Martin Lechler, 1569], Bl. y-yii).

69. Michael Herr, Gründtlicher underricht/ wahrhafte und eygentliche Beschreibung ... aller vierfüßigen thier (Straßburg: Barth. Beck, 1546).

70. Ebd., Bl. Ljb.

71. Ebd.

72. Ebd.

73. Zum Basilisken vgl. Laurence A. Breiner, "The Basilisk", in South, Hg., Mythical and Fabulous Creatures, S. 113-24.

74. Plinii Secundi Naturalis Historiae, Buch 8, S. 78-79. [Die gleiche Kraft besitzt auch der Basilisk, eine Schlangenart. Er ist heimisch in der Provinz Kyrenaika, ist nicht länger als zwölf Finger und hat am Kopf einen weißen Fleck, der ihn wie ein Diadem schmückt. Durch sein Zischen verjagt er alle Schlangen und bewegt nicht, wie die anderen, seinen Körper durch vielfache Windungen, sondern geht stolz und halb aufgerichtet einher. Er läßt die Sträucher absterben, nicht nur durch die Berührung, sondern auch schon durch den Anhauch, versengt die Kräuter und sprengt die Steine: Eine solche Stärke hat dieses Untier. Man glaubte, daß jemand ihn einst zu Pferde mit einem Speer erlegt habe und daß das wirkende Gift an diesem emporstieg und nicht nur dem Reiter, sondern auch dem Pferd den Tod brachte. Und dieses gewaltige Ungeheuer-denn häufig haben Könige es tot zu sehen gewünscht-wird durch die Ausdünstung des Wiesels umgebracht: so sehr gefiel es der Natur, nichts ohne eine Gegenkraft zu lassen. Man wirft die Wiesel in die Höhlen (der Basilisken), die man leicht an dem ausgedörrten Boden erkennt. Diese töten durch ihren Geruch, sterben aber zugleich selbst, und der Streit der Natur ist bereinigt.]

75. C. Iulii Solini Collectanea rerum memorabilium, hg. v. Theodor Mommsen (Berlin: Weidmann, 1905; Nachdruck 1958), S. 126.

76. Isidori Hispalensis Episcopi, Buch 12, 3, 6-7.

77. Albertus Magnus, De Animalibus, Bl. 201r (im Druck 101r). [Der Basilisk ist eine Schlange, die in lateinischer Übersetzung "Kleiner König" heißt, denn das meint basiliscus im Griechischen. Der Grund für diesen Namen ist zweifach. Einer besteht darin, daß er ein gekröntes Haupt zu haben scheint: Er hat nämlich auf dem Kopf tropfenförmige Auswüchse von weißer und violetter Farbe, als sei er mit einer Königskrone mit hervorleuchtenden Edelsteinen gekrönt.]

78. Münster, Cosmographey Oder beschreibung Aller Länder, S. 1386.

79. Thomas Cantimpratensis Liber de Natura Rerum, S. 279.

80. Ebd., S. 205. [Der alte Hahn im hinfälligen Alter bringt ein Ei hervor, aus 
dem der Basilisk entsteht. Aber für diese Erzeugung müssen viele Faktoren zusammenwirken. In den warmen und weichen Mist legt er sein Ei, und dort wird es ausgebrütet anstatt durch den Vater, und nach langer Zeit kommt das Küken heraus und wächst innerhalb eines Jahres heran wie die Küken. Es haben aber diese Tiere einen Schwanz wie eine Schlange und den übrigen Körper wie ein Hahn. Es sagen aber die, die bezeugen, die Entstehung dieses Tieres gesehen zu haben, daß das Ei keine Schale habe, sondern eine sehr starke Haut, damit es den stärksten Schlägen widerstehen könne. Es gibt auch Vertreter der Meinung, dieses Hahnenei werde von einer Schlange oder Kröte ausgebrütet, aber das ist unsicher, und wir lassen es offen. Jedenfalls finden wir in den Schriften der Alten, daß es eine Basiliskenart gibt, die aus dem Ei eines hinfälligen Hahns entsteht.]

81. Vincentius Bellovacensis, Speculum naturale, Sp. 1202 und 1474.

82. Albertus Magnus, De Animalibus, Bl. 201r. [Einige sagen, daß er (der Basilisk) aus einem Hahnenei entsteht: Aber das ist mit Sicherheit falsch und unmöglich.]

83. Lycosthenes / Herold, Wunderwerck, S. 23.

84. Thierbuch Alberti Magni, Bl. YVb.

85. Eine ähnliche Illustration findet sich in Schallers New Thierbuch (Bl. fiij), der, auf Plinius basierend, vom Hahnenei kein Wort sagt. Die Darstellung des Basilisken als Hahn mit Schlangenschwanz scheint zuerst im Hortus sanitatis aufzutauchen, der die einschlägige Passage von Thomas von Cantimpré vollständig zitiert und den Basilisken folgerichtig unter de avibus abhandelt (Kap. 8, Bl. H).

86. Ulysse Aldrovandi, Serpentum et draconum historiae libri duo (Bologna: Ferronius, 1640), S. 362-63. [Beim Autor des 'Liber de natura rerum' wird eine Basiliskenart genannt, die aus dem Ei eines hinfälligen Hahns entsteht. Diese Meinung scheint Chrystophorus Encelius, ein höchst gelehrter Mann, zu bestätigen, der in seinem Werke "de re metallica" zwei Arten von Basilisken feststellt, nämlich den zahmen und den wilden. Er sagt, daß der Hahn der Fasanen ... seinen Schnabel in den Mund des Weibchens steckt und so sein Sperma nach Art der Schlangen hineingießt. Dies erscheint glaubwürdig.]

87. Jacques Grévin, De venenis libri duo (Antwerpen: Plantin, 1571); französische Fassung: Deux livres des venins, (Antwerpen: Plantin, 1568).

88. Ebd., S. 85. [Die unterschiedlichen und bemerkenswerten Eigenschaften, die die Autoren dem Basilisken zulegen, sind der Grund, warum ich glaube, seine Geschichte sei erdichtet oder es hätten wenigstens die Autoren, die etwas über ihn gesagt oder geschrieben haben, ihr Lampenöl und ihre Mühe verschwendet. Ich will aber mit Galenus (im Buch über die Theriaca) bestätigen, daß der Basilisk mit dem Strahl seiner Augen oder durch bloßes Zischen die umbringt, die ihn sehen oder hören oder die er anblickt. . . Galenus, im Buch 10 über die einfachen Heilmittel, gibt aber zu, ihn niemals gesehen zu haben, und scheint den Bericht über ihn in Zweifel zu ziehen. Und in der Tat ist es nicht wenig vernunftwidrig, zu behaupten, er entstehe aus dem Ei eines alten Hahns, wie das Volk es glaubt; aber das sind Altweibergeschichten und widerstreitet geradewegs dem Naturgesetz, wie der hervorragende Albertus 
Magnus in einer Schrift hinterlassen hat. Dies läßt mich glauben, daß alles erlogen ist. ... Aber ich will deswegen nicht behaupten, man könne überhaupt keine Basilisken finden. Ich meine jedoch, daß sie weniger gefährlich sind, als man gemeinhin behauptet. Es ist aber wahr, daß sie unter den Schlangen die giftigsten sind.]

89. Zum Phönix vgl. Douglas J. McMillan, "The Phoenix", in South, Hg., Mythical and Fabulous Creatures, S. 59-74; Jean Hubaux, Le mythe du phénix dans les littératures grecque et latine (Liège: E. Droz, 1939).

90. Plinii Secundi Naturalis Historiae, Buch 10, 2, S. 16. [Bei den Äthiopiern und Indern gibt es äußerst verschiedenfarbige und unbeschreibbare Vögel und vor allem den berühmten Phönix in Arabien - vielleicht nur ein Märchen-, der einzige auf der ganzen Erde und sehr schwierig zu sehen.]

91. Gesnerus redivivus, Buch 3 ("De avibus"), S. 693. [Wir lesen in den Commentariis navigationum, daß der Phönix nicht gänzlich erfunden ist. Man trifft ihn im südlichen Indien an, und er wird von den Einwohnern "Semenda" genannt; Scaliger.]

92. Plinii Secundi Naturalis Historiae, Buch 10, S. 16-19.

93. Albertus Magnus, De Animalibus, Bl. 192v. [Der Phönix sei ein Vogel in den östlichen Teilen Arabiens, - so schreiben diejenigen, die mehr die Geheimnisse der Theologie erforschen als die Natur. Sie sagen auch, daß dieser Vogel ohne männliche und geschlechtliche Vermischung, als einziges Exemplar seiner Art in der Welt allein 340 Jahre lebt. Wie sie sagen, ist er von der Größe des Adlers und hat einen Kopf wie ein Pfau. Er hat büschelartige Auswüchse um den Hals, er ist von purpurgoldenem Glanz. Er hat einen langen, purpurfarbenen Schwanz mit einzelnen eingestreuten rosafarbenen Federn, ähnlich wie der Schwanz eines Pfaus.]

94. Konrad von Megenberg, Das Buch der Natur, hg. v. Franz Pfeiffer (Stuttgart: Aue, 1861; Nachdruck Hildesheim: Olms, 1962), S. 186-87.

95. Hortus sanitatis, Kap. 48, Bl. Jiija.

96. Münster, Cosmographey Oder beschreibung Aller Länder, S. 1310.

97. Ebd.

98. Franck, Weltbuch, S. 192.

99. Lycosthenes/Herold, Wunderwerck, S. 31.

100. Thierbuch Alberti Magni, Bl. Oiija-b.

101. Schaller, Ein new Thierbuch, Vorwort, Bl. Aiiib: "Was aber die künstliche Teutsche Verß oder Reimen belangen thut/ seind dieselbigen kurtzweiligkeyt halben wol zu lesen / aber angezogener Author hat dieselbigen nit der gestalt gedicht / daß also ein gnügliche beschreibung geschehen sey/ eins jeden Thiers / sondern in wenig tagen/ dem Teutschen Leser / so dieses Büchlein mehrers theils der Figuren halben gebrauchen wirdt/ dieselbigen verfasset."

102. Ebd., Bl. Aiva.

103. Franck, Weltbuch, Titelblatt.

104. Thierbuch Alberti Magni, "Zum Leser", Bl. Aija.

105. Herr, Gründtlicher underricht, "Vorred", Bl. Ava.

106. Ebd., Bl. Aija-b.

107. Ebd., Bl. Ljb. 
108. Bernhard von Breydenbach, Die Reise ins Heilige Land, übert. v. Elisabeth Geck (Wiesbaden: G. Pressler, 1961).

109. Herr, Gründtlicher underricht, "Vorred", Bl. Ava.

110. Eine Modifikation deutet sich ca. 100 Jahre später im Gesnerus redivivus an. Das Vorwort nennt dort die "Erfahrung" die "Lehrmeisterin . . . aller Dienge." Damit rückt sie nicht unbedingt in den Rang einer kritischen Instanz; gemeint ist eher die Vermehrung des Wissens durch die neuen Entdekkungen, die natürlich auch zur Korrektur des Tradierten führen kann. Das Titelblatt schmücken neben Eseln, Wisenten, Elchen und Giraffen das Einhorn und die capre de India von Bernhard von Breydenbachs Holzschnitt.

111. Zum Einhorn vgl. Malcolm South, "The Unicorn", in South, Hg., Mythical and Fabulous Creatures, S. 5-26; Rüdiger Robert Beer, Einhorn: Fabelwelt und Wirklichkeit (München: Callwey, 1972); Michael Green, De historia et veritate unicornis (Philadelphia: Running Press, 1983); Nancy Hathaway, The Unicorn (New York: Viking Press, 1980); Matti Megged, The Animal That Never Was (In Search of the Unicorn) (New York: Lumen Books, 1992).

112. Eine Fülle von Text- und Bildbelegen bei Beer, Einhorn.

113. U. a. auf der Malerei der Emporenbrüstung der Stephans-Kirche in Tangermünde. Beer (Einhorn, S. 41) führt als Gegenbeispiel einen Holzschnitt von Tobias Stimmer von 1576 an. Dort verweigert das Einhorn in seinem Hochmut die Besteigung der Arche. Das Problem war Diskussionsgegenstand bis ins 17. Jahrhundert (ebd., S. 41-50).

114. Plinii Secundi Naturalis Historiae, Buch 8, 7, S. 60-61.

115. Ebd., Buch 8, 76, S. 64. [Die Orsäer in Indien jagen ... als wildestes Tier aber das Einhorn, das sonst am Körper dem Pferde, am Kopf aber dem Hirsch, an den Beinen dem Elefanten, am Schwanz dem Eber ähnlich ist, dumpf brüllt, während ein zwei Ellen langes schwarzes Horn mitten auf der Stirne hervorragt. Lebend soll sich dieses Wild nicht fangen lassen.]

116. C. Iulii Solini Collectanea rerum memorabilium, 52, 39-40, S. 190.

117. So Bartholomäus Anglicus, De rerum proprietatibus, S. 1106-7 und Vincentius Bellovacensis, Speculum naturale, Sp. 1435.

118. So Thomas Cantimpratensis Liber de Natura Rerum, S. 168 und Konrad von Megenberg, Das Buch der Natur, S. 161.

119. Isidori Hispalensis Episcopi, Buch 12, 2, 12-13: “Idem et monoceron, id est unicornus, eo quod unum cornu in media fronte habeat pedum quattuor ita acutum et validum ut quidquid inpetierit, aut ventilet aut perforet. Nam et cum elephantis saepe certamen habet, et in ventre vulneratum prosternit. Tantae autem esse fortitudinis ut nulla venantium virtute capiatur; sed, sicut asserunt qui naturas animalium scripserunt, virgo puella praeponitur, quae venienti sinum aperit, in quo ille omni ferocitate deposita caput ponit, sicque soporatus velut inermis capitur" [Das Monoceros, das ist Einhorn, weil es ein Horn von vier Fuß Länge mitten auf der Stirn hat, so spitz und stark, daß es, wen es damit spießt, entweder in die Luft wirft oder durchbohrt. Es kämpft ständig mit den Elephanten und tötet sie, indem es sie am Bauch verwundet. So groß soll seine Stärke sein, daß es durch keine Kunst der Jäger gefangen werden kann. Aber, wie die Verfasser zoologischer Werke versichern, wird 
eine Jungfrau hingesetzt, die dem herbeikommenden Tier ihren Schoß öffnet, und darein legt es, aller Wildheit beraubt, seinen Kopf, schläft ein und wird so ohne Waffen gefangen].

120. Albertus Magnus, De Animalibus, Bl. 183v. [Das Einhorn ist von mäßiger Größe im Verhältnis zu seiner Stärke, von der Farbe des Buchsbaums und mit zweigespaltenen Hufen.]

121. Herr, Gründtlicher underricht, Bl. XLVijb-XLViija.

122. Ebd.

123. Die Beschreibungen können sich dabei auf eine schon länger bestehende Bildtradition stützen. Während der Londoner Physiologus aus dem 12. Jahrhundert (British Museum Harley 4751) das Einhorn noch elephantenfüßig und schweineschwänzig zeigt (Beer, Einhorn, Abb. 9), werden vom 13. Jahrhundert an die Darstellungen als Spalthufer die Regel, während der Schweineschwanz noch lange erhalten bleibt. Die zeitlichen Divergenzen zwischen verbaler und bildlicher Darstellung bedürften einer eigenen Untersuchung.

124. Gesnerus redivivus, Buch 1, S. 781. [Diese Abbildung ist etwa so, wie sie heute von den Malern gemalt wird; Sicheres (über das Aussehen) weiß ich nicht.]

125. Ebd. [Das Monoceros, das ist das wilde Einhorn, wird von Verschiedenen unterschiedlich beschrieben.]

126. Ebd. [Es ist nicht verwunderlich, daß ein so über die ganze Erde verstreutes Tier, das niemals nach Europa gebracht worden ist, von den europäischen Autoren dem Hörensagen nach und fast nie nach Augenschein dem Gedächtnis überliefert worden ist.]

127. Fratris Felicis Fabri Evangetorium in terrae sanctae, hg. v. Cunradus Dietericus Hassler, 3 Bde. (Stuttgart: Literarischer Verein, 1843), 3:441. [Gegen Mittag sahen wir auf dem Berggipfel ein Tier stehen, das zu uns zurückschaute. Als wir es sahen, glaubten wir, es sei ein Kamel, und wunderten uns, wie ein Kamel in der Einsamkeit leben könne, und es erhob sich eine Diskussion, ob es wilde Kamele gäbe. Calinus (der Führer) aber kam zu uns heran und erklärte uns, dieses Tier sei ein Rhinozeros oder Einhorn, und er zeigte uns sein eines Horn, das aus seiner Stirn ragte. Mit großem Eifer betrachteten wir dieses edle Tier und beklagten heftig, daß es uns nicht näher war, damit wir es genauer beobachten konnten. Denn dieses Tier ist einzigartig in vieler Hinsicht: Zunächst heißt es, daß es ein besonders wildes Tier sei und ein Horn von vier Fuß Länge mitten auf der Stirn habe, daß es, wen es damit spießt, entweder in die Luft wirft oder durchbohrt.]

128. Der mitteldeutsche Marco Polo, hg. v. Horst von Tscharner (Berlin: Weidmann, 1935), S. 55.

129. Johann Heinrich Zedler, Großes vollständiges Universal-Lexikon, 64 Bde. (1732-50; Nachdruck Graz: Akademische Drucks- und Verlagsanstalt, 196164), 8:560.

130. Allgemeine Encyclopädie der Wissenschaften und Künste, hg. v. J. S. Ersch und J. G. Gruber, 32. Theil (ca. 1840; Nachdruck Graz: Akademische Drucksund Verlagsanstalt, 1971), S. 305. 
131. Allgemeine Realencyclopädie oder Conversations-Lexikon für das katholische Deutschland, hg. v. Wilhelm Binder (Regensburg: G. J. Manz, 1847), 3:881.

132. 4. Mos. 23.22; 5. Mos. 33.17; Hiob 39.9-12; Ps. 22.22; Ps. 29.5-6; Ps. 92-111; Jes. 34.6-7.

133. Gesnerus redivivus, Buch 3, "Praefatio" [S. 1]. [Die Namen der Autoren sollen überall genannt werden; nicht nur, damit jedem das seine wird (was dankbaren Menschen geziemt), denn alle haben in nützlicher und guter $\mathrm{Ab}$ sicht geschrieben, sondern auch wegen der Sicherheit in der Sache. Es ist jemandem nämlich mehr oder weniger zu glauben, je nachdem, ob es abweichende Meinungen gibt, wieviel Erfahrung er hat, wo er gelebt hat und ob in einem früheren oder späteren Jahrhundert. Und was durch das Zeugnis mehrerer bestätigt wird, verdient sicherlich größeren Glauben.]

134. Thierbuch Alberti Magni, Bl. Aij.

135. Herr, Gründtlicher underricht, Bl. Avb.

136. Ebd., Bl. Aiijb.

137. Ebd., Bl. Aiiija-b.

138. Ebd., Bl. Ava.

139. In Parenthese sei erwähnt, daß Sebastian Franck eine besonders originelle Lösung des Autoritätenproblems erdenkt: Der soziale Rang des Auftraggebers oder Adressaten ist ein unmittelbarer Indikator für die Glaubwürdigkeit eines Autors: "Wir haben auch nit die lugenhafft histori S. Brandon / reyß vnnd Mörfart / Dietrichs von Bern / oder die poppen Joannis de monte villa angemaßt / oder die Fabel Berosi hierein gesetzt/ sunder souil vns müglich ist der warheyt geflissen / vnd niemandt imitiert / dann glaubwirdigen angenummen weltschreibern / die yr reiß vnd historien großmechtigen künigen vnd keysern haben dediciert / da ye nit zuuermutten ist / das sy disen lugen haben zugeschriben / vnd mit eittlen erdichten worten hoffiert" (Franck, Weltbuch, "Vorred", Bl. ib).

140. Zur Verspätung der "kopernikanischen Wende" in den Köpfen vgl. u. a. Fritz Saxl, "Some Classical and Medieval Ideas in Renaissance Cosmography", in Fritz Saxl: A Volume of Memorial Essays, hg. v. D. J. Gordon (London: Nelson, 1952), S. 245-60.

141. Ioachimi Camerarii Norica sive de Ostentis Libri duo (Wittenberg: Georg Rhan, 1532).

142. Ebd., Bl. D[VI]v. [Gegen den gewohnten Lauf der Natur.]

143. Ebd., Bl. F[VIII]v.

144. Dieser Tatbestand betrifft nur die wissenschaftliche Literatur. Auf den Flugblättern etwa erlebt der Wunderbegriff geradezu eine Inflation. Als ein Beispiel unter vielen wäre zu nennen: "warhafftig vnd wunderbarlich Monster, oder Pottfisch, in der gestaltt wie eines Wallfisches, welcher aus dem Möer sich versandet hat . . . Anno Domini 1598", in Deutsche Illustrierte Flugblätter des 16. und 17. Jahrhunderts, hg. v. Wolfgang Harms (Tübingen: Niemeyer, 1985), 4:407. Einen eindrucksvollen Katalog populärer Wundergeschichten, auch von Tieren, bietet Rudolf Schenda, Die französische ProdigienLiteratur in der zweiten Hälfte des 16. Jahrhunderts (München: M. Hueber, 1961). 


\section{Thomas Cramer}

145. Gesnerus redivivus, Buch 3, "Praefatio" [S. *1-2].

146. Ebd. [Dinge, die sich (in den Quellen) auf die Philologie, die Grammatik und auf die Literatur beziehen, sollen nicht ausgelassen, sondern abgetrennt werden.]

147. Ebd. [Aus diesen (Einzel-)Kommentaren soll danach die Epitome verfertigt werden, so daß das Sichere oder zumindest das Wahrscheinliche genau ausgewählt wird, und wie ich gesagt habe, soll es um die Sachen gehen, nicht um die Wörter. Gegenstände der Philologie oder Grammatik, Literarisches, Sprichwörter, Gleichnisse, Fabulae, Abergläubisches, überflüssiges, Zweifelhaftes, Falsches, Dunkles, zu Bekämpfendes und dergleichen mehr ist wegzulassen.]

148. Ebd., Vorwort [S. *1].

149. Herr, Gründtlicher underricht, Titel.

150. Thierbuch Alberti Magni, "Zum Leser", Bl. Aija. 


\section{Die Wissenschaft von den Hexen: Jean Bodin und sein Übersetzer Johann Fischart als Demonologen}

\section{Gerhild Scholz Williams}

Jean Bodin und Johann Fischart hatten mehr gemeinsam als ihre Vornamen. Sie waren Zeitgenossen, Juristen beide, außerordentlich gelehrt und sprachgewandt und vereint in der leidenschaftlichen Überzeugung, daß Hexen die Ordnung ihrer Welt bedrohten, und daß die meisten Hexen Frauen waren. Im Jahre 1580 veröffentlichte Jean Bodin (1529-96) eine der, wie sich sehr bald herausstellen sollte, einflußreichsten Hexenschriften der frühen Neuzeit mit dem Titel De la Démonomanie des sorciers. ${ }^{1}$ Die geballte Agression, die Angst und die Drohung impliziert in den drei Substantiven dieses Titels- "demon", "manie" und "sorciers" - beeindrucken noch heute den Leser. Sie stehen, so Bodin in der Einleitung, "pour la rage qu'ils [die Zauberer und Hexen] ont de courir apres les Diables." Ein Jahr nach Erscheinen dieses Traktats, 1581, übersetzt der Straßburger Jurist Johann Fischart Bodins Werk ins Deutsche. ${ }^{2}$

Fischarts grundsätzliche Übereinstimmung mit Bodins Methodologie und Weltanschauung ist von Anbeginn klar. Er habe, so sagt er, die fünf Bücher der Démonomanie voll von "unzahlige[n] frembden fragen/ Disputationen/ fäll/ Geheimnussen vnnd Erklärungen der Rechten / ja bei nahe der Welt lauff innhalten" mit zusätzlichen Marginalien und intratextuellen, mit Klammern angedeuteten Kommentaren versehen, um seiner Leserschaft das Verständnis zu erleichtern. Zur Stützung der Argumente seiner Vorlage zitiert Fischart viele, seinen deutschen Lesern vertraute Gewährsmänner, so zum Beispiel Johannes Gropius Becanus, "historicus der Statt Antorff." Dieser habe ein Buch über die "älte und herlichkeit der Teutschen Sprach" geschrieben, "welches er Hermathena nennt." Becanus' Bericht über einen Psalter mit rot angestrichenen Zauberpsalmen beweise, so Fischart, daß der Mißbrauch von Psaltern in magischen Riten nicht ungewöhnlich und daß zauberische Riten und Objekte allgegenwärtig seien. So habe er, Fischart, gehört, daß die Italiener und Spanier auf 
ihrem Marsch in die Niederlande in ihrem Gepäck Zauberbücher mitgeführt hätten, "Segen und Beschwerungen, die man jnen für allen vnfall mit zutragen gegeben hätte." Man wisse auch, daß "etliche Teutsche das Nothemd gern pflegen bei jnen zutragen/ welchs doch auff eine gar abschewlich weiß zubereitet wird" (S. 21). Um vor Verletzungen zu schützen, mußte ein Nothemd, so das Handbuch des deutschen Aberglaubens, von einer reinen Jungfrau unter Anrufung des Teufels gewebt und genäht werden. Nothemden hatten noch im Dreißigjährigen Krieg Hochkonjunktur. ${ }^{3}$

Nicht unerwartet zeigt sich Fischart an Sprachgeschichte, Etymologien und mündlich tradierter Information besonders interessiert. So erklärt er, daß Weissagen von dem alten "Gewißsagen/ oder sächBisch/ Witsagen/ nach dem Spruch/Was wir wissen oder witen", käme, "aber weil sie [die Deutschen] für Weißheit vnnd weiß/ mehrtheils schwartz sagten / bekamen sie den Namen Schwartzkünstler" (S. 26). Es kommt auch vor, daß Fischart Informationen unterschlägt, weil er glaubt, daß sie seinen Lesern schaden könnten. So verschweigt er Zauberzahlen und Sprüche; aber auch die Beschreibung, daß die Bewohner der "occidentalischen Newen Insulen . . . am Halß ein Bild der Pederastia oder Buberonigkeit ... hat getragen" will er den "Teutschen jhrer dieses lasters vnschuld halben nit unvertolmetschen" (S. 178). Bodins historiographische Prämisse, daß Geographie und Klima die Entwicklungsgeschichte der Menschheit beinflussen, liefert in der Démonomanie und in Fischarts Kommentaren Argumente für die Rechtmäßigkeit der Hexenverfolgưngen. Die Individualgeschichte findet in der Globalgeschichte ihre Entsprechung. Bodins "kosmographischer Blick", wie Lestringant es nennt ${ }^{4}$, läßt ihn die Kannibalen in Brasilien und die Hexen und Menschenfresser in Europa mit einem Blick umfassen. Die Existenz von Wilden und von Hexen wird als Realisierung des Bösen in der Welt glaubhaft. Der Beobachter, der Berichterstatter teilt als géographistorien seine Welt mit diesem Bösen; um ihm nicht anheimzufallen, muß er sie mit Hilfe seines Wissens bekämpfen.

Ein Großteil des frühneuzeitlichen Wissenschaftsapparats-Philosophie, Theologie, Geschichte, Geographie, Klimatologie und alle der Magie zugehörenden Wissenskategorien-wird mobilisiert, damit der Leser der Démonomanie sich der Fülle der Beweise und deren Überzeugungskraft schwer entziehen kann. Dafür sprechen die häufigen $\mathrm{Zi}$ tate, negative wie auch positive, und der offensichtliche Respekt, den Fischart Bodin entgegenbringt, obwohl er anfangs Bedenken darüber äußert, daß Bodin zuviele jüdische Schriften benutzt. Trotz der dem modernen Leser manchmal redundant anmutenden Argumente steht 
außer Zweifel, daß Bodin-auch wenn die Identifikation und Bestrafung der Hexen zeitweilig in den Hingergrund gedrängt zu werden scheint, dieses zentrale Thema nicht aus den Augen verliert. Ziel des ganzen beeindruckenden Informationsarsenals ist und bleibt die als Hexe verdächtigte Frau und die Frage, wie mit ihr zum Schutz der Gesellschaft zu verfahren sei.

Der Symbiose von Wissenschaft, Politik, Religion und Literatur in diesen Dämonologien möchte ich im folgenden nachgehen.

\section{I}

Mit der Démonomanie traten Jean Bodin und sein Übersetzer Johann Fischart in die Hexendebatte ein, die mit dem Malleus Maleficarum (1487) des Heinrich Institoris etwa hundert Jahre zuvor einen wichtigen definitorisch und juristisch richtungsweisenden Impetus erhalten hatte. ${ }^{5}$ Fast achtzig Jahre nach der Veröffentlichung des Malleus und nach einer Periode relativer Ruhe in den Verfolgungen, hatte sich die Hexenproblematik zu der Zeit, als der Jülicher Arzt Johann Weyer mit dem Traktat De Praestigiis Daemonum (1563) Aufsehen erregte, mit erneuter Dringlichkeit in das Bewußtsein der Gelehrten gedrängt. ${ }^{6}$ Nach eigener Aussage verstand Bodin die Démonomanie als seine Antwort auf Weyer und dessen Hauptthese, Hexen seien zu Unrecht als gefährliche Teufelskomplizen verschrien und gefürchtet. Er, Bodin, wendet sich scharf gegen Weyers Hyphothese, es handle sich bei den Hexen um arme, pathologisch depressive, melancholische alte Frauen, die zu bedauern und mit Gebet und Fürsorge zu heilen, aber nicht hinzurichten, seien. Bodin lehnte diese Haltung als theologisch, juristisch und wissenschaftlich unhaltbar und als politisch höchst gefährlich kategorisch ab.

Bodins Angriff auf Weyers Traktat erschien in Form einer gelehrten, sorgfältig strukturierten Polemik, die ihre Wirkung auf zeitgenössische Leser nicht verfehlte. Nachdem er das ganze Arsenal gelehrten Hexenwissens aus Vergangenheit und Gegenwart, aus Heils-, Welt- und Rechtsgeschichte, Theologie und Naturphilosophie Revue passieren läßt, geht Bodin am Ende zum Direktangriff auf Weyers Thesen über, denen er ein ganzes Kapitel widmet. Zwischendrin polemisiert er gegen seinen Kontrahenten mit Invektiven wie, Weyer, so Fischarts Übersetzung, sei "ein Beschürmer der Hexen, fein Vorfechter der Hexen", und "der Unholden Beschürmer" (S. 70, 112, 153). Mit dem Vorwurf, Weyer habe als Arzt von Juristerei und Theologie keine Ahnung, versucht Bodin, Weyers Glaubwürdigkeit zu untergraben. ${ }^{7}$ 
Fischart, dieser Expertenkontroverse gewärtig, bemüht sich sehr, seinem Leser verständlich zu machen, warum gerade er als Jurist einen Traktat übersetzt, dessen Argumente weit über das hinausgehen, was von einem Anwalt oder Justizbeamten erwartet werden konnte.

Etwa achtzig Jahre nachdem Heinrich Institoris als geachtete auctoritas in der Hexendebatte Eingang gefunden hatte, führte die WeyerBodin Kontroverse dazu, daß Institoris, Weyer und Bodin zu einer unheiligen Allianz zusammenwuchsen, zum tonangebenden Triumvirat der Hexenmanie zweier Jahrhunderte avancierten. ${ }^{8}$ Ihre Traktate sind nicht nur drei der einflußreichsten Stimmen in der Debatte, häufig zitiert und im Zitat legitimiert, sie vertreten darüberhinaus drei der für die Hexenverfolgungen wichtigsten Wissensgebiete, die Theologie/ Inquisition, die Medizin und die weltliche Jurisprudenz. Zusammen stellen die drei Werke wirkungsgeschichtlich alles in den Schatten, was zum Thema geschrieben und gedruckt wurde.

Zur gleichen Zeit wuchs, angefangen mit der Rezeption der Schriften Ficinos und Giovanni Picos, das Interesse der Gelehrten und wohlhabenden Laien an der Magie als göttlicher Wissenschaft. Die Hexe fand sich als Hauptagierende in der satanischen Magie und somit als Feindin der politischen und sozialen Ordnung denunziert und mit Hilfe eines zunehmend formalistischen Rechtsapparats ihrer Strafe zugeführt. ${ }^{9}$ Die Auseinandersetzung war mehr als ein Kampf um wissenschaftliches Terrain, mehr aber auch als ein besonders gefährlicher Ausdruck der Geringschätzung der Frau; es handelte sich vielmehr um eine grundsätzliche Auseinandersetzung mit der Frage, wem Wissen und damit Macht zustünden, und welche Rollen Männer und Frauen in der nachreformatorischen religiösen, wissenschaftlichen und sozialen Ordnung spielen sollten. ${ }^{10}$

Trotz seiner orthodoxen Hexentheorien war es Bodin nicht unbekannt, daß die Beschäftigung mit dem Okkulten, Unsichtbaren, Vesteckten, auch wenn es der Ausrottung der Hexen galt, die Gefahr mit sich brachte, selbst in den Verdacht der Heterodoxie, der Hexerei, zu geraten. In der Tat wurde er 1587 und 1590 in Laon der Hexerei verdächtigt. Der Grund dafür scheint der Besitz verbotener Schriften und die seinen gelehrten Zeitgenossen verdächtige Neigung zur jüdisch-kabalistischen Philosophie gewesen zu sein. Fischart will seinen Lesern diese Kritik an Bodin nicht vorenthalten, wenn er einleitend feststellt, "dann damit ich auch diß für ein anhang hie bei vngemeldt nicht lasse/ sehr viel Gelehrten dieses an jhm als sträfflich taxieren vnnd halten / das er viel zu viel auff der Rabinen Schriften / Außlegungen vnd Glossen angebacht [sic] vnd verpicht ist/ vnnd auß jhnen die Vbermenschlichsten sachen/ vnnd Vnergründtlichsten Geheimnussen 
vnterstehet zuerforschen vnd zueruieren . . . vnd inn offentlichem Truck außsprenget" ("Vorwarnung").

Obwohl Fischart Bodins angebliche Neigung zu jüdischem Schrifttum nicht gutheißt, ist er der Meinung, Bodin verdiene es, gehört zu werden, solange seine Schriften der Wahrheitsfindung dienten. Weise, nicht naseweis solle der Leser urteilen.

Auch wenn ich mich hier auf Bodins Werk im Spiegel der FischartÜbersetzung beschränke, sollte man Institoris und Weyer während der folgenden Ausführungen nicht aus dem Auge verlieren. Die Wirkung der drei Texte zusammen war größer als die Summe ihrer Aussagen. Ebensowenig kann man übersehen, daß mit diesen drei Schriften und ihren zahllosen Nachahmern die unerbittlich verfolgte, als Hexe verdächtigte Frau theologisch, medizinisch und rechtlich unabhängig und als Hauptperson gelehrten Interesses die Bühne der Geschichte betritt. Diese Frau ist für ihre Zeitgenossen von furchterregender theologischer, aber auch politischer und gesellschaftlicher Souveränität, denn der ihr von Gott verliehene freie Wille, ihre Fähigkeit, in vollem Bewußtsein der Konsequenzen sündigen zu können, macht sie strafmündig und rechtsfähig. Ihr unfreiwilliger Eintritt in die Wissenschaftsdiskussion macht sie aber auch wehrlos gegenüber den Gelehrten und den Juristen, die, fasziniert von ihrem angeblich satanischem Wissen, die grausamsten Verletzungen ihrer körperlichen und geistigen Integrität nicht scheuten.

\section{II}

Als Johann Fischart Bodins Démonomanie ein Jahr nach Erscheinen (1581) ins Deutsche übersetzte, fügt er seinem Titel eine Erklärung über die Genese der Schrift hinzu, so wie er sie versteht. In einer Marginalnotiz heißt es, "dieweil Doctor Weier seim Buch ein milten Titul geben De praestigijs, etc. von betrug vnnd blendung der Hexen etc. hat man den Titul hie gescherpfft" ("Vorrede vom Zauberwerck", [S. 3]). Fischart tut das Seine, den Text hier und da zusätzlich zu "scherpffen". So übersetzt er Bodins assemblees des Sorcieres als Hexenreichstag und stellt damit von Beginn an fest, daß er, wie Bodin vor ihm, das Hexenunwesen als organisierte, subversive Aggression gegen die geistliche und weltliche Ordnung fürchtet und zu bekämpfen sich anschickt ("Vorrede vom Zauberwerck", [S. 3]; S. 109).

Die in dem beachtlichen zeitgenössischen verlegerischen Erfolg und Leserinteresse spürbare Aktualität des Originals und der Übersetzung steht in scharfem Gegensatz zu dem durchweg negativen Urteil, mit 
dem die Kritik der letzten zweihundert Jahre dieser Schrift begegnet ist. ${ }^{11}$ Adolf Hauffen gab vor einigen Jahrzehnten den kritischen Ton an; er sei deshalb stellvertretend für viele zitiert. Hauffen meint, die Schrift sei erfüllt von "Weitschweifigkeit und Prunken mit leerer, abgeschmackter Gelehrtheit, [so]wie [mit] Erbarmungslosigkeit"12. Die wenigen Worte, mit denen Julian Franklin, der Herausgeber der neuesten Textauswahl aus den Six livres de la République (1992), auf die Démonomanie eingeht, signalisieren ebenfalls Ratlosigkeit. Er nennt den Text "distressing and all too influential", bevor er sich dem ihm vertrauteren Staatstheoretiker Bodin zuwendet. ${ }^{13}$

An der allgemeinen Geringschätzigkeit und dem Unbehagen gegenüber Bodins Werk über die Hexen hat sich bis heute nicht viel geändert. Im Gegenteil: man übertrug sie auch auf Fischarts Übersetzung. In den gängigen deutschen Lexika wird Fischarts Übersetzung als "unerquicklich" 14 zumeist mit wenigen Worten übergangen; oft fehlt die Schrift in Fischarts Bio- und Bibliographie ganz. ${ }^{15}$ Die spürbare Verlegenheit, eine der hervorragendsten Dichterpersönlichkeiten des 16. Jahrhunderts mit einem der berüchtigsten Hexentraktate der frühen Neuzeit in Verbindung bringen zu müssen-einem Traktat, der noch dazu die heutzutage gern als "bahnbrechend" bezeichneten Aufklärungsbemühungen des Johann Weyer mit einem Schlag zunichte gemacht zu haben schien-erschwert unsere Beschäftigung mit beiden Werken erheblich. ${ }^{16}$ Vage Aussagen und interpretative Ausweichmanöver sind typisch für die kritische Diskussion. Metzlers Autorenlexikon (1986) betont den Konflikt zwischen den in Fischarts anderen Literaturwerken angedeuteten Anfängen der europäischen Aufklärung und seiner Mitarbeit an der Verbreitung "von zwei der unvernünftigsten, düstersten Erzeugnisse der Weltliteratur" ${ }^{17}$. Das Bertelsmannsche Literaturlexikon (1989) gibt sich neutraler, erwähnt die Übersetzungen und beschreibt Fischarts Arbeiten als Entwurf "ideologischer Muster und praktischer Anleitungen zur Entwicklung eines frühneuzeitlichen Weltbildes sowie dessen gewalttätige Etablierung"18. In Deutsche Literatur: Eine Sozialgeschichte (1991) erscheint das Werk als der Ort, in dem die magischen Vorstellungen einer vorbürgerlichen Welt zum letzten Mal heraufbeschworen werden. ${ }^{19}$

Fritz von Bezold unternahm vor neunzig Jahren in der Historischen Zeitschrift den Versuch, dem Traktat im Kontext von Bodins Gesamtwerk gerechtzuwerden. Bezold nennt die Démonomanie "ein höchst persönliches Werk", und vermeidet damit eine allzu scharfe Verurteilung. ${ }^{20}$ Ebenfalls einen Versuch der Annäherung unternimmt Christopher Baxter mit seiner Annahme, Bodins Werk sei hauptsächlich "a brilliant refutation of Weyer", geprägt von "astonished outrage" gegenüber der im wissenschaftlichen Kontext der Zeit und in Bodins 
Epistemologie keinesfalls logisch schlüssigen Bemühungen Weyers, das Hexenphänomen zu pathologisieren..$^{21}$

Die zeitgenössische Reaktion auf beide Werke war anders als die unsrige. ${ }^{22}$ Schon fünf Jahre nach der Erstausgabe-im Jahre 1586-ließ Fischart seiner Übersetzung beim gleichen Verleger, Jobin, eine von ihm selbst durchgesehene und verbesserte Neuausgabe folgen. Er halte es, so in der Vorrede, "wie bei gewissen Völckern [wo] man je von fünf zu fünff Jaren pflegt die Tempel auff ein newes zu reinigen/ weißgen / vnnd zuschmucken / vnnd die darein auffgehenckte Opffer oder verehrungen zuernewern vnd zuerfrischen" (Vorrede, S. iii). Ein unveränderter Nachdruck dieser Ausgabe, der auch meiner Arbeit zugrunde liegt, erschien 1591 in Straßburg, ebenfalls bei Jobin. Fischarts Übersetzung erreichte einen nicht unbeachtlichen Verkaufs- und Anwendungserfolg. Wolfgang Behringer hat nachgewiesen, daß Fischarts Übersetzung neben dem Malleus bei den Hexenprozessen in Rottenburg/Sonthofen (1586-87) als Prozeßhandbuch diente. ${ }^{23}$

Im Gegensatz zu der mit Ratlosigkeit gepaarten Kritik aus dem 20. Jahrhundert wird bei näherer Betrachtung der zeitgenössischen Reaktionen klar, daß Fischarts Beschäftigung mit der Bodinschrift keinesfalls ein Ausrutscher in einer ansonsten bewundernswürdigen literarischen Karriere war. Von der Übersetzung und Kommentierung des Bodinschen Hexentraktats beeindruckt, drängte der mit Fischart befreundete Straßburger Verleger Zetzner auf eine Neuherausgabe des Malleus Maleficarum. ${ }^{24}$ Hundert Jahre nach dessen Ersterscheinung, zum Osterfest 1582, legt Fischart den Malleus als Teil einer zweibändigen Hexenausgabe der gelehrten Öffentlichkeit vor. Band 1 enthält den Malleus und Niders Formicarius; Band 2 besteht aus neun lateinischen Abhandlungen über das Hexenwesen, darunter Traktate von Molitor, Thomas Murner und Bartholomeus de Spina. Nachdem einige dieser Schriften viele Jahrzehnte nicht mehr gedruckt worden waren, erregten sie nun, zweifellos in Reaktion auf die Bodin-Weyer Kontroverse und auf die in den achtziger Jahren des 16. Jahrhunderts in Südwestdeutschland und Frankreich stark zunehmenden Hexenverfolgungen, die Aufmerksamheit der europäischen Rechtswissenschaftler und Gelehrten. Neuauflagen erscheinen in den Jahren 1588 und 1600. Die Popularität des Sammelsuriums bestätigend werden 1614 und 1669 zwei unautorisierte Ausgaben auf den Markt gebracht. ${ }^{25}$

\section{III}

In Fischart fand Bodin einen in jeder Hinsicht kongenialen Übersetzer. Die Hexer (sorciers) der Démonomanie vervielfältigen sich in Fischarts 
Titel und dringen in wilden und bedrohlichen Worthäufungen auf den Leser ein, als wollten sie ihn überwältigen: Vom Außgelaßnen wütigen Teüffelßheer Allerhand Zauberern/Hexen/ vnnd Hexenmeistern/Vnholden/ Teuffelsbeschwerern/ Warsagern/Schwartzkünstlern/Vergifftern/ Augenverblendern, etc. Der auf Furcht und Schrecken, aber auch auf Instruktion und Unterhaltung vorbereitete Leser kommt voll auf seine Kosten. In seiner Vorrede erklärt Fischart seinem Publikum, er habe Bodins Original "ins Teutsche gebracht/ vnd nun zum andernmahl an vilen enden vermehrt vnd erklärt." Auch habe er sich bemüht, für jeden Leser etwas darzubieten, "daß jhm muntet vnd schmecket." Als Jurist habe er anfangs gezögert, das Werk "zu transferieren vnnd dem Teutschen Leser gemeyn zumachen" (Vorrede, S. ii), denn man solle bei dem bleiben, was man gelernt hat. Aber in Bodin sei er einem Juristen begegnet, der "als ein Rechtsgelehrter/ [jhme] diese Matery nicht weniger dann anderer Scientz zugethane vnnd Verwandte/ zu tractieren [hat] gemäß vnd fugsam geachtet." Fischart habe demzufolge das Ganze so ausgeführt, "daß [gleichwol] andern Künsten vnd Faculteten jhre Iudicia darbei vnabgestrickt vnnd vnbenommen bleiben." Niemand solle ihm deshalb vorwerfen, er habe sich "inn frembde vnd meiner Profession vngemäße Tractation vnd handlung hiemit händ eingeschlagen" (Vorrede, S. ii). Es ging also nicht darum, nun ausnahmsweise in weniger geachtete Wissensgebiete auszuweichen oder gar abzusteigen, sondern lediglich um die Frage, ob ein Jurist zur Stützung seiner Thesen Information aus Quellen auswerten konnte, die außerhalb seiner Expertise lagen. Und offensichtlich konnte er daswie Bodin vor ihm auch. Mit Hilfe seiner Übersetzung will Fischart Klarheit in Hexenfragen schaffen zum gemeinen Nutzen "vnnd Vatterland $\mathrm{zu}$ vorstand" und vor allem für die Obrigkeit "so den Gesatzen/ sie in Würden vnd kräften zuerhalten/ vorgesetzt/ . . . von Gott zu trost den Frommen/ vnnd zu trotz den vnfrommen ist geordnet/ vnd deßhalben mit Schwerdt vnd Stab Inthronisiert vnd Investiert" (Vorrede, S. iii). Zusammen mit der juristischen Diskussion und Instruktion erscheinen viele Exempla aus der Vergangenheit und Gegenwart, wundersame Geschichten, historische Ereignisse und unerhörte Begebenheiten. Verglichen mit Bodin/Fischart erscheint uns der vielfach zitierte Malleus einseitig, schlecht organisiert und klobigungelenk.

Fischarts Übersetzungs- und Editionstätigkeit und die rege Produktion ähnlicher Schriften bestätigen die Aktzeptanz von, ja die Forderung der gelehrten oder zumindest der lesekundigen europäischen Öffentlichkeit nach solchen Traktaten. Auch beweist die schnelle Genese dieses Subgenres der gelehrten Literatur, daß Texte 
dieser Art mehreren frühneuzeitlichen Erwartungen und Bedürfnissen entsprachen. Die Kompilation und Organisation alten und neuen Wissens, die Diskussion der wissenschaftlichen, politischen und gesellschaftlichen Konsequenzen der Hexengefahr, führten dazu, daß die frühneuzeitlichen misogynen Obsessionen den Rang laikaler wissenschaftlicher Theoriebildung erreichen konnten. Die Frage "warum derartig monströse Vorstellungen große Teile der kulturellen Elite dieser Zeit so plagten, daß sie sich mit größter Akribie einer Systematisierung des Schreckens widmeten", ist weniger schwer zu beantworten, wenn man beide Werke als Teil der Verwissenschaftlichung und Politisierung der Hexendebatte akzeptiert. Fischarts Arbeit an und mit Bodins Vorlage ist ein überzeugendes Beispiel dafür, daß führende Intellektuelle "eine wissenschaftliche Teildisziplin, die Dämonologie, form[t]en, und ihr eine Methodik angedeihen" liessen. ${ }^{26}$ Damit ist die Frage nach dem "Warum" der Hexenverfolgungen zwar keinesfalls gelöst; wohl aber sehen wir mit größerer Klarheit, welche Rolle die verheerende Kollaboration von Wissenschaft, Recht, Theologie, Politik und Medizin in der Gattungs- und Funktionsgeschichte der Hexentraktate spielt. Bodins Werk und Fischarts Übersetzung geben dem heutigen Leser eine partielle Antwort auf die Frage, wie das Erkenntnis- und Informationssystem beschaffen war, das sich die Ausrottung einer Irrealität, der als Hexen angeklagten Frauen, zur Aufgabe machen konnte. Und wie, unerwartet und ungeplant-in den hier zur Debatte stehenden Texten jedoch unüberhörbar-die Frau unabhängig und im Sinne des auch ihr von Gott verliehenen freien Willens rechtlich mündig zu ihrer Zerstörung beizutragen gezwungen werden konnte. ${ }^{27}$

\section{IV}

Auf der Suche nach auktorialer Legitimierung und finanzieller Unterstützung widmen Bodin und Fischart ihre Werke Mäzenen, von denen sie annehmen konnten, daß sie ihre Überzeugung von der Realität der Hexen und deren Bedrohlichkeit teilten. Fischart nennt Eberhart, Herrn zu Rapoltsstein Hohenack vnd Geroltzeck am Wasichin als Rezipienten seiner gelehrten Anstrengungen. Er preist Eberhart als der weltlichen und geistlichen Gerechtigkeit ebenso zugetan, wie den $\mathrm{Cul}$ tioribus Linguis $\mathcal{E}$ literis. Bodin richtet seinen Traktat an den "Monseignevr M. Chrestofle de Thov Chevalier Seignevr de Coeli, Premier President en Parlement, et Conseiller du Roy en son priué Conseil", also an ein Mitglied der politischen Prominenz Frankreichs. Die Vorreden lassen erkennen, was die Autoren bezweckten: Angesprochen 
werden Männer, deren Interesse an der Hexerei als wissenschaftliches, rechtliches und theologisches Problem vorausgesetzt wird, die aber auch literarische und rhetorische Qualität erwarten (Vorrede, S. iii). Darüber hinaus war das Hauptanliegen der Autoren und der Adressaten in einem Punkt identisch: Die öffentliche Ordnung mußte gewahrt, der Integriät der Gerichte mußte entsprochen werden. ${ }^{28}$

Das komplexe Zusammenspiel von juristischem Anliegen-Hexen müssen identifiziert und unschädlich gemacht werden-und unterhaltsamer und lehrreicher Lektüre wird nicht nur in der Editionsgeschichte, den Widmungen und den Vorreden an den Leser deutlich, auch die Druckgeschichte zeigt, daß die Beschäftigung mit Hexenfragen damals im Mittelpunkt des Gelehrteninteresses stand und große Aufmerksamkeit bei den Druckern fand. Das in mehreren Editionen reproduzierte Druckeremblem der Bodinschen Erstausgabe zeigt Jacques du Puys' barock-klassizistisch stilisierten Brunnen, neben dem die knieende Samariterin (à la Samaritaine) einen an einem Seil befestigten Schöpfeimer ergreift. ${ }^{29}$ Der Brunnen, das Wasser, die Geste des Schöpfens und die den Brunnen umgebenden Frauenfiguren, lassen in diesem Emblem eine Allegorie der Ordnung, der Gerechtigkeit und des Weisheit verheißenden Strebens nach Wissen vermuten. In der Tat zeigt ein Verzeichnis der Druckerzeugnisse des Hauses Jacques du Puys, daß wissenschaftliche, d. h. gelehrte Publikationen das Druckprogramm beherrschten. Neben Jean Bodins vielfältigen Veröffentlichungen finden wir Boethius, Gregor IX, Aristoteles, Euclid, Comines, Galenus, Carion, um nur einige wenige zu nennen. In dem Programm fehlt unterhaltende Literatur fast völlig. ${ }^{30}$

Das Haus Bernhard Jobin, wo Fischarts Werke gedruckt wurden, evoziert ähnliche Assoziationen. Beiderseits des medaillonförmigen Emblems lesen wir die Worte "constans sapientia", "in Weisheit beständig." Die Liste der Veröffentlichungen weist in der Mehrzahl, doch nicht ausschließlich, gelehrte Literatur, u. a. einige Auflagen von Paracelsus' Werken, Calvin, Toxites, Frischlin, Plutarch, Heliodorus auf. ${ }^{31}$ Bodins und Fischarts Titel, die Démonomanie und Vom Ausgelaßnen wütigen Teüffelßheer erscheinen in Druckprogrammen, deren Hauptinteresse der gelehrten Literatur galt. Die Hexentraktate gehören zweifelsohne voll und ganz zu dieser Kategorie.

Die in der zweiten Hälfte des Jahrhunderts zunehmende Verwissenschaftlichung der Hexendebatte macht das Bestreben der laikalen und kirchlichen Mächte deutlich, den Kampf gegen die Hexen in die ordnenden Bahnen wissenschaftlicher Erklärungen und juristischen Prozederes zu lenken. ${ }^{32}$ Dieser Agenda entspricht auch das Zusammenspiel von komplexer Narrativik und monothematischer Inhaltsan- 
gabe, das dem Werk vorausgeht. Das Inhaltsverzeichnis spricht lediglich von Hexen und dämonischer Magie; damit ist der thematischen Vielfalt und der wissenschaftlichen Stringenz des Originals und der Übersetzung keinesfalls Genüge getan. Dagegen spiegelt die Vielzahl der Stichwörter und Namen, die Fischart am Ende seiner Übersetzung zu einem detaillierten Index zusammenfaßt, die Wissensfülle und Detailfreude wider, die in diesem Genre ihresgleichen sucht, und die bestätigt, daß der Hexentraktat weit über das Malleus-Modell hinausgewachsen ist. ${ }^{33}$

\section{V}

Die Organisation des Traktats zeigt an, daß Bodins Dämonologie epistemologisch einen weiteren Bogen spannt, als seine beiden Vorgänger Institoris und Weyer. Der Hexenhammer kommt sofort zur Sache, "Ob es Zauberei gebe, erste Frage." Auf der nächsten Seite schon treffen wir auf die Exposition der Hauptthemen, "die Hexe, der Teufel und die Zulassung Gottes" ${ }^{34}$. Johann Weyer zieht den Kreis etwas weiter; er beginnt mit dem Teufel und dessen Geschichte. Einer mittelalterlichen Summa nicht unähnlich, listet er alles auf, was relevant erscheint, alte und neue Autoritäten einbegriffen (Buch 1).

Auch Bodin hält sich nicht lange mit einleitenden Formalitäten auf; das erste Kapitel des ersten Buches beginnt mit seiner Definition, "Sorcier est celuy qui par moyens Diaboliques sciemment s'efforce de paruenir à quelque chose" (S. 1) ${ }^{35}$. Diesem Hexer, der, wie nicht anders zu erwarten, in den folgenden Seiten zumeist zur Frau mutiert, gilt die Aufmerksamkeit der "eschole souueraine de Iustice", der "premiers Orateurs de l'Europe", der Versammlung der Richter und Advokaten des Parlaments von Paris, "le plus illustre que le Soleil puisse voir en touts les Empires et Républiques de la terre" ("Epistre", S. 2). Hexenumtriebe beschäftigen das höchste Gericht im Land; Hexenangelegenheiten sind Staatsangelegenheiten.

Die Hexe, deren Stereotyp sich gegen Ende des Jahrhunderts fest im Bewußtsein der Gelehrten und der Laien etabliert hatte-sie war meistens älter, meistens arm, oft alleinstehend-will in dieses Konzept nicht so recht hineinpassen. Bodin ist auf dergleichen Einwände vorbereitet; er begegnet ihnen mit juristisch präziser Beweisführung und einer spannenden Hexengeschichte gleich zu Beginn des Traktats. Er berichtet über einen Sensationsprozeß, dem er selbst beigewohnt hatte. Im Jahre 1575 war Johanna Hartwielerin, die Hexe von Compiegne, in Laon lebendig verbrannt worden. Alle seit der Veröffentlichung 
des Hexenhammers bekannten Charakteristiken der Teufelsverfallenheit waren im Fall der Hartwielerin präsent: die Anverlobung der Hartwielerin schon als Baby an den Teufel; Gottesverleugnung und Satanskopulation der zwölfjährigen Johanna; häufige Beiwohnung des Teufels mit Johanna bis zu ihrem 65. Lebensjahr, selbst während der Ehemann an ihrer Seite schlief; verdächtiges, heimatloses Herumziehen von Mutter und Tochter; der Tod der Mutter Jahre zuvor auf dem Scheiterhaufen; Beteiligung am Hexensabbath und Schadenzauber.

Im Anschluß an diese als Augenzeugenbericht beglaubigte Anekdote erklärt Bodin, daß er seinen Traktat als dringend notwendige Aufklärungsschrift verstehe. Es gäbe leider zahllose Gelehrte, Richter und Herrscher, "welche schreiben / lehren/ publicieren vnnd vorgeben/ daß es [das Hexenwesen] nichts zu bedeuten hab[e]." Bodin wisse von einem Theologen, daß er sich verpflichtet habe, zu predigen, daß "Hexen sag/ Fabelwerck vnd vnmöglich ding seie/ vnnd deßhalben kein glauben darauffzusetzen" (S. 4). In diesen von Religionskriegen, Reformation und Gegenreformation geschüttelten Zeiten wüchse die Zahl der Hexen täglich; es gäbe keinen Schutz; sie kämen nun auch in Schwärmen über die Grenze aus Italien nach Frankreich, wo die Verfolgung an Härte und Disziplin zu wünschen übrigließe, und wo Verdacht bestünde, daß selbst Mitglieder der königlichen Familie verbotenen magischen Künsten nachhingen. ${ }^{36}$

Die Harmonie des göttlichen Kosmos, die staatliche und gesellschaftliche Ordnung, die Bodin in seinem geschichtstheoretischen Traktakt, dem Methodus ad facilem historiarum cognitionem (1566) und in den Six livres de la République (1576) als das Ideal menschlich-göttlicher Koexistenz beschrieben hatte, sah er in allen europäischen Ländern, ja sogar in Übersee, ernsthaft von den Hexen bedroht. Der Angst des einfachen Volkes stand die zunehmende Unruhe und das Bewußtsein der eigenen Ohnmacht bei den Gelehrten wenig nach. Entsprechend dieser allgemein gereizten und verängstigten Stimmung entlud sich bei der Festnahme und dem Prozeß der Hartwielerin der Volkszorn so geballt, daß es schwerfiel, angesichts der Hexenpanik bürgerliche Ordnung und juristische Distanz zu bewahren. ${ }^{37}$ Obwohl Bodin die Bestrafung der Hexen als absolut notwendig verteidigt, findet er das Drängen des Volkes auf Soforturteil, fast könnte man sagen auf Lynchjustiz, zwar verständlich und berechtigt, er lehnt solche Racheakte jedoch als juristisch unzulässig ab. Der Forderung des Volkes, die Johanna Hartwilerein stante pede zu verbrennen, begegnet er mit der Bedachtsamkeit des Richters, der in "der sachen gebürlich [zu] verfahren" und "die fürsehung vnnd ordnung" ("Vorrede vom Zauberwerck", [S. 2]) einzuhalten sich zu bemühen hat und verpflichtet ist. ${ }^{38}$ Femejustiz bringt die menschliche Ordnung in Gefahr und ist dem Staat wenig zuträglich. 
Bodin hatte seine standhafte Verteidigung juristischer Integrität lange vor der Abfassung der Démonomanie im Methodus ad facilem historiarum cognitionem dargelegt. Dort beschreibt er die Welt als der Ort göttlicher Vorsehung und menschlicher Ordnung, als eine Welt, die der Erkenntnisfähigkeit des Menschen prinzipiell zugänglich sei. Die göttliche, die natürliche und die menschliche Geschichte spiegelten die gottgewollte Ordnung wider, in der das menschliche Wollen dem göttlichen Willen folgt; täglich entstehen neue Gesetze, neue Bräuche und Institutionen. Es ist Anliegen der Démonomanie, das Wirken der Hexen und Zauberer als gefährlichen Störfaktor in dieser göttlichen, natürlichen und menschlichen Geschichte zu entlarven. ${ }^{39}$ Bodin und Fischart sind der Meinung, noch schlimmer als die Sensationsberichte der sexuellen und kannibalistischen Auschweifungen der Hexen und Zauberer sei es, daß diese die Ordnung der Familie und damit die der gesamten staatlichen Gemeinschaft zu untergraben sich zur Aufgabe gemacht und Satan geschworen hatten. ${ }^{40}$

Bodin und Fischart betonen wiederholt, daß das Interesse vieler Fürsten und Gelehrten an Zauberbüchern und hermetisch-arkanem Wissen der Forderung, Hexen zu entlarven und mit aller Schärfe des Gesetzes zu verfolgen und auszurotten, hindernd im Wege stehe (S. 24). Bis in die höchsten gesellschaftlichen und intellektuellen Schichten seien diese gefährliche Neugierde, dieser zerstörerische Wissensdrang vorgedrungen. Wenn Richter und Obrigkeiten die Zauberer laufen ließen, anstatt sie mit aller Härte zu bestrafen, sollten sie "aufs schärpffste vnter die straff genommen werden" (S. 251).

Bodin macht mit seiner Kritik an der unangebrachten und sträflichen Milde der Obrigkeit selbst vor dem Thron nicht halt. Wiederholt wendet er sich gegen König Karl IX., der dem notorischen Zauberer Trois Eschelles das Leben geschenkt hatte. Dies sei ein Skandal, besonders im Hinblick darauf, daß dieser Zauberer zugegeben habe, selbst an Hexensabbathen teilgenommen und viele Adlige dort gesehen zu haben. Trois Eschelles schätzte die Zahl der Zauberer und Hexen im Königreich Frankreich auf 3000. Als Strafe für seine gefährliche Milde, so Bodin, sei König Karl IX. überraschend in noch jungen Jahren gestorben; und über Frankreich sei das Chaos der Glaubenskriege hereingebrochen $(S .151,185)$. In der Person des Königs verbinden sich für Bodin Herrschaftsanspruch und Ordnungsgebot. Die negative Sofortwirkung Karls juristischer Lauheit in Hexenangelegenheiten hätte kaum schärfer betont werden können.

Fischart nimmt die Symbiose von Hexengefahr und Staatsgefährdung an mehreren Stellen auf und erweitert sie um einiges. Im Zusammenhang mit Bodins Beschreibung teuflischer Laster, ganz besonders der Menschenfresserei, kommentiert Fischart des längeren den 
Handelswert von Menschenfleisch in Pariser Apotheken und die Grausamkeiten der Spanier in der Neuen und der Franzosen in der Alten Welt. Mumia, einbalsamiertes Menschenfleisch, war eine im sechzehnten Jahrhundert begehrte Zutat zu Medikamenten für die Heilung von Kranken und die Auferweckung von Toten. Fischart beruft sich auf den königlichen Kosmographen Thevet als Gewährsperson..$^{41}$ Und er beschreibt weiter, wie die Spanier nicht nur Menschenfresser bestraft, sondern selbst ihre Feinde verzehrt hätten. Noch furchtbarer findet er, daß nicht nur in fernen Ländern Rachgier und Chaos regierten, sondern auch in Frankreich die Glaubenskriege die politische Ordnung erschüttert und die menschliche Würde zerstört hätten.

In einem längeren Exkursus zum Thema zitiert Fischart den Calvinisten und Brasilienreisenden Jean de Léry, dessen Berichte über die Menschenfresser das Amerikabild von Generationen europäischer Leser geprägt hatten. ${ }^{42}$ De Léry habe zu seinem Entsetzen feststellen müssen, daß das Verhalten seiner Landsleute während der Religionskriege dem der "neuen Menschen" nicht unähnlich sei, "das sie namlich den Canibaln / vnd Leutfressenden Wilden Leuten nichts haben zuerweisen / weil sie damals / nach dem sie jhre wehrlose MitChristen vnd Landsleut zu Leon ermördt/ vnd in den Fluß Saone geworffen/ sie wider / rumm herauß gezogen / auffgeschnitten / das Schmaltz herauß genommen. ... Auch/ die Lebern vnnd Hertzen/ sampt anderen stucken Menschliches Leibs gefressen" (S. 239).

Fischart geht in seiner Beschreibung weit über das hinaus, was de Léry selbst geschrieben hatte. ${ }^{43}$ In dessen Bericht über die Belagerung von Sancerre (1573) ist lediglich zu lesen, daß ein Ehepaar aus verzweifelter Hungersnot etwas von der Leiche ihrer dreijährigen Tochter gegessen habe.

Das Chaos als Ausdruck völliger Umkehrung alles Vertrauten, als Indiz satanischer Unordnung, findet Bodin nicht nur unter dem Volk oder in einer bestimmten sozialen Schicht. Satans Welt gehorcht Regeln, die in perverser Umkehrung die Ordnung menschlichen Zusammenlebens persiflieren. Satanische Verschreibungen, so Bodin, kommen auf zweierlei Arten zustande. Da sind zuerst die "außgetruckten" Pakte, "darzu sich allein die gröbsten vnd einfaltigsten / vnnd gewonlich die Weiber gern finden vnd einlassen" 44 . Daneben aber, wesentlich gefährlicher, gäbe es viele "gescheide Leut/ vnd die guts geschlechts vnnd herkommens", die durch Abgötterei "vnnd vnter dem schein der Religion verführen" (S. 17). Gemeint damit sind Atheisten, Libertiner, Epikureer, aber auch Katholiken und falsche Protestanten..$^{45}$ Zur Stützung seiner Thesen bietet Bodin sein gesamtes Wissen auf: Philosophie, Naturwissenschaft, Literatur, Rechtswissen und Medizin, oder, wie Fischart übersetzt und erweitert, "unzählige Historien/ Urtheil/ 
Vergichten/ Uberwesungen/ Verzeugung/Bekanntnusse/ vnnd Exquierung" (S. 113). Die Zeitgenossen konnten sich offensichtlich der Schlüssigkeit dieser Argumentation, dieser Mischung aus autorisierten Quellen der Antike und der neueren Geschichte, aus Augenzeugenberichten und Geständnissen der Hexen, schwer entziehen. "Zweiffelklüglinge", so in Fischarts Übersetzung, "sollen gleichwol diß wissen/ daß nicht weniger Gottlosigkeit ist/ inn zweiffel ziehen/ob möglich / das Zauberer vnd Hexen seien / als inn zweiffel ziehen / ob ein Gott sey / der durch sein Wort vnd Gesatz das ein so wol als dz ander hat vergewisset vnd certifiziert" ("Vorrede vom Zauberwerck", [S. 16]). Häresie, so Bodin und Fischart, sei bei aller Abscheulichkeit dem Atheismus, der grundsätzlichen Gottesleugnung vorzuziehen. ${ }^{46}$

\section{VI}

Bodins Erkenntnissystem basiert auf der frühneuzeitlichen Überzeugung, daß die Naturgesetze und die menschliche Erkenntnisfähigkeit denselben göttlichen Kontrollen unterliegen. ${ }^{47}$ Die Hexe repräsentiert das Wissen, das als teuflische curiositas in den Abgrund führt; nach diesem Wissen streben alle als Hexen verdammten Frauen und die als Zauberer oder Atheisten und Libertiner verschrienen Männer. Bodin war überzeugt, daß die Hexen ohne je Bücher gelesen zu haben, $\mathrm{Zu}$ gang zu geheimem Wissen gewinnen konnten, weil "alte Weiber warn / die nie keinen Plutarchum/ noch Herodotum/ noch Philostratum / noch anderer Völcker Gesatz gesehen noch gelesen / noch mit den Hexen auß Frankreich vnnd Italien jemals sprach gehalten vnd sich verglichen: wie sie so artlich inn allen sachen vnd puncten vberein stimmen", und daß "dergleichen Historien/ so sich auch bei vnderschiedenen Völckern/ vnd zu weit vnterschiedlichen zeiten begeben / allezeit zusammen treffen vnd stimmen" ("Vorrede vom Zauberwerck", [S. 10-11]). Es sei vielfach bezeugt, daß Besessene Griechisch, Latein und andere Sprachen lesen und sprechen. Als Gewährsmann wird Melanchthon herangezogen, von dem gesagt wird, er habe in Sachsen eine Frau, die weder lesen noch schreiben konnte, Latein sprechen und den Krieg mit Sachsen voraussagen hören (S. 189). Dieser satanischen curiositas gegenüber stand das legitime Wissen, gewonnen aus Erkenntnis, Erfahrung und Rationalität, zusammengetragen aus den Schriften der Vergangenheit und Beobachtungen der Gegenwart. Dies ist die Weisheit der Juristen, der Gelehrten und der Herrscher, gewonnen aus der "saincte escriture, ains aussi tous les Academiciens, Peripateticiens, Stoïciens, \& Arabes."

Es ist offensichtlich, daß Bodin und Fischart ihre Schrift als einen 
Beitrag zu diesem legitimen Wissen verstehen, als Weg zum Verständnis der Hexenbedrohung. Die mit dem Buchdruck über Europa hereinbrechende Informationsflut transformiert nun auch dieses Medium, die Hexenschrift, die Dämonologie. Die traditionellen Informationsverarbeitungssysteme, der Kommentar, die Summa, die Florilegien werden verdrängt von Enzyklopädien und Miszellensammlungen. Es geht darum, eine neue, den gelehrten Ansprüchen genügende Ordnung in das Informationschaos zu bringen, die "expandierende Textvielfalt" für eine weite, nun nicht mehr klar zu identifizierende Leserschaft zusammenzustellen und übersichtlich zu machen. ${ }^{48}$ Schon die Wahl der Titel dieser Sammelwerke signalisiert in vielen Fällen den neuen Ordnungsimperativ, das Architektonische, das gebändigte Chaos, die Struktur, die Hierarchisierung der Information. Jakob Zwingers vielbändiges Theatrum vitae humanae (zuerst 1565), Crolls Basilica chymica (1609), das De amphitheatro magio judicium (1604), Bodins geschichtstheoretische Schrift, der Methodus und sein Universae naturae Theatrum (1596) erscheinen als in Schrift und Zahl gebändigter Wissensüberfluß, als rationale Konstrukte, vergleichbar Palästen, die aus formlosem Baumaterialen entstehen; oder sie ähneln dem Theater, wo das Chaos des Daseins auf der Bühne gebändigt wird. Die Titel vermitteln den Eindruck, daß Geschichts- und Naturerkenntnis dem ordnenden Zugriff des Menschen gehorchen kann und muß. Im Métho$d u s$ erklärt Bodin programmatisch, "nach denselben Grundsätzen und Methoden (der Ordnung), wie sie bei der Vermittlung der Wissenschaften zur Anwendung kommen, müssen wir, denke ich, auch bei den Wissenschaften der Geschichte handeln" (S. 13) Am Ende seines Lebens beschreibt er noch einmal seine Vorstellung von der Natur als höchstem Ausdruck dieser Ordnung. Im Universae Naturae Theatrum (1596) heißt es: "il n'y a rien au monde qui soit plus plaisant à voir, ou qui recrée avec plus grand volupté l'esprit de l'homme, ou qui soit plus commode que l'ordre" 49.

Diesem Ordnungs- und Organisationsbedürfnis folgt Bodin auch in seiner Démonomanie. Organisation und Hierarchisierung scheinbar unübersichtlichen Wissens-der Ethik, Religion, Geschichte, Literatur, Musik, Kosmologie und Geographie-sind die Prinzipien, das geistige Handwerkszeug, mit deren Hilfe er die Hexen und Zauberer der willentlichen Apostasie und Häresie zu überführen sucht. Sein Traktat und Fischarts übersetzung entsprachen zweifelsohne dem Zeitgeist; zwischen 1560 und 1630 ergoß sich eine Flut ähnlicher Veröffentlichung auf den europäischen Markt. ${ }^{50}$ In diesem System der Wissensvermittlung liegt der Wahrheitsanspruch, dem sich weder die Gelehrten noch die Hexen entziehen konnten. ${ }^{51}$ Die Texte, auf die Bodin 
sich bei der Formulierung seiner Hexenpolemik stützt, gewinnen ihre Überzeugungskraft nicht nur daraus, daß sie über furchterregende und bedrohliche Phänomene berichten, sondern weil ihre Wissensfülle als Beweis für deren Realität akzeptiert wird. ${ }^{52}$

\section{VII}

Bodins wissenschaftliche Beweisführung und seine rhetorische Argumentation folgen im Großen und Ganzen einem festen Schema. Ein Beispiel mag dies zeigen. Ganz am Anfang, in der Vorrede an den Leser, konstruiert Bodin eine für die Überzeugungsstrategie des ganzen Hexentraktats wichtige Kette von Argumenten. Er beginnt mit der Aussage, daß es mehr als 100.000 Hexen und Hexenmeister in Frankreich gäbe. Damit diese Aussage als wahr akzeptiert werden kann, reiht er eine Anzahl von Beweisen, Argumenten und Historien aus der Vergangenheit und Gegenwart aneinander, bis zu guter Letzt Gegenargumente unmöglich und unnötig scheinen. Fischart übersetzt und aktualisiert mit Hilfe von Kommentaren und Marginalien. An einer Reihe von Argumenten und Beweisen sei gezeigt, wie das im Einzelfalle funktioniert:

1. Juristisch-kritisch: Die Fahrlässigkeit der Regierenden läßt viele der Zauberei verdächtigen Männer und Frauen entkommen; auch werden sie oft zu mild bestraft.

2. Biblisch: Gottes Zorn, der allen Wahrsagern und Zauberern den Tod angedroht hat, wird die Menschen treffen.

3. Historisch-philosophisch: Seit Menschengedenken verurteilen alle Philosophen die Hexen, außer denen, die der epikureischen Sekte angehörten. Im Gegensatz zu den gottlosen Epikureern hat Aristoteles bewiesen, daß es Dämonen gibt.

4. Geographisch: Nicht nur in Frankreich, sondern auch in Schweden, Norwegen (oft wird auch die Neue Welt erwähnt) und auf den Vulkanischen Inseln gibt es Hexen. Das habe u. a. Bischof Oleus Magnus von Norwegen bewiesen, bei dem zu lesen sei, daß "bey den Völckern gegen Mitternacht man an sehr viel Orten diese Täntz der Teufel und Hexen erfahre." Fischart fügt in einer Marginalsglosse "Deutschland im Schwarzwald" hinzu (S. 104). An einer anderen Stelle wird diese geographische Beweisführung durch eine klimatische gestärkt: Im Norden sei es dunkler, die Nächte seien länger, die Hexen hätten mehr Zeit für ihr Zerstörungswerk. Der Teufel habe zu Jesaja gesagt, er wolle auf den Nordwind steigen, 
"vnd Gott gleich sein." Das spräche für die Gewalt Satans, die "er hat vber die Völcker/ so gegen Nord gelegen: Welche von Bösen Geistern vnnd Zauberern sehr vbel verschreit seind" (S. 114).

5. Psychologisch-kritisch: Die menschliche Blödigkeit erschwert es, die Existenz und Bedrohlichkeit der Hexen zu verstehen. Man muß die eigene Unwissenheit erkennen und bekämpfen; das ist die größte Ehre, die man Gott erweisen kann.

6. Philosophisch-theologisch: Auch wenn Aristoteles-sprich die heidnischen Philosophen - viel gewußt hat, so war Hiob-sprich die jüdisch-christlichen Patriarchen, Propheten und Apostel-doch um vieles weiser.

Sollte Wissensfülle und die Autorität seiner Zeugen nicht genügen, greift Bodin zurück auf das Argument jenseits aller Diskussion: Gott kann, wenn es ihm gefällt, jederzeit die Natur wider die Natur handeln lassen. Dem Menschen bleibt das Verständnis dieser geheimen Vorgänge verschlossen (4-6). Als Beispiel berichtet Bodin in der Vorrede von einigen neugierigen Inquisitoren, die sich in Como von Hexen zum Sabbath hatten mitnehmen lassen, um die Hexen zu "beschnarch[t]en und bemaulgaff[t]en" (S. 13). Diesen Fürwitz mußten sie mit ihrem Leben bezahlen. Hätten sie die Heilige Schrift gelesen, so Bodin, hätten sie gewußt, daß die Welt voller Wunder sei. Man müsse manches noch Unverständliche gläubig akzeptieren, ohne alles persönlich in Augenschein nehmen zu müssen. Man wisse, und Fischart bestätigt dies in einer Marginalie, daß die Schiffahrt "inn Americam vnd Indien wider die Natur" geschieht. Augustin und Laktanz hätten die Antipoden und die Gegenfüßler für unmöglich gehalten, "welches doch heut so ein klare Sach / vnnd so vnwidersprechlich / als klarheit der Sonnen offenbar vnd erwisen ist" ("Vorrede vom Zauberwerck", [S. 13]).

Bodin und-seinen Marginalglossen zu entnehmen-auch Fischart waren überzeugt, daß selbst zweifelhafte erscheinende Berichte als glaubwürdig akzeptiert werden müßten, wenn mehrere Berichterstatter in den grundsätzlichen Prämissen übereinstimmten. Kompilationen von Fakten - und die hier zu Debatte stehende Schrift ist zum Großteil gerade das-verbürgen die Wahrheit und Wahrhaftigkeit der menschlichen Erfahrung und göttlichen Vorsehung (S. 79). Selbst mysteriöse Wesen wie Werwölfe, die von Herodot, Pomponius und "bei allen Alten so verschreit/ vnnd inn allen Orientischen Landen so gemeyn gewesen" (S. 116), sind Bodin und seinen Zeitgenossen nicht unbekannt. "Indeed", so schreibt er auch im Methodus, "Caspar Peucer, a man of great erudition and not at all trifling, as well as Languet, famous no less for his education than for his long wanderings over all of 
Europe, affirmed this to me." Und als Antwort auf die antizipierte Frage des Lesers nach der Verläßlichkeit von Informationsquellen gibt Bodin $\mathrm{zu}$, "whether it might happen through occult force of powerful nature . . o or by divine revenge . . . is not clear to me" (S. 79). In Vom Außgelaßnen wütigen Teüffelßheer lesen wir zum Thema Werwölfe, daß das alles zwar sehr "frembde sach [sei]. Aber noch frembder", sagt Bodin, komme es ihm vor, "das solchs vil nicht glauben können / so sie doch sehen/ das alle Völcker auff dem Gantzen Erdrich/ vnnd die Alte sampt der Jungen Welt hierüber vberein stimmen" (S. 123). "Sehen" ist in diesem Falle Lesen, und Gelesenes wird durch Erfahrung bestätigt. Auch hier fungiert Caspar Peucer, nun noch genauer identifiziert als "Melanchthons Tochtermann", als Zeuge. Von ihm wurde gesagt, er habe "allzeit gemeint / es sey mit den Verwandlungen eine Fabel", er habe sich jedoch von vielen Kaufleuten aus Liffland eines Besseren belehren lassen müssen. In diesem fernen Land gäbe es viele Werwölfe, besonders während des Christmonats; Fischart fügt erklärend hinzu, "welchen auch etliche den Wolffmonat nennen" (S. 122, 126). Verallgemeinernd meint Bodin, es gäbe mehr Geister in den Dörfern, als in den Städten, und noch häufiger seien sie in der Einöde und bei den Wassern zu finden (S. 193). Fischart fügt an anderer Stelle hinzu, daß in den dichten Wäldern von Lusignan und in Deutschland in der Ortnau auf Stauffenberg Wesen in weiblicher Gestalt mit Männern Buhlschaft getrieben hätten. Fischarts Marginalie verweist auf Paracelsus, er ist offensichtlich mit der Melusinen-Sage vertraut und akzeptiert sie am Ende des 16. Jahrhunderts durchaus noch als wahr (S. 67). ${ }^{53}$ All dies fügt sich zusammen zu einer, wie Funkenstein es nennt, "weltlichen Theologie", zu einem von einem Laien für Laien organisierten Wissenssystem, auf dessen Basis theologische und geschichtliche Wahrheiten-die Existenz des Bösen in der Welt in der Form von Hexen und Werwölfen etwa-durch vielfach bestätigte Erfahrungsberichte und gelehrtes Wissen erklärt und Strategien zur Bekämpfung entwickelt werden. ${ }^{54}$ Erfahrungswissen und Wirklichkeitserkenntnis verbinden sich zu einem nahtlosen Verweis- und Beweissystem. ${ }^{55}$ Dämonen gab es schon immer, auch heute und in allen Ländern.

\section{VIII}

Hier nun kommen Bodins und Fischarts Bemühungen zu einem unerwarteten jedoch logisch schlüssigen Ergebnis. Bodins gesamtes Wissen und die Kommentare von Fischart führen trotz der Bemühungen beider Juristen und trotz des sorgfältig strukturierten juristische For- 


\section{Gerhild Scholz Williams}

malismus nicht zu dem von ihm angestrebten lückenlosen Beweissystem, sondern zur Aufwertung der Frau als juristische persona. Die als Hexe angeklagte Frau steht dem Richter trotz aller körperlicher und geistiger Malträtierung im Vollbesitz ihrer, ihr von Gott verliehenen Willensfreiheit gegenüber. Nur wenn bewiesen werden kann, daß sie "vorsetzlich vnd wissentlich" dem Teufel folgt, konnte eine als Hexe verdächtige Frau inquiriert, verurteilt und hingerichtet werden. Es war unerläßlich, daß sie, auf welchem Weg auch immer, zu einem Geständnis, wiederum "freiwillig" und bei vollen Bewußtsein, bewegt werden konnte (S. 1). Die Begegnung der Frau, dieses minderwertigen, ebenso verachteten wie gefürchteten Geschöpfes, mit dem frühneuzeitlichen juristischen Wahrheits- und Gerechtigkeitsimperativ produziert die mit Sicherheit unbeabsichtigte und gefährliche Aufwertung der Frau als rechtlich autonomes Geschöpf. Die weltlichen und kirchlichen Juristen mußten auf der Eigenverantwortung der Frau bestehen, um ihre Verurteilung überhaupt rechtlich vertreten zu können. Auch wenn weibliche Schwäche-Fischart nennt es mehrmals ihre "Blödigkeit", diese Mischung aus fleischlicher Schwäche und aus Unmündigkeit, Unwissen und Fleischeslust-gegenüber satanischer Verführung unermüdlich betont wird, sind die Hexentheoretiker gezwungen, die Frau als in ihren Handlungsentscheidungen frei zu akzeptieren. Diese Tatsache hatte unerwartetete praktische und rechtliche Konsequenzen. Um die Mitte des 16. Jahrhunderts wurden Frauen und solche, denen man jedwede gesellschaftliche Autonomie und Autorität absprachKinder, Ehrlose und Meineidige-als Zeugen vor Gericht voll akzeptiert. ${ }^{56}$ Selbst eine als Hexe in Verruf geratene Frau konnte als Rechtsperson vor Gericht aussagen, allerdings nur für die Anklage, nie für die Verteidigung. "Merke", heißt es schon im Malleus, "daß Exkommunizierte, ebenso wie Infame und Verbrecher, Sklaven gegen ihre Herren zur Verhandlung und zum Zeugnis in jedweder Glaubenssache zugelassen werden; ebenso wie Ketzer gegen Ketzer zum Zeugnis zugelassen wird, so auch Hexer gegen Hexe, jedoch mangels anderer Beweise und immer gegen und nicht für" (Buch 3, S. 42).

Frauen und Ehrlose wurden als Zeugen wichtig, weil sie dem Gericht zu den für die Verurteilung notwendigen Indizien verhelfen konnten, ohne die Geständnisse und Verurteilungen erheblich erschwert wurden. Für Institoris galt noch die Regel, daß zwei Frauen anstelle eines Mannes aussagen konnten. Auch Bodin erwähnt diese Regel. Er meint nun aber, daß im Falle von Hexenprozessen eine Zeugin genüge, auch wenn man den Frauen normalerweise weniger traue als den Männern, und "inn den Venedigischen Statuten / des 1524. Jars außgegangen vnd im gantzen Orient recht vnd breuchlich daz allzeit 
zwey Weiber für eins Manns / vnnd vier für ein par Männer Zeugnuß Gelten" (S. 213-14). Das geistliche Recht lehne Frauen zwar als Zeugen $\mathrm{ab}$, "in betrachtung $\mathrm{dz}$ es ein blöd geschlecht vnnd ein schwacher Werckzeug ist" (S. 214). In weltlichen Gerichtssachen zeichnete sich jedoch eine Änderung ab. Weil zuviele Verbrechen ungestraft blieben, sollte man "den Weibern dißfalls Glauben zustellen" ganz gleich, ob sie ohne Ehre seien, oder wie die lateinische Juristen meinen, "geschmächt oder Ingnominiosae weren/gleich wie ein Ehren verwegen vnzüchttig Weib deßgleichen sein mag. Dann die Juristen ziehen Weiber deßhalben zur Zeugnuß / damit die Ubelthaten nit vngestrafft durchwischen" (S. 214). ${ }^{57}$ Der Zweck heiligt die Mittel; der Aufwertung der Frau als Zeugin vor Gericht im Dienste der religiösen und gesellschaftlichen Ordnung steht die fortdauernde Abwertung der Frau als Hexe gegenüber. Die Schwere des Verbrechens macht es möglich, daß selbst verdächtigte Hexen gegen andere Frauen und Männer, Vater gegen Sohn, Mutter gegen Tochter, Kinder gegen ihre Eltern auszusagen erst ermutigt und dann gezwungen werden.

\section{IX}

Bodin und sein Übersetzer Fischart haben zur Verfolgung der Frau als Hexe entscheidend beigetragen. Der Grund lag nicht nur in der Misogynie dieser Zeit, die beide Männer teilten. Er ist vielmehr darin zu suchen, daß sie und ihre Nachahmer die Hexenproblematik in einer Form präsentierten, die sie als Wissenschaft im Sinne dieser Zeit annehmbar machte. Es ging ihnen weniger um die Frage, ob es Hexen gab oder nicht-das stand selbst für einen Großteil der Gegner der Verfolgungen überhaupt nicht zur Debatte-als darum, wie die Welt beschaffen war, in der Hexen und Dämonen ihr Unwesen treiben konnten, und was der Staat unternehmen mußte, um seine Bürger vor diesen zu schützen. Dieser Aufgabe widmeten die Dämonologen ihre ganze Gelehrsamkeit und Eloquenz. Information über Hexen war nun nicht mehr nur der Stoff von Zauberbüchern oder neuen Zeitungen, von theologischen Traktaten und Pönitenz- und Inquisitionshandbüchern: Hexenverfolgungen verdienten - oder besser-forderten das ganze Gewicht laikalen Wissens, aller politischen, religiösen und geschichtstheoretischen Erkenntnisse. Die neue Art der Wissensverarbeitung, der rasch ansteigenden Produktion und Verbreitung von Druckerzeugnissen, die zunehmende Aufwertung der Magie als legitime Wissenschaft, kamen dieser Neuformulierung der Dämonologie gerade recht. Ganz gleich, ob sie in der Vernichtungsmaschinerie ihr 


\section{Gerhild Scholz Williams}

Leben verlor oder nicht, die Frau konnte dieser Art von gelehrter Aufmerksamkeit in den meisten Fällen genausowenig entkommen wie die Gelehrten, Theologen, Beamten, Richter oder interessierten Laien sich ihrer von Angst und Informationshunger gemischten Faszination zu entziehen in der Lage waren. Die frühneuzeitliche Misogynie, wie systemimmanent auch immer, hätte die Frau kaum in dem uns bekannten Ausmaß verfolgen können, hätten sich Wissenschaft, Politik, Recht und Theologie nicht so unheilvoll verbunden. Das Ende der Verfolgungen kam nicht, weil die Gelehrten die Theorien von der Realität der Hexen ein für alle Male als unhaltbar zurückgewiesen hätten; es kam, weil man zugeben mußte-und selbst Bodin deutet das schon an一, daß es kaum juristisch verläßliche Mittel gäbe, die Frau als Hexe zweifelsfrei der Teufelsbuhlschaft und des Schadenzaubers zu überführen. Die Integrität des juristischen procedere trug am Ende den Sieg davon, nicht die Einsicht, daß die den Frauen vorgeworfenen Verbrechen lediglich im Reich der Phantasie existierten. ${ }^{58}$

\section{Anmerkungen}

1. Jean Bodin, De la démonomanie des sorciers (Paris: Samaritaine, 1580; Nachdruck Hildesheim: Olms, 1988).

2. De Magorum daemonomania. Vom Außgelaßnen Wütigen Teüffelsheer Allerhand Zauberern/Hexen vnnd Hexenmeistern/Vnholden/Teuffelsbeschwerern/ Warsagern/Schwartzkünstlern/Vergifftern/Augenverblendern. etc. Wie die vermög aller Recht erkant/eingetrieben/gehindert/erkündigt/erforscht/Peinlich ersucht ond gestrafft werden sollen. Gegen des Herrn Doctor J. Wier Buch von der Geister verführungen/durch den Edlen vnd Hochgelehrten Herrn Johann Bodin/der Rechten D. ond des Parlements Rhats inn Franckreich außgegangen. Vnd nun erstmals durch den auch Ernvesten vnd Hochgelehrten H. Johann Fischart/der Rechten D. etc auß Frantzösischer sprach trewlich in Teutsche gebracht/ ond nun zum andernmahl an vilen enden vermehrt vnd erklärt. Mit Röm: Key: May: Freyheit auff zehen Jar. (Straßburg: Berhart Jobin, 1591). Zitiert nach Jean Bodin, Vom aussgelasnen wütigen Teuffelsheer ... (Graz: Akademische Druck- und Verlagsanstalt, 1973); Seitenangaben im Text.

3. Handbuch des deutschen Aberglaubens (Berlin: de Gruyter, 1930-31), 3: 1714.

4. Frank Lestringant, "Jean Bodin Cosmograph", in Jean Bodin: Actes du Colloque Interdisciplinaire d'Angers, hg. v. Georges Cesbron (Angers: Presses de l'Université d'Angers, 1985), S. 137.

5. Jakob Sprenger u. Heinrich Institoris, Der Hexenhammer. Malleus Maleficarum, übers. von J. W. R Schmidt (München: Deutscher Taschenbuch Verlag, 1990).

6. Meiner Arbeit liegt die neue englische Übersetzung zugrunde: George 
Mora et al., Hg., Witches, Devils, and Doctors in the Renaissance: Johann Weyer, De praestigiis daemonum (Binghamton, N.Y.: Medieval and Renaissance Texts and Studies, 1991).

7. H. C. Erik Midelfort hat nachgewiesen, daß Bodin Weyer zu Unrecht juristische Ignoranz angelastet hatte. Weyer habe über derart ausgedehnte juristische Kenntnisse verfügt, daß man ein Jurastudium vermuten könnte ("Johann Weyer in medizinischer, theologischer und rechtsgeschichtlicher Hinsicht", in Vom Unfug des Hexen-Processes: Gegner der Hexenverfolgungen von Johann Weyer bis Friedrich Spee, hg. v. Hartmut Lehmann u. Otto Ulbricht [Wiesbaden: Harrassowitz, 1992], S. 60).

8. Diese Gemeinsamkeit in der Rezeption erweist sich noch heute als unwiderstehlich; in einem neuen Buch über die Rechtstheorie und Hexerei werden Bodin und Weyer bindestrichverbunden zusammen diskutiert: Michael Siefener, Hexerei im Spiegel der Rechtstheorie: Das crimen magiae in der Literatur von 1574 bis 1608 (Frankfurt a. M.: Peter Lang, 1992).

9. Hier sei angemerkt, daß die Inquisition sich in manchen Fällen milder und rationalistischer zeigte, als die weltlichen Gerichte: Gustav Henningsen, The Witches' Advocate: Basque Witchcraft and the Spanish Inquisition (1609-1614) (Reno: Nevada University Press, 1980); Gustav Henningsen, John Tedeschi u. Charles Amiel, The Inquisition in Early Modern Europe: Studies in Sources and Methods (Dekalb: Northern Illinois University Press, 1986).

10. Siehe hierzu auch Stephen Pumfrey, Paolo L. Rossi u. Maurice Slawinski, Hgg., Science, Culture and Popular Belief in Renaissance Europe (Manchester: Manchester University Press, 1991).

11. Siehe die Editionsliste in Siefener, Hexerei, S. 11.

12. Adolf Hauffen, "Fischart-Studien", Euphorion 4 (1897): 5.

13. Jean Bodin, On Sovereignty: Four Chapters from the Six Books of the Commonwealth, hg. v. Julian H. Franklin (Cambridge: Cambridge University Press, 1992), S. xi. Die bisher ausführlichste Würdigung erfuhr das Werk in der Kölner Dissertation von Ursula Lange aus dem Jahre 1970, Untersuchungen zu Bodins "Démonomanie" (Frankfurt a. M.: Klostermann, 1970).

14. "Fischart, Johann", in Allgemeine deutsche Bibliographie (Leipzig: Verlag von Duncker \& Humboldt, 1878), 7:33.

15. Sie fehlt im Deutschen Dichterlexikon (1988) ebenso wie im Brockhaus (1978), in Meyers Enzyklopädie (1973) und schließlich in Kindlers Literaturlexikon (1989).

16. Zur Diskussion, warum Weyers Schriften und die anderer Hexengegner bei ihren Zeitgenossen ein relativ geringes Echo fanden, siehe Stuart Clark, "Glaube und Skepsis in der deutschen Hexenliteratur von Johann Weyer bis Friedrich Spee", in Lehmann u. Ulbricht, Hgg., Vom Unfug des Hexen-Processes, S. $11-30$.

17. Metzler Autorenlexikon: Deutschsprachige Dichter und Schriftsteller vom Mittelalter bis zur Gegenwart, hg. v. Bernd Lutz (Stuttgart: Metzler, 1986), S. 149.

18. Literaturlexikon: Autoren und Werke deutscher Sprache, hg. v. Walther Killy, 15 Bde. (Gütersloh: Bertelsmann, 1989) 3:385.

19. Hans-Jürgen Bachorski, "Johann Fischart", in Deutsche Literatur: Eine 
Sozialgeschichte. Bd. 2. Von der Handschrift zum Buchdruck: Spätmittelalter, Reformation, Humanismus. 1350-1572, hg. v. Ingrid Bennewitz and Ulrich Müller (Hamburg: Rowohlt, 1991), S. 216.

20. Fritz von Bezold, "Jean Bodin als Okkultist und seine Démonomanie", Historische Zeitschrift 105 (1910): 20-21, 54.

21. Christopher R. Baxter, “Jean Bodin's De la démonomanie des sorciers: The Logic of Persecution", in The Damned Art: Essays in the Literature of Witchcraft, hg. v. Sidney Anglo (London: Routledge \& Paul, 1977), S. 77.

22. Trotz seines nicht unbeachtlichen Erfolgs hörte man schon sehr bald negative Stimmen; diese scheinen hauptsächlich auf die angeblich jüdischen Einflüsse in seinem Werk zu konzentrieren. Im Jahre 1596 erscheint das Werk auf dem Index. Vgl. Bezold, "Jean Bodin als Okkultist", S. 20-21, 54.

23. Wolfgang Behringer, "Erträge und Perspektiven der Hexenforschung", Historische Zeitschrift 249 (1989): 8.

24. André Schnyder, "Der Malleus Maleficarum: Fragen und Beobachtungen zu seiner Druckgeschichte sowie zur Rezeption bei Bodin, Binsfeld und Delrio", Archiv für Kulturgeschichte 74 (1992): 323-64.

25. Vgl. Adolf Hauffen, Johann Fischart: Ein Literaturbild aus der Zeit der Gegenreformation (Berlin: de Gruyter, 1921), S. 259, 261.

26. Walter Rummel, "Gutenberg, der Teufel und die Mutter Gottes von Eberthausen: Erste Hexenverfolgung im Trierer Land", in Ketzer, Zauberer, Hexen: Die Anfänge der europäischen Hexenverfolgung, hg. v. Andreas Blauert (Frankfurt a. M.: Suhrkamp, 1990), S. 93.

27. Andreas Blauert, "Die Erforschung der Anfänge der europäischen Hexenverfolgungen", in Blauert, Hg., Ketzer, Zauberer, Hexen, S. 27.

28. Alfred Soman, "The Parlement of Paris and the Great Witch Hunt (13651640)", The Sixteenth Century Journal 9 (1978): 44.

29. Marie-Thérèse Isaac, "De la démonomanie des sorciers: Histoire d'un livre à travers ses éditions", in Cesbron, Hg., Jean Bodin, S. 394-96. Ich danke Thomas DaCosta Kaufmann für den Hinweis auf dieses Emblem.

30. H. M. Adams, Hg., Catalogue of Books Printed on the Continent of Europe, 1501-1600, in Cambridge Libraries, 2 Bde. (Cambridge: Cambridge University Press, 1967), 2:445-46.

31. Jobin war in erster Ehe mit Fischarts ältester Schwester verheiratet. Siehe dazu Hauffen, Johann Fischart, S. 43; A. F. Johnson u. V. Scholderer, Short-Title Catalogue of Books Printed in the German-Speaking Countries and German Books Printed in Other Countries from 1455 to 1600 Now at the British Museum (London: Trustees of the British Museum, 1962) S. 1065.

32. Zachary S. Schiffman, On the Treshold of Modernity: Relativism in the French Renaissance (Baltimore: Johns Hopkins University Press, 1991), S. 82.

33. Marie-Thérèse Isaac, "De la démonomanie des sorciers: Histoire d'un livre à travers ses éditions", in Cesborn, Hg., Jean Bodin, S. 377-91.

34. Sprenger u. Institores, Der Hexenhammer, S. 3.

35. Jean Bodin, De la démonomanie des sorciers (Paris: Iacques du Puys Libraire Iuré, à la Samaritaine, 1580; Nachdruck Hildesheim: Olms, 1988).

36. Katharina von Medici war von dem Zeitpunkt ihrer Übersiedlung nach 
Paris an beschuldigt worden, sie habe Zauberer aus Italien an den Hof gebracht; Hexeninfiltration war zu einem internationalen Phänomen und Problem geworden. Siehe Bezold, "Jean Bodin als Okkultist", S. 11.

37. Rummel, "Gutenberg, der Teufel und die Mutter Gottes", S. 108.

38. Alfred Soman, Sorcellerie et justice criminelle: Le Parlement de Paris (Brookfield, Vt.: Variorum, 1992), S. 39; Blauert, "Die Erforschung der Anfänge der europäischen Hexenverfolgungen", S. 11-43.

39. Maxime Préaud, "La démonomanie des sorciers fille de la République", in Cesborn, Hg., Jean Bodin, S. 423.

40. William H. Greenleaf, "Jean Bodin and the Idea of Order", in Bodin: Verhandlungen der Internationalen Bodin Tagung in München, hg. v. Horst Denzer (München: Beck, 1973), S. 11.

41. Siehe Frank Lestringant, André Thevet: Cosmographe des derniers Valois (Geneva: Librairie Droz, 1991).

42. Frédéric Tinquely, "Jean de Léry et les vestiges de la penseé analogique", Bibliothèque d'Humanisme et Renaissance 52 (1995): 25-45.

43. Géralde Nakam, Au lendemain de la Saint-Barthélemy: Guerre civile et famine. Histoire mémorable du Siège de Sancerre (1573) de Jean de Léry (Paris: Editions Anthropos, 1975), S. 291: “Simon Potard, Eugene, sa femme, et une vieille femme qui se tenoit avec eux nommée Philippes de la Feüille, autrement l'Emerie, avoyent mangé la teste, la cervelle, la foye et la fressure d'une leur fille aagée d'environ trois ans, mort toutefois de faim et en lengeur." Er habe während seines Aufenthalts in Brasilien oft gesehen, daß Menschenfleisch gegessen wurde, "si n'en ay-je jamais eu telle terreur que j'eus frayeur de voir ce piteux spectacle." Vgl. Jean de Léry, Histoire d'un voyage fait en la terre de Brésil. 1557, hg. v. Frank Lestringant (Paris: Max Chaleil, 1992); ders., Le huguenot et le sauvage: L'Amérique et la controverse coloniale en France au temps des guerres de religion (1555-1589) (Paris: Klincksieck, 1990).

44. Bodin bezieht sich hier möglicherweise auf die im 16. Jahrhundert zunehmende und vielfach kritisierte Praxis, vorgedruckte Verträge unterschreiben zu lassen. Diesen Hinweis verdanke ich Michael Stolleis, Frankfurt.

45. $\mathrm{Zu}$ diesem Thema allgemein siehe Louise Godard de Donville, Le libertine des origines à 1665: Un produit des apologètes (Paris, Seattle, Tübingen: Papers on French Seventeenth Century Literature, 1989); T. Gregory, Hg., Ricerche su letteratura libertina et letteratura clandestina nel seicento (Florenz: Nuovo Italia Editrice, 1981).

46. Gilles Roussineau, "Peur et répression du mal dans 'La démonomanie des sorciers'", in Cesborn, Hg., Jean Bodin, S. 413.

47. Fernand Hallyn, The Poetic Structure of the World of Copernicus and Kepler (New York: Zone Books, 1990), S. 129.

48. Helmut Zedelmaier, Bibliotheca universalis und Bibliotheca selecta: Das Problem der Ordnung des gelehrten Wissens in der frühen Neuzeit. Beihefte zum Archiv für Kulturgeschichte, 33 (Köln: Böhlau, 1992), S. 242.

49. Philippe Dejan, "Jean Bodin et l'idée de méthode au XVIe siècle", in Cesborn, Hg., Jean Bodin, S. 124.

50. Eine sechs Jahre später erscheinenden Hexenenzyklopädie indiziert im 


\section{Gerhild Scholz Williams}

Titel ähnliche Organisationsbestrebungen; es ist dies das Theatrum de veneficiis, "das ist: Von Teufelsgespenst, Zauberern vnd Giftbereitern, Schwartzkünstlern, Hexen vnd Vnholden, vieler fürnemmen Historien vnd Exempel. . . . Sampt etlicher hingerichteter zaüberischer Weiber gethaner Bekanntnuß, Examination, Prob, Vrgicht vnd Straff. . . . Allen Vögten, Schuldtheissen, Amptleuten des weltlichen Schwerdts, \&c. sehr nützlich vnd dienstlich zu wissen, vnd keines wegs zu verachten." Siehe Diane M. Del Cervo, Hg., Witchcraft in Europe and America: A Guide to the Microfilm Collection (Reading: Research Publications, 1983), S. 49.

51. Robert Markley, "Representing Order: Natural Philosophy, Mathematics, and Theology in the Newtonian Revolution", in Chaos and Order: Complex Dynamics in Literature and Science, hg. v. N. Katherine Hayles (Chicago: University of Chicago Press, 1991), S. 125-48.

52. Brian P. Copenhaver, "Natural Magic, Hermetism, and Occultism in Early Modern Science", in Reappraisals of the Scientific Revolution hg. v. David Lindberg u. Robert Westman (Cambridge: Cambridge University Press, 1990), S. 265, 269; und ebd., S. xxiv.

53. André Schnyder, “Johann Fischart als Bearbeiter eines mittelalterlichen Märes: Veränderungen ästhetischer Darstellungsverfahren und kultureller Deutungsmuster im Peter von Stauffenberg", Wirkendes Wort 29 (1989): 15-43.

54. Amos Funkenstein, Theology and the Scientific Imagination from the Middle Ages to the Seventeenth Century (Princeton: Princeton University Press, 1986), S. 3 .

55. Zedelmaier, Bibliotheca universalis, S. 7, 8, 21.

56. Edward Peters, Inquisition (New York: Free Press, 1988).

57. Siehe hierzu auch Anne Llewellyn Barstow, Witchcraze: A New History of the European Witch Hunts (San Francisco: Pandora, 1994), S. 41: "That European women first emerged into full legal adulthood as witches, that they were first accorded independent legal status in order to be prosecuted for witchcraft, indicates both their vulnarability and the level of antifeminism in modern European society."

58. Siehe auch Gerhild Scholz Williams, Defining Dominion: The Discourses of Magic and Witchcraft in Early Modern France and Germany (Ann Arbor: University of Michigan Press, 1995). 


\title{
10. Science and Pseudoscience: Athanasius Kircher's Mundus Subterraneus and His Scrvtinivm ... Pestis
}

\author{
Gerhard F. Strasser
}

\section{Athanasius Kircher as a Scientist-Problems of Reception}

The history of Athanasius Kircher's reception shows that, of all the men of science in the early modern period, Kircher has been among the most controversial. The late John Fletcher has presented a sampling of comments on the German scholar's work ${ }^{1}$ that range from effusive praise among his contemporaries to severe condemnation in Georg Adolf Erman's positivist assessment in his 1882 article in the Allgemeine deutsche Biographie. Kircher's near three-score works served as an instant reference source for several generations of scientists and literary authors alike; the late seventeenth-century custom of meticulously and eruditely documenting such references in "Anmerckungen," as practiced by Daniel Casper von Lohenstein or Philipp von Zesen, proves Kircher's Mundus Subterraneus, with its spectacular illustrations, to have been a particular favorite. ${ }^{2}$

For the purposes of this analysis, I have selected the two most relevant works from among his scientific publications. The Mundus Subterraneus first appeared in $1664-65 ;^{3}$ a second edition came out in 1668, followed by a third, greatly revised one in 1678. All editions were published in Amsterdam, where a Dutch translation appeared in 1682. Kircher's book on the plague, Scrotinivm ... Pestis, came out in Rome in $1658 ;{ }^{4}$ it was reissued with an introduction by Christian Lange in Leipzig in 1659, 1671, and a third time one hundred years later, in 1771. It was also published in a Dutch translation in Amsterdam in 1669. A German rendition appeared in Augsburg in 1680, and a Latin reedition came out in Graz in 1740. Kircher's works dealing with matters Egyptian and Chinese continue to be primarily the subject of historical investigation. Mundus Subterraneus and Scrotinivm Pestis show in a paradigmatic way the German Jesuit's scientific interests and allow for an intriguing analysis of his modus operandi-an admixture of 
firsthand investigation echoing the "New Science" of the period, and of its evaluation within the strictures of a clear theological and ontological tradition.

\section{Volcanology and the Theory of Global Water Circulation in Mundus Subterraneus}

Kircher's Vita ${ }^{5}$ cites a number of life-threatening incidents in his early years from which he felt he was miraculously saved; it provides background material for the Jesuit's thirty-year-long preoccupation with subterranean and "terranean" matters. On a return voyage from Malta to Rome via Naples, Kircher witnessed and "lived through" the eruptions of the volcanoes Ætna, Stromboli, and Vesuvius along with the concomitant earth and sea quakes. In his Vita-and, more importantly, on the opening pages of Mundus Subterraneus - he described various aspects of volcanic eruptions before his arrival at Naples: the plumes of smoke covering almost all of Sicily, the tidal waves in the Straits of Messina, or the terrifying disappearance of the city of San Eufémia in the agitated seas. The thirty-five-year-old Kircher, who purportedly had undertaken speleological explorations in caves of his native Rhön area in his youth, ${ }^{6}$ debated the subterranean interconnection of the three volcanic eruptions once he espied the plume over the third one, Mount Vesuvius. He resolved to investigate its smoldering crater. With the aid of a dearly paid local guide, and entrusting his life once again to his Lord and the Virgin Mary, he climbed the side of the mountain in the dead of night and shuddered in terror when he finally saw the boiling masses of subterranean fires inside the crater. Nonetheless, at dawn he took measurements with his pantometer and finally had himself lowered down, tied to a rope, onto a rock inside the crater in order to further study the fiery lava. All this happened with the Jesuit scholar fully aware of the fate of Pliny the Elder, who in A.D. 79 attempted a similar exploration but died from asphyxiation.

This brief summary of the extensive account given such prominent place in the "Praefatio" to Mundus Subterraneus can nonetheless indicate the pivotal role that the entire experience played in the conception of Kircher's two-volume book. Such an assumption is enhanced by the highly unusual inclusion-in the middle of the preface-of the first of several exquisite, double folio-size engravings: the illustration of Vesuvius in full eruption (Typus Montis Vesuvii, Prout ab Authore $A^{\circ}$. 1638. visus fuit; see fig. 1). As so much of the material is narrated in an unexpectedly emotional tone in the "Praefatio," the scientific discussion of 


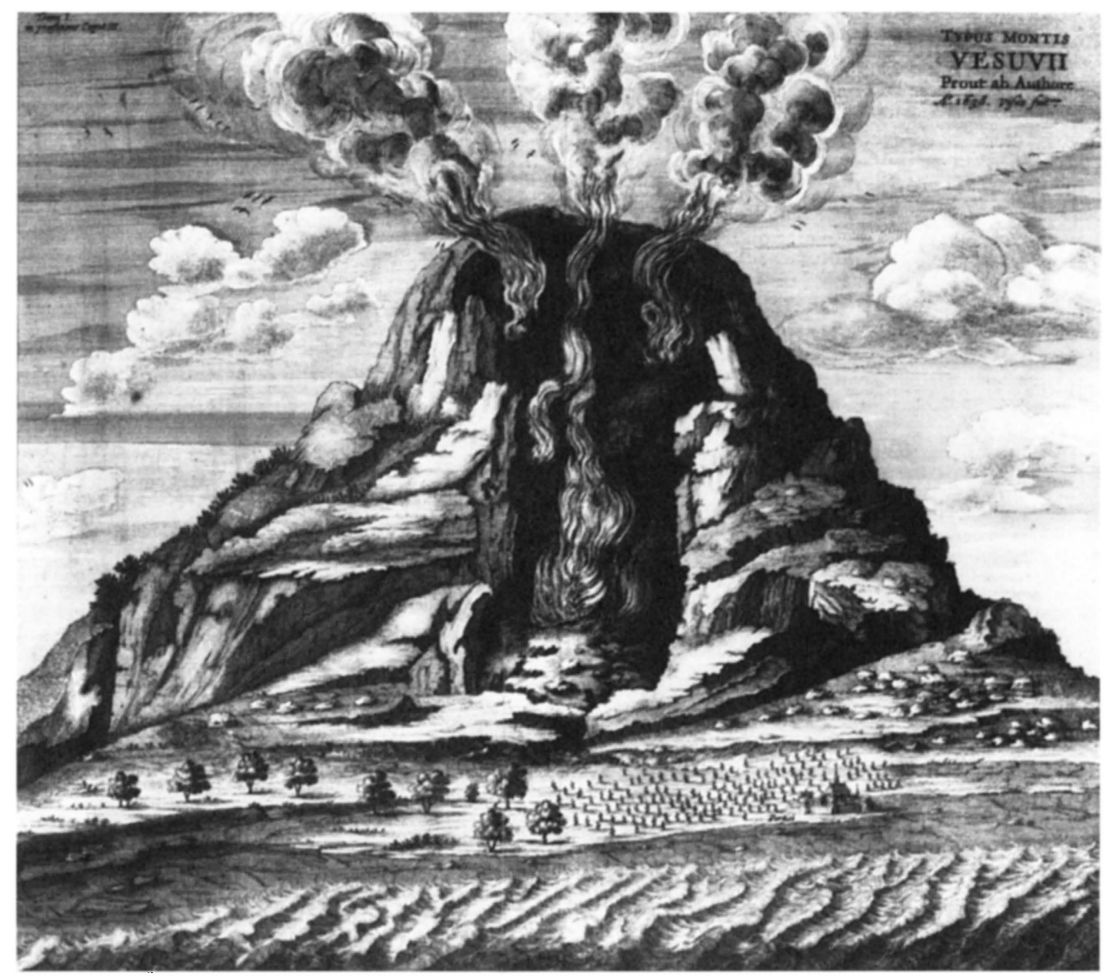

Fig. 1. Athanasius Kircher, Mundus Subterraneus. Mount Vesuvius in full eruption. Courtesy, Herzog August Bibliothek, Wolfenbüttel, Germany.

the outbreak is taken up much later in book 4 . There, Mons Ætna is reproduced in a similar vein (fig. 2). ${ }^{7}$ I have furnished further proof of the key position of Kircher's exposure to the power of the subterranean world in my analysis of the manuscript of an earlier, partial version of Mundus Subterraneus, which included detailed sketches of a number of the book's illustrations. Among them, Kircher's own drawing of the outbreak of Vesuvius stood out; it was the only one beautifully colored by Johann Paul Schor, a German artist working in Rome (fig. 3 ). ${ }^{8}$ This earlier version, with the sketch of a frontispiece entitled Geocosmvs siue Mundus Subterraneus, was drafted almost ten years before the publication of the two-volume book and contains nearly verbatim the material from the printed "Praefatio." It is one of the few sections the author did not have to rework before the long-delayed appearance of the two-part undertaking.

Kircher's preoccupation with celestial and terrestrial matters in the 


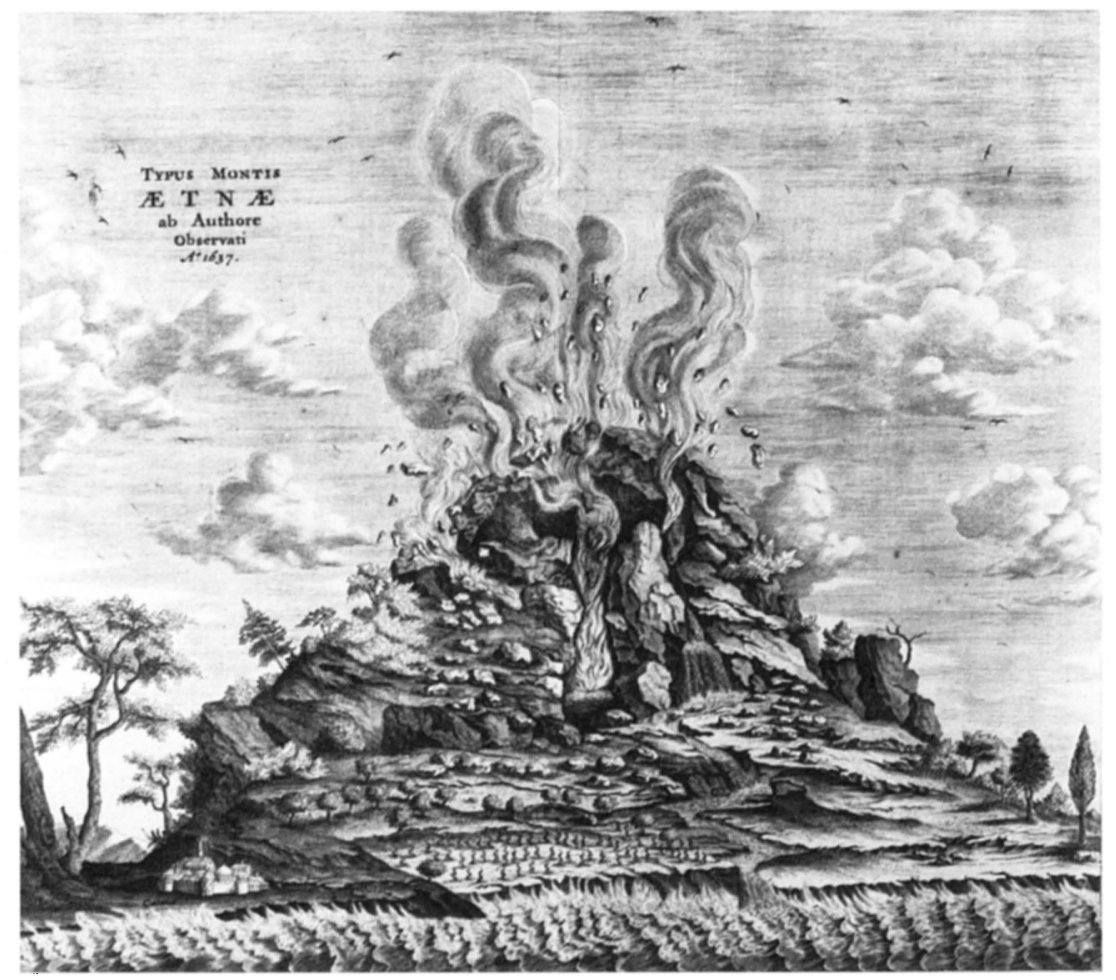

Fig. 2. Kircher, Mundus Subterraneus. Mount Ætna in full eruption. Courtesy, Herzog August Bibliothek, Wolfenbüttel, Germany.

1650s is also borne out by the publication of two complementary works illustrating the scholar's cosmological views. The Itinerarivm Exstaticum [sic] qvo Mvndi Opificivm id est Coelestis expansi of $1656^{9}$ explicated the planetary space of the expanded yet still closed system of Tycho Brahe that offered the Jesuits an acceptable compromise between the Ptolemaic and Copernican world views; the compendium volume, the Iter Extaticom II. qui \& Mundi Subterranei Prodromvs dicitur, appeared one year later and dealt with the "inner" world. In the tradition of learned dialogues, Kircher's well-tried Prodromvs or "harbinger" publications ${ }^{10}$ anticipate the larger-and more expansive-tomes. The first part shows the "rapture" of Cosmiel, the Virgilian guide in both books, with the celestial universe; the second volume introduces Theodidactus, homo curiosus $\mathcal{E}$ scientificus, to the intriguing horizons of a lower world. The Iter Extaticum II., then, feeds right into the new experience of the subterranean sphere as set forth in the 1656 manuscript sections and the Mundus Subterraneus of 1664-65. 


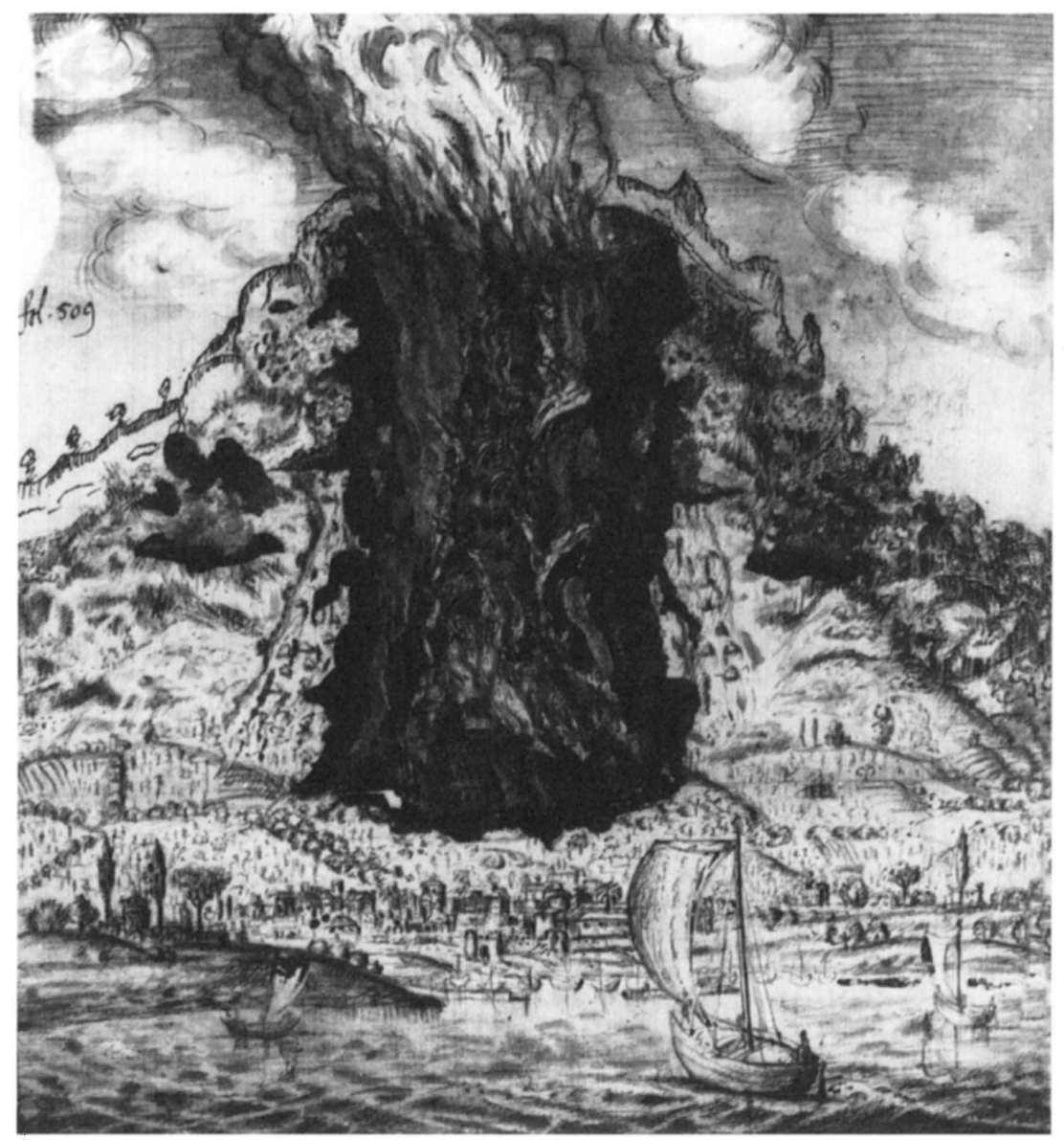

Fig. 3. Kircher's drawing of the outbreak of Mount Vesuvius in full eruption, completed by Johann Paul Schor. Courtesy, Biblioteca Nazionale Centrale Vittorio Emmanuele II, Rome, Italy.

In his new book, Mundus combinatus, Thomas Leinkauf paradigmatically uses some of Kircher's works to analyze the universal science of the baroque. He stresses the importance of the vehicle of the "ecstatic journey" in the preparatory books, which-together with the young Kircher's key experience of the volcanic activities-leads to his analysis of the phenomena of the hitherto unknown netherworld. Let us have a brief look at the Jesuit's concept of volcanism, which he set forth in book 4 (aptly titled, Pyrographikos) of his Mundus Subterraneus. His own observations, measurements of the increase in temperature in mine shafts, and the earliest quantitative calculations of the mass of 
lava flows enabled him to go beyond the inherited concept of the Greek natural philosophers. He accepted Plato's idea of an ignis centralis, knew Pliny's and Aristotle's theories, and-while remaining within the classical framework - was the first to devise a detailed system accounting for volcanic eruptions. ${ }^{11}$ In another of his spectacular illustrations (fig. 4, Systema Ideale Pyrophylaciorum Subterraneorum), Kircher presented a cross-section of the earth with an inexhaustible central fire. This fire, supplied with oxygen through the tidal forces that pump air into the earth's center, fed numerous secondary, more peripheral combustion chambers through underground fissures. Kircher posited that these canales pyragogi sometimes break through the surface, thus forming volcanoes, which thereby become the air vents (or "chimneys") of the earth's innermost activities. ${ }^{12}$ The illustration of this intricate "pyragogic" system in Mundus Subterraneus is thus the first attempt at representing a highly involved theory of volcanism that was to be a matter of debate for centuries. It competed with modern volcanic models that are still being refined and are associated with the tectonic structure of the earth's surface. Kircher's visualization, however, was so impressive that his ideas survived in geological literature into the beginning of this century. ${ }^{13}$

The seventeenth-century Jesuit himself provides the underpinning for his view of the "inner world," which to him is perfectly compatible with his volcanic explorations. Nonetheless, his examinations could not penetrate to the core of the earth, as he realized. For this reason, he felt that all that his "geocosmic" system (as represented in the illustration of the ignis centralis) could reflect for certain was God's masterful work. ${ }^{14}$ Thomas Leinkauf has documented the various steps that Kircher took to "reevaluate" his daring undertaking of devoting a major publication to the subterranean, "night" side of the known world. It was this dirty and horrible "subearthly" area of greatest repulsion of light and brightness that Greek philosophy and even Christian interpretation had relegated to the lowest hierarchical order. It is significant that the Jesuit led from the introductory report on his volcanologic experience right into the comparison of this subterranean world with a fabrica and architectura analogous with the human body. ${ }^{15}$ Kircher's redefinition carries over to Liber Primus, which he significantly calls Centrographicus or Centrosophia, with its opening section entitled, "De mirifica Centri Natura \& maximo Dei Opificio." In this early segment the author highlights the importance of the centrum of the earth, the center of gravity, which is ultimately the center of his elaborations in fields as diverse as geography, climatology, or cartography.

It is this reevaluation of the netherworld, this reattribution of "dignity" to the earth for which Kircher pays with a compromising 


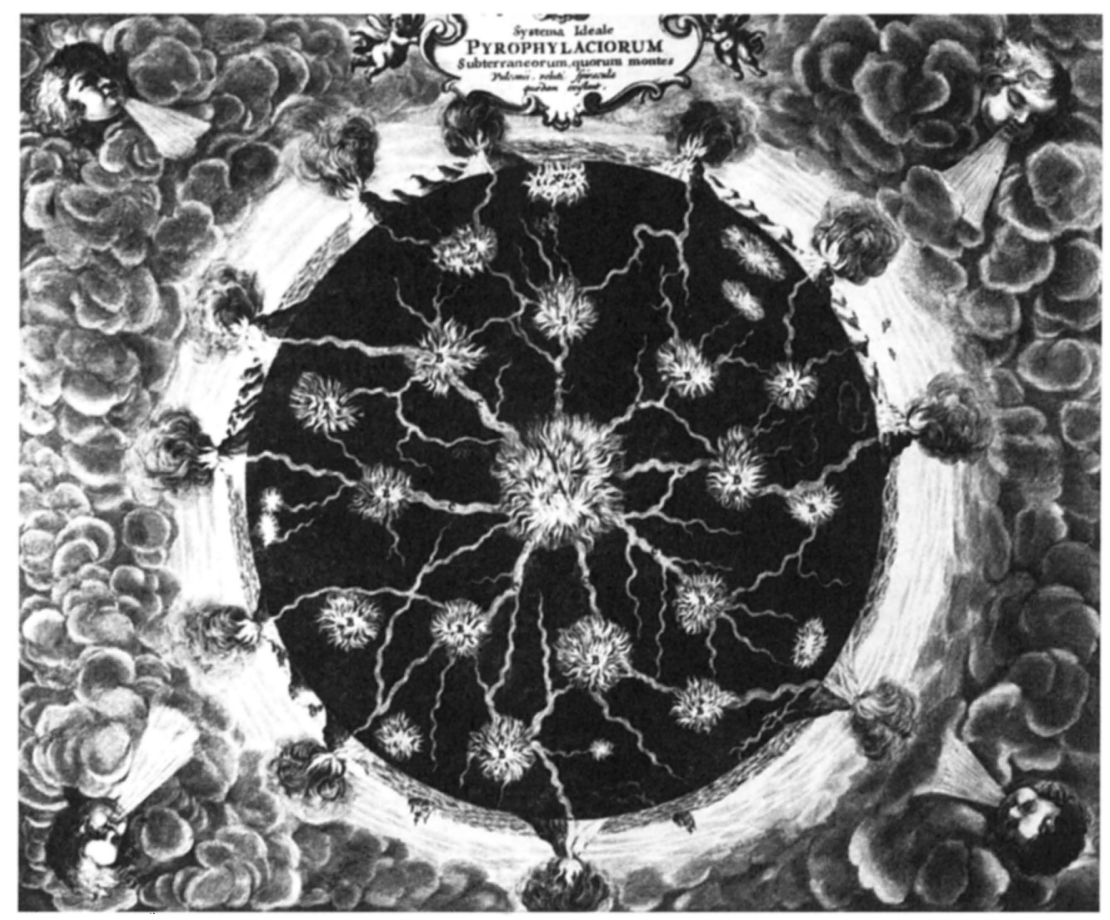

Fig. 4. Kircher, Mundus Subterraneus. Cross section of the earth showing the central fire and the interconnected system of "canals" leading to the erupting volcanoes on the periphery. Courtesy, Herzog August Bibliothek, Wolfenbüttel, Germany.

stance: ${ }^{16}$ he cannot undercut the theological ordo rerum with a wholehearted espousal of the New Science, but neither can he force the new physics back into the traditional position of the geocentric universe. (This is where the Tycho Brahe world view figures in so significantly.) The German Jesuit could temporarily restore this dignity of the earth only by compensating for a hierarchy demanded by the church "durch das Engagement Gottes (in physikalischer und heilsgeschichtlicher Hinsicht) für die Welt in der Welt, . . . durch eine intensive Verschränkung von Welt und Gott," to quote Leinkauf. It goes without saying that positivist scholars would make this "pseudoscientific" approach of Kircher the target of sometimes severe criticism; the accomplishments in the Mundus Subteraneus were seen totally out of this theological and ontological context. While crediting the author for "paying at least lip service to the new experimental science ... and supplying a certain amount of useful practical knowledge and applied science," as 
well as for condemning alchemy, Lynn Thorndike felt as recently as 1958 that Kircher devoted "more space to past error and magic, and to fantastic hypotheses of his own, than ... to new scientific truth." 17

The Jesuit's theological view of the ordo rerum discussed here has greatly influenced his explanation of the global circulation of water. By positing vast underground channels through which water recirculates back to the mountain peaks, as will be seen, Kircher connects with his volcanological system: such subterranean water can come in contact with magma and contribute to the explosion of volcanoes-a modern theory that in Kircher's instance, however, is based on wrong assumptions.

Books 3 and 5 of Mundus Subterraneus are devoted to water circulation, lakes, rivers, fountains, and their origin. In Hydrographicus, the third book, the author explicates his theory of a prestabilized equilibrium of the various forces that contribute to this system. As with volcanism, he synthesizes tradition. ${ }^{18}$ Thales of Miletus and Leonardo da Vinci had compared the circulation of water with the flux and reflux of blood in the human body; they had explained the rising of water to the peaks of mountains with the natural subterranean heat that would force water up. In his Harmonices mundi libri quinque of 1619, Johannes Kepler had espoused a similar theory; Kircher, who was in close contact with the newly established Royal Society, was also influenced by William Harvey's discovery of the circulation of the blood, which he cites in the second volume. ${ }^{19}$

In his own theory, the Jesuit scholar had to account for his philosophical assumption of a prestabilized equilibrium within the universe. He also had to accommodate the biblical explanation taken from Ecclesiastes 1:7, which he quoted in the preface to book 5: "All streams run to the sea, but the sea is not full; to the place where the streams flow, there they flow again." 20 These considerations forced Kircher to create an innovative system, which posited that all the great rivers of the world have their sources high up in the mountains. While some of his contemporaries were beginning to prove through exact calculations that the rains and snowmelt would suffice to feed rivers and streams, ${ }^{21}$ Kircher did not consider these supplies adequate. This brought about his ingenious hypothesis that there existed vast reservoirs beneath the summits of the highest ranges of the four known continents. Such hydrophylacia or storehouses of water are featured in a series of illustrations of the world's major mountains and rivers in book 2 (fig. 5, the Tabula Geographica Hydrophylacium Asiæ Majoris). ${ }^{22}$ They are also the subject of further discussion in the fifth book, where a group of mountains is cut open to reveal such caverns. Rivers are seen flowing from 


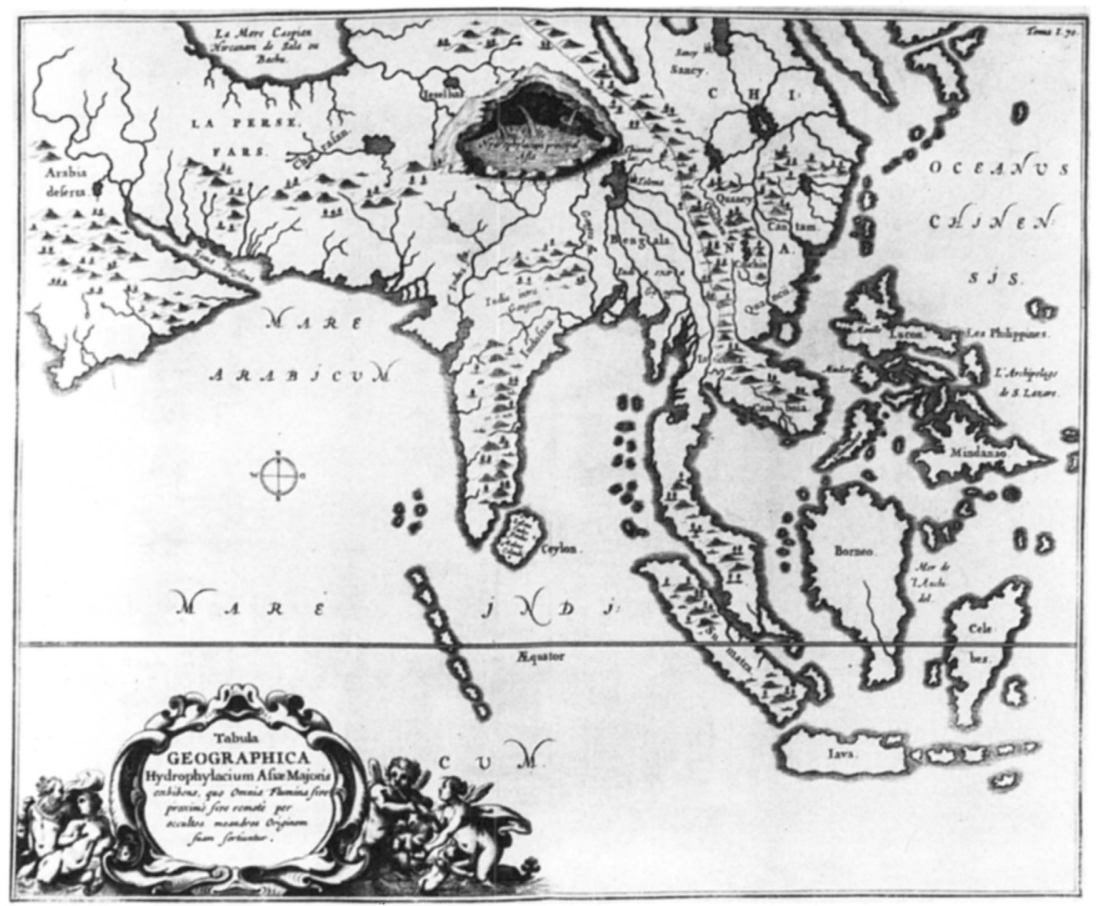

Fig. 5. Kircher, Mundus Subterraneus. Water storage system of central Asia with location of major rivers. Courtesy, Herzog August Bibliothek, Wolfenbüttel, Germany.

the base of these mountains, while the hydrophylacia are continuously being fed from the bottom of the nearby sea through channels or conduits represented in a dark shading (fig. 6). ${ }^{23}$ In numerous smaller drawings, Kircher illustrates physical experiments that show how heated water rises to the top of a vessel or how water may be sucked up to a higher level by means of a vacuum developed above it. The author also takes into account tidal forces, the power of the winds, and even the capillary action of liquids. All of them further help pump seawater drawn from the bottom of the oceans and heated along its subterranean passage past the earth's inner fires to the hydrophylacia near the mountain peaks. Seeing this diagram, one can well imagine the influence that Leonardo's or William Harvey's theories may have exerted on the Jesuit scholar.

Overall, Kircher does not consider evaporation a major contributing force to the natural circulation of the waters and in the maintenance of 


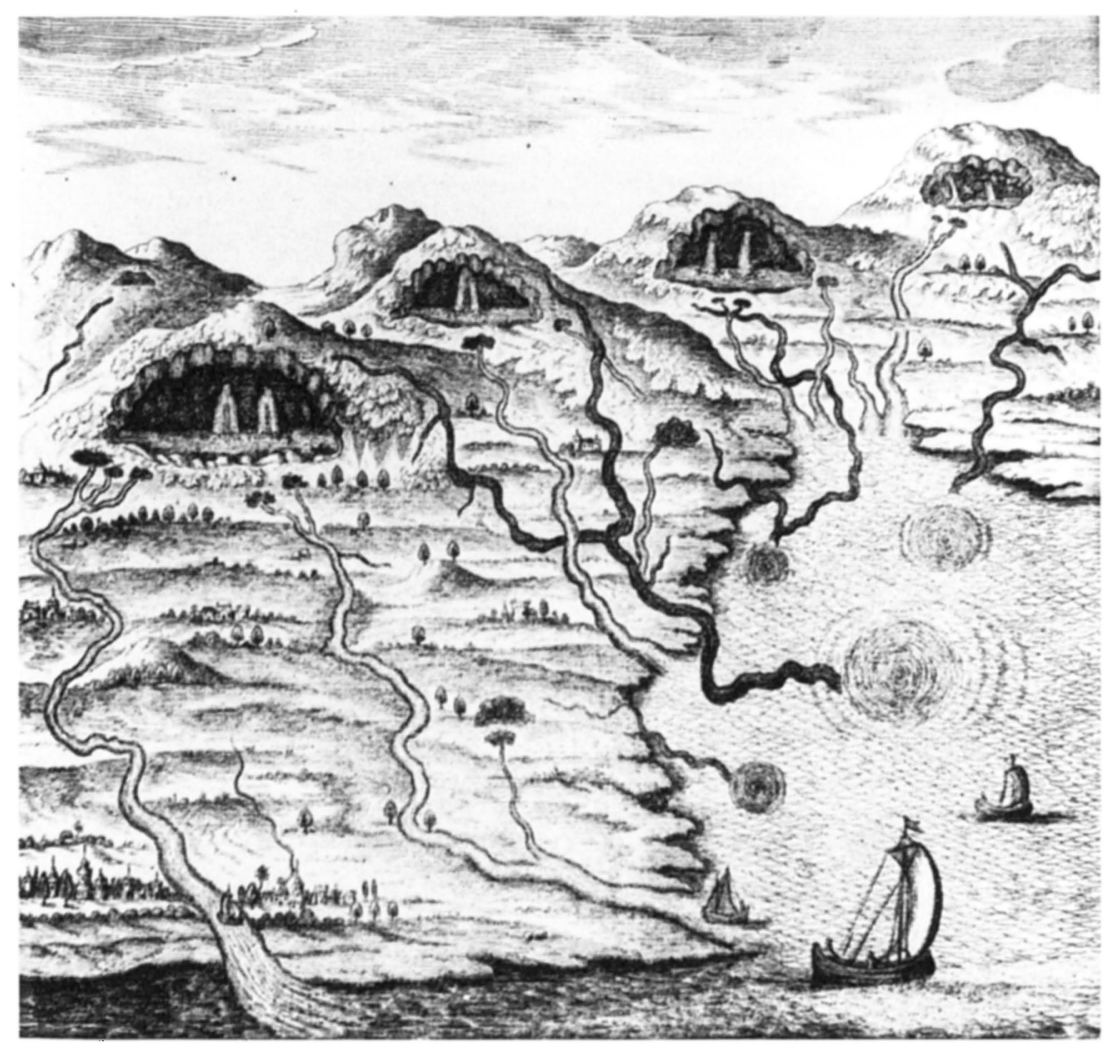

Fig. 6. Kircher, Mundus Subterraneus. Water circulation system with "storehouses" cut open, rivers (white), the sea, and underground return conduits (black) replenishing the storehouses. Courtesy, Herzog August Bibliothek, Wolfenbüttel, Germany.

a universal equilibrium. For this reason, he needs intake channels at the bottom of the oceans to prevent bodies of water like the Mediterranean from overflowing. He is the first to provide physical maps of the earth showing the oceans' surface currents, ${ }^{24}$ where he highlights the eastwesterly flow in the tropics and explains it with the great amount of evaporation in these latitudes. He correctly feels that this loss needs to be compensated with an influx of water from less sun-drenched areas. But-as happens so often with Kircher-he does not stop there and goes beyond credible maritime reports; apart from horizontal currents, he also hypothesizes a vertical movement of water from north to south. In the regions of the North Pole, a giant whirlpool is supposed to suck 
in the waters to an underground passage. On their unknown ways through the fissures and cavities of the earth's center, these masses are purified by the subterranean fires and are finally expelled at the South Pole, thus creating a northward current that-Kircher explains-makes any voyages toward the polar area virtually impossible. ${ }^{25}$

As is the case with the Jesuit's volcanological theories, his hypotheses of an immense subterranean network of channels regulating the flux and reflux of the earth's waters have to be considered within the framework of his philosophical and theological convictions. Both systems are intricately interwoven and contribute to Kircher's overall efforts to show how masterfully the Naturae Opifex has balanced the interplay of fire and water, which leads the Jesuit to restore the dignity of the lower world, an integral part of God's universe.

\section{Kircher's Notion of a contagium animatum in His Scrvtinivm ... Pestis}

Although the theory of an interconnection between geology and medicine goes back to the Middle Ages, serious discussions in the fields of cosmology, geology or hydrology, and medicine by one and the same author were rare in the seventeenth century. Kircher's Itinerarivm Exstaticum of 1656, the almost simultaneous preparation of part of the Mundus Subterraneus manuscript, or the 1657 Iter Extaticom [sic] II. would no longer be followed by a significant publication in the medical domain. As early as 1646, however, the German Jesuit had described his work with the newly invented microscopes in his Ars magna Lvcis et $V m b r{ }^{26}$ in a section entitled, "De mira rerum naturalium constitutione per Smicroscopium [sic] inuestiganda." Among the microscopes illustrated (fig. 7; A-B), we find the simple instrument that Kircher had been given in 1644 by Cardinal Carlo de' Medici. It may well have been made by the Florentine Evangelista Torricelli, the inventor of this type of microscope, who laid the foundation for Antoni van Leeuwenhoek's improved version of 1676 that truly opened up the new world of animalcula. ${ }^{27}$

The 1646 observations provide the starting point for any discussion of Kircher's theory of a contagium animatum. The scholar was fascinated by the new form of magic (he called it Magia Dioptrica) that enabled him to investigate the world of the microscosm. Very similar to his views of the subterranean universe expressed a decade later, the new instrument made him discover counterparts to the known macrocosm. ${ }^{28}$ Thus the Jesuit detected "fleas that looked like wingless locusts" and 


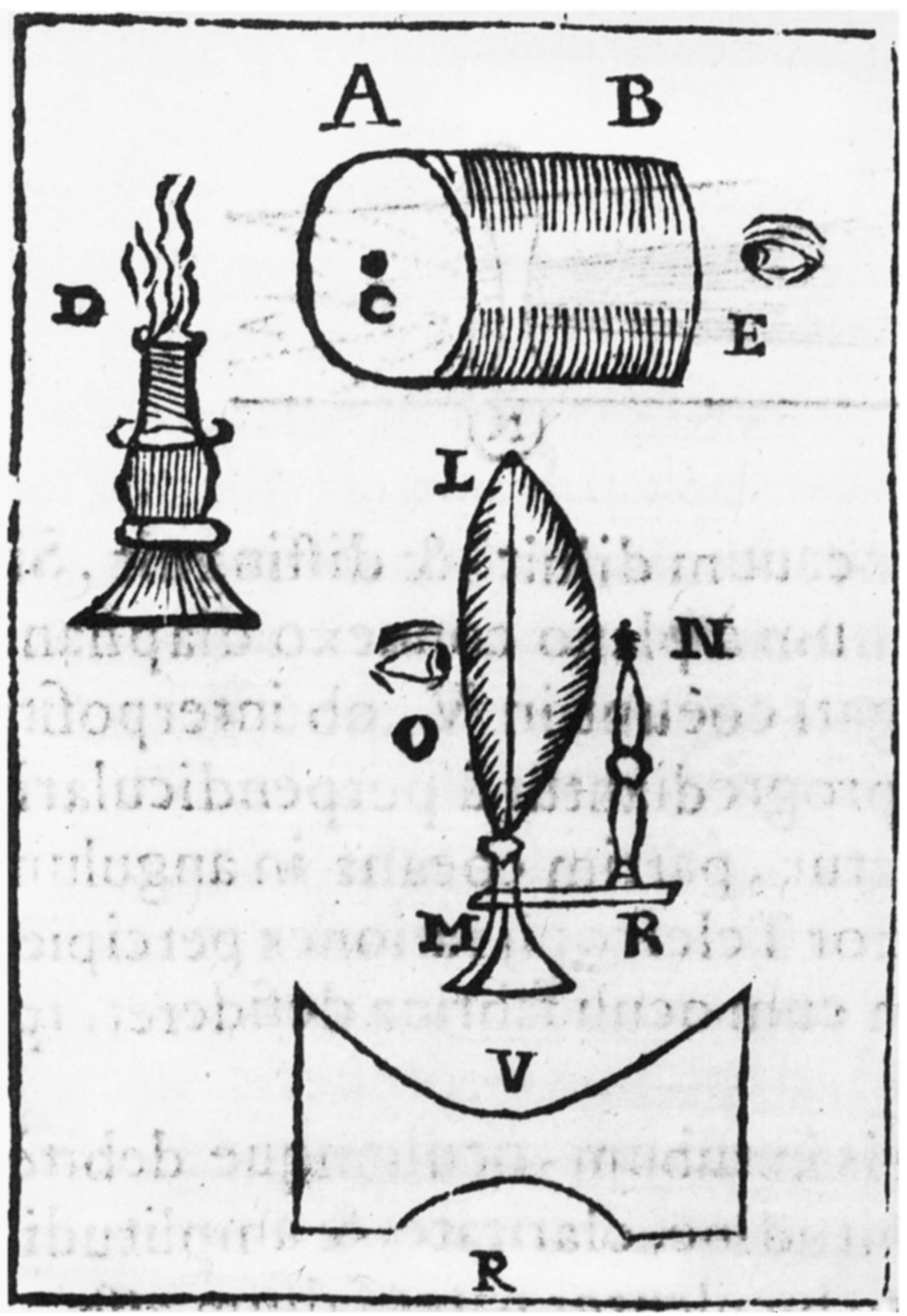

Fig. 7. Kircher, Ars magna Lvcis et Vmbræ. Early microscopes, among them $(A-B)$ the one given to Kircher in 1644 by Cardinal Carlo de' Medici. Courtesy, Herzog August Bibliothek, Wolfenbüttel, Germany. 
"mites that suggested hairy bears"; he found human hairs to be hollowed out with little canals and tubes-an optical illusion commonly noted by early users of microscopes, as Luigi Belloni points out. Belloni considers Kircher's observation even more problematic; it states that "vinegar and milk teem with innumerable quantities of worms" and questions why the Jesuit omitted to discuss "the wonders to be seen ... in the verminous blood of those sick with fever." 29

By 1646, to put this section in proper perspective, some of the phenomena that Kircher noted had already been described: as early as 1610, Galilei Galileo had identified limbs and eyes of insects; by 1628, William Harvey was demonstrating the pulsing hearts of wasps, hornets, flies, and lice; Nicolas Claude Fabri de Peiresc of Avignon, whom Kircher befriended a decade later, "had written to a correspondent in 1622 of the occhiale by means of which fleas were magnified to the size of wingless locusts, and cheese mites to the size of flies." ${ }^{30}$ Kircher's cryptic references to the "verminous blood of fever patients," though, and to the multitude of minute animals are different matters that may indeed point to the Jesuit's own medical discoveries. As these references cannot be elucidated from within the 1646 passage (which remained unchanged in the 1671 edition), only the Scrotiniom of 1658 may shed light on them.

Coming right after Kircher's work on the cosmos, which would resume in the 1660s, his book on the plague certainly was not planned. His English contemporary, Marchamont Nedham, conjectured why the Jesuit felt the need to embark on this medical project: "the occasion of Kircher's writing was the strange nature of the Pestilence which ... anno 1656 ... [raged at] Rome, the symptoms whereof were such as agreed not with the old Descriptions, and baffled all the old Antidotes and Cordials, and puzzled the Physicians in all their Consultations about the Causes and Cure of it." ${ }^{31}$ It should not surprise that the Jesuit scholar was given free access to the plague hospitals and was able to work with some of the most experienced Roman doctors.

Kircher dedicates the Scrotinivm to Pope Alexander VII and dutifully opens the first section of his treatise ("De origine, causis, \& effectibus Pestis") with a chapter on the plague as a scourge, or, as the 1680 German translation has it, "Daß die Pest ein Pfeil und Geisel GOttes [sic] seye zu Abstraffung der Sünden." 32 Very quickly, however, does he switch to the natural causes of pestilence. In chapter 3 the author lists the various modes by which the disease may be generated through putrefaction. Chapter 6 discusses dietary causes of the plague and remains very much on traditional ground. Without mentioning Girolamo Fracastoro (1484-1553) or his relevant work of 1546, De Contagionibus 
et Contagiosis Morbis et Eorum Curatione Libri III, Kircher increasingly dwells on the contagiousness of the plague, a theory for which he cites classical authors. ${ }^{33}$

In chapter 7, however, he goes one step further, as the German title indicates, "Daß auß der Verfaulung immerdar kleine und unsichtbare vergiffte Corpuscula in die umbligende und nächste Leiber außgeblasen werden / welche $A u ß=$ und Anblasungen der Samen der Pestilentz genennet wird." It is in this section that Kircher "makes his real contribution," Charles-Edward A. Winslow, a twentieth-century historian of ideas, felt. More recently, Antoinette Stettler, a Swiss medical historian, went so far as to posit: "Im Rahmen der Pestschriften des 17. Jahrhunderts war es tatsächlich ein Novum, daß er bei seiner Pestbetrachtung nun die größte Emphase eben auf die Vorstellung der Fäulnis und des Parasitenbefalls legte." 34

Kircher states his argument as follows: "Die Pestilentzische Dämpff auß den todten Leibern/ so an der Pest gestorben/ mehren die Pest und bringen sie weiter" and claims that the latent germs (seminaria) of plague internally promote putrefaction while externally causing corruption of the air. ${ }^{35}$ In his conclusion he reiterates the point: "Weilen aber dise Corpuscula gemeiniglich noch kein Leben haben/ wann doch darzu komt die äusserliche Hitz deß schon zuvor verderbten und angezündeten Luffts / so werden auß denen Corpu[s]culis unzahlbarlich vil unsichtbare Würmlein/ daß so vil zuvor Corpuscula gewesen/ so vil hernach Würm erwachsen; also daß man disen Außfluß der gifftigen Exhalation nicht mehr eine todte / sondern ein lebendige Effluenz nennen kann." Kircher feels that these ideas of actual living effluvia (animata effluuia) may sound strange and even inconceivable to the reader, but he notes they have been confirmed through years of "Experienzien ... durch die fürtreffliche Gläser/ so Microscopia genennet werden." And while the subsequent six experiments that he describes to buttress his argument certainly do not meet modern standards-and were the subject of criticism beginning with his younger contemporary, Francesco Redi ${ }^{36}$ - the fact remains that Kircher was the first to include such direct observations.

In the following chapters, the author elaborates on his theory ("Hæc verò effluuia animata esse ex insensibilibus animatis corpusculis constituta"), ${ }^{37}$ but he also discusses how the disease could be artificially created and reiterates the belief that Jews poisoned the wells in the Middle Ages or the idea that particular stellar conjunctions may cause the plague. The second section of the book deals with the nature of this disease and initially disproves the notion of Franciscus Mercurius van Helmont (and indirectly Theophrastus Paracelsus) that the plague 
could be caused by human imagination alone. Kircher postulates that "Der Samen der Pest muß alzeit vorherogehn" before the disease can erupt. ${ }^{38}$

Chapter 4, the longest and most important one of the second part, is devoted to the various ways in which the contagion is spread, namely by direct contact, transmission through the airways, or fomites, that is linen, clothing, shoes, and other such items. Restating his earlier position, the author reiterates: "Jch hab oben gelehret/ daß die Pest gemeiniglich lebendig seye / dann der Krancke ... überaus tauglich ist/ Würm herfür zu bringen. Dise Würmlein aber / durch welche die Pest fortgeführt und erweittert wird/ seyn so klein und subtil/ daß sie mit dem freyen Aug nicht köndten gesehen werden / und allein von einem fürtrefflichen Microscopio . . können beobachtet werden." 39

Kircher describes how these little worms spread like specks of dust and find their way into the deepest pores of some other party. Then follows the second reference to the putrid blood of fever patients in which the Jesuit scholar in his own, compromising stance combines modern technology with biblical tradition: he learned from the "faule Blut deren / so das Fieber haben / welches ich ein oder zwey Stund nach der Aderlaß / so voll der Würmen gefunden hab / daß ich darüber schier erstaunet bin/ und von der Zeit an erfahren hab/ daß der Mensch nicht nur todt/ sonder[n] auch lebendig voll der unzahlbaren unsichtbaren Würmen seye/ daß daher sich wol reimet/ was Job gesagt. $P u$ tredini dixi pater meus es, Mater mea \& Sóror mea vermibus." The author claims that all this was also observed by a Roman physican, Julius Placentibus, during the dissection of buboes, which the latter undertook at his request. And while much of what he is saying may seem beyond belief to many medical men, Kircher-showing strong faith in the evolution of science-proposes that "many things lie hidden in Nature . . which the acumen of our time has disclosed through the help of the eye armed [with the microscope] and, as the saying goes, has demonstrated ad oculum." 40

The rest of this chapter contains a detailed discussion of twelve different modes of infection and includes some sound ideas among a farrago of theories. After having elaborated on the first two ways mentioned earlier, namely by direct contact and fomites, Kircher suggests that domestic animals and also flies could act as passive carriers: "So gar die Muggen/ so bey den Pest=Krancken umfliegen/ sie berühren/ oder auf die verstorbene Cörpel [sic] sitzen/ und dero Safft saugen/so bald sie in andere Häuser fliegen / . . . haben die Pest und Contagion. verursachet, wie Mercurialis bezeuget." 41 There are other means that sound plausible, such as transmission by plague physicians or through 
the air to a distance of not more than five or six feet, but there are also spurious modes of infection that are frequently based on tradition and hearsay, such as sight, sound, and smell or substances like wine, oil, butter, and metals of all sorts.

These theories are the main points of the first two sections of the Scrotiniom (the third one deals with prophylaxis and has no bearing on this discussion). In recent years, the assessment of Kircher's contribution to medical science seems to have hinged on his ability to have actually seen the corpuscles or "worms" that he is so vividly describing. There is no doubt that the power of his simple microscope would have never reached a magnification required for the discovery of anything like the plague bacterium. Although the author does refer to compound microscopes in his Ars Magna Lvcis \& Vmbræ, the only illustration of them is found in Filippo Buonanni's Musæum Kircherianum of $1709^{42}$ - without any assurance, though, that Kircher had actually used it in the 1650s. In a recent article based on his earlier experiments, Luigi Belloni ${ }^{43}$ wondered what the seventeenth-century scholar would have seen had he indeed used compound microscopes without achromatic lenses of the type reproduced by Buonanni. With the help of several historical microscopes, Belloni proved that-regardless of the object examined or the length of exposure-the resulting image resembled a jumble of tissue that indeed looked as if it were teeming with little worms (figs. 8 and 9). Belloni's conclusion-to an extent anticipating Thomas Leinkauf's ideas-deserves to be quoted in full: "Meines Erachtens darf sich die Historiographie nicht damit begnügen, den früheren Gelehrten diesen oder jenen Fehler, diese oder jene Fälschung vorzuwerfen. Sie muß vielmehr versuchen, deren Ursprung zu verstehen, und zwar nicht nur durch Erforschung der damaligen Denkweise, sondern auch durch die Nachprüfung mit Hilfe von Instrumenten jener Zeit."

Despite Kircher's credulity and superstition as displayed in the Scrvtinivm, among other works, the German Jesuit deserves credit for being the first to present effectively the theory that living organisms were the primary cause of disease. "It does not matter much what Kircher saw; it was sufficient that he saw organisms below the threshold of unaided vision, and made the inference of still more minute manifestations of life beyond what he saw," an objective reviewer of Kircher's medical work noted in the 1940s. ${ }^{44}$ Antoinette Stettler goes even further and claims that there was no conceptual but only a technical development between Kircher's intuition and Alexandre Yersin's discovery of the plague bacterium-although this accomplishment took two hundred years. ${ }^{45}$ 


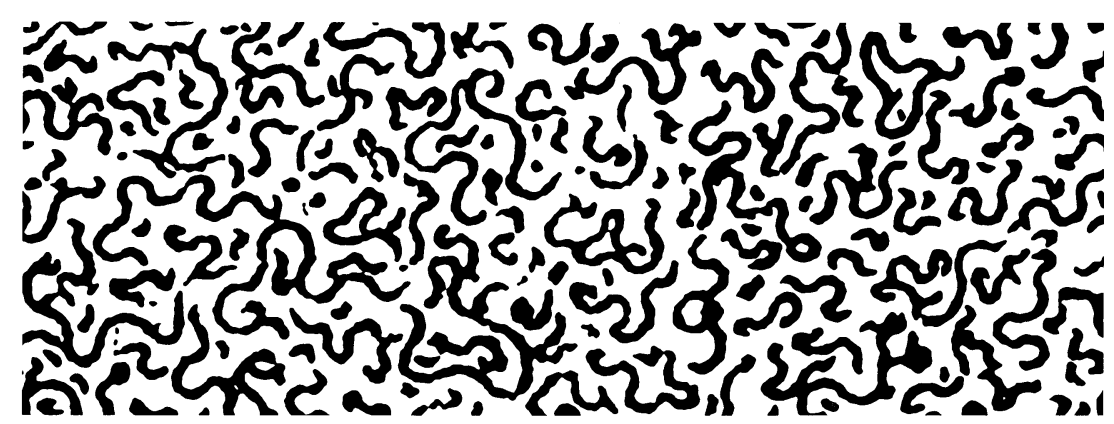

Fig. 8. Thomas Willis, Pharmaceutice rationalis (1674). Illustrations of a tissue sample resembling a mass of little worms. Courtesy, Signora Maria Pia Belloni and Medizinhistorisches Journal.

Kircher's emphasis of the role of insects in the spread of contagious diseases, an idea he received from Girolamo Mercuriali, also put him on the forefront of medical research of his period. ${ }^{46}$ Nonetheless, "the major defect in his epidemiological theory," Charles-Edward A. Winslow stated in his overall assessment, "was his dominant (though not consistent) conception that the living germs of disease were spontaneously generated by the decomposition of organic matter." This misconception, as we have seen, was corrected by Francesco Redi and his theory of biogenesis only a decade after the publication of the Scrotinivm.

\section{Conclusion}

In light of the recent reassessments of Kircher's Mundus Subterraneus and Scrotinivm ... Pestis that have guided this discussion, the contrast between science and pseudoscience that served as a starting point of this analysis may no longer appear so striking. Both works show the Jesuit's concern with worlds that lay beyond the concept of human penetration, be it the subterranean universe that Kircher's interest in the "inner world" raised to the level of the highest hierarchical order, be it the microcosmic dimension beyond man's unaided vision. Both works show his reconciliation-however temporary-of scholarly interests, influenced by the New Science of his times, and theology, which would not allow him to undercut the God-given ordo rerum. The recent, succinct evaluation of Kircher's importance within the Jesuit community by the French historian Jean Lacouture may close this analysis: "En 


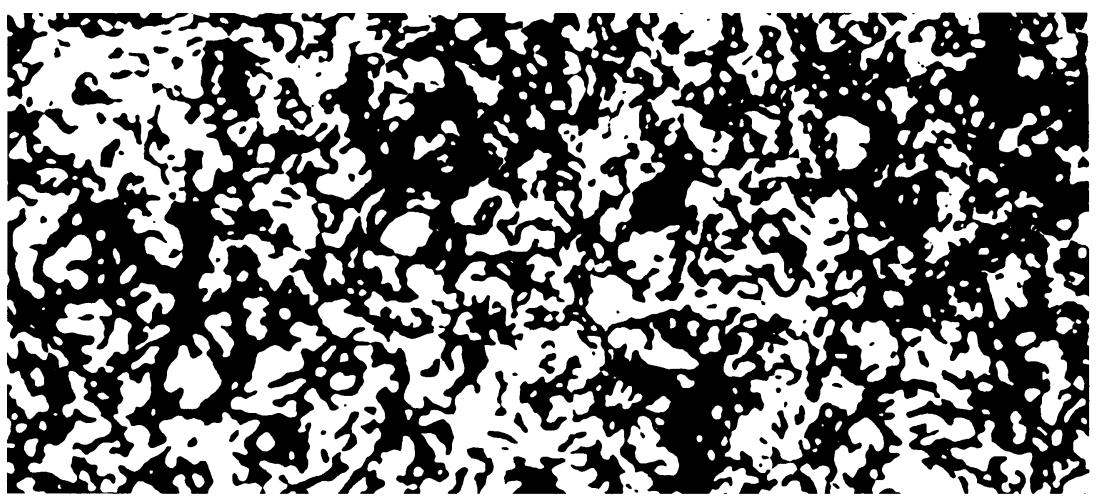

Fig. 9. Twentieth-century recreation of the previous image using eighteenthcentury historical microscopes. Courtesy, Signora Maria Pia Belloni and Medizinhistorisches Journal.

Athanasius Kircher le polymathe se manifeste ... cet esprit de connaissance et d'entreprise, de confiance en l'homme et d'espérance commune par la convergence, qui fait la grandeur de cette cathédrale des ambiguïtés-la Compagnie de Jésus." ${ }^{47}$ This "convergence" of knowledge may well have been Kircher's most important contribution to the greatness-albeit ephemeral-of the Society of Jesus.

\section{Notes}

Some material from this chapter appeared in my article "Ein Polyhistor als Pathologe: Athanasius Kirchers Durchgründung der laidigen ansteckenden ... Pestilenz," in Ars medica: Verlorene Einheit der Medizin, ed. Peter Kröner, Thomas Rütten, Karin Weisemann, and Urban Wiesing (Stuttgart: Gustav Fischer Verlag, 1995), pp. 55-64.

1. "Athanasius Kircher im Spiegel der Sekundärliteratur," in Universale Bildung im Barock: Der Gelehrte Athanasius Kircher, ed. Reinhard Dieterle et al., Ausstellungskatalog der Stadt Rastatt (Rastatt: Stadt Rastatt, 1981), pp. 45-50.

2. See John Fletcher, "Athanasius Kircher und die deutsche Literatur," in Universale Bildung, pp. 31-39.

3. Mundus Subterraneus, In XII. Libros digestus . . , 2 vols. (Amsterdam: Jansson \& Weyerstraet, 1664-65).

4. Scrotinivm Physico-Medicum Contagiosæ Luis, quæ dicitur Pestis (Rome: Mascardi, 1658); German translation: Natürliche und Medicinalische Durchgründung der laidingen ansteckenden Sucht/ und so genanten Pestilentz (Augsburg: Brandan, 1680).

5. Vita Admodum Reverendi P. Athanasii Kircheri Societ. Jesu, ed. Hieronymus Langenmantel (Augsburg, 1684; reprint, n.p., 1931). German translation by 
Nikolaus Seng, Selbstbiographie des P. Athanasius Kircher aus der Gesellschaft Jesu (Fulda: Actiendruckerei, 1901); reference to the earthquake and volcanic eruptions on pp. 41-48. Narration of the event in Mundus Subterraneus, "Praefatio," fol. 1r-6v. For the following see also Gerhard F. Strasser, "Spectaculum Vesuvii: Zu zwei neuentdeckten Handschriften von Athanasius Kircher mit seinen Illustrationsvorlagen," in Theatrum Europaeum: Festschrift für Elida Maria Szarota, ed. Richard Brinkmann, Karl-Heinz Habersetzer, Paul Raabe, Karl-Ludwig Selig, and Blake Lee Spahr (Munich: Fink, 1982), pp. 363-84, here pp. 365-68.

6. Robert Lenoble, La Géologie au milieu du XVIIe siècle, Les Conférences du Palais de la Découverte, Série D, No. 27 (Paris: Université, 1954), pp. 21-30. The reference is vague and cannot be confirmed.

7. Mundus Subterraneus, 1, following p. 186.

8. "Mundus subterraneus quo Universae Naturae divitiae et occulta miracula reuelata ... in decem libros digestum," Biblioteca Nazionale Centrale Vittorio Emmanuele II, Rome, Fondo Gesuitico 562, 170 pages. Schor's composition is on fol. $164 \mathrm{v}$. For a detailed analysis of this manuscript see Strasser, "Spectaculum Vesuvii: Zu zwei neuentdeckten Handschriften von Athanasius Kircher mit seinen Illustrationsvorlagen," especially pp. 363-64 and 373-78.

9. Rome: Mascardi, 1656; second edition with important explanations and theological safeguards by Kircher's disciple, Kaspar Schott, S.J.: Würzburg and Nuremberg: Endter, 1660; a reissue: Würzburg: Endter, 1671. The second part appeared only once: Rome: Mascardi, 1657. See Thomas Leinkauf: Mundus combinatus. Studien zur Struktur der barocken Universalwissenschaft am Beispiel Athanasius Kirchers SJ (1602-1680) (Berlin: Akademie Verlag, 1993), pp. 29-34. On Tycho Brahe's "compromise" system and the Jesuits' willing espousal of these ideas, see Robert J. W. Evans, The Making of the Habsburg Monarchy, 15501700: An Interpretation (Oxford: Clarendon Press, 1979), pp. 332-40.

10. As early as 1636, Kircher had published a Prodromvs Coptvs sive Ægyptiacvs (Rome: Congr. de propaganda Fide), which ultimately prepared his publications in the field of Egyptology.

11. Karl Sapper, "Athanasius Kircher als Geograph," in Aus der Vergangenheit der Universität Würzburg, ed. Max Buchner (Berlin: Springer, 1932), pp. 355-62, here pp. 360-61; Christoph Krüger et al., eds., Vulkane (Vienna and Munich: Schroll, 1970), p. 20; Maurice Krafft, Vulkane, Feuer der Erde: Die Geschichte der Vulkanologie, trans. Jörg Keller (Ravensburg: Maier, 1993), pp. 46-47. Illustration in Mundus Subterraneus, 1, following p. 180.

12. This "chimney" theory enabled Kircher to consider "chimney sweeping activities" as a means of preventing future eruptions. See Krafft, Vulkane, p. 46.

13. Karl Sapper, "Athanasius Kircher als Geograph," himself one of the century's important volcanologists, refers to Alphons Stübel, a volcanologist at the turn of the century, and his theory of peripheral centers as expressed in his report: Ein Wort über den Sitz der vulkanischen Kräfte in der Gegenwart, Mittheilungen aus dem Museum für Völkerkunde zu Leipzig, Abth. für Länderkunde (Leipzig: M. Weg, 1901). 
14. Mundus Subterraneus, 1, pp. 168-69. For the following cf. Leinkauf, Mundus combinatus, pp. 221-31.

15. Mundus Subterraneus, 1, 6r; elaboration on pp. 111, 175, 182, 192-93. Opening section of book 1 on pp. 1-14. See Leinkauf, Mundus combinatus, pp. 221-22.

16. See Leinkauf, Mundus combinatus, pp. 229-31 (quotation on p. 231), and also his earlier article: "Die Centrosophia des Athanasius Kircher SJ: Geometrisches Paradigma und geozentrisches Interesse," Berichte zur Wissenschaftsgeschichte 14 (1991): 217-29.

17. "The Underground World of Kircher and Becher," in A History of Magic and Experimental Science. Vols. VII and VIII: The Seventeenth Century (New York: Columbia University Press, 1958), 7:567-89; quotation on p. 577.

18. For the following see Helmut Hölder, Geologie und Paläontologie in Texten und ihrer Geschichte, Orbis Academicus, 2.11 (Freiburg: Alber, 1960), pp. 27477. Cf. Sapper, “Athanasius Kircher als Geograph,” pp. 356-57.

19. Mundus Subterraneus, 2, 374.

20. Mundus Subterraneus, 1, 226: "Omnia flumina intrant in mare, \& mare non redundat, ad locum, unde exeunt flumina revertuntur, ut iterum fluant." English version taken from The Holy Bible, revised standard version (New York: Collins, 1971), p. 587.

21. Hölder, Geologie und Paläontologie, and Sapper, "Athanasius Kircher als Geograph," list Bernard Palissy, Discours admirables de la nature des eaux et fontaines (Paris: Martin le jeune, 1580), where this idea is touched upon, and in particular the empirical calculations of Pierre Perrault, De l'origine des fontaines (Paris: Le Petit, 1674), along with the Burgundian prior Edme Mariotte's Traité du mouvement des eaux et des autres corps fluides (Paris: E. Michallet, 1686) as important sources that refuted Kircher's theory of the circulation of water by the time or soon after the revised edition of Mundus Subterraneus appeared in 1678. Kircher's discussion of the inadequacy of water supplies through precipitation appears in 1, 233-34.

22. Mundus Subterraneus, 1, following p. 70.

23. Mundus Subterraneus, 1, 233; detailed illustration of a single hydrophylacium on the following page. See also Frank Dawson, The Birth and Development of the Geological Sciences (Baltimore: Williams and Wilkins, 1938), pp. $432-39$, here p. 433.

24. Mundus Subterraneus, 1, 134. For the following see Sapper, "Athanasius Kircher als Geograph," pp. 358-59.

25. Mundus Subterraneus, 1, 160, 124, 144, and subsequent illustrations. Kircher claims that this north-south seawater circulation system also accounts for the extreme difficulties sailing vessels were having in reaching greater southern latitudes.

26. Rome: Scheus; discussion about microscopes on pp. 834-35. Second ed. Amsterdam: Jansson, 1671, with this section and illustration unchanged (pp. 727-31; incorrect pagination, pp. 728-29 omitted).

27. See Luigi Belloni, "Athanasius Kircher: Seine Mikroskopie, die Animalcula und die Pestwürmer," Medizinhistorisches Journal 20 (1985): 58-65, and his 
earlier article, "Appunti per una storia pre-Leeuwenhoekiana degli 'animalcula,'" Gesnerus 23 (1966): 13-22.

28. For the importance of magic in this period, cf. Keith Thomas, Religion and the Decline of Magic: Studies in Popular Beliefs in Sixteenth- and SeventeenthCentury England (London: Weidenfeld and Nicolson, 1971), pp. 107-27. For the following see Harry Beal Torrey, "Athanasius Kircher and the Progress of Medicine," Osiris 5 (1938): 246-75 (some of the translations are taken from pp. 253-54), and Belloni, "Athanạsius Kircher: Seine Mikroskopie, die Animalcula und die Pestwürmer," pp. 60-61.

29. "Omitto hìc quàm multa ... de sanguine febrientium verminoso," Ars magna Lvcis et Vmbræ, p. 834. For the following overview, see Torrey, "Athanasius Kircher and the Progress of Medicine," pp. 251-54.

30. Charles Singer, "The Dawn of Microscopical Discovery," Journal of the Royal Microscopical Society (1915): 317, quoted by Torrey, “Athanasius Kircher and the Progress of Medicine," p. 254.

31. Marchamont Nedham, Medela medicina: A Plea for the Free Profession and a Renovation of the Art of Physick (London: R. Lownds, 1665), p. 179, quoted in John E. Fletcher, "Medical Men and Medicine in the Correspondence of Athanasius Kircher (1602-1680)," Janus 56 (1969): 259-77, here p. 260.

32. Durchgründung der... Pestilentz, p. 1. Natural causes, p. 4. A few English summaries of the Scrotinivm exist. The most detailed is given in CharlesEdward A. Winslow, The Conquest of Epidemic Disease: A Chapter in the History of Ideas (Princeton, 1943; reprint, New York: Hafner, 1967), chap. 8, “The Conception of A Contagium Animatum," pp. 144-60, in particular pp. 146-52. An article by Ralph H. Major is helpful: "Athanasius Kircher," Annals of Medical History, 3d ser., 1 (1939): 105-20, especially pp. 117-19.

33. See also Fabio Troncarelli, "La paura dell'Idra. Kircher e la peste di Roma," in Enciclopedismo in Roma Barocca: Athansius Kircher e il Museo del Collegio Romano tra Wunderkammer e museo scientifico, ed. Maristella Casciato, Maria Grazia Ianniello, and Maria Vitale (Venice: Marsilio, 1986), pp. 139-50, here p. 141.

34. Winslow, The Conquest of Epidemic Disease, pp. 146-47. Antoinette Stettler, "Der ärztliche Pestbegriff in historischer Sicht," Gesnerus 36 (1979): 127-39, here pp. 135-36.

35. This and the following quotations are taken from Scrotinivm PhysicoMedicom, pp. 37-38; Durchgründung der . . Pestilentz, pp. 45-46. Cf. E. Scharitzer, "Athanasius Kircher und die Lehre vom 'Contagium animatum,'” Münchner Medizinische Wochenschrift 41 (1961): 1989-91.

36. In his highly critical article, Torrey, "Athanasius Kircher and the Progress of Medicine," here pp. 256-60, provided a summarizing translation of Kircher's six experiments and contrasted them with the methods put forth in Redi's publication. In Esperienze Intorno alla Generazione degl' Insetti (Florence, 1668), Redi disproved the theory of spontaneous generation of insects.

37. Scrotinivm Physico-Medicum, p. 51; Durchgründung der . . Pestilentz, p. 61. "Daß aber dise Corpuscula lebendig seyndt." Poisoning of wells: Scrvtinivm 
Physico-Medicvm, pp. 69-70; Durchgründung der . . Pestilentz, p. 80. Chapter 11 deals with the "Krafft der Sternen."

38. Durchgründung der ... Pestilentz, pp. 136-37; Scrotinivm Physico-Medicvm, pp. 114-16. On Paracelsus's and van Helmont's theories of disease see Margaret Pelling, "Contagion / Germ Theory / Specificity," in Companion Encyclopedia of the History of Medicine, ed. William Frederick Bynum and Roy Porter, 2 vols. (London: Routledge, 1993), 1:309-34, here p. 319.

39. Durchgründung der ... Pestilentz, p. 169; Scrvtinivm Physico-Medicvm, p. 141.

40. Winslow, The Conquest of Epidemic Disease, p. 149; Scrotinivm PhysicoMedicvm, p. 142, Durchgründung der . . Pestilentz, pp. 170-71. Twelve modes of infection: Scrvtinivm Physico-Medicvm, pp. 142-64, Durchgründung der . . . Pestilentz, pp. 171-99.

41. The reference is to Hieronymus Mercurialis, De Peste in Universum, praesertim vero de Veneta et Patavina (Basel, 1577).

42. Rome: Geogius Plachus, 1709. Illustration of compound microscope reproduced in Major, "Athanasius Kircher," p. 119. Cf. Major's discussion on pp. 118-20 along with that of Winslow, The Conquest of Epidemic Disease, pp. 150-55. Torrey, "Athanasius Kircher and the Progress of Medicine," pp. 270-71, reaches the opposite conclusions.

43. "Athanasius Kircher: Seine Mikroskopie, die Animalcula und die Pestwürmer," illustrations on pp. 63 and 64, extended quotation on p. 65; and Belloni, “Micrografia illusoria e 'Animalcula,'” Physis 4 (1962): 65-73, with earlier versions of these illustrations on pp. 66-67.

44. G. L. Hendrickson, quoted by Winslow, The Conquest of Epidemic Disease, pp. 151-52; my emphasis.

45. Stettler, "Der ärztliche Pestbegriff in historischer Sicht," pp. 135-36.

46. Major, "Athanasius Kircher," p. 119. The closing argument is Winslow's, The Conquest of Epidemic Disease, pp. 150-51.

47. Jésuites: Une multibiographie, 2 vols., vol. 2: Les revenants (Paris: Éditions du Seuil, 1991-92), pp. 266-68. 


\section{Part IV. Science and the Body}





\title{
11. Carnal Knowledge: Writing about Sex in Early Modern Germany
}

\author{
James A. Parente, Jr.
}

Literary and cultural studies of early modern Europe are in the midst of a sexual revolution. Topics that previously were deemed indecorous for civilized discourse, such as the body, lust, desire, rape, homosexuality, prostitution, and pornography are now examined with an astonishing frequency and a disarming frankness. Inspired by the theoretical work of Michel Foucault on the history of sexuality and Norbert Elias on the civilizing process, feminist scholarship on sex and gender, and historians of the body such as Thomas Laqueur, early modernists, chiefly in Anglo-Italian Renaissance studies, are rereading canonical texts, and even the idea of the Renaissance itself, in startlingly original and unorthodox ways. Feminist art historians are uncovering the erotic subtext of biblical canvases, Italianists revel in the exploration of the culture of illicit sexuality, both in literature and society, and an ever increasing number of English early modernists are reexamining contemporary notions of gender, sexuality, love, and marriage. ${ }^{1}$

The majority of this research on sex has been undertaken by social historians, such as Lawrence Stone for England and Guido Ruggiero for Italy, or historians of women, most recently Merry Wiesner for early modern Germany, all of whom harbor a historian's instinctual reservation about literary works as sources and a healthy suspicion of arguments devised by literary scholars. ${ }^{2}$ Such an emphasis is not surprising, for the social construction of gender and sexual mores has been part of the movement toward the history of everyday life, and, by extension, the history of sexuality since the late 1970s. What is new, however, since the mid-1980s, is the rediscovery of history, or materialist culture, by literary scholars, the so-called new historicists, and the importation of the topics of the recent social history into literary study. ${ }^{3}$

The research of this new but often uneasy alliance between social historians and literary scholars of sexuality encompasses a broad range of topics, many of which had been accepted as unchanging cultural phenomena. Central to this revival of interest is the recognition of the historical and cultural contingency of hitherto unchallenged notions of 
the body and sexual mores. To demonstrate this argument, social scientists focus on the social construction of gender (male, female), love, sexual behavior, and sexual rituals such as courtship, marriage, and divorce ${ }^{4}$ Feminist scholars extend this investigation of marital customs into the birthing room to reveal the social origins of birthing practices, the problematic role ascribed to midwives, and the cultural determinants of medical protocol. ${ }^{5}$ And historians of sexuality examine the discrepancy between theological and legal prescriptions and actual sexual practice: because of their efforts we are better informed about bedroom behavior; techniques of sexual arousal and satisfaction; sexual violence, especially rape; prostitution; and definitions of virginity. ${ }^{6}$ Literary historians have built on these findings to explore the representations of love, both homosexual and heterosexual, sexual (mis)conduct, erotic desire, and the composition and style of sexual handbooks and pornography. ${ }^{7}$ In short, Renaissance scholars have never been better informed about a topic that, until very recently, they thought they knew so much. Nor have they ever been more acutely aware of the vast amount of research that remains to be done.

Early modern Germanists remain, for the most part, nonplussed by these developments. Such placidity, though certainly disturbing, is not surprising, for Germanists, especially early modernists, have traditionally remained isolated from literary-critical trends in other fields. Because of the inaccessibility of many sixteenth- and seventeenth-century texts and the staggering amount of unmined material about the early modern Holy Roman Empire, Germanists have been constrained to occupy themselves with many necessary, but mundane, tasks. Despite significant advances in the past twenty-five years, the cataloging and editing of primary works, and the composition of bibliographic reference tools, remain essential prerequisites to any literary-historical or cultural-historical analysis. Only rarely can early modern Germanists peer beyond the library walls to absorb the developments in other seemingly grander and more mature national literatures, and wonder about the applicability and utility of those methods for their own research.

The following remarks are intended to demonstrate the advantages to be gained for Germanists from the recent writing about sex in the early modern period. This topic has recently been introduced to early modern studies by Germanists on both sides of the Atlantic: feminist scholars such as Ingrid Bennewitz, Lynne Tatlock, and Linda Feldman have enhanced our knowledge about gender in early modern prose; ${ }^{8}$ David Price has revealed an ideology of violence toward women in Protestant drama and humanist lyric; ${ }^{9}$ Michael Schröter has provided a 
cultural analysis of wedding-night rituals; ${ }^{10}$ and Sigrid Brauner, Jonathan Clark, and Helmut Brackert have provided much data about sexuality and witchcraft. ${ }^{11}$ But I should like to push this investigation further in two related directions. First, I shall argue that our knowledge of early modern German literature has been based on an innate indifference toward sexual matters. The canon of great works established for this period, and the terms devised to discuss it, betray a reluctance to valorize texts or parts of texts that deal frankly with sex. Furthermore our displeasure with such texts has been inscribed into the aesthetic value system at the root of the early modern canon. The result of our repression of sexually disturbing content has been the creation of a conservative, untroubled, and unabashedly Christian-moralistic view of early modern literature in which acts of transgression, deviancy, or subversion have been either contained or extirpated. Second, in order to demonstrate that early modern texts are rarely so tidy and unambiguously transparent, I shall demonstrate the complex, if not contradictory, representation of sexuality in an unexpected place, humanist religious drama, a place where I refused to acknowledge it before, and propose a series of explanations for its paradoxical appearance there.

The first obstacle inhibiting the acknowledgment of sex in standard literary-historical characterizations of the early modern era is the Germanists' clear preference for high culture. Generally, canonical status is ascribed to works representative of elite (i.e., learned, bookish) culture, where sexual content has often been neutralized by the purported moralistic agenda of a text. In contrast, writing emanating from the low, popular strata of society or, to speak with Bakhtin, from the visceral, transgressive realm (lower body stratum) became the location where sexual matters were freely discussed, indeed, sex was accorded, by definition, a large space..$^{12}$ To be sure, this division into high and low realms was based on the tacit assumption that the Germanist knew in which camp his (rarely her) sympathies should lie. The transgressive disorder of low culture as evidenced by late medieval Fastnachtspiele and sixteenth-century Schwänke with their inversion of established social and marital roles for husband and wife could be forborne as long as the chaos was an artifice legally condoned and socially regulated by the local authorities. High culture's apparent control of the texts of low culture merely reconfirmed the authorities' status and power, and by extension the repression of sexual instinct. ${ }^{13}$

The marginalization and, at times, denigration of low culture was fostered by the perennially troubling question about whether the Holy Roman Empire experienced a Renaissance. For Germanists-and, indeed, despite recent disclaimers, for many early modernists - the word 
"Renaissance" has been understood as a heuristic term used to describe the revolutionary achievements by representatives of high culture, generally humanist-trained scholars, poets, painters, and musicians. In German literary history, despite recent attempts to rehabilitate the literature of the sixteenth century, the argument still prevails that the religious controversies of that period, especially its latter half (i.e., after the death of Luther in 1546), deadened the brief flowering of humanist culture around 1500 with its concomitant idealization of the beautiful and aggressive attempt to establish the ancients as literary models. Instead, so generations of literary historians have mournfully observed, just when humanist Latin writing was successfully transformed into the vernacular (Ulrich von Hutten is proposed here as cultural hero), German writing was appropriated by religious reformers and reduced to a didactic, rather than aesthetic, medium. ${ }^{14}$ There were, of course, exceptions to this tendency toward excessive moralization and tedium (e.g., Paul Rebhun's Susanna), but such appearances of German elegantia were rare, even within Rebhun's own writings.

What lies at the root of the Renaissance question, and the Germanist fervor for high culture, however, is the latent inferiority complex of German literary historians about their past. Among early modern literary scholars, Germanists are arguably the most easily embarrassed. Shunned by their fellow Renaissance researchers, especially in North America, who wisely devoted their energies to English and Romance literatures, Germanists have been shamed into admitting that their Renaissance, if it occurred, was at best postponed. But even then, at the beginning of the seventeenth century (during the so-called Opitzian revival), Germanists find little relief for their anxiety. When they peer beyond the boundaries of the empire toward other European literatures, they see the heyday of Shakespearean and Jacobean culture in England, the glorious beginnings of French neoclassicism in Paris, the triumph of Tasso, Guarini, and Marino in Italy, and the climax of the Spanish and Dutch Golden Age. In all literary genres, the Germans finally appear to be coming of age as much as a century after the Renaissance is alleged to have begun.

This problem involving the Renaissance and high culture is, as early modernists well know, a problem in perspective. If we recast the problem in sociological terms, what we will actually perceive is the privileging of humanist Gelehrtenkultur over literary works composed by the nonhumanist-trained writers, most of whom belonged to the lowermiddle or artisan class. The fact that many women writers did not have this humanist background (though there are exceptions) ensured, until recently, their lowly existence, if not exclusion, from the literary 
canon. ${ }^{15}$ Ironically, many German humanists had had humble social origins-Petrus Luder, Conrad Celtes, Johannes Reuchlin-but their cultivation of the educational ideal of the good and well-spoken man (vir bonus et peritus) and, most important, their study and imitation of the writers of Greco-Roman antiquity ensured them, so they believed, a social place high above the rabble of nonhumanists. ${ }^{16}$ In other words, knowledge of antiquity, the imitation of the ancients, and the pursuit of classical elegantia, be it in Latin or the vernacular, became the prerequisites for membership in the pantheon of memorable German Renaissance writers.

Since the early days of the discipline, Germanists have derived methodological support from classical philology. ${ }^{17}$ Many nineteenthcentury Germanists such as Johannes Bolte and Wilhelm Scherer and, more recently, Wilfried Barner were initially trained as classicists, and imported the techniques and aesthetic values of that discipline into the field. It is not surprising, therefore, that these scholars and their students would favor early modern humanist writing over other forms of literary expression. Other early modern writers who did not frequent humanist schools, but whose work betrays an extraordinary command of ancient and modern learning, such as Jörg Wickram and H. J. C. Grimmelshausen, are permitted into this privileged canonical group. And a similar elevation is accorded writers such as Johann Fischart, who, though a student of Johannes Sturm's humanist gymnasium, cultivated an inimitable style in his Geschichtsklitterung and other satirical works. The fact that the works produced by these writers dealt often with sexual matters-the humanists produced an extraordinary corpus of erotic verse that at times borders on the pornographic - is passed over quickly so that their literary-historical functions as symbols of the, albeit late, German Renaissance will become more apparent. In other words, the establishment of the early modern canon depended very much on the containment of any elements that prevented an appreciation of early modern German writing as the aesthetic equal to works produced by Renaissance contemporaries and by the ancients.

As defenders of high culture, Germanists have devised a variety of strategies to avoid confronting the sexual content of an early modern text. In the first place, moralistic readings of texts are constructed that counteract the sometimes frank sexuality expressed there. Such readings are generally buttressed by reference to the author's dedicatory preface where moralistic intentions are often explicated in great detail, or by textual references, such as epilogues or the verse choruses of Renaissance and baroque school drama, where transgressive acts are unequivocally denounced. There are many examples of such techniques: 
the epilogue to Grimmelshausen's Courasche, in which readers who have been treated to the male fantasy of the sexually insatiable female, are warned that such a narrative has been designed to make plain the dangers of the flesh and the need for sexual continence; ${ }^{18}$ or, as in the case of von Lohenstein's Sophonisbe, the condemnation of the female protagonist's commingling of lust with political ambition by her Roman conqueror, who, however, represents an empire as equally corrupt as that of the vanquished queen. ${ }^{19}$ For many baroque scholars, the incongruities in these texts are explained away as anachronistic misperceptions by modern readers, who have found disharmony where there is none. Since early modernists place great weight on authorial intention, those readers who challenge such statements run the risk of being dismissed as speculative and irresponsible interpreters.

The problem here extends beyond an unwillingness to discuss sex, especially female sexuality, in other than moralistic terms. It encompasses the much more challenging problem of reading didactic authorial statements critically and, in fact, believing the author in the first place. Any careful reader of early modern literature knows that the unspoken subtext of an authorial preface or dedicatory letter is much more significant key to unlocking the secrets of a text than the author's declarations, or protestations. Humanist writers, for example, were especially adept in this regard: following their ancient models, they often misrepresented their sources, or cast themselves as greater intellectual lights than they actually were. Many devised moralistic readings of clearly pagan texts so as to justify their philological study of them. And still others created a didactic facade for racy material so as to escape the often careless eye of the censor. ${ }^{20}$

There are many discrepancies between an author's moralistic prescriptions and actual literary practice, but I should like to mention a rather egregious example from the late seventeenth century, one of the least explored areas of the early modern canon. This has always been a troubling age for the early modern Germanist: the texts, mostly novels, are interminably long; the idealized courtly culture of the baroque is in the process of dissolution, and the new bourgeois ideal of the clever man (the so-called homo politicus) appears to have replaced the less worldly Christian hero of earlier generations. This is also the time when the publication of German-language books increased, as did their readership, and authors began to pander, so literary historians have argued, to popular tastes. ${ }^{21}$

The clear sign of such popularization was the publication of works in which the sexual escapades of aristocrats and the upper-middle-class were chronicled in intricate detail. Scores of novels appeared in the last 
decades of the century that have "Liebe/Amor" in the title; indeed, the novelist August Bohse-Talander appears to have little else on his mind: he produced, among many others, works entitled Liebes-Cabinet der Damen (1685); Amor am Hofe (1689); Die Eifersucht der Verliebten (1689); Schauplatz der Unglückselig Verliebten (1693), and Der Liebe Irrgarten (1696).22 Germanists have devised the problematic term galante Dichtung to describe the highly mannered and often humorous way the protagonists of these works pursued each other and managed variously either to lure each other to bed or to avoid being led there. ${ }^{23}$

The overtly sexual (i.e., decadent) content of many of these works has ensured their dismissal as frivolous outpourings of an intellectually bankrupt generation. But they are goldmines for literary scholars interested in the representation of sexuality. ${ }^{24}$ Consider the example of Johannes Riemer's 1681 novel Der politische Stockfisch. Here, as usual, the author introduces his work with an extensive preface about the need for the prudent man to marry well. Such an undertaking is especially difficult, so the argument goes, for it is impossible to find a woman who combines wealth, beauty, and learning, let alone bedroom talents, in present-day society where deception is practiced with abandon. Riemer's narrative promises to explicate the survival tactics of his male hero, Solande, in this dangerous environment and to reward him for his success with a wealthy, level-headed, and chaste wife. ${ }^{25}$

In writing about the uncertainties and perils of the world, and especially about the challenges confronting the allegedly superior-looking male hero from womankind, Riemer produces a text that today would be designated soft-core pornography. For much of the middle section of the novel, the chapters devoted to the protagonist's adventures in Paris-always a dangerous city for German heroes (e.g., Simplicissimus as Beau Aleman) - the reader is treated to series of attempts by women of various shapes and station to make passionate love to Solande. There is the overheated Madame Bloise who feigns disinterest in sex to lure the prudish Solande to her chamber; Madame Valesse whose passion remains insatiable because of her marriage to an older man; and Moirette, the forty-year-old virgin whose elegant manner of speaking appeals to his ear but whose misshapen body repulses his desire. There are still others: foolish maids and noblewomen such Madame Bonville, also married to an older man, who claims to be enamored by Solande's virtue, but whose letters to him betray pressing carnal urges (even the narrator doubts that $\mathrm{M}$. Bonville could maintain her chaste passion once she starts touching his body!) And finally, there is yet another unhappily married, sex-starved woman, Castrette, who has Solande brought to her bedroom for a night of love, a prospect not 
unappealing to the hero, only to have him pass out from excessive wine-consumption just as they are about to consummate their desire. These failed attempts to bed Solande set the stage for the ideal union at the novel's end, so the reader is led to suppose, with the young, beautiful, and wealthy Floramene, who, in contrast, possesses no knowledge about sex, conception, or pregnancy.

Riemer's prefatory remarks stress the utility of his novel for ambitious youth on the make. But his clearly misogynistic stance betrays a fascination with the other sex that undermines the work's moral lesson. The text fosters the narcissistic fantasy of male superiority in physical beauty and sexual deportment. The illusion of male virtuousness in the face of female degeneracy is maintained even though Solande is hardly an unwilling victim of the plots the would-be seductresses spin around him. Solande's chastity prevails not because of his innate love of virtue, but for circumstantial reasons, chiefly his own physical or mental reluctance to accede to his admirers' wishes. As far as Solande's sexual desires are concerned, they rage furiously with little sign of abatement; only coitus, in this context a postmarital event, has been postponed. The narrative tension in the novel thus alternates between sexual arousal, the chronicling of the desires of Solande and his would-be mistresses (will he, or won't he?) and the deferment and, at times, suppression of desire. In a work designed as a warning about the perils of womankind, the narrator thus teases the prurient reader by lingering all too languorously on the erotic details that the clever hero should avoid. ${ }^{26}$

The concealment of Riemer's erotic, if not pornographic, content behind worldly wise misogynist warnings about womankind demonstrates the need to penetrate beyond the pious proclamations in early modern prefaces to assess the validity of the author's alleged intentions. It should also serve as a warning about the danger of superficially categorizing literary works under convenient headings, such as politischer Roman, for such innocuous designations may well disguise only a marginally moralistic program. Another popular evasive tactic that early modern Germanists employ to escape the eroticism of a text is the deflection of the reader's attention from a work's sexually arousing content toward stylistic matters. Instead of confronting a text's representation of sexuality and the ideological presuppositions of such a stance, many Germanists have been content to assess the virtuosity or conventionality of the language and, if appropriate, the artful imitation of a classical or Renaissance literary model.

There are many examples of the Germanist preference for style over ideology in the criticism of early modern literature, but this tendency 
has been most pronounced in discussions on early modern lyric. This trend, a product of the apolitical posture favored by German and North American critics in the 1950s and 1960s (one thinks of Karl Otto Conrady on Neo-Latin lyric, or of Marvin Schindler on Gryphius) ${ }^{27}$ began to dissipate in the mid-1970s with Wolfram Mauser's sociohistorical study of Gryphius's poetry, and in the 1980s with Hans-Georg Kemper's history of early modern lyric, but stylistic readings are still being produced (e.g., Fritz Cohen on von Hofmannswaldau). ${ }^{28}$ This obsession with style is most evident, and most unsettling, in the criticism that deals with early modern erotic verse. Here discussions of style serve to neutralize even the frankest display of erotic content and divert the reader's attention away from inherently misogynist, if not sexually violent, representations of male desire.

Underlying this seemingly harmless approach to erotic lyric is the ideologically pernicious assumption by most commentators that such verses are fundamentally innocuous. Erotic lyric, chiefly the Neo-Latin and German verses inspired by the Roman erotic elegists (Ovid, Catullus, and Propertius) and their Renaissance imitators, is preserved from serious analysis by the famous irony that usually accompanies these rhapsodic descriptions of sexual longing and fulfillment. The verses are regarded as virtuoso word games, whose intent seems more aesthetic than carnal, in which the poet devises ever more elaborate metaphors for his passion or the body of his beloved. The game of wooing and bedding the object of desire remains, so most commentators would have us understand, a game, not so much of actual love but of the rhetoric of desire. ${ }^{29}$

As a result of this flight into aesthetics, commentators, generally all men, seemed to have reached the tacit conclusion that such lyrics require no further discussion. Consider, for example, the criticism on the ever popular Janus Secundus, whose cycle of nineteen verses, the Basia (Kiss Poems), kept humanist Latin scholars entranced through the age of Goethe. To be sure, all readers know very well what these poems are about on the literal level, namely, techniques for experiencing the perfect kiss, a desideratum that keeps the reader in suspense because of its unattainability. But the criticism focuses on the inventiveness of Secundus's language and his transformation of ancient sources with little thought about the reasons for his imitation of the playful banter of Roman erotic verse in the $1530 \mathrm{~s} .{ }^{30}$ What is sorely missing is any historical analysis of Secundus's fascination with love, the denigration and violation of women, and with sex in general, and why he (and his fellow humanists) adopt this posture at this time. What, indeed, does all this northern humanist bellowing about sex in increasingly artful ways, 
from Conrad Celtes to Kaspar Barth, have to do with the humanists' moral-philosophical ideas or their sociopolitical program? Why do they insist on maintaining an ironic distance toward sexual matters, and on combining sex with artifice? Why not simply dispense with niceties and write unadulterated pornography as the Italian humanist Aretino and his imitators did? ${ }^{31}$

The solutions to these problems are much too complex to be dealt with here and vary in the case of each poet. More important, we need to be more self-aware of the questions that remain unanswered through the adoption of a purely literary approach. We have been much too prudish in acknowledging what these poems are actually about, and much too dispassionate in assuming that as sophisticated, mature readers any discussion of the frank corporality of these texts is both unnecessary and jejune. As philologists we may temporarily console ourselves with the thought that we need only be concerned with words and rhetorical strategies, but as early modernists with a new, more critical perspective on history, we are constrained to acknowledge the elements of Renaissance and baroque culture that we have ignored and repressed.

Once we have spoken about the avoidance of writing about sex by Germanists, the question naturally arises: What can be gained by this approach? Obviously the response could be, though it should not, that in addressing these new issues Germanists, especially in North America, may perhaps be taken seriously, or, at least, listened to by early modern colleagues in Anglo-Romance studies. This is highly doubtful. More important, as hinted in the discussion of traditional Germanist criticism, we Germanists should be forced to rethink our assumptions about the nature of early modern writing and to come to a new understanding about the relationship of texts to broad ideological issues that informed the construction of sexuality and gender in the period.

By way of example, I should like to return to sixteenth-century humanist culture, and specifically to humanist biblical drama, where I have worked before, and where, like a traditional Germanist, I worked tirelessly to explain away the many textual incongruities, especially as they related to sex. ${ }^{32}$ Humanist religious drama was a rather curious phenomenon, for it was written by Christian schoolmen, some of them clerics, eager to preserve the form and language of Roman comedy without its ribald content. Early humanists such as Celtes and Melanchthon were enamored of the language and plots of Terence's comedies with their passionate lovers, whores, pimps, and nonstop action, and they devised, often unsuccessfully, moral justifications for the pedagogical utility of studying such texts in the Christian classroom. 
But alongside these enthusiasts, there arose a group of humanist reformers, the writers in the so-called Christian Terence tradition, who replaced the romantic plots of Terentian comedy with expansive elaborations of Old Testament heroes and New Testament parables. The more talented playwrights in this style, the Netherlanders Gulielmus Gnapheus and Petrus Papeus, created tightly organized works in which biblical heroes such as the prodigal son and the Good Samaritan exemplify ideal Christian behavior through their avoidance of, and triumph over, characters like the amoral servants, whores, and pimps of Terence, whom they encounter on their fictionalized adventures.

What has always remained troubling is that the humanist playwrights introduced morally questionable episodes and characters into their new biblical plays just when they claimed to have banished such elements from the stage. This is especially true for female figures, for many humanist playwrights recast the courtesans of Roman comedy into the seductresses of biblical fame, for example Potiphar's wife, Delilah, and the bane of John the Baptist, Herod's wife, Herodias. Even the virtuous women who appear, such as the Apocryphal Susanna or the many virgin martyrs of Catholic school theater, serve as an occasion for foregrounding sexual desire, for their mere presence results in erotically charged declarations of passion and even sexual violence (viz., attempted rape and physical mutilation). ${ }^{33}$ Why is sex such a dominant topic here when the writers are allegedly attempting to suppress it? When one recalls that many of these same humanists spent their schooldays reading erotic verse and even, as in case of the poet-dramatist Kaspar Barth, writing collections of it, ${ }^{34}$ the question becomes even more vexing. What can we make of this Christian humanist obsession with sex?

Of course, temporary, unthreatening resolutions of these issues can be reached in the usual way. In the first place, one could argue, and I have done so, for the moral utility of immorality. This argument, which is grounded in the church fathers' apologia for the reading of classical literature, was often mentioned by these Christian humanist playwrights in their dedicatory letters and verse prologues to defend their introduction of immoral figures. In addition, one could even say that the vivid punishments or harsh rejection of sexually irrepressible characters served as a deterrent to Christian misconduct. ${ }^{35}$ And in still other cases where a playwright's moral intentions seem subordinated to his aesthetic program, as was true for the rhetorically charged biblical plays of the renegade Benedictine, Jacob Cornelius Lummenaeus à Marca, one could argue, as I have done, that the frank seduction scene, essentially a striptease, between Samson and Delilah (Lummenaeus 
was writing for an audience of cardinals in Rome), was in itself insignificant and merely an excuse for verbal pyrotechnics. ${ }^{36}$ But the problem still remains: why did the humanists write so much about carnal desire? Why not about other sins?

In light of my earlier criticism about the shortcomings of such moralistic and stylistic approaches, let me offer some tentative explanations for the eroticism here by confronting, rather than fleeing from its presence. In the first place, the humanists' fascination with sex is not surprising, despite their moral protestations, for their advanced classes in grammar and rhetoric, where humanist school dramas were usually performed by an all-male group of actors, coincided with the sexual maturation of their students. ${ }^{37}$ Through these public presentations, students demonstrated their fluid command of language skills, be it Latin or German, and, in the case of the sexually charged biblical dramas, one hoped, their mastery of sexual desire.

But the problem is more complicated than it first appears, for the control of sexual desire in many instances does not necessarily imply the denigration of male desire, or its suppression, but rather its valorization. There is no doubt that the humanist playwrights embellished the speech and actions of a pagan seductress such as Potiphar's wife not simply to revel in the language, but to pander to the sexual fantasies and voyeuristic urgings of the student performers and readers. Consider the Old Testament Joseph (1530) of the early sixteenth-century humanist Cornelius Crocus. In this work a great deal of space is devoted to the sexual outpourings of Potiphar's disappointed wife, Sephirah, as she enumerates the physical pleasures that she will bestow on Joseph if he will sleep with her. Joseph stoically refuses, but only after the performers and readers have been treated to an extensive exploration and description of lust. ${ }^{38}$ In fact, although Crocus rarely lapses into the obscene, the frankness of his language disturbed later editors and imitators of this text so much that they eliminated these passages from their versions. ${ }^{39}$ What is significant here is not that the potential sexual arousal of the original audience is being prevented, but that Crocus remains unperturbed by such a reaction.

The apparent paradox of humanist religious drama-namely, that the playwrights, in christianizing pagan theater, retained many of its objectionable immoral elements-is, thus, a misperception on the part of German literary historians. Partially blinded by our own puritanical attitudes, we have neglected to see that the lesson the humanists wished to transmit was not that carnal desire was intrinsically evil, or sinful, but that the inability to control desire is. What male viewers and performers mastered through exposure to these texts was that the ob- 
jects of desire, chiefly women, were the repositories of evil, rather than their smitten lovers, for their mere presence could tempt men to neglect their customary rational control of themselves and their world. Even virtuous women such as Susanna as presented in Rebhun's play (1536) and elsewhere, or the virgin martyrs of sixteenth-century Jesuit theater, are not free from censure, because of the lust they incited in their male admirers. The only real danger that the humanists warned against was that men, as a consequence of carnal inflammation, might act immorally, or sinfully, and thereby lose the privileged position of power that they held in society.

The main lesson of the sexual encounters in humanist religious theater is, therefore, the need for sexual discipline. ${ }^{40}$ Such an intent corresponds with the humanist pedagogical project in general, namely, the acquisition and retention of social station and political power in the early modern towns and territories. Christian humanists promulgated the moral-philosophical system in which pursuit of virtue and the good, rather than the satisfaction of desire and personal ambition, was accorded the highest place. But the key quality to be acquired was not virtue itself, a highly problematic goal in light of Christian man's fallen state, but self-discipline. Such a project is apparent, for example, in the famous prodigal-son play Acolastus (1529) of Gulielmus Gnapheus, which has generally been read in accord with the author's stated intention as an allegory of Christian man's salvation. ${ }^{41}$ If the perspective is shifted slightly so that the sociopolitical agenda behind the choice of this parable for dramatization is foregrounded, then the disobedience of the prodigal, rather than his forgiveness, becomes the focal point. The work's three central acts in which the prodigal becomes enslaved to the fulfillment of all carnal pleasures-the most inventive and liveliest parts of the play_can be read as a bourgeois humanist nightmare in which the loss of wealth and station is attributed to the absence of sexual discipline. The humanist ethos that the religious dramatists were at pains to convey was that the control of the body, a quintessentially male talent, and the practice of disciplined sex entitled the man who mastered these skills to the administration of wealth and power in the early modern state.

Our reevaluation of humanist religious drama has contributed to the restoration of sex as a dominant subject in early modern writing, which many Germanists, still entrenched in the value system of the puritanical nineteenth century where their discipline was born, can no longer ignore. We must confront our accustomed reluctance to penetrate beyond our elitist notions of the Renaissance, our credulous adherence to politicized statements of moralistic authorial intentions, and our 
single-minded focus on aesthetic matters that are rarely as innocent as we suppose. We need to put sex and its related topic, gender, back into the discussion of early modern texts and into our notion of early modern German literary history. In this way, we may well discover that the phallocentrism and obscenity of nonhumanist, traditionally nonRenaissance culture is equally present and welcomed by the humanists themselves; that galante Dichtung does not represent a condemnation, but rather a revalorization of carnal knowledge; and that the humanist predilection for erotic discourse, both in lyrics and on the stage, reflects a linguistic and ethical self-confidence about the manipulation of desire. Such views are long overdue, but there is still much work to be completed. Only through the rehabilitation of the sexual content of early modern literature can we hope to tear away at the ethereal elitism that has traditionally surrounded these works, and uncover the ideological presuppositions that informed the constitution of early modern society and its texts.

\section{Notes}

1. The fundamental texts include: Michel Foucault, The History of Sexuality, 3 vols., trans. Robert Hurley (New York: Random House/Vintage, 1980, 1985, 1986); Norbert Elias, Über den Prozeß der Zivilisation, 2 vols. (Frankfurt a. M.: Suhrkamp Taschenbuch, 1976); Hans Peter Duerr, Nacktheit und Scham: Der Mythos vom Zivilisationsprozeß (Frankfurt a. M.: Suhrkamp, 1988); Thomas Laqueur, Making Sex: Body and Gender from the Greeks to Freud (Cambridge, Mass.: Harvard University Press, 1990). An early treatment of this subject from the sociohistorical perspective, based on the first edition of Elias's study (1936), is "Sociogenese en evolutie van het probleem der seksuele propædeuse tussen de 16de en de 18de eeuw vooral in Frankrijk en Duitsland: Bijdrage tot de studie van de burgerlijke seksuele moraal," 2 vols. (Ph.D. diss., Ghent, 1967). Useful collections appearing in Anglo-Romance studies are Edward Muir and Guido Ruggiero, eds., Sex and Gender in Historical Perspective (Baltimore: Johns Hopkins University Press, 1990); James Grantham Turner, ed., Sexuality and Gender in Early Modern Europe: Institutions, Texts, Images (Cambridge: Cambridge University Press, 1993); Lawrence D. Kritzman, The Rhetoric of Sexuality and the Literature of the French Renaissance (Cambridge: Cambridge University Press, 1991); Claude J. Summers and Ted-Larry Pebworth, eds., Renaissance Discourses of Desire (Columbia: University of Missouri Press, 1993). For art-historical analyses of the sexuality of biblical canvases, see Madlyn Millner Kahr, "Delilah," and Mary D. Garrard, "Artemisia and Susanna," in Feminism and Art History: Questioning the Litany, ed. Norma Broude and Mary D. Garrard (New York: Harper and Row, 1982), pp. 119-45, $147-71$. 
2. Lawrence Stone, The Family, Sex and Marriage in England, 1500-1800 (New York: Harper and Row, 1977); Guido Ruggiero, The Boundaries of Eros: Sex, Crime, and Sexuality in Renaissance Venice (New York: Oxford University Press, 1985); Guido Ruggiero, Binding Passions: Tale of Magic, Marriage and Power at the End of the Renaissance (New York: Oxford University Press, 1993); Merry E. Wiesner, Women and Gender in Early Modern Europe (Cambridge: Cambridge University Press, 1993).

3. On New Historicism in general, see H. Aram Veeser, ed., The New Historicism (New York: Routledge, 1989); for its applicability to German studies, see the special issue of Monatshefte 84, no. 2 (1992).

4. In addition to the seminal work of Lawrence Stone for England, see Martin Ingram, Church Courts, Sex and Marriage in England, 1570-1640 (Cambridge: Cambridge University Press, 1990); Richard Davenport-Hines, Sex, Death, and Punishment: Attitudes to Sex and Sexuality in Britain since the Renaissance (London: Collins, 1990); and G. J. Barker-Benfield, The Culture of Sensibility: Sex and Society in Eighteenth-Century Britain (Chicago: University of Chicago Press, 1992). On gender construction, see David T. Evans, Sexual Citizenship: The Material Construction of Sexualities (New York: Routledge, 1993); on love, see Niklas Luhmann, Liebe als Passion: Zur Codierung von Intimität (Frankfurt a. M.: Suhrkamp, 1986).

5. Barbara Duden, The Woman beneath the Skin: A Doctor's Patients in Eighteenth-Century Germany, trans. Thomas Dunlap (Cambridge, Mass.: Harvard University Press, 1991).

6. See the exemplary study by James A. Brundage, Law, Sex and Christian Society in Medieval Europe (Chicago: University of Chicago Press, 1987), pp. 487575, whose purview extends through the Counter-Reformation. Also useful for Renaissance notions of gender is Joan Cadden, Meanings of Sex Difference in the Middle Ages (Cambridge: Cambridge University Press, 1993). For a more modern survey of the variety of topics addressed by historians of sexuality, see John C. Fout, ed., Forbidden History: The State, Society, and the Regulation of Sexuality in Modern Europe (Chicago: University of Chicago Press, 1992). Fout also serves as the editor of the Journal of the History of Sexuality, which regularly contains articles on sexual practices in early modern Europe.

7. For example, Anthony Low, The Reinvention of Love: Poetry, Politics, and Culture from Sidney to Milton (Cambridge: Cambridge University Press, 1993); Mary Beth Rose, The Expense of Spirit: Love and Sexuality in English Renaissance Drama (Ithaca, N.Y.: Cornell University Press, 1988); Ann Rosalind Jones, The Currency of Eros: Women's Love Lyric in Europe, 1540-1620 (Bloomington: Indiana University Press, 1990); David O. Frantz, Festum Voluptatis: A Study of Renaissance Erotica (Columbus: Ohio State University Press, 1989); Joan DeJean, "The Politics of Pornography: L'École des filles," in The Invention of Pornography: Obscenity and the Origins of Modernity, 1500-1800, ed. Lynn Hunt (New York: Zone Books, 1993), pp. 109-23. The largest collection of writing about sex for medieval and sixteenth-century Germanists is Hans Jürgen Bachorski, ed., Ordnung und Lust: Bilder von Liebe, Ehe und Sexualität in Spätmittelalter und Früher Neuzeit (Trier: Wissenschaftlicher Verlag, 1991). In general, eighteenth- 
century German scholars have produced more about sex than their Renaissance and baroque colleagues: for example, Anke Meyer-Knees, Verführung und sexuelle Gewalt: Untersuchungen zum medizinischen Diskurs im achtzehnten Jahrhundert (Tübingen: Stauffenburg Verlag, 1992).

8. Ingrid Bennewitz, “'Du bist mir Apoll' / 'Du bist mir Helena.': 'Figuren' der Liebe im frühneuhochdeutschen Prosaroman," in Bachorski, Ordnung und Lust, pp. 185-210; Lynne Tatlock, "Speculum Feminarum: Gendered Perspectives on Obstetrics and Gynecology in Early Modern Germany," Signs 17 (1992): 725-60; Linda Ellen Feldman, "Converging Difference: Reflections on Marginalism, Postmodernism and the Memoirs of Glückel von Hameln," Daphnis 22 (1993): 669-700.

9. David Price, "When Women Would Rule: Reversal of Gender Hierarchy in Sixteenth-Century German Drama," Daphnis 20 (1991): 147-66, and "The Poetics of License in Janus Secundus's Basia," Sixteenth Century Journal 23 (1992): 289-301.

10. Michael Schröter, "Zur Intimisierung der Hochzeitsnacht im 16. Jahrhundert: Eine zivilisationstheoretische Studie," in Bachorski, Ordnung und Lust, pp. 359-414.

11. Sigrid Brauner, "The Demonization of the Shrew: Witchcraft and Gender Relations in Shrovetide Plays by Hans Sachs," Daphnis 20 (1991): 131-45; Jonathan Clark, "Inside / Out: Body Politics against Large Bodies," Daphnis 20 (1991): 101-30; Helmut Brackert, "Zur Sexualisierung des Hexenmusters in der Frühen Neuzeit," in Bachorski, Ordnung und Lust, pp. 337-58.

12. Mikhail Bakhtin, Rabelais and His World, trans. Hélène Iswolsky (Bloomington: Indiana University Press, 1984), pp. 368-436.

13. For the promulgation of licentiousness for the purposes of consolidating ideological control of the masses, see Peter Stallybrass and Allon White, The Politics and Poetics of Transgression (Ithaca, N.Y.: Cornell University Press, 1986), pp. 1-26.

14. For an example of the devaluation of late sixteenth-century literature, see Barbara Könneker, "Deutsche Literatur im Zeitalter des Humanismus und der Reformation," in Deutsche Literatur in Humanismus und Barock, ed. B. Könneker and Conrad Wiedemann (Frankfurt a. M.: Athenaion, 1973), pp. 31-32. This view still persists in the two volumes on early modern German literature in the recent Deutsche Literatur: Eine Sozialgeschichte, ed. Horst Glaser; see volume 2, Von der Handschrift zum Buchdruck: Spätmittelalter-ReformationHumanismus 1320-1572, ed. Ingrid Bennewitz and Ulrich Müller (Reinbek: Rowohlt, 1991), and volume 3, Zwischen Gegenreformation und Frühaufklärung: Späthumanismus, Barock 1572-1740, ed. Harald Steinhagen (Reinbek: Rowohlt, 1985). The 1572 division proves misleading, for late humanist writers such as Melissus Schede and Nicodemus Frischlin, both active in the last quarter of the 1500s, are absent from the third volume, and mentioned unexpectedly in passing in the second; other late humanists such as Kaspar Barth are omitted.

15. See the essays in the second section of Gisela Brinker-Gabler, ed., Deutsche Literatur von Frauen, vol. 1 (Munich: Beck, 1988), pp. 113-289; Barbara Becker-Cantarino, Der lange Weg zur Mündigkeit: Frau und Literatur 
(1500-1800) (Stuttgart: Metzler, 1987). The most recent collection dedicated to rehabiliating the status of early modern women in Germany is Lynne Tatlock and Christiane Bohnert, eds. The Graph of Sex and the German Text: Gendered Culture in Early Modern Germany, 1500-1700, Chloe, Beihefte zum Daphnis, no. 19 (Amsterdam: Rodopi, 1994).

16. James A. Parente, Jr., "Empowering Readers: Humanism, Politics, and Money in Early Moden German Drama," in The Harvest of Humanism in Central Europe, ed. Manfred Fleischer (St. Louis: Concordia, 1992), pp. 263-80.

17. For example, Karl Müllenhoff, "Die deutsche Philologie, die Schule, und die klassische Philologie" (1854), in Eine Wissenschaft etabliert sich, 1810-1870, ed. Johannes Janota, Texte zur Wissenschaftsgeschichte der Germanistik, 3 (Tübingen: Niemeyer, 1980), pp. 277-303.

18. For an excellent analysis of earlier Courasche criticism and the problems arising from a moralistic reading of the work, see Linda Ellen Feldman, "The Rape of Frau Welt: Transgression, Allegory and the Grotesque Body in Grimmelshausen's Courasche," Daphnis 20 (1991): 61-80.

19. Rolf Tarot, "Zu Lohensteins Sophonisbe," Euphorion 59 (1965): 72-96. For a more nuanced interpretation of the ideological program behind Lohenstein's characterization of the queen, see Adalbert Wichert, Literatur, Rhetorik und Jurisprudenz im 17. Jahrhundert: Daniel Casper von Lohenstein und sein Werk, eine exemplarische Studie, Studien und Texte zur Sozialgeschichte der Literatur, 32 (Tübingen: Niemeyer, 1991), pp. 135-59.

20. James A. Parente, Jr., Religious Drama and the Humanist Tradition: Christian Theater in Germany and the Netherlands, 1500-1680 (Leiden: Brill, 1987), pp. 13-60.

21. Albert Martino, "Barockpoesie, Publikum und Verbürgerlichung der literarischen Intelligenz," Internationales Archiv für Sozialgeschichte der deutschen Literatur 1 (1976): 107-45; John A. McCarthy, "The Gallant Novel and the German Enlightenment," Deutsche Vierteljahrsschrift für Literaturwissenschaft und Geistesgeschichte 59 (1985): 47-78.

22. Herbert Singer, Der galante Roman, 2d ed. (Stuttgart: Metzler, 1966), pp. 33-35.

23. The terms galant/galanterie did not originally refer to sexual matters, but to the mannered, courtly behavior of the virtuous cavalier. In the early eighteenth century, with the publication of works such as K. L. W. Freiherr von Pöllnitz's La Saxe galante (1734), the term increasingly referred to the sexual escapades of the aristocrats and princes. Horst Glaser, "Galante Poesie," in Steinhagen, Zwischen Gegenreformation und Frühaufklärung, pp. 394-97.

24. Singer (Der galante Roman, p. 12) called them aesthetically insignificant, but "ein Arsenal kultursoziologischer Dokumente von unschätzbarem Wert."

25. Johannes Riemer, Der politische Stockfisch, in Werke, vol. 1, ed. Helmut Krause (Berlin: de Gruyter, 1979), pp. 329-32.

26. At the end of the preface, Riemer quotes Saint Paul about the dangers of the flesh that can only be tempered by a happy marriage; such moralistic disclaimers, however, are undermined by the novel's sexual content. Riemer, Der politische Stockfisch, p. 332. 
27. Karl Otto Conrady, Lateinische Dichtungstradition und deutsche Lyrik des 17. Jahrhunderts (Bonn: Bouvier, 1962); Marvin S. Schindler, Sonnets of Andreas Gryphius (Gainesville: University of Florida Press, 1971).

28. Wolfram Mauser, Dichtung, Religion und Gesellschaft im 17. Jahrhundert: Die "Sonnete" des Andreas Gryphius (Munich: Fink, 1976); Hans-Georg Kemper, Deutsche Lyrik der frühen Neuzeit, 6 vols. [5 vols. to date] (Tübingen: Niemeyer, 1987-[91]); Fritz G. Cohen, The Poetry of Christian Hofmann von Hofmannswaldau: A New Reading (Columbia, S.C.: Camden House, 1986).

29. See the discussion of the beloved as "synthetic lady" in Glaser, "Galante Poesie," pp. 404-5.

30. See the critique of earlier Secundus criticism in Price, "The Poetics of License," pp. 289-90.

31. Frantz, Festum Voluptatis, pp. 43-90.

32. Parente, Religious Drama, pp. 9-60; Parente, "The Paganization of Biblical Tragedy: The Dramas of Jacob Cornelius Lummenaeus à Marca (15701629)," Humanistica Lovaniensia 38 (1989): 209-37.

33. See, for example, the sexually charged dramas on Saint Catherine of Alexandria, the most popular virgin martyr in the sixteenth-century Jesuit school repertoire. For an analysis of the most influential Catharina of that period, see Parente, "Counter-Reformation Polemic and Senecan Tragedy: The Dramas of Gregorius Holonius (1531?-1594)," Humanistica Lovaniensia 30 (1981): 156-80.

34. Kaspar Barth, Amabilia (1612), and the more expansive 1613 collection Amphitheatrum Gratiarum libris XV, Anacreonte modimperante constitutum (also known as Erotopaegnion in its 1623 version). The extensive writings of Barth have yet to be examined in the context of late humanism in the empire. For a basic overview of Barth's works, see Johannes Hoffmeister, Kaspar von Barths Leben, Werke und sein deutscher Phönix, Beiträge zur neueren deutschen Literaturgeschichte, 19 (Heidelberg: Winter, 1931), especially pp. 42-56 for the poetry.

35. Parente, Religious Drama, pp. 13-30.

36. Parente, "The Paganization of Biblical Tragedy," pp. 225-35.

37. In a famous essay, Walter Ong likened the humanist educational process to a puberty rite, by which young men were disciplined through Latin instruction to assume mature roles as adults in society. Although Ong does not mention the humanists' predilection for erotic versifying, the subjugation of sexual drives clearly relates to the students' preparation for later civic life. Walter Ong, "Latin Language Study as a Renaissance Puberty Rite," Studies in Philology 56 (1959): 103-24.

38. Cornelius Crocus, Joseph (Antwerp: Joannes Steelsius) 1538), sig. B3-C3.

39. Antonius Schottus, the seventeenth-century editor of Crocus's works, expurgated the immoral language of the Joseph-Sephirah seduction scene before approving the work for school performance. Bibliotheca Belgica, vol. 6 (Brussels: Culture et Civilisation, 1970), p. 189.

40. For a discussion of this process in the late Middle Ages, see Michael Schröter, "Staatsbildung und Triebskontrolle: Zur gesellschaftlichen Regu- 
lierung des Sexualverhaltens vom 13. bis 16. Jahrhundert," in Macht und Zivilisation: Materialien zu Norbert Elias' Zivilisationstheorie, ed. Peter Gleichmann, Johan Goudsblom, and Hermann Korte (Frankfurt a. M.: Suhrkamp Taschenbuch, 1984), pp. 148-92.

41. Gulielmus Gnapheus, Acolastus, introd. and trans. W. E. D. Atkinson (London, Ontario: Humanities Department, University of Western Ontario, 1964), pp. 47-72; Stephen L. Wailes, "Is Gnapheus' Acolastus a Lutheran Play?" in Semper Idem et Novus, ed. Francis G. Gentry (Göppingen: Kümmerle, 1988), pp. 345-57. 


\title{
12. Carnal Knowledge and the Populating of Paradise: Johann Gottfried Schnabel's Insel Felsenburg
}

\author{
Lynne Tatlock
}

Die sinnlichen Vergnügungen sind nach der Natur der Menschen eine wirkliche Bedürfniß für einen wohleingerichteten Staat. ${ }^{1}$

Der Republic [ist] allerdings daran gelegen . . . daß einer Stadt oder Landes Einwohner sich verheyrathen, Kinder zeugen, und also dem Statum Politicum unterhalten mögen. ${ }^{2}$

But towards the extinction of the passion between the sexes, no observable progress whatever has hitherto been made. ${ }^{3}$

The Robinsonade seems tailor-made for a symposium on knowledge, science, and literature. After all, Daniel Defoe's seminal Robinson Crusoe distinguishes itself with its meticulous descriptions of its protagonist's experimentation, his systematization of his life on the island, his taming and cultivation of nature. Crusoe's survival depends on coming to know the island and learning to exploit its resources: "I saw large plants of alloes, but did not then understand them. I saw several sugar canes, but wild and, for want of cultivation, imperfect. I contented my self with these discoveries for this time, and came back musing with my self what course I might take to know the vertue and goodness of any of the fruites or plants which I should discover." 4 By contrast, the most famous German imitation of Defoe's Crusoe, Johann Gottfried Schnabel's eighteenth-century best seller, the four-volume Wunderliche Fata einiger Seefahrer (1731-43), will on first reading fail to meet any such readerly expectation: the narrative devotes little space to exploration of the island and, without much effort on the part of its colonizers, the island simply yields its riches. Indeed, fifteen years ago Jan Knopf convincingly argued that the protagonists of Schnabel's Insel Felsenburg conspicuously lack the curiosity that characterizes Crusoe and the modern spirit of inquiry in general: "Die Kernvokabeln neuzeitlichen Selbstverständnisses erschienen wieder negativ besetzt: 'Neugierde' 
und 'Vorwitz' sind wieder Eigenschaften, die den Menschen nicht selbstbewußt auszeichnen, sie sind wieder Herausforderungen von Unbekanntem, das dem Menschen nicht bekannt werden darf, weil es nicht für ihn ist." ${ }^{5}$ The Felsenburger, Knopf insists, never exhibit an inclination - "Lust" - to explore other countries, never even thoroughly explore the island itself. Instead, Knopf maintained, they seek peace and quiet and withdraw from history, the world, and its experiences: "[Schnabel] ging es weder darum, die Entdeckung einer neuen Welt vorzuführen, einer Welt, der man - wie Robinson Crusoe-die menschliche Wirtschaftlichkeit erst abbringen muß, indem man sie entdeckt, bearbeitet und zwingt, den Menschen nützlich zu sein, noch darum eine zukünftige Projektion eines idealen Staats . . zu entwerfen ... , hier wird vielmehr die Flucht vor der Wirklichkeit demonstriert." 6 Yet even as Knopf identified the lack of experience, indeed, the lack of desire to experience the world, the flight from reality, he overlooked-or perhaps dismissed as merely domestic-what Bernhard Fischer has recently discussed as the book's central experience: the sexual union of Albertus Julius and Concordia. Fischer has astutely maintained that Schnabel's text depicts human society as rooted in sexuality. ${ }^{7}$ Like Fischer, I, too, will place sexuality at the center of my investigation, for the entire colony of Felsenburg and thus the book itself issue from it. Unlike Fischer, however, I am interested primarily in the construction of male sexuality as key to the knowledge that the text creates.

I intend to explore the engendering, regulation, and satisfaction of male desire in this text and the knowledge generated and applied in the process. I am interested in the ways the narrative relates technologies of the male self to technologies of the state, that is, how it transforms male sexual economy into political economy, domestic science into political science. My reading of this novel will insist on the continuum of the private and the political. Unlike Fischer, however, who views Schnabel's novel as a bourgeois critique of absolutism-albeit an ineffectual one-I will argue that in this text male autobiography interlocks with the political economy of eighteenth-century mercantilism, indeed, that Schnabel's colony in many respects participates in the political thought of the cameralist system of eighteenth-century enlightened despotism.

On the opening page of the Wunderliche Fata the fictitious editor commends Albertus Julius's "Geschichts-Beschreibung" to the special de- 


\section{Lynne Tatlock}

light, "zu besonderer Gemüths-Ergötzung," of a masculine-gendered reader, a "geneigter Leser" (1: sig. 2 ):(r). ${ }^{8}$ While the masculine gender of a putatively generic and universal reader might appear unremarkable, a fictional reader response to this text from the late eighteenth century alerts us to the possibility that Schnabel's novel particularly appealed to male readers. The narrator of Karl Philipp Moritz's autobiographical novel Anton Reiser (1786-90) describes one of the secret pleasures of Anton's childhood, his solitary reading of Insel Felsenburg:

Die Erzählung von der Insel Felsenburg tat auf Anton eine sehr starke Wirkung, denn nun gingen eine Zeitlang seine Ideen auf nichts Geringers, als einmal eine große Rolle in der Welt zu spielen, und erst einen kleinen, denn immer größern Zirkel von Menschen um sich her zu ziehen, von welchen er der Mittelpunkt wäre: dies erstreckte sich immer weiter, und seine ausschweifende Einbildungskraft ließ ihn endlich sogar Tiere, Pflanzen, und leblose Kreaturen, kurz alles, was ihn umgab, mit in die Sphäre seines Daseins hineinziehen, und alles mußte sich um ihn, als den einzigen Mittelpunkt, umher bewegen, bis ihm schwindelte. Dieses Spiel seiner Einbildungskraft machte ihm damals oft wonnevollre Stunden, als er je nachher wieder genossen hat. ${ }^{9}$

The boy Anton's eager adoption and adaptation of Albertus's story as well as his pleasure in reading it suggest that this fantasy offers a model of "masculine" self-realization. Indeed, it presents him not with a model of quiescence but rather with a fantasy of activity and pleasure; Anton is not tranquilized but rather highly stimulated. So inspired is he by Albertus's example that he imagines himself a second Adam, the father of humankind with dominion over the plants and animals. He has clearly recognized that Albertus not only authored himself by telling his life story but literally fathered an entire colony "von mehr als 300 . Seelen," a colony that will live on after his death. What is more, through this text Anton discovers himself and his capacity for pleasure ("wonnevolle Stunden").

Anton Reiser is not, however, the first male character to be given pleasure by Albertus's life story; as it happens, this distinction belongs to the fictitious author of the book himself, Eberhard Julius. Indeed, Eberhard, who frequently sought and found a cure for his melancholy in books, ${ }^{10}$ reacts quite strongly to the first account of his great great uncle's biography: "Der Capitain [hatte] . . mich [damit] in erstaunendes Vergnügen gesetzt" $(1: 25)$. In fact, unlike Crusoe, who goes to sea because he desires adventure, Eberhard sets sail for the island on account of his uncle's story, a story that, as we shall see, holds the promise 
of sexual satisfaction as well as progeny. On the island Eberhard Julius will marry and, as it were, come into his own. In fact he becomes an agent in more than one sense of the word. And apparently Albertus's biography has permanently cured Eberhard's melancholy, for it is never mentioned again. Schnabel's model of "masculine" self-realization, this powerful therapy, deserves a closer look.

\section{II}

The title page and introduction to the original volume of Insel Felsenburg leave no doubt as to the narrative's center: the book consists of "Albert Julii Geschichts-Beschreibung, und was Mons. Eberhard Julius, zur Erläuterung derselben, diesem unglücklichen Passagier sonsten beygelegt und zugeschickt hatte" (1: sig. 4 ):(v). ${ }^{11}$ While I will also examine the larger structure created by the collected biographies of the settlers, my investigation focuses primarily on this narrative center, on the story of Albertus Julius and therefore on the first, best, and most enduringly popular volume of Schnabel's serial novel. ${ }^{12}$ Like the tale of Alexander Selkirk, the prototype for Robinson Crusoe, the central fate of the Wunderliche Fata begins innocuously enough as a "plain Man's Story." But unlike Selkirk, Albertus undergoes a marvelous transformation over the course of the narrative. His story recounts its protagonist's coming to a prodigious manhood, his transformation from passive victimization to active agency, a fatherless child's metamorphosis into the patriarch of a flourishing and populous nation. Albertus's discovery of his own sexuality constitutes a critical moment in this metamorphosis.

Although born into middle-class respectability to a father who was a loyal servant (Etaats-Bediente [1:110-11]) of a German prince, Albertus and his brother were orphaned at a tender age and left to beg on the street. The brief description of these early years unmistakably belongs to a well-known seventeenth-century genre, the picaresque novel. Like many a seventeenth-century picaro, Albertus becomes for a time a "Spielball des Glücks." The world acts upon him and he muddles through as best he can, sometimes using his wits and sometimes acting foolishly. In the Europe of this text he is unable to establish himself in any sense of the word-one of his misadventures symbolically involves a mixup with a pair of pants, "daß ich in der Angst unrechte Hosen und an statt der Meinigen des Herrn Praeceptoris seine ergriffen" (1:116). Indeed, young Albertus's story promises readers little more than a tale of failed masculinity, "denn ich wuste mich selbst nicht zu 
resolviren, was ich in Zukunfft vor eine Profession oder Lebens-Art erwehlen wolte" (1:117). He seems powerless, even uninterested in taking initiative. Indeed, even as seventeenth-century Europe teems with men who are ruled by uncontrollable desires of all kinds, in particular lust and greed, young Albertus appears to lack any such "secret moving springs in the affections." 13

Fortunately Albertus meets a Dutch aristocrat, to whom he recounts the history of his brief but precarious life. So taken with Albertus's anecdotes-"ungemein vergnügt" (1:120)-is Mons. van Leuven that he hires him as his servant, assigning him no duties but to entertain him. Although he as yet has very little to tell, Albertus has already found in van Leuven an appreciative and grateful male audience. ${ }^{14}$ Schnabel's text thus signals early on that the autobiographical mode may function as a means of social bonding, indeed a pleasurable one. I shall return to this point.

Despite his new association with the enterprising van Leuven, Albertus finds himself further than ever from achieving any sort of authoritative "masculine" identity: van Leuven dresses his young servant as a woman, commanding that he behave as if he were his wife and, ever passive, Albertus obliges his master. Eventually it becomes clear that this ambiguous disguise is part of a plan to abduct van Leuven's true love, Concordia Plürs, but its effect on Albertus lingers. Even after he once again clothes himself in trousers, he does not easily win back his male status. He remains curiously "feminized," identified with Concordia rather than with his master van Leuven. In fact, on the voyage Albertus and Concordia become violently seasick and both are unconscious when the ship founders on a sandbank: "Weiter weiß ich nicht, wie mir geschehen ist, indem mich entweder eine Ohnmacht oder allzustarcker Schlaf überfiel, aus welchem ich mich nicht eher als des andern Tages ermuntern konte, da sich mein schwacher Cörper auf einer Sand-Banck an der Sonne liegend befand" (1:139). The most enterprising man, van Leuven, has dragged Albertus ashore along with his wife. Albertus's passivity at this crucial moment contrasts starkly with Crusoe's mad swim for shore. Indeed, unlike Defoe's protagonist, Albertus has up to his arrival on the island appeared devoid of desire of any kind.

If Albertus has for a time been positioned as a woman, the island offers him the possibility of renegotiating his social and sexual identity. Four people have survived the shipwreck: three men-his master van Leuven, the ship's captain Lemelie, and Albertus himself-and one woman. The tally of survivors in and of itself raises the specter of scarcity even before the characters themselves consciously begin to 
worry about starving to death and long before Lemelie offers his immodest proposal for populating the island.

Scarcity has a profound effect on Albertus, who begins to show initiative, indeed, unexpectedly proves himself the most worthy man. He is not imprudent like Lemelie who begins to eat everything in sight without a thought to the future, nor is he unrealistic like van Leuven who only makes vain predictions of a happier future (1:151-52). Albertus begins to explore the island and discovers the seals who satiate the company's hunger. Encouraged by his successes and unafraid of heights, he climbs higher and higher in search of food. One day he has a curious experience-or rather he describes a discovery in a curious manner:

[Ich kletterte] immer höher von einer Spitze zur andern . . , und nicht eher nachließ, biß ich auf den allerhöchsten Gipffel gelangt war, allwo alle meine Sinnen auf einmahl mit dem allergrösten Vergnügen von der Welt erfüllet wurden. Denn es fiel mir durch einen eintzigen Blick das gantze Lust-Revier dieser Felsen-Insul in die Augen, welches rings herum von der Natur mit dergleichen starcken Pfeilern und Mauern umgeben, und so zu sagen, verborgen gehalten wird. Ich weiß gewiß, daß ich länger als eine Stunde in der größten Entzückung gestanden habe, denn es kam mir nicht anders vor, als wenn ich die schönsten blühenden Bäume, das herum spatzirende Wild, und andere Annehmlichkeiten dieser Gegend, nur im blossen Traume sähe (1:156-57).

Albertus ostensibly narrates a sighting but wastes little time talking about seeing. Rather he seems to have been struck by a thunderbolt; he describes not a vision but a total bodily sensation of pleasure. What is this greatest of all pleasures and why is it important?

August Langen insists that in pietist circles "Vergnügen" tended to refer to contentment, not sexual pleasure: "Vergnügen und seine Sippe wird im Pietismus im Sinne des älteren vergenügen $=$ zufrieden stellen (also noch nicht $=$ voluptas, das im 18. Jahrhundert aufkommt . . .) häufig gebraucht." ${ }^{15}$ I would argue that Schnabel's use of the word in the Wunderliche Fata includes both of the senses of "Vergnügen" that Langen describes-the new and the old-and, moreover, that Schnabel, like many of his contemporaries, was quite conscious that the two meanings were not so far apart, that sexual pleasure was essential to other kinds of satisfaction and general well-being, indeed happiness. In 1719 , for example, the prolific medical writer L. Christoph de Hellwig remarked on the therapeutic value of orgasm: "Das ich mit wenigen viel sage, es ist kein kräfftiger remedium uns zu curiren, als eine or- 
dentliche Liebe und Anfügung an ein Weibes=Bild, und diese Wollust überschüttet uns mit vielem Guten, sie machet unsere Seele vergnügt und vermehret die Kräffte unsers Leibes." 16 Indeed, the Canon of Avicenna, which had dominated medieval medicine, cited coitus as vital to men's well-being and as a particularly effective antidote to melancholy. Sex brought about "the 'expulsion' of a dominant train of thought or of an obsession, the acquisition of boldness, the control of excessive anger, and, of course, the dissolution of the spermatic vapours that accumulate in the brain of the melancholics." 17 Although Schnabel's text does not exactly advocate sexual pleasure for its own sake, it does, as I shall explain, insist on it as necessary to human health and happiness and thus to the building of a prosperous state.

What does Albertus's reaction to his sighting of the interior of the island tell us about his physiology and its place in the divine order? When recalling this moment, Albertus says quite explicitly that he had caught a glimpse of paradise and, like that of Milton's Adam, Albertus's first encounter with paradise bears a striking resemblance to a sexual experience: "All things smiled" [and] "with fragrance and with joy my heart overflow'd." ${ }^{18}$ Indeed, when describing this "allergröste Vergnügen," he uses the same vocabulary that Schnabel uses elsewhere to refer to orgasm. In Schnabel's infamous risqué novel Der im Irrgarten der Liebe herumtaumelnde Kavalier (1746), for example, a baroness assures the protagonist of her gratitude for nights of pleasure: "Euch, aber, mein Leben, bin ich noch jetzt unendlich verbunden für das entzükkende Vergnügen, welches Ihr mir in einigen Nächten zu Ariqua verursacht und wovon ich das Angedenken noch unter meinem Herzen trage." ${ }^{19}$ Since in the eighteenth century female orgasm was thought to be necessary for conception, there is no mistaking the meaning of "entzückende Vergnügen" here. Indeed, these are precisely the words that Albertus uses to describe his own wedding night: "[Ich] fand in ihren Liebesvollen Umarmungen ein solches entzückendes Vergnügen" (1:268). As for the sighting of paradise, in case we missed the point, the narrator flags the sexual analogy by describing the deep contented sleep that follows Albertus's first exploration of paradise and the embarrassment he feels about having slept so long: "Meine Ruhe war dermassen vergnügt, daß ich mich nicht eher als des andern Morgens, etwa zwey Stunden nach Aufgang der Sonnen ermuntern konte. Ich schämete mich vor mir selbst, so lange geschlaffen zu haben" $(1: 161)$.

Having identified the vocabulary of sexuality Albertus uses, the question of its significance remains. Albertus's first encounter with this second Eden in fact constitutes a double discovery. Not only has he discovered a paradise, and perhaps had a presentiment of paradisal liv- 
ing, he has finally discovered himself and experienced his own sexuality, a sexuality that, as we soon learn, must be satisfied for the island truly to become his paradise. If church commentaries on the biblical myth linked human sexuality to the departure from Eden, Schnabel links it quite specifically to the return.

In fact sexual thematics become explicit in Albertus's autobiography only after his discovery of the interior of the island-the analogy to female anatomy is perhaps too obvious to deserve mention. Lemelie, who has been somewhat suspect all along, shows his true colors when they enter the interior of the island and proposes a libertine solution to the shortage of women: "Was solte es wohl hindern, wenn wir uns ... alle 3. mit einer Frau behülffen, fleißig Kinder zeugen und dieselbe sodann auch mit einander verheiratheten" $(1: 167)$. Lemelie's lasciviousness, his "geile Brunst," eventually drives him to violence, the murder of van Leuven, the attempted rape of Concordia, and, indeed, his own untimely violent death-in hot pursuit of Albertus, who has thwarted his designs, he accidentally but significantly impales himself on Albertus's bayonet.

After Lemelie's death only Concordia and Albertus remain on the island, a neatly symmetrical heterosexual arrangement that raises reader expectation of a future union. The narrative, however, delays Albertus's and the reader's gratification. Albertus swears an oath that he will never pester Concordia with untoward sexual demands "weiln ich lieber Zeit-Lebens unvergnügt und Ehe-Loß leben, als euer Ehre und Tugend die geringste Gewalt anthun" (1:223). Yet even as he forswears Concordia, his oath itself could not make plainer that he considers sex vital to a happy life. As it turns out Albertus had underestimated the vitality of his sexuality when he swore the oath. Indeed, after about a year and a half he finds himself so melancholy and so filled with desire that he wants nothing more than to leave the island and find a wife. For him the island is paradise only if he has a mate; otherwise it is unbearable: ${ }^{20}$ "Wie vergnügt wolte ich, als ein anderer Adam, meine gantze Lebens-Zeit in diesem Paradiese zubringen, wenn nur nicht meine besten Jugend-Jahre, ohne eine geliebte Eva zu umarmen verrauchen solten" (1:257). He insists in his prayers that his longing is "keine geile Brunst, sondern [hat] deine heilige Ordnung zum Grunde" (1:257). Nevertheless, he also implies that his desire is not specific to a particular object when he mentions that he considered the possibility of waiting until Concordia's daughter was of marriageable age. Indeed, we recall that his first experience of desire on the island was independent of a specific woman. In other words Albertus identifies sexual desire as simply part of the condition of being human or rather, as the novel on 
the whole does not depict women as desirous creatures, specifically part of the condition of being male. With respect to origin, then, Lemelie's "geile Brunst," which the book clearly condemns, differs very little from Albertus's "Liebes-Gluth" (1:258), which the book condones as belong to God's divine order.

In his very useful article Fischer has attempted to differentiate between Lemelie's sexuality, "einer asozialen, ja gesellschaftsfeindlichen, rein egoistischen Triebnatur, deren Index der reine Lustgewinn ist: der 'geilen Brunst,'" and Albertus's, "einer ursprünglich gesellschaftsgründenden, vernünftigen Natur, deren Index die Fortpflanzung ist: der 'keuschen Liebe.'" 21 While appealing in its simplicity, the dichotomy Fischer proposes between sexual pleasure for its own sake and sex in service of reproduction does not take account of the text's implicit insistence on sexual pleasure as vital to "masculine" agency and hence to civilization. Fischer overstates the case, then, when he argues that in rationalizing sexuality Schnabel constitutes marriage as an institution of repression-as if delectation no longer had any place on the island or in the book itself. ${ }^{22}$

Fischer of course correctly identifies the foregrounding of reproduction on the island. In the love lament "Soll meiner Jugend beste Krafft / In diser Einsamkeit ersterben?" (1:255) Albertus himself pointedly couples his desire to his generative capacity. Furthermore, in this narration of an earthly paradise Albertus's union with Concordia explicitly enables the fulfillment of God's first commandment to humankind in the first story of creation: "Be fruitful and multiply, and fill the earth and subdue it; and have dominion over the fish of the sea and over the birds of the air and over every living thing that moves upon the earth." 23 But whereas in the twentieth century it is easy enough to uncouple sexual pleasure from reproduction, Schnabel's eighteenth-century text constructs sexual pleasure and reproduction as a continuum that forms the basis for human happiness, a view Schnabel shared with many of his contemporaries. In 1734 the author of the entry "Ehestand" in Zedler's Großes Universal-Lexikon wrote in answer to the question as to whether people capable of reproduction were obliged to marry:

Da nun der weite Erden-Creiß zu Erhaltung so vieler Menschen hinlänglich ist; der Mensch auch hiernächst die Krafft, sein Geschlecht zu vermehren, bey sich empfindet; und endlich eine solche Vermehrung, in Betrachtung, daß die Kräffte der grossen Gesellschafft dadurch zunehmen, zugleich auch das Werck der Zeugung mit einer Annehmlichkeit verbunden ist, den letzten Entzweck derer Menschen, welcher ihr wahres Wohlseyn und 
Vergnügen ist, keines Weges verhindert, sondern vielmehr befördert: so ist diese Fortpflantzung des menschlichen Geschlechtes eine Folge des Göttlichen Willens, und eine denen Menschen obliegende Schuldigkeit. ${ }^{24}$

Indeed, in the early eighteenth century passionate lovemaking was thought not only vital to but a sign of fertility. As Thomas Laqueur explains, it was commonplace that the body have through its pleasures a sign of its capacity to generate. ${ }^{25}$ Conversely, numerous offspring signified sexual fulfillment. Anke Meyer-Knees has also noted the "Verbindung von Gefühl-Sexualität-Fortpflanzung als menschheitserhaltende Notwendigkeit" in eighteenth-century medical discourse. ${ }^{26}$ While Schnabel certainly establishes the utility of the institution of marriage, I would argue that he offers his male readers marriage not as an institution that represses pleasure but one that regulates it, thereby increasing it. ${ }^{27} \mathrm{Or}$, to put it another way, marriage converts the destructive and dissipated flames of "geile Brunst" into red hot, civilizationforging "Liebes-Gluth." I shall explain.

Schnabel's second popular novel Der im Irrgarten der Liebe herumtaumelnder Kavalier tells the cautionary tale of an aristocratic man who is out of control. The hapless hero, Gratianus Elbenstein, is in some sense a harmless Lemelie, not so much dangerous to society as to himself. His fate contrasts markedly with the bourgeois Albertus Julius's success story. Elbenstein always eagerly and willingly submits to women's blandishments despite his many resolutions to mend his ways. Nevertheless, after a series of erotic adventures, he finally reaps the reward of his sinful youth in bankruptcy. The text insists on an analogy between his disastrous personal finances and his licentious sexual economy: complicated financial affairs decimate his wealth and "der Gram und Kummer, welchen er deswegen einnahm, brachte ihn dergestalt von Kräften, daß er schwachheitshalber seine Funktion nicht mehr verrichten konnte, sondern sich genötigt sah, seine Charge zu resignieren" (p. 366). If this is his punishment for libertinage, we can conclude that if, rather than dissipate his sexual energy, he had, so to speak, husbanded his resources, he would, like Albertus, be happy and strong of body, the father of many children (unlike Elbenstein not just a single troublesome son [p. 365]) as well as rich.

In contrast to Elbenstein, who generally hops into bed at a moment's notice, Albertus and Concordia delay the consummation of their sexual union, thus building up sexual tension and reader anticipation. After three nights of singing and praying the time has finally arrived: "In der vierdten Nacht aber opfferte ich meiner rechtmäßigen Ehe-Liebste die 
erste Krafft meiner Jugend, und fand in ihren Liebesvollen Umarmungen ein solches entzückendes Vergnügen, dessen unvergleichliche Vollkommenheit ich mir vor der Zeit nimmermehr vorstellen können" (1:268). This explosion of sexual energy has predictable consequences: "Wenige Tage darauf verspürete [Concordia] die Zeichen ihrer Schwangerschafft . . ." (1:268); as if to emphasize the benefits of delayed gratification and the founding-father Albertus's particular virility, this passionate night yields not a single child but twins. ${ }^{28}$ Within his marriage to Concordia, Albertus's pleasure is, then, not repressed but encouraged and extended. The Hausvater Albertus differs from the roué Elbenstein in that the Hausvater channels his pleasure with far-reaching beneficial results, not the least of which is that he lives to be over one hundred years old and to see his "Geschlecht" multiplied. "Geschlecht" should be understood in this context in the sense of family and in the several senses of sex; indeed, here bloodline is identical with sex. The quintessential bourgeois Albertus thus substantiates the wellknown Foucauldian argument that the bourgeoisie was "occupied, from the mid-eighteenth century on, with creating its own sexuality and forming a specific body based on it, a 'class' body with its health, hygiene, descent, and race: the autosexualization of its body, the incarnation of sex in its body, the endogamy of sex and the body." ${ }^{29}$ Unlike Robinson Crusoe who proves to be a "rather bad colonist," 30 Albertus lives "vergnügt" in the interior of the island of Felsenburg, having reached the destination of his desire. Marriage has enabled this male subject to regulate himself, thus leading to his true happiness, just as in the writings of eighteenth-century cameralists "'good government' and the promotion of happiness turn out to involve an ever-extending work of regulation." 31

\section{III}

How then does domestic economy relate to political economy? Both Knopf and Fischer see Schnabel's reliance on autobiographies that focus largely on how the settlers reach the island and not so much on what they do once they arrive there as one of the signs of the poverty of a work that appears at least superficially to belong to the genre of Staatsroman, a genre that is supposed to project an ideal state. If, however, we scrutinize the first volume of Schnabel's novel from a perspective broader than that of the individual narratives, we can see that it not only projects a model state of sorts but that it predicts its increasing vigor. Indeed, Schnabel's text describes what Keith Tribe has identified 
as the utopia of the eighteenth-century political economies "in which economic well-being was the prerequisite of political power." 32 Schnabel's interest in contemporary statecraft manifests itself in at least two important ways in the novel and precisely these manifestations concern me in this section of my essay. Here again, after a brief excursus on political economy in the eighteenth century, Albertus's sexuality will constitute the starting point.

In 1741, ten years after the publication of the first volume of the Insel Felsenburg and two years before the publication of its fourth and final volume, one Johann Peter Süßmilch, a Berlin military pastor, published a pathbreaking work entitled Die göttliche Ordnung in den Veränderungen des menschlichen Geschlechts, aus der Geburt, Tod, und Fortpflanzung desselben. ${ }^{33}$ Süßmilch, who two years later was elected to the Royal Academy of Sciences, has gone down in history as the father of modern demographical statistics. By comparing registers of births and deaths Süßmilch was able to calculate fertility and mortality rates and population growth. He reckoned that overall the human race was constantly multiplying; on average the population doubled once every 100 years. The statistics he was compiling - the word itself remarks on the importance of these numbers to the state-would, he insisted, provide an index of the health of a particular state: "Ich bemerke noch hierbey, daß man aus diesen Listen von dem Zustande, von der $A b=$ oder Aufnahme eines Staats urtheilen könne. Da die Force und die Einkünfte eines Landes auf der Anzahl derer Einwohner beruhen" (p. 17). Moreover, he noted, "Da der nunmehro in Gott ruhende König Friedrich Wilhelm bey nahe 30. Jahr regieret, in 30. Jahren aber die Zahl der Einwohner dieser Lande sich um 1/3 vermehret: so erkennet man hieraus wie die friedliche Regierung desselben, die Gott in dessen würdigsten Sohne und Nachfolger noch lange fortdauren lassen, eben so anzusehen sey, als wenn er einige Länder erobert hätte, die den dritten Theil aller Einwohner der Preußischen und Brandenburgischen Lande enthalten" (p. 17). Süßmilch's words recall those of Frederick the Great himself, who maintained in his Anti-Machiavel: "La force d'un état ne consiste point dans l'étendue d'un pays, ni dans la possession d'une vaste solitude ou d'un immense désert, mais dans la richesse des habitants et dans leur nombre. L'intérêt d'un prince est donc de peupler un pays, de le rendre florissant, et non de le dévaster et de le détruire." 34

Our post-Malthusian age easily forgets that before Malthus European political economists judged the wealth of the nations to rest on their populations. In 1656 Veit Ludwig von Seckendorff insisted, for example: "So ist auch in einem Regiement kein besserer Schatz / alß die Mänge vieler Leute und Unterthanen." 35 Sixty years later, in 1716, the 
German statesman Julius Bernhard von Rohr reaffirmed the point: "Das beste Mittel ein Land zu bereichern, ist, darauf zu dencken, daß viel Volck in das Land gezogen werden, und auch alle Unterthanen durch fleißige Arbeit ihre Nahrung und Erwerb haben mögen. Denn eine grosse Menge wohlgenehrter Unterthanen ist der rechte Schatz eines Landes." 36 Increasing the population was critical since, so the political economists believed, Europe was underpopulated; huge tracts of land lay fallow because there were not enough laborers to cultivate them. ${ }^{37}$ "Diese Bevölkerung," maintained the statesman and one time professor of "Kameralistik" Johann Heinrich Gottlob von Justi in 1756, "ist die innerliche Cultivirung, welche der äusserlichen die Seele und das Leben geben muß. ... [S]o muß es als einen Grundsatz in dieser Abtheilung ansehen, daß ein Land nie zu viel Einwohner haben kann, welcher Grundsatz wider alle Einwürfe leicht zu retten ist." 38 The populating of the state constituted a cardinal principal of German cameralism and thus of contemporary German statecraft. ${ }^{39}$ Indeed, already in 1668 Becher had concluded that is was "derohalben leichtlich zuerachten / daß die vornehmste Staats-Regul/ oder maxima einer Stadt oder Lands seyn sol/ Volckreiche Nahrung; angesehen/ weder der Landsfürst/ Städt oder Länder considerabel seyn/ wann sie arm von Volck seyn/ dann sie können sich nicht defendiren auß Mangl der Menschen." 40

The statistician Süßmilch proposed three methods for increasing the population: increasing the birthrate, increasing life expectancy, and importing people. Frederick William I had experimented with the latter method when in 1731 he invited the 20,000 Salzburger expelled by the Archbishop Leopold Anton, Freiherr von Firmian, to settle East Prussia. ${ }^{41}$ When the Salzburger passed through Stolberg on their trek to the northeast, Schnabel commemorated the event with his Nachricht, welchergestalt die Salzburgischen Emigranten in Stolberg am 2. bis 4. August 1732 empfangen wurden (1733). ${ }^{42}$ But Frederick William was only emulating the policies of his grandfather, the Great Elector, who in the late seventeenth century had invited the French Huguenots to settle around Berlin with considerable economic advantage to the region..$^{43}$

In his treatise on population Süßmilch maintains that the greatest deterrent to the birthrate is "der ehelose Stand." In pondering fertility rates he calculates not only the number of children produced in each marriage but, more important, how many new marriages result from the original one. He does not suggest that the population be multiplied by a grotesque increase in the number of children each individual woman bears (pp. 115-16). Rather, he insists, ubiquitous and early marriage guarantees a high birthrate. Süßmilch notes that the birth of 
twins in particular promotes population growth and furthermore emphasizes that there must be an equal number of men and women since neither polyandry nor polygamy contributes to increased birthrate. The "götíliche Ordnung," as Süßmilch characterizes it, is coupling two by two.

The colonizing, that is, the narration, of Felsenburg pursues all three of the strategies Süßmilch proposes: fertility maximized through timely and ubiquitous marriage and fortuitously by the frequent birth of twins, increased life expectancy, and recruitment of settlers. The twelve-page genealogical chart with which Schnabel (or perhaps his publisher) furnished the first volume renders explicit what has been implicit all along. These pages clearly illustrate the relationship between Albertus's sexual economy and this novel's political economy. While in the genealogy as in the autobiography Albertus Julius constitutes the primary instance, the personal knowledge of individuals that the reader had acquired through the medium of autobiography has been reshaped and transformed into a more impersonal knowledge of an entire nation. Telling has returned as tally. Schnabel's table provides a schematic overview that allows the reader to analyze and take stock of the fortunes of not just Albertus Julius but of the nation of Julius. Schnabel's genealogy thus re-presents carnal knowledge in the form that Foucault claims is at the center of knowledge in the seventeenth and eighteenth centuries: the table, that is, a display of "simple elements and their progressive combination," a display of knowledge "in a system contemporary with itself." 44

What are the particular characteristics of this genealogical chart and what does it tell the reader? It is worth recalling that the royal genealogical chart traditionally summoned the authority of a distant, even mythological, past to legitimate the present. It began in the past with an illustrious ancestor and concluded in the present with the would-be illustrious descendant, clearly identifying both the ancestor and the descendant. Schnabel's chart has a different orientation; here the distant past plays no role whatsoever. The chart begins with Albertus Julius's parents, as is necessary to show the relationship of the insular Juliuses to the European line. The story the genealogy tells is, however, unmistakably the story of the island nation, for the European branch of the family turns out to have been remarkably unprolific and, symbolically, Eberhard Julius is one of two surviving family members from a mere third generation.

The genealogy identifies Albertus as Albertus Julius I and thus clearly represents him as the founder of a Julius dynasty, one that is of course synonymous with the entire Julius nation. One page of the 
genealogy is devoted to each of the ten tribes (Stämme), the descendants of Albertus's nine children and one adoptive child on through the fifth generation of island inhabitants. Each page concludes with the total number of women and men and summations of the deceased and living of each sex. Most striking is that from the third generation on the descendants are for the most part anonymous, indeed, identified only as male or female. The chart provides the explanation for the cryptic notation: "Der geneigte Leser beliebe . . . zu excusiren, daß nicht alle diese Personen mit ihren Tauff-Nahmen benennet sind, welches . . . unnöthige Weitläufftigkeiten verursacht hätte" (1:488). These colonists will never tell their life stories, only occupy a place in a reproductive system. Indeed, there is no reason to do so, for they are natives and received the redundant name Julius at birth; they need not be naturalized. Their numbers not their stories are important. The chart provides clear indication that Albertus's descendants will continue to multiply on into the future and herein lies the key criterion for the founding father's success. The final tally, 429 living and dead, attests to a population growth that would later have astounded even Malthus. Schnabel's triumphant tally anticipates the cameralist Justi's maxim "Man setzet nicht gerne Kinder in die Welt, wenn man selbst unglücklich ist; und man mithin voraus siehet, daß die Kinder nicht glücklicher seyn werden." 45 One only has to read Justi on the subject of "Policeywissenschaft," that is, the regulation of social life for the benefit of the state, to realize that Knopf's dictum "Die Insel Felsenburg ist nicht ... ein Staatsroman" is perhaps too hasty a conclusion. ${ }^{46}$ The absence of an explicit articulation of the laws regulating social life on the island does not mean that the laws themselves are absent. They are simply hidden, the private regulations of the conjugal bed. Certainly, the regular marriage and multiplication of the population recorded by the genealogical chart indicate that the regulations dictated by "Policeywissenschaft" are operating better than any cameralist could have dared hope.

I have claimed that the novel exhibits at least two clear manifestations of contemporary ideas of statecraft. The genealogy is one of these. With its projection of Albertus's seed into an anonymous fifth generation this chart predicts an unbroken and endless multiplication into the future, the prospectus of a vigorous state. The second manifestation is to be found in the cumulative structure of the novel itself. ${ }^{47}$ Knopf in fact accurately identified the character of this structure, only to dismiss it as unbearably rigid and by implication uninteresting: "Das starre System, das soziologisch die Gruppe der Inselbewohner umschließt und das sich erzählerisch darin niederschlägt, daß jede neu hinzukommende Person-als eine Art Generalbeichte-ihre Lebensgeschichte 
erzählen muß, trägt die Fortsetzbarkeit in sich; einmal gefunden, lassen sich die Einzelfälle dazu beliebig und mechanisch vervielfältigen; und eben diese Reproduzierbarkeit zeigen die weiteren Teile des Romans, die keineswegs da enden müssen, wo sie jetzt enden." 48 On the island of Felsenburg the public recitation of each new immigrant's autobiography, what Knopf terms a "Generalbeichte," functions as a powerful means of social bonding. In his very narrative structure Schnabel invented a means of grafting a new and vital immigrant population onto the established population. Within this scheme the mechanics of writing a serial novel and the mechanics of crafting a powerful state dovetail. Of course, as Knopf notes, by making the recitation of the autobiography a part of the naturalization process, Schnabel hit upon a scheme that could have enabled him to continue his narrative endlessly: as long as the Felsenburger required know-how and spouses, the novel could have continued to expand the panoply of "wunderliche Fata." The nature of the economy that informs the narrative is unmistakable: like the mercantilist economies of its age, it is acquisitive. And like the politics of population growth, it speculates on the future, banking on its ability endlessly to renew the reader's pleasure.

\section{IV}

With the reader's pleasure we have come full circle. The fictitious editor has made no bones about it: the reader's pleasure in reading, the repeated piquing and satisfaction of his curiosity, constitutes the book's only explicitly articulated justification..$^{49}$ In the introduction to the first volume the fictitious editor of the Insel Felsenburg reported that he initially had taken up Eberhard Julius's manuscript because he believed it to be an alchemical text whose arcane knowledge could be exploited to economic advantage. Instead he found "verschiedene Passagen . . . woran mein Gemüth eine ziemliche Belustigung fand" (1: sig. ):(4v). I would suggest that in fact at some level he correctly identified the nature of the manuscript when he supposed it to be an alchemical text; indeed, Albertus's individual story and the serial novel itself ought to remind us that pleasure-sexual pleasure-is the quintessential something-out-of-nothing-much that can be exploited to economic advantage.

Within the scheme of Schnabel's novel, the controlled arousal and satisfaction of (male) desire-this technology of self-by no means leads to bankruptcy, lassitude, or quiescence. Quite the contrary. It becomes an integral part of the expanding edifice of the narrative. Karl 
Philipp Moritz did indeed identify the potentially powerful effect of this novel on the male reader: it enables Anton Reiser blissfully to imagine himself the center of a pleasantly waxing world that he dominates.

With the Insel Felsenburg the "Hof-Balbier" and "Stadtchirurgus" Johann Gottfried Schnabel constructed a regulated and regulatory pleasure that was essential to the well-being of the (male) individual and thus to the weal of the state. And, if the narrative itself had a practical side, it was to offer male readers-as did Albertus's story a discomposed and despondent Eberhard Julius - a vicarious pleasure, a tonic of sorts "to purge away spleen, melancholy and ill affections." 50 Without a particularly large stretch of the imagination the reader could identify with the "I" of each autobiography-and especially with Albertus Julius - as the "I" made its way toward the bliss of the island. That the salutary activity the novel generated was all in the reader's head goes without saying, or at least it is another story.

\section{Notes}

I would like to thank Joseph F. Loewenstein and Michael Sherberg for careful readings of the manuscript in progress.

1. Johann Heinrich Gottlob von Justi, Grundsätze der Policeywissenschaft, 3d ed., ed. Johann Beckmann (1782; reprint, Frankfurt a. M.: Sauer \& Auvermann KG, 1969), p. 249.

2. P. J. Marperger, Wohlgemeynter Vorschlag von Verheyrathung Armer Bürgers Töchter und Dienst-Mägde (Hamburg and Leipzig: Schillerischer Buchladen, 1717), p. 9.

3. Thomas Robert Malthus, An Essay on the Principle of Population (1798), in An Essay on the Principle of Population: Text, Sources and Background, Criticism, ed. Philip Appleman (New York: Norton, 1976), p. 78.

4. Daniel Defoe, The Life and Adventures of Robinson Crusoe, ed. and introd. Angus Ross (Harmondsworth: Penguin, 1965), p. 113.

5. Jan Knopf, Frühzeit des Bürgers: Erfahrene und verleugnete Realität in den Romanen Wickrams, Grimmelshausens, Schnabels (Stuttgart: Metzler, 1978), pp. 105-6.

6. Ibid., p. 107.

7. Bernhard Fischer, "Der moralische Naturzustand und die Vernunft der Familie. Eine Studie zu Schnabels Wunderlichen FATA," Deutsche Vierteljahrsschrift 61 (1987): 68-88.

8. Unless otherwise stated, volume and page number of the following edition of Schnabel's Wunderliche Fata einiger Seefahrer are quoted: Johann Gottfried Schnabel, Wunderliche Fata einiger Seefahrer absonderlich Alberti Julii, 4 vols. (1731-43; reprint, Hildesheim: Olms, 1973). 
9. Karl Philipp Moritz, Anton Reiser. Ein psychologischer Roman (Stuttgart: Reclam, 1972), p. 34.

10. "es war kein einziges divertissement, so mir von meinem Vater, so wohl auch andern Freunden gemacht wurde, vermögend, das einwurtzelende melancholische Wesen aus meinem Gehirne zu vertreiben. Derowegen nahm die Zuflucht zu den Büchern und suchte darinnen mein verlohrnes Vergnügen, welches sich denn nicht selten in selbigen finden ließ" (Schnabel, Insel Felsenburg, 1:3).

11. The title page also gives Albertus's story preeminence; it reads Wunderliche FATA einiger See-Fahrer, absonderlich ALBERTI JULII, eines gebohrnen Sachsens, Welcher in seinem 18den Jahre zu Schiffe gegangen, durch Schiff-Bruch selb 4te an eine grausame Klippe geworffen worden, nach deren Ubersteigung das schönste Land entdeckt, sich daselbst mit seiner Gefährtin verheyrathet, aus solcher Ehe eine Familie von mehr als 300. Seelen erzeuget, das Land vortrefflich angebauet, durch besondere Zufälle erstaunens-würdige Schätze gesammlet, seine in Teutschland ausgekundschafften Freunde glücklich gemacht, am Ende des 1728sten Jahres, als in seinem Hunderten Jahre, annoch frisch und gesund gelebt, und vermuthlich noch $z u$ dato lebt, entworffen Von dessen Bruders-Sohnes-Sohnes-Sohne, Mos. Eberhard Julio, Curieusen Lesern aber zum vermuthlichen Gemüths-Vergnügen ausgefertiget, auch par Commission dem Drucke übergeben Von GISANDERN.

12. Grohnert correctly maintains that volumes three and four exhibit a "Schwund an künstlerischer Geschlossenheit und die Zunahme an Irrationalismen" (Dietrich Grohnert, "Robinson zwischen Trivialität und Sozialutopie. Bemerkungen zu Entstehung und Autorenabsicht deutscher Robinsonaden," Wissenschaftliche Zeitschrift der Pädagogischen Hochschule "Karl Liebknecht" Potsdam 16 [1972]: 418). Of the four volumes, volume one has received the most attention, from Achim von Arnim's reworking of it as "Albert und Concordia" and "Albert diktiert weiter" in Der Wintergarten (1809) to the Reclam edition which includes only the first volume of Schnabel's novel (Johann Gottfried Schnabel, Insel Felsenburg, ed. Volker Meid and Ingeborg Springer-Strand. [Stuttgart: Reclam, 1979]).

13. Defoe puts these words into Robinson Crusoe's mouth to describe desire (Defoe, Robinson Crusoe, p. 193).

14. I have elsewhere suggested that when male characters recount their histories to a male audience they are enacting a male bonding of sorts. When fictional males bond, they renegotiate fictions of masculinity. See Lynne Tatlock "Männliches Objekt, weibliches Subjekt: Zur Geschlechterdifferenz in Johann Beers Doppelroman," in Weißenfels als Ort literarischer und künstlerischer Kultur im Barockzeitalter, ed. Roswitha Jacobsen, Chloe. Beihefte zum Daphnis, 18 (Amsterdam: Rodopi, 1994), 209-30 and Lynne Tatlock, "Ab ovo: Reconceiving the Masculinity of the Autobiographical Subject," in The Graph of Sex and the German Text: Gendered Culture in Early Modern Germany, 1500-1700, ed. Lynne Tatlock and Christiane Bohnert, Chloe. Beihefte zum Daphnis, 19 (Amsterdam: Rodopi, 1994), 383-412.

15. August Langen, Der Wortschatz des deutschen Pietismus, $2 \mathrm{~d}$ ed. (Tübingen: Niemeyer, 1968), p. 365. 
16. L. Christoph de Hellwig, Neu-entdeckte Heimlichkeiten der Frauenzimmer (Frankfurt and Leipzig, 1719), p. 200. Quoted by Anke Meyer-Knees, Verführung und sexuelle Gewalt: Untersuchung zum medizinischen und juristischen Diskurs im 18. Jahrhundert, Probleme der Semiotik, 12 (Tübingen: Stauffenburg Verlag, 1992), p. 34. Johann August Oehme had similar advice for women: "Weit rathsamer ist es, wenn sich dieselben in Ehestand begeben, um durch die darinne enthaltene Liebes-Ergötzlichkeiten dem bevorstehenden grössern Ubell abzuhelffen, denn auff diese Weise kan die Gesundheit auff die angenehmste Art hergestellet werden" (Johann August Oehme, Sophia oder weibliche Klugheit, commentary and glossary by Hans-Joachim Poeckern [1742; reprint, Leipzig: Edition Leipzig, Verlag für Kunst und Wissenschaft, 1983], p. 203).

17. Danielle Jacquart and Claude Thomasset, Sexuality and Medicine in the Middle Ages, trans. Matthew Adamson (Princeton: Princeton University Press, 1988), p. 83. Originally published as Sexualité et savoir médical au Moyen Age (Paris: Presses Universitaires de France, 1985). Jacquart and Thomasset refer here to Avicenna's Canon. The authors also cite Ishâq ibn-'Imrân's treatise on melancholy where it is claimed that "on the one hand, too rigorously an ascetic life risks causing the illness of melancholy; on the other hand, this illness can find relief thanks to coitus" (Jacquart and Thomasset, Sexuality, p. 83).

18. Paradise Lost (8.265-66), quoted by James Grantham Turner, One Flesh: Paradisal Marriage and Sexual Relations in the Age of Milton (Oxford: Clarendon Press, 1987), p. 239. Turner further points out that upon viewing the fruit trees of Eden, appetite stirs within Adam analogous to sexual arousal. "Even before the creation of Eve," Turner maintains, "Adam discovers that erotic love includes and surpasses every other response to the world" (Turner, One Flesh, p. 239).

19. Unless otherwise stated, the following edition of Schnabel's Kavalier is quoted: Johann Gottfried Schnabel, Der im Irrgarten der Liebe herumtaumelnde Kavalier, ed. and afterword Hans Mayer (Munich: Rogner \& Bernhard, 1968), p. 187.

20. The "Lebens-Beschreibung" of Don Cyrillo de Valaro, the last surviving member of a Felsenburg settlement from the previous century, offers a dystopic vision of life on the island without women. Indeed, to Don Cyrillo's horror, the lack of women had led some of the men to copulate with the apes: "daß meine 3. noch übrigen Lands-Leute seit etlichen Monathen 3. Aeffinnen an sich gewöhnet hätten, mit welchen sie sehr öffters, so wohl bey Tage als Nacht eine solche schändliche Wollust zu treiben pflegten" (1:598).

21. Fischer, "Der moralische Naturzustand," p. 81.

22. In fact even Lemelie does not separate pleasure from reproduction. His suggestion is framed as a proposal for effectively populating the island.

23. Genesis 1:28.

24. Johann Heinrich Zedler, Großes vollständiges Universal-Lexicon aller Wissenschaften und Künste (1732-50), s.v. "Ehestand."

25. Thomas Laqueur, Making Sex: Body and Gender from the Greeks to Freud (Cambridge, Mass.: Harvard University Press, 1990), p. 49. 
26. Meyer-Knees quotes Pierre Roussel (Physiologie des weiblichen Geschlechts [Berlin, 1786], pp. 115-16): “Einen so höchst wichtige Art unsrer natürlichen Pflichten, durfte nicht vom Eigensinn oder unsern willkührlichen EntschlieBungen abhängen, wir mußten nothwendig durch einen solchen Naturtrieb dazu angetrieben werden, der alle Betrachtungen und Räsonnements unnütze machte" (Meyer-Knees, Verführung und sexuelle Gewalt, p. 31).

27. Schnabel's text thus supports Foucault's assertion in The History of Sexuality that we are mistaken if we understand the bourgeoisie to have repressed sexuality. Foucault maintains rather that "what was involved was not an asceticism, in any case not a renunciation of pleasure or a disqualification of the flesh, but on the contrary an intensification of the body, a problematization of health and its operational terms: it was a question of techniques for maximizing life. The primary concern was rather the body, vigor, longevity, progeniture, and descent of the classes that 'ruled.'" Michel Foucault, An Introduction, vol. 1 of The History of Sexuality, trans. Robert Hurley (New York: Random House, 1978), pp. 122-23.

28. In Johann Christoph Ettner's Die unvorsichte Hebamme, a fictitious midwife explains the necessary conditions for conceiving twins:

Ich halte davor / daß wann so wol der Mann starck/ als auch die Frau guter Art ist / und eine willige Mutter hat; daß wofern die Caressen verdoppelt werden/ die Mutter im Anziehen zweyfache Vermischung des Saamens mache / und einige Eyer in denen Mutterhörnern / ausser daß der Saamen des Weibes zweymal (wie es denn wol zuweilen in einem Beyschlaf 3. und mehrmal auf Seiten des Weibes zu geschehen pflegt) in die Mutter geworffen werde / von des Mannes Saamen ausgehenden Geist imprægnirt werden / und sodann so wol als die andere Frucht das (rudimentum) Anfang der Nabelschnur an die Mutter setze: Diejenigen Frauen die Zwillinge / Dreylinge und mehr Kinder getragen haben / sagen: Daß sie zu der Zeit/ wann sie caressirt worden sind / erstlich so eine ungemeine Lust empfanden / daß sie nicht gewust / wie ihnen geschehen / und haben eine Zeitlang gleichsam entzuckt gelegen" (Johann Christoph Ettner, Des Getreuen Eckarths Unvorsichtige Heb-Amme [Leipzig: Johann Friedrich Braun, 1715], pp. 441-42).

29. Foucault, Introduction, p. 124.

30. David Trotter, Circulation: Defoe, Dickens, and the Economies of the Novel (New York: St. Martin's Press, 1988), p. 35.

31. Keith Tribe, Governing Economy: The Reformation of German Economic Discourse, 1750-1840 (Cambridge: Cambridge University Press, 1988), p. 31.

32. Tribe, Governing Economy, p. 21. Tribe refers here specifically to Wilhelm von Schröder's (1640-88) Fürstliche Schatz- und Rentkammer (1686). Tribe's larger point is that "'the state' as a separate entity from the ruler's household cannot be said to exist" (p. 21) and furthermore that rulers of early modern states understood the state to be a household that they were to manage. The state was thus treated as "a generic term for socio-political organization" (p. 28). 
33. Unless otherwise stated, the following edition of Süßmilch's Die göttliche Ordnung is quoted: Johann Peter Süßmilch, Die göttliche Ordnung in den Veränderungen des menschlichen Geschlechts, aus der Geburt, Tod, und Fortpflanzung desselben (Berlin: J. C. Spener, 1741).

34. Frederick of Prussia, L'Antimachiavel, in Oeuvres de Frédéric le Grand (Berlin: Rodolphe Decker, 1848), 8:77. "The might of a state does not at all consist in the extent of its lands, nor in the possession of vast wastes or immense deserts but in the wealth of its inhabitants and in their number. The interest of a prince is thus to populate a country, to make it flourish, not to devastate and destroy it." (Quoted and translated by Tribe, Governing Economy, p. 19.) Paul Sonnino lists the two original editions as Examen du Prince de Machiavel (The Hague: Van Duren, 1741 [1740]) and Essai de critique sur le Prince de Machiavel (The Hague: Paupie, 1740); see Frederick of Prussia, The Refutation of Machiavelli's "Prince" or Anti-Machiavel, introd. and trans. and notes by Paul Sonnino (Athens: Ohio University Press, 1981), p. 21. It is unclear whether Süßmilch had actually read Frederick the Great's work when he wrote his own treatise; he in fact writes as if Frederick William were still the reigning monarch.

35. Veit Ludwig von Seckendorff, Teutscher Fürsten-Stat (Frankfurt a. M.: Thomas Matthias Götz, 1656), p. 95.

36. Julius Bernhard von Rohr, Compendieuse Haußhaltungs-Bibliotheck (Leipzig: Johann Christian Martini, 1716), p. 47.

37. Frances Ferguson, "Malthus, Godwin, Wordsworth, and the Spirit of Solitude," in Literature and the Body: Essays on Populations and Persons, ed. Elaine Scarry, Selected Papers from the English Institute, n.s., 12 (Baltimore: Johns Hopkins University Press, 1988), pp. 106-24, especially pp. 106-10. Malthus argued that "the power of population is indefinitely greater than the power in the earth to produce subsistence for man. Population, when unchecked, increases in a geometrical ratio. Subsistence increases only in an arithmetical ratio. A slight acquaintance with numbers will shew the immensity of the first power in comparison of the second" (Malthus, An Essay on the Principle of Population, p. 20). For a discussion of population theory before Malthus, see Charles Emil Stangeland, Pre-Malthusian Doctrines of Population: A Study in the History of Economic Theory (1904; reprint, New York: Augustus M. Kelley, 1966).

38. Justi, Grundsätze der Policeywissenschaft, pp. 76-77. Justi's work is based on that of political economists from the preceding 100 years like Paul Jacob Marperger (Wohlgemeynter Vorschlag von Verheyrathung Armer Bürgers Töchter und Dienst-Mägde [1717]), Justus Christoph Dithmar (Einleitung in die Oeconomische-Policei-und Kameralwissenschaften [1731]), Johann Hermann Fürstenau (Gründliche Anleitung zu der Haushaltungs-Kunst [1736]), Julius Bernhard von Rohr (Compendieuse Haußhaltungs-Bibliotheck [1716], Einleitung zur StaatsKlugheit [1718]), Johann Veit von Seckendorff (Teutscher Fürsten-Stat [1656]), Wilhelm von Schröder (Fürstliche Schatz- und Rent-Cammer [1686]), and Johann Joachim Becher (Politischer Discurs Von den eigentlichen Ursachen/deß Auf-und 
Abnehmens/der Städt/Länder und Republicken [1668]). His work, Justi claims, differs from that of his predecessors in that it offers "das erste System einer Policey ..., worin diese Wissenschaft vollständig, von andern Wissenschaften abgesondert und in einem, auf die Natur der Sache gegründeten, Zusammenhange erscheinet. Der gemeinste Fehler in Ansehung der Policey ist Zeither gewesen, daß man dieselbe mit der Staatskunst in eine Brühe geworfen und unter einander abgehandelt hat" (Justi, Grundsätze der Policeywissenschaft, sig. *3r-*3v).

39. Stephan Buchholz, Recht, Religion und Ehe: Orientierungswandel und gelehrte Kontroversen im übergang vom 17. zum 18. Jahrhundert, Studien zur Europäischen Rechtsgeschichte, no. 36 (Frankfurt a. M.: Vittorio Klostermann, 1988), p. 408.

40. Johann Joachim Becher, Politischer Discurs Von den eigentlichen Ursachen/ deß Auf- und Abnehmens/der Städt/Länder und Republicken/in specie, Wie ein Land Volckreich und Nahrhaft zu machen/ und in eine rechte Societatem civilem zu bringen (Frankfurt: Johann David Zunner, 1668), p. 2.

41. See Mack Walker, The Salzburg Transaction: Expulsion and Redemption in Eighteenth-Century Germany (Ithaca, N.Y.: Cornell University Press, 1992).

Friedrich Wilhelm I fostered the teaching of what came to be known as "Cameralwissenschaft" at the university. On July 24, 1727, he commanded that Simon Peter Gasser, professor of law, be appointed to a chair in "Oeconomie, Policey und Cammersachen" at the university in Halle. That same year the historian J. C. Dithmar was appointed professor of "Kameral-ökonomie und Polizeiwissenschaft" at a second Prussian university, Frankfurt an der Oder (Tribe, Governing Economy, pp. 42-43). When his father, Friedrich I, founded the Friedrichs-Universität in Halle 1692, he appointed the cameralist Veit Ludwig von Seckendorff its chancellor. Seckendorff died, however, before the university was officially opened in 1694 .

42. Johann Gottfried Schnabel, Nachricht, welchergestalt die Salzburgischen Emigranten in Stolberg am 2. bis 4. August 1732 empfangen wurden [pamphlet] (n.p.: n.p., 1733).

43. Walker, The Salzburg Transaction, pp. 70-71.

44. Michel Foucault, The Order of Things: An Archaeology of the Human Sciences (New York: Pantheon Books, 1971), pp. 74-75.

45. Justi, Grundsätze der Policeywissenschaft, p. 87.

46. Knopf, Frühzeit des Bürgers, p. 93. The special province of "Policey" is in Justi's view "das gesamte Vermögen des Staats durch gute innerliche Verfassungen zu erhalten und zu vergrössern und der Republik alle innerliche Macht und Stärke zu verschaffen, deren sie nach ihrer Beschaffenheit nur immer fähig ist. Zu dem Ende suchet sie die Länder zu cultiviren, den Nahrungstand zu verbessern und gute Zucht und Ordnung in dem gemeinen Wesen zu erhalten" (Justi, Grundsätze der Policeywissenschaft, sig. *3v-*4r).

47. Grohnert has in fact maintained that Schnabel's novel itself is a product of mercantilism, that is, that the entire "Robinson-Welle" to which "Insel Felsenburg" belongs derives from "ebenfalls merkantilen und schließlich sehr 


\section{Lynne Tatlock}

profitablen verlegerischen Manipulationen mit einem sich seit dem Erfolg des 'Robinson Crusoe' abzeichnenden Lesergeschmack" (Grohnert, "Robinson zwischen Trivialität und Sozialutopie," p. 413).

48. Knopf, Frühzeit des Bürgers, p. 94.

49. At the conclusion of the first volume the editor renews his promise of readerly pleasure, assuring his public that the second volume will satisfy the curiosity piqued in the first part: "Es soll von ihrer künfftigen Aufführung und Vereheligung, im Andern Theile dieser Felsenburgischen Geschicht, des geneigten Lesers curiosität möglichste Satisfaction empfangen" (1:473). As yet another guarantee, the advertisement that appears on the following three pages promises a sequel on the condition that the first one has created pleasure ("einiges Vergnügen erwecken" [1:475]), that is, aroused and satisfied the reader's curiosity.

50. Foreword to Henry Fielding's Joseph Andrews (1742), quoted by Günther Blaicher, Freie Zeit-Langeweile-Literatur. Studien zur therapeutischen Funktion der englischen Prosaliteratur im 18. Jahrhundert, Quellen und Forschungen zur Sprach- und Kulturgeschichte der germanischen Völker, n.s., 69 (193) (Berlin: de Gruyter, 1977), p. 119. Blaicher argues that the eighteenth-century English novel justifies itself to a leisure-class readership by insisting on the therapeutic value of the stimulated and active imagination. 


\title{
13. "Selbstbeschmutzung": Der Gelehrte und sein Leib/Körper in Adam Bernds Eigene Lebens-Beschreibung (1738)
}

\author{
Stephan K. Schindler
}

Die dekonstruktive Kritik an der traditionellen Psychoanalyse, der IchPsychologie und der transzendentalen Subjektphilosophie erreichte bereits in den siebziger Jahren ihren zumindest rhetorischen Höhepunkt. Am Leitfaden des wünschenden Leibes und seiner Realitätsproduktionen entwickelten der französische Philosoph Gilles Deleuze und der italienische Psychiater Félix Guattari eine psychokybernetische Analyse des Menschen, mit der sie die repressive Souveränität des in Familie, Gesellschaft und Geschlecht territorialisierten Subjektes zu unterwandern suchten. So ersetzten sie die in totalitäre Mangellogik ödipalisierte Seele mit sogenannten "Wunschmaschinen"1, die vom ziellosen Chaos libidinöser Energien, willkürlicher Organverkoppelungen und gestörter Informationen gesteuert werden:

Es funktioniert überall, bald rastlos, dann wieder mit Unterbrechungen. Es atmet, wärmt, ißt. Es scheißt, es fickt. Das Es. . . . überall sind es Maschinen im wahrsten Sinne des Wortes: Maschinen von Maschinen, mit ihren Kupplungen und Schaltungen. Angeschlossen eine Organmaschine an eine Quellemaschine: der Strom, von dieser hervorgebracht, wird von jener unterbrochen. Die Brust ist eine Maschine zur Herstellung von Milch, und mit ihr verkoppelt die Mundmaschine. Der Mund des Appetitlosen hält die Schwebe zwischen einer Eßmaschine, einer Analmaschine, einer Sprechmaschine, einer Atmungsmaschine (Asthma-Anfall). In diesem Sinne ist jeder Bastler; einem jeden seine kleinen Maschinen. ${ }^{2}$

Um das Unbewußte und damit den Leib aus der Normativität gesellschaftlicher und familiärer Beschriftung zu befreien, rehabilitierten Deleuze und Guattari die Partialobjekte und ihren polymorphperversen Gebrauch. Es ging ihnen also, vereinfacht gesagt, um eine Aufwertung all jener lustvollen oder schmerzhaften Leibeszustände, 
die wir täglich erfahren, aber zugleich als anderen, nämlich exaltierten und unnützen Körper deklassieren. Insbesondere Körperproduktionen, die nicht zur Erhaltung der Gattung oder der Arbeitskraft dienen, gelten noch heute als "krank" oder "pervers", was z. B. die Pathologisierung der prämenstrualen Depression (engl. PMS), der Eßlust, der Homosexualität oder der Masturbation hinreichend illustriert.

Seitdem die neuzeitlichen Wissenschaften die Seele als Agenten der Vergesellschaftung radikal vom Körper abgetrennt haben, sind wir auch von unserem Leib total entfremdet, den wir als objektivierten Körper der Sprache, dem Wissen und der instrumentellen Manipulation anderer, z. B. den Medizinern und Psychiatern, überantworten. ${ }^{3}$ Dennoch sind die Erfahrungen mit dem abgedrängten Leib jenseits seiner gesellschaftlich-reproduktiven Nützlichkeit nicht völlig sprachlos, sondern zirkulieren als "volles Sprechen" in der poetischen und psychotischen Rede, auf die sich Deleuze und Guattari explizit beziehen. So zitieren sie neben literarischen Klassikern auch die Denkwürdigkeiten eines Nervenkranken ${ }^{4}, \mathrm{~d}$. h. die Imaginationen des transsexuellen Senatspräsidenten beim Oberlandesgericht Dresden Dr. jur. Daniel Paul Schreber, als Zeugnis für ein "anderes" Verständnis des eigenen Körpers: "Präsident Schreber hat die Himmelsstrahlen im Arsch. Himmelsarsch. Und seid ohne Sorge, es funktioniert; Präsident Schreber spürt etwas, produziert etwas, und vermag darüber hinaus dessen Theorie zu entwickeln. Was eintritt sind Maschineneffekte, nicht Wirkungen von Metaphern" ${ }^{5}$.

Allen Unkenrufen der Philosophen zum Trotz ist diese ästhetisierte Aneignung der somatischen Selbstauslegung des "Kranken" nach einem von ihm erstellten, "irrationalen" Kausalitätsmodell nicht das Ende des wissenschaftlichen Diskurses. ${ }^{6}$ Ein Blick in die Geschichte der deutschen Psychologie genügt, um zu erkennen, daß eine ähnliche Beschreibung des eigenen entrückten Leibes und dessen ebenso "verrückte" Ätiologie den Beginn der modernen Seelenkunde initiieren. Der Bildungsbürger Schreber hat nämlich einen interessanten Vorläufer in der Frühaufklärung: den evangelischen Prediger, Gelehrten und Selbsterforscher Adam Bernd.

Dessen 1738 veröffentlichte Eigene Lebens-Beschreibung ${ }^{7}$ präsentiert eine durchaus mit Schreber vergleichbare autobiographische Leibesinspektion, die ebenfalls im Analen die Wahrheit des Subjekts sucht, denn auch Bernd hat "Himmelsstrahlen" im Hintern, auch für ihn deutet Gottes Fingerzeig auf die Därme. Doch während Schrebers kosmologische Organphantasien zum berühmtesten deutschen Fall von Paranoia aufsteigen ${ }^{8}$, wird der als "Zwangsneurotiker" ${ }^{9}$ titulierte Bernd bereits von Max Dessoir als "der erste dekadente Psycholog" 
gewürdigt. ${ }^{10}$ Dieser Unterschied zwischen psychotischem Patienten und neurotischem Gelehrten ergibt sich allein schon daraus, daß Schreber das "mißratene" Produkt von genau jenen disziplinarischen Körpertechnologien ist, die erst im Anschluß an Bernds Irritationen mit dem eigenen Leib z. B. in Form der psychologischen Pädagogik erfunden werden. ${ }^{11}$ Zudem schreibt Bernd in einer Zeit, in der die verrückte und akademische Rede in der Selbstbeobachtung noch nicht absolut getrennt sind, mußte doch die eine der anderen erst das Anschauungsmaterial für die Analyse des Ichs besorgen, wobei die Unsicherheit über die Differenz zwischen neu entdeckten, sprachlosen Leibeszuständen und bloßen "Einbildungen" dazu führte, die philosophische Selbsterkenntnis nach Maßgabe der empirischen Psychologie verobjektivieren zu wollen. ${ }^{12}$

Gegenüber Schrebers phantasmatischer Körpertheorie, die sich allein schon deshalb als Alptraum der medizinisch-psychiatrischen Vernunft darstellt, weil sie deren Ordnungskategorien (Geschlechtsidentität, Anatomie, Physiologie, Realitätskonzept) eigenwillig vertauscht, hält sich Bernd gerade umgekehrt an die zu seiner Zeit entwickelte Rationalisierung des Körpers. Was die Lektüre von Bernds Schrift heute so interessant gestaltet, ist nicht nur seine Stellung innerhalb der Konstruktionsgeschichte des modernen Subjektbegriffs in Erfahrungsseelenkunde und bürgerlicher Autobiographie ${ }^{13}$, sondern insbesondere sein Bemühen, die erfahrene Sinnlichkeit des eigenen Leibes in wissenschaftliche Metaphern des theoretischen Modells "Körper" zu übersetzen. Dabei stößt Bernd bereits auf das fundamentale Problem der Aufklärung: Im Akt seiner vernünftigen Selbstbegründung versucht das Subjekt den eigenen Leib als das Andere der Vernunft von sich abzuspalten und als vergeistigte Natur, aber zugleich fremden Körper wieder anzueignen. Im Übergang vom irrationalen Sündenleib der religiös legitimierten und gesellschaftlich durchgesetzten Triebkontrolle zum physiologisch-psychologischen Objekt der Selbsterforschung entsteht so der "Körper" als Text, der die Entfremdung vom eigenen Leib dokumentiert.

Nach seiner öffentlichen Diskriminierung als Häretiker durch die orthodoxe Amtskirche gibt Adam Bernd seine Eigene Lebens-Beschreibung heraus. Der Sohn eines Breslauer Gemüsebauers und einer Pietistin schildert seinen beruflichen Auf- bzw. Abstieg im theologischen "Bermuda-Dreieck" Breslau, Leipzig, Halle und beschreibt seine intellektuelle Verstrickung in Katholizismus, Pietismus und aufgeklärter Gelehrsamkeit, was ihm letztlich den Vorwurf des Indifferentismus und das Ende seiner Karriere einbringt. ${ }^{14}$ Doch Bernds Autobiographie unterscheidet sich sowohl von der typisierten Gelehrtenbiographie 
seines Zeitgenossen Christian Wolff als auch vom vorbildlichen Exempel der pietistischen Erbauungsliteratur gerade dadurch, daß der $\mathrm{Au}$ tor nur von einem "miserablen und Jammer-vollen Leben" (S. 16) zu berichten weiß, welches maßgeblich von den zyklisch wiederkehrenden "Krankheiten, und übele Dispositiones meines Leibes ... GemütsPlagen und Anfechtungen" (S. 17) geprägt ist. Obwohl vielleicht anfänglich als Apologie konzipiert, macht schon der Untertitel deutlich, daß es Bernd um die "Entdeckung" und "Beschreibung" einer "noch unbekannten Leibes- und Gemüths-Plage" geht mit dem Ziel, die "Unwissenden" zu unterrichten, die "Gelehrten" zum "Nachdencken" anzuregen, die "Sünder" abzuschrecken und die "Betrübten" zu trösten (Titel).

Der Komplexität dieser didaktischen Ausrichtung folgt auf mehreren hundert Seiten die verwirrende tagebuchartige Schilderung eines Lebens als psychosomatische Krankengeschichte, in der sich alle zeitgenössischen Bilder einer aus den Fugen geratenen Körper-SeeleVerbindung zu einem Horrorkabinett der Anomalien versammeln. Bernd leidet hauptsächlich an Störungen des Magen-Darm-Traktes, der Nieren und der Blase, was er ausführlich darstellt: Er hat häufig Verstopfungen, Blähungen oder Durchfall, wohl deshalb auch starke "Hæmorrhoides" und sogar öfter "Sedes cruentatæ [Stuhlgänge mit Blut]" (S. 374), darüberhinaus kann er seinen Harndrang nicht kontrollieren; schließlich wird er auch von verschiedenen Fiebern, "Spasmi und convulsivischen Bewegungen im Leibe" (S. 309) heimgesucht. Diese somatischen Beschwerden werden von psychischen Irritationen begleitet, denn Bernd berichtet auch von Angstzuständen, die sich zu chronischen Depressionen ausweiten. Seine von ihm selbst als solche ausgewiesenen "Einbildungen" manifestieren sich in verschiedenen Zwangsvorstellungen, die schließlich in der Idee gipfeln, "bei lebendigem Leib zu verwesen" (S. 255). Mit dieser Entblößung seines "schmutzigen" Selbsts betritt Bernd autobiographisches Neuland, denn er veröffentlicht eine Intimsphäre, die von der manifesten Skatologie bis hin zum vorgestellten Suizid das Makel der öffentlichen Schande trägt. ${ }^{15}$ Während autobiographische Bekenntnisse des 19. und 20. Jahrhunderts den verdrängten kreatürlichen Leib gerade durch die Benennung des gesellschaftlich Ausgesparten hinter seiner medizinischen Bevormundung wieder sichtbar machen ${ }^{16}$, versucht Bernd die für seine Zeit überaus detailliert beschriebenen körperlichen und seelischen "Peinlichkeiten" im Rahmen medizinischer wie moderner anthropologischer Theoriebildung zu erklären.

Mit cartesianischem Gestus fragt Bernd so beharrlich nach dem Nexus zwischen Körperdisfunktion und seelischen Empfindungen, 
daß er auf ein zeitgenössisches Defizit trifft, denn weder Medizin noch Theologie können ihm bei seinen Leiden den erwarteten ätiologischen Rat geben: "ein schwaches Haupt mit seinen Ursachen ist und bleibt ein Geheimnis, das noch kein Philosophus und Arzt ganz ausstudiret, und die Würkungen desselben a priori völlig demonstriret" (S. 134) hat. ${ }^{17}$ Deshalb muß Bernd immer wieder auf das zurückgreifen, was er "durch eigene Erfahrung" (S. 5) an seinem Körper registriert. Damit macht er den entscheidenden Schritt von der starren Typologie der barocken Affektenlehre hin zur individualisierten dynamischen Fallbeschreibung der empirischen Psychologie, womit er sich gleichsam auf der Höhe zeitgenössischer Diskurse befindet. ${ }^{18}$ In seinem Vorschlag zur brandenburgischen Medizinalordnung hatte bereits Leibniz 1685 gefordert, Medizin und Naturkunde nicht auf Urteile a priori zu gründen, sondern auf das, was "aus der erfahrung vermittelst fleißiger beobachtung entdecket" wird. ${ }^{19}$ Während Leibniz noch an die administrative Fremdbeobachtung zur Volkshygiene im Sinne der MedizinalPolizey dachte, wendet Bernd den ärztlichen Blick auf den eigenen Leib an und überführt das Gesehene/Gefühlte in die Nosographie, indem er minuziös alle Leibeszustände aufschreibt:

Ich war 1) verstopft im Leibe, 2) hatte keinen Appetit zu Essen und Trinken, 3) stieß es mir den ganzen Tag auf, 4) der Ober-Teil des Magens war geschwollen, 5) es drückte mich auf der rechten Brust, und fieng mich es auch an zuweilen auf derselben $\mathrm{zu}$ stechen, so gar, daß ich des Nachts nicht auf der rechten Seite liegen kunte, 6) wenn ich mich kaum des Abends ins Bette gelegt hatte, so brach der Schweiß Haufen-Weise heraus, und währte bis an Morgen. 7) Ich kunte vor Schwindel auf der Gasse nicht mehr gehen, 8) öfters spürte ich starkes Herz-Klopfen, 9) das Fleisch fiel zusehends vom Leibe, und kamen alle Adern hervor, 10) in vola und in der Fläche der Hände und der Füße hatte ich solche Hitze, . . . 11) nach der Mahlzeit war der rechte Backe, und das rechte Ohr-Läpgen Feuerrot, und die linke Seite hingegen blaß (260).

Mit dieser Liste von Fehlfunktionen, die uns heute als typische Unregelmäßigkeiten im Stoffwechselprozeß erscheinen, wendet Bernd Methoden der rationalen Körperanalyse an, denn er versucht komplexe physiologische Prozesse und physiognomische Erscheinungen mittels konkret-objektiver Beschreibung lesbar zu machen. ${ }^{20}$ Er zerlegt die vom Wohlbefinden abweichenden Körperproduktionen in geordnete empirische Daten, indem er sie als einzelne Symptome anatomisch lokalisiert. Bernd kann jedoch nicht nur die naive Arztfrage, "Wo tut es denn weh?", befriedigend beantworten, er bemüht sich auch zum 
Unwillen seiner Ärzte um eigene diagnostische Vorschläge. Neben ausgedehnten ernährungsphysiologischen Erklärungen für seine körperlichen Gebrechen konstruiert er mögliche Wechselbeziehungen $\mathrm{zu}$ seinen psychischen Leiden. Letztere sind aber für Bernd terminologisch äußerst schwer zu bestimmen, weshalb er sie entweder im Rückgriff auf religiöse Deutungsmuster als "Sünden-Angst", "HöllenAngst", "Todes-Angst" (S. 230) etikettiert oder in ausgedehnten Fallbeschreibungen (seine Messerphobie, seine Analphantasien oder Selbstmordwünsche) episch breit darstellt.

Um den fragmentierten Körper und dessen verwirrte Seele wieder in ein Funktionsganzes zu bringen, wendet sich Bernd an die Sinngebung medizinischer Abstraktion und subsumiert das Zusammenspiel der Symptome unter der Kranheitsbezeichnung: "Melancholie". ${ }^{21}$ Hierbei vermischt er in eklektischer Manier zeitgenössische, zum Teil antagonistische Erklärungsmodelle naturwissenschaftlicher, moralphilosophischer und physikotheologischer Provenienz ${ }^{22}$ : Er beruft sich auf die "schwarze Galle" (S. 6) der traditionellen Humoralpathologie und Affektenlehre, die "Lebens-Geister" der vitalistischen "Pneumatic" oder psychologischen Physiologie (S. 156-67) und die Einbildungen der "Melancholia hypochondriaca" (S. 178, 198, 376). Auf der Suche nach monokausalen Erklärungen für seine vielfältigen Symptome gelangt Bernd zum komplexen Mechanismus von physiologischen, diätetischen oder psychologischen Krankheitsursachen. Demnach verläuft seine Krankheit verkürzt nach folgendem Schema: Eine äußere Sensation evoziert über die Sinne einen Affekt (z. B. Furcht), der wiederum mittels der Nerven die "Lebens-Geister" und durch sie auch die körperlichen Säfte in einem Maße infiziert (S. 159-60), daß der Leib mittels Durchfall geschwächt wird, was ihn wiederum sensibel für die "imaginatio involuntaria" (z. B. die Selbstmordvorstellungen) macht, woraus sich dann erneut Rückkoppelungseffekte ergeben.

Diese an die organische Leib-Seele-Konzeption des Halleschen Arztes Georg Ernst Stahl erinnernde Konzeption ${ }^{23}$ verbindet Bernd mit philosophischen Konzepten zur Erklärung von Krankheitsursachen wie z. B. Nicole Malebranches okkasionalistischer Theorie der Einbildungskraft. Dessen Anekdoten zur pränatalen Identitätsbildung-die physio-psychische Konstitution des Embryos via mütterlichen Säftekreislaufs-wendet Bernd auf sich selbst an und glaubt seine eigene "kränkliche verderbte übele Leibes-Dispositio aus Mutter-Leibe" (S. 23) bekommen zu haben. Bei solchem Determinismus lassen sich dann selbst die Einbildungen des Kranken auf physiologische Grundlagen rückbeziehen. Doch Bernd ist ein Meister in der willkürlichen Verknüpfung sich widersprechender Theoreme und bastelt wie Schre- 
ber an Erklärungen, die auf seinen Fall "passen". So insistiert er darauf, daß die "malade imaginaire" (S. 258) für den Hypochonder (bzw. für Bernd selbst) deshalb eine "reale" Krankheit ist, weil "ein vernünftiger Mensch" sie als solche per logischen Schluß folgert: "Wer sich einbildet, daß er krank ist, der statuiret und schließet, daß er krank sei" (S. 260). Der Versuch, Rationalität in die Selbstauslegung des Körpers zu bringen, impliziert hier die grundsätzliche Übersetzbarkeit von Empfindungen in medizinisch definierte Symptome, wobei nur letztere auf den Prüfstand der Vernunftwahrheiten gelangen. Bernd behauptet nämlich, daß nicht die Einbildung als subjektive Leiberfahrung "wahr" oder "falsch" sein kann, sondern nur die "Rationes" und "Conclusion" (S. 260) der diagnostischen Argumentation. Demnach indiziert der Begriff "Einbildung" lediglich eine Wissenslücke der Ätiologie, was u. a. darin liegt, daß "die Medici in Benennung der Krankheiten nicht eines Sinnes" (S. 257) sind. Mit dieser Kritik löst Bernd diverse Krankheitsbilder der Psychosomatik und Psychopathologie (vom Durchfall bis zu seinen unwillentlichen Selbstmordnöten) aus der Eigenverantwortlichkeit des Kranken. Allerdings unterminiert er selbst wieder seine durchaus revolutionären Einsichten zur medizinischen Ethik der Arzt-Patient-Beziehung, indem er Krankheiten einen übergeordneten Sinn unterstellen will. Seine rationalistischnaturalistische Ätiologie und sein materialistischer Begriff der Seele, die er im Gehirn als Schaltzentrale der "Nerven und Fibren" (S. 152) lokalisiert, führen den Prediger nämlich in eine theologische Sackgasse.

Da er den Teufel als Krankheitsverursacher explizit ablehnt und seine Gemütsplage "leichte aus der Natur und aus den Kräften der Imagination" (S. 40) erklären kann, müßte der psychochemische Mechanismus der Leib-Seele-Konnexion auch zwangsläufig die Moralisierung der Seele überflüssig machen. Um nicht ganz in die Häresie abzurutschen, beruft sich Bernd auf die traditionelle Idee, daß psychophysiologische Prozesse religiöse Bedeutung haben. Einerseits soll die geschwächte Leibesdisposition erst die psychische Bereitschaft zum Sündigen hervorrufen, andererseits kann aber der Leib selbst mit Krankheiten auf die Sünden der Seele reagieren. Im Rekurs auf das pietistische Trauergebot proklamiert Bernd, "der Miltz ist der schärfste Moraliste auf Erden" (S. 170), was die somatisch evozierte Schwermut in eine göttliche Prüfung umwandelt. ${ }^{24}$ Dieser komplexen Vermischung von religiösem Krankheits- und physiologischem Sündenbewußtsein entspricht die in der Regel wenig erfolgreiche Therapie: Im Durcheinander von Aderlaß, diversen Diäten, Abführmitteln und Gebeten führt Bernd den geschwächten Zustand seines Körpers therapeutisch 
selbst herbei, perpetuiert so seine Krankheiten und damit auch sein Sündigen. Damit wird die Leibesinspektion zur Lebensaufgabe.

Was Bernd am eigenen Leib wahrnimmt bzw. erst produziert und mit Hilfe divergenter Klassifikationsmodelle zu systematisieren und dadurch zu kontrollieren versucht, läßt sich als Anfänge der empirischen Psychologie des frühen 18. Jahrhunderts oder Erfahrungsseelenkunde bezeichnen, die all jene Leibeserfahrungen archiviert, die mit der Symptomatologie religiöser oder populärphilosophischer Affektenlehren nicht mehr vollständig erfaßbar sind und die andererseits von der Schulmedizin als "Einbildungen" abgetan werden. ${ }^{25}$ Erst gegen Ende des 18. Jahrhunderts scheint Bernds Aufruf, "geistliche und leibliche Arznei-Mittel mit einander [zu] verknüpfe[n]" (S. 190), von den säkularisierten Seelenkundlern gehört zu werden. Die Begründer des seit 1783 erscheinenden Magazins zur Erfahrungsseelenkunde (C. F. Pockels, K. Ph. Moritz, M. Mendelssohn, M. Herz, u. a.) knüpfen an Bernds "psychologia empirica" an und schaffen Datenbänke der kranken Seelen. Indem die "philsophischen Ärzte" 26 die "Eintheilungen in der Arzneiwissenschaft auf die Erfahrungsseelenkunde" beziehen, erfinden sie neue Ordnungskategorien für die psychologische Anthropologie ("Seelennaturkunde", "Seelenkrankheitskunde", "Seelenzeichenkunde", "Seelendiätätik"). ${ }^{27}$ So wird eine neue wissenschaftliche Disziplin vom Menschen gewonnen, aber ein Leib verloren.

Die germanistische Forschung hat sich im Wesentlichen damit begnügt, Bernds Ätiologie der Melancholie im Rahmen pietistischer, ethischer und empirisch psychologischer Diskurse zu rekonstruieren, sich aber schwer damit getan, nach den gesellschaftlichen bzw. individuellen Ursachen seiner Körper-Seele-Krise zu fragen. ${ }^{28}$ Das liegt u. a. daran, daß selbst heutzutage die Psychopathologie mit ihrer Bestimmung der zyklothymen bzw. endogenen Depression kaum über Bernds Phänomenologie der Melancholie hinausgeht, beschreibt sie doch einen ähnlichen Symptomenkomplex: "1. Verstimmung 2. Vitalstörungen 3. Hemmung 4. Wahn 5. Suizidalität 6. körperliche Störungen, insbesondere Biorhythmusstörungen" ${ }^{29}$. Es ist schon erstaunlich, $\mathrm{daß}$ selbst die biogenetischen, psychoanalytischen oder psychologischsoziogenetischen Erklärungsmodelle mit ihren phänomenologischdeskriptiven oder anthropologisch-daseinsanalytischen Ansätzen wenig Neues darüber zu sagen haben, wie denn Melancholie ätiologisch zu bestimmen sei. ${ }^{30}$ Im Prinzip halten sie an Bernds impliziter Dichotomie von normalen versus pathologischen Zuständen fest und tappen wie der Frühaufklärer im Dunkeln, wenn sie nach den seelischen oder körperlichen Ursachen der Depression fragen. Es scheint, daß die 
"schwarze Galle" (oder wie immer man biochemische Prozesse nennen will), die affektive Reaktion auf die Umwelt oder die Suggestion immer noch den Kern depressiver Erkrankungen ausmachen. Da die Melancholie und in analoger Weise die Hypochondrie jedoch genau zu dem Zeitpunkt so massenhaft auftreten, wo sich die bürgerliche Gesellschaft formiert, gelten sie zugleich als die ersten modernen Zivilisationskrankheiten. ${ }^{31}$

So deutete bereits der Anthropologe Wolf Lepenies die Melancholie als "bürgerlichen Eskapismus" des 18. Jahrhunderts, als Kompensation für politische Machtlosigkeit oder als Effekt verinnerlichter Langeweile im Zuge der Isolierung bürgerlicher Individuen. ${ }^{32}$ Demgegenüber stellt sich aber die Frage, inwiefern das moderne Subjekt zwangsläufig im Zivilisationsprozeß "krank" wird, weil es dem Autonomiephantasma folgt, sich selbst in einer Gesellschaft konstituieren zu wollen, deren Ideologie der Selbstbestimmung spezifische Repressionsstrukturen impliziert. Zum einen gründet sich die bürgerliche Gesellschaft auf die Subjektproduktion in der institutionalisierten Fremdbestimmung (Familie, Schule, Arbeit), zum anderen meint sie mit Selbstbestimmung de facto Selbstbeherrschung. Im Zuge der Rationalisierung quasinatürlicher Prozesse wird nämlich das (männliche) Individuum zum "freien" Subjekt erst durch die Verinnerlichung des normativen Bezugs zur Außenwelt. In der Alltagspraxis soll das erzogene Subjekt eigenständig den Leib vernünftigen Regeln unterwerfen, um sich so adäquat auf die Versprechen bürgerlicher Selbstbestimmung (z. B. soziale Mobilität, Kapitalerwerb, Liebesheirat) vorzubereiten. Erst durch diese Disziplinierung des Leibes, die spätesten seit dem Ende des 17. Jahrhunderts alle Bereiche leiblichen Daseins (Hygiene, Ernährung, Arbeit, Sexualität) betrifft, wird aus dem Naturwesen Mensch das vernünftige bürgerliche Subjekt. ${ }^{33}$ Diese als Befreiung des Subjektes verstandene Transformation des "gesellschaftliche[n] Zwang[s] zum Selbstzwang" 34 hat im frühen 18. Jahrhundert eine herausragende Exemplarfigur: den Prediger als Prototyp des sozialen Aufsteigers, als diszipliniertes Vorbild für die bürgerliche Stadtgemeinde, als "Ursprung des modernen Intellektuellen . . reflektiert und klassenlos" 35 . Bernds Autobiographie veranschaulicht allerdings, inwiefern die bürgerlichen Autonomiebestrebungen, soweit sie sich auf Descartes' vernünftige Seele als Zentrum des Ichs beziehen, zwar Stand, Familie und geographischen Raum überwinden können, nicht jedoch den Leib, der sich gegen die Idealisierung des vernünftigen Selbsts sperrt.

Bernds Obsession, seinen Leib beobachten zu müssen, ergibt sich allein schon aus dem rationalistischen Auftrag des nosce te ipsum. Da weder der väterliche Name noch Gottes führende Hand die Identität 
des Individuums und sein Wohlbefinden hinreichend garantieren können, soll im Akt der Selbstbegründung jedes Subjekt sein eigenes Gemüt erforschen, soweit dieses in Affekten oder auf dem Körper lesbar und dadurch kontrollierbar ist. ${ }^{36}$ Hierbei kommt der Seele eine äußerst ambivalente Funktion zu: einerseits bildet sie das Medium der Wahrnehmung der "Affektrepräsentation von Sozialordnungen", z. B. die am Leib erfahrenen, eklatanten Widersprüche zwischen dem brutalen Wettbewerbsdenken bürgerlicher Geschäftskonkurrenz und den Forderungen nach religiös-rationalistischer Gleichheit; andererseits fungiert sie zugleich als Agent eben dieser Modernisierung. ${ }^{37}$ Dem repressiven Apparat zentralisierender Staatsmacht entspricht nämlich ein von Eltern, Pfarrern, Pädagogen und rationalistischen Psychologen implementiertes Zentralorgan, welches den Leib und das individuelle Begehren über die Affektregulierung kontrolliert. So geben z. B. Christian Thomasius und Christoph August Heumann in ihren populärphilosophischen Abhandlungen zur "politischen Klugheit" des vernünftigen Bürgers Anleitungen zur Bestimmung und Kontrolle der Affekte auf der Grundlage der Temperamentenlehre, wobei sie das individuelle Tugendverhalten zur Grundlage des Staatswohls erheben. ${ }^{38}$ Auf diese Weise werden alle sozialen Störungen im Streben nach gemeinschaftlicher wie persönlicher Glückseligkeit dem Individuum angelastet, denn es wird für alle erfahrenen seelischen und körperlichen Modernisierungsfolgen ( $\mathrm{z}$. B. was man heute "Stre $B$ " nennen würde) selbst verantwortlich gemacht. Entgegen seiner theoretischen Einsichten hat Bernd das Prinzip der Eigenverantwortung für seelischkörperliche Gebrechen in einem Maße verinnerlicht, daß er immer wieder seine eigenen beruflichen Schwierigkeiten (z. B. seine Niederlagen im akademischen und religionspolitischen Intrigenspiel) auf seine psychisch-physische Konstitution zurückführt und sich deshalb in der Selbstanalyse kurieren will. Der von Theologie, Medizin und Popularphilosophie postulierten Leib-Seele-Harmonie-gleichgültig ob diese als Gottes gnädige Fügung oder als vernünftige Natur betrachtet wirdwidersetzt sich aber der Leib schon im Akt der Selbstbeobachtung.

Der idiosynkratische Leib drängt sich in all seiner Kreatürlichkeit dem Bewußtsein als alltägliche Abweichung vom abstrakten Ideal des normalen Körpers auf. Soll die Selbstbeobachtung eine kathartische Funktion haben, dann muß sich Bernd bei der Introspektion aller präkognitiven Leiberfahrungen entledigen, damit seine Einbildungen, Launen und Affekte-kurz: die innere Natur des Selbstbeobachterssein Denken nicht negativ beeinflußen. Empfindungen, Vorstellungen oder Bedürfnisse stehen dem objektiven Verständnis des Körpers im Wege, denn wenn "unser Leib urteilet" (S. 169), handelt es sich meist um 
subjektive Fehlurteile. Deshalb ist, wie noch Immanuel Kant sechzig Jahre später schreibt, die Unterscheidung zwischen wirklicher "Krankheit" und falschem "Gefühl der Krankheit" nur durch "das Objektivieren seiner selbst" möglich. ${ }^{39}$ Rationale Naturerkenntnis am eigenen Leib erfordert vom Ich, den Leib der sinnlichen Erfahrung in den szientifisch normierten "Körper" (physiologisch-anatomisches Objekt) zu transformieren..$^{40}$ Dies geschieht durch den am Körper des personalen Anderen geschulten Blick (z. B. in Physiognomie und Anatomie), der den subjektiven Leib zum objektivierten Fremdkörper macht. ${ }^{41}$ Diese Befreiung vom eigenen Leib in der Körpererkenntnis bringt allerdings auch eine Veränderung der Wahrnehmung und Besprechung des Wahrgenommenen mit sich, was wiederum Einfluß auf die psychische Befindlichkeit des Wahrnehmenden hat. Während der gesunde Körper vom Bewußtsein kaum registriert und deshalb auch nicht dargestellt wird, manifestiert sich die Bewußtwerdung des kranken Körpers im Aussagefeld der Negativitäten, "denn das wahre Ich wird nie krank" 42 .

So beschreibt auch Bernd seinen Körper als einen Mikrokosmos der Unordnung und Disfunktionen: verstopfte Gefässe, zu dicke oder zu dünne Flüssigkeiten, gestörte Organfunktionen, extreme Temperaturschwankungen, Übertragungsfehler in der neurophysiologischen Mechanik. Dieses körperliche Chaos löst Affekte der Furcht und des Schreckens allein schon im Akt der Erkenntnis aus, weil es sich jeder Vorstellung nach körperlich-seelischer Ganzheit entzieht. Bernd kann sich zudem nie sicher sein, inwiefern die Objektivierung des subjektiven Leibes und damit das Bewußtsein über körperliche Fehlfunktionen sogar psychische Krankheiten erst evoziert. Durch die intellektuelle Introversion erkennt bzw. konstituiert das nach autonomer, ganzheitlicher Identität strebende Subjekt die Zerrissenheit der Körper-Seele-Verbindung: die vom Bewußtsein unabhängigen Körperproduktionen als auch die nicht mit der Vernunft in Einklang zu bringenden "Affecten", die wiederum "im Leibe eine große Veränderung nach sich ziehen" (S. 157). So findet die Psychopathologie Einlaß in die (professionelle) Konstituierung des vernünftigen Subjekts, was schon Bernds Zeitgenossen bekannt war: Melancholie, Hypochondrie und Wahnsinn gelten seit dem 17. Jahrhundert als typische Gelehrtenkrankheiten. ${ }^{43}$

Um der in Wahnvorstellungen drohenden Selbstauflösung als absoluter Negation der Selbstkonstituierung zu entgehen, versucht Bernd jedoch immer wieder mit Hilfe der (pietistisch geschulten) Zentralimagination, die fragmentierten Körperteile und Affekte wieder in ein systematisches Funktionsgeschehen einzureihen. Fällt ihm keine 
(populär-)wissenschaftliche Antwort mehr ein, das irritierte Verhältnis zum eigenen (Fremd-)Körper zu harmonisieren, dann beruft er sich auf Gott, der "nach seiner Gnade dem Leibe aufhilft, oder der Seele ein größer Maß des Vertrauens schenkt, den Leib zu überwinden" (S. 146). Nun gelingt die völlige Überwindung des Leibes beim Denken gerade deshalb nicht, weil das gleiche Medium, welches die Dissozation von Körper und Seele aufheben soll, auch der irrationalen Sinnlichkeit des Leibes in die Hände spielt. Die Einbildungskraft verhilft nämlich nicht nur dem Denken zu seinen Vorstellungen, sondern verstärkt oder evoziert das körperliche Bedürfnis, was Bernd wieder in ein kausales animistisch-physiologisches Verhältnis setzt: "so oft man beim Meditiren und Concipiren die Lebens-Geister im Kopfe anstrenget", schwächt man auch "die Kraft der Lebens-Geister im Unterleibe" (S. 306). Auf diese Weise kann das Denken selbst zum Abführmittel werden: wenn Bernd verstopft ist, muß er sich nur "etwas Schweres ... denken ... ., da ich denn gar bald meinen Endzweck erhalte" (S. 307). Doch Bernds Durchfall ist weder das pietistische Gnadengeschenk Gottes noch eine nur physiologische Fehlfunktion, sondern das (gewünschte) Resultat autoerotischer Körperproduktionen.

Zwischen Anus und Imagination probt der Leib den Aufstand gegen die religiös-rationale Triebkontrolle der Selbstbeobachtung: über die Einbildungskraft schleicht sich verbotene Lust mit dem Körper in die einsame Leibesinspektion. ${ }^{4}{ }^{4}$ Körperliche Disfunktionen stacheln die Seele zu den wildesten Bildern an, denn Bernd durchforscht nicht nur unentwegt seine Gedärme, er stößt auch gerade im Akt der imaginativen Selbsterforschung auf die ausgesparte Sexualität, die bei ihm auffällig oft um Fäkalphantasien kreist. Als er wieder einmal glaubt, "am Durchfall sterben [zu] müssen", verliert er die moralische Kontrolle über seine Vorstellungen: "Denn auf die selbstmörderischen Gedanken, oder auch zu denselben, kamen nun auch die abscheulichsten, und unflätigsten Gedanken, so von natürlichen Dingen und Excrementis hergenommen, und, welches erschrecklich zu sagen, auf göttliche Dinge im Gemüte schnelle appliciret [bezogen] wurden. Ich mag sie nicht specificiren, um keines Menschen Imagination dadurch zu vergiften, und etwan anzustecken" (S. 133).

Gegenüber seiner sonstigen realistischen Offenheit kommt der gesprächige Bernd auf einmal ins Stocken, wenn er nicht verraten will, welche "unflätigen" Phantasien er denn hat. ${ }^{45}$ Es kann sich hierbei nur um sexuelle Bilder handeln, denn Bernd bricht immer dann die Beschreibung ab oder verlagert den persönlichen Fall ins Allgemeine, wenn es um die "Geilheit" geht, deren seltsamen Verlust er schon im Vorwort (S. 11) hinter Vergleichen versteckt. Zwar erwähnt er die 
"Sünden und lasterhaften Gewohnheiten" (S. 68) seiner Jugend, aber beläßt es bei Andeutungen über Pubertätsriten, wohl der gemeinschaftliche Bordellbesuch oder kollektive Onanie, wobei ihn gerade die "erschreckliche[n] Sauereien" der anderen "eckeln" (S. 72). Erst nach der Hälfte der gesamten Lebensgeschichte, just in dem Moment, als ihn eine Frau begehrt, lüftet Bernd sein Geheimnis, warum ihm legitime Sexualität versperrt ist: "Denn Gott hat mich in der Welt da angegriffen, wo ich am empfindlichsten gewesen, ... und durch schreckliche Anfechtungen, und einen gewissen unglücklichen Fall in der ersten Jugend meinen Leib in den Zustand gesetzt, daß ich an kein Heiraten jemals gedenken dürfen" (S. 208). Es bleibt ungeklärt, ob es sich bei dem "Unfall" um die physische Beschädigung seines Genitals handelt ${ }^{46}$, und er sich deshalb so vor Frauen und insbesondere Huren fürchtet, oder ob sich sein sexuelles Begehren auf Männer richtet. Hingegen ist kaum zu übersehen, daß Bernds sexuelles Sündenbewußtsein immer wieder die "Anfechtungen" der Onanie in den Bereich des Analen legt, also genau dorthin, wo die Leibesinspektion nach der Wahrheit des kranken Subjektes sucht.

Im Zentrum der Selbstbeobachtung erscheinen die natürlichen Ausscheidungen als Prüfstein der Seele. Wie jedes Kleinkind erfährt Bernd die Lust an der eigenen Körperproduktion, aber auch den Zwang, diese Produktion zu reglementieren und ihre Produkte wegzugeben. Von der diätetisch-hygienischen Kontrolle der Exkremente in der Kleinkinderziehung des 18. Jahrhundert bis zur Pathologisierung der "Partialobjekte" in der traditionellen Psychoanalyse gilt der lustlose geregelte Stuhlgang als Beweis, den natürlichen Leib erfolgreich zivilisiert zu haben. ${ }^{47}$ Gleichzeitig wird hier die ganze Ambivalenz der bürgerlichen Disziplinierung des Leibes deutlich, denn der Selbstbeobachter Bernd sieht sich zugleich dem Zwang ausgesetzt, zu begehren, wovor er doch den "größten Abscheu" (S. 128) hat: Kot. ${ }^{48}$ Als wolle er heutigen psychoanalytischen Interpretationen Vorschub leisten: Bernd liefert selbst mögliche Erklärungsmuster für seine Analfixierung, wenn er seine Konditionierung als Kind in der pietistisch-kleinbürgerlichen Familie erzählt" ${ }^{49}$, in der orale und genitale Vorgänge "anal interpretiert werden" ${ }^{50}$. Bei der Körperpflege verwünscht die Mutter das Kind, es im schmutzigen Badewasser "ersaufen [zu] lassen" (S. 25); man hält dem kleinen Bernd "Küh- und Pferde-Mist vor die Nase" (S. 24), um ihn vom Nasenbluten zu befreien; schließlich erzählt die Schwester einen Traum, in dem sie ihren Bruder in einer "Tonne, so mit Pflaummus ... angefüllet", das "vielmehr wahrhafter Kot gewesen", untergehen sieht (S. 47-48). Solche skatologischen Anekdoten kehren bei Bernd nicht nur in der religiösen Metaphorik wieder, "selbst im Kot 
der Sünden bis über die Ohren" (S. 127) zu stecken, sondern nehmen in der versuchten Selbstheilung reale Formen an.

Mit Hilfe von Diäten, Tabakrauchen, Abführmitteln und Klistieren beeinflußt Bernd seine Verdauung unter dem Vorwand der Melancholietherapie. Doch wenn Bernd in den körperlichen Säftehaushalt eingreift, geschieht das auch, um die "fleischliche Wollust" zu bekämpfen: "ich ließe das närrische Fleisch wüten, und toben, wie es wollte: zwänge mich von der Tat zu enthalten, und suchte mit strenger Diæt, und Vermeidung aller hitzigen gesalzenen Speisen und Getränken, ja auch durch gewisse Arznei-Mittel die salzichten Teile aus dem Geblüte zu vertreiben" (S. 321). In der Therapie wird aus dem Leib eine psychochemische Produktionsmaschine, in die man oben etwas hineinsteckt, um unten ein "veredeltes" Produkt als Beweis für den gesunden Körper zu erhalten. Zwar glaubt Bernd mittels experimenteller Säfteregulation das sexuelle Begehren zu bremsen, aber im künstlich herbeigeführten Durchfall-Bernd schafft es, "denselben Tag 30 Sedes [Stuhlgänge]" (S. 308) zu haben-artikuliert sich das Geheimnis einer anderen Lust, die nicht veröffentlicht werden darf. Schließlich entkräftet die häufig durchgeführte Manipulation der Verdauung den Körper (insbesondere die Schließmuskeln) in einer Weise, daß der Pfarrer zu ungewöhnlichen Präventivmaßnahmen greifen muß. Aus Angst unwillkürlich während seiner vielbesuchten Predigten in der Leipziger Peterskirche öffentlich defäkieren oder urinieren zu müssen, besinnt sich Bernd auf Unfallverhütung. Er steckt sich "Gläser" in den Rock und bindet sich "einen Schwamm um den Unter-Leib" (S. 335), obwohl er zugleich weiß, daß "kaum etliche Tropfen in der Blase vorhanden waren" (S. 334). Mit Erschrecken hat er nämlich feststellen müssen, daß der Leib seinem Willen nicht unbedingt gehorcht, denn "indem ich mich stark anstrenge, und das Gedächtnis forcire, so merke ich, daß das Wasser unten fort will" (S. 333). Auch wenn man heute leicht Bernds Leiden am Leib mit medizinischen Diagnosen (Infektion der Harnröhre, Verdauungsstörungen, Prostatakrebs, usw.) erklären könnte, legt der Text eine andere Deutung frei. Wer soviel Zeit und Anstrengung auf analaggressive Produktion verwendet, muß doch irgendeine Lust verspüren, den eigenen Körper solchen Prozeduren zu unterwerfen. Aber genau den lustvollen Umgang mit dem krank gemachten Leib spart Bernd seltsamerweise aus, obwohl er ihn theoretisch befragt: "Sollte aber dasjenige Teil des Leibes, so des Schmerzens fähig, nicht durch andere Bewegung eben so gut eines gleichen Grades der Wollust fähig sein?" (S. 235).

Bernds experimentelle Leibesinspektion führt zwar von der Schmerzbewältigung zur angedeuteten analen Autoerotik, dringt je- 
doch weder zur Befreiung der Partialobjekte noch zu deren Sublimierung in der normierten Sexualität vor. Die mechanistische Verkoppelung der Körperteile zur Lustbereitung blieb der Literatur des Marquis de Sade vorbehalten. Stattdessen verschwindet der Leib als Oberfläche der Lust zusehends in der Analyse der Seele, in der sich das Verstehenwollen des Leibes zu seiner Begrenzung verschiebt. Die Lebens-Beschreibung endet nämlich mit der "erfolgreichen" Wende ins Neurotische. Bernd geht den typischen Gang des rationalen Gelehrten, der nach erfolgloser Bewußtmachung des Leibes diesen nur noch $\mathrm{zu}$ kontrollieren sucht, indem er all jenes aus seinem Lebensalltag ausschließt, was mit der Vernunft nicht in Einklang zu bringen ist. So wie sein hypochondrischer Nachfolger Kant ${ }^{51}$ meidet Bernd die Frauen, die er in Analogiespielen mit den unreinen Säften gleichsetzt, desexualisiert seine Umgebung, hält sich nicht mehr mit Träumen und Einbildungen auf, sondern übt sich aus Angst "vor allem Ungwöhnlichen und vor allem Ungestalten" (S. 393) in Schönschrift und erläßt "613 Gesetze" (S. 394) für die eigene Haushaltung. ${ }^{52}$ Damit fügt sich Bernd selbst zu, was anderen, wie z. B. dem oben zitierten Schreber, durch ihre Väter, Lehrer und Ärzte in institutionalisierten Räumen auf den Leib geschrieben wird. Bereits gegen Ende des 18. Jahrhunderts schafft die Entwicklungspsychologie mit ihrer Definition des normierten Selbst die universelle Grundlage, den Leib mittels moderner Körpertechnologien von der mütterlichen Alphabetisierung bis zu den philanthropistischen Turnübungen der Kontrolle einer Seele zu unterwerfen, die vom Leib nichts mehr weiß, der als Körper endgültig den anderen anvertraut wird.

Vom Leib und seiner schweigenden Sinnlichkeit wird in der auf Bernds Autobiographie folgenden Literatur kaum noch geredet. Stattdessen verschiebt sich das Unbehagen mit dem Leiblichen zur Dichtung der "Seelenkonflikte", hatte doch schon der philanthropische Erfahrungsseelenkundler C. F. Pockels gerade darin den Wert von Bernds Lebens-Beschreibung gesehen, daß sie "den reichhaltigsten Stof zu einem psychologischen Romane in sich enthält" 53. Bernds hypersensible Nachfolger, der Selbstmörder Werther oder der Melancholiker Anton Reiser, werden $\mathrm{u}$. a. deshalb zu literarischen Helden, weil ihre Leiden vom Autor abgetrennt und ästhetisiert werden und nicht mehr den Schmutz der sexuell aufgeladenen Partialobjekte ungeniert entblößen. Während die "kranken Seelen" eines Werther oder Reiser kanonische Insignien der deutschen Literaturgeschichte werden, wandert der schmutzige Leib in "triviale" Texte, von Mozarts "peinlichen" Briefen an seine Mutter bis hin zum Kitsch und Kinderreim ${ }^{54}$, um erst im 20. Jahrhundert, dann aber als Rekurs aufs Widerwärtige, Groteske oder 
Vulgäre, literaturfähig zu werden. ${ }^{55}$ Bernds gelehrter Versuch, seine leiblichen Produktionen mit Hilfe von Rationalitätsmodellen zu verstehen, zu erklären, letztlich aber einzuschränken, steht am Anfang der repressiven Aufklärung über die eigene Natur. ${ }^{56}$ Die über die Sauberkeitserziehung, über die Geschlechter- und Generationentrennung und über die Funktionalisierung des Körpers allen bürgerlichen Kindern eingetrichterte Sexualunterdrückung macht den eigenen Leib zum Kolonialgebiet, auf dem sich das integrale Ich behaupten muß. Das Produkt dieser "Selbstbeherrschung" ist hinlänglich bekannt: der Beamten-, Soldaten- und Industriekörper (aber auch der Sportkörper) des disziplinierten Mannes hat die mit Frau assoziierten Substanzen, Flüssigkeiten und Öffnungen seines Leibes unter der absoluten Kontrolle eines Körperpanzers, der statt der Lust körperfeindlichen Zwecken dient. ${ }^{57}$

\section{Anmerkungen}

1. Gilles Deleuze u. Félix Guattari, Anti-Ödipus: Kapitalismus und Schizophrenie I, übers. v. Bernd Schwibs (Frankfurt a. M.: Suhrkamp, 1977), S. 7-63.

2. Ebd., S. 7.

3. Vgl. Gernot Böhme, Anthropologie in pragmatischer Hinsicht: Darmstädter Vorlesungen (Frankfurt a. M.: Suhrkamp, 1985), S. 113-26 und grundlegend Michel Foucault, Die Geburt der Klinik: Eine Archäologie des ärztlichen Blickes, übers. v. Walter Seitter (Frankfurt a. M.: Fischer, 1988).

4. 1903 als didaktische Apologie nach mehrfacher Hospitalisierung und zwei Entmündigungsprozessen veröffentlicht, vgl. Daniel Paul Schreber, Denkwürdigkeiten eines Nervenkranken, hg. v. Samuel M. Weber (Frankfurt a. M.: Ullstein, 1973), S. 61-70.

5. Deleuze u. Guattari, Anti-Ödipus, S. 7.

6. Siehe z. B. Manfred Franks vehemente Kritik an Deleuze u. Guattari: “Die Welt als Wunsch und Repräsentation oder Gegen ein anarcho-strukturalistisches Zeitalter", in Fugen. Deutsch-französisches Jahrbuch für Text-Analytik, hg. von Manfred Frank, Friedrich A. Kittler u. Samuel Weber (Olten: Walter, 1980), S. 269-78.

7. Adam Bernd, Eigene Lebens-Beschreibung (München: Winkler, 1973). Von hier ab erfolgen Seitenangaben im Text.

8. Vgl. Samuel M. Weber, "Die Parabel”, in Schreber, Denkwürdigkeiten, S. 5-58.

9. Bernd Neumann, Rollenzwang und Identität: Zur Theorie der Autobiographie (Frankfurt a. M.: Athenäum, 1970), S. 19.

10. Max Dessoir, Geschichte der neueren deutschen Psychologie, 2. Auflage (Nachdruck der Ausgabe Berlin 1902, Amsterdam: Bonset, 1964), S. 305.

11. Vgl. grundlegend die Quellensammlung Schwarze Pädagogik: Quellen zur Naturgeschichte der bürgerlichen Erziehung, hg. v. Katharina Rutschky (Frank- 
furt a. M.: Ullstein, 1988), in der auch die pädagogischen Anleitungen zur Disziplinierung des Körpers von Schrebers Vater abgedruckt sind.

12. Thomas Müller, Rhetorik und bürgerliche Identität: Studien zur Rolle der Psychologie in der Frühaufklärung (Tübingen: Niemeyer, 1990), S. 49-58.

13. Hinreichend analysiert von Hans-Jürgen Schings, Melancholie und Aufklärung: Melancholiker und ihre Kritiker in Erfahrungsseelenkunde und Literatur des 18. Jahrhunderts (Stuttgart: Metzler, 1977), S. 73-126; Helmut Pfotenhauer, Literarische Anthropologie: Selbstbiographien und ihre Geschichte am Leitfaden des Leibes (Stuttgart: Metzler, 1987), S. 55-76.

14. Zum Theologiestreit vgl. Schings, Melancholie, S. 97-107.

15. Vgl. Jürgen Lehmann, Bekennen. Erzählen. Berichten. Studien zu Theorie und Geschichte der Autobiographie (Tübingen: Niemeyer, 1988), S. 89-110.

16. Ein typisches Beispiel der Autobiographie als subjektive Antwort auf die medizinischen Toderklärung des Körpers ist Fritz Zorn, Mars (München: Kindler, 1977).

17. Für weitere Belege siehe z. B. auch S. 148: "Man findet von dieser Gemüts-Plage wenig in Büchern"; und S. 201: "Ich wünschte eine Schrift zu lesen, in welcher deutlich gezeiget wäre, was zum Wesen eines verrückten Menschens, und verwirrten Verstandes erfordert werde."

18. Zum Wandel der Psychologie von der affirmativen Affektenlehre zur dynamischen Theorie der "Gemütsbewegungen" vgl. Rüdiger Campe, Affekt und Ausdruck: Zur Umwandlung der literarischen Rede im 17. und 18. Jahrhundert (Tübingen: Niemeyer, 1990), S. 355-78.

19. Gottfried Wilhelm Leibniz, "Vorschlag zu einer Medizinal-Behörde" (1685), zitiert nach Manfred Stürzbecher, Beiträge zur Berliner Medizingeschichte: Quellen und Studien zur Geschichte des Gesundheitswesens vom 17. bis zum 19. Jahrhundert (Berlin: de Gruyter, 1966), S. 38.

20. Zur Konstruktion des menschlichen Körpers als Objekt wissenschaftlicher Metaphorologie vgl. Barbara Maria Stafford, Body Criticism: Imaging the Unseen in Enlightenment Art and Medicine (Cambridge, Mass.: MIT Press, 1991).

21. Vgl. hierzu grundlegend Schings, Melancholie, S. 107-18.

22. Vgl. Volker Hoffmann, "Nachwort", in Bernd, Eigene Lebens-Beschreibung, S. 403-26; Pfotenhauer, Literarische Anthropologie, S. 58-70.

23. Zu Stahls Bedeutung in der Melancholiediskussion vgl. Wolfram Mauser, "Glückseligkeit und Melancholie in der deutschen Literatur des frühen 18. Jahrhunderts", in Melancholie in Literatur und Kunst (Hürtgenwald: Guido Pressler, 1990), S. 59-68.

24. Vgl. Schings, Melancholie, S. 118-26.

25. Vgl. Hoffmann, "Nachwort", S. 422-26.

26. Lothar Müller, Die kranke Seele und das Licht der Erkenntnis (Frankfurt a. M.: Athenäum, 1987), S. 48-88.

27. Gnothi Sauton oder Magazin zur Erfahrungsseelenkunde als ein Lehrbuch für Gelehrte und Ungelehrte, hg. v. Karl Philipp Moritz, 10 Bde. (Nördlingen: Franz Greno, 1986), 1:8.

28. So z. B. Schings und Pfotenhauer. Zur Kritik daran vgl. Müller, Rhetorik, S. 113-14. 
29. Wolfram Schmitt, "Zur Phänomenologie und Theorie der Melancholie", in Melancholie in Literatur und Kunst, S. 14.

30. Ebd., S. 18-27.

31. Vgl. Ulrich Nassen, "Trübsinn und Indigestion: Zum medizinischen und literarischen Diskurs über Hypochondrie im 18. Jahrhundert", in Frank u. a., Hgg., Fugen, S. 171-86 und Mauser, "Glückseligkeit", S. 48-88.

32. Wolf Lepenies, Melancholie und Gesellschaft (Frankfurt a. M.: Suhrkamp, 1969), S. 79-117.

33. Vgl. Helga Glantschnig, Liebe als Dressur: Kindererziehung in der Aufklärung (Frankfurt a. M.: Campus, 1987), S. 16-44; Hartmut Böhme u. Gernot Böhme, Das Andere der Vernunft: Zur Entwicklung von Rationalitätsstrukturen am Beispiel Kants (Frankfurt a. M.: Suhrkamp, 1983), S. 50-70.

34. Norbert Elias, Über den Prozeß der Zivilisation, 2. Aufl., 2 Bde. (Bern: Francke, 1969), 2:312.

35. Böhme u. Böhme, Das Andere der Vernunft, S. 398.

36. Vgl. Müller, Rhetorik, S. 47-111.

37. Vgl. Michael Reiter, "Pietismus", in Die Seele: Ihre Geschichte im Abendland, hg. v. Gerd Jüttemann, Michael Sonntag u. Christoph Wulf (Weinheim: Psychologie Verlags Union, 1991), S. 198-213.

38. Christian Thomasius, Kurtzer Entwurf der Politischen Klugheit (Frankfurt und Leipzig: J. Großens Erben, 1710); Christoph August Heumann, Der Politische Philosophus, das ist vernunftsmässige Anweisung zur Klugheit im gemeinen Leben (Faksimiledruck der Ausgabe Frankfurt und Leipzig 1724, Frankfurt a. M.: Athenäum, 1972).

39. Immanuel Kant, "Ein Schreiben an Herrn Professor Hufeland zu Jena im Jahre 1797", zitiert nach Christoph Wilhelm Hufeland, Makrobiotik oder die Kunst, das menschliche Leben zu verlängern (Frankfurt a. M.: Insel, 1984), S. 239.

40. Vgl. grundlegend Werner Kutschmann, Der Naturwissenschaftler und sein Körper (Frankfurt a. M.: Suhrkamp, 1986).

41. Vgl. Müller, Rhetorik, S. 107-11.

42. Kant, "Ein Schreiben", S. 240; vgl. auch Kutschmann, Der Naturwissenschaftler, S. 400-404.

43. Kutschmann, Der Naturwissenschaftler, S. 400; Böhme u. Böhme, Das Andere, S. 420-23; vgl. auch Samuel Auguste David Tissot, Von der Gesundheit der Gelehrten: und anderer Leute, die bey ihren Geschäften wenige Bewegung machen (Augsburg: Joseph Wolff, 1771).

44. Auf diesen Zusammenhang geht Schings, Melancholie, überhaupt nicht ein; vgl. dagegen Neumann, Identität, S. 63-72; Hoffmann, "Nachwort", S. 403-7 und Pfotenhauer, Literarische Anthropologie, S. 64-65.

45. Bereits der Erfahrungsseelenkundler C. F. Pockels beschwerte sich darüber, daß Bernd nicht mehr über die "heimliche[n] Sünden der Wollust" zu berichten weiß, siehe [C. F. Pockels], "Auszug aus M. Adam Bernds eigener Lebensbeschreibung", in Moritz, Hg., Gnothi Sauton, 5:87.

46. Diese Annahme vertritt Hoffmann, "Nachwort", S. 405.

47. Böhme u. Böhme, Das Andere der Vernunft, S. 64-66. 
48. Vgl. hierzu Pockels, "Auszug", 5: 92-93, der in diesem Zusammenhang auf die "natürliche" Ambivalenz des "Wunsches", des "Gemüths" und der Einbildungskraft hinweist.

49. Bernds Beitrag zur physiologischen Psychologie der Kindheit habe ich an anderer Stelle untersucht, vgl. Stephan K. Schindler, Das Subjekt als Kind: Die Erfindung der Kindheit im Roman des 18. Jahrhunderts (Berlin: E. Schmidt, 1994), S. 113-20.

50. Hoffmann, "Nachwort", S. 405; vgl. auch Neumann, Identität, S. 65-66 und Pfotenhauer, Literarische Anthropologie, S. 64-65.

51. Vgl. dazu Böhme u. Böhme, Das Andere der Vernunft, S.427-94.

52. Dieses Verhalten ließe sich mit Freud als Etablierung des "analen Charakters" (Sparsamkeit, Ordentlichkeit und Eigensinn) bezeichnen, siehe Sigmund Freud, "Charakter und Analerotik", in Studienausgabe, hg. v. Alexander Mitscherlich, u. a., 5. Aufl. (Frankfurt a. M.: Fischer, 1989), 7:23-30.

53. [C. F. Pockels], "Auszug aus M. Adam Bernds eigner Lebensbeschreibung. Fortsetzung", in Moritz, Hg., Gnothi Sauton, 5:112.

54. Vgl. Alan Dundes, Life is Like a Chicken Coop Ladder: A Study of German National Character Through Folklore (Detroit: Wayne State University Press, 1989); Ernest Borneman, Sex im Volksmund: Der obszöne Wortschatz der Deutschen (1971; Nachdruck Reinbek bei Hamburg: Rowohlt, 1991).

55. Zur Nachkriegsliteratur siehe Dieter Rollfinke u. Jacqueline Rollfinke, The Call of Human Nature: The Role of Scatology in Modern German Literature (Amherst: University of Massachusetts Press, 1986); Peter Rühmkorf, Über das Volksvermögen: Exkurse in den literarischen Untergrund (Reinbek bei Hamburg: Rowohlt, 1967).

56. Zur Abschaffung des Körpers (und der von der rationalen Norm abweichenden Libidoströme der Partialobjekte) in der modernen Selbstreflexion siehe Manfred Pohlen, Margarethe Bautz-Holzherr, Eine andere Aufklärung: Das Freudsche Subjekt in der Analyse (Frankfurt a. M.: Suhrkamp, 1991), S. 404-95.

57. Vgl. die bahnbrechende Analyse von Klaus Theweleit, Männerphantasien, 2 Bde. (Frankfurt a. M.: Stroemfeld / Roter Stern, 1986); hier insbesondere Band 1: "Frauen, Fluten, Körper, Geschichte", S. 521-47. 



\section{Index}

Abaelard, 58

Adams, H. M., 216 (n. 30)

Alantsee, Lucas, 8, 14, 16, 32, 34, 38-40, 47 (n. 40)

Albertus Magnus, 159-71, 175-76

Aldrovandi, Ulysse, 154, 164, 177

Ambrosius, 166

Amiel, Charles, 215 (n. 9)

Anglicus, Bartholomäus, 159, 166, 169

Apin, Sigmund, 76

Aquilecchia, Giovanni, 146 (n. 1)

Areopagita, Dionysius, 134

Aretino, 252

Aristotle, 108-9, 170

Armstrong, Elizabeth, 45 (n. 32)

Aschbach, Joseph Ritter von, 41 (n. 2)

Assmann, Aleida, 112 (n. 12)

Atkinson, Geoffroy, 179 (n. 6)

Augustine, 96, 153-58

Austin, John L., 10, 28-29, 36

Bachorski, Hans-Jürgen, 215 (n. 19), 257 (n. 7)

Bacon, Francis, 50

Baeumer, Max L., 83 (n. 1)

Baker, Steve, 180 (n. 6)

Bakhtin, Mikhail M., 245

Balogh, Josef, 113 (n. 21)

Barclay, Joan, 179 (n. 6)

Barker-Benfield, G. J., 257 (n. 4)

Barner, Wilfried, 247

Barstow, Anne Llewellyn, 218 (n. 57)

Barth, Kaspar, 252-53

Bartsch, Waltraud, 185 (n. 61)

Baumgarten, Alexander Gottlieb, 78-79

Bautz-Holzherr, Margarethe, 303 (n. 56)

Baxter, Christopher, 198

Becanus, Johannes Gropius, 193

Becher, Johann Joachim, 274, 282 (n. 38)

Becker-Cantarino, Barbara, 258 (n. 15)

Beer, Michael, 189 (n. 111)

Behringer, Wolfgang, 199

Beierwaltes, Werner, 140

Belloni, Luigi, 231, 234
Bennewitz, Ingrid, 244

Bernd, Adam, 285-300

Bernard of Clairvaux, 102

Bezold, Fritz von, 198

Bierling, Friedrich Wilhelm, 87 (n. 41)

Blaicher, Günther, 284 (n. 50)

Blauert, Andreas, 216 (n. 27)

Bloch, Raymond, 179 (n. 6)

Blum, Paul Richard, 146 (n. 9)

Blumenberg, Hans, 109-10, 132

Boas-Hall, Marie, 179 (n. 6)

Bodin, Jean, 193-214

Boerner, Ge. Theoph., 87 (n. 42)

Bohéries, Arnulf von, 114 (n. 29)

Böhme, Gernot, 300 (n. 3), 302 (n. 33)

Böhme, Hartmut, 302 (n. 33)

Bohnert, Christiane, 259 (n. 15)

Bohse-Talander, August, 248

Bolte, Johannes, 247

Borneman, Ernest, 303 (n. 54)

Brackert, Helmut, 245

Brahe, Tycho, 122, 222, 225

Brauner, Sigrid, 245

Breiner, Laurence, A., 186 (n. 73)

Breydenbach, Bernhard von, 169, 172-73

Brinker-Gabler, Gisela, 258 (n. 15)

Brinkus, Gerd, 68 (n. 22)

Brooks, Peter, 127 (n. 2)

Browne, Malcolm, 178 (n. 1)

Brundage, James A., 257 (n. 6)

Bruno, Giordano, 131-46

Buchholz, Stephan, 283 (n. 39)

Buck, August, 67 (n. 4)

Buonanni, Filippo, 234

Cadden, Joan, 257 (n. 6)

Callot, Emile, 179 (n. 6)

Camerarius, Joachim, 177

Camille, Michael, 111 (n. 3)

Campe, Rüdiger, 301 (n. 18)

Capella, Martianus, 98-99

Carruthers, Mary J., 67 (n. 11), 113 (n. 22)

Castiglione, Balthasar, 105-6

Céard, Jean, 179 (n. 6) 
Celtis, Conrad, 44 (n. 17), 247, 249

Christ, Johann Friedrich, 76, 79-82

Clanchy, Michael T., 114 (n. 32)

Clark, Jonathan, 245

Clark, Stuart, 215 (n. 16)

Clark, Willene B., 179 (n. 6)

Clark, William, 127 (n. 3)

Clutton-Brook, Juliet, 184 (n. 50)

Cohen, Daniel, 179 (n. 6)

Cohen, Fritz, 251

Collimitius, 8

Columbus, Christopher, 168

Conrady, Karl Otto, 251

Copenhaver, Brian P., 218 (n. 52)

Copernicus, Nicolaus, 133-34

Corsano, Antonio, 132

Crocus, Cornelius, 254

Culler, Jonathan, 39-40, 48 (n. 50)

Curtius, Ernst Robert, 97, 112 (n. 7), 148 (n. 30)

Cusanus, Nicolaus, 135-36, 144

Davenport-Hines, Richard, 257 (n. 4)

Dawson, Frank, 238 (n. 23)

Defoe, Daniel, 262, 266

Dejan, Philippe, 217 (n. 49)

DeJean, Joan, 257 (n. 7)

Delaunay, Pierre, 179 (n. 6)

Deleuze, Gilles, 285-86

Derrida, Jacques, 39, 48 (n. 49)

Descartes, René, 293

Dessoir, Max, 286

Dithmar, Justus Christoph, 282 (n. 38)

Donville, Louise Godard de, 217 (n. 45)

Duden, Barbara, 257 (n. 5)

Duerr, Hans Peter, 256 (n. 1)

Dundes, Alan, 303 (n. 54)

du Puys, Jacques, 202

Dürer, Albrecht, 23, 46 (n. 37)

Eberlein, K. K., 72-73

Eco, Umberto, 111

Economou, George D., 147 (n. 18)

Eiermann, Wolf, 88 (n. 51)

Einem, Herbert von, 83 (n. 1)

Einstein, Albert, 125

Elias, Norbert, 243, 302 (n. 34)

Erman, Georg Adolf, 219

Ersch, J. S., 173-74

Eschenbach, Wolfram von, 105
Espagne, Michel, 83 (n. 1)

Ettner, Johann Christoph, 281 (n. 28)

Evans, David T., 257 (n. 4)

Evans, Robert J. W., 237 (n. 9)

Fabri, Felix, 172, 174

Fabri, Nicolas de Peiresc, 231

Fancelli, Maria, 83 (n. 1)

Feldman, Linda Ellen, 244, 259 (n. 18)

Fellmann, Ferdinand, 144, 146 (n. 9)

Ferguson, Frances, 282 (n. 37)

Feyerabend, Siegmund, 167

Ficino, Marsilio, 135-36, 196

Fielding, Henry, 284 (n. 50)

Fischart, Johann, 193-214, 247

Fischer, Bernhard, 263, 270, 272

Fischer von Erlach, Johann Bernhard, 75

Fletcher, John, 219, 236 (n. 2)

Flint, Valerie I., 180 (n. 6)

Foucault, Michel, 243, 272, 274, 281

$$
\text { (n. 27), } 300 \text { (n. 3) }
$$

Fout, John C., 257 (n. 6)

Fracastoro, Girolamo, 231

Franck, Sebastian, 155, 168, 191 (n. 139)

Frank, Manfred, 300 (n. 6)

Franklin, Julian, 198

Frantz, David O., 257 (n. 7)

Frederick the Great, 273

Freud, Sigmund, 303 (n. 52)

Fried, Michael, 83 (n. 1)

Frischlin, Nicodemus, 258 (n. 14)

Fuchs, Leonhard, 9

Funkenstein, Amos, 218 (n. 54)

Fürstenau, Johann Hermann, 282 (n. 38)

Galilei, Galileo, 134, 231

Gellius, Aulus, 152

Gerhardt, Christoph, 179 (n. 6)

Gesner, Conrad, 155-56, 159-61, 165, $171-72,175-78,182$ (n. 23), 189 (n. 110)

Giesecke, Michael, 11, 15, 23, 44 (nn. 23, 25), 66 (n. 3)

Glantschnig, Helga, 302 (n. 33)

Glaser, Horst, 259 (n. 23)

Gnapheus, Gulielmus, 253, 255

Goethe, Johann Wolfgang von, 123, 125, 126 (n. 1), 128 (n. 26), 130 (n. 37)

Goody, Jack, 114 (n. 32)

Grafton, Anthony, 127 (n. 5)

Green, Michael, 189 (n. 111) 
Greenblatt, Stephen, 117

Greenleaf, William H., 217 (n. 40)

Gregory, T., 217 (n. 45)

Grévins, Jacques, 164

Grimmelshausen, H. J. C., 247

Grohnert, Dietrich, 279 (n. 12), 283 (n. 47)

Gruber, J. G., 173-74

Grüneck, Joseph, 52-55, 58

Guattari, Félix, 285-86

Guiton, Jean, 115 (n. 35)

Hallyn, Fernand, 123-24, 127 (n. 3), 217 (n. 47)

Harvey, William, 226-27, 231

Haskell, Francis, 83 (n. 1), 88 (n. 58)

Hathaway, Nancy, 189 (n. 111)

Hauffen, Adolf, 198, 216 (n. 25)

Haug, Walter, 111 (n. 1), 146 (n. 15), 147 (n. 16)

Hayles, Katherine, 118

Heinrich von Hesler, 94-95

Hellwig, L. Christoph de, 267

Henkel, Arthur, 147 (n. 22)

Henningsen, Gustav, 215 (n. 9)

Henricus Grammateus, 8-10, 14, 16-18, $20,23,26-28,30-31,38,40-41$

Herodot, 168

Herold, Johannes, 153, 155, 164, 166, 182 (n. 24)

Herr, Michael, 161, 168-69, 171, 175-76, 178

Herz, Markus, 292

Hesekiel, 95

Heumann, Christoph August, 294

Hirsch, Rudolf, 44 (nn. 17, 23)

Hoffmann, Volker, 301 (n. 22)

Hoffmeister, Johannes, 260 (n. 34)

Hölder, Helmut, 238 (n. 18)

Holton, Gerald, 127 (n. 6)

Homer, 141

Hubaux, Jean, 188 (n. 89)

Huch, Ernst, 78

Huet, Marie-Hélène, 180 (n. 6)

Hugo von Trimberg, 104

Huschenbett, Dietrich, 179 (n. 6)

Hutten, Ulrich von, 246

Ingram, Martin, 257 (n. 4)

Institoris, Heinrich, 195-97, 203

Isaac, Marie-Thérèse, 216 (n. 29)
Isidore of Seville, 156, 158-60, 163, 166, $168,170-72$

Jacquart, Danielle, 280 (n. 17)

Jeanneret, Michel, 97, 180 (n. 6)

Jobin, Bernhard, 202

Johnson, A. F., 42 (n. 7), 216 (n. 31)

Jones, Ann Rosalind, 257 (n. 7)

Justi, Carl, 88 (n. 57)

Justi, Johann Heinrich Gottlob von, 274, 278 (n. 1)

Kahr, Madlyn Millner, 256 (n. 1)

Kanold, Johann, 73

Kant, Immanuel, 295, 299

Keckermann, Bartholomäus, 74

Kelber, Werner H., 107

Keller, Abraham C., 115 (n. 35)

Kemmerich, Dieterich Hermann, 85 (n. 20)

Kemper, Hans-Georg, 251

Kepler, Johannes, 118-26, 226

Kircher, Athanasius, 219-36

Kirschbaum, Engelbert, 112 (n. 16)

Kittel, Erich, 46 (n. 40)

Klingender, Francis, 179 (n. 6)

Knopf, Jan, 262-63, 272, 276-77

Koestler, Arthur, 127 (n. 6)

Köller, Wilhelm, 109-10

Kollmann, Judith J., 184 (n. 50)

Könneker, Barbara, 258 (n. 14)

Kornmann, Heinrich, 154

Krafft, Maurice, 237 (n. 11)

Kristeller, Paul Oskar, 87 (n. 46)

Kritzman, Lawrence D., 256 (n. 1)

Krubsacius, Friedrich August, 79

Krüger, Christoph, 237 (n. 11)

Kultermann, Udo, 83 (n. 1)

Kundtmann, Johann Christian, 73

Kunoth, George, 86 (n. 29)

Kutschmann, Werner, 302 (n. 40)

Lacouture, Jean, 235

Lambert, Abbé, 75

Lange, Klaus, 112 (n. 5)

Langen, August, 267

Laqueur, Thomas, 243, 271

Leclerq, Jean, 102

Lecouteux, Claude, 179 (n. 6)

Lehmann, Ernst Herbert, 84 (n. 7), 301

(n. 15) 
Leibniz, Gottfried Wilhelm, 289

Leinkauf, Thomas, 223-25, 234, 237 (n. 9), 238 (n. 16)

Lenoble, Robert, 237 (n. 6)

Leonardo da Vinci, 226-27

Lepenies, Wolf, 83 (n. 1), 293

Léry, Jean de, 206

Lestringant, Frank, 194, 217 (n. 41)

Lohenstein, Daniel Casper von, 219, 248

Low, Anthony, 257 (n. 7)

Luckmann, Thomas, 113 (n. 26)

Luder, Petrus, 247

Luhmann, Niklas, 257 (n. 4)

Lummenaeus à Marca, Jacob Cornelius, 253-54

Luppius, J. Samuel, 87 (n. 48)

Luther, Martin, 23, 46 (n. 37)

Lycosthenes, Conrad, 153, 155, 164, 166, 182 (n. 24)

McCarthy, John A., 259 (n. 21)

McMillan, Douglas J., 188 (n. 89)

McMunn, Meradith T., 179 (n. 6)

Macrobius, 133

Major, Ralph H., 239 (n. 32)

Malebranche, Nicole, 290

Malthus, Thomas Robert, 273, 276, 278 (n. 3), 282 (n. 37)

Marco Polo, 173

Margetts, John, 179 (n. 6)

Margolin, Jean-Claude, 179 (n. 6)

Mariotte, Edme, 238 (n. 21)

Markley, Robert, 218 (n. 51)

Marperger, Paul Jacob, 278 (n. 2), 282 (n. 38)

Martino, Albert, 259 (n. 21)

Mästlin, Michael, 119, 121-22

Mauser, Wolfram, 251, 301 (n. 23)

Maximilian, 8-10, 14, 49-70

Megasthenes, 170

Megenberg, Thomas von, 166, 169

Megged, Matti, 189 (n. 111)

Meier, Christel, 179 (n. 6)

Meisner, Heinrich Otto, 44 (n. 16)

Melanchthon, Philipp, 207, 211

Mendelssohn, Moses, 292

Mercuriali, Girolamo, 235

Mercurialis, Hieronymus, 240 (n. 41)

Merleau-Ponty, Maurice, 113 (n. 26)

Meyer-Knees, Anke, 258 (n. 7), 271
Michaels, Walter B., 127 (n. 2)

Michel, Paul-Henri, 146 (n. 3)

Midelfort, Erik, 215 (n. 7)

Milton, John, 268

Möller, D. G., 84 (n. 16)

Monier, Pierre, 73

Mora, George, 214 (n. 6)

Morelli, Giovanni, 76

Morhof, D. G., 74

Moritz, Karl Philipp, 264, 278, 292

Mozart, Wolfgang Amadeus, 299

Muhlack, Ulrich, 85 (n. 26)

Muir, Edward, 256 (n. 1)

Müllenhoff, Karl, 259 (n. 17)

Müller, Jan-Dirk, 43 (n. 13), 66 (nn. 1, 2), 68 (n. 27), 179 (n. 6)

Müller, Lothar, 301 (n. 26)

Müller, Thomas, 301 (n. 12)

Münster, Sebastian, 151, 155, 161, 163-64, 166

Murray, David, 42 (n. 10)

Nakam, Géralde, 217 (n. 43)

Nassen, Ulrich, 302 (n. 31)

Nedham, Marchamont, 231

Negelein, Gustav Philipp, 76

Nettesheim, Agrippa von, 177

Neumann, Bernd, 300 (n. 9)

Newman, Jane O., 46 (n. 37)

Nietzsche, Friedrich, 123

Nissen, Claus, 179 (n. 6)

Notker der Deutsche, 99

Nowicki, Andrezej, 146 (n. 2)

Oechslin, Werner, 86 (nn. 28, 29)

Oehme, Johann August, 280 (n. 16)

Ohly, Friedrich, 114 (n. 29)

Olschki, Leonardo, 132

Ong, Walter, 260 (n. 37)

Ordericus Vitalis, 105

Otfrid von Weißenburg, 104

Otto, Stephan, 132

Ovid, 105

Palissy, Bernard, 238 (n. 21)

Panofsky, Erwin, 85 (n. 26)

Papeus, Petrus, 253

Paracelsus, Theophrastus, 232

Parente, James A., Jr., 259 (nn. 16, 20), 260 (n. 33) 
Pebworth, Ted-Larry, 256 (n. 1)

Pelling, Margaret, 240 (n. 38)

Perrault, Pierre, 238 (n. 21)

Petit, Georges, 179 (n. 6)

Petrarca, Francesco, 58, 101

Peucer, Caspar, 210-11

Pfotenhauer, Helmut, 301 (n. 13)

Pico della Mirandola, Giovanni, 196

Plato, 136

Pliny the Elder (Plinius), 68 (n. 25), 155, $160-71,220$

Plutarch, 114 (n. 32)

Pockels, Carl Friedrich, 292, 299, 302

(n. 45), 303 (n. 48)

Pohlen, Manfred, 303 (n. 56)

Pohlmann, Hansjörg, 15, 43 (n. 15), 44 (nn. 19, 23), 45 (n. 29)

Pollack, Robert, 118, 127 (n. 3)

Poppe, Bernard, 87 (n. 43)

Porter, Roy, 3 (n. 1)

Potts, Alex, 83 (n. 1)

Prange, Christian Friedrich, 82

Préaud, Maxime, 217 (n. 39)

Price, David, 244

Priester Wernher, 100

Pseudoaristeas, 100-101

Ptolemy, 120-22

Pumfrey, Stephen, 215 (n. 10)

Quintilian, 100

Rabelais, François, 97, 106-7

Rebhun, Paul, 246, 255

Redi, Francesco, 235, 239 (n. 36)

Reimann, Johann Friedrich, 85 (n. 21)

Reiske, Johann, 77

Reiter, Michael, 302 (n. 37)

Reuchlin, Johannes, 247

Reuwich, Erhart, 173

Ricoeur, Paul, 109

Riemer, Johannes, 248-49

Röcke, Werner, 183 (n. 40)

Rohr, Julius Bernhard von, 274

Rollfinke, Dieter, 303 (n. 55)

Rollfinke, Jacqueline, 303 (n. 55)

Rose, Mary Beth, 257 (n. 7)

Rossi, Paolo L., 215 (n. 10)

Rothmaler, Hulderich, 79

Roussel, Pierre, 281 (n. 26)

Roussineau, Gilles, 217 (n. 46)
Rowland, Beryl, 179 (n. 6)

Ruggiero, Guido, 243, 256 (n. 1)

Ruh, Kurt, 146 (n. 13)

Rühmkorf, Peter, 303 (n. 55)

Rummel, Walter, 216 (n. 26)

Rutschky, Katharina, 300 (n. 11)

Ryff, Walther, 160, 164, 167-68, 175-76, 178

Sade, Marquis de, 299

Salig, Christian August, 76

Salvestrini, Virgilio, 146 (n. 2)

Sandrart, Joachim von, 71-72

Sapper, Karl, 237 (nn. 11, 13)

Saxl, Fritz, 191 (n. 140)

Schaller, Georg, 167, 185 (n. 68), 187 (n. 85)

Scharitzer, E., 239 (n. 35)

Schede, Melissus, 258 (n. 14)

Schenda, Rudolf, 191 (n. 144)

Scherer, Wilhelm, 247

Schiffman, Zachary S., 216 (n. 32)

Schindler, Marvin, 251

Schindler, Stephan K., 303 (n. 49)

Schings, Hans-Jürgen, 301 (n. 13)

Schlosser, Julius von, 72

Schmeizel, Martin, 77

Schmidt, Arno, 98

Schmitt, Wolfram, 302 (n. 29)

Schnabel, Johann Gottfried, 262-78

Schneider, Manfred, 112 (n. 16)

Schnyder, André, 216 (n. 24), 218 (n. 53)

Scholderer, V., 42 (n. 7), 216 (n. 31)

Schöne, Albrecht, 147 (n. 22)

Schor, Johann Paul, 221, 223

Schottenloher, Karl, 43 (nn. 15, 16), 44

(n. 19)

Schreber, Daniel Paul, 286-87, 290, 299

Schröder, Wilhelm von, 281 (n. 32), 282 (n. 38)

Schröter, Michael, 244, 260 (n. 40)

Schulze, Johann Heinrich, 80-81

Schwarz, Christoff Gottlieb, 76, 81-82

Seckendorff, Veit Ludwig von, 273, 283 (n. 41)

Secundus, Janus, 251

Seeliger, Gerhard, 47 (n. 43)

Siefener, Michael, 215 (n. 8)

Singer, Charles, 239 (n. 30)

Singer, Herbert, 259 (n. 22)

Slawinski, Maurice, 215 (n. 10) 


\section{Index}

Solinus, $163,166,170$

Soman, Alfred, 216 (n. 28), 217 (n. 38)

South, Malcolm, 179 (n. 6), 189 (n. 111)

Spiegel, Jacob, 8-9, 27, 39

Sprandel-Kraft, Lore, 44 (n. 22)

Stafford, Barbara Maria, 301 (n. 20)

Stahl, Georg Ernst, 290

Stallybrass, Peter, 258 (n. 13)

Stangeland, Charles Emil, 282 (n. 37)

Stephens, Trent D., 180 (n. 6)

Stettler, Antoinette, 232, 234

Stone, Lawrence, 243

Strasser, Gerhard F., 237 (n. 5)

Stryk, Samuel, 88 (n. 50)

Stryke, Johann Samuel, 87 (n. 39)

Stübel, Alphons, 237 (n. 13)

Stüchs, Johannes, 8-9, 14

Summers, Claude J., 256 (n. 1)

Süßmilch, Johann Peter, 273-75

Suutala, Maria, 179 (n. 6)

Tannstetter, Jörg, 8

Tarot, Rolf, 259 (n. 19)

Tatlock, Lynne, 244, 259 (n. 15), 279 (n. 14)

Tedeschi, John, 215 (n. 9)

Tennant, Elaine C., 42 (nn. 9, 12)

Thales of Miletus, 226

Théodorides, Jean, 179 (n. 6)

Theweleit, Klaus, 303 (n. 57)

Thomas, Keith, 239 (n. 28)

Thomasius, Christian, 294

Thomasset, Claude, 280 (n. 17)

Thomas von Cantimpré, 157-59, 163-64, 166,187 (n. 85)

Thorndike, Lynn, 226

Thüring von Ringoltingen, 36, 39, 47 (n. 46)

Tietze, H., 42 (n. 7 )

Tietze-Conrat, E., 42 (n. 7)

Tinquely, Frédéric, 217 (n. 42)

Tissot, Samuel Auguste David, 302 (n. 43)

Tocco, Felice, 132

Toeller, Monika, 44 (n. 23)

Torrey, Harry Beal, 239 (nn. 28, 36)

Torricelli, Evangelista, 229

Treitzsaurwein, Marx, 52, 56, 65

Tribe, Keith, 272-73, 281 (n. 31)

Troncarelli, Fabio, 239 (n. 33)

Trotter, David, 281 (n. 30)

Tscherte, Johann, 8, 16, 18, 20, 42 (n. 7)
Turner, James Grantham, 256 (n. 1), 280

(n. 18)

Unterkircher, Franz, 41 (n. 3)

Valentini, D. Michael Bernhard, 84 (n. 15)

van Helmont, Franciscus M., 232

van Leeuwenhoek, Antoni, 229

Veeser, H. Aram, 257 (n. 3)

Vincent of Beauvais, 159, 163, 166, 169, 175,183 (n. 38)

Waetzoldt, Wilhelm, 88 (n. 54)

Wailes, Stephen L., 261 (n. 41)

Walker, Mack, 283 (n. 41)

Weber, Samuel M., 300 (n. 8)

Weninger, Robert, 112 (n. 13)

Westman, R. S., 129 (n. 35)

Weyer, Johann, 195-99, 203

White, Allon, 258 (n. 13)

Wichert, Adalbert, 259 (n. 19)

Wickram, Jörg, 247

Wiesner, Merry, 243

Wigginton, Waller B., 180 (n. 6)

Wightman, William P. D., 179 (n. 6)

Wilk, Franciscus, 87 (n. 38)

Will, Georg Andreas, 79, 85 (n. 22)

Williams, Gerhild Scholz, 218 (n. 58)

Willis, James A., 112 (n. 14)

Willis, Thomas, 235

Wilthelm, Alexander, 76, 81-82

Winckelmann, Johann Joachim, 71-73, 75,

$78,80-82,83$ (n. 1)

Wind, Edgar, 86 (n. 35)

Winslow, Charles-Edward A., 232, 235,

239 (n. 32)

Wissig-Bavig, Gabriele, 111 (n. 2)

Wittkower, Rudolf, 152

Wolff, Christian, 288

Yates, Frances A., 146 (n. 9)

Yersin, Alexandre, 234

Zalewska, Katarzyna, 180 (n. 6)

Zedelmaier, Helmut, 217 (n. 48)

Zedler, Johann Heinrich, 173, 270

Zesen, Philipp von, 219

Zorn, Fritz, 301 (n. 16)

Zumthor, Paul, 102, 113 (nn. 25, 27) 
Early modern Germany saw the dissemination of vast quantities of information at unprecedented speed. Popular knowledge, scientific inquiry, and scholarship influenced the political order, poetic expression, public opinion, and mechanisms of social control. This collection presents twelve essays by distinguished scholars regarding the transcendent nature of the Divine, the natural world, the body, sexuality, intellectual property, aesthetics, demons, and witches.

The contributors are Thomas Cramer, Walter Haug, C. Stephen Jaeger, Thomas DaCosta Kaufmann, Jan-Dirk Måller, James A. Parente, Jr., Stephan K. Schindler, Gerhard F. Strasser, Lynne Tatlock, Elaine Tennant, Horst Wenzel, and Gerhild Scholz Williams.

\section{UNC PRESS}

